\author{
Universidade de São Paulo \\ Faculdade de Filosofia, Letras e Ciências Humanas \\ Departamento de Geografia \\ Programa de Pós-Graduação em Geografia Humana
}

\title{
Entre as ruínas do muro: a história da geografia crítica sob a ótica da ideia de estrutura
}

Versão corrigida

Breno Viotto Pedrosa

São Paulo

Julho de 2013 


\author{
Universidade de São Paulo \\ Faculdade de Filosofia, Letras e Ciências Humanas \\ Departamento de Geografia \\ Programa de Pós-Graduação em Geografia Humana
}

\title{
Entre as ruínas do muro: a história da geografia crítica sob a ótica da ideia de estrutura
}

Versão corrigida

\author{
Breno Viotto Pedrosa \\ Orientador: Armen Mamigonian
}

Tese apresentada ao Programa de PósGraduação em Geografia Humana do Departamento da Faculdade de Filosofia, Letras e Ciências Humanas da Universidade de São Paulo para obtenção do título de Doutor.

São Paulo

Julho de 2013 
Nome: PEDROSA, Breno Viotto

Título: Entre as ruínas no muro: a história da geografia crítica sob a ótica da ideia de estrutura

Tese apresentada à Faculdade de Letras, Filosofia e Ciências Humanas da Universidade de São Paulo para obtenção do título de Doutor em Geografia Humana

Aprovado em:

Banca Examinadora

Prof. Dr. Instituição:

Julgamento: Assinatura:

Prof. Dr. Instituição:

Julgamento: Assinatura:

Prof. Dr. Instituição:

Julgamento: Assinatura:

Prof. Dr. Instituição:

Julgamento: Assinatura:

Prof. Dr. Instituição: Julgamento: Assinatura: 


\section{Resumo}

Esta tese busca analisar a história da geografia crítica na França e nos Estados Unidos, principalmente através da concepção de estrutura. A partir de uma compreensão preliminar dos geógrafos anarquistas do século XIX, seguimos para a análise do marxismo e do debate sobre o materialismo geográfico entre geopolíticos e intérpretes do pensamento marxiano na geografia.

Após a limitação da possibilidade histórica do desenvolvimento de uma geografia de esquerda na Alemanha, nos voltamos para a análise da geografia francesa que interage com o marxismo devido à resistência ao nazismo e à necessidade de emancipar-se de algumas concepções do pensamento vidaliano.

Acompanhamos, então, o rico desenvolvimento da geografia de esquerda como as análises de geografia urbana e econômica, assim como a introdução da temática do subdesenvolvimento.

A geografia de esquerda desacelera-se com a crise do marxismo e a ascensão da nova geografia. Contudo, pouco tempo depois, o descrédito da geografia quantitativa, o contexto mundial de lutas revolucionárias e os eventos de maio de 68 fazem surgir a geografia crítica. No caso francês, exploramos as relações entre a geografia de esquerda e o surgimento da geografia crítica; para os Estados Unidos, tentamos demonstrar como alguns de seus desenvolvimentos originam-se da nova geografia quantitativa.

Através do estruturalismo althusseriano e os intelectuais que o atacaram, surge o processo de transformação epistemológica e de instituicionalização em que geógrafos outrora marginalizados começam a integrar a academia e desfrutar de um grande capital cultural. No entanto, a institucionalização representa a normatização e a desradicalização. A ascensão do pós-modernismo conjuntamente ao esmorecimento do marxismo em âmbito internacional faz com que o projeto da geografia crítica altere-se profundamente, abrindo precedentes para a consolidação cada vez mais intensa do pós-estruturalismo no final da década de 1980. 


\section{Abstract}

This thesis analyzes the history of critical geography in France and the United States, primarily through the conception of the structure. Our approach will preliminary understand the nineteenth-century anarchist geographers followed by the analysis of marxism's rise and geographical materialism debate among geopoliticals and interpreters of Marxian thought in geography.

After the impossibility to develop a left geography in Germany, we turn to the analysis of French geography interacts with marxism tied to the resistance to nazism and the need to emancipate itself from some conceptions of Vidal de la Blache thought. We see the rich development of left geography in his urban and economic analysis, as well in introducting the theme of underdevelopment.

The left geography decelerates with the crisis of marxism and the rise of new geography. However, shortly after the discrediting of quantitative geography, the global context of revolutionary struggles and the events of May 68 give rise to critical geography. In the french case, we explore the relations between the left geography and the emergence of critical geography, and explaning about United States we tried to demonstrate how some of their new developments came from quantitative geography.

Through the althusserian structuralism and his criticals is possible to see the epistemological and institutional transformations in which geographers formerly marginalized begin to integrate the university and enjoy a great cultural capital. However, institutionalization is normalization and deradicalization. The insurgency of postmodernism with the demise internationally marxism makes changes in critical geography setting precedents for increasingly consolidation of post-structuralism in the late 1980s. 


\section{Agradecimentos}

Durante os cincos anos de desenvolvimento desta tese tive a oportunidade de conviver com muitas pessoas que enriqueceram as reflexões e permitiram um grande crescimento pessoal. Agradeço primeiramente aos colegas e alunos da Escola Municipal Olyntho Voltarelli e do Colégio Nossa Senhora de Sion. Lecionar nos primeiros anos de pesquisa limitou o trabalho, em contrapartida me fez crescer muito profissionalmente e pessoalmente. A atuação na escola aprimorou o manejo da geografia como um todo, convocando para a responsabilidade da militância das ideias através da educação.

Agradeço também a todos os membros da rede Terra Brasilis de pesquisa em história do pensamento geográfico, em especial pessoas que contribuíram com críticas às minhas reflexões iniciais e que oferecem um espaço muito rico de debate. Muito obrigado a Sergio Nunes, Rita de Cássia Anselmo, Letícia Parente, Rogata Del Gaudio, Mariana Lamego, Perla Zusman, Larissa Lira, David Palácios e Paulo Bomfim. Além do exercício intelectual, vocês todos ofereceram o afago terno da amizade que espantou a solidão e o isolamento nas fases mais difíceis.

Existem três professores na Universidade de São Paulo que desde o início do processo de pesquisa sempre me apoiaram e acolheram. Élvio Martins, Manoel Fernandes e Fábio Contel ajudaram-me muito, ensinaram coisas importantes e sempre mostram-se dispostos a me auxiliar para enfrentar a burocracia universitária. Eles também não hesitaram em declarar quando não estavam de acordo com minhas concepções, o que me levou a fortalecer meus argumentos.

A convivência do Laboplan foi outro elemento importante para mim. Agradeço aos amigos Daniel Huertas, Jane Barbosa, Dhiego Medeiros, Fábio Tozzi, Paul Clívilan, Mait Bertollo, Aline Santos, Jonatas Mendonça, Villy Creuz, Fernando J. Coscioni, Flávia Grimm e Rafael "Xavier" Pacchiega; e aos professores Ricardo Mendes, María Monica Arroyo, Maria Adélia Aparecida de Souza, María Laura Silveira e Antônio Alfredo Telles com quem pude aprender e conviver durante o tempo de pesquisa. A ajuda de lole llíada Lopes também foi essencial para a percepção de problemáticas sobre o território. As conversas com Lidiane Soares Rodrigues, mesmo quando a maior parte do trabalho já estava feita, foram igualmente indispensáveis para repensar muitos elementos que configuraram a tese.

Outro elemento fundamental foi o estágio de três meses que realizei na École des Hautes Études en Sciences Sociales, em Paris. Agradeço a recepção 
institucional de Marie-Vic Ozouf e pela ajuda de Marie-Claire Robic que apresentoume uma bibliografia que abriu novos horizontes de pesquisa. Agradeço ainda Federico Ferretti e João Jeannine pela amizade e pelo companheirismo.

Desde de que comecei a trabalhar com o professor Armen tive um contato maior com seus alunos. Apesar de todos estarem dispersos pelo Brasil, as ocasiões em que pudemos nos encontrar sempre foram importantes. Agradeço ao Lucas Emerique, Lucas Ferreira, Melissa Giacomelli, Elias Jabbour, Carlos Espíndola, Antônio Toledo "Gordo", Evandro Andaku, Marco Aurélio da Silva, José Messias Bastos, Marta Luedemann, Domingos Sávio Corrêa, Elias Jabbour e Tássia Castelli.

Agradeço ainda o sensei Morihiro Yamauchi, seu filho Jeremias S. Yamauchi e Daniel G. Nozaki por terem me conduzido na prática do karatê. Sem a disciplina, a determinação e o autocontrole adquiridos através de alguns anos de treinamento eu certamente não conseguiria ter concluído este projeto. Agradeço ainda os amigos Carlos Moreira Junior, Tiago F. Batista e Mauricio R. Cruz.

Finalmente existem algumas pessoas que me aconselharam, ouviram e orientaram durante todo o percurso. Sem o apoio delas esta tese não teria se realizado. A primeira pessoa é minha mãe, Maria de Fátima Viotto, que passou comigo todos momentos de dificuldade e alegria, acalmando meu espírito nos momentos de desânimo. Ela me ensinou a viver, e mais recentemente legou-me os segredos da profissão de professor que ela exerce há muitos anos. Agradeço ainda meu pai, João B. Pedrosa que sempre estimulou minha vida intelectual e me incentivou a seguir a carreira na universidade.

Agradeço a Ana Elisa Pereira, mais conhecida como "Aninha" do Laboplan. Ela foi uma amiga muito leal que sempre esteve de braços e coração abertos para apoiar-me diante dos mais diferentes percalços. Aninha sempre teve um bom conselho e uma boa conversa para oferecer e sou muito grato a tudo. A última pessoa é meu orientador, o professor Armen Mamigonian. Basta pouco tempo de convívio para conhecer sua generosidade, determinação, honestidade e seu espírito aguerrido e provocador. Guardo na mente e nas anotações boa parte de nossas conversas que serviram-me como estímulos intensos para continuar a pesquisa e focar-me em assuntos pouco explorados ou valorizados pelos geógrafos. Armen mostrou-me vários caminhos e deu liberdade para que eu fizesse minha própria trajetória; mas o mais importante é que ele me ensinou a continuar lutando sempre. Muito obrigado! 
Acrescento meu agradecimento ao Conselho Nacional de Desenvolvimento Científico e Tecnológico (CNPq), que concedeu-me uma bolsa de estudos a partir de agosto de 2011, e à Bolsa de Mobilidade Internacional Santander, que possibilitou meu estágio na França. 
Índice

$\begin{array}{ll}\text { Introdução } & 14\end{array}$

Parte I - Os antecedentes da geografia crítica 25

$1.1 \mathrm{O}$ anarquismo geográfico de Reclus e Kropotkin 28

1.2 Plekhânov e a geografia 34

1.3 A relação entre marxismo, positivismo e darwinismo no início do século $\quad 37$ $X X$

1.4 Geografia, história e marxismo: a sinergia de três campos em busca de $\quad 44$ uma base institucional

1.5 A geografia alemã marxista: economia, geopolítica e materialismo geográfico

2.1 Os geógrafos de esquerda na França, um início esquecido

2.2 A geografia não era tão reacionária como dizem 70

$\begin{array}{ll}2.3 \text { As propostas da geografia de esquerda } & 77\end{array}$

$2.4 \mathrm{O}$ urbano e o rural $\quad 89$

2.5 Geografia social, sociologia e população $\quad 95$

2.6 Planejamento, economia e geografia: da revolução nacional ao 101 descongestionamento industrial

2.7 Planejamento, socialismo e geografia: apologia à racionalidade 108 planificadora no contexto da guerra fria

2.8 A dialética do relevo 112

2.9 A disseminação da geografia marxista entre os discípulos 114

3.1 1956: a crise do marxismo e seus desdobramentos 122

3.2 A nova geografia e o contexto da guerra fria nos Estados Unidos 130

3.3 Edgar Kant, Hägerstrand e a escola de Lund 136

3.4 O início tardio da nova geografia na França e a reorganização da $\quad 140$ esquerda

3.5 Rochefort e a síntese ativa do planejamento 
1.2 Maio de 1968 e a geografia

1.30 surgimento da geografia crítica

1.4 Bunge, Harvey e a geografia do gueto

1.5 Da análise urbana ao capitalismo mundial

$2.1 \mathrm{O}$ estruturalismo althusseriano

2.2 A crise da geografia

2.4 Os novos periódicos e suas transformações

2.5 A organização categorial

2.6 A escola do regulacionismo

2.7 A crítica que se inicia na história

2.8 A controvérsia Claval

3.1 A crise do pensamento marxista no início da década de 1980

3.2 A teoria da estruturação e a volta ao regionalismo

3.3 O realismo filosófico

3.4 Os debates em meados da década de 1980

3.5 A geopolítica e o pós-modernismo

3.6 A consolidação da pós-modernidade $\quad 289$

3.7 O pós-modernismo na geografia 297 
Referências bibliográficas

\section{Índice de quadros}

Quadro 1 - Conjunto de artigos representativos publicados na revista La Pensée

Quadro 2 - Publicações do grupo de geógrafos de esquerda no Congresso da UGI realizado no Brasil em 1956

Quadro 3 - Esquema conceitual de H. Lefèbvre

Quadro 4 - Concepções de Estrutura

Quadro 5 - Os geógrafos, temas e áreas de pesquisa

Gráfico 1 - Artigos de geógrafos ou temática radial nos Anais da Associação 220 Americana de Geógrafos de 1970 a 1989 
"A ciência só realiza progressos reais quando uma nova verdade já encontra um meio preparado para aceitá-la"

Kropotkin 


\section{Introdução}

A grande indagação que nos move no decorrer desta tese é como se forma e se altera a geografia crítica nos Estados Unidos e na França. Esse termo tem um uso amplo que se apresenta muitas vezes de maneira ambígua, refletindo os percalços de sua autodefinição enquanto campo de estudos e sua acepção atual que abriga toda e qualquer geografia que realize algum tipo de crítica social. A problemática da definição da geografia crítica remete diretamente à hipótese inicial de nosso trabalho: remontando a um panorama inicial pouco discutido no pósguerra, ela tem características que se modificaram desde sua origem no início da década de 1970 tornando-se muito diferente no que diz respeito às agendas de pesquisa, aos temas e referências teóricas mais utilizadas se compararmos com a prática de seus pesquisadores no final da década de 1980.

A dinâmica de tais mudanças será o tema central deste trabalho, entretanto nosso fio condutor para analisar essa história densa que envolve contextos complexos e geógrafos de extensa produção será a ideia de estrutura.

Queremos demonstrar que a concepção de estrutura pode ser utilizada para compreender o desenvolvimento da geografia crítica, bem como das alterações de seu sentido e abrangência. $O$ itinerário que seguiremos remete à seguinte periodização: (1) o surgimento na França do pós-guerra de uma geografia de esquerda, militante do partido comunista francês, que utilizou a ideia de estrutura como ferramenta de análise social; (2) fruto do pensamento questionador e radical do movimento de maio de 1968 e da busca do pensamento alternativo à ortodoxia, vemos a ascensão da influência do estruturalismo de Althusser na França e nos Estados Unidos, paralelamente às tentativas de renovação da geografia baseadas nos aportes do marxismo; (3) no início da década de 1980 identificamos críticas à ideia de estrutura com grande presença e influência do pensamento pósestruturalista e pós-moderno, resultando em um ecletismo metodológico e epistemológico nesta ciência.

É na última fase da periodização que o rótulo geografia crítica abrigará uma variedade maior de práticas e geógrafos ao contrário do que ocorria no início de sua consolidação no campo das ideias, momento que o processo de renovação ressaltava e enaltecia a ligação com o marxismo, o anarquismo e a preocupação com a mudança social revolucionária no sentido clássico. Contudo, cabe esclarecer que nosso referencial de geografia crítica evoca os intelectuais que tentaram renovar 
a disciplina a partir do marxismo; portanto, no transcurso desta tese ela se refere à ligação entre o campo disciplinar da geografia e a ampla tradição de ideias conhecida por marxismo.

Quanto à nossa abordagem metodológica, optamos pela história social das ideias, ou seja, pela análise do processo de institucionalização da geografia crítica, da formação das redes e grupos de pesquisa, das ideias que são transmitidas entre as escolas nacionais, ou ainda da construção do reconhecimento e prestígio científico da geografia crítica dentro da comunidade de geógrafos. Pretendemos explorar a formação, as continuidades, descontinuidades e paralelismos do pensamento geográfico marxista dentro daquilo que Berdoulay (1981, p. 15-37) chama de "abordagem contextualista".

Berdoulay (1981, p. 9-16) demonstra como o contexto histórico está relacionado com as intencionalidades dos grupos sociais e com o conhecimento que é produzido dentro das universidades. A cada época as sucessivas gerações de intelectuais dão respostas ao contexto histórico mediante negociações entre sociedade e grupos de pesquisa. O resultado desse processo, a longo prazo, é a formação de coletivos científicos hegemônicos aceitos e prestigiados socialmente, em detrimento de outros que caem na marginalidade.

Não podemos negar a forte impressão e inspiração que a obra de François Dosse nos causou em todo o processo de pesquisa. Em um dos raros momentos em que fala sobre seu método diz que:

\footnotetext{
[a] história intelectual, espremida entre as lógicas diacrônicas da história das ideias e as lógicas sincrônicas das cartografias e recortes sócioculturais, é uma área incerta, um entroncamento entre a pluralidade das abordagens possíveis e a vontade de retraçar os contornos de uma história global (DOSSE, 2004, p. 301).
}

Bourdieu (1984) em sua análise sobre a sociologia da ciência será outra referência fundamental, pois sua obra tenta compreender como se estabelecem e se modificam os critérios de cientificidade, ou seja, como determinados grupos dentro da universidade se organizam através das estratégias de ganho de prestígio e 
formam um capital cultural $^{1}$, que concerne 0 reconhecimento social obtido por cientistas através de sua prática profissional. Bourdieu também nos é fundamental por tratar do processo de constituição da ciência enquanto prática social:

\begin{abstract}
A ciência nada mais pode fazer senão tentar estabelecer a verdade dessas lutas pela verdade, apreender a lógica objetiva segundo a qual se determinam as coisas em jogo e os campos, as estratégias e as vitórias, produzir representações e instrumentos de pensamento que, com desiguais probabilidades de êxito, aspiram à universalização, quer dizer, à estrutura histórica do campo em que se geram e funcionam (BOURDIEU, 2010, p. 294).
\end{abstract}

A partir dessa abordagem, indagamos quais as estratégias da geografia crítica para estabelecer-se como discurso universal no campo da geografia, quem foram os responsáveis pelo processo e ainda qual o apoio institucional que possibilitou sua consolidação. Outro ponto importante é investigar se ocorre o surgimento de novos subcampos dentro da geografia durante esse processo. $O$ campo nada mais é que:

(...) o universo no qual estão inseridos os agentes e as instituições que produzem, reproduzem ou difundem a arte, a literatura ou a ciência. Esse universo é um mundo social como os outros, mas obedece a leis sociais mais ou menos específicas (BOURDIEU, 2003, p. 20).

Quanto mais autônomo o campo, maior o poder de resistência ou refração aos acontecimentos sociais dentro de um contexto histórico, assim como sua capacidade de transfigurar as pressões ou posições externas é proporcional ao poder de seus integrantes (BOURDIEU, 2003, p. 22-23). Isso nos encaminha para um visão mais crítica acerca das demandas sociais, tão debatidas na história da geografia, porque o campo pode internalizar discussões da sociedade e modificarse, mas ele também é capaz de exteriorizar seus próprios debates para sociedade.

A estrutura do campo é determinada pela distribuição do seu capital científico em um determinado momento, porém este capital pode ser dividido em temporal e epistemólogico - ou ainda institucional e puro. O primeiro diz respeito ao poder institucional (chefia de institutos, laboratórios, cargos de liderança nas associações

\footnotetext{
1 Como nos coloca Bourdieu o capital cultural se originaria do trabalho pessoal do intelectual, como cursos, livros, manuais, dicionários, enciclopédias. No entanto, ele é permutável entre grupos que comungam de as mesmas agendas de pesquisa ou objetos de estudo afins. O capital cultural contém uma dimensão política e dependeria da capacidade de divulgação das obras científicas, de seu alcance e aceitabilidade de uma forma geral. Sinteticamente "o poder dentro de uma instituição cultural implica em uma forma de autoridade propriamente cultural, um tipo de carisma de instituição" (BOURDIEU, 1984, p. 128).
} 
de geografia) e o segundo refere-se a uma influência científica per se, ou seja, o reconhecimento social da prática dentro do próprio campo (BOURDIEU, 2003, 24-29).

Como expõe Bourdieu (2003, p. 29), a definição e a representação do campo é um assunto de eterna disputa entre a comunidade científica, e nós veremos que isso se aplica muito bem para a geografia crítica. As regras do campo ou os critérios de cientificidade consolidam-se com o próprio movimento do campo na sua prática e transformação histórica. As normas estão postas em um dado momento, mas estão sempre sujeitas à redefinições.

Cabe dizer ainda que não queremos fazer uma análise individual, mas dos grupos que se formaram e da movimentação das ideias no interior da comunidade científica, mesmo que a trajetória individual seja extremamente relevante nesse processo. O enfoque individual e isolado de cada pesquisador certamente iria nos privar de uma visão de síntese.

Partiremos do pressuposto de que o desenvolvimento da geografia segue um movimento anárquico, ou seja, que não se encaixa adequadamente em nenhum dos modelos pré-estabelecidos (como os de Kuhn ou Lakatos). Isso deve-se, em parte, pelo fato desses modelos de desenvolvimento serem pensados para ciências naturais e físicas. As ciências humanas seguem outras trajetórias agregando elementos de outras ciências e ainda das artes e da filosofia. Essa postura foi amplamente discutida por Claval (1998, p. 13) que fez uma recuperação das abordagens para se fazer história da ciência, e que acaba por adotar a postura anárquica de Feyerabend mais aberta às mudanças históricas. No entanto, não queremos que o "movimento histórico anárquico" caia em um vazio metodológico e historiográfico, uma vez que optamos pela sociologia das ideias.

O enfoque nos paralelismos e o fato de explorarmos a geografia de esquerda antes da geografia crítica busca desmistificar uma certa visão etapista e evolucionista da disciplina. Na verdade, veremos que no campo geográfico o marxismo, a herança vidaliana, a nova geografia e o existencialismo oferecem ideias fundamentais para o desenvolvimento ou a estagnação da disciplina. 
Quanto ao panorama histórico, buscamos adentrar nos meandros deste contexto na medida em que forem relevantes para a compreensão do desenvolvimento da geografia crítica. O risco de apoiar-se muito em contextos históricos sem uma boa pesquisa documental pode eventualmente induzir à relações falsas, como demonstra Claval:

\begin{abstract}
O contexto no qual a pesquisa toma seu lugar é indefinido: o que é importante perceber são as utilizações que os conhecimentos poderão servir; existem necessidades que precisam ser satisfeitas, ou seja, uma demanda social (...) Suas preocupações são motivadas pelas grandes questões de sua época tanto quanto pelos problemas especificamente ligados ao espaço. A curiosidade geográfica muda segundo nossos interesses, sobretudo naquilo que pesa sobre o destino dos povos (...) (CLAVAL, 1984, p. 11)2.
\end{abstract}

No entanto, mesmo nos apoiando apenas nos contextos pertinentes ao trabalho, ainda assim não estamos completamente livres das possibilidades de falsas associações:

Existe um perigo comum a toda história das ideias: se preocupando somente da lógica profunda do pensamento, se negligência algumas vezes os encadeamentos reais, e/ou supõe as relações onde não existe nada mais que o acaso, a justaposição ou a coincidência (CLAVAL, 1972, p. $73)^{3}$.

Dito isso, novamente esclarecemos acerca da controvérsia ao redor da geografia crítica: atualmente, existe uma ideia um tanto anacrônica no cenário internacional de que a geografia radical é herdeira do marxismo engajado e que a geografia crítica está próxima à denúncia e crítica social, distante da militância política, gerando, portanto, um conformismo (GINTRAC, 2012). Tal diferenciação certamente soa estranha ao leitor brasileiro, que provavelmente toma os adjetivos crítica e radical por sinônimos. Apontamos essa interpretação de diferença profunda entre as duas geografias como anacrônica, porque no momento de surgimento e ganho institucional acelerado, a geografia crítica ou radical era associada predominantemente ao marxismo - e de certa forma ao anarquismo - muito distante da crítica social pontual do pós-estruturalismo, que estava ainda em processo de consolidação nos intercâmbios entre França e Estados Unidos.

\footnotetext{
2 Tradução nossa. Apenas na primeira citação de cada texto indicaremos caso a tradução seja nossa.

3 Tradução nossa.
} 
Em um dicionário de geografia encontramos a seguinte definição: "Embora não exista uma distinção radical a ser elaborada entre as duas, a geografia crítica apresenta-se atualmente mais difusa, menos institucionalizada, mais teoricamente eclética e, alguns argumentam, menos focada politicamente" (JOHNSTON et al., 2008 , p. 127$)^{4}$. O termo "crítica", que pode remeter ao sentido de raiz ou origem dentro da tradição filosófica alemã a partir de Kant, tornou-se cada vez mais próximo das ideias pós-estruturalistas, principalmente no último período que delimitamos.

Admitir que a geografia crítica é una ou é idêntica em todos países não corresponde à realidade. Desejamos evidenciar que embora as chamadas escolas nacionais não esgotam seu conteúdo e sua originalidade, a influência e a transmissão de conhecimento pelo mundo têm repercussões profundas dentro dos contextos locais. Desejamos justamente elucidar os debates do centro do sistema mundial (EUA e França) que se propagaram pelo mundo e acabaram pautando ou influenciando as geografias nacionais. Dessa forma, cremos que a ideia de estrutura foi um vetor importante do debate transmitido pelo mundo, como é o caso do marxismo althusseriano com fortes desdobramentos na América Latina com consequências importantes dentro da geografia.

Poder-se-ia pensar também que esse trabalho busca classificar os mais e os menos marxistas, aqueles que gozam de uma pureza teórica, metodológica e política. Não é esse o nosso objetivo, pois queremos entender o processo de como a geografia marxista ligada aos partidos e lutas políticas se institucionalizou, perdeu algumas de suas antigas características e metamorfoseou-se em outras denominações.

Elucidamos que nosso interesse recai nas leituras que os geógrafos fizeram de suas referências metodológicas - de autores tais como Marx, Althusser, Lefèbvre e não um retorno aos clássicos em busca de alguma espécie de interpretação "verdadeira" olvidada pelos percursores do debate marxista na geografia. Isso não nos impedirá de consultar essas referências maiores, porém não temos o objetivo de fazer proposições epistemológicas profundas a partir do balanço entre as interpretações passadas e as novas leituras possíveis.

Diante do exposto, poderíamos encarar as relações entre marxismo e geografia de duas maneiras. A primeira delas é fazer como Quaini (2002), em sua célebre obra Marxismo e Geografia que buscou a presença de um conteúdo

\footnotetext{
4 Tradução nossa.
} 
geográfico em algumas produções de Marx. Oliveira (1982, p. 67) criticou esse preciosismo ou corporativismo disciplinar que muitas vezes faz cair numa ilusão de ausência do debate geográfico no marxismo. Adotamos a mesma posição de Oliveira, porque Quaini tem um escopo limitado ao jargão disciplinar sem ressaltar os processos sociais e históricos analisados em O Capital, A ideologia alemã, dentre outros trabalhos que apresentam caráter eminentemente geográfico. Portanto, para compreender o capitalismo de sua época, Marx e Engels tiveram que mobilizar categorias, variáveis e conceitos próprios da geografia de forma consciente ou inconsciente. Basta lembrar a discussão sobre renda e valor da terra nos fins d'O capital, ou então a análise do imperialismo inglês e suas relações coloniais.

Não por acaso, um periódico especializado em artigos sobre a biografia e produção dos geógrafos publicou um texto sobre Marx. Discute-se o papel dado ao determinismo ambiental e o poder das técnicas em enfraquecer o meio ambiente, o modo de produção asiático e a eventual ausência da análise da questão espacial no pensamento de Marx; este último aspecto é uma grande querela que molestou a geografia durante bastante tempo (SHAW, 2000, p. 79-82). Contudo, Shaw (2000, p. 82) conclui taxativamente "o impacto do método marxiano, particularmente na análise do espaço econômico urbano e na geografia do desenvolvimento desigual, foi enorme".

O mesmo ocorre com os que dão continuidade à tradição marxista. A discussão do imperialismo feita por Lênin, Bukharin e Rosa Luxemburgo, a análise sobre a questão agrária de Kautsky, ou mesmo Walter Benjamin em seus escritos sobre a Paris do final do século XIX revelam a perspectiva geográfica. Sendo assim, a segunda maneira de encarar a relação entre o marxismo e a geografia é justamente alargar o escopo de análise levando em consideração essas relações ora mais tênues, ora mais explícitas. Apesar do marxismo ter uma grande pluralidade inerente ao seu desenvolvimento, é importante ver sua continuidade como tradição:

E, decerto, a extraordinária influência de Marx sobre o conjunto da história da humanidade não pode ser separada do fato de que ele redefiniu radicalmente a filosofia, vendo-a como o empreendimento coletivo ao qual muitas gerações trazem a sua contribuição, em correspondência com as exigências e as possibilidades de sua situação. Nesse sentido, em vista de uma radical reorientação de toda a estrutura do conhecimento como um grande empreendimento coletivo, pode existir apenas o 'marxismo' e não 'os marxismos': esses representam especificações sócio-políticas que têm em comum a mesma orientação de base, e faz parte do espírito da nova concepção do mundo o fato de que deve encontrar sua articulação através 
de contínuas redefinições e inovações, a partir do momento em que as condições do seu desenvolvimento ulterior alteram-se, de modo significativo, com a história e com o progresso do conhecimento (MÉSZÁROS, 1983, p. 170).

Existem heterogeneidades dentro do próprio marxismo, mas fica clara a ênfase em seu caráter unificador, pois independentemente das correntes interpretativas existe um ponto de partida comum para todas as tendências. Devemos atentar para o fato de que Mészáros não está falando dos partidos ou das correntes políticas, mas "do conhecimento como um grande empreendimento coletivo", que constitui uma herança compartilhada por várias gerações. De fato, existem diversas correntes teóricas dentro do próprio marxismo, e mesmo que alguns privilegiem certas categorias em detrimento de outras, persiste um conjunto de problemáticas delimitadas tradicionalmente em várias obras de Marx e Engels. Esse é o fio condutor que legitima a constituição dessa heterogeneidade sob apenas uma tradição de pensamento, apesar das disputas políticas que surgiram entre as correntes políticas do marxismo.

No entanto, as heterogeneidades sociopolíticas ou mesmo interpretativas não podem ser arrasadas pela ideia de um só marxismo e por isso admitimos marxismos. Os vários marxismos estão uns mais próximos, outros mais distantes, porém com o mesmo conjunto de categorias de análise e um contexto filosófico mais ou menos semelhante. Contudo, nosso objeto de estudo ainda se relaciona com o pós-marxismo, e no tocante a isto acreditamos existir uma ruptura e um deslocamento do campo historicamente consolidado, mesmo que ele se insira na interpretação de muitos no espectro político da esquerda.

Uma divisão clássica que está presente em todo trabalho é o de marxismo ocidental e oriental. Trabalharemos melhor essa diferenciação no decorrer de nosso estudo, mas inicialmente cabe destacar que o termo marxismo ocidental pode ser atribuído a Karl Korsch muitos anos antes da popularização do estudo de Perry Anderson. Korsch utilizou a expressão para referir-se às correntes críticas à União Soviética e apesar dele não der dado muita importância à classificação, anos mais tarde, Merleau-Ponty a utiliza para separar-se do marxismo ortodoxo e ao mesmo tempo valorizar as raízes weberianas do jovem Lukács (THERBORN, 2012, p. 74).

A práxis é outro problema que se impõe com o fenômeno do pesquisador militante ativamente político que utiliza o seu conhecimento da realidade concreta como força transformadora do mundo. Dessa maneira, do ponto de vista da 
classificação do conhecimento seria uma contradição separar teoria e prática no marxismo. No entanto, na realidade observamos com frequência, no marxismo ocidental, uma separação da práxis ou uma minimização e empobrecimento da ação política direta com um direcionamento para a filosofia.

Antes de falar sobre a geografia crítica, precisamos explorar o hiato na práxis entre a investigação da realidade e a ação política. Basta lembrar que nem sempre os partidos políticos ou organizações sindicais estão diretamente ligadas ao conhecimento marxista gerado pelos intelectuais e nem os sindicalistas estão próximos do fazer teórico. Outro elemento que indica esse fato é a possibilidade de se utilizar do marxismo sem ser politicamente marxista. Oliveira (1982, p. 70) e Anderson (2004, p. 130-157) apontam para essa separação entre teoria social e prática, o que revela uma tradição das ideias científicas e uma política que inicialmente caminharam juntas, mas que atualmente estão tendencialmente separadas, ou seja, por vezes se tocam e comumente se distanciam. Apesar desse quadro, pensamos que apenas as posturas dos intelectuais guardam em si um conteúdo político e podem apresentar-se como ação efetiva de luta política. A política das ideias ou das disputas pelas visões de mundo e interpretações científicas têm várias consequências no âmbito da academia, em eventualmente, no Estado e na sociedade.

Contudo, esse hiato não acompanhou o marxismo desde suas origens, pois surge em um processo de transição que vai da Revolução de 1917 até após a Segunda Guerra Mundial, período em que é absorvido com força pelas universidades e será institucionalizado. Ao mesmo tempo em que surgem os intelectuais marxistas da academia, existe um intercâmbio maior entre a universidade e o pensamento marxista devido ao poder ideológico da ascensão da União Soviética como sistema social alternativo planejado e supostamente mais justo, baseado no socialismo científico. Podemos dizer que essa cisão entre teoria e prática tem como uma de suas consequências a fragilização do compromisso político, como aponta Anderson (2004, p. 130-157). Assim, de um lado temos o marxismo ocidental mais ligado à filosofia, e de outro o marxismo soviético, que relaciona-se com a política em sua dimensão prática.

Esse paradoxo acompanha-nos durante todo o percuso, pois no caso francês uma parte importante da geração de geógrafos ligados ao partido comunista francês deixa de atuar após a invasão da Hungria em 1956, enquanto nos Estados Unidos, 
onde não há uma grande tradição de partidos comunistas, o marxismo desenvolvese mais ligado à filosofia do que à prática política.

Poder-se-ia pensar então que houve uma grande fragmentação ou que existiram várias geografias críticas, entretanto, os geógrafos utilizaram muitas fontes em comum, o que marca a formação de determinados nichos ou grupos de pesquisa dentro do campo, influenciados pelos partidos políticos no caso francês e por ideias esquerdistas nos Estados Unidos. Cabe refletir adiante como as referências em comum participam da renovação da geografia e da formação de seus subcampos.

Veremos que o movimento inicial é o surgimento da geografia social, da população e econômica com Pierre George. Temos a institucionalização de subcampos que buscaram pensar o modelo soviético de desenvolvimento e o processo de industrialização no pós-guerra, e mais recentemente a introdução do debate de gênero, classe social e raça alguns anos antes de 1989. Isso demonstra a reestruturação do campo de estudos da geografia, seja através da criação de novos subcampos, seja através de seu remodelamento.

Como nos aponta Bourdieu (1984, p. 74), cada grupo de pesquisa ligado a um objeto de pesquisa - ou campo de estudo - apresenta determinados critérios de cientificidade específicos. No entanto, os critérios de cientificidade, o vocabulário e até mesmo os hábitos das ciências naturais desfrutam de uma hegemonia dentro das universidades. Ou seja, eles tentam se estabelecer como referência única, homogeneizando os critérios de outros campos para assim gozar de um maior prestígio perante a sociedade e aos grupos dentro da academia. Possuem um maior capital cultural e uma maior capacidade de distinção social, podendo portanto afirmar-se como verdade. A geografia por ser uma ciência tanto natural, quanto social sofre diante deste paradoxo, mas a geografia crítica tentará afirmar a geografia como ciência exclusivamente social.

Um outro elemento importante é que nosso objetivo, ao classificar os autores ou vinculá-los à determinadas tradições de pensamento, não é o de simplificar ou rotular suas ideias. Ao contrário, o que desejamos é tentar discutir e apontar qual a posição de cada autor dentro do campo, lembrando que suas escolhas refletem uma postura política que permite vislumbrar sua concepção de mundo e projeto intelectual.

Como veremos adiante, na disputa entre ciências naturais e sociais no complexo quadro do marxismo do início do século $\mathrm{XX}$ identifica-se um período em 
que as ciências naturais e o darwinismo polarizam grande parte do pensamento social, o que cria uma relação tensa entre a visão romântica de ciência de Marx e o positivismo naturalizante que permeia o pensamento de Engels.

Feitas essas ressalvas iniciais, seguiremos a forma de exposição sugerida pela periodização mencionada acima. Na primeira parte do trabalho exploraremos minimamente o pensamento anarquista geográfico do final do século XIX, a interpretação marxista do materialismo geográfico através do pensamento ratzeliano, e o quadro universitário francês que foi influenciado pelo marxismo e pelo partido comunista. Veremos que essa situação, mesmo em um período de crise e descrença no marxismo, forneceu subsídios para o surgimento da geografia crítica, inserindo temas de pesquisa novos se comparados aos da agenda de pesquisa vidaliana. Ao mesmo tempo, no mundo anglo-saxão, em meados do século $X X$, a ascensão da nova geografia causa uma mudança na visão da organização disciplinar. Contudo, a quase ausência de crítica social faz com que os geógrafos reflitam sobre suas práticas, as contradições sociais e os efeitos de suas ações na sociedade. Notemos que nos dois casos a presença de uma geografia aplicada aos problemas sociais constitui uma força motriz importante para as transformações da geografia.

$\mathrm{Na}$ segunda parte de nossa argumentação exploraremos os dois últimos períodos propostos: o momento de institucionalização da geografia crítica, em que de uma forma geral o marxismo e o estruturalismo têm grande força nos debates; e a crescente crítica ao estruturalismo e seus desdobramentos iniciais, como, por exemplo, a escola da regulação, a teoria da estruturação de A. Giddens ou o realismo filosófico de Bhaskar. Defendemos que essas críticas são parcialmente responsáveis pela hegemonia do pós-modernismo. Não é possível compreender a ascensão da geografia pós-moderna e seu impacto no pensamento marxista resultando no ecletismo metodológico e em novas posições acerca do método e da filosofia do conhecimento - sem compreender o longo antecedente de trocas entre o pensamento francês pós-moderno e a crítica literária norte-americana. De forma gradativa, essa matriz filosófica migra do campo literário para as ciências sociais e, no que nos diz respeito, para a geografia.

Cabe esclarecer que cada capítulo desta tese foi pensado para ser uma unidade mais ou menos independente e coerente, o que pode, em certas ocasiões, causar a repetição de algumas informações. 


\section{Parte I - Os antecedentes da geografia crítica}

Não é possível ignorar que o pensamento de crítica social, oriundo do socialismo, como o anarquismo e o marxismo no final do século XIX, produziram trabalhos de temática geográfica que tiveram um significativo impacto social. Kropotkin, Reclus e Plekhânov, para citar os mais célebres, influenciaram muitos pensadores posteriores. Buscaremos analisar minimamente aspectos do pensamento desses autores para tentar balizar sua contribuição na geografia. Encontraremos posições muito discrepantes: enquanto Stálin, por exemplo, pauta-se em Reclus para reivindicar uma posição oficial do partido comunista acerca do determinismo geográfico, Jean Dresch tem uma certa aversão ao pensamento reclusiano devido ao uso exacerbado da estatística.

Com o objetivo de mostrar a continuidade e descontinuidade da tradição crítica, antes de analisarmos as condições da geografia francesa, faremos uma rápida incursão na geografia alemã mais precisamente na figura de Wittfogel e o debate do que ficou conhecido como materialismo geográfico. Sua obra é de suma importância para a crítica da geopolítica e para a conformação da discussão sobre o modo de produção asiático. Com a irrupção nazista e o boicote da União Soviética, as condições concretas para o desenvolvimento de uma geografia inspirada pelo marxismo afloram na França, onde a militiância política contra o fascismo, o nazismo e o anticolonialimo serão fatores chave para o enlace dos intelectuais no entre guerras e no final da Segunda Guerra Mundial. Aliás, a vitória da União Soviética no conflito mundial contribuiu para que muitas pessoas ao redor do mundo demonstrassem simpatia ao socialismo real.

Adiante veremos que a geografia francesa, gestada pelo marxismo com origem na tradição regional vidaliana, institucionaliza-se articulando mestres e discípulos militantes ou simpáticos à esquerda em grupos de pesquisa e de solidariedade. No momento do pós-guerra, a preocupação será com a modernização da disciplina frente aos temas tradicionais do aparato vidaliano.

Entretanto, paulatinamente, durante a guerra fria o socialismo real vai perdendo o prestígio acumulado na vitória contra o nazismo, e outros focos de luta revolucionária surgem alargando a reflexão sobre a revolução ou sobre a construção do socialismo. Figuras importantes da geografia francesa se afastarão gradualmente da órbita soviética. Como evento fundamental do processo de retração do marxismo ortodoxo escolhemos o surgimento da geografia ativa, pois alguns anos após sua 
publicação e impulsionada pelo pensamento radical de maio de 1968 surgiria a geografia crítica como proposta tardia de constituição do conhecimento geográfico sob a base marxista.

Dentro do campo da história do pensamento geográfico existe um consenso de que a geografia crítica teve seu início em fins da década de 1960 e começo da década de 1970 - com o início de publicações importantes como Antipode e Hérodote. No entanto, não podemos ignorar que durante grande parte do transcurso da geografia moderna houve uma latência do marxismo.

A mobilização consciente ou inconsciente de categorias geográficas no vasto horizonte de temas englobados pela disciplina foi explorado na obra de Marx e Engels. Contudo, no tocante à formação de Marx, em sua juventude, não podemos deixar de indicar que ele foi aluno do geógrafo Karl Ritter ${ }^{5}$, fato que influenciou seu pensamento como indica Pierre Vilar:

Será oportuno partir de Marx estudante. Numa atmosfera universitária impregnada de hegelianismo, mas onde Hegel, apesar de tudo, já pertencia ao passado, jamais foi estabelecido com exatidão o que o jovem Marx acolheu ou rechaçou das lições recebidas menos indiretamente: as de um Ritter, de um Savigny. Os que enxergam em Marx, antes de mais nada, um determinista, puderam sugerir que o determinismo geográfico de Ritter não foi alheio a sua formação. Parece-me supérfulo afirmar que não existe nele um determinismo econômico; e que é mais estranho a seu pensamento do que as tentativas que se realizaram hoje no sentido de reduzir, mediante um jogo matemático, a implantação humana às condições do espaço. Decerto, Marx jamais deixa de recordar a presença, na base de toda história e de toda economia, das 'condições geológicas, orográficas, hidrográficas, climáticas, etc.'; como já Hegel havia feito, precisando que toda historiografia (Geschichtsschreibung) deve partir dessas bases naturais e de sua modificação pelos homens no curso da história (Geschichte). Antes de poder 'fazer a história' (...) o homem deve se confrontar com certas condições. Esse apelo à evidência será retomado com frequência no interior de uma teoria de conjunto, na qual a capacidade de domínio do homem sobre a natureza é o critério de fundo. A natureza não impõe, já que a técnica é capaz - mais dia, menos dia - de vencê-la. Mas, a cada nível alcançado, a natureza - dentro de certos limites a precisar - pro-põe ou o-põe (VILAR, 1983, p. 92-93).

Vilar nos contempla com uma interessante reflexão sobre a relação entre o homem e o meio no cerne do pensamento marxiano, delimitando-o fora da esfera de um total determinismo geográfico. O leitor atento de $A$ ideologia alemã poderá

\footnotetext{
5 Outro momento interessante foi quando em 1845 Marx encontra-se com Alexander von Humboldt. Marx publica declarações polêmicas sobre a aristocracia alemã na revista Vörwarts! e o Rei Luís Felipe da França envia Humboldt pessoalmente para entregar a Karl Marx um vaso de porcelana e uma carta do Rei Guilherme IV protestando contra os insultos (WHEEN, 2001, p. 89-90). Um fato pouco conhecido é que Humboldt foi simpatizante da revolução de 1848 posicionando-se a favor da unificação da Alemanha, das liberdades políticas e do desmantelamento do Estado feudal. Quando suas cartas vieram a público causaram grande escândalo nos meios aristocráticos (RUPKE, 2005, p. 337-339).
} 
acompanhar a démarche de sua postura prometêica pautada na razão e na técnica distante do determinismo geográfico. Contudo, poucos geógrafos buscaram explorar o papel de Ritter na formação de Marx.

É possível ainda perceber a analogia do pensamento marxiano ao uso tecnológico e à evolução. A tecnologia ganha um sentido amplo envolvendo ferramentas, divisão do trabalho, máquinas e torna-se extensão do corpo humano, complementa a vida social, domina a natureza e produz riqueza. A natureza humaniza-se e o homem se naturaliza, mas o aprofundamento do uso tecnológico aliena o trabalho. A própria técnica, portanto, deve ser libertada das contradições capitalistas (GRUNDMANN, 1991, p. 139-140). A analogia da evolução natural comparada com a tecnológica ou econômica, ou a da acumulação do desenvolvimento histórico como camadas da geologia, ou ainda dos ciclos econômicos e da queda tendencial da taxa de lucros com os movimentos mecânicos e astrofísicos são algumas metáforas naturalizantes presentes na obra de Marx (GRUNDMANN, 1991, p. 140 e 205). Esse tipo de metáfora terá vida longa na geografia, mas enquanto no nosso campo disciplinar elas acomodam-se sem grande polêmicas, no marxismo serão alvo de frequentes debates em diversos contextos e momentos históricos.

Os meados do século XIX foram berço do nascimento e consolidação do marxismo impulsionado em parte pela experiência da Comuna de Paris e pela organização da Primeira Internacional. Foi nessa arena que Marx debateria com anarquistas, entre eles Bakunin e seu colega geógrafo Élisée Reclus, que também havia sido aluno de seu mestre Ritter.

Esse foi um período de franca expansão da geografia, conhecimento direcionado para a dominação e exploração das terras distantes da Europa. A consolidação da influência do pensamento de Darwin representou a possibilidade de uma gênese atéia e racional do homem e do mundo, além de fortificar os critérios científicos das ciências naturais (GOULD, 1997, p. 10-25), mas criou ideologias que muitas vezes justificaram a dominação colonial. O grande sucesso e desenvolvimento da biologia sob a égide do espírito darwiniano acaba por polarizar as ciências do homem. Engels, Reclus, Ratzel, para citar alguns, alçam o darwinismo como um referencial científico de peso para suas obras. 


\subsection{0 anarquismo geográfico de Reclus e Kropotkin}

Comecemos por Élisée Reclus (1830-1905) geógrafo francês que utiliza o arcabouço metodológico do darwinismo, é anarquista e militante de esquerda. Reclus luta na Comuna de Paris e apesar de sua obra repercutir entre a classe popular e a intelectualidade da época obterá reconhecimento institucional no campo de forma generalizada somente no final de sua vida (CAPEL, 1988, p. 301). Um de seus principais discípulos foi Patrick Geddes, ligado a Le Play, um importante concorrente de Vidal de la Blache no nível institucional e epistemológico na França.

Além de Darwin e a adoção da ideia de cooperação para o desenvolvimento da humanidade, outro autor importante é Karl Ritter. Reclus foi seu discípulo e tornase divulgador de suas ideias na França, principalmente no tocante ao método comparativo. Para Capel, a obra de Reclus é claramente evolucionista devido a sua inspiração naturalista (CAPEL, 1988, p. 300-302), porém a teleologia da evolução remete à ideia célebre de que o homem é a natureza ganhando consciência de si, o que ilustra claramente a busca humana da harmonia com a natureza através do trabalho e da organização social, ambos elementos primordiais para seu o melhoramento.

Outra influência importante na obra de Reclus é o anarquista russo Mikhail Bakunin. Eles encontram-se em 1864, o que faz com que Reclus se torne anarquista, contra o Estado e enfatizando a libertação individual (ANDRADE, 1985, p. 15). Alinhado com o colega russo na Primeira Internacional estabelece uma nítida oposição a Marx. No entanto, na sua geografia vemos a utilização de termos como "luta de classes" e a busca por leis de evolução social a partir do seu referencial anarquista - organização social e conscientização popular, por exemplo.

Crítico da ecologia, Reclus despreza o uso exacerbado do termo dialética por considerá-lo inacessível ao grande público, mas inaugura uma análise da sociedade e do meio ambiente que leva em conta as relação dos diversos elementos visíveis e invisíveis da paisagem. A dialética de Reclus se inspira em Vico, por exemplo, a partir da concepção que um progresso significa também um regresso e em Proudhon que destaca os pares em equilíbrio instável sem que necessariamente se crie uma síntese (PELLETIER, 2009, p. 33).

Ao invés de ecologia, Reclus opta pelo uso do termo mesologia (mésologie, no original), pois a ideia de meio é "epistemologicamente e ontologicamente mais 
apropriada (...) como combinação do homem e da natureza e, como 'harmonia secreta"' (PELLETIER, 2009, p. 112). Essa escolha não é em vão, já que Haeckel e seus discípulos ecólogos valorizavam a concorrência em detrimento da cooperação.

A obra de Reclus nos oferece uma série de metáforas naturalizantes e organicistas, mas para Pelletier (2009, p. 42 e 116) elas servem mais como uma figura de estilo do que uma fundamentação do processo de explicação. Nesse sentido, existe uma ligação importante entre a estética e a ética no seu pensamento que busca traçar a relação harmoniosa com a natureza e sua transformação ao invés de um fetichismo conservacionista, que concebe a natureza como algo intocável. Assim o anarquismo engaja-se em uma visão de mundo prática que busca criticar, analisar e reorganizar a sociedade e a geografia apresentando "uma posição dialética que tende a um antropocentrismo sem arrogância, humilde mas voluntarista" (PELLETIER, 2009, p. 164).

Através de Rousseau, pensa o desenvolvimento desigual entre os povos ou ainda o papel da natureza na sociedade, como demonstra Horacio Capel:

Existem tendências 'naturais' ao aparecimento de certas configurações políticas, como a fragmentação da Europa ou a criação de vastas unidades na Ásia, e é também o relevo que explica o fracionamento dos povos e a aparição de entidades políticas peculiares, tais como a cidade grega (CAPEL, 1988, p. 303) $)^{6}$.

Na geografia de Reclus, ainda aparecem como temas:

(...) o problema da exploração defeituosa da terra como resultado da estrutura social da propriedade ou da exploração; o tema da colonização e o imperialismo europeu; a incidência do mercado mundial na atividade e vida dos produtores; a situação dos recursos terrestres, que ele considera suficientes para alimentar a população mundial (CAPEL, 1988, p. 305).

Andrade (1985, p. 10-12) divide a obra de Reclus em dois sentidos: o da prática política anarquista, e o científico associado ao conhecimento geográfico. Contudo, devemos atentar para o fato dessa divisão não ser muito rígida, porque Reclus ganha a vida publicando livros e materiais para a editora Hachette após sofrer uma série de consequências pessoais causadas pela sua militância política -como sua prisão devido a participação da Comuna de Paris. Apesar de Andrade apontar esse aspecto, cremos que a faceta de militante anarquista sempre acompanhou o geógrafo e a sua visão de mundo.

\footnotetext{
6 Tradução nossa.
} 
Reclus utiliza o termo geografia social, que teria similitudes ao que atualmente se chama geografia humana, contudo, o adjetivo social remonta a necessidade de uma organização socialista da sociedade. Na virada o século o diálogo entre os socialistas e os anarquistas era intenso (PELLETIER, 2009, p. 36).

Segundo Andrade (1985, p. 20) pode-se destacar três fundamentos básicos da geografia de Reclus: (1) o desenvolvimento desigual dos indivíduos resulta nas classes sociais; (2) o sistema desigual está em equilíbrio, mas pode entrar em crise pela luta dos oprimidos; e (3) nenhuma evolução positiva pode ocorrer sem o esforço do indivíduo. A evolução seria a formação de uma sociedade mais livre (ANDRADE, 1985, p. 20) através da consciência individual, pois para Reclus (2002, p. 24-27) a ideia de revolução está relacionada à de evolução. Essa ilação remete a Herder e à influência do pensamento alemão em sua geografia, sendo a revolução uma mudança qualitativa causada pela evolução.

Ao não se considerar a postura anarquista e humanista de Reclus, é impossível interpretar sua opinião sobre a colonização da Argélia. A dualidade acerca do colonialismo desaparece quando analisamos as diversas críticas que o geógrafo fez ao colonialismo britânico e francês. O termo colonização no século XIX, como demonstra Ferretti (2013, p. 3), expressava qualquer tipo de migração europeia para outros continentes. Isso significava a possibilidade da colonização anarquista e socialista em outros países, de forma a respeitar os nativos e em um ambiente longe das estruturas sociais tradicionais da Europa. Reclus condena veementemente os crimes coloniais, bem como o isolamento das novas colônias anarquistas. Para Ferretti:

\footnotetext{
(...) a ideia de exploração de possibilidades agrícolas no Norte da África pela colonização de trabalhadores europeus não foi incoerente com o pensamento socialista (em um tempo em que concepções como 'anticolonialismo' ou a 'teoria do imperialismo' eram desconhecidas), nem incoerente com a ideia de Reclus acerca da unidade histórica e cultural da bacia do mediterrâneo (FERRETTI, 2013, p. 8).
}

Reclus que leu Saint-Simon na juventude acreditava nas sociedades organizadas racionalmente pela colonização e desprezava as fronteiras nacionais artificiais que tolhem a liberdade dos homens de se mover e habitar. Independentemente disso, veremos adiante que é somente no pós-guerra que a esquerda francesa toma posturas mais radicais no que diz respeito aos movimentos de descolonização. A mentalidade de que a colonização traz melhorias - uma 
espécie de fardo civilizatório - é um fenômeno de longa duração da política francesa. Talvez derive daí a controvérsia ao redor de sua postura sobre a Argélia.

Devido à sua militância política e suas sucessivas viagens através do mundo, Reclus consegue articular uma rede de colaboradores que enviam informações e materiais que contribuem para a feitura de sua Geografia universal. Além disso, ele contou com materiais de viagem da Sociedade Francesa de Geografia para realizar sua obra maior sobre a geografia do mundo.

Durante seu exílio na Suíça, por exemplo, poderíamos elencar a ligação com Charles Perron, parceiro de trabalhos cartográficos e com os russos P. Kropotkin - 0 qual abordaremos abaixo - e L. Metchnikoff, autor de A civilização e os grande rios históricos, de 1889, obra que influenciará o pensamento de Plekhânov e Wittfogel. Enquanto Kropotkin escreveria os artigos sobre o Extremo Oriente e sobre a Sibéria na coleção Géographie universelle, Reclus faria o prefácio de seu livro A conquista do pão e organizaria uma coletânea com seus textos publicados na revista La Révolte. Entretanto, mesmo distante do âmbito institucional acadêmico, Reclus consegue renome como cientista e insere-se no final de sua vida na Universidade Livre de Bruxelas.

É muito interessante a confluência de temas entre Engels e Reclus: ambos escrevem obras sobre a origem da família, o problema do êxodo rural e sobre as condições urbanas (ANDRADE, 1985, p. 32). Além disso, Reclus não fica à parte dos debates da esquerda, pois na sua obra estão presentes reflexões sobre a traição da Revolução Francesa, o caso Dreyfus ${ }^{7}$, a lei de Bronze dos salários ${ }^{8}$ e o arcaísmo da igreja (RECLUS, 2002, p. 24-27). Esses encontros de temáticas mostram que anarquistas e marxistas compartilhavam e atuavam na mesma arena de discussão de ideias.

Se em um momento inicial de sua trajetória, devido ao contato com Bakunin, Reclus tem uma postura mais individualista, aos poucos vai absorvendo e agregando a cooperação como componente da organização social. Aproxima-se do

\footnotetext{
7 O caso Dreyfus refere-se a um capitão do exército francês que foi acusado de traição sem provas concretas. O que fomentou seu caso foi o fato de Dreyfus ser judeu e de supostamente ser traidor da pátria francesa, pois não teria o mesmo laço nacional dos outros franceses. O caso Dreyfus relevou o anti-semitismo que permeava a sociedade francesa e acabou por revelar a face chauvinista da direita francesa.

8 A lei de bronze do salário foi uma teoria da economia política que repercutiu muito entre o movimento operário e a burguesia, tendo influência nas leis de diminuição das horas de trabalho. Um economista da época afirmou que o patrão só ganhava o lucro do trabalho na última hora de trabalho dos operários e que se o governo inglês a diminuísse da jornada, as fábricas não se sustentariam. Marx, no livro I d'O Capital demonstrou o caráter falacioso da lei de bronze.
} 
romantismo e do bucolismo agrário em parte devido à sua relação com Kropotkin (ANDRADE, 1985, p. 82), propondo o anarquismo como variável universal independente das formações nacionais (RECLUS, 2002, p. 27). O bucolismo - e certamente este não é o melhor termo para definir a visão dos anarquistas - era uma solução para superação da dicotomia entre campo e cidade.

Piotr Kropotkin (1842-1921) é, por sua vez, egresso da nobreza russa e adota o ideário anarquista como visão de mundo. Devido à atividade subversiva, Kropotkin (2007, p. 5) é exilado da Rússia em 1876 e só consegue retornar em 1917 com 75 anos de idade. Sua perspectiva dentro do anarquismo é de crítica ao individualismo de Bakunin e Proudhon, bem como de captação da ação política feita pelos partidos comunistas ou social-democratas por toda Europa (KROPOTKIN, 2007, p. 6).

Foi um grande crítico do Estado, uma vez que seu poder tolheria a ação local de auto-organização da sociedade. Os grupos sociais viveriam sua plenitude na comuna rural ou urbana, e o Estado significaria a dissolução dessas escalas de organização mais funcionais. Sua instauração antecede a morte da civilização em um movimento contraditório que a fortalece ao mesmo tempo em que causa sua destruição. Essa crítica encaminha para uma apologia da livre iniciativa, da liberdade individual e da organização política local, tendo sempre em vista a cooperação social (KROPOTKIN, 2000, p. 92-93).

Embora as concepções políticas de Kropotkin dialogassem de alguma forma com o leninismo, ele se revolta com o fechamento da DUMA, a comissão destinada à criação da constituição, e com o tratamento dado aos camponeses durante a guerra civil. Depois de 1917, próximo do fim de sua vida, Kropotkin não assume nenhum cargo na União Soviética, mas continua dando sua contribuição para revolução tendo acesso a Lênin e queixando-se, por exemplo, do uso de castigos corporais no campo (SHUB, 1953, p. 228-232).

Kropotkin (2007, p. 7) admitia que a revolução seria feita por um pequeno grupo de pessoas que insuflariam sua força moral, pois não basta apenas a base material para a revolta da população. Contraditoriamente, a insistência no componente moral contrasta com a vontade imediata de tomar o poder. Todas essas problemáticas remontam claramente aos debates sobre a revolução na Rússia e as querelas entre os eslavófilos e os ocidentalistas, ou seja, entre aqueles que acreditavam nos valores tradicionais russos e nos que defendiam a modernização nos moldes ocidentais. A insistência de Kropoktin no aspecto moral remete a uma eventual valorização da ética camponesa com suas raízes cristãs ou ainda na 
exaltação à natureza, o que nos leva a identifcar uma ligação com o pensamento de Tolstói. Apesar desse diálogo, o pensamento que funda a postura de Kropotkin se relaciona com a teoria da cooperação entre os homens, e a valorização da natureza e do homem moderno advém da interpretação da Naturphilosophie de Oken e Schelling muito debatida nos círculos anarquistas ${ }^{9}$.

Vinculando à crítica do Estado e da propriedade privada, Kropotkin faz questão de denunciar a divisão entre campo e cidade, que esvazia a autonomia do lugar como reprodutor da vida e como unidade geográfica que permite a dissolução dos conflitos sociais.

Em A conquista do pão, (KROPOTKIN, 2007, p. 21-22) vemos desmascarada as teses de Malthus. Kropotkin ressalta como a distribuição dos alimentos poderia relacionar-se com uma ideia de justiça social. Indica a grande capacidade de produtividade rural e o abastecimento desigual, além de mostrar o processo de exploração do trabalhador, o caráter positivo do desenvolvimento técnico e sua capacidade de gerar mais riqueza. No entanto, as técnicas seriam direcionadas apenas para o beneficiamento de alguns e não de toda coletividade (KROPOTKIN, 2007, p. 23-24).

O seu grito de revolta contra a propriedade privada pauta-se na produção como trabalho social absoluto, que por isso não poderia se constituir como propriedade individual: "Tudo é de todos! $E$ como tal o homem e a mulher contribuíram com sua cota individual de trabalho, tem direito a uma cota de tudo o que será produzido pelo todo"10 (KROPOTKIN, 2007, p. 30).

No seu exílio em Londres, Kropotkin teve uma vida intelectual e política ativa, participando na Sociedade Real de Geografia. Lá debate publicamente com Mackinder acerca da função e do objeto de estudo da geografia, atitude de grande impacto uma vez que a Sociedade constituía uma arena de disputa intelectual onde os interesses de dentro e fora do campo estavam envolvidos. Curiosamente Mackinder e Kropotkin estavam inspirados pelo darwinismo, porém Mackinder baseava-se na competição natural dentro da espécie humana (VESENTINI, 2008, p. 15).

Vale ressaltar que Kropotkin com seus escritos sobre a vida no campo, sua tendência contra o Estado e contra a cidade burguesa, inspirará muitas ideias na

\footnotetext{
${ }^{9}$ Agradeço imensamente a Federico Ferretti por ter me indicado essa variável no pensamento de Kropotkin e Reclus.

10 Tradução nossa.
} 
arquitetura, no urbanismo e até mesmo na agronomia como é o caso de Chayanov que na União Soviética defenderá a economia camponesa. Kropotkin e Reclus serão uma fonte importante do pensamento anarquista mundial e não seria exagero dizer que a força de suas ideias chega até os dias de hoje ${ }^{11}$.

\subsection{Plekhânov e a geografia}

Outro pensador de renome que se dedicou aos temas da geografia, porém um pouco mais jovem e explicitamente ligado ao marxismo, foi Plekhânov ${ }^{12}$ (1856-1918). Intelectual de com vasta cultura e campos de atuação, Plekhânov escreve sobre geografia, teoria da história e crítica literária.

Plekhânov inicia sua carreira estudando no Instituto de Mineração de São Petersburgo, mas desperta para política ao tentar compreender os motivos da chegada tardia do capitalismo na Rússia e opondo-se ao despotismo czarista (GETZLER, 1989, p. 106-108).

Considerado como um dos principais introdutores do marxismo na Rússia, Plekhânov concebe o contato dos intelectuais russos com o marxismo uma etapa do processo de ocidentalização (WALICKI, 1989, p. 66-67). Tradutor do Manifesto do Partido Comunista para o russo, mesmo exilado na Suíça tem um papel político importante na revolução de 1905 e posteriormente na de 1917.

Militante do partido social-democrata russo, depois de um período inicial de concordância rompe com Lênin e permanece do lado dos mencheviques, o que acaba por engendrar algumas concepções do marxismo da Segunda Internacional e da social-democracia alemã em seu pensamento (LÊNIN, 1984, p. 97-104).

Dentro da ala menchevique, Plekhânov é aliado da fração de Martov, que tem uma interpretação economicista e etapista da tradição marxista. Apesar dessas afinidades, opõe-se a Bernestein, a Conrad e ao neokantinismo na época em voga dentro da Segunda Internacional declarando-se contra as estratégias reformistas (GETZLER, 1989, p. 113 e 120). A sua ideia principal era que o proletariado russo deveria levar ao fim o projeto de modernização da Rússia iniciado pelo Czar Pedro, o grande. A conscientização do proletariado é a pedra de toque de sua ação política,

\footnotetext{
11 Reclus, por exemplo, chegou ao Brasil com muita força através dos migrantes italianos simpáticos ao anarquismo.

12 Incluímos Plekhânov porque compartilhamos da visão de Santos (2002, p. 48-49) de que esse marxista possui uma obra com um conteúdo significativamente geográfico.
} 
com a instauração do capitalismo através de uma longa fase de desenvolvimento das forças produtivas que culminaria no socialismo.

Por conta desse raciocínio histórico e da influência do positivismo, Plekhânov acaba por prender-se muito ao processo de desenvolvimento dos modos de produção como etapas da evolução humana. O resultado é a obrigatoriedade histórica de desenvolver cada modo de produção para que se chegue ao socialismo (WALICKI, 1989, p. 66-67).

Devido ao caráter feudal e arcaico da sociedade russa, Plekhânov indaga como seu país poderia avançar para o socialismo se ainda não havia experienciado plenamente a democracia. Segundo o pensador, essa drástica transição poderia criar uma casta socialista governante, o que em parte ocorreu durante o socialismo real.

Apesar de ter se dedicado à reflexão da rica literatura russa do século XIX e aos estudos sobre a teoria da história, Plekhânov esteve imerso no pensamento científico que lhe era contemporâneo. Suas teorias apresentam-se de forma harmônica com o pensamento naturalista e positivista de sua época (GETZLER, 1989, p. 112). No entanto, Plekhânov:

(...) ao contrário dos luminares da ortodoxia marxista, estudou Hegel e
mostrou possuir um conceito de dialética infinitamente superior ao de
Kautsky, de Bernstein e de outros expoentes da social-democracia alemã.
Já no início dos anos [18]90, ele observava que a antítese abstrata da
revolução e evolução é superada precisamente pela dialética, que se
esforça por mostrar como - em determinadas condições - 'a mudança
gradual deve necessariamente levar a um salto' (STEINBERG, 1989, p.
220).

A conservação do pensamento hegeliano, apesar da forte presença do positivismo, seria de grande importância na época em que boa parte dos revisionistas reagiam à primeira crise do marxismo utilizando as formulações de Kant sobre a ética para pensar o devir histórico embutido na ideia de comunismo. Ou seja, parte da Segunda Internacional liderada por Bernstein escolheu afastar-se do pensamento hegeliano em função do kantismo.

Cabe lembrar que o retorno ao hegelianismo será feito também por Lênin para combater as tendências da Segunda Internacional e o marxismo austríaco direcionado ao positivismo lógico que culminaria no círculo de Viena.

Curiosamente, Plekhânov conhecia a obra de Elisée Reclus e a utilizava como fonte de alguns de seus estudos (GETZLER, 1989, p. 142), no entanto além 
do geógrafo francês, seu compatriota anarquista, Metchnikoff, também o influenciava - eles todos se conhecem durante o exílio na Suíça (BASSIN, 1992, p. 10).

Para Ratzel e para Plekhânov, a influência do meio é medida pelas relações sociais. A identificação do revolucionário russo com Ratzel é tamanha que ele defende fervorosamente as afinidades entre seu pensamento e o materialismo histórico e dialético (BASSIN, 1992, p. 11). Plekhânov cita Ratzel para que tais comparações ganhem plausibilidade.

O etapismo, que remete ao evolucionismo darwinista, acompanha um forte determinismo geográfico ${ }^{13}$ inspirado por Ratzel e Metchnikoff, sendo que as peculiaridades do quadro natural influenciam no desenvolvimento das forças produtivas e consequentemente nas relações sociais (MATLEY, 1966, p. 99).

O meio ambiente influenciaria o desenvolvimento do modo de produção ${ }^{14}$. A natureza determina as bases materiais da reprodução social: "as condições ambientais dão origem a certos tipos de formações econômicas e relações, e estas então formam os agente ativos na determinação da organização política assim como

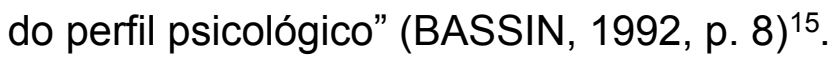

Entretanto, seu determinismo não cai em um fatalismo, pois existe uma valorização do método ecológico que busca uma unidade orgânica entre natureza e sociedade (BASSIN, 1992, p. 6) ${ }^{16}$. Com a ascensão da ecologia populariza-se a ideia que:

(...) a natureza ambiental externa exercia uma, ou de fato, a influência determinante na evolução orgânica da vida. Essa perspectiva do 'materialismo geográfico', como ele foi chamado, provou ser extremamente atrativa, como representação de um materialismo, como uma explicação causal e adequadamente 'científica', veracidade que foi aparentemente confirmada no reino orgânico natural e que foi eminentemente útil para os propósitos antropológicos (BASSIN, 1996, p. 318) ${ }^{17}$.

\footnotetext{
${ }^{13}$ Apesar de utilizarmos a expressão "determinismo geográfico" não o concebemos como classicamente foi feito por L. Febvre que forjou a grande controvérsia entre determinismo e possibilismo. Estamos remetendo a uma concepção da geografia que reconhece e enfatiza a relevância de alguns elementos naturais que podem interferir ou influenciar a organização das sociedade a longo ou médio prazo.

14 Segundo Matley (1966, p. 99), Bukharin e Trotsky também receberam essa influência ao admitir que o quadro natural e a base técnica seriam subsídios para o desenvolvimento do socialismo real.

15 Tradução nossa.

16 Para Bassin (1992, p. 6), Engels, Kautsky, Heinrich Cunow, G. Graf e o jovem K. Wittfogel seguem esse mesmo caminho.

17 Tradução nossa.
} 
Na sua visão, Darwin e Marx seriam complementares, o que permite admitir paralelos entre a luta de classes e a sobrevivência do mais apto ou leis e princípios que se aplicam para sociedade e natureza (BASSIN, 1992). Entretanto, existe uma dialética entre a opressão e a libertação proposta pelo quadro natural, uma vez que os elementos naturais auxiliam no desenvolvimento. Contudo, o homem nunca se emancipará completamente da natureza.

Diferentemente de Lombroso, Plekhânov nega o racismo e através de uma perspectiva ratzelina, defende que as influências do meio no homem não são captadas imediatamente e têm um efeito sobretudo social e não individual (BASSIN, 1992, p. 8). É a inspiração ratzeliana de uma influência geográfica lenta que diferencia o pensamento de Plekhânov do resto dos marxistas da Segunda Internacional que veem essa relação de forma mais imediata (BASSIN, 1996, p. 322).

Como Bassin ressalta, existe uma ambiguidade em seu determinismo que remete ao do próprio Ratzel, porque existe uma imprecisão quantitativa e qualitativa de quanto exatamente o meio determina a sociedade, ou seja, quais são os limites explicativos da natureza como elemento da formação social.

Em um debate muito interessante, Plekhânov dialoga com Fredrick Jackson Turner, um dos estudiosos da expansão da fronteira norte-americana e também leitor de Ratzel. Enquanto nos Estados Unidos a fronteira movediça teria criado o espírito democrático e a ruptura com as tradições, na Rússia a natureza inóspita teria atrasado a chegada do capitalismo e mantido a autarquia czarista ${ }^{18}$.

\subsection{A relação entre marxismo, positivismo e darwinismo no início do século XX}

Independente das contribuições de Reclus, Kropotkin e Plekhânov na passagem do século XIX para o XX, a presença do marxismo fazia-se muito forte nas ciências paralelamente às propostas vindas das ciências naturais:

\footnotetext{
18 A Rússia para Plekhânov seria atrasada devido à colonização de terras distantes, o que impulsionou parte da população para áreas inóspitas, onde o indivíduo luta diariamente pela sua sobrevivência física (fome, doenças, frio, etc.). A solução seria abrir mão do expansionismo territorial e desenvolver as relações de produção capitalistas, uma vez que o crescimento da fronteira foi uma estratégia que conservou o longo declínio da velha ordem aristocrática russa. A migração dificulta a articulação da luta social e a criação de uma consciência de classe (BASSIN, 1992, p. 14).
} 
A influência de Hegel pode ser reconhecida na obra de Ratzel ${ }^{19}$ e mesmo nos trabalhos de Ritter. Marx teria igualmente influenciado em muitos pontos o trabalho de Ratzel, de Vidal de La Blache, de Jean Brunhes. Todavia, e por múltiplas razões, foi a herança idealista e positivista que, afinal de contas, acabou por se impor à geografia, isto é, a geografia oficial: o cartesianismo, o comtismo e o kantismo eram frequentemente apoiados e misturados aos princípios de Newton e também ao darwinismo e ao spencerismo. (...) Que o positivismo haja contaminado até mesmo o marxismo nos dá a medida da importância que adquiriu em uma fase tão importante da história científica. Jean Brunhes seria um exemplo desse casamento entre marxismo e positivismo, embora nessa galeria Plekhânov talvez guarde o lugar de destaque. Uma aliança desse gênero justifica que se dê lugar exagerado a conceitos originários das ciências naturais, impostos às ciências humanas sob o pretexto de lhes oferecer aquela categoria científica que então elas procuravam a todo custo (SANTOS, 2002, p. 48).

Sem compreender essa relação que Milton Santos expôs no excerto acima não é possível ver a composição do marxismo, nem a possibilidade de aproximação entre ele e a geografia em um contexto em que os critérios das ciências naturais são extremamente valorizados. Os autores que analisamos acima gravitam no estatuto científico positivista, estando sob influência do darwinismo ao mesmo tempo que se vinculam à visão romântica e histórica de ciência presente no pensamento marxiano. Diante dessa problemática, como podemos pensar a questão do estatuto científico do marxismo no início do século XX?

Desde o surgimento do marxismo temos sua afirmação através do socialismo científico que se opunha ao socialismo utópico comum na França (Charles Fourier) e Inglaterra (Robert Owen) contemporâneos de Marx e Engels.

Contudo, no tempo da Segunda Internacional os pensadores filiados ao marxismo apoiaram-se fortemente na prática científica da época, embasada nas ideias de Darwin, Spencer, entre outros, e fizeram comparações entre a luta de classes e luta pela sobrevivência darwiniana, o que gerou o problema da naturalização das relações sociais. Concomitante a isso, temos uma simplificação e sínteses mal elaboradas das principais obras de Marx, que acabaram criando um marxismo vulgar, deturpando e simplificando o sentido original de suas ideias (ANDREUCCI, 1989, p. 31).

Se por um lado a vulgarização do marxismo teve um efeito empobrecedor, por outro atingiu uma proporção mundial e criou uma atmosfera de estimulo à formação

\footnotetext{
19 Acrescentamos que sua Geografia política remete nítidamente ao projeto de construção de um Estado forte no molde hegeliano, com Ratzel refletindo sobre sua composição territorial e sua lógica de colonização. Tal fato vem na esteira da fundação da geografia moderna que é um processo complexo no qual o positivismo e o romantismo alemão travaram um diálogo nas obras de Humboldt e Ritter, por exemplo. Sobre o assunto vide Pereira (2009).
} 
intelectual do proletariado ao redor do globo. Não seria exagero atribuir ao marxismo, nesse momento histórico, a promoção de uma visão de mundo científica e ateia vinculada ao materialismo filosófico.

Parece-nos que o marxismo, formado distante das academias com uma penetração inicial nos movimentos sociais, busca o capital cultural acadêmico em determinados momentos históricos com o objetivo de ter uma maior atuação e respeitabilidade intelectual na sociedade - e até mesmo uma base institucional paralela aos partidos na luta política.

Isso significou abrir mão de parte dos critérios de cientificidade mais originais do pensamento marxiano e absorver elementos externos ligados à racionalidade hegemônica, neste caso, do positivismo e principalmente do legado das ciências naturais. Talvez até o próprio Engels, com o objetivo de fazer progredir o materialismo dialético, tenha cedido a esse processo. Como demonstra Hunt (2010, p. 143-211), Engels era um homem de seu tempo, encantado pelos avanços científicos e se esforçou para atrelar o socialismo ao contexto do avanço acadêmico. Isso põe o marxismo na trilha do apelo popular através de panfletos e propagandas na década de 1880. Apesar do positivismo e da ligação com as ciências naturais, Engels teve o papel de sistematizador de vários aspectos do materialismo histórico e das leis da dialética (HUNT, 2006, p. 241).

Não por acaso, na véspera da Primeira Guerra mundial o marxismo já havia se espalhado pelo mundo mesmo que as pessoas não conhecessem profundamente O capital. O que havia se difundido era "um marxismo pobre, sobretudo a esquemas transformados em argumentação para discussões que não se aprofundavam" (ANDREUCCI, 1989, p. 70).

Karl Korsch (1966, p. 84-85) indica que tanto o objetivo de Hegel como o de Engels era justamente aplicar as leis da dialética e acabar com a separação entre ciência e filosofia. Porém, Hegel dissolve "as ciências particulares na filosofia, enquanto Engels, inversamente, absorve a filosofia nas ciências particulares" (KORSCH, 1966 20 , p. 85). Aqui surge um elemento importante que diferencia o marxismo do positivismo, uma vez que para o último a tendência é aprofundar cada vez mais o processo de divisão do trabalho intelectual. No entanto, a interpretação de Korsch é que o marxismo acaba por incorporar a cisão entre filosofia e ciência:

20 Lembrando que a edição original dessa obra é do ano de 1923, ampliada e revista em 1930. 
Neste contexto, é já importante constatar que Engels, embora manifestando-se pela 'ciência positiva' quer contudo, ao mesmo tempo, deixar 'substituir autonomamente' um domínio preciso e limitado da 'filosofia anterior' (a teoria do pensamento e suas leis - a lógica formal e a dialética). O problema decisivo consiste, sem dúvida, na questão de saber o que é que o conceito de ciência ou ciência positiva significa, na realidade para Marx-Engels (KORSCH, 1966, p. 85).

Com esse processo de absorção invertida evidenciado Korsch, Engels se aproximaria muito do positivismo clássico. Entretanto, a ideia de "positivo" para Marx e Engels nada mais seria do que a transformação social rumo a supressão dos contextos sociais em que a filosofia e ciências foram formadas (KORSCH, 1966, p. 103). Ou seja, a supressão da ciência burguesa, que possui como uma de suas características mais eminentes a pretensão de neutralidade, supostamente acima da filosofia crítica e das instituições sociais. Essa problemática que será corrente na geografia crítica, apresenta-se de forma semelhante na obra de Korsch e no contexto do debate marxista do entre guerras. Sua conclusão final ruma em direção à ideia de que a filosofia não poderá se superar a não ser que se realize na prática, remetendo à tese formulada por Marx.

Em seu ensaio sobre o marxismo ocidental, em uma interpretação que vai ao encontro do pensamento de Korsch, Russell Jacoby argumenta que enquanto o socialismo real manteve a visão científica positivista de Engels concomitantemente à sua implementação política, no ocidente o marxismo manteve-se mais distante desta perspectiva, resguardando o modo hegeliano de ver a ciência, operando com pares dialéticos como consciência e inconsciência, aparência e essência. A "Wissenschaft de Hegel está saturada de história; ela finalmente constitui o protesto de Hegel contra às ciências empíricas e positivas" (JACOBY, 1981, p. 25) ${ }^{21}$. Essa postura reforçou ainda mais o aprofundamento do marxismo ocidental no campo da especulação filosófica.

Engels apropriado no oriente "legitimou o marxismo como uma ciência objetiva e sistemática", enquanto na Europa marxistas como Arturo Labriola utilizavam as teses de Feuerbach contra o seu materialismo (JACOBY, 1981, p. 53). Dessa forma: 
O Hegel que espreitou por trás do marxismo dividiu-se em duas tradições, científica e histórica. As tradições hegelianas distintas não se produziram por si só no marxismo soviético e ocidental; eles representaram e informaram o marxismo subsequente. O marxismo soviético foi regularmente sustentado por um Hegel científico, e o marxismo europeu por um Hegel histórico. Cada um demarcou um terreno comum e uma linguagem: leis universais da natureza e da sociedade e processos históricos de consciência e ação (JACOBY, 1981, p. 57).

Jacoby complementa:

De acordo com Mondolfo o problema inicial para Marx foi o conhecimento; para Engels foi o ser. Consequentemente, Marx partiu da crítica da consciência e moveu-se para uma filosofia da práxis enquanto Engels, enraizado em uma filosofia natural, concluiu com o materialismo. Muito do dogmatismo e obscuridade de Engels resultou da falta de um conceito de práxis revolucionária (JACOBY, 1981, p. 57).

A práxis e a consequente transformação social dão o tom da crítica feroz à Segunda Internacional e ao marxismo que se pauta mais no positivismo do que na dialética. Segundo Hobsbawn:

Na realidade, o protesto (...) não era tanto contra a análise marxista em si mesma e sim contra o evolucionismo e as 'incrustações positivistas e naturalistas' com as quais - segundo uma expressão do jovem Gramsci, em 1917 - a social-democracia estava prejudicando o marxismo; ou então era contra a curiosa mistura de Marx com Darwin, Spencer e outros pensadores positivistas, amálgama que frequentemente passava por ser o marxismo (HOBSBAWN, 1989, p. 83).

Como ressaltamos acima, o marxismo da Segunda Internacional estava ligado ao positivismo e à filosofia kantiana, que constituíam uma alternativa à controvérsia das formulações hegelianas e sua ambiguidade que inspirava tanto o socialismo revolucionário da época (jovem Hegel), quanto dava respaldo ao Estado forte e autoritário da unificação bismarkiana.

Durante os anos 1890, o marxismo enfrenta sua primeira crise devido, em parte, à morte de Marx, à revisão que sua obra sofre pelos sociais-democratas, notadamente Bernestein, e ainda por conta do questionamento do caráter utópico do socialismo. A virada de século foi um período em que o capitalismo desenvolvia-se com alto crescimento econômico (HOBSBAWN, 1989, p. 117-118) o que coincide com a ascensão de Nietzsche acolhido por alguns pensadores anarquistas e por uma parte da classe média na Europa, com reverberações entre os populistas 
russos $^{22}$ (HOBSBAWN, 1989, p. 119). Posteriormente, durante outras crises do marxismo, veremos a presença de Nietzsche, que influenciará o pós-estruturalismo no último quartel do século $X X$.

Cabe dizer ainda que o marxismo da Segunda Internacional Comunista se difunde de uma forma muito rígida não respeitando os desenvolvimentos locais, diferentemente do que vai acontecer, inicialmente, na Terceira Internacional Comunista (ANDREUCCI, 1989, p. 34). Sinteticamente, poderíamos dizer que:

\begin{abstract}
O desenvolvimento da 'política cultural' do movimento operário permaneceu limitado, contudo, a uma cultura subalterna e improvisada, caracterizada pelo cientificismo, pelo mito primitivo do progresso, por um gosto pela informação indiferenciada e eclética que era típica de muitas 'universidades populares' e das 'cátedras ambulantes'. A passagem de uma cultura do tipo enciclopédico a escolhas conscientes (...) se verificou de modo decisivo, mas uma transformação começou a se realizar quando, com o desenvolvimento do partido político, com seu crescimento, se colocou o problema da formação de quadros (ANDREUCCI, 1989, p. 46-47).
\end{abstract}

Não podemos esquecer que nesse momento o marxismo lentamente institucionaliza-se nas universidades e ganha força nas cátedras de diversas ciências.

Apesar desse processo generalizado, ressaltamos que alguns não se deixaram seduzir por uma naturalização do pensamento marxista e pelo uso metafórico de concepções das ciências naturais ${ }^{23}$, como é o caso de Lênin (1984, p. 40-72). Inclusive, pensamos que é a partir da fundação da Terceira Internacional e da consolidação da União Soviética é que esse processo vai começar a se reverter. Contudo, ele malogrará sob o stalinismo, pois não haverá tempo para a renovação dos quadros científicos, uma vez que a conversão da Segunda Internacional para a Terceira Internacional é muito rápida, no furor da revolução, como mostra Kriegel no caso francês (1978, p. 140-210). Como a autora demonstra, entre 1921-22, a maioria dos partidários da Segunda Internacional migram e são aceitos na Terceira. Sem tempo hábil para uma drástica mudança na tradição científica dos quadros políticos após a morte de Lênin e os processos de consolidação do stalinismo na União Soviética, encontraremos novas formas de reprodução da velha tradição de

\footnotetext{
${ }^{22}$ Fração política contemporânea ao movimento que desemboca na revolução de 1917.

${ }^{23}$ Ao contrário de Lênin, Kautsky foi um dos que se apoiou fortemente nessas premissas, jogando a dialética para um segundo plano e elaborando a teoria dos "instintos sociais" ou da luta pela sobrevivência no interior da sociedade (WALDENBERG, 1989, p. 304-305).
} 
cientificismo positivista no socialismo real. A hegemonia stalinista que tem início em 1929 e os subsequentes expurgos políticos significarão um desmantelamento das ciências sociais dentro da União Soviética e um incentivo às ciências naturais mais afastadas de temáticas políticas. Nas palavras de Hobsbawn, o desdobramento da política de Stálin é claro:

\begin{abstract}
Assim, a interpretação histórica do 'materialismo histórico e dialético' predominantemente neste período [década de 1930/1940] - tornada canônica para os comunistas graças à autoridade de Stálin - (...) derivava da ortodoxia marxista do período da Segunda Internacional, que teve Kautsky como porta-voz, baseado por sua vez na codificação realidade pelo último Engels de seus ensinamentos e de Marx: uma versão do marxismo que o dotava, ao mesmo tempo, da autoridade da ciência, da certeza do método e da precisão científica, bem como da pretensão de interpretar todos os fenômenos do universo por meio do materialismo dialético; se a dialética era de derivação hegeliana, o materialismo se atinha essencialmente à linha dos philosophes franceses do século XVIII. Era uma interpretação na qual - como no Feuerbach de Engels - as ciências naturais triunfantes no século XIX se uniam ao marxismo, depois de renunciar ao materialismo setecentista superficial, estático e mecânico, como o próprio progresso das ciências induzia a fazer, segundo Engels, após as três decisivas descobertas da célula, da transformação da energia e da teoria darwnista da evolução (HOBSBAWN, 1989a, p. 282).
\end{abstract}

Certamente, em um momento inicial a Terceira Internacional fomenta critérios de cientificidade específicos do marxismo puramente histórico que ganham mais força em oposição ao revisionismo, naturalismo e cientificismo da Segunda Internacional. O contragolpe de Lênin representa uma nova estratégia de ganho e capital cultural pautado fortemente no advento histórico da Revolução de 1917, no retorno à dialética e nas obras de vulgarização do pensamento filosófico hegeliano, que dura até a ascensão de Stálin e da criação do marxismo-leninismo em sua versão oficial. Mesmo diante da transição muito rápida, fruto da revolução de 1917, a tendência ao reforçamento - no sentido de retorno ao pensamento marxiano e hegeliano - do marxismo mede forças com a Segunda Internacional. O período de transição conflui com o período de formação de vários partidos políticos ao redor do mundo, ligados à Terceira Internacional e à possibilidade da revolução socialista na periferia do sistema.

Mészáros (1983, p. 173-180) nos aponta alguns critérios exclusivos de cientificidade do marxismo: interdisciplinaridade ou não separação de objetos de estudo exclusivos que pertençam a uma só ciência; o esforço da construção de uma totalidade contrastando com a busca por leis gerais rígidas e imutáveis; a presença da lógica dialética. A totalidade seria uma síntese dos processos sociais e 
econômicos em larga escala, recorrendo ao conteúdo histórico da análise de processos sociais ${ }^{24}$. Esses são alguns aspectos que diferem o marxismo do positivismo, mas não o invalidam enquanto conhecimento científico, apesar desses critérios não serem hegemônicos.

Ainda sobre o processo de vulgarização, a transmissão e a tradição oral tinham extrema importância em conferências, comícios ou no trabalho individual de argumentação com cada operário (ANDREUCCI, 1989, p. 51). Andreucci (1989, p. 63), aponta que o primeiro livro d'O capital teve mais influência que o segundo ou o terceiro no movimento operário. Infelizmente somos propensos a pensar que essa é uma tendência que continua até hoje, devido ao caráter introdutório e o amplo espectro do primeiro volume d'O capital25. Vários pontos centrais da doutrina marxista estão presentes nele, como a teoria do valor, as formas do valor, as reflexões sobre a natureza da mercadoria, a transformação do dinheiro em capital, o processo de extração da mais-valia relativa e absoluta, o papel do maquinário em relação ao valor, a divisão do trabalho e por fim reflexões generalizada sobre a condição do proletariado (MARX, 2006).

\subsection{Geografia, história e marxismo: a sinergia de três campos em busca de uma base institucional}

Na primeira metade do século $X X$ temos um amplo conjunto de geógrafos que milita nos partidos comunistas de vários países da Europa. Alguns deles envolveram-se mais profundamente no marxismo, propondo uma agenda de pesquisa; outros, de maneira mais tênue, absorveram apenas alguns de seus aspectos; enquanto um terceiro grupo participa politicamente, mas suas contribuições serão apropriadas para a consolidação da geografia neo-positivista.

No entanto, é consenso que nenhum trabalho desses geógrafos terá uma repercussão de larga escala no marxismo - talvez Wittfogel seja a exceção. Isso comprova-se ao constatarmos que na tradição do pensamento marxista quase não existem geógrafos eminentes. Buscaremos então explorar um pouco mais o

\footnotetext{
24 Alguns questionam se a própria práxis não seria um componente metodológico, que se obliterado faz com que o método perca seu sentido.

25 Sob outra perspectiva nos perguntamos se atualmente os Grundisse de Marx não se tornaram mais influentes que o próprio O Capital. Alguns se iludem pensando que é apenas através dos Grundisse que seria possível compreender o pensamento de Marx, ou que nesses manuscritos existiriam uma espécie de revelação acerca da estrutura de seu pensamento.
} 
pensamento desses geógrafos que mais tarde caíram em esquecimento e não serão tratados com grande destaque pela geografia crítica. Após 1970, existirá muito mais destaque aos geógrafos do século XIX do que aqueles dos anos 1940 e 1950 que tentaram conferir um aporte marxista para a geografia. Entretanto, não é possível compreender o surgimento da geografia crítica sem analisar a geografia de esquerda que existia antes.

Como havíamos comentado acima, a fundação da Terceira Internacional provoca transformações nas formas de difusão do marxismo. De acordo com Agosti (1988, p. 108-119), após vários congressos e discussões decide-se que não deveria haver um partido mundial através da Terceira Internacional. Deliberou-se ainda que o desenvolvimento particular dos partidos comunistas em cada nação deveria ser respeitado, e que eles seriam congregados na Internacional. Cria-se então um novo período de "vulgarização" do marxismo:

Os anos 1924-1929 são caracterizados também por fenômenos que contrastam com a imagem de uma tendência linear e irreversível ao enrijecimento dogmático. De modo análogo ao que ocorreu com a vulgarização segundo-intercionalista dos anos 90 do século passado, com o 'marxismo-leninismo' o marxismo conheceu, na segunda metade dos anos 20 deste século, não apenas um processo de deformação, mas também de afirmação, ou seja, de difusão e de articulação em âmbitos geográficos e movimentos sociais nos quais não penetrara antes. Precisamente a campanha de bolchevização dos partidos comunistas não é inútil recordar - serviu como impulso para um intenso empenho na publicação ou republicação, em edições de grande tiragem, dos clássicos da literatura marxista, e para um esforço sem precedentes no sentido da formação de um 'sistema educacional comunista' que tem entre os seus instrumentos toda uma gama de escolas noturnas, dominicais, por correspondência, etc. Ainda que vulgarizado, e por vezes censurado, o marxismo da Terceira Internacional penetrou e vicejou em vastos estratos sociais e, de qualquer modo, constituiu um fermento para elaborações teóricas novas, sobretudo nos países coloniais e semicoloniais (AGOSTI, 1988, p. 143-144).

Muitos geógrafos contemporâneos se perguntam como existiria a possibilidade de uma aproximação entre a geografia francesa, nos moldes de Vidal de la Blache, e o marxismo. Outros ainda se perguntam como o marxismo adquiriu força de atração tão intensa perante a intelectualidade, principalmente na França. Depois de 1917 e até mais ou menos 1950 pensamos que o marxismo representa e engloba uma variedade de posturas políticas progressistas apresentadas aqui mais ou menos em ordem cronológica: (1) luta contra as desigualdades sociais e preconceitos étnicos como o antissemitismo - e aqui em particular o caso Dreyfus sugere o tema desde a virada do século; (2) o caráter educacional de divulgação do 
conhecimento científico ligado ao marxismo, como no movimento dos jornais e das universidade populares; (3) possibilidade real de construção e experimentação de uma utopia social; (4) luta contra o fascismo e o nazismo; (5) luta contra o imperialismo e a dominação colonial; e (6) possibilidade de um progresso racional diante das arbitrariedades do capitalismo de livre mercado (pensado a partir de JUDT, 2007 e WINOCK, 2000). Outro elemento importante é que, enquanto a militância do fascismo e do nazismo eram refratárias, ou seja, o engajamento político era uma reação de desespero contra a degeneração social e econômica no âmbito nacional, o engajamento comunista dava-se essencialmente pela esperança progressista de uma sociedade racionalmente científica e justa com ambições de uma união internacional (GOULEMOT, 2009, p. 355-360).

Diante dessa atmosfera favorável à popularização científica existe uma reafirmação do cientificismo e uma recuperação histórica do ideário iluminista com a divulgação do conhecimento. O marxismo não tinha um papel menor nesse processo de propagação do conhecimento, entretanto:

(...) colocou-se o problema da relação entre a tradição 'iluminista' e positivista nos meios científicos franceses nos anos 1930 e as questões levantadas pela revolução científica e epistemológica ocorrida na virada do século XIX para o século XX - discutidas à luz do marxismo, nesses mesmos meios (IUMATTI, 2008, p. 1).

Agrava-se novamente a problemática da relação de uma ciência positivista e de uma ciência histórica e dialética, processo que se inicia em fins do século XIX como vimos. Löwy (2003, p. 180-181), versando sobre a exaltação da ciência positiva francesa, vai indicar que é justamente uma obsessão por critérios e rigor científico que vai deixar a ciência francesa vulnerável ao cientificismo soviético. Isso porque não haverá fronteiras entre ciências humanas e ciências naturais, elemento que vinha do positivismo e que se reaviva através da ciência soviética, como nas formulações do geneticista Lyssenko, por exemplo. Futuramente, é Althusser quem formulará a doutrina das duas ciências, enfocando mais sua análise no continente histórico, fazendo uma nova divisão científica inspirado pelo positivismo. Isso é importante para a geografia, uma vez que poucos irão insistir na ideia de dialética da natureza, como é o caso de Jean Tricart, pois muitos desviarão do tema. Contudo, mesmo entre os geógrafos de esquerda a tradição de estudar geomorfologia no 
início da carreira, típica do habitus vidaliano propagado por De Martonne, será muito valorizada.

Além desses fatores da conjuntura histórica, Dosse (1994, p. 33) mostra que após a vitória no plano institucional da geografia vidaliana existiu uma clara troca de experiência de pesquisa entre os geógrafos e os historiadores da primeira geração da escola dos Annales. Aliás, não é por mero acaso que o historiador Lucien Febvre escreve A terra e a evolução humana em uma nítida tentativa de opor e distinguir as ideias da geografia alemã determinista e da francesa possibilista. "Em 1922, L. Febvre colocou a influência de Ratzel no seu devido lugar, mostrando que não é no terreno da geografia humana geral que os franceses fizeram sua obra original" 26 , mas através da geografia regional (BROC, 1977, p. 93).

Lucien Febvre adota o pensamento de Vidal para dar impulso à nova história e apesar de ter ajudado a consolidar um agenda de pesquisa que se pretendia hegemônica frente à morfologia social e à geografia alemã, seu objetivo era absorver a geografia e eclipsá-la. O geógrafo deveria tratar o estudo social pelo viés histórico o que causa uma série de reações de C. Vallaux ou Demangeon que acusam Febvre de ser exageradamente crítico com a geografia humana (DOSSE, 2004, p. 118-119). No entanto, essa relação não deixa de criar laços fortes entre o modo de pensar da geografia e da história, além da continuação do apoio institucional entre Febvre, Demangeon e Jules Sion (DOSSE, 2004, p. 125).

Ainda nessa geração, Pierre Vilar, um historiador com muitos trabalhos sobre a Espanha e que foi aluno de Max Sorre no início de sua carreira. Seu orientador Ihe apresenta Marc Bloch, também da primeira geração da escola dos Annales. Vilar torna-se um intelectual marxista preocupado com uma história materialista, dialogando com Sartre e Paul Nizan. Marc Bloch milita em movimentos da esquerda antes de ser brutalmente assinado na invasão nazista. Dosse (1994, p. 64) também deixa claro que apesar de Lucien Febvre não utilizar o marxismo, conhecia sua proposta e a considerava uma história apaixonada 27.

É importante frisar aqui que Caio Prado Jr. era assinante dos Annales d'Histoire Economique et Sociale e que participava da União Racionalista na França (IUMATTI, 2008, p. 7), órgão no qual L. Febvre também estava envolvido. A União

\footnotetext{
26 Tradução nossa.

$27 \mathrm{Na}$ juventude Febvre flertou com o anarquismo e com o sindicalismo revolucionário; ver EREÑO ALTUNA, J.-A. Lucien Lebvre: combates por el socialismo. Bilbao: Universidade de Deusto, 1994.
} 
tinha como objetivo a organização de enciclopédias para a vulgarização do conhecimento das ciências e o fomento de um maior senso crítico na população, projeto que acabou atraindo intelectuais progressistas e de esquerda. O projeto era muito similar às ideias dos iluministas, porém com base em um racionalismo marxista. A esquerda francesa ampliava-se pautada na ideia de que o marxismo e o socialismo se consolidariam através da educação das massas e da vulgarização não só do marxismo em si, mas do conhecimento científico como um todo.

A União tinha ainda um caráter similar ao front populaire, onde os cientistas marxistas uniam-se aos liberais progressistas ou humanistas. Constituía-se uma grande frente heterogênea na qual Febvre foi responsável pela organização de uma enciclopédia. Caio Prado entra em contato com os frutos da União através da visita de uma exposição por ela organizada no Palais de la Découverte (IUMATTI, 2008, p. 8-9 $)^{28}$. Com o enfraquecimento da União, muitos cientistas envolvem-se na fundação da revista La Pensée - Revue du Racionalisme Moderne, que se relaciona diretamente com o Partido Comunista Francês no pós-guerra e publica textos de geógrafos de esquerda (IUMATTI, 2008, p. 12).

Alguns pesquisadores da primeira geração da escola dos Annales fazem em seus trabalhos de história uma clara apologia à União Soviética, inclusive com citações dos discursos de Stálin e Molotov, apesar de já começarem a aparecer as primeiras denúncias dos gulags. Dosse (1994, p. 64-72) também demonstra um número muito maior de historiadores do que de geógrafos no início do século $X X$. Mesmo assim Vidal de la Blache conseguiu influenciar amplamente os historiadores. Geógrafos e historiadores uniram-se, por exemplo, contra os avanços da sociologia e a substituição da morfologia social no lugar da geografia:

\begin{abstract}
Enquanto a geografia marxista alemã foi uma explosão de curta duração, na França a presença do marxismo se fez mais lentamente, mas com mais frutos. A primeira manifestação de fôlego da esquerdização de parte da intelectualidade francesa foi a publicação a partir de 1929 dos Annales d'histoire économique et sociale, revista inspirada nos Annales de géographie e que contou no seu comitê de redação com dois geógrafos de peso, A. Demangeon e A. Siegfried. Marc Bloch e Lucien Febvre, seus fundadores foram influenciados pelas ideias marxistas e de
\end{abstract}

\footnotetext{
${ }^{28}$ Cabe ressaltar que é nesse mesmo período que a Associação de Geógrafos Brasileiros (AGB) será fundada com o auxílio de Caio Prado Jr. e com o incentivo de P. Deffontainnes. Inicialmente, a AGB constitui um espaço de discussão que além de brasileiros envolve a maioria dos professores da missão francesa como Lévi-Strauss que apresenta uma conferência sobre os Bororo no Brasil central, F. Braudel, Arbousse Bastide e Jean Maugüé que havia sido professor de Caio. Destaca-se ainda a tentativa precoce da AGB de se integrar a União Geográfica Internacional (UGI) e a tentativa de intercâmbio com a União Soviética por iniciativa de Caio (SEABRA, 2008, p. 62).
} 
interdisciplinaridade. M. Bloch (1886-1944), como J. Ancel, dedicado à geografia política, e outros intelectuais franceses, morreu fuzilado, resistindo ao nazismo. Numerosos estudantes de geografia que em 1928-29 faziam suas agregações ou seus diplomas de estudos superiores $^{29}$ em Paris, como J. Dresch e P. Monbeig, passaram por um processo de esquerdização, assim como alguns professores. A. Cholley, por exemplo, destacou as classes sociais no povoamento rural francês no 'Présentation de une carte de la repartitiva de l'habitat rurale' (UGI-Paris, 1939), numa das primeiras manifestações de geografia social, na opinião de P. Claval (MAMIGONIAN, 2005, p. 206-207).

Isso demonstra uma sinergia institucional e do ponto de vista das ideias, além de um arcabouço de ideias em comuns, incluindo aí o marxismo. Claval (1998, p. 131) ressalta que a contribuição dos geógrafos para com os historiadores estimulou a habilidade de observação dos vestígios históricos na paisagem, deixando de lado o reinado absoluto da fonte documental. Mesmo que Bloch já considerasse as limitações do viés regional, o aporte vidaliano foi inovador, pois:

(...) implica em um discurso geográfico construído sob o modo histórico: tendo renunciado ao princípio explicativo que implicava o determinismo, os geógrafos dão um sentido àquilo que eles observam retendo-o como momento de um percurso histórico (CLAVAL, 1998, p. 208) 30 .

A junção do grupo dos Annales e do vidaliano forma uma grande rede de mútuo apoio contra a sociologia, ou para afirmação das duas disciplinas. Quando o cenário muda e essa aproximação entre geografia e história atenuam-se, é ao redor de André Cholley que surgirá uma nova rede envolvendo os geógrafos de esquerda.

1.5 A geografia alemã marxista: economia, geopolítica e materialismo geográfico

Entretanto, antes de prosseguirmos na geografia francesa, vamos nos debruçar sobre esse desenvolvimento explosivo dentro da geografia alemã. Inicialmente abordaremos um geógrafo Walter Christaller (1893-1969) e logo após Karl Wittfogel (1896-1988). Certamente, na escala nacional o clima aqui é distinto da euforia francesa rumo às luzes do homem moderno. O ambiente de pessimismo na

29 No sistema educacional francês a agregação é um exame que permite os professores lecionarem nos liceus de ensino secundário e em alguns casos no ensino superior. A agregação é uma prova pública que habilita o candidato e o diferencia do professor certificado (certifiés, no francês). Já o diploma de estudos superiores (também conhecido pela sigla DES) é um grau de especialização acadêmica que atualmente equivale ao mestrado e destina-se ao prestígio no ensino superior.

30 Tradução nossa. 
Alemanha proliferava-se não apenas em função da derrota na Primeira Guerra Mundial, mas também por causa da revolução comunista frustrada em 1919 que acabou reforçando as ideias da direita política.

Nesse contexto é que se desenvolvem as obras dos dois autores. Christaller envolve-se com a geografia através do viés econômico e tem dificuldades de ser reconhecido dentro do campo disciplinar. Wittfogel debate mais com a tradição disciplinar da geografia e da geopolítica, ainda que desfrutasse de uma posição importante no grupo da escola de Frankfurt e posteriormente nas instituições norteamericanas.

Walter Christaller (1893-1969) nasceu em um família pequeno-burguesa e intelectualizada, seu bisavô, por exemplo, havia sido correspondente de A. von Humboldt. Na juventude, Christaller lutou na Primeira Guerra Mundial, experiência que o conduziu a uma postura socialista e pacifista já que fora militante do partido comunista na juventude. Entretanto, ele se afasta da militância devido a falta de recursos para sobrevivência e posteriormente inicia sua carreira estudando economia e filosofia. Ao retornar da primeira guerra ele enfrenta muitas dificuldades exercendo as profissões de mineiro, pedreiro e jornalista, até que em 1925 começa a trabalhar em um escritório de construção civil em Berlim. Orientado por Robert Gradman em 1932 desenvolve sua a dissertação sobre Os lugares centrais, obra que não terá um reconhecimento imediato. Em 1937 apresenta uma tese sobre os padrões de ocupação rural na Alemanha e sua relação com os governos locais (HOTTER et al., 1983, p. 11).

Somente em 1938 Christaller obtém a licença para lecionar no ensino superior e, por recomendação de F. Metz, vai para Universidade de Freiburg ${ }^{31}$. Lá, a comunidade de geógrafos não o recebe bem, pois ele tem posturas marxistas, é um pesquisador nomeado tardiamente e ainda é visto pelos colegas como um pensador demasiadamente especializado em economia (HOTTER et al., 1983, p. 12). Hotter (et al., 1983, p. 12) aponta a falta de sucesso na academia como um dos motivos de sua integração ao governo nazista. Ainda em 1938, Christaller participa do congresso da UGI em Amsterdã e apresenta sua tese sobre a localização industrial que é controvertida por seus pares (ROBIC et al., 1996, p. 215).

\footnotetext{
${ }^{31}$ A mesma universidade que abrigava o economista liberal F. Hayek, o filósofo E. Husserl e seu eminente aluno M. Heidegger que se tornará reitor e membro do partido nazista durante o Terceiro Reich.
} 
A concepção central de seu pensamento é o estudo dos lugares através da elaboração de modelos econômicos, o que resulta na teoria dos lugares centrais. A ideia de lugares centrais e de Estado isolado como modelo vem de von Thünen. A grande contribuição da teoria dos lugares centrais é desvendar a estrutura da ocupação espacial e seus fluxos, compondo um modelo hierárquico que complementa a compreensão regional. A sua preocupação maior - talvez reflexo da teoria de von Thünen - é com a valorização das mercadorias e a distribuição dos serviços (HOTTER et al., 1983, p. 13). Futuramente, o princípio da difusão de Hägerstrand se inspira no sistema de mercados pensado por Christaller.

Contudo, Christaller participou de uma comissão chefiada por Himmler na Segunda Guerra para a intensificação da ocupação alemã na Europa. Várias regiões foram interpretadas e planejadas a partir da teoria das localidades centrais, e algumas encaixaram-se no modelo de Christaller através da coerção física, o que significou a migração forçada para o estabelecimento de novas áreas de colonização da população alemã (RÖSSLER, 1988, p. 8-9).

No pós-guerra, Christaller integra o partido comunista alemão, onde permanece como membro até 1953. Seu planejamento agora segue ideias comunistas com a intenção de criar distritos eleitorais que pudessem favorecer o partido, postura que mais uma vez desagrada a comunidade acadêmica. Devido ao seu passado nazista e à atividade comunista no pós-guerra ele é acusado de espionagem em Frankfurt. Não por acaso, Christaller ocupava uma cadeira do partido comunista no conselho da cidade. A acusação termina sem provas, entretanto seu visto para os Estados Unidos é negado permanentemente, situação que contrasta com seu prestígio na nova geografia norte-americana (HOTTER et al., 1983, p. 11-13). Em 1959, Unwin (1995, p. 154) sugere que Christaller tenha passado para o partido social-democrata.

Apesar desse inusitado percurso, a teoria dos lugares centrais baseia-se na economia clássica liberal é uma fonte profícua para a arquitetura, o urbanismo e o planejamento regional. É importante lembrar que no entre guerras temos também a continuação da influência do círculo de Viena, simpático ao marxismo, que dará 
subsídios para a nova geografia ${ }^{32}$ e será uma das raízes da chamada economia espacial: "A economia espacial tinha-se constituído progressivamente, de JohannHeinrich von Thünen para a agricultura (1826-1851), Alfred Weber para a indústria (1909) e August Lösch para as atividades e serviços" (CLAVAL, 2011, p. 185), autores que seguramente influenciaram Christaller. Apesar das importantes contribuições de Christaller sobre a teoria dos lugares centrais e a hierarquia urbana seu pensamento pode ter mais afinidade com a lógica do Estado ou do mercado de acordo com a interpretação dada. Veremos mais adiante a reapropriação de suas teorias.

Wittfogel mais ligado ao marxismo formou-se e participou do Instituto de Pesquisa Social na década de 1920/1930, que futuramente daria origem ao grupo conhecido como escola de Frankfurt. Ele é militante do Partido Comunista Alemão (KPD) e aproxima-se do pensamento de Heder, Montesquieu, Hegel e Ritter como fontes de inspiração para sua obra (PEET, 1985, p. 4), sendo uma das suas principais contribuições o estudo d'O despotismo oriental, que versa sobre a organização dos Estados do oriente e sobre o conceito de modo de produção asiático.

O geógrafo alemão é convidado para participar do Instituto em 1925, pois era conhecido de Korsch e valorizado por sua participação no ensino operário e pelos seus estudos sobre a China. Sua tese sobre as forças produtivas agrícolas da China, orientada por Carl Grünberg, quase não recebe observações de seus pares. Assim, Wittfogel usa o pseudônimo de Carl Peterson para comentar o próprio trabalho (WITTFOGEL, 1992, p. 3).

O Instituto conformava uma instituição singular onde, era possível discutir livremente o marxismo e a história do pensamento operário. Nesse período inicial, a presença de Lukács no pensamento do grupo era muito forte, e quanto mais Adorno explora a ideia de que na experiência capitalista não se vive a vida verdadeira, mais intensamente o marxismo é incorporado no grupo (WIGGERHAUS, 2002, p. 38-42).

32 Como nos mostra Marramao (1989, p. 326-327), o Círculo de Viena agregou uma série de pensadores marxistas. No início dos anos de 1920, Mach formula o empírico-criticismo que agregou uma boa parte dos pensadores de esquerda. Seu pensamento, pautado fortemente na matemática, influenciou ramos do conhecimento, como a arquitetura, que constituiu o projeto de construção da Viena Vermelha. Os desdobramentos desse debate foram tão fortes que gerou o austro-marxismo ao redor da figura de Otto Bauer e a criação de uma Internacional Comunista própria chamada vulgarmente de Internacional dois e meio. Obviamente os austro-marxistas receberam outras influências além das formulações de Mach. No entanto, Lênin, em sua obra filosófica Materialismo e empiro-criticismo, dedica-se a demonstrar os equívocos de Mach e seu distanciamento dos fundamentos originais da filosofia marxista, direcionando o marxismo mais uma vez para a trilha do hegelianismo como mencionamos acima. 
Muito provavelmente a relação de Wittfogel com os soviéticos se deu através do intercâmbio da escola de Frankfurt com o Instituto Marx-Engels de Moscou e pela participação de um congresso sobre Hegel, ambos em 1931.

Stálin, no ano de 1931, em um dos congressos do Partido Comunista Russo, determinou o fim do debate acerca do modo de produção asiático. Wittfogel é marginalizado, pois como Plekhânov e outros marxistas, indicava que a União Soviética poderia consolidar-se como um país de traços asiáticos mesmo depois da revolução. Ainda em 1931, Wittfogel foi um dos únicos a abandonar os estudos para lutar contra o nazismo. Ele se concentra em textos sobre o regime e suas consequências nocivas para a ciência, postura que the rende uma prisão. A esposa de Wittfogel pede ajuda para o geopolítico Haushofer, que acaba mobilizando seus contatos entre os nazistas, mas somente após enaltecer sua vitória institucional temporária. Wittfogel é libertado em 1934 do campo de concentração na cidade de Esterwegen e ruma para os Estados Unidos (RÖSSLER, 1988, p. 8; TUATHAIL, 1994, p. 319).

Como nos aponta Gallissot (1991, p. 266), Wittfogel nunca foi da ortodoxia da Terceira Internacional e aponta Otto Bauer - de Viena - e Rosa Luxemburgo como suas principais influências. Entretanto, se a maioria dos convocados a participar do Instituto identificavam-se com a social-democracia, Wittfogel era uma ponta de lança mais radial atuando fora do padrão:

Foi assim que se chegou a uma situação que correspondia da melhor forma possível à estratégia de Horkheimer: Wittfogel, mantido pelo Instituto, falava e escrevia fora do quadro do Instituto sobre antissemitismo, as causas sociais e econômicas da nacional-socialismo e de seus êxitos de massa, ao passo que, na Zeitschrift für Sozialforchung não havia nem sequer vestígios desses temas, e os acontecimentos políticos e econômicos da época, catastróficos, só eram descritos, na maioria dos ensaios, por conceitos quiméricos, como 'crise' ou 'capitalismo monopolítico' (WIGGERHAUS, 2002, p. 148).

Em 1935 Wittefogel faz seu segundo trabalho de campo para China, ocasião em que auxilia Fromm aplicando questionários sobre o papel da autoridade na família chinesa (WIGGERHAUS, 2002, p. 204). Uma terceira viagem à China é realizada em 1939, financiado pela Fundação Rockfeller, o que demonstra uma rápida inserção nas instituições norte-americanas, mesmo com o desligamento precoce do grupo de Horkheimer durante o exílio. A assinatura do pacto Ribbentrop- 
Molotov marca o início de seu distanciamento do marxismo (WITTFOGEL, 1992, p. 4).

Como nos mostra Mamigonian, esse foi apenas um caso da diáspora intelectual da esquerda:

\begin{abstract}
Com a fundação em 1924 da chamada Escola de Frankfurt (Adorno, Marcuse e outros) surgiram as primeiras tentativas de uma geografia marxista na Alemanha, com K. A. Wittfogel e W. Christaller. A subida do nazismo ao poder em 1933 não só provocou enorme êxodo intelectual (o romancista T. Mann, o geógrafo L. Waibel entre outros), como abortou a tentativa acima referida (MAMIGONIAN, 2005, p. 206).
\end{abstract}

Além do tema sobre o modo de produção asiático, sobre o qual discorreremos abaixo, Wittfogel torna-se célebre por criticar profundamente a geopolítica. Inclusive um de seus artigos é publicado na Zeitschrift für Geopolitik - a Revista de Geopolítica - em que destoa dos conteúdos dos participantes nazistas (SILVA, 2007, p. 30). Na revista, Wittfogel é apresentado como um comunista que se interessa por geopolítica e pela teoria burguesa (KLEINSCHMAGER, 1988, p. 27).

Devido ao debate promovido por Plekhânov, à Segunda Internacional, o darwinismo e a obra ratzeliana, a geopolítica tinha muito peso no República de Weimar, mesmo entre os marxistas. A geopolítica representa um retorno ao materialismo geográfico do século XIX e serve de complemento para uma parte da esquerda que acreditava que o marxismo havia falhado nas relações entre homem e meio. Wittfogel detalhadamente demonstra que a dialética da natureza está ligada ao desenvolvido histórico das formações sociais (TUATHAIL, 1994, p.316).

O debate sobre o materialismo geográfico era tão importante que através de Korsch (1966, p. 156) descobrimos Woltmann, que escreve um livro chamado $O$ materialismo dialético, e a partir da ideia de múltiplas determinações de Marx postula materialismos que influenciariam a constituição da sociedade. Dentre vários itens propõe em quarto lugar:

4. O materialismo geográfico, que põe a descoberto a influência das relações econômicas, das forças produtivas e do estado da técnica sobre a evolução social e intelectual. O materialismo geográfico e o econômico constituem a concepção materialista da história no sentido restrito (WOLTMANN apud KORSCH, 1966, p. 156).

Fica clara a importância da ideia de materialismo geográfico, de raíz ratzeliana, para a geração alemã do entre guerra - concepção que Plekhânov já 
havia destacado. Esse materialismo demanda o estudo da história humana frente ao quadro natural, pois ele determina a sociedade uma vez que se integra à explicação do processo econômico (BASSIN, 1996, p. 319). Woltmann, que era socialdemocrata, acaba sendo cooptado pelo nazismo (KORSCH, 1966, p. 156-158) e o materialismo geográfico que poderia ser debatido no âmbito do marxismo - com Plekhânov, Wittfogel, Graf, para citar alguns - acaba sendo suprimido do campo da geografia e da política por ter sido apropriado fortemente pela geopolítica nazista. Entretanto, não podemos ignorar que a concepção geográfica de Ratzel desemboca em uma interpretação de análise materialista, e que esta ligação permitiu uma apropriação pela esquerda marxista.

Como aponta Bassin (1996, p. 323), existia um grupo que buscou desenvolver uma geopolítica proletária que cruza a geografia aplicada e materialismo histórico para compreender os problemas políticos atuais. São eles: Engelbert Graf, James Francis Horabin, Alexander (Sandór) Radó. Todos admitem o determinismo mediado pela estrutura da organização econômica, queixam-se da ausência do componente geográfico-ambiental no marxismo, são influenciados por Ratzel e veem o Estado como metáfora de um organismo vivo (BASSIN, 1996, p. 323-324). Graf, inclusive, não se posiciona contra a ideia de espaço vital (lebensraum), marco científico que dá legitimidade à geopolítica extraído da interpretação do pensamento ratzeliano.

Lukács surge nesse contexto como uma voz de contestação contra o darwinismo e a dialética da natureza ${ }^{33}$. O quadro natural seria algo externo à sociedade, que funciona com leis científicas diferentes, o que não significa que a natureza não tenha um grau de importância na esfera social (BASSIN, 1996, p. 325). A sociedade seria independente da natureza que está subjulgada e apropriada pelo capitalismo.

Paralelamente a Lukács, Wittfogel acompanha todo o debate e identifica a tendência do materialismo geográfico de origem ratzeliana em que a natureza atua sobre o homem direta ou indiretamente, concepção esta que encontra-se cristalizada na geopolítica. O pensamento de Lukács, que separa a natureza rendese a um fetichismo, porque a natureza considerada sem a sociedade remonta ao idealismo kantiano e não a uma visão dialética da questão (BASSIN, 1996, p. 329).

33 Diferentemente de K. Korsch, que aceita o determinismo ambiental mediado pelas forças materiais de produção (BASSIN, 1996, p. 326). 
Lukács, posteriormente retrata-se dessa perspectiva reconsiderando a dialética da natureza.

O ponto de vista da geopolítica para Wittfogel, segundo Kleinschmager (1988, p. 26-27), é que as forças políticas têm um papel secundário se comparadas com as forças econômicas de produção. Em função disso, os nazistas o criticam por pensar o homem apenas do ponto de vista da alienação econômica, e por supervalorizar o processo de produção compondo uma possível variação da geopolítica tradicional que se baseava principalmente na política e na lógica do Estado. O mesmo argumento é utilizado por Wittfogel para criticar Ratzel e Richthofen, que ignoram o fator trabalho para focarem-se demasiadamente no naturalismo do homem ecológico apartado de suas relações sociais e de produção material (WITTFOGEL, 1992, p. 10-11).

Para criticar a tradição geográfica, os geopolíticos de esquerda e de direita, Wittfogel publica "Geopolítica, materialismo geográfico e marxismo" 34 na revista Sob a Bandeira do Marxismo, de Viena, em 1929. Infelizmente, o texto é fragmentado em três partes publicados nos cadernos 1, 4 e 5 da revista, o que certamente amenizou seu poder de impacto.

Contemporaneamente, na França, J. Ancel e Demangeon fazem críticas à geopolítica. Ancel, por exemplo, a desqualifica atacando a vaga ideia de raça e o caráter anticientífico do espaço vital (CLAVAL, 1993, p. 85). Além dessas confluências, Troll ainda nos indica que a originalidade de Wittfogel foi ver a relação entre homem e natureza a partir do trabalho e de sua organização (TROLL, 1949, p. 126-134).

Através do trabalho e da técnica, Wittfogel quer mostrar como a natureza se faz presente, porém não determina o desenvolvimento social (MATLEY, 1966, p. 100). Mesmo que alguns intérpretes digam que sua obra beira o determinismo, Wittfogel faz questão de esclarecer que o ambiente facilita ou impõe obstáculos ao homem, mas em última instância a organização social e a técnica são os elementos fundamenteis.

No artigo, entretanto, expõe o principal problema do marxismo da Segunda Internacional, que consistia em não considerar as influências do meio através das forças materiais de produção, observando apenas o paralelismo entre luta de classes e seleção natural. Assim, a natureza influencia a produção e esta por sua

\footnotetext{
${ }^{34}$ Esse texto foi traduzido e publicado na Seleção de textos, AGB São Paulo, nº 20, 1992.
} 
vez ecoa na política, ao contrário do que pensa Graf e parte dos geopolíticos de esquerda (BASSIN, 1996, p. 328-329). A política não é, portanto, uma variável independente da sociedade que se estabelece em um campo de disputa isolado. $\mathrm{O}$ surgimento da geopolítica não pode ser dissociado da expansão do capitalismo monopolístico, e nesse sentido Wittfogel acredita que o erro de Haushofer é ignorar a preeminência econômica assumindo uma postura mais ligada aos ideias aristocráticos do que burgueses (TUAHTAIL, 1994, p. 319).

Para Wittfogel, a natureza só tem valor social quanto apropriada pelo homem, e isto fundamenta sua visão prometêica de que a técnica molda o quadro natural à sua imagem. Tal postura coloca em evidência a máxima de Ratzel, que exalta a maior dependência da natureza quanto mais avançada for a economia de uma sociedade (BASSIN, 1996, p. 330). A natureza é a fonte da riqueza material e induz os meios de produção.

De maneira dúbia, o pensamento marxiano tem dois sentidos ao falar sobre a exploração das forças naturais de produção: o crescente domínio da natureza aumenta a produção da riqueza material, seja pela diminuição do esforço necessário ou pela maior da abundância de bens (GRUNDMANN, 1991, p. 4). Outro elemento importante para essa discussão é que Marx coloca a relação entre homem e meio como trans-histórica, ou seja, independente do modo de produção ou das condições históricas, ela se estabelece através da formação de um conflito e uma unidade com a natureza (GRUNDMANN, 1991, p. 7 e 61)

Wittfogel não analisa somente os contemporâneos, pois associa o determinismo ao pensamento burguês através da obra de Montesquieu, Herder, Hegel e Ritter, raciocínio que vai inspirar a aversão pelo determinismo geográfico dentro da escola soviética de geografia (MATLEY, 1966, p. 103). Veremos que, curiosamente, M. Quaini percorreu esse mesmo itinerário histórico ao recontar a história da geografia humana.

Como podemos perceber, Wittfogel (1992, p. 73) é um pensador que busca sempre a origem das ideias. Depois de seu levantamento sobre a ciência burguesa, ele identifica que a concepção de que a natureza subordina a sociedade está em Hegel, todavia afirma que o trabalho é o verdadeiro fundamento geográfico da história. Após rememorar as múltiplas determinações de Marx ou, a determinação arbitrária, em que vários elementos contam na explicação de uma conjuntura, o geógrafo alemão defende que o determinismo é principalmente técnico e não 
natural, embora a natureza defina as forças produtivas (WITTFOGEL, 1992, p. 27 e 80). Sua perspectiva, portanto, repousa sobre uma interpretação social embasada na economia, na tecnologia e nas disposições naturais.

A recuperação de Wittfogel tem como objetivo resolver um problema fundamental da teoria marxista, que teve em Plekhânov um de seus grandes introdutores: a ambivalência entre a tendência positivista-naturalista (relacionada ao darwinismo social de maneira simples) e progressista-modernista (ligada à concepção tecnicista do metabolismo sociedade-natureza) na visão do materialismo geográfico (BASSIN, 1996, p. 331). Contudo, a forte ênfase que Wittfogel confere à vinculação entre natureza e meios de produção, ou ainda as passagens em que admite que as leis naturais são externas à sociedade, sendo o homem uma criatura sem total livre arbítrio frente aos elementos do quadro natural, fundamentam as acusações de seu determinismo ambiental, mesmo que ele afirme o contrário.

Concomitante à controvérsia com os geopolíticos, Wittfogel envolve-se nos debates sobre o modo de produção asiático a partir de seu interesse sobre a sociedade chinesa. Sua ideia inicial é que as sociedades sob o modo de produção asiático se auto-reproduzem de uma maneira isolada (PEET, 1985, p. 5-8), e que as sociedades asiáticas estagnariam-se devido à agricultura fértil, diferentemente da Europa ocidental, que possui uma má produção agrícola. Entretanto, Wittfogel diversas vezes insinua que somente o capitalismo seria capaz de romper com essa estagnação agrícola ${ }^{35}$.

Através da leitura geográfica do modo de produção asiático e das sociedades orientais, seu objetivo é estabelecer um modelo de formação social - lembrando que algumas áreas da América do Sul também são vistas como sociedades "orientais". O elemento fundamental que constituiria a organização das sociedades orientais seria o Estado, fruto de dois elementos básicos: da ascensão de um grupo social capaz de coerção em ampla escala, portanto controlador da força militar; e da distribuição da água destinada à agricultura de alta produtividade.

Esse panorama se evidenciaria em vários locais da Ásia, um pouco independentemente do quadro natural, ou seja, em uma quantidade razoável de conjunturas físico-naturais. Isso fundamenta sua visão de que a técnica e a

35 Muito provavelmente essa ideia sobre o oriente junta-se ao marxismo através da filosofia da história de Hegel, que vê os impérios orientais como estagnados e estáveis e portanto fora da história universal (SINGER, 2012, p. 24). 
organização econômica se refletem na política, sendo elementos fundamentais da formação social.

A partir do raciocínio do Estado como controlador da distribuição da água, Wittfogel (1977, p. 15-28) utiliza o termo "sociedades hidráulicas" para referir-se à organização pautada no quadro agrário que combina elementos arcaicos e modernos. De uma forma simplificada, o arcaísmo daria respaldo à modernização imposta pelo Estado, destinada a determinados setores sociais conciliando-os com as tradições consolidadas (superestrutura) (WITTFOGEL, 1977, p. 15-28).

A sociedade hidráulica teria uma tendência centrípeta, ou seja, dispersaria a população no campo ao contrário da centralização demográfica provocada pelas indústrias e pela concentração manufatureira européia. O resultado disso é uma organização militar dos povos em movimento, contrastando com a centralização do poder político ao redor da casta governante. O governo hidráulico detendo o meio de produção água controla a produção agrícola, fonte principal de riqueza, e através desta hegemonia, que se manifesta burocraticamente, acaba administrando a manufatura, o comércio e outras atividades que seriam complementares (WITTFOGEL, 1977, p. 44).

Haveria, então, uma diferenciação entre sociedades hidráulicas absolutas e relativas: as primeiras têm predominância da agricultura, e as segundas apresentam uma diversificação maior das atividades econômicas, surgidas espontaneamente, o que tenderia a tirar o primado da atividade agrícola, mas não a hegemonia políticomilitar do grupo controlador das obras hidráulicas (WITTFOGEL, 1977, p. 203-206).

O objetivo de Wittfogel é uma diferenciação entre o modo de produção asiático e o feudalismo europeu e além do aspecto da organização política, as sociedades são comparadas também do ponto de vista cultural. Nesse sentido, Wittfogel faz um grande esforço para encontrar traços comuns em várias culturas do oriente.

Essas diferenciações entre oriente e ocidente são baseadas nos escritos de Marx, Engels e Lênin, além de Vargas e Raziónov, que eram simpáticos à interpretação das sociedades orientais na União Soviética, ao contrário de Stálin (WITTFOGEL, 1977, p. 460-490).

Outro elemento relevante para sua cassação teórica, é o fato da estagnação asiática ser explicada pela ausência da luta de classe, porque nelas não existiria proletariado, ao contrário das sociedades industriais. Para um país que vindicava ser 
o baluarte do socialismo do mundo, surgir de uma sociedade sem luta de classes poderia representar um sério problema da teoria política. A Rússia deveria, portanto, ter uma formação histórica fundada no feudalismo europeu, postura que caminha contra uma interpretação da ocorrência de Estados "asiáticos" administrados por uma casta burocrática (PEET, 1985, p. 9).

Entretanto, aqui é interessante notar que além de finalizar a discussão sobre o modo e produção asiático, Stálin ainda tinha o interesse de rechaçar o determinismo para impor sua própria visão sobre a controvérsia geográfica. Em sua versão oficial, o quadro natural não teria influência nenhuma no desenvolvimento social e o meio geográfico é algo externo à sociedade, pois a vontade humana, o trabalho e a técnica seriam capazes de dobrar facilmente as intempéries da natureza (MATLEY, 1966, p. 107). Saushkin acredita que a perspectiva prometêica ${ }^{36}$ venha de Reclus, autor que Stálin lia na juventude. Deriva daí a concepção do trabalho e da técnica como aprimoradores da natureza, tornando-a mais salubre, produtiva e farta para a população (MATLEY, 1966, p. 108).

Contudo, reparem que Reclus e Metchnikoff faziam parte da mesma rede anarquista e ao lado de Plekhânov e Wittfogel, todos tinham uma visão prometêica da relação entre homem e natureza. A diferença sutil é que Plekhânov admitia o determinismo ambiental, enquanto os outros só reconhecem a importância relativa da natureza. Bassin ressalta que:

O apelo do determinismo para a esquerda pode ser vista prontamente dentro da geografia, por exemplo, no trabalho dos anarquistas revolucionários como Elisée Reclus e Lev Mechnikov37; o fato mais demonstrativo é que a maioria dos discípulos mais proeminetes de Marx incorporaram o dogma do determinismo ambiental em suas teorias sociais (BASSIN, 1992, p. 5) 38 .

A concepção prometêica não determinista favorecia o planejamento soviético e eliminava os obstáculos intelectuais para a sua concretização, corroborando com a ideia da superioridade do socialismo como sistema social planejado e com o triunfalismo da doutrina da inevitabilidade histórica do stalinismo.

\footnotetext{
36 O termo remete ao mito de Prometeu, titã que roubou o fogo de Zeus e o entregou aos homens. O titã foi punido gravemente, mas seu sacrifício permitiu que a humanidade conhecesse uma maneira de dominar a força da natureza para o seu desenvolvimento.

37 Metchnikoff, de acordo com a transliteração inglesa e não francesa como utilizamos até agora.

38 Tradução nossa.
} 
A dualidade entre a importância do meio e da técnica está presente numa obra como A ideologia alemã de Marx. Meio ambiente e tecnologia são elementos fundamentais no desenvolvimento histórico das sociedades:

\begin{abstract}
Assumindo uma aproximação histórica para o problema nós podemos concluir que Marx concebeu em princípio três fatores como 'forças dirigentes' : (1) a natureza: o determinismo geográfico; (2) a tecnologia: o desenvolvimento autônomo, a lógica interna e a evolução; (3) seres humanos: suas necessidades, o desenvolvimento da tecnologia transformando a natureza (GRUNDMANN, 1991, p. 111)39
\end{abstract}

Apesar da cassação, o argumento de Wittfogel de que o determinismo seria um reflexo da exploração burguesa persiste no pensamento de Stálin e dos geógrafos russos após a revolução (BASSIN, 1992, p. 4). A ideologia embutida na ciência burguesa é que Deus predestinaria os povos através de uma natureza rica em recursos naturais e amena nos obstáculos a serem vencidos.

Para além disso, sua obra foi muito criticada justamente por uma falta de citações, ou uma falta de lastro no arcabouço marxista. Por exemplo, a ideia de que um grupo monopolizaria o uso da água foge um pouco das elucubrações presentes em A ideologia alemã de Marx sobre as sociedades asiáticas (WITTFOGEL, 1977, p. 28-29). Com a reedição de seu livro, Wittfogel (1997, p. X-XXX) escreve um longo prefácio, procurando reafirmar suas teses e apresentando os argumentos de Marx e Engels ${ }^{40}$.

O refúgio nos Estados Unidos não representou um alívio para Wittfogel, porque os membros da escola de Frankfurt o colocam em uma posição secundária devido à valorização da psicanálise e da filosofia. Após ser preso em um campo de concentração e ter suas teorias negadas na União Soviética, agora seus colegas de pesquisa o renegam e as relações se rompem oficialmente em 1947, quando Wittfogel vai trabalhar no Projeto de História da China na Universidade de Columbia, em Washington. Nesse período, ele se posiciona contra o socialismo real e durante o macarthismo critica Marx e a União Soviética, fazendo uma associação nítida entre totalitarismo e escravismo, além de denunciar antigos colegas que trabalhavam no

\footnotetext{
39 Tradução nossa.

40 Curiosamente, depois da primeira edição e devido às transformações do mundo, Wittfogel (1977, p. 514) insere uma nota argumentando que o Japão não é uma sociedade oriental, reflexo do amplo desenvolvimento que sofreu após a Segunda Guerra Mundial. O Japão teria vivido um feudalismo muito próximo do europeu.
} 
Institute of Pacific Relations, instituição que abrigava simpatizantes do partido comunista chinês ${ }^{41}$ (PEET, 1982, p. 9-10).

Além disso, Wittfogel nega o desenvolvimento linear dos modos de produção e diz que o modo de produção asiático é uma possibilidade de desenvolvimento multilinear. Contudo, distanciar-se do marxismo real ou teórico foi uma postura geral da rede de Horkheimer como estratégia para receber apoio institucional dos Estados Unidos no ápice da guerra fria (WIGGERHAUS, 2002, p. 472-479). Ernst Bloch, por exemplo, terá uma postura diferente, mantendo-se simpático ao socialismo real até o final da vida.

Se na Alemanha o nazismo virtualmente liquidou a esquerda, na França a resistência aos regimes de direita fez mais uma vez florescer uma vocação de Paris que vinha desde o início do século: além de aspirar ao papel de capital cultural mundial, a cidade era um grande centro de conspiração de intelectuais de esquerda e de exilados por motivos políticos. Congregavam-se ali anarquista, comunistas e socialistas, e o intercâmbio provocado por essa centralidade impulsionou às ligações entre o pensamento político francês e o russo - e posteriormente soviético. Gradualmente, desde a virada do século o anarquismo apoia-se no marxismo como mostra Hobsbawn:

\begin{abstract}
Até os anos trinta de nosso século, muitos dos intelectuais mais conhecidos do partido comunista francês não podem ser seriamente considerados como teóricos marxistas, ainda que naquele período vários deles (mas não todos) começariam a se considerar como tais. A revista ideológica do partido, La Pensée ${ }^{42}$, fundada em 1938, tem até hoje o subtítulo 'revista do racionalismo moderno'. O anarquismo, ao contrário, apesar da notória hostilidade entre Marx e Bakunin, assimilou amplamente a análise marxista, excluídos alguns pontos. Isso não é surpreendente, já que, até a exclusão dos anarquistas da Internacional (ocorrida em 1896, e em certos países mais tarde), frequentemente não se podia traçar no interior do movimento revolucionário uma nítida linha de separação entre eles e os marxistas, de vez que uns e outros eram expressões da mesma matriz de revolução e esperança (HOBSBAWN, 1989, p. 82).
\end{abstract}

41 "Em 1951, quando se tentou provar ao Institute of Pacific Relations que alguns de seus colaboradores comunistas tinham contribuído para a queda de Chang Kai-Chek e para a vitória dos comunistas chineses, Wittfogel também teve que comparecer a comissão de McCarran, um subcomitê do Senate Internal Secutiry. O comunista arrependido deu um triste espetáculo acusando um antigo colaborador do ISR, Moses Finkelstein, de ter sido comunista" (WIGGERHAUS, 2002, p. 417).

42 Essa revista congregava a intelectualidade de esquerda de várias áreas do conhecimento acadêmico. Será nessa revista que Jean Dresch publicará seus textos sobre a crise da geografia, como veremos adiante. 
A resistência ao nazismo e ao fascismo, a tradição radical e a mentalidade cientificista, como dissemos acima, influenciaram grande parte da intelectualidade e reverberaram dentro dos campos científicos. Com a geografia não podia ser diferente, já que a cooperação com a história na disputa contra a sociologia havia posto em evidência a União Soviética e seu modelo de desenvolvimento (MEGALE, 1984, p. 12; MAMIGONIAN, 2005, p. 210).

Se o pacto Ribbentrop-Molotov de não agressão entre União Soviética e Alemanha fez muitos pensadores de esquerda acharem que Stálin os havia traído, a ocupação nazista demonstra o poderio técnico e estratégico do nazismo. Contudo, a vitória da União Soviética aumentará o poder ideológico da propaganda, fato que impulsionará a difusão do marxismo no mundo.

Alguns anos antes, na véspera do conflito mundial, nos Estados Unidos o New Deal aplica as políticas keynesianas de investimentos do Estado em serviços públicos como forma de reverter a crise econômica. A nova demanda pelo planejamento afeta diretamente a geografia, assim como a geopolítica no entre guerras.

Do ponto de vista do desenvolvimento do marxismo, foi nessa década que os Manuscritos Econômicos-Filosóficos de Marx foram publicados. O efeito prático de sua divulgação no ocidente foi uma renovação das discussões acerca da filosofia marxista, mesmo que alguns intelectuais tenham deixado de debater parte significativa das ideias presentes nos Manuscritos. Entretanto, isso foi mais um fator que promoveu a divulgação das ideias de Marx.

No entanto, a persistência do cientificismo da Segunda Internacional - ou pequeno racionalismo - como base filosófica na atmosfera intelectual, vai provocar a demanda de Sartre e Merleau-Ponty por uma filosofia mais atual e sofisticada.

Para além disso, temos que ter em mente que nessa época o alinhamento com a Terceira Internacional acarretava a predominância da política do front populaire, ou seja, a união estratégica entre burguesia de vanguarda e proletariado para a chegada ao poder - não por acaso que grande parte da intelectualidade das fileiras do partido comunista francês vem de famílias burguesas e pequenoburguesas (profissionais liberais, funcionários públicos, professores, jornalistas etc.). No caso dos geógrafos, a situação não é diferente. Está dado o panorama intelectual que se impõe para o aprofundamento da aproximação entre geografia e marxismo na França. 


\title{
2.1 Os geógrafos de esquerda na França, um início esquecido
}

No final da década de 1930, fruto da relação com a escola dos Anais e dos contextos da França, como vimos, a geografia passa por um processo de esquerdização. Pierre George sob a recomendação de A. Cholley, publica em 1938 um livro intitulado Géographie economique et sociale de la France ${ }^{43}$. Surgem ainda artigos marxistas em uma coleção organizada por Deffontainnes, e o trabalho de R. Clozier sobre o sistema ferroviário e de metrô, que se refere a uma geografia dinâmica, voltada para circulação (MAMIGONIAN, 2005, p. 210). Clozier defende sua tese em 1940 sobre a Gare du Nord, importante estação ferroviária de Paris, tema que também o leva a dissertar sobre os problemas sociais da periferia e das migrações (CLAVAL, 1998, p. 208).

Beauguitte traça o cenário institucional da época:

\begin{abstract}
A Sorbonne contava, em 1939, com cinco professores universitários (Jacques Ancel, André Cholley, Albert Demangeon, Emmanuel de Martonne, Charles Robequain), um professor horista (Marcel Larnande) e dois assistentes (Pierre Birot, Jean Gottmann), quase um terço dos geógrafos acadêmicos. Paradoxalmente, os geógrafos não tinham nenhuma revista parisiense para divulgar seu trabalho (BEAUGUITTE, 2010, p. 3).
\end{abstract}

Como vemos, o campo da geografia na época não era muito grande. Cholley faz parte de grupo restrito da Sorbonne, o que permite acumular o capital cultural e projetar sua figura e seus alunos através de publicações e de um amplo lastro institucional${ }^{44}$. Apesar desse pequeno espaço institucional, Robequain cria em 1938 a cadeira de geografia colonial e em 1945 cria-se a cadeira de geografia política ocupada por R. Dion, apesar do mal estar que ronda a geopolítica devido aos nazistas (GOTTMANN, 1946, p. 87).

De Martonne e Demangeon, sendo os alunos mais prestigiados de Vidal de la Blache - certamente com a proeminência do primeiro - acabam cindindo seus

\footnotetext{
${ }^{43}$ Abaixo apresentaremos uma análise dessa obra reeditada e reelaborada em 1946 após a Segunda Guerra Mundial.

44 Cholley era diretor do Instituto de Geografia, do laboratório do Conselho Nacional de Pesquisa Científica (CNRS) instalado no Instituto, presidente do concurso de agregação e dos Annales de géographie de 1941 até 1968. Ele ainda coordenava as edições Baillère com uma coleção dirigida aos liceus que modernizou o ensino da geografia e contou com contribuições de George, Dresch, Clozier, Birot, entre outros (BATAILLON, 2009, p. 42-43).
} 
interesses em geografia física e humana. N'A geografia física de De Martonne, o reconhecimento dos métodos das ciências naturais e da geomorfologia corroboram para a valorização deste subcampo em detrimento da geografia humana, que ainda buscava uma identidade e um método que lhe conferisse renome. Nesse contexto, Cholley encaminha-se para estudos geomorfológicos, o que não significa que irá ignorar a geografia humana.

De Martonne, através de sua relação com a geomorfologia, passa a tratar a região como uma estrutura através do método anatômico, decifrando sua topologia através da descrição:

(...) mais precisamente, nós seríamos tentados a dizer que o método do autor é anatômico e estrutural: ele busca primeiro colocar em destaque uma estrutura (geralmente física) e em seguida encaixam-se os detalhes. A escolha dessa técnica nos parece de fato límpida em uma geomorfologia que rompeu com a exegese das estruturas geológicas e das superfícies de aplainamento. Além disso, o ambientalismo imperdoável de De Martonne não reconhece nenhuma censura entre aquilo que é da ordem do humano (ORAIN, 2001, p. 306-307) $)^{45}$.

O que quer dizer que ao explicar a estrutura do relevo teríamos a chave para compreender a estrutura da ocupação humana. O método anatômico aplica-se aos fatos naturais, mas se prolonga na explicação dos fatos humanos (ORAIN, 2001 p. 307).

Gregory (1978, p. 81) acrescenta o fato de que na controvérsia entre Durkheim com sua concepção de morfologia social e Vidal, inspirado por Ratzel, existia uma disputa pelo termo estrutura social. A ideia de estrutura promovida por Vidal e principalmente por De Martonne, como vimos, iria alguns anos depois confrontar-se com o althusserianismo:

\footnotetext{
De fato, quando o estruturalismo foi finalmente conectado à disciplina, cerca de cinquenta anos depois, ele estava em uma forma que tinha poucas ligações diretas com a tradição durkheimiana como um todo: esse segundo encontro derivou-se do estruturalismo operacional de Jean Piaget e do marxismo estrutural de Louis Althusser (GREGORY, 1978, p. 81) ${ }^{46}$.
}

Assim, a ideia de estrutura sempre foi um elemento de fundo no campo disciplinar geografia e na geografia francesa isso se evidencia com mais intensidade. Se inicialmente ela entra no campo disciplinar através das metáforas

\footnotetext{
45 Tradução nossa.

46 Tradução nossa.
} 
organicistas de Ratzel, existe uma transformação quando ocorre o contato com a geomorfologia. Aqui, o apelo morfológico do relevo vindo da análise formal da vida traduz-se na estrutura que embasa as formas da terra e da ocupação humana. Quando esse método dedica-se à análise social, vê o homem como fator de transformação terrestre, produtor de uma topologia no espaço ${ }^{47}$.

Não é por acaso que os herdeiros de De Martonne se debruçaram sobre o hábitat e a compartimentação geográfica relacionando ambos com a atividade de produção e consumo através da economia. Esse será o caminho percorrido pelos alunos de Cholley, formados em geografia física, mas com ricos e numerosos ensejos na geografia humana.

As discípulos dos alunos de Cholley, influenciados por essas ideias distanciavam-se lentamente da tradição de pensamento vidaliano e se chocarão com a ascensão do estruturalismo althusseriano. Berdoulay (1981) indica que a segunda geração da escola de Vidal travou contato com a filosofia de Bergson em busca de aportes filosóficos para geografia. Possivelmente, a concepção de materialismo e de conhecimento de Cholley pode ter dialogado com Gaston Bachelard como uma resposta ao desafio do neokantismo que chegava à geografia francesa pelo pensamento alemão ${ }^{48}$. Bachelard também foi importante para Althusser, mas os geógrafos aproximam-se do althusserianismo mais como uma tendência geral das ciências humanas do que necessariamente uma afinidade filosófica.

O contato com o estruturalismo marxista causa a mesma ruptura no mundo anglo-saxão. O campo disciplinar quer se renovar apropriando um aparato explicativo que envolva o espaço, as contradições sociais e uma práxis que permita tornar o mundo mais justo. Ao verificarmos os antecedentes do caso norteamericano, uma leitura atenta da obra de Carl O. Sauer pode revelar uma

\footnotetext{
47 De certa forma, essa tradição continua ecoando contemporaneamente. Desmarais e Ritchot (2000), por exemplo, tentaram utilizar a proposta morfológico-estrutural para elaborar um método que abarcasse fenômenos físicos e humanos.

48 Como demonstra Carvalho (1986, p. 10-14) a proposta do materialismo racional é ser um meio termo entre o ideialismo transcendental e o realismo filosófico. Em um claro diálogo com Bergson, Bachelard tenta demonstrar, a partir de uma epistemologia antropológica, como o conhecimento está disposto em uma dialética de complementaridade entre várias áreas do conhecimento de maneira aberta e ativa com o objetivo de organizar racionalmente os diversos tipos de matéria dispostos a partir de diferentes princípios e aplicações. Tal perspectiva pode dialogar com a dimensão física, natural e humana concebida pelo método das combinações de Cholley.
} 
preocupação morfológica e estrutural semelhante, embora em um ambiente distante do marxismo, portanto, o termo estrutura persiste no campo ${ }^{49}$.

A análise geomorfológica associada à cartografia e ao bloco diagrama constituíam elementos básicos a serem manejados pelo geógrafo treinado. Entretanto, para Bataillon (1981, p. 147) foi o fato da geografia humana ter um estatuto científico pobre que permitiu a inserção de conceitos e ideias vindas do marxismo, que além de seu valor ideológico refletia a necessidade da busca de uma explicação mais complexa para os fenômenos sociais em função da organização urbano-industrial, bem como a constituição de novos espaços produzidos pelo socialismo.

George indica a importância editorial de A. Cholley, que nessa época:

(...) foi simultaneamente o interlocutor das Edições de Médicis, da Presses Universitaires de France e reuniu os autores entre seus colegas e seus alunos para a coleção de Geografia econômica e social (Edições de Médicis) e a coleção Orbis (Presses Universitaires de France) (GEORGE, 1990, p. 236) $)^{50}$.

Atualmente alguns autores reconhecem as articulações ao redor da militância política que foram subestimadas pela história da geografia:

É convencional pelos autores de direita e esquerda diminuir o impacto intelectual do marxismo na geografia francesa nesse período e argumentar que ela manteve-se conservadora, com práticas vidalianas in situ. Entretanto, isso é uma simplificação: o marxismo tem um impacto profundo em um número de áreas, dentre as quais os problemas do desenvolvimento (HEPPLE, 2000, p. 271) ${ }^{51}$.

Seguramente, André Cholley é uma espécie de patrono do grupo que envolvia Pierre George, Jean Tricart e Jean Dresch, formando uma rede ou grupo científico e político que se dedica à geografia influenciada pelo marxismo. Desses três geógrafos surgirá uma segunda geração de alunos também militantes e interessados no funcionamento do capitalismo. A postura política de Cholley era pelo

\footnotetext{
49 Carl Sauer, através da tradição do pensamento e da geografia alemã, dá uma importância central ao método morfológico, às formas e funções da paisagem e à estrutura, que compreende conjuntos que originam as áreas culturais. Contudo essa é uma tradição que ele recupera também da geografia da Antiguidade.

50 Tradução nossa.

${ }^{51}$ Tradução nossa.
} 
fortalecimento de uma frente única, que envolveria um consenso da esquerda, o que confluiria com a postura de seus alunos filiados ao partido em função da resistência.

Racine (1981, p.119) valoriza as reflexões epistemológicas oriundas dessa geografia de esquerda, porém diz que elas terão um sentido diferente do esforço de teorização da geografia crítica da década de 1970. A inovação no final da década de 1940 remete às agendas de pesquisa, à inserção de novos temas e à introdução lenta de conceitos marxistas.

Entretanto, nesse início esquecido a união entre a militância de esquerda e as ideias vindas da geomorfologia estrutural derivam na concepção de estrutura social que perpassa a obra de alguns autores:

Estruturas sociais: a expressão define os elementos da organização social considerada como fundamental e as relações dinâmicas entre esses elementos. Ordem das coisas que regem as relações, as infraestruturas (em particular a organização econômica da sociedade) e as superestruturas (CABANNE, 1992, p. 393) ${ }^{52}$.

Cabe lembrar ainda que nos anos 1930 a França encontrava-se atrasada em relação ao debate sobre o planejamento, se comparada com a Alemanha, os Países Baixos, a Grã-Bretanha ou a Itália. Assim, o congresso promovido pela União Geográfica Internacional (UGI), em 1931, na cidade de Paris, serve como vetor modernizador da geografia francesa, devido à divulgação do conceito de frentes pioneiras por Bowman que se depara com o argumento neo-malthusiano da superpopulação (ROBIC, 2006, p. 39-40). O planejamento do crescimento urbano e seu remodelamento são discutidos, bem como o trinômio geografia urbana, geografia da população e geografia da colonização, encadeamento que futuramente reajustado será importante para o projeto disciplinar de Pierre George. Outras áreas do conhecimento como a arquitetura e o urbanismo, também se engajariam para suprimir o atraso francês, portanto, a geografia deveria se posicionar delimitando seu campo de atuação (CLAVAL, 1998, p. 162-163).

A concepção do subcampo da geografia urbana francesa mostra-se defasada. Mesmo que classicamente houvessem estímulos no início do século XX como a viajem de Vidal de la Blache aos Estados Unidos, a monografia urbana sobre

\footnotetext{
52 Tradução nossa.
} 
Grenoble, de Raoul Blanchard ${ }^{53}$, de 1910, complementados pelos textos sobre a vida urbana de Brunhes e Demangeon, existiam novas demandas sociais. De acordo com Abreu (2006, p. 135), a ideia dos primeiros trabalhos de geografia urbana era a busca pela síntese urbana que abrangesse o "sítio, a posição a evolução histórica, a fisionomia e estrutura, as funções urbanas e o raio de ação da cidade".

O intercâmbio proporcionado pelos eventos da UGI na década de 1930 explica a presença marginal da escola de Chicago entre os geógrafos franceses (ROBIC, 2006, p. 43) e posteriormente o contato com a obra de Christaller. O pensamento de Chicago estimula análises naturalizantes, mas seu aparato teóricometodológico não é completamente incorporado (ABREU, 2006, p. 130). O planejamento e o hábitat, enfatizados devido às preocupações geradas pelo congresso, estimula os geógrafos à prática em detrimento das elaborações epistemológicas.

O congresso da UGI de 1931 em Paris foi uma espécie de modelo para os futuros eventos e se por um lado a questão colonial e/ou o imperialismo mobiliza muitos geógrafos a uma visão crítica do mundo, por outro ela é tão candente que junto ao evento dos geógrafos ocorre uma exposição colonial para ostentar os domínios franceses (CLOUT, 2005, p. 19-22).

No mesmo congresso, Chabot apresenta um trabalho sobre as relações cidade-campo e as zonas de influência das cidade, ideia que terá muita força na geografia urbana francesa (BOYER, 2008, p. 271). Chabot e George entram em contato com a obra de Christaller novamente no encontro da UGI de 1938, em Amsterdã. Contrariamente ao senso comum:

\begin{abstract}
A afirmação da geografia urbana se faz, então, conforme analisa Robic, nos encontros internacionais, sobretudo depois do congresso de Paris de 1931, de Varsóvia em 1934 e o de Amsterdam em 1938, em que se discutem as relações estreitas entre cidade e campo, ou seja, as funções da cidade na estruturação do território de uma região, temas também presentes, vimos, na obra de Monbeig. Trabalhos como o de Walter Christaller e sua teoria dos lugares centrais suscitam de conjuntos de cidades, estudos comparativos sobre zonas de influência de metrópoles regionais e não apenas monografias como antes (SALGUEIRO, 2006, p. 108).
\end{abstract}

53 Após o trabalho de monografia urbana, Blanchard publica em 1922 artigos sobre o planejamento industrial para área dos Alpes, mas acaba sendo vetado pela ideologia liberal do governo e do empresariado (CLAVAL, 1998, p. 160). 
Na geografia francesa, a obra de Christaller tem o caráter seminal de estruturar a ideia de organização regional no pensamento de Chabot, Tricart e Rocherfort, por exemplo. No entanto, eles não procuraram regularidades ou os seus minuciosos mecanismos de funcionamento pautados em modelos matemáticos como ocorreu a partir da nova geografia (CLAVAL, 1998, p. 288). A ideia de Christaller é mais flexível entre os franceses, abrindo possibilidade para novas perspectivas e aplicações menos rígidas.

No entanto, se os anos 1930 foram ricos em debates na França, mesmo que - Departamento de Geografia da Sorbonne fosse pequeno, no pós-guerra a geografia ainda tem prestígio. No mundo anglo-saxão esse período acompanha o fechamento do curso de geografia em Harvard, nos Estados Unidos, com graves consequências para o campo ${ }^{54}$.

\subsection{A geografia não era tão reacionária como dizem}

Como dissemos, muitos geógrafos se radicalizaram em função da luta na resistência contra o nazismo. O caso de Dresch ainda teve o agravante de sua militância anticolonial. Vamos debater um pouco o contexto geral dos alunos de Cholley e dos geógrafos de esquerda antes e depois da Segunda Guerra. Começaremos por Pierre George, um dos mais célebres e precoces alunos de Cholley.

No tocante a trajetória de George é impossível negar a forte influência marxista, principalmente no início de sua extensa carreira. George é aprovado em primeiro lugar no exame de agregação em história e geografia, no ano de 1930, com apenas 21 anos de idade.

Na sua tese defendida em 1936 sobre a região do Baixo Ródano, George lida principalmente com a geografia rural da região, sua paisagem e a dinâmica agrícola frente ao êxodo rural (RENARD, 2008, p. 289). Seu orientador é A. Cholley, que o critica por escrever mal e de forma impessoal, porém o trabalho tem ao todo 692 páginas e George torna-se doutor com apenas 25 anos de idade (CLOUT, 2010, p. 36). Mais tarde, assim como Tricart, George desenvolve a temática do fato rural e

${ }^{54}$ Existia uma demanda no pós-guerra pela autonomia do Departamento de Geografia, porém com a separação, os geólogos a atacam fortemente. Quem participava da comissão pela defesa da geografia era I. Bowman, que influenciado por Davis acreditava na força da geografia física. Todavia, seu esforço não foi suficiente para a sobrevivência do curso (SMITH, 1987, p. 155-162). 
urbano. Clout (2010, p. 40) diz que George afasta-se da geografia física por ter diferenças interpretativas com Cholley.

Como evidencia Mercier (2008, p. 264), na década de 1930 George é extremamente nacionalista, inspiração que se conjuga ao legado vidaliano. Nesse período seus trabalhos baseiam-se na descrição da paisagem buscando sínteses harmônicas que sirvam para a geografia regional. O foco na beleza paisagística e na busca de uma personalidade para cada região através dos aspectos físicos e culturais aparece com força. Em sua autobiografia, George (1990) ressalta esse período patriótico e Claval (1993, p. 60-79) destaca que a análise do mundo rural através dos estudos regionais dos gêneros de vida exalta os valores conservadores da direita francesa, dentre eles um certo tipo de nacionalismo.

Antes da defesa de sua tese George começa a lecionar em um liceu, em Prytanée de la Flèche, participa do sindicato nacional dos professores e em 1935, nas eleições municipais, faz parte de uma lista da união de ação antifascista. A autoridade militar o afasta do ensino e George ingressa no Comitê de Vigilância Intelectual Antifascista e adere ao Partido Comunista. Além de participar de um congresso sobre liberdade acadêmica em Oxford, George começa a publicar textos sobre geografia econômica no Cahiers du Bolchevisme ${ }^{55}$ (JULLIARD e WINOCK, 1996, p. 532).

Antes mesmo de se envolver com o partido, faz duas viagens à URSS, uma em 1933 e outra em 1936. Futuramente, ele viajaria com Dresch até o Uzbequistão, evento que Ihe proporciona uma visão mais crítica do socialismo, e em 1956 visita o leste europeu, provavelmente com Tricart (CLOUT, 2010, p. 41).

Os vidalianos apresentavam uma grande resistência ao êxodo rural e ao processo de industrialização focando a análise no campo. O governo Vichy apropriase e reproduz a mística da terra pautada em um estadismo agrário que valoriza o espírito francês a partir da exploração familiar da terra. Os camponeses seriam obrigados a competir com outras regiões fora da França, o que justifica a coesão belicista em prol da nação. Cholley e George teriam reproduzido essa visão, mas modernizaram-se rapidamente ao perceber sua real natureza (CHANET, 1993, p. $9-15)$.

55 Os textos de George publicados, todos em 1937, são: "Les richesses naturelles de la France et leur distribuition" ( $\left.n^{\circ} 4-5\right)$, "L'économie agricole de la France" ( $\left.n^{\circ} 6-7\right)$ e "Le transport et commerce en France" (n० 9-10). 
Perto do ano de 1938 George é escolhido para analisar as publicações em línguas eslavas na Bibliografia Geográfica Internacional por indicação de De Martonne (CLOUT, 2010, p. 36). Em pouco tempo ele se especializa na cultura eslava, aprende russo e mesmo antes da guerra já havia reunido uma significativa quantidade de dados e informações sobre a União Soviética e os países do leste europeu (JULLIARD e WINOCK, 1996, p. 532). Apesar de futuramente ele deixar de lado a bibliografia dos dissidentes do socialismo, poucas pessoas dentro do partido tiveram o estofo intelectual que George desenvolveu acerca da União Soviética durante quinze anos de pesquisa direta e duas pequenas viagens de campo (MAUREL, 2008, p. 320). Em 1946 ele integra a Universidade de Lille, tendo como colega Pinchemel e muito provavelmente Max Sorre, situação que pode ter significado o estreitamento de seus laços. Sorre, que havia lutado na Primeira Guerra Mundial, adere ao front populaire e durante o governo Vichy tem sua carreira ameaçada. Em 1948 George vai para Sorbonne (ROCHEFORT, 2008, p. 248).

É preciso ressaltar que a preocupação com a nação francesa era um elemento que mobilizava muito os geógrafos no entre guerras, mesmo que neste período histórico suas pontencialidades para auxiliar a pátria não tenham se desenvolvido plenamente:

(...) o entre guerras e seus problemas econômicos (reconstrução depois da primeira guerra, concentração industrial, crescimento urbano, êxodo rural) e a ocupação são períodos marcantes. As formas de engajamento são então múltiplas tratando-se do urbanismo ou da contribuição ao soerguimento nacional nos anos 1917-1925 e mais tarde na elaboração de um diagnóstico da situação industrial (Cavaillès, Demangeon), de uma reflexão prospectiva sobre o planejamento do território como aquele que desenvolveram P. George, J. Weulersse, P. Coutin e J. Delvert na Delegação geral do equipamento nacional ou J.-F. Gravier na Fundação francesa para o estudo dos problemas humanos e depois no Ministério da reconstrução e do urbanismo; ou ainda a formação dos futuros quadros de Estado na prática do trabalho de campo e na 'descoberta da França' em vista da renovação nacional. A propósito dessas diversas implicações nos eventos, as pesquisas que estavam acontecendo ou para acontecer carregam os esclarecimentos bem-vindos sobre as origens ou as razões das intervenções dos geógrafos fora da esfera acadêmica (TISSIER, 2001, p. $364-365)^{56}$.

Abaixo explicaremos a inserção de George na delegação, entretanto, o excerto acima nos mostra como essa tradição consolida-se antes da ascensão da geração de alunos de Cholley.

56 Tradução nossa. 
Temos uma série de situação dúbias que envolvem o início da carreira de George. Ligado ao nacionalismo e assimilado pela velha guarda vidaliana, o jovem geógrafo tinha atritos com o mestre Cholley e decide não seguir carreira na geografia física. Apesar de ser antifacista e ter sofrido pressões antes da guerra, ele integra comissões do governo Vichy. Essa trajetória tortuosa foi uma exceção comparada a de parte da geografia francesa que rapidamente engajou-se na resistência.

Suret-Canale ${ }^{57}$ (1981, p. 10), geógrafo que acaba desenvolvendo sua carreira na história, luta na resistência contra o nazismo quando explode a Segunda Guerra, e participara da juventude comunista nos tempos de paz. Devido a sua ligação com o marxismo, relata as dificuldades enfrentadas na época, como, por exemplo, o ingresso como professor na Universidade de Rennes, uma vez que Chabot e Le Lannou vetariam candidatos de esquerda. Além dos cargos negados, ele indica as restrições de publicação que também ocorriam devido à sua filiação política. É somente depois de 1968 que o cenário modifica-se e as restrições à esquerda cessam (SURET-CANALE, 1981, p. 9-11). Mesmo com as barreiras institucionais é inegável que a geografia marxista ganha uma desenvoltura precoce no pós-guerra com a presença de professores comprometidos com a luta socialista nas universidades.

O ingresso do grupo no sistema universitário transfere o capital cultural institucional que Cholley já havia acumulado. Em entrevista, Raymond Rochefort confirma que na área de geografia a Sorbonne havia se tornado um bastião de comunistas e todos haviam adotado o marxismo após a resistência contra o nazismo: "nós éramos então comunistas sem aprofundar o marxismo para além de pequenos fascículos de Stálin" (ROCHEFORT, 1981, p. 33) ${ }^{58}$. Essa posição não pode ser generalizada, pois alguns dos pertencentes ao grupo aprofundaram sua leitura para além dos manuais stalinistas.

\footnotetext{
57 Suret-Canale nos fala rapidamente de sua biografia. De maneira sintética: ele vai trabalhar como professor de liceu na África e envolve-se, em 1950, na luta operária em Dakar. Lá conclui sua tese sobre Os camponeses do Senegal. Na França é vetado de participar do CNRS - Centre Nacional de Recherche Scientifique -, pois é secretário federal do partido comunista francês. Em 1958, é chamado para trabalho no governo de Guiné. Em 1963, é convocado pela embaixada francesa ameaçam retirar sua cidadania francesa. Em 1966, consegue ingressar no CNRS com auxílio político de terceiros. Uma vez dentro dessa instituição tem muitas dificuldades para dar prosseguimento aos seus trabalhos e acaba enveredando para a história, abandonando temporariamente a geografia (SURET-CANALE, 1981, p. 9-11).
} 
Como demostra Bataillon, o jornal Combat propagandeava a ideia de transformar a resistência ao nazismo em movimento revolucionário para a tomada do poder. A revolução era uma possibilidade real devido ao prestígio da União Soviética, vencedora do nazismo, e a nova sociedade socialista instigava a imaginação dos planejadores franceses como Pierre George. Parte da propaganda soviética baseia-se nos verdadeiros milagres que o planejamento é capaz de fazer. O seguinte excerto confirma essa ideia:

\begin{abstract}
Os ensinamentos de Pierre George, cujo prestígio é grande, (...) dão uma grande segurança aos seus estudantes para acoplar seus desejos de ação a seus desejos de conhecimento. Ele deseja classificar através de uma tipologia evolutiva bastante simplista, as sociedade 'primitivas' tomadas por suas estruturas coloniais em vias de descolonização, desembocando sem dúvida nas sociedades capitalistas, que seguradamente vão se transformar em sociedades socialistas. Isso significa sociedades racionais, em que a organização é concebida sobretudo como técnica [planejamento] que vai garantir o progresso social (BATAILLON, 2006, p. 8) $)^{59}$.
\end{abstract}

Do grupo de George, apenas Michel Rochefort e Lacoste não lutaram na resistência, pois eram muito jovens. Lacoste vivia no Marrocos, seu pai era geólogo e trabalhava neste país. Em 1940, começa a militar no partido comunista argelino. Kayser chega até a lutar na guerra, mas é afastado em 1944 após contrair uma grave pneumonia (BATAILLON, 2006, p. 2-5).

Jean Dresch, antes da guerra, no período em que trabalhava no liceu no Marrocos, envolve-se com o grupo de esquerda Jovens Marroquinos e publica um artigo sobre os problemas econômicos e sociais desse país na revista L'Espoir, ligada diretamente ao partido comunista do Marrocos. Durante a guerra, ele combateu na França como oficial dos atiradores marroquinos e retorna ao Marrocos em 1940, mas é expulso pelo general Noguès em 1941 por motivos políticos (JULLIARD e WINOCK, 1996, p. 370). Marcado, Dresch não consegue incorporar-se na universidade e engaja-se na resistência da região parisiense, tornando-se membro do Estado Maior de Rol-Tanguy. No final dos conflitos, em 1945, ele participa com Michel Leivis de uma missão que deveria avaliar o trabalho forçado na Costa do Marfim, o que ajuda a criar uma lei contra este tipo de atividade. Após essas ações, Dresch trabalha por um curto período na Universidade de Estrasburgo até ingressar na Sorbonne (JULLIARD e WINOCK, 1996, p. 370-371).

59 Tradução nossa. 
Fora do grupo, até mesmo Pierre Gourou, que anos mais tarde seria taxado de imperialista por promover a geografia tropical, organizou a resistência ao nazismo em Bordeaux. Ele foi militante do front populaire e antes da guerra participou de uma comissão responsável pela renovação do sistema colonial francês ao lado de intelectuais de esquerda (BOUQUET, 2008, p. 193).

Daniel Foucher torna-se um militante antifascista em um primeiro momento e engaja-se na resistência contra a ocupação a partir de 1940. Meynier, pouco ligado à esquerda, é preso pela Gestapo em 1944 (BROC, 1993, p. 250) ${ }^{60}$. A experiência da guerra conjuntamente à má impressão da obra ratzeliana, decorrente da controvérsia promovida por Lucien Febvre, acabam associando trabalhos de geopolítica e de geografia política à direita (CLAVAL, 2011, p. 258). Para Claval, esse é um dos motivos da marginalização de Jean Gottmann na geografia francesa.

Entretanto, por ser judeu, Gottmann era o único acima de qualquer suspeita capaz de escrever sobre geografia política. Tendo sofrido ao máximo os efeitos da ocupação, ele poderia pensar os temas da política já que nunca se aliaria aos nazistas ${ }^{61}$. A situação de Gottmann torna-se tão insustentável que ele acaba se exilando e no exterior, onde encontra um ambiente propício para continuação de seu projeto intelectual.

Se vários geógrafos engajaram-se militarmente contra o regime, nas revistas de geografia o que encontramos são textos contra o regime de ocupação abordando a demografia dos prisioneiros, relatos dos campos de trabalho e até a denúncia da censura. Daniel Foucher62 burla a censura e aos poucos inclui no conteúdo das publicações discussões sobre aspectos urbanos e culturais na geografia (BEAUGUITTE, 2010, p.12-11). Mesmo com a luta no front de batalha a atividade acadêmica no campo das ideias continua:

A escolha de referências por alguns autores também surpreende. Numa
época antibolchevista, um artigo sobre a agricultura soviética cita Marx,
Engels e Lênin [em um texto de Péchoux publicado em 1941]. Enquanto a
repressão antissemita aumenta as referências às obras de Marc Bloch e às
de Jacques Ancel tornaram-se mais sistemáticas e mais detalhadas do que
antes da guerra. Infelizmente, isto não impede que os escritores judeus

60 Até mesmo Brunhes, antes de sua morte em 1930, tem um engajamento político junto à militância católica social.

61 O regime Vichy obrigou De Martonne a tirar os créditos de um mapa que Gottmann fez sobre a aridez no mundo.

62 Após a guerra, Foucher será o reorganizador da faculdade de letras em Toulouse (GRAS, 1975, p. 174) 
sejam eliminados do sumário de revistas a partir de 1942 (BEAUGUITTE, 2010, p. 11).

Bloch influencia bastante a geografia agrária através de seus estudos sobre o feudalismo e sua concepção de estrutura agrária - como, por exemplo, na obra de Daniel Foucher (BATAILLON, 1981, p. 133). Segundo Claval (1998, p. 188), a estrutura agrária de Bloch permitiu aos geógrafos ir além da ideia de hábitat e paisagem, ultrapassando a descrição da aparência dos fenômenos e chegando a uma análise do mundo rural totalizante.

Após a guerra, o próprio Gottmann ao fazer um balanço da geografia francesa, indica que o período de 1940-1945 foi uma época fortuita para o surgimento de novos periódicos em geografia, com o Instituto de Geografia em Paris sob direção de A. Cholley (GOTTMANN, 1946, p. 87).

Cholley participou da formação de vários alunos e apesar de ter escrito um guia do estudo e ter feito importantes reflexões epistemológicas sobre a ideia de combinações em geografia, seu ramo prioritário de pesquisa é a geomorfologia. Curiosamente, boa parte de seus alunos atuarão no planejamento territorial e na geografia urbana, como é o caso de Tricart, Beaujeu-Garnier, Pinchemel, André Journaux e Pierre George (BATAILLON, 2009, p. 27-28).

A presença de Cholley e seu modo integrado de pensar o espaço geográfico através da combinação de elementos físicos, naturais e humanos de ritmos discrepantes não foi elemento menor no nascimento de uma geografia pragmática, ativa, com apreço pelo trabalho de campo, que se ramifica em diversas concepções no decorrer do século ${ }^{63}$. Devido a ideia de combinações geográficas, muitos autores atribuem a Cholley a formação de um método mais sistemático para a geografia:

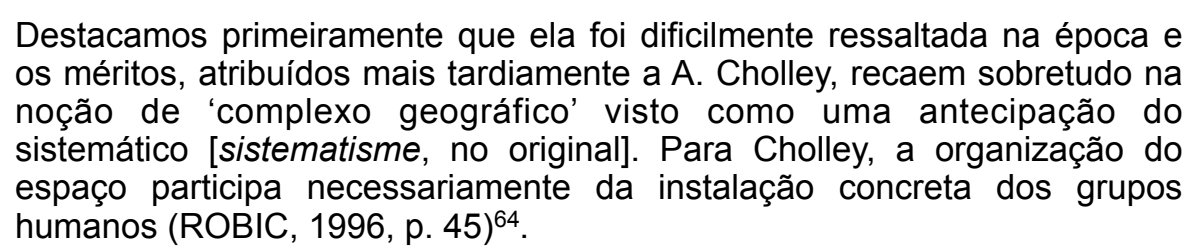

Ou ainda:

\footnotetext{
63 Para mais detalhes sobre as teorias de Cholley, seu contexto histórico, econômico e social ver Mamigonian (2003).

64 Tradução nossa.
} 
O sucesso da ideia de estrutura e da de sistema tem em parte uma influência profunda advinda sobretudo da geração que tentou então renovar a geografia, d'O Guia do estudante de André Cholley: passa-se facilmente do estudo das 'combinações' (este é o conceito que ele utiliza nessa obra) para as estruturas ou os sistemas (CLAVAL, 1998, p. 335) ${ }^{65}$.

A tradição do pensamento de Saint-Simon influencia Cholley no que diz respeito à necessidade de organização, aproximando-o do pensamento planificador da década de 1930 (ROBIC, 1996, p. 44-45). A raíz saint-simoniana de Cholley vincula o planejamento à racionalidade.

\title{
2.3 As propostas da geografia de esquerda
}

Paralelamente a isso, Santos (1982a, p. 131) mostra que em 1943 Jean Dresch oferece um programa para a construção da geografia marxista:

\begin{abstract}
Santos (...) relembra geógrafos que falavam inglês e faziam trabalhos inspirados no marxismo, como Jean Dresch, sobre o fluxo de capitais na África, e Jean Tricart analisando o conflito de classe e a ecologia humana, ambos vindos da Segunda Guerra, e o discurso presidencial de Keith Buchanan na Sociedade Neo-Zeolandesa de Geografia, em que há necessidade do estudo 'da absoluta primazia do Estado; especialmente no mundo não-ocidental (JOHNSTON, 1997, p. 322) ${ }^{66}$.
\end{abstract}

Dresch é herdeiro do legado de De Martonne e Demangeon por intermédio de Cholley e defende sua tese em 1941. Um dos pioneiros na geografia das excolônias $^{67}$, após a Segunda Guerra ele estuda a África negra, abordando o cultivo predatório destinado à exportação e a cidade colonial com sua economia e administração moderna, mas que desorganiza a agricultura tradicional (BATAILLON, 2009, p. 116-117). Sua ênfase no imperialismo e nas relações entre metrópole e colônia sob um viés geográfico é inovadora. Sua postura diante do fato colonial será sempre intransigente: independência e autonomia para as colônias, uma posição que não era predominante no partido comunista francês.

\footnotetext{
65 Tradução nossa.

66 Tradução nossa.

67 Contemporaneamente a Dresch, Bataillon (2009, p. 26) elenca na mesma geração André Meynier, Louis Papy, Pierre Monbeig e Pierre Birot. Monbeig era inclusive aluno de Demangeon e estava ligado a um grupo de alunos da École Normale Supérieure de origem sociais distintas que acabam militando na esquerda (BATAILLON, 1981, p. 149).
} 
Em uma coletânea de textos sobre as ex-colônias francesas, Dresch (1979, 8-9) destaca que na geografia da década de 1940 existia pouco interesse pelos países do império francês ou pela explicação de fenômenos sociais de grande repercussão como a ascensão do fascismo ou o crash da bolsa de 1929. O quadro só mudaria entre 1952 e 1964 com movimentos de descolonização por todo o mundo.

O objetivo maior de sua obra é estudar a geografia física dos lugares, mas Dresch depara-se com um povoamento de longa história e ao envolver-se no estudo regional procura compreendê-la desafiando o sentido clássico da especialização e separação da geografia, postura que mantém até o final de sua carreira (DRESCH, 1979, p. 10).

Dresch é nomeado na Sorbonne para substituir Augustin Bernard, professor que se dedicou amplamente ao estudo e a colonização da Argélia e do Norte da África. Bernard é completamente favorável à dominação modernizadora contra a estagnação da sociedade oriental (DEPREST, 2009, p. 263-264). Segundo Deprest (2009, p. 263), a nomeação de Dresch é uma sensibilização ao anticolonialismo do pós-guerra e vai ao encontro do processo de dissolução do império francês. No entanto, não podemos deixar de pensar que o partido comunista tem algum peso nessa equação. Ao assumir a vaga, Dresch não causa ruptura profunda e aproveita os estudos de Bernard para enriquecer e dar o tom desejado às suas pesquisas ${ }^{68}$.

Cabe aqui fazer um esclarecimento entre a relação de Dresch e a questão colonial dentro do partido comunista francês. Como vimos, houve na França uma rápida migração entre os esquerdistas alinhados com as ideias da Segunda Internacional para a Terceira. A questão colonial sempre foi motivo de orgulho nacional na sociedade francesa, porém a Terceira Internacional teve um apelo anticolonialista favorável à construção do socialismo em países não inteiramente desenvolvidos do ponto de vista capitalista. $O$ antifascismo e o antirracismo eram outros elementos de esquerda que se ligam diretamente com a questão colonial (LIAUZU, 2010, p. 338-339). Contudo, na França os socialistas na década de 1920 se manifestam a favor da assimilação e da formação de um autogoverno republicano que manteria o laço colonial. Esse projeto ganharia força anos depois entre os

\footnotetext{
68 Bernard, que tinha atritos com Vidal e seus discípulos, teve que lutar durante um tempo significativo para fundar uma cadeira de geografia em Paris sobre seus temas de interesse (DEPREST, 2009, p. 275-281).
} 
partidários da esquerda, tal como no posicionamento de Merleau-Ponty sobre a situação da Argélia (LIAUZU, 2010, p. 232-233).

O drama da Segunda Guerra na Europa fez com que os comunistas dessem pouca atenção às colônias, uma vez que o inimigo nazista era a prioridade. Assim, no fim do conflito os países europeus têm dificuldade de reconhecer a cidadania dos povos coloniais (LIAUZU, 2010, p. 363).

A tendência do partido comunista era manter-se neutro, ou ainda, mais preocupado com as questões internas da França até que a guerra da Argélia obriga uma tomada de posição (LIAUZU, 2010). O partido apoia o início da guerra, o que causa o abandono de alguns militantes, e transita para uma posição contra a dissolução do império francês a favor da igualdade entre colônia e metrópole, reflexo da falta de debate e da lentidão na deliberação sobre a independência da Indochina alguns anos antes. A independência total, na conjuntura da guerra fria, era vista como uma aliança ao imperialismo inglês ou norte-americano concomitante ao retorno do poder das elites locais frequentemente retrógradas politicamente (LIAUZU, 2010, p. 380-381).

Uma exceção nos seus quadros era Dresch, que sempre defendeu a independência e o fim dos laços coloniais. Sendo assim, Dresch e sua pauta não eram a regra dentro do partido comunista e mesmo não se alinhando com a corrente dominante, parece que devido a seu prestígio acadêmico e a seriedade de sua militância não sofreu grandes represálias ${ }^{69}$. Entretanto, a aproximação entre a geografia, o marxismo e os estudos coloniais não se dava sem dificuldades. Jean Chabot $^{70}$ :

(...) aluno de Dresch, membro como ele do partido comunista francês, anticolonialista engajado, igualmente participante da União racionalista (o que ele poderia pensar das religiões animistas?), esse geógrafo fez do Chade seu terreno de estudos e não podia apegar-se à dúvida quanto deveria colocar em harmonia suas convicções políticas (ou filosóficas, ou éticas) e suas observações (BOUQUET, 2008, p. 195).

\footnotetext{
69 Marcel Prenant, que tinha um filho geógrafo e trabalhava com biologia, publica obras sobre raça, meio ambiente e mestiçagem na época da fundação do Museu do Homem em Paris, fruto da política do front populaire. A obra de Prenant buscava desmistificar a ideia de raça demonstrando seu caráter não-científico. O paralelismo entre Dresch e Prenant pode revelar mais do que um projeto intelectual com muitas afinidades. Entretanto, as pistas que levantamos até agora não permitem nenhuma conclusão taxativa além do contato entre ambos (LIAUZU, 2010, p. 338-339).
}

70 Não confundir com o geógrafo Georges Chabot, mencionado apenas como Chabot neste trabalho. 
A proposta de Dresch consistia em analisar os fatores técnicos e econômicos para compreender as transformações do mundo, atentando para a não separação entre geografia humana e econômica. Existe em sua obra uma aversão à especialização exacerbada e o elogio à geografia como ciência de síntese. Apesar de admitir que os métodos da geografia física ainda estão em formação, seria através da geografia regional que a geografia física e humana se tornariam inseparáveis (DRESCH, 1980, p. 24-25).

Para o geógrafo, seria importante ter uma boa cultura geral sem que se caísse em um "academicismo burguês" (DRESCH, 1980, p. 9-10) e sempre seria necessário levar em conta que a geografia nasceu do triunfo da classe burguesa. Além de ser responsável pelas expedições comerciais, Dresch aponta a geografia como elemento importante da formação da consciência nacional.

Mesmo que Pierre George e Jean Dresch sejam contemporâneos e ambos militantes do partido comunista, possuem uma concepção de método diferente: enquanto George recupera a ideia de espaço geográfico presente na obra de Max Sorre, Dresch, em 1948, encara a geografia como "uma ciência, ainda que tome emprestado seus métodos de outras ciências, nas quais busca apoio" (DRESCH, 198071, p. 13). Essa mesma posição será reproduzida por Pierre George em 1972 (p. 7-14), no seu livro Os métodos da geografia. Dresch indica essa relação porque é impossível realizar uma geografia temática ou tópica sem dialogar com as outras disciplinas. Esse debate tem ampla projeção, pois a postura do geógrafo deveria ser de coordenador dos grupos interdisciplinares (DRESCH, 1980, p. 26).

Alguns anos mais tarde, George admite a geografia como uma "ciência que mobiliza o conhecimento dos métodos e dos resultados de um bom número de ciências associadas" (GEORGE, 1972, p. 7) ou ainda que a "unidade não pode ser metodológica de cada uma das ciências de que se vale para chegar ao conhecimento analítico dos dados incluídos nas combinações que constituem o objeto de seus estudos fragmentários ou globais" (GEORGE, 1972, p. 9). Talvez essas formulações sejam a maneira como George e Dresch tenham encarado a concepção da não divisão intelectual da pesquisa tão presente no marxismo. Como vemos, é possível identificar a influência de Cholley em tal perspectiva combinatória.

71 Como indicado nas referências bibliográficas, esse texto é originalmente publicado em 1948 na revista La Pensée e traduzido pela Associação de Geógrafos Brasileiros de São Paulo em 1980. Curiosamente, depois desse texto de 1948, Dresch publica outros trabalhos sobre a crise da geografia que ainda não conhecem tradução para o português. Nessa sucessão de artigos verifica-se que seu projeto de geografia sofre poucas alterações. 
Cabe lembrar que a questão do método na geografia humana era, na época, de extrema importância. Um dos argumentos para o fechamento do curso de geografia em Harvard sustentava que a geografia humana era essencialmente descritiva e não científica. Agrega-se a esse contexto a possibilidade de atividades comunistas pela geografia, além das disputas de financiamento científico do New Deal que privilegiavam as ciências naturais (SMITH, 1987, p. 165-168) ${ }^{72}$.

Dresch (1980, p. 12-15) ainda destaca o papel da geografia social como sendo responsável por colocar em debate a questão do socialismo e da União Soviética no pós-guerra. Nesse sentido, a obra de Pierre George foi fundante e está embebida na ideologia marxista-soviética. Hoje a visão mais comum dentro do campo é perceber a geografia social como um subcampo menor dentro da geografia humana, mas o projeto de George almejava uma equivalência entre ambas (CLOUT, 2010, p. 42) ${ }^{73}$. Apesar do reconhecimento do pioneirismo de George, Dresch critica seu colega e indaga:

\begin{abstract}
A Geografia Social não seria mais que a geografia tradicional dos gêneros de vida, isolados da estrutura econômica da sociedade capitalista, que desse modo permite a manutenção das formas tradicionais de economia e sociedade, espaços em movimentação que provocam o nascimento de formas novas de economia no capitalismo, e por vezes, a retomada de novas estruturas que não são simples 'experiências'? Como compreender as formas de produção e as relações de produção, as estruturas sociais ditas tradicionais e suas transformações, fazendo abstração das condições modernas de produção e troca? (DRESCH, 1980, p. 22).
\end{abstract}

$\mathrm{Na}$ passagem acima é possível notar que a ideia de estrutura tem uma importância significativa para a nascente geografia marxista, conservando o sentido organizacional, funcional e morfológico que ressaltamos acima. Um outro aspecto da crítica de Dresch é que George não teria se emancipado do pensamento vidaliano, criando um sistema classificatório ligado precariamente à ideia de modo de produção. Ou seja, George permanece apenas na aparência do fenômeno sem compreender os processos de modernização que modificam a conjuntura.

\footnotetext{
72 Smith (1987, p. 168-169) ainda aponta outros motivos para decadência da geografia: a maior parte do movimento de colonização interna dos Estados Unidos e de suas áreas de influência na América já haviam se consolidado suficientemente; não existe mais expansão das fronteiras naturais; o determinismo geográfico estava desacreditado e a geografia era considerada um campo do conhecimento muito amplo.

73 É importante destacar que para E. Reclus a geografia social tinha a mesma conotação. Isso pode evidenciar que provavelmente P. George, J. Tricart e J. Dresch foram leitores de Reclus.
} 
Não é só o pensamento vidaliano que é alvo de Dresch. E. Reclus não escapa das críticas pois é associado à geografia descritiva e ao uso excessivo de técnicas matemáticas. Existe em seu pensamento uma forte relação com às origens históricas dos processos sociais discordante da visão estática e formalista oferecida pela estatística:

\begin{abstract}
As cifras, as casas, a cidade, procedem de noções abstratas, mais ou menos isoladas da estrutura econômica, das técnicas de produção de troca, das relações sociais. Faz-se a distinção mesmo em geografia política, como se o Estado e as fronteiras não passassem de construções abstratas da imagem do homem cidadão, que a ideologia burguesa distingue do homem-privado como se a vida dos grupos humanos não passasse de elementos indissociáveis (DRESCH, 1980, p. 16-17).
\end{abstract}

Retomando a questão da geografia social para George, o estudo da economia política teve um papel relevante na segunda geração de geógrafos vidalianos e George a utiliza como apoio para expressar o pensamento marxista de maneira um pouco mais explícita ${ }^{74}$. Ao lermos Géographie économique \& sociale de la France (GEORGE, 1946) encontramos um tratado de geografia da França, reeditado um ano após o final da Segunda Guerra Mundial ${ }^{75}$, em uma primeira fase do pensamento de George antes da promoção da geografia ativa. Ao analisarmos essa obra indicamos que talvez ela seja uma transição entre a geografia regional, nos moldes "tradicionais" franceses, para uma geografia renovada. Apesar da inovação, como ressaltou Dresch, ela ainda guarda muitas características vidalianas.

Uma característica que denota a transição em Géographie é o uso da escala regional para a construção de um projeto social de desenvolvimento das forças produtivas face à formação histórica da sociedade francesa. Como de hábito, George parte do quadro natural francês - clima, relevo, etc. -, esboçando uma espécie de inventário dos recursos naturais e suas possibilidades de uso. Isso indica a possibilidade de crescimento e estrangulamento econômico de acordo com as reversas naturais (GEORGE, 1946, p. 13-16).

\footnotetext{
74 Lembrando que outros geógrafos, como Demangeon, Jean Brunhes, Max Sorre, ou seja, aqueles da segunda geração da escola vidaliana, faziam debates sobre economia política. O mesmo ocorre com autores dessa tradição nas gerações precedentes, como Pierre Monbeig. Demangeon inclusive chega a fazer algumas resenhas criticando o trabalho de George, do ponto de vista da econômica política (PAILHÉ, 1981).

75 Essa obra é publicada conjuntamente a outras que têm preocupações ou que giram em torno da problemática da URSS na Europa: Économie de l'URSS (1945) e Géographie Sociale du Monde (1946), obras que foram revisadas várias vezes. A primeira edição do Géographie économique \& sociale, de menor circulação, é de 1938.
} 
Após esse breve inventário, George parte para uma rápida análise demográfica e em seguida analisa o campo francês. Como dissemos, o recorte é eminentemente regional, entretanto as preocupações do autor gravitam em torno das condições de trabalho, dos modos de se produzir, da propriedade da terra, das relações de trabalho no campo, dos sindicatos e cooperativas, do distanciamento entre cidade e campo, da produção nacional de diversos gêneros, e finalmente das relações comerciais internacionais e o balanço de importações da França.

O crédito rural também é analisado com especial atenção, pois George não ignora a tradição rural dos pequenos produtores, uma importante força política apesar da industrialização. Grande parte das variáveis tratadas na obra são analisadas através de estatísticas ou dados quantitativos sempre, visando a síntese e almejando a independência da produção nacional com a diminuição das desigualdades internas. Curiosamente, a parte do livro dedicado ao mundo rural é muito mais extensa que a das indústrias, provavelmente devido a ampla tradição de estudos rurais da geografia francesa do início do século $\mathrm{XX}$.

No tocante às indústrias (GEORGE, 1946, p. 135-186), temos novamente a preocupação com as condições de trabalho, a produção nacional, em elencar quais são as indústrias modernas e as prioridades na reconstrução pós-guerra. Ressaltase ainda a presença de indústrias artesanais regionais e indica-se um bolsão de concentração industrial no Leste da França. Finalmente, a conclusão do livro analisa as infra-estruturas francesas, o problema do isolamento de algumas regiões, as principais rotas de circulação e destaca o estabelecimento de portos e a sua importância para o comércio internacional.

O livro segue internamente uma lógica que pode ser identificada em outras obras de George, principalmente no início da carreira: "A maioria dessas obras se dividem em duas partes respectivamente sobre as condições de desenvolvimento e as forças produtivas, e em seguida, sobre os sistemas econômicos e sociais" (DESHAIES, 2008, p. 304).

Próximo da data de reedição da Géographie, podemos verificar um dos ápices da radicalidade de George marcado por um breve momento explicitamente stalinista, bem como o fluxo representativo de suas obras sobre a União Soviética.

Em 1945 é publicado um curso de economia política organizado por George. Os tópicos abordados no curso revelam um teor materialista explícito: "a economia como motor da história, a economia antes do nascimento do capitalismo, as origens do capitalismo na França" (GEORGE, 1945, p. 2). Na melhor moda do stalinismo, o 
projeto apresentado no curso demonstra a importância de descobrir leis através do estudo histórico para compreender o movimento da sociedade. Segundo seu projeto, a análise dos elementos econômicos resultaria no conhecimento científico político verdadeiramente democrático e livre de mistificações (GEORGE, 1945, p. 4-5).

O manuscrito não revela as circunstâncias em que o curso foi concebido, todavia nesse momento George defende o pacto Ribbentrop-Molotov, trata da revolução russa e seu sucesso em unir operários e camponeses através do motor econômico da sociedade visando à emancipação comum. Porém, a revolução realizada historicamente e feita pelo povo demonstra "que a história não é um mecanismo cego submisso a um movimento de relógio insensível à ação humana: o motor econômico" (GEORGE, 1945, p. 8) ${ }^{76}$. Ou seja, somente a revolução socialista liberta o homem do mecaniscismo desumano do capitalismo, o que revela uma faceta humanista de sua interpretação marxista.

$\mathrm{Na}$ exposição de todo o curso, as citações de Engels são mais recorrentes que as de Marx. Curiosamente, seu trabalho sobre geografia regional do Baixo Ródano serve de argumento histórico para demonstrar como se inicia a formação dos capitais franceses. George demonstra como ao redor de Lyon, ainda no século XVII, forma-se uma burguesia surgida do artesanato e das pequenas oficinas. Ao mesmo tempo em que traça as origens, George ressalta os primeiros processos de concentração e a extração da mais-valia (GEORGE, 1945, p. 23).

Apesar de George ter se envolvido profundamente com o partido comunista, não é possível compreender a ascensão de sua carreira e o percurso de sua obra antes de 1956 sem ter em mente a curiosidade e o interesse pelo sistema soviético. Obviamente, o partido comunista francês sai vitorioso no pós-guerra, pois foi um articulador importante da resistência. Na sequência do término da guerra, isso confere um lastro institucional razoável ${ }^{77}$. Dessa maneira:

A curiosidade francesa a respeito do sistema soviético procede de motivações diversas. Ela se inscreve primeiramente na problemática da mudança social e da modernização que caracteriza o debate das ciências sociais e políticas do pós-guerra. É nessa perspectiva que a $6^{\circ}$ seção da Escola Prática de Altos Estudos e o Instituto de Estudos Políticos [este último recebe George como professor de geografia econômica], duas novas escolas em 1945, oferecem alguns lugares aos pesquisadores e aos

\footnotetext{
76 Tradução nossa.

$77 \mathrm{Na}$ França, existem rumores de que o próprio partido teria negociado as vagas dos comunistas dentro das universidades. A incorporação de Dresch e George se encaixariam nessa negociação de áreas do conhecimento esquerdizadas.
} 
professores sobre a União Soviética, assim como os administradores modernistas tais como o Instituto Nacional de Estudos Demográficos ou a Documentação Francesa consagram uma parte de seu trabalho a eles. A União Soviética torna-se um objeto de análise que interessa não apenas por si só, mas por aquilo que pode se tornar o futuro da sociedade francesa, da democracia, da paz e do comunismo. (...). A União Soviética funciona como um modelo e depois um contramodelo, num contexto geral marcado por uma forte presença do PCF na vida política e intelectual francesa, e pelo ativismo de uma pequena minoria de 'dissidentes' cujas fileiras aumentam sobretudo após 1956 (DULLIN, 2000, p. 48) ${ }^{78}$.

Logo após o curso, George publica em 1945 L'economie de I'URSS na coleção Que sais-je?, e em 1947 o livro L'Urss, que confirma o contexto delimitado acima. Podemos perceber ainda outras áreas do conhecimento, como a demografia, cuja atuação de George será significativa, ligadas à compreensão do sistema soviético. Destacamos ainda o uso do termo "sistema social" que pressupõe um funcionamento coerente, delimitado e apresentado na forma de modelo. Dullin (2000, p. 50) demonstra que o movimento histórico do grupo de estudiosos da União Soviética foi de construir um modelo de sociedade no socialismo real, para desconstrui-lo a partir das denúncias dos abusos do poder em meados da década de 1950, para finalmente reconstruir tudo e atingir uma compreensão mais sofisticada do todo. O par sistema e estrutura, ambos modelares, pode ter impulsionado ainda mais mudanças na geografia por meio da obra dos geógrafos de esquerda.

O próximo passo após compreender o sistema soviético seria compará-lo a outros sistemas observando o papel da economia, do Estado e dos partidos políticos. Assim o terceiro mundo também é analisado sobre o auspício dessa orientação, bem como os países capitalistas. O resultado final é a regionalização clássica entre Oeste-Leste que reflete a divisão do globo na guerra fria (DULLIN, 2000 , p. 50). Como veremos, o grupo de George também estuda o terceiro mundo, e após a publicação das obras sobre a União Soviética, em 1946, ele lança L'economie des États-Unis o que demonstra o uso da perspectiva comparativista. Sauvy também fazia parte desse movimento maior da academia francesa e buscava comparar a economia liberal e a socialista (DULLIN, 2000, p. 50). Mais adiante veremos que seu relacionamento com George tem consequências importantes.

Pouco tempo após o fim do conflito mundial, em 1948 e 1949 respectivamente, Dresch e George tornam-se professores da Sorbonne, e Tricart em Estrasburgo, como ressaltamos. No início dos anos 1950 eles já possuíam um lastro 
institucional significativo. George, por exemplo, leciona simultaneamente na universidade particular Sciences-Po, o que permite reunir estudantes para pesquisar as mudanças econômicas, demográficas e sociais da França no pós-guerra (JULLIARD e WINOCK, 1996, p. 370 e 532). Para Suret-Canale (1981, p. 12), a geografia era um campo de estudos que se organizou diferentemente e aceitou os marxistas, um caso de exceção do que corriqueiramente acontecia na universidade, que tendia sempre a deixar os comunistas de fora. Segundo Claval:

\begin{abstract}
No final dos anos 1940 e no começo dos anos 1950, o Instituto de geografia conta com uma forte proporção de estudantes partidários das ideias de esquerda. Eles tinham a oportunidade de acompanhar seus mestres depois das reuniões de célula. Uma certa familiaridade e uma cumplicidade se instalam entre uns e outros. No grupo de geógrafos comunistas, a composição varia com as chegadas e as partidas anuais de toda instituição que vive na unissonância da universidade. Elenca-se Bernard Kayser, Raymond Guglielmo, Yves Lacoste, François DurandDastès, Raymond Dugrand, etc. Jean Tricart era associado antes de sua nomeação como mestre de conferências na Universidade de Estrasburgo. O marxismo afirma-se como um movimento filosófico. Aqueles que aderem tentam completar as orientações epistemológicas (CLAVAL, 1998, p. $281)^{79}$.
\end{abstract}

Nos anos de 1947-1948, Yves Lacoste conhece Bernard Kayser no Instituto de Geografia, em Paris, logo após a guerra. Lacoste, que era nascido no Marrocos, relata que:

Todo o nosso pequeno grupo era membro do Partido Comunista. Naquela época, quando chegávamos à Sorbonne, se éramos progressistas, pelo menos em geografia não podíamos ser outra coisa senão comunistas (ZANOTELLI, 2005, p. 41, grifos nossos).

E Kayser complementa:

79 Tradução nossa. 
Nós éramos unidos em torno de dois professores com os quais não tínhamos nenhuma discussão, eram Pierre George e Jean Dresch. Pierre George, que hoje é membro do Instituto, era verdadeiramente nosso mestre, na medida em que seguíamos seus cursos, seus ensinamentos e estávamos completamente subjugados pela clareza de seu pensamento, por sua pedagogia, por sua ciência também. Dessa forma, nós éramos fundamentalmente alunos de Pierre George, geógrafo marxista, embora ele diga que nunca foi marxista. Porém, antes da guerra, ele publicou nas Edições Sociais, uma editora comunista, um certo número de livros. Esses livros representavam o início de uma geografia de esquerda, se não queremos dizer marxista. Pierre George era verdadeiramente nosso mestre e Lacoste era muito próximo a ele, inclusive através da família. $E$ havia também Jean Dresch, com quem o diálogo era mais fácil, mas um diálogo que dizia respeito mais à situação política imediata do que aos problemas doutrinários. De fato, nós estávamos mais próximos de George do ponto de vista intelectual. Mas eles eram incontestavelmente nossos mestres, nossos dois mestres. Não posso dizer que discutíamos muito com ele sobre a forma de como seríamos orientados, sobre nossa vocação ou sobre o que era a geografia. Nós discutíamos muito entre nós, em particular sobre o que poderia ser uma geografia marxista, uma geografia progressista e sobre nossa atitude diante dos países de planificação, os países do Leste europeu, etc. Nós éramos um pouco os que refletiam sobre a disciplina (ZANOTELLI, 2005, p. 42, grifos nossos).

Bataillon (2006, p. 6-7) coloca que Dresch era orientador de Lacoste e André Prenant. Enquanto George se responsabilizava pelas teses de Dugrand, Guglielmo, Kayser e Rochefort, sendo que mais tarde ele também viria a ser orientador de Lacoste. Esses eram os principais geógrafos na segunda geração influenciada pelo partido comunista.

Todos eles vieram de famílias de esquerda, com exceção de Dugrand, e a fonte de renda familiar vinha do sistema de ensino superior, de liceus, ou de profissões liberais. O próprio Jean Dresch era filho de um reitor universitário (JULLIARD e WINOCK, 1996, p. 370). Tais origens conferiram-Ihes capital cultural, ou seja, a possibilidade de conhecer melhor a geografia através de viagens na infância - isso é frequentemente dito nas entrevistas analisadas por Bataillon (2006, p. 6-10) - além de uma maior acessibilidade ao mundo acadêmico, seja do ponto de vista institucional, suas regras, mecanismos internos, hábitos sociais ou simplesmente facilidade ao acesso do conhecimento científico.

É importante ressaltar que a maioria das teses de estado defendidas eram sobre geografia física, englobando muitas vezes o prestigiado subcampo da geomorfologia, deixado como herança por De Martonne ${ }^{80}$. Bataillon (2009, p. 52-54) comenta que no diploma de estudos superiores (DES - Diplome d'Études Superières) a maioria dos estudantes ainda escolhia temas ligados à geografia física

80 Lacoste, por exemplo, gostaria de estudar a geomorfologia da Argélia, mas a guerra de independência malogra seus planos (ZATONELLI, 2005 e BATAILLON, 2006). Dugrand, após desenvolver os trabalhos da geografia marxista, trabalha como conselheiro em órgãos estatais e acaba no final da carreira dedicando-se à biogeografia. 
devido ao renome e ao rigor científico. É justamente Pierre George quem vai, lentamente, conferir respeitabilidade à geografia humana, acompanhado de Dresch e Tricart pois são responsáveis pela:

\begin{abstract}
(...) formatação, na França, de uma geografia humana que serve de ferramenta principal de descrição e de análise das sociedades concretas depois da segunda guerra mundial, antes que os sociólogos se mutipliquem (...). Essa análise das sociedades contemporâneas está ancorada, no seu início, no marxismo esquematizado de Pierre George mais preocupado com as etapas de desenvolvimento das forças produtivas segundo a evolução tecnológica que com os conflitos internos no seio da sociedade. Todo esse grupo participou de lutas sociais em que cada um apresentava-se como geógrafo, o que trouxe inovações na disciplina, mas permanece a matriz da geografia francesa tal qual estava formada nos anos 1930 (BATAILLON, 2009, p.28).
\end{abstract}

Para Deshaies (2008, p. 310), Pierre George é um dos primeiros geógrafos a afirmar a geografia humana como ciência social, rompendo com a visão naturalista do gênero de vida e colocando ênfase na estrutura sócioeconômica. Independentemente do prestígio da geomorfologia, Claval, de uma forma provocativa, indica que a filiação à geografia física era menos arriscada politicamente:

(...) os jovens geógrafos inscritos no partido comunista estão muito conscientes do risco que correm ao orientarem-se para a geografia humana: o perigo de verem-se acusados de desvios ideológicos é muito superior do que se incorre que se fala das formas de relevo ou das formações vegetais. François Durand-Dastès diz claramente: é esta ameaça que o leva a estudar o clima da Índia em vez das realidades sociais, econômicas e culturais do subcontinente (CLAVAL, 2011, p. 259-260).

Mas Claval não deixa claro se a opressão era cometida pelo partido comunista ou pelos grupos militantes na universidade. George e Dresch fizeram opções contrárias às orientações do partido e aparentemente não sofreram nenhuma retaliação grave em função disso. O fato é que, como veremos adiante, Claval vê a união entre geografia e marxismo como um retrocesso. A leitura de Claval tem sentido no caso de Durand-Dastès e assemelha-se ao que houve na geografia soviética durante o período stalinista. No entanto, veremos que muitos geógrafos continuam pesquisando sobre geografia humana mesmo desvinculados do partido comunista. Para Claval, o principal problema não é o marxismo enquanto método, mas a sua força ideológica e doutrinária capaz de "deformar" o conhecimento. 
Ainda nos anos subsequentes ao término da guerra, o grupo de geógrafos marxistas organiza uma série de excursões de trem e carro para o oeste da França onde frequentemente encontravam André Cholley no local de estudos. A primeira excursão acontece, em 1946, na Alsácia reconquistada, com um grupo predominantemente comunista mas com a inusitada presença de alguns católicos de direita (BATAILLON, 2006, p. 8-10).

A presença de George polarizava a militância de jovens geógrafos em Paris. Entretanto, longe da capital, Roger Brunet ingressa na Universidade de Toulouse e entre 1948-1951 participa da direção dos estudantes comunistas em um ambiente instigado pelo antirracismo e o anticolonialismo. Ao aprofundar sua militância marxista, ele entra precocemente em contato com a obra de Henri Lefèbvre (BATAILLON, 2009, p. 45).

Brunet, vindo de uma família de funcionários públicos de cargos baixos, era simpático ao front populaire. Em Toulouse, sua formação na escola pública, republicana e laica resulta no envolvimento com o partido comunista devido principalmente ao anti-imperialismo. Na biblioteca de sua cidade estuda o marxismo de maneira independente e opta pela geografia após perceber que as ciências exatas e naturais não permitiriam seu aprofundamento no conhecimento da história social (BRUNET, 2003, p. 13-14).

Os geógrafos envolvidos na militância comunista ainda faziam grupos de estudos para obter sucesso nos exames universitários. O próprio Bataillon e DurandDastès receberam ajuda de Dresch e George quando eram aspirantes ao exame de agregação em geografia, assim como Frémont ${ }^{81}$ e Brunet participaram de grupos que reproduziam a solidariedade da luta política - a única exceção era Paul Claval que não participou de numa equipe de estudos.

Com as propostas de Dresch e George, a articulação de trabalhos de campo e a formação de debates promovidos pelo grupo ligado ao partido não tardaria o aparecimento dos primeiros trabalhos frutos da efervescência do pós-guerra.

\subsection{0 urbano e o rural}

\footnotetext{
81 Mesmo que Armand Frémont posteriormente tenha trabalhado com a geografia humanista, desde o início da renovação dos debates teóricos na França ele tenta dialogar com o marxismo estruturalista através de sua concepção de espaço vivido (BATAILLON, 2009, p. 152-153).
} 
Em 1949, Tricart lança o primeiro volume do Cours de géographie humaine l'hábitat rural, que seria seguido por um fascículo sobre o hábitat urbano em 1954 (MAMIGONIAN, 2005, p. 214). No primeiro volume, Tricart (1949, p. 164) deseja compreender como as classes sociais organizam-se no espaço agrário e para isso demonstra a importância da distribuição espacial das fazendas, seus diversos tipos de funcionamento e os materiais utilizados nas construções e no trabalho cotidiano. Analisa ainda como a evolução econômica do lugar muda o ordenamento das classes sociais e pode causar a concentração fundiária ${ }^{82}$.

Tricart dedica-se a questão da mecanização e da mudança dos usos de materiais de construção a partir da inserção das regiões rurais na economia industrial nacional ou mundial. Em seu estudo utiliza os seguintes critérios de classificação a partir das unidades de produção agrícola: 1. sítio; 2. função; 3. forma de ocupação; e 4. estrutura (TRICART, 1949, p. 172). Esse último elemento dá uma relevância especial à história regional, que considera o "complexo de fatos econômicos e sociais, colocando o estudo do hábitat na perspectiva do materialismo histórico" (MAMIGONIAN, 2005, p.213-214).

Quando Pierre George estuda o fato rural seu percurso de análise é similar83. Nenhum dos dois geógrafos especializaram-se no tema, o que pode ter contribuído para uma convivência de ambos sem grandes conflitos no campo de estudos:

\begin{abstract}
Ele opera um exame sistemático das principais relações entre o homem e a terra, mostrando as interações entre os fatos de densidade, as relações jurídicas e sociais, as relações geográficas e técnicas, e as formas de produção. Depois, ele usa uma classificação dos tipos agricultura, passando aos diferentes modos de utilização dos solos em paisagens tropicais, depois agricultura seca, até as diferentes formas de agricultura irrigada e a agricultura nos países socialistas (RENARD, 2008, p. 290) ${ }^{84}$.
\end{abstract}

Cholley publicou um texto em 1946 sobre o complexo agrário e suas componentes. Certamente, a maneira de analisar o campo para George e Tricart foi uma herança de seu mestre, mesmo que George apresente ambições globais de

\footnotetext{
82 Sob o auspício de Tricart, M. Rochefort será um dos primeiros a estudar a penetração dos capitais no campo francês. Sobre a questão fundiária, Kayer, Dugrand, Elbaï e Balbonaux são alguns alunos de George que estudam o tema (RENARD, 2008, p. 290).

83 Lembrando que a obra A geografia agrícola do mundo é de 1946 e O campo - fato rural através do mundo é de 1956. Mesmo com uma distancia grande entre as duas obras, em ambas George sempre recorre ao estudo dos exemplos concretos.
}

84 Tradução nossa. 
enquadramento do fato rural (RENARD, 2008, p. 287). A visão de sistemas agrícolas facilita a percepção da mecanização do campo.

Se comparadas, a geografia rural recebe menos atenção que a urbana. Seguramente, nessa escolha pesam os trabalhos rurais da fase áurea do pensamento vidaliano e a demanda pela modernização da geografia através da análise do urbano e da indústria.

O segundo volume do curso de geografia humana de Tricart, sobre o hábitat urbano, é um manual extremamente completo. Uma das premissas fundamentais é utilizar o lote e as construções urbanas como unidade fundamental de análise. Além disso, Tricart discute o modelo da escola de Chicago, a obra de Christaller e a rede de cidades, a relação entre cidade e região e o planejamento intraurbano (TRICART, 1957, p. 172-210). A visão estrutural persiste em sua análise:

\begin{abstract}
A cidade é caracterizada por uma paisagem, nós dissemos. Essa paisagem reflete uma estrutura. O estudo das estruturas urbanas é um outro problema. Ele é muito complexo caso repouse sob uma noção sintética agrupando um elemento concreto, a paisagem urbana, com uma trama de fatos em que se combinam dados de ordens diferentes. A morfologia de um quarteirão da cidade ou de uma rua é o resultado de fatos históricos, econômicos, sociais, intelectuais (concepção de tal ou tal urbanista ou arquiteto que o construiu totalmente ou em parte), frequentemente políticos (a ditadura de Napoleão III, fundada sob o esmagamento do impulso social republicano de 1848 explica os cortes estratégicos de Haussmann). O estudo da morfologia urbana é portanto um dos problemas centrais que coloca o hábitat urbano. Nós estudaremos em detalhes seus diversos dados fundamentais (TRICART, 1957, p. 3$)^{85}$.
\end{abstract}

O foco da morfologia urbana contrasta com a estrutura urbana, que envolve uma dimensão mais ampla do fato urbano. Tricart (1957, p. 4) cita as obras de Dresch, sobre as cidades do Congo, e de George, sobre a periferia de Paris como exemplos de trabalhos sobre morfologia urbana.

Como no hábitat rural, Tricart associa a estrutura social entendida como divisão por classes com os tipos de materiais utilizados nas construções urbanas. caso didático são as favelas no terceiro mundo, feitas de materiais naturais em meados do século XX. Assim, "a estrutura social e econômica é portanto um dos elementos essenciais da explicação da paisagem urbana" (TRICART, 1957, p. 19). Mais adiante ele afirma que a estrutura é um fato histórico da cidade (TRICART, 1957, p. 109).

85 Tradução nossa. 
Apesar de podermos identificar algumas rupturas com a monografia urbana clássica da escola vidaliana, Tricart, como bom geomorfólogo, não deixa de lado o clima, o relevo e a vegetação do sítio urbano, ou ainda ideias que resultaram em boas análises, como a situação da cidade.

Esse é um dos ensejos que permite criticar o planejamento dos urbanistas e os planos que tratam o espaço como um elemento geométrico, ou que não consideram o quadro histórico (TRICART, 1957, p. 72). Na obra, todavia, ainda é possível encontrar metáforas naturalizantes, como a comparação entre o crescimento urbano e o biológico, ou entre a estrutura social e a do relevo. Isso ocorre quando Tricart utiliza um raciocínio geomorfológica para explicar o funcionamento social: "exatamente como na geomorfologia, as relações de causalidade não são automáticas - a estrutura pode influenciar diretamente e intimamente as formas como ela pode muito bem não aparecer" (TRICART, 1957, p. 139). Ou seja, existe uma independência relativa entre estrutura e forma no relevo e na morfologia urbana.

Fora o legado da escola vidaliana, o contato com a escola de Chicago é um outro elemento que reforça as metáforas naturalizantes. A circulação urbana, a relação orgânica entre os bairros e a própria ideia de estruturas são alguns exemplos disso (TRICART, 1957, p. 170). Entretanto, devemos ter em mente que seu manual tem caráter didático e seu objetivo é apresentar todas as formas possíveis de analisar a cidade, mas isso não significa que ele não tenha uma concepção de método acerca da geografia urbana.

De acordo com Abreu (2006, p. 149), a absorção de Tricart, em 1957, ocorre de maneira muito rápida no Brasil. Os geógrafos deixam de lado um enfoque mais monográfico de geografia urbana e começam a estudar a estrutura urbana entendida "de forma dinâmica, a partir das relações que se estabeleciam entre cada parte da cidade". Além de ser herdeiro do capital cultural de Cholley, Tricart também recebe seu legado no campo da didática. Bataillon (2009, p. 100-101) indica que seus manuais e cursos de geografia são utilizados de uma forma generalizada e copiados excessivamente devido à excelente exposição das ideias.

Além do estudo do hábitat, nesse período Tricart realiza trabalhos sobre a geografia econômica da China e da África ocidental, sem limitar-se apenas à geomorfologia. Entre 1948 e 1950 temos a divulgação das ideias sobre fontes 
energéticas de Sorre, Tricart e George ${ }^{86}$, um tema que tradicionalmente havia sido pouco trabalhado pela geografia francesa (MAMIGONIAN, 2005, p. 212-213). Não por acaso, Joseph (2010, p. 8) ressalta que, concomitante aos interesses dos geógrafos, a biblioteca da Sorbonne adquire obras sobre geografia econômica e geografia urbana.

Para Guglielmo (2008, p. 256), George é um dos pioneiros no estudo da geografia das indústrias, pois ele percebe que a visão geográfica engloba todo o processo produtivo, sua capacidade de gerar divisões do trabalho e de influenciar na vida econômica da população. Além disso, ele percebe a relação entre indústria e urbanização e seus estudos sobre localização industrial (GUGLIELMO, 2008, p. 257). Observamos acima que o industrial teve um papel importante na sua obra sobre a geografia social da França e sua apropriação do tema pode ter ofuscado o desenvolvimento de perspectivas originais e complexas como a de J. Chardonnet.

Diretamente associado ao fato industrial aparecem os processos de urbanização. Da mesma forma que Tricart, George (1983, p. 74 e 167), em sua obra de geografia urbana, cita a estrutura como um organismo urbano, mas ao mesmo tempo fala sobre a estrutura do trabalho na cidade, com seu comércio, artesanato, indústria e serviços. Sua aproximação do fato urbano ocorre através das paisagens urbanas, dos equipamentos, dos mecanismos econômicos e de sua influência regional (BRUN, 2008, p. 277-278). A abordagem histórica da cidade e a morfologia urbana também são valorizadas, pois são justamente os longos movimentos da economia e as mudanças técnicas que alteram a cidade (BRUN, 2008, p. 280).

George, no entanto, recusa-se a utilizar a ideia de hábitat, apesar de sua afinidade com Sorre: "ele se recusa a fazer de peça central um sistema de pensamento que arrisca diluir a complexidade e a especificidade do fato urbano em uma versão, às vezes muito globalizante e incompleta, das relação entre a terra e o homem" (BRUN, 2008, p. 279).

Se o hábitat tem um papel secundário, a ideia de periferia resurge na obra de George advinda do Tableau de Géographie de Vidal de la Blache ${ }^{87}$ :

\footnotetext{
86 Outro elemento pouco analisado que denota o papel do pensamento de Sorre na obra de George é o fato de ambos terem estudado as possíveis ilações e diferenciações metodológicas entre sociologia e geografia. Sorre escreve a obra Rencontres de la geógraphie et sociologie (Paris: Ed. Marcel Rivière, 1957) e George (1966) escreve Sociologie et Géographie, em 1966.

87 Tissier (1992, p. 262-263) demonstra que a periferia é vista na obra de Demangeon como uma metáfora naturalista de submersão/incorporação, ou seja, a periferia é o campo sendo assimilado pela cidade.
} 
"A periferia, esta parte da capital cujo geógrafo dos anos 30 não pode darse conta devido à referência do meio natural (sítio) ou as grandes correntes de troca (posição), mas que por um dinamismo local produz e diferencia o espaço urbano. A geografia dos anos 40 reconhece as estruturas urbanas cuja periferia é o elemento mais recente, nascido e dominado por último" (TISSIER, 1992, p. 258) ${ }^{88}$.

Tissier ainda acrescenta, sobre os autores que trabalham com a ideia de estrutura urbana:

\begin{abstract}
A ênfase é colocada sobre o ajuste das estruturas urbanas e, para a maior parte dos autores, suas noções são largas e mais compreensíveis que a simples morfologia material, cujos planos em diferentes escalas deram a imagem. A noção de estrutura tem uma dimensão econômica, social, e na obra de alguns, política. O espaço urbano, e notadamente a periferia, é considerado como um campo no qual atuam os agentes econômicos e sociais. As metáforas organicistas ou mecanistas que permanecem essencialmente sobre as convergências das formas não estão mais na moda (TISSIER, 1992, p. 259).
\end{abstract}

Talvez Tissier subestime o papel das metáforas mecanicistas e naturalizantes que continuaram a alimentar o imaginário dos geógrafos marxistas, porém, como vemos, ele indica que elas saem de moda rapidamente. Contudo, Rochefort indica que o pensamento de George tenta sistematizar e fechar um panorama inventivo dos estudos urbanos no pós-guerra:

(...) [existe] um certo número de tendências convergentes da geografia urbana na França, para confrontar os problemas urbanos com as relações sociais de produção, e de uma maneira mais geral algumas visões das estruturas sócioeconômicas que se podem chamar de marxistas, e que relevam o materialismo dialético de uma maneira um pouco frouxa. $A$ primeira coisa que me despertou para isso é o artigo de Dresch sobre as cidades coloniais em 1943. É evidente que existe lá uma ideia: as cidades não podem ser as mesmas em todo lugar porque existem problemas de situações (nesse momento não falávamos de formação social) de sistemas socioeconômicos engendrados pelo colonialismo, que chegou às sociedades diferentes trazendo fenômenos urbanos diferentes. Essa foi uma retomada de uma maneira talvez mais marginal em comparação com uma concepção marxista fechada, por Pierre George em sua confrontação com os sistemas econômicos e sociais no 'A cidade, o fato urbano no mundo'. Esse era um esforço para aproximar os fenômenos estruturais sociais: mesmo muito vago, a geração da qual faço parte recebeu uma herança, sentiu a relação entre organização do espaço e estrutura social (ROCHEFORT, 1983, p. 65) ${ }^{89}$.

\title{
Para George, não bastaria somente estudar a paisagem urbana, seu crescimento e demografia, pois o fenômeno da periferia exige uma análise
}

\footnotetext{
88 Tradução nossa.

89 Tradução nossa.
} 
decorrente de uma mudança quantitativa e qualitativa. Assim, seu raciocínio volta-se novamente para a geografia social e os processos de concentração econômica do capitalismo, que resulta, segundo Tissier (1992, p. 260), de um marxismo sumário ou sintético. Para esse mesmo autor, o estudo do hábitat urbano seria muito próximo dessa ideia de estrutura urbana, que revelaria os "fatores indiretos da luta de classes" (TISSIER, 1992, p. 260). Concordamos com essa visão, pois mesmo que Tricart recupere a ideia de estrutura da escola de Chicago, ela tem uma influência relativamente pequena, pois seu pensamento porta uma originalidade na análise urbana que também está presente em Dresch, George e em seus alunos. A estratégia de não utilizar o termo hábitat talvez procure evitar conflitos com outros membros do grupo, como o próprio Tricart. Entretanto, em 1963 George perderia as nuances radicais de sua análise, deixando de mencionar o comportamento político e a composição social da periferia, além de desvinculá-la do proletariado.

O resultado dos estudos urbanos é a conclusão que os grupos sociais distribuem-se de acordo com o preço dos imóveis, de acordo com estratégias sociais de atração ou expulsão em determinados bairros. Assim, "a periferia é para Pierre George a forma urbana moderna na qual dividem-se as classes sociais criadas ou transformadas pela concentração econômica" (TISSIER, 1992, p. 261). A periferia é onde grande parte das disfunções da sociedade liberal aparecem.

Apesar do uso de metáforas naturalizantes, a busca pelas desfuncionalidades e contradições sociais é uma ruptura importante em um campo disciplinar que sempre teve mais afinidade com as ideias de equilíbrio e harmonia, como na visão vidaliana dos gêneros de vida (BOYER et al., 1983, p. 13). Mesmo com a influência do organicismo, o que predomina de maneira geral é uma perspectiva funcionalista aberta a uma complexificação cada vez mais profunda, o que encaminha o estudo da relação entre cidade e campo ou das redes urbanas (CLAVAL, 1983, p. 27).

Troin $(2008$, p. 18) deixa claro que George teve contato com os modelos de Burguess e o escritos da escola de Chicago, porém o objetivo maior de seu trabalho inicial sobre o fato urbano é a comparação entre as cidades do mundo consequentemente avaliando como se dá o fato urbano em cada um dos sistemas sociais esquadrinhados por sua geografia social do mundo.

Durante um certo período, George foi diretor do centro de pesquisa sobre o urbanismo (BRUN, 2008, p. 282). Entretanto, à medida que ele se afasta do marxismo, suas obras tornam-se cada vez mais descritivas (BRUN, 2008, p. 283). Os estudos de geografia urbana conseguem timidamente perceber a importância da 
especulação imobiliária ${ }^{90}$ e da propriedade da terra como elementos importantes no processo de crescimento da cidade. Podemos perceber que através da preocupação comparativa de George, no terceiro mundo, a questão fundiária tem forte peso na composição da classe dominante (ROCHEFORT, 2008, p. 251).

\subsection{Geografia social, sociologia e população}

As reflexões de George caminham a todo vapor em direção ao alavancamento do crescimento econômico francês, buscando a independência externa após a reconstrução da nação. Seu diagnóstico pautado na economia política sobre as condições das forças produtivas agrada aos comunistas e à classe burguesa, opção que não podemos deixar de relacionar com a antiga estratégia do front populaire. Apesar de George não utilizar explicitamente o arcabouço teóricometodológico do marxismo, sua força ideológica penetra fortemente seu pensamento.

Isso evidencia-se tanto por sua postura política, quanto nas escolha das variáveis de análise. Tal fato releva mudanças importantes na geografia, como avaliou Meynier:

\footnotetext{
Pierre George formula a regra que: ' $O$ ponto de partida da geografia humana nos parece ser o inventário das forças produtivas'. O mesmo autor nos dá ainda uma nova definição: a geografia humana se tornou o estudo do homem produtor e consumidor (MEYNIER, 1969, p. 153) ${ }^{91}$.
}

Assim, a geografia francesa, que outrora preocupava-se principalmente com produtor passa a ser mais complexa, uma vez que George junta o estudo da produção com o estudo do consumo, fazendo confluir geografia econômica e regional de acordo com a tradição. Entretanto, Manzagol (2008, p. 326) diz ainda que George vai além, insistindo no sistema social e na necessidade de uma geografia geral que se paute na análise regional. Suas generalizações caminham, portanto, da escala regional para a mundial.

Uma das tentativas de conciliar as duas coisas é quando George, por exemplo, retoma a ideia de espaço geográfico de Max Sorre. O objetivo de Sorre era

\footnotetext{
90 Ao contrário do que se pode pensar, o tema da especulação não é tão novo nos estudos urbanos. Maurice Halbwachs vai em 1930 para Universidade de Chicago onde complementa sua formação de sociólogo, e em seu retorno à França dedica-se de maneira pioneira ao estudo da especulação imobiliária (CLAVAL, 1998, p. 189).
}

91 Tradução nossa. 
elaborar uma ideia de espaço que não fosse simplesmente geométrico ou matemático. George a retoma tomando cuidado para afastar-se da concepção do espaço kantiano, definindo-o como suporte das relações sociais ou ainda como forma de representação da matéria92 (PAILHÉ, 1981, p. 25).

Ainda na publicação da primeira edição do livro Geografia Social do Mundo, de acordo com Méo (2008, p. 5-6), George estabelece três concepções básicas que se desdobraram em seu pensamento: (1) os fatos sociais e econômicos são revestidos de uma dimensão espacial que deve ser compreendia e analisada pela geografia, concepção derivada de seu diálogo com Sorre e da ênfase na relação entre sociologia e geografia; (2) o espaço geográfico registra os impactos e os fatos sociais, refletindo as etapas da história e a forma contemporânea como a sociedade produz seu espaço; (3) as sociedades no mundo dividem-se em grandes sistemas que se distinguem "sempre pelas organizações sociais (compreendendo aí suas dimensões econômicas e políticas) diferentes" (MÉO, 2008, p. 6) ${ }^{93}$.

A partir da publicação de George sobre a geografia social do mundo ocorre o reforçamento da consolidação da geografia social enquanto subcampo da disciplina:

\begin{abstract}
Essa possibilidade veio a ser mais explorada depois de 1945, no contexto da reconstrução pós-guerra, o sucesso eleitoral da esquerda e o crescimento da influência do marxismo entre os intelectuais franceses. Novas palavras começaram a ser usadas nesse período para definir o social: 'organização' e 'estrutura' entraram na linguagem de geógrafos como Pierre George e Abel Chatelain com rápidas conotações, mostrando que a sociedade possui uma 'espessura' conceitual que não possuía sob a clássica geografia vidaliana. O social tendeu a tornar-se um todo articulado e um produtor ativo de geografias, não sendo mais uma mera 'coisa' implicando uma entidade transparente entre o meio e a pessoa. George foi a figura central, particularmente porque introduziu categorias de análise marxistas na geografia, algo que veio muito mais tardiamente na geografia anglófona. Já na sua Géographie économique et sociale de la France, publicada em 1938, ele usou termos como proletariado industrial, 'exploração capitalista' (...) e desigualdade - a diferenciação social dos gêneros de vida - foi claramente uma questão central para ele. (PHILO e SODERSTROM, 2004, p. 117) ${ }^{94}$.
\end{abstract}

A geografia social do mundo é um desdobramento de suas primeiras aproximações com o marxismo, classificando o mundo em estruturas sociais que apresentam processos específicos, como a urbanização e a industrialização. 0 espaço, tendo em vista esse panorama, apresenta-se como um mosaico de trabalho

\footnotetext{
92 Ele usa uma ideia semelhante a Marx, que considera as relações sociais como matéria concreta.

93 Tradução nossa.

94 Tradução nossa.
} 
humano em diferentes estágios técnicos (PHILO e SODERSTROM, 2004, p. 117-118).

Em um projeto de geografia social paralelo, Abel Chatelain, também ligado à esquerda, pretendia fazer uma geografia da classe burguesa da França explorando suas ideologias. Ele trabalhou em Lyon de 1930 até 1960 e no início da carreira dedicava-se à geografia histórica, sendo menos influenciado pelo economicismo que Pierre George (PHILO e SODERSTROM, 2004, p. 118; CLAVAL, 1998, p. 290). Abel Chatelain e Renée Rochefort foram intelectuais importantes para George, o primeiro, por exemplo, tratava o social e o econômico sem separações, o que leva a uma confluência entre estrutura e organização social (DESHAIES, 2008, p. 306). No entanto:

\begin{abstract}
Contrariamente a Pierre George, Abel Chatelain explorou campos inovadores no fim dos anos 1940 como a burguesia (1947), o trabalho das mulheres (1948), os jornais e sua influência (1948 e 1949) a educação e a laicidade (1952), a indústria turística e a abertura de novos locais de geografia social (1953). Assim, desde os anos 1940 observa-se a emergência de duas visões concernentes à geografia social que se perpetuam até os dias de hoje (DESHAIES, 2008, p. 307) ${ }^{95}$.
\end{abstract}

Não conseguimos identificar se a geografia de Chatelain continua até hoje, todavia é fácil perceber que o projeto de George venceu. Talvez, a relação demasiadamente aberta com a sociologia e o desprendimento das categorias tradicionais da geografia não tenha ajudado Chatelain a convencer a comunidade.

Contudo, o diálogo interdisciplinar de George baseia-se na contribuição do sociólogo Gurvitch, que admite o estudo da realidade por todas as ciências sociais particulares. Gurvitch, de origem russa, exila-se na França depois do sufocamento do debates das ciências sociais na União Soviética durante a década de 1930. Para Therborn (2012, p. 83), ele deixa de ser marxista e torna-se apenas sociólogo com esse processo, ou seja, restringe demasiadamente seu trabalho. A geografia então faz uma análise horizontal, observando as relações sociais e elaborando tipologias para diferentes organizações. O espaço é sempre menos mutável e flexível que seu conteúdo social. Assim:

Esse espaço geográfico não é portanto, para George, um simples quadro. Ele funciona também como uma matriz, um 'molde', um cadinho do social forjado pela história e pelas condições físicas (...) do ambiente, capaz de retroagir sobre o social, de influenciá-lo (MÉO, 2008, p. 6).

95 Tradução nossa. 
Porém, como Méo (2008, p. 9-10) demonstra, seu marxismo vai ser simplista, pois a ideia de trabalho vai ser visto como atividade humana, esvaziando-o da construção ontológica do homem ou mesmo de seu valor antropológico marxista.

Se o trabalho tem um valor menor no seu pensamento, as estruturas são fundamentais para a análise social, pois segundo Brun no mesmo Geografia e sociologia:

(...) aparece claramente sua preocupação de analisar não somente as estruturas econômicas, mas mais precisamente os laços entre as organizações da produção, estruturas do trabalho e divisões locais, nas suas relações com a evolução das formas de urbanização (pode-se destacar que ele se refere aqui explicitamente a Marx) (BRUN, 2008, p. $284)^{96}$

Como vemos, seu marxismo pauta-se bastante no viés classificatório da funcionalidade e da organização social através dos termos proletariado, burguesia, modos de produção, desigualdades sociais ou ainda relações de dominação entre países desenvolvidos e subdesenvolvidos em uma fase mais tardia. Em sua autobiografia, George (1990, p. 232-233) indica que a geografia dos recursos naturais, da energia e os estudos demográficos são todos derivados dos seus 20 anos de atuação dentro do Centro de Estudos de Urbanismo e que esta instituição foi importante para sua relação com o pensamento de G. Gurvitch.

Alguns anos mais tarde, George escreve uma nota sobre Max Sorre em que destaca a ligação deste com G. Friedmann e G. Gurvitch. Além disso, ele relaciona o pensamento de Sorre ao de $\mathrm{H}$. Lefèbvre através da sociologia do cotidiano e do estudo dos impactos da modernidade. $\mathrm{Na}$ mesma nota arremata sem grande explicações "as fronteiras são ilusórias entre a geografia urbana e a sociologia urbana" (GEORGE, 1975, p. 193), certamente uma afirmação muito forte tendo em vista todo esforço de diferenciação entre os dois campos. Surpreende ainda a ligação com Lefèbvre em uma época distante de seu profundo impacto na geografia.

Em meados da década de 1950, Pierre George inicia um outro diálogo interdisciplinar importante, introduzindo a variável população na geografia. O conceito de população aos poucos ganha um sentido muito próximo ao de sociedade, constituindo uma geografia que se torna inseparável da síntese das forças produtivas (POURTIER, 2008, p. 15-16).

96 Tradução nossa. 
Em 1951, A. Sauvy ainda não havia criado a nomenclatura de terceiro mundo ${ }^{97}$, que surge apenas em 1960, mas George já havia classificado as populações em agrícolas, industriais e de economia socialista. Através da geografia da população, George associa as diferentes taxas de crescimento populacional e as condições econômicas dos países. George faz uma espécie de geografia mundial, com técnicas estatísticas comparando as situações populacionais e a divisão nos três setores econômicos, elaborado por Jean Fourastié 98 para diversos países (CLAVAL, 1998, p. 276).

Alguns anos mais tarde, George classifica sociedades industriais e préindustriais em seu Geografia e Sociologia, de 1966, e distingue as primeiras, que dependem de fatores econômicos predominantemente, das outras, que se submetem aos fatores naturais. Após a criação da nomenclatura de Sauvy, George apenas adapta seus sistemas classificatórios que têm como objetivo fundamental combater as ideias malthusianas sobre os limites do crescimento populacional. $\mathrm{Na}$ mesma época ele (1990, p. 232-233) envolve-se na temática do crescimento dos países novos, como Canadá e Brasil.

George observa, a partir da obra de René Dumont, que o problema da população está ligado à capacidade distributiva da sociedade (POURTIER, 2008, p. 15-16). Além disso, seu trabalho é pioneiro em explorar a questão das migrações relacionando-a com o novo campo que inaugura, o da geografia da população, que traz articulações entre geografia e sociologia sem que haja uma primazia da estatística. A visão estrutural persiste na análise da população, onde é latente a busca pela estrutura econômica que oferece elementos de explicação para a geografia humana. $O$ trabalho competente de George e sua amizade com Sauvy rendeu-lhe o cargo de diretor do Instituto de Demografia da Universidade de Paris I, como vimos uma das frentes envolvidas no projeto francês para compreender o sistema socialista (ROCHEFORT, 2008, p. 249).

Entretanto, um olhar atento à geografia da população evidencia contradições. Se por um lado a geografia econômica de George é inovadora e incorpora a variável da população, inserindo-a em uma estrutura social, histórica e em relações de

\footnotetext{
97 Hobsbawn (1991, p. 15-42) ressalta que apesar dessa nomenclatura ser externa ao marxismo, ela vai sendo gradualmente incorporada.

98 Trata-se da clássica divisão entre setor primário, envolvendo agricultura, mineração e atividades extrativistas, secundário, remetendo à indústria, e terciário, englobando serviços, comércio e finanças.
} 
trabalho, por outro ela esconde as classes sociais. Apesar de oferecer uma alternativa ao gênero de vida, a análise de classes fica em suspenso, encoberta pela categoria homogênea de classificação entre setor produtivo e não produtivo, ou ainda pela características socioprofissionais da população (PAILHÉ, 2003, p. 56). Rochefort (2008, p. 249) confirma essa visão, dizendo que George não fala sobre luta de classes, e busca não indicar diretamente o marxismo, pois seu pensamento refere-se apenas às profissões através do inquérito estatístico.

A preocupação sociológica e a sofisticação da geografia humana também inserem a variável meio ambiente dentro do conjunto de preocupações de George. Veyret (2008, p. 28) diz que a concepção de espaço e meio de George, influenciaram Tricart e Bertrand, que acabam dando origem à ideia de geossistemas. George colocaria a sociedade no centro do meio ambiente, pois "contribuiu para passar da geografia naturalista para a geografia ciência social, sem renegar os componentes 'físicos'” (VEYRET, 2008, p. 29). O meio ambiente é contínuo e está em situação dialética com as ações e reações que envolvem todos seus elementos. Veremos que Tricart tem uma visão mais complexa sobre essa dialética. Talvez Veyret esteja superestimando no papel de George, mas de qualquer forma isso mostra a complexidade do autor e uma faceta importante que integra seu pensamento.

\subsection{Planejamento, economia e geografia: da revolução nacional ao} descongestionamento industrial

Outro ponto nodal desse percurso é a interface entre o campo da economia e o da geografia. A contribuição de Perroux, na década de 1950, destaca o planejamento nos moldes socialistas e o pensamento do economista Keynes, que trazem aos olhos do ocidente a importância e a preocupação com a ação governamental para mediar os problemas sociais e econômicos. Sua obra ganha evidência nesse panorama e possui uma relação forte com a geografia, buscando unir o debate entre estruturalismo e economia no planejamento estatal.

No entanto, cabe compreender melhor quem era Perroux antes da guerra, como sua obra foi concebida e qual era seu diálogo com a geografia. Se Christaller foi o precursor de uma renovação na compreensão da estrutura da economia urbana em escala regional, Perroux oferece uma contribuição original para os geógrafos que buscavam instrumentos de planejamento nesta mesma escala. 
Depois da Segunda Guerra, Perroux é um dos primeiros a "introduzir a noção de espaço na análise econômica, [que] seria inseparável de um pensamento político convencido da necessidade de ultrapassar a nação e fazer da economia uma ciência

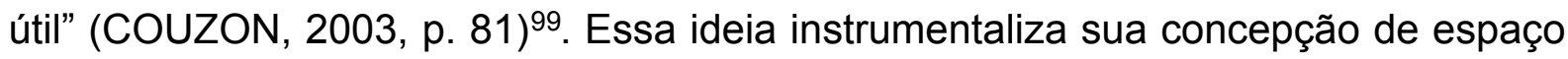
- que para o geógrafo tem um sentido de espaço econômico.

Durante os anos de 1930, Perroux engajou-se no movimento de direita, Esprit, que simpatizava com medidas autoritárias para organização da econômica. Ele participaria do governo Vichy, como colaborador da ocupação, e inspira algumas das ideias de Pétain ${ }^{100}$. Perroux é claramente a favor de uma revolução nacional comunal com objetivo de organizar as forças produtivas de maneira rígida e lançar a França como potência capitalista. Ele recupera a obra de Carl Schmitt e seu estado de exceção para utilizá-la contra o nazismo e a favor da revolução nacional (JULLIARD e WINOCK, 1996, p. 877).

Alguns anos antes da ocupação nazista, Perroux escreve obras contra Hitler, o que provavelmente lhe poupará de processos após a queda do regime Vichy diferentemente de outros escritores ou intelectuais que receberam a pena sumária ${ }^{101}$.

No entanto, sua economia toma como base a ideia de que ela não pode se separar da filosofia, sociologia e da política, adotando como ponto de partida a concepção anti-individualista do sociólogo alemão Tönnies. O personalismo alemão ganha força em seu pensamento, utilizado para criticar o individualismo dos lluministas e ao mesmo tempo um possível coletivismo que despersonaliza o homem. Dessa maneira, o seu ideal político seria um federalismo descentralizado que tem base nas comunidades locais (COUZON, 2003, p. 82-84). O pensamento de Schumpeter também tem um peso importante em sua obra, sendo Perroux um dos seus primeiros introdutores na França durante a década de 1930 (JULLIARD e WINOCK, 1996, p. 877).

Na mesma rede de Perroux, encontramos Jean-François Gravier ${ }^{102}$ diretor no Centro de Síntese Regional da Delegação Geral de Equipamento Nacional durante o

\footnotetext{
99 Tradução nossa.

100 Marechal Pétain foi o líder do governo Vichy entre os anos de 1940 e 1944.

101 Uma das obras seria: PERROUX, François. Des mythes hitlériens à l'Europe allemande. Lyon: Bosc Frères e M\&L Riou, 1935.

102 Curiosamente, Gravier é desde 1934 militante ativo do movimento Jeune Droite [Jovem Direita]. Porém em janeiro de 1945 é integrado no ministério da Reconstrução e em 1949 no comissariado geral do planejamento (COUZON, 2003, p.85).
} 
governo Vichy, e que publica em 1947 o livro Paris e o deserto francês, uma obra nitidamente favorável ao espraiamento da indústria por toda a França para criar economias regionais harmônicas. Sua ideia, diferente de seu colega Dessus, defende planos de acordo com a potencialidade de cada região a partir dos polos de atração das metrópoles regionais (COUZON, 2001, p. 168).

Através de uma concepção muito próxima à federação nacional de Perroux ambos autores, no período de 1941-1942, vão analisar a formação dos pays, dos cantões e das províncias, investigando a possibilidade de um renascimento territorial a partir da escala regional. O objetivo é engendrar revoluções econômicas que vão desancar os pequenos rincões rurais da França e formar complexos regionais integrados. Sinteticamente:

A organização do espaço primeiro é comandada pela especialização das produções em função das aptidões naturais ou das vantagens adquiridas, e pela existência de limites de alcance no domínio de serviços. E ela que explica a formação de redes urbanas hierarquizadas e de regiões polarizadas (CLAVAL, 2011, p. 200).

Passada a época sinistra do nazismo, com a diluição do grupo da revolução nacionalista, Perroux e outros intelectuais agrupam-se no periódico La Revue Économique e acabam por ingressar nos altos escalões do planejamento público (DOSSE, 2007, p. 231). Eles participam do Instituto de Ciências Econômicas Aplicadas, dialogando com as ideias keynesianas ${ }^{103}$ contra concepções que gravitavam em torno das ideias econômicas de Walras.

A geografia, no entanto, teve um papel importante nesse processo:

A emergência da política de planejamento do território na França entre 1942 e 1950 é traduzida pelo encontro da ciência geográfica e a ação política e administrativa. Nesse sentido, ela representou um momento histórico nos debates sobre o sentido e as modalidades do engajamento do geógrafo na vida cidadã [vie de la cité] ${ }^{104}$ que estava atenuada depois da intervenção dos geógrafos na questão da regionalização administrativa no limiar dos séculos XIX e XX (COUZON, 2001, p. 171)

103 Dosse (2007a, p. 353) nos indica que com a ascensão da CEPAL (Comissão Econômica para América Latina e Caribe) temos aproximações entre o estruturalismo e o keynesianismo. Talvez Perroux, nesse contexto, tenha bastante importância.

104 Cité, no francês, tem o sentido de cidade, mas também pode referir à cidadania e à vida administrativa. Optamos por essa tradução, já que o foco dos geógrafos era o planejamento da cidade em escala regional e ao mesmo tempo a busca de um sistema social mais equitativo.

105 Tradução nossa. 
Um fato pouco conhecido e discutido na geografia é que George também ligou-se de alguma maneira ao grupo de economistas próximos a Perroux e suas ideias. O planejamento, que na concepção de Pierre George era um ramo pertencente à geografia, é tomado pelo pensamento econômico e torna-se mais eficiente, uma vez que reflete somente sobre a variável econômica atendendo às empresas privadas e ao Estado interessado no desenvolvimento. A economia, com o auxílio da geografia, pretende resolver o problema das desigualdades regionais.

Perroux oferece um espaço geográfico econômico que articula várias escalas - mundial, nacional, regional - dentro de arcabouço de explicação teórica sistemática e uma proposta prática para a solução de desigualdades espaciais que a geografia da época não foi capaz de demonstrar. Isso deve-se, sem sombra de dúvidas, ao amplo apoio institucional de Perroux e ao fato de a geografia econômica ser somente um ramo da disciplina.

Apesar de não analisar profundamente a questão da integração econômica entre as regiões e sua autonomia relativa, Perroux compõe uma doutrina contra o imperialismo econômico estrangeiro ao mesmo tempo em que o próprio crescimento econômico dirigido pelo Estado resolve os contradições da estrutura da economia.

Em 1943 George participa de uma comissão dirigida por G. Dessus encarregada de estudar as condições geográficas da reconstrução nacional (JULLIARD e WINOCK, 1996, p. 532). Curiosamente, sua integração no grupo ocorreu antes do final da Segunda Guerra Mundial, no Ministério da Economia Nacional, ao lado economistas e engenheiros. O tema da localização industrial é crucial:

Pierre George aprofunda, em 1945, a relação de 1944 sobre o estudo estatístico das dimensões dos estabelecimentos industriais, que traz à luz o papel das pequenas e médias empresas por ramo industrial para mensurar um tamanho ótimo para os estabelecimentos, conhecimento necessário a toda prescrição sobre a localização das indústrias. O que dá todo o sentido para essa relação, é sua retomada em um livro com a coautoria de Gabriel Dessus, Pierre George e Jacques Weulersse intitulado Materiais para uma geografia voluntária da indústria francesa (1949). Um título eloquente que ilustra as proposições concretas apresentadas em particular por Gabriel Dessus, mas as quais aderem os três autores: não estamos na torre de marfim da universidade. O que está proposto é uma série de reflexões coordenadas e informativas sobre a necessária redistribuição da indústria francesa, indispensável para o descongestionamento dos centros (afrouxamento), o reequilíbrio territorial, a descentralização mais que dispersão, favorecendo notadamente as cidade de 10.000 até 50.000 habitantes próximas das metrópoles regionais (MANZAGOL, 2008, p. 329). ${ }^{106}$

106 Tradução nossa. 
Jacques Weulerse já havia estudado em 1943 indústrias no meio rural para compreender seu comportamento em uma situação de isolamento, e G. Dessus analisa o descongestionamento industrial em 1944 (COUZON, 2001, p. 161-163).

A obra de George, Dessus e Weulerse gerou sérios problemas, pois na época, toda a esquerda posicionou-se contra a política de descentralização industrial. As mudanças das fábricas buscavam reduzir as tensões entre os trabalhadores e os patrões, bem como os custos sociais da produção (GUGLIELMO, 2008 , p. 256). Contudo, além do problema da distribuição industrial, a análise envolvia o estudo da população, a migração para os centros industriais e o baixo desenvolvimento das moradias e da educação nas províncias em função da falta de indústrias (COUZON, 2001, p. 163).

A ideia de descentralização industrial já havia sido defendida anteriormente na década de 1930, inspirada no voluntarismo do desenvolvimento econômico de Jean Brunhes, Max Sorre e do historiador econômico Henri Hauser. Essa medida diminuiria o êxodo rural e dividiria equilibradamente as fábricas pelo território nacional (JULLIARD e WINOCK, 1996, p. 59).

O grande problema seria a dispersão do proletariado pelo território francês, e George integrante do partido reconhece seu erro, optando por não rebater as acusações (MANZAGOL, 2008, p. 329). No entanto, além da dor moral, parece que George não sofreu nenhum abalo ou coerção maior pelo partido, mesmo que ele integrasse uma rede de pesquisadores de direita que alguns anos atrás defendia a revolução nacional. Um dos projetos do governo de Vichy era a defesa de um agrarismo com paz no campo e descongestionamento das metrópoles (ROBIC, 1996 , p. 44), e por isso temos a associação com o projeto político da direita. Contudo, a controvérsia de George é fruto de um dilema acerca do planejamento francês:

A emergência da noção de organização do espaço, símbolo de uma aspiração a uma outra geografia portanto, nasceu na França, menos da prática da geografia aplicada como no War Service americano (...) ou no Raumordning nazista (...) que sucumbe ao choque da derrota. Ela está simultaneamente ligada ao sentimento de um dado novo. Na Liberação, sua manifestação é dupla: constitui-se pelas premissas do planejamento do território e opera no novo quadro mental de um mundo finito e interdependente. E muito rapidamente um jogo espacial é negociado no plano nacional: a confiança na harmonia territorial rompeu com o estatuto de grande potência pertencente à Metrópole. Deve-se pensar na colonização interior (ROBIC, 1996, p. 45). 
Muitos anos depois, George reavaliaria sua postura na época e refletiria sobre a responsabilidade social do geógrafo. Sua conclusão é que a inserção nesse grupo marcou uma ruptura com a tradição imobilista da geografia, já que seu trabalho tinha o objetivo fundamental de reconstruir a França no pós-guerra (COUZON, 2001, p. 163).

O problema econômico fundamental para o grupo de Perroux seria a discrepância de poder entre os atores econômicos, o que gera as economias dominantes: "A análise conceitual da economia dominante e do efeito de dominação desembocariam em uma interpretação inédita e inovadora da noção de espaço econômico" (COUZON, 2003, p. 86). O espaço econômico, por sua vez, abrange os atores distribuídos desigualmente:

\footnotetext{
Nem espaço geográfico, nem espaço político concreto, o espaço econômico é um conceito diretamente produto do modelo real de uma economia fundada sob a potência que sintetiza o conjunto das relações econômicas - dito de outra forma, as relações de força - existentes entre as unidades econômicas (COUZON, 2003, p.87). ${ }^{107}$
}

Dentro desse contexto, o meio é assimétrico e algumas dessas assimetrias são irreversíveis, pois estão ligados aos fatores naturais. A assimetria causa a polarização do espaço, seja de forma induzida pelo planejamento, seja devido à homogeneidade de suas estruturas econômicas. Ela é também um parâmetro para analisar as relações internacionais e o poder dos diferentes espaços econômicos nacionais.

Em 1949 Perroux trava debate com Walter Isard, professor de Harvard e criador da ciência regional (COUZON, 2003, p. 87). Isard preocupa-se com uma microeconomia keynesiana, porém defende o liberalismo como um ótimo difusor do crescimento econômico. Perroux discorda dessa visão e concebe as áreas desenvolvidas e deprimidas como centro e periferia, admitindo as desigualdades sociais geradas pelo crescimento econômico (CLAVAL, 2011, p.199). Entretanto, é possível uma influência do pensamento de Isard no âmbito dos economistas, apesar das críticas. As discordâncias dos alunos de Perroux também podem ter influenciado os geógrafos, uma vez que George, por exemplo, será muito crítico à quantificação total da análise social.

Conforme ocorrem as transformações do capitalismo pós-guerra, Perroux renova seus instrumentos de análise e estuda mobilização das atividades 
econômicas, ou seja, atividades que começam a se desenvolver fora do âmbito nacional. O resultado do debate e da presença de Isard é a criação em 1961 da Associação de Ciência Regional de Língua Francesa controlada por Perroux e Boudeville (BENKO e SCOTT, 2004, p. 54).

O espaço nacional é visto como um "receptáculo" (contenant, no original), detentor de uma série de atividades, e o espaço econômico abrange três aspectos: (1) como conteúdo de um planejamento; (2) como campo de forças; e (3) como conjunto homogêneo. Os lucros e as relações comerciais envolvem uma dimensão que está fora ou além da dimensão espacial das fronteiras. Contraditoriamente, a tendência do capitalismo é a separação cada vez mais intensa do espaço banal e do econômico, uma vez que as empresas e os capitais se tornariam transnacionais gradativamente. Aliás, a postura de Perroux constitui uma disjunção territorial, porque raramente os limites dos espaços políticos, econômicos, técnicos, jurídicos, religiosos ou culturais se sobrepõe em uma mesma área (COUZON, 2003, p. 92).

Perroux supre suas ideias da geografia em pelo menos dois aspectos: consulta algumas as obras de Pierre George ${ }^{108}$ sobre a desindustrialização e extrai a ideia de espaço banal de Jean Gottmann. Este último demonstra que a geografia, através da observação banal das ações humanas, explica a vida social, sua origem e a constituição de seu espaço, enquanto a economia trataria da satisfação das necessidades do homem (COUZON, 2003, p. 93).

O espaço do geógrafo define-se pela atividade e presença humana, compreendendo o mundo e a economia, elucidando os modos de agir no mundo. A visão de Gottmann corrobora com a de Perroux no sentido que as regiões são compartimentações econômicas e o espaço banal aparece como suporte material da atividade econômica, como um quadro concreto em contraste com o espaço econômico abstrato. Contudo, Perroux faz uma distinção nítida entre o espaço banal, a região econômica e região-plano (CLAVAL, 1998, p. 262-263) como estratégia de delimitar bem os campos de estudo. A estrutura para Perroux "é marcada pela lentidão dos seus ritmos, em geral cíclicos, movidos por mecanismos profundos" (DOSSE, 2007, p. 233) ${ }^{109}$.

$\mathrm{Na}$ segunda metade da década de 1950, uma parte dos economistas influenciados por Perroux conhecem a obra de Christaller, e a região ganha uma ${ }^{108}$ GEORGE, Pierre; DESSUS, Gabriel, WEULERSSE. Matériaux pour une géographie volontaire de
l'industrie française publicado no Cahiers de la Fodation nationale des sciences politiques em 1949.

109 Não podemos deixar de ressaltar aqui a similaridade da ideia com as formulações de Braudel. 
base eminentemente urbana, concatenada com os fluxos econômicos e os polos de desenvolvimento (CLAVAL, 1998, p. 263).

Como vimos, no entre guerras a geografia havia firmado relações com a história para consolidar-se como campo científico. Agora, a nova sinergia entre geografia e economia prolifera-se além da obra de George e de seus alunos, porque convoca o geógrafo para ação social, ao mesmo tempo que reforça a visão regional da geografia. Gottmann e Étienne Julliard apresentam uma postura favorável à planificação regional, mas com críticas ao pensamento dos economistas. Os geógrafos refletem sobre qual seria o papel da geografia diante das colaborações da economia, questionamento que influenciará a geografia ativa, a geografia aplicada de Philopponeau, e ainda a geografia voluntária de Jean Labasse.

Se o motor do planejamento para o grupo ligado aos economistas era o binômio polo de desenvolvido e estruturação regional a partir da hierarquia, a visão de Labasse buscava entender, de forma paralela, a região a partir da articulação entre as redes bancárias e a formação dos capitais regionais. Pode-se elencar ainda Jean Chardonnet, que procura analisar as grandes metrópoles - e consequentemente das regiões - através dos complexos industriais (CLAVAL, 1998, p. 263). Essas visões não são exatamente opostas às ideias do grupo de Perroux, porém são alternativas para se pensar a estruturação regional.

Se, por um lado, vemos que a relação entre geografia e planejamento modifica-se a partir da colaboração dos economistas, por outro é inegável que parte das estratégias de planificação malograram, pois tentaram utilizar o capital das próprias empresas para combater as desigualdades. Tal modalidade gradativamente torna-se pouca atrativa para as empresas que tinham um incentivo fiscal ilusório.

Entretanto, a teoria econômica dos polos de crescimento, que fomentariam o desenvolvimento das regiões "atrasadas", introduz um debate acerca do estruturalismo econômico na geografia. A solução do polo é identificar os complexos patológicos dentro da economia nacional e lançar um grande investimento capaz de impulsionar outras atividades. Veremos agora que, para além da dimensão imediata e nacionalista do planejamento, George tem uma leitura importante sobre o socialismo que se insere no contexto da guerra fria.

2.7 Planejamento, socialismo e geografia: apologia à racionalidade planificadora no contexto da guerra fria 
Apesar do caráter inovador, George tenta conciliar a geografia tradicional francesa - herança que acreditava ter um viés ideológico - e o marxismo, mas não obtém completo sucesso (PAILHÉ, 1981, p. 22). A conciliação entre marxismo e geografia tradicional francesa conduziu:

\begin{abstract}
Para além das modificações de vocabulário (colocando em evidência os recursos pelas sociedades humanas / forças produtivas, evolução dos tipos de civilização / sistemas econômicos e sociais, homem / grupos humanos), há uma verdadeira recolocação das categorias da geografia clássica, que efetua P. George, dando assim uma nova dimensão à herança vidaliana que assumia o risco de reduzir a geografia a um saber eclético. Nós estamos aí bem longe de uma 'reconciliação', de uma 'convergência', mas se sabe que as leituras de P. George tiveram sempre a característica principal de serem 'reducionistas' (PAILHÉ, 1981, p. 23).
\end{abstract}

Pailhé (1981, p. 20), em um artigo sobre a obra de George entre o período de 1946 e 1956, diz que, neste intervalo, suas obras sobre geografia humana e econômica têm um enfoque principalmente regional. Sua conclusão é que predomina no conjunto da obra de George o marxismo com uma tendência economicista, o que corrobora com o conteúdo do curso ministrado em 1945 (PAILHÉ, 1981, p. 27).

Para Claval (1998, p. 278), isso ocorre porque George sempre parte do modo de produção, no entanto a maneira que a esfera econômica é abordada consiste mais na descrição do que na explicação dos fatos geográficos, diferentemente de Dresch, por exemplo, que tenta compreender o movimento dos capitais no império francês. Somos da opinião de que esse traço do pensamento de George é fruto de sua influência vidaliana combinada com o pouco aprofundamento na aplicação do marxismo. O contato com o marxismo inovou sua obra, todavia o receio de afastarse da tradição disciplinar manteve o enfoque descritivo ${ }^{110}$.

$\mathrm{O}$ aspecto positivo do economicismo é que sua geografia torna-se mais complexa. Mesmo que não haja discussão de método explícita, o contato com o marxismo gerava mudanças que se consolidariam fortemente:

\footnotetext{
110 Isso não quer dizer que não tenha ocorrido alguma forma de afastamento dos vidalianos, uma vez que Claval (1998, p. 276) queixa-se de George ter perdido a tradição do trabalho de campo, além de ter feito uso de dados estatais dos serviços de documentação e ter substituído a verve literária por uma linguagem fria e impessoal. Discordamos de Claval, porque George manteve uma certa tradição de trabalho de campo, e quanto aos demais aspectos, parece-nos que George não inova somente os temas do campo geográfico, mas tenta modernizá-lo como um todo, modificando seu habitus, tornando-o mais profissional, interessado na ação do planejamento e no reconhecimento de outros campos e da sociedade. A ruptura com o caráter literário nacionalista de seu pensamento ocorreu quando George viu os riscos da revolução nacional fascista, conservadora e avessa a certos aspectos da modernidade, como vimos anteriormente.
} 
É pelo estudo dos mecanismos econômicos e pela exploração de sua dimensão espacial que a renovação começa aproximadamente em 1955: a economia se estrutura em circuitos; as forças que estão atuando neles determinam a localização de diferentes tipos de produtores. A hierarquia das redes de transporte e de comunicação reflete as necessidades de comércio e os condicionam (BATAILLON, 2009, p. 179-180).

Apesar de Bataillon ter ressaltado mais os aspectos espacialistas e menos os históricos, o importante é ver que existe uma mudança significativa na geografia. A necessidade de observar a realidade de uma maneira mais sistemática suscita a visão estrutural, seja da organização do espaço, seja da organização histórica sucessão de modos de produção ou mudanças na economia mundial, por exemplo.

Concomitante aos estudos regionais, temos obras de vulgarização destinadas aos estudantes, publicadas na coleção Que sais-je?, livros que são constantemente atualizados através de reedições. Pailhé ressalta que George tem mais publicações acadêmicas do que em livros e revistas do partido comunista, o que denota seu comprometimento maior no campo acadêmico. Entretanto, por estar ligado ao partido, George inspira-se na geografia dos países da Europa Oriental para agregar elementos contra a considerada geografia burguesa (PAILHÉ, 1981, p. 20).

Desde o pós-guerra, o tom de George é de complacência para com o planejamento na Europa Oriental, mesmo nos países que foram prejudicados em prol da economia soviética. Em 1968, como veremos, George volta a defender o planejamento centralizado (PAILHÉ, 1981, p. 20), porém não podemos negar que o estudo sobre a União Soviética foi um ato de ousadia tendo em vista a deflagração da guerra fria ${ }^{111}$. Assim:

A primeira edição de L'URSS (1947) contém algumas marcas de sua época. P. George coloca em evidência a necessidade de uma tomada de consciência do fato político (p. 205), analisa a mobilização das forças e valores humanos (p. 256-260) incluindo o stakhanovismo ${ }^{112}$, cita Stálin no texto e nas bibliografias ao final de cada capítulo, mas conserva sempre uma certa distância que se nota, por exemplo, nas notas bibliográficas. Em uma palavra, tal obra é designada como 'favorável no seu conjunto', uma outra 'mais reservada', ou ainda aquela 'escrita durante a ocupação alemã com a preocupação de não conter desagrados aos ocupantes' (PAILHÉ, 1981, p. 21).

111 Devido ao seu perfil militante, George fica impedido de entrar nos Estados Unidos por 15 anos (CLOUT, 2010, p. 38).

112 A. Stakhanov foi um operário de minas que através do trabalho nos moldes tayloristas na União Soviética atingiu índices altíssimos de produtividade. A partir de seu desempenho Stálin o exalta e promove uma política para bonificar os trabalhadores soviéticos de acordo com sua produtividade como uma forma de estímulo. Assim, referencia-se a cota mínima de trabalho obrigatório e a bonificação para os que a ultrapassam. 
George emula em suas obras a dualidade comunismo versus capitalismo com de uma retórica entusiasmada que reforça o recrutamento através do convencimento lógico. As coletivizações no campo, por exemplo, são vistas como formas de dissolução da propriedade feudal no espaço rural europeu (MAUREL, 2008, p. 322).

Ainda no trabalho sobre a URSS estão presentes os clássicos da ciência proletária, como Mithourine e Lyssenko, citados no corpo do texto (PAILHÉ, 1981, p. 21). A presença do stalinismo e o enfoque econômico teriam reflexos profundos em sua obra, como conferimos acima:

Esse economicismo conduz P. George às análises evolucionistas-finalistas.
O desenvolvimento da URSS é visto não em termos de processos, mas em
termos de uma longa linha reta, pontilhada de armadilhas, mas indo no
sentido de um crescimento harmonioso, conduzindo a considerar a URSS
como um verdadeiro modelo, em que tenderiam as economias
democráticas populares (...) No total, o socialismo caracteriza-se
essencialmente pelo aspecto racional da economia, o qual se define
prioritariamente pela planificação (PAILHÉ, 1981, p. 27).

O planejamento territorial é um elemento importante que instrumentaliza a racionalidade econômica e que carateriza o modelo soviético, diferenciando-o do capitalismo. Contudo, sua simpatia pessoal pela planificação persiste por muitos anos.

Para Maurel (2008, p. 321), até a edição de 1962 de L'URSS, George manteve uma visão geral positiva do socialismo e do planejamento. O fundamento da sociedade sem classe:

(...) favoreceu a impregnação do marxismo, cuja geografia fez sua a terminologia e a fraseologia para definir princípios de organização da economia socialista, considerando a 'socialização dos meios de produção' e fazendo elogio à 'emulação socialista' lançada pela grande campanha do Stakhanovismo (MAUREL, 2008, p. 321).

Seus trabalhos de planejamento auxiliariam o partido comunista se ele chegasse ao poder através da revolução ou democraticamente. Entretanto, se isso não acontecesse, sua obra poderia voltar-se para a social-democracia, inserindo o planejamento como um componente de transição gradual para o socialismo, ou mesmo poderia convencer os liberais das benesses do planejamento, trazendo o desenvolvimento e diminuindo as desigualdades sociais. Não é por mera obra do destino que George trabalha na comissão destinada à problemática da indústria, em Paris, comandada por Perroux. 
O prestígio da geografia de George e do partido comunista francês, no entanto, decaem diante de uma série de conjunturas históricas. Entretanto, no âmbito internacional, na década de 1950 Pierre George já era conhecido como um geógrafo pró-socialismo: "no Japão dos anos 1950, prefere-se difundir os escritos de Deffontaines ao invés de Pierre George que era comunista" (DELFOSSE, 1998, p. $157)^{113}$.

A militância também chega nas escolas pelos livros didáticos. Em um manual publicado em 1953 e assinado por Cholley (1953, p. 2-7), que conta também com as colaborações de Birot, Dresch, Clozier e George, este último faz apologia aberta à economia socialista racional e apresenta o planejamento como diretriz básica de seu desenvolvimento.

Como vimos, Dresch (1980, p. 22) faz críticas ao trabalho de George e ainda declara: "de minha parte sou menos entusiasta para com P. George. Minha atitude é talvez mesmo mais de crítica do que de congratulação". Para Dresch existiria uma dissociação entre organização da sociedade e sua produção social entendida enquanto processo $\mathrm{e}$ isso teria repercussão na ideia de um planejamento centralizado longe da dialética social. George permaneceria, como na geografia vidaliana, focado nas formas estáticas e materiais da organização da vida e da relação entre homem e meio, pois "uma interpretação marxista não se satisfaz somente com o emprego de uma terminologia formal" (DRESCH, 1980, p. 22).

Lembremos que estamos falando de um debate que se arrasta desde os fins da década de 1940, com dois projetos de geografia marxista em disputa: de um lado Dresch, que tenta formular uma geografia por um viés mais fiel a teoria marxista; e de outro, George, que tem uma mentalidade voltada ao desenvolvimento das forças produtivas, às políticas de planejamento por parte do Estado, bem como uma conciliação com a geografia vidaliana. A natureza prática de sua geografia se desdobra na geografia ativa quando o furor da esquerda dos anos de 1930 e do pósguerra perde vigor.

Konick (1995, p. 148) afirma que Pierre George é capaz de evocar todas as categorias de análise próprias do marxismo, mas as despe de todo conteúdo crítico e revolucionário. Tal afirmação tem um fundo de verdade, porém o balanço demonstra o seu engajamento um tanto "desenvolvimentista"114, ou seja, um

\footnotetext{
113 Tradução nossa.

114 Empregamos aspas uma vez que reconhecemos o teor anacrônico e descontextualizado que o uso do termo causa.
} 
nacionalismo combinado com o crescimento econômico como fórmula de independência e dissolução das desigualdades regionais.

\subsection{A dialética do relevo}

A influência do stalinismo no pensamento de George é inegável, porém ele não é o único. A doutrina do zdanovismo ${ }^{115}$ atinge fortemente Jean Tricart, que publica um texto em 1953 na revista La Pensée ${ }^{116}$. Inspirado por essa ideia, ele adota a geomorfologia climática e opõe-se à geomorfologia estrutural de Davis introduzida por Vidal de la Blache e divulgada na França por De Martonne (BROC, 1974, p.544). Através de uma leitura claramente zdanovista, os seguidores de Davis reproduzem a geormorfologia burguesa, enquanto o novo modelo climático comporia a nova ciência proletária (SURET-CANALE, 1981, p. 16; DOSSE, 2007a, p. 386).

Cailleux auxilia Tricart na sua crítica e ambos consideram o ciclo do peneplano de Davis um tipo ideal desatento aos processos do relevo (BROC, 2010, p. 451). Tricart diz que as superfícies de erosão normal poderiam formar-se em climas passados e o papel do geomorfólogo seria compreender o relevo por meio da associação entre forma, processo e paisagem (CLAVAL, 1998, p. 245). Além disso, a abordagem de Davis contribuiria para fragmentação da geomorfologia, com análises que se distanciam de outros subcampos da geografia física. Uma aproximação mais sistemática da empiria permitiu que as gerações futuras, como, por exemplo, G. Bertrand, elaborassem o método dos geossistemas, em que a evolução da estrutura natural é vista em conjunto (BROC, 2010, p. 499).

Se, de um lado, podemos identificar uma estratégia de autoafirmação, de outro tal postura pode ser fruto do antiamericanismo muito valorizado na cultura de esquerda. A polarização no campo da geomorfologia também pode se referir a um ataque ao establishment vidaliano. Entretanto, essa estratégia institucional não se restringe aos anos dourados do stalinismo, pois na década de 1970 temos o zdanovismo com outra roupagem, denunciando a geografia como conhecimento burguês e reacionário.

\footnotetext{
115 A partir das elaborações de Zdanov, terceiro secretário do partido comunista russo, estabelece-se uma divisão política entre o campo cultural da burguesia e do proletariado, o que acirra ainda mais a polarização da Guerra Fria. Essa ideias influenciam as produções estéticas e culturais, promovendo o realismo soviético como orientação preponderante.

116 A referência completa é: TRICART, Jean. "Premier essai sur la geomorfologie et la pensée marxiste" in La Pensée, Paris, $n^{\circ} 47,1953$, p. 62-72. A controvérsia ganha uma dimensão tão intensa para Tricart que ele cria em 1950 a Revue de Géomorphologie Dynamique.
} 
Entretanto, não nos deixemos enganar, pois a concepção de dialética presente na obra de Jean Tricart é complexa e provavelmente influenciou seus contemporâneos. Tricart baseia-se na leitura de Hegel feita por Kojève, na época muito em voga na França, em que a dialética remete à relação entre senhor e escravo, ou seja, ela basicamente se constitui como um conflito em que a identidade antagônica e afirmativa de cada uma das partes pauta-se na luta. Essa é uma leitura de Hegel com viés extremamente antropológico, como afirma Vaz:

\begin{abstract}
Embora nela compareçam temas antropológicos fundamentais, de resto já presentes na filosofia do Espírito de lena, a leitura da Fenomenologia [do espírito] não pode ser feita numa perspectiva redutivamente antropológica, como pretendeu o célebre hegelianista Alexandre Kojève, inspirando-se, de resto, na tradição marxista reavivada na década de 20 pela publicação dos chamados Manuscritos econômicos-filosóficos de Marx (VAZ, 2009, p.111).
\end{abstract}

Tricart utiliza a dialética da natureza para sua geomorfologia escultural, mais dinâmica que a lenta abordagem estrutural, identificando elementos na paisagem que estão em conflito. Se no futuro a visão zdanovista vai ser ultrapassada, a dialética como conflito persiste em seu pensamento. Basta observarmos o conceito de resistasia, ou o equilíbrio da paisagem nos fenômenos naturais, como deslizamentos de encostas, ou ainda a contraposição dialética entre as forças internas e externas da crosta terrestre (BROC, 2010, p. 465). Para captar essa dialética, Tricart analisa a paisagem em seus diversos elementos, como clima, relevo, solo e vegetação, o que permite identificar o desequilibro natural e a luta pela sua reorganização estável com menor ocorrência de fenômenos capazes de alterála. Além disso, "Tricart propõe uma nova grade fundada no duplo princípio dinâmico (os processos) e dimensional (a escala)" (BROC, 2010, p. 469).

$O$ debate de Tricart reflete um momento frutífero para a geografia de esquerda, uma vez que em 1956 tudo mudaria. A geografia de esquerda estava agora bem articulada e os discípulos de Tricart, George e Dresch começavam a desenvolver seus próprios trabalhos e críticas à escola francesa de geografia.

\title{
2.9 A disseminação da geografia marxista entre os discípulos
}

Suret-Canale evidencia um fato pouco debatido e apreciado pelos geógrafos:

Havia um 'Círculo de Historiadores e Geógrafos Comunistas', que foi criado em 3 de março de 1949 e que funcionava no quadro da Federação do Sena do PCF. Ele comportava uma 'Comissão de Geografia', que não parece ter uma grande atividade antes de 1953. É nesse ano que se 
constitui um 'Círculo de Geógrafos' distinto do restante (seu boletim n¹ data de novembro de 1953). Havia igualmente os círculos de geógrafos em Estrasbrugo e em Toulouse. Nas 'Jornadas de Estudos Intelectuais Comunistas', ocorridos em Ivry em 29 e 30 de março de 1953, os geógrafos intervinham no quadro da Comissão de Historiadores e propuseram um certo número de orientações. Um colóquio dos geógrafos comunistas (com participação da província) devia ocorrer em Paris nos dias 28 e 29 de junho de 1953. Eu participei das jornadas em Ivry e desse colóquio eu conservei as minhas anotações, que se juntam com os documentos (memorandos e boletins) (SURET-CANALE, 1981, p. 15).

Curiosamente Ivry é uma prefeitura na periferia de Paris, ou seja, área de estudo e interesse de George, como vimos. O contexto do encontro se fazia em um panorama tenso:

\begin{abstract}
Eu não estou orgulhoso daquilo que escrevi no relatório para os geógrafos na Jornada dos Intelectuais Comunistas de Ivry, em 1953. Mas, deve-se lembrar que mal saímos da guerra da Coreia, que a França não havia saído ainda da guerra da Indochina, que Stálin mal havia morrido. Existiam os bons de um lado e os maus de outro. Se não éramos, stalinistas estávamos entre os maus. Eu vivi isso. (MEMÓRIAS, 1990, p. 41).
\end{abstract}

Surpreendentemente, o tema da jornada em Ivry era "A crise da geografia contemporânea" (SURET-CANALE, 1981, p. 15). No encontro, faz-se um balanço das obras de geografia da época e adota-se uma postura contra o determinismo geográfico. A crítica ao ensino da geografia, ao colonialismo, à ideia de gênero de vida e a reivindicação da aproximação com a geografia soviética foram algumas resoluções do encontro. No memorando de 15 de maio de 1953, os geógrafos pedem: "reintegração na geografia das realidades relativas às relações de produção, às classes sociais e à luta de classes, negados ou ocultados pela geografia tradicional" (SURET-CANALE, 1981, p. 15). Ainda na Jornada:

\begin{abstract}
Inicialmente, tínhamos 4 sessões previstas: B. Kayser: a luta de classes, realidade geográfica; R. Guglielmo: por um estudo marxista das cidades; J. Dresch: a luta contra a noção de 'gênero de vida'; P. George: a geografia aplicada (a orientação e a utilização da geografia no mundo capitalista e no mundo socialista) (SURET-CANALE, 1981, p. 15).
\end{abstract}

Contudo, as sessões foram reduzidas apenas para duas, aumentando o tempo das discussões. O segundo dia da Jornada foi dedicado ao aprimoramento das técnicas de geografia urbana. "Entre os interventores - outros falariam no colóquio - eu noto os nomes de André Prenant, de Rochefort, de Wolkowitsch, de Bastié, de Roncayolo, de Dugrand" (SURET-CANALE, 1981, p.15). O resultado concreto dos debates é o lançamento de uma série de artigos nas revistas do partido comunista francês, tanto na La Pensée, quanto na La Nouvelle Critique. Esta última, 
criada em 1948, no ápice da guerra fria, é um lugar explícito de contraposição ao crescimento do existencialismo e de divulgação do zdanovismo, abrangendo várias áreas do conhecimento.

Mesmo que ambas fossem comunistas "a corrente materialista, enciclopedista e humanista na linha de Helvétius é difundida na La Pensée" enquanto "a corrente socialista, científica e stalinista, no sentido de se referir a Stálin, está mais presente na La Nouvelle Critique" (JULLIARD e WINOCK, 1996, p. 837).

Curiosamente, Dresch e George são patronos fundadores da revista La Pensée, o que demonstra a importância de ambos e do campo disciplinar da geografia no âmbito da esquerda política. Abaixo apresentamos um quadro com a seleção de alguns textos publicados na revista:

Quadro 1 - Conjunto de artigos representativos publicados na revista La Pensée (tradução nossa).

\begin{tabular}{|c|c|c|c|}
\hline Autor & Título & $\begin{array}{l}\text { Número } \\
\text { e ano }\end{array}$ & Comentário \\
\hline $\begin{array}{l}\text { GEORGE, } \\
\text { Pierre }\end{array}$ & $\begin{array}{l}\text { Teríamos nós esquecido da } \\
\text { obra de Ernest Denis? }\end{array}$ & $\begin{array}{l}\mathrm{n}^{\circ} 1 \\
1939\end{array}$ & $\begin{array}{l}\text { Denis é um dos } \\
\text { pioneiros nos } \\
\text { estudos eslavos na } \\
\text { França }\end{array}$ \\
\hline Anônimo & $\begin{array}{l}\text { Geografia econômica e social } \\
\text { da França }\end{array}$ & $\begin{array}{l}\mathrm{n}^{\circ} 1 \\
1939\end{array}$ & $\begin{array}{l}\text { Resenha da obra de } \\
\text { George }\end{array}$ \\
\hline $\begin{array}{l}\text { KAYSER, } \\
\text { Bernard }\end{array}$ & $\begin{array}{l}\text { Do objetivismo ao } \\
\text { confusionismo no ensino da } \\
\text { geografia }\end{array}$ & $\begin{array}{l}n^{\circ} 35 \\
1951\end{array}$ & \\
\hline $\begin{array}{l}\text { PRENANT, } \\
\text { Marcel }\end{array}$ & $\begin{array}{l}\text { Aspectos do planejamento } \\
\text { científico na Hungria }\end{array}$ & $\begin{array}{l}n^{\circ} 35 \\
1951\end{array}$ & \\
\hline $\begin{array}{l}\text { TRICART, } \\
\text { Jean }\end{array}$ & $\begin{array}{l}\text { Primeiro ensaio sobre a } \\
\text { geomorfologia e o pensamento } \\
\text { marxista }\end{array}$ & $\begin{array}{l}n^{\circ} 47 \\
1953\end{array}$ & \\
\hline $\begin{array}{l}\text { GEORGE, } \\
\text { Pierre }\end{array}$ & O recrutamento dos mestres & $\begin{array}{l}n^{\circ} 67 \\
1955\end{array}$ & \\
\hline $\begin{array}{l}\text { LACOSTE, } \\
\text { Yves e } \\
\text { PRENANT, } \\
\text { André }\end{array}$ & $\begin{array}{l}\text { Alguns dados do problema } \\
\text { argelino }\end{array}$ & $\begin{array}{l}n^{\circ} 67 \\
1956\end{array}$ & \\
\hline
\end{tabular}




\begin{tabular}{|l|l|l|l|}
\hline \multicolumn{1}{|c|}{ Autor } & \multicolumn{1}{|c|}{ Título } & $\begin{array}{c}\text { Número } \\
\text { e ano }\end{array}$ & \multicolumn{1}{c|}{ Comentário } \\
\hline $\begin{array}{l}\text { TRICART, } \\
\text { Jean }\end{array}$ & $\begin{array}{l}\text { A geomorfologia e o } \\
\text { pensamento marxista }\end{array}$ & $\begin{array}{l}n^{\circ} 69, \\
1956\end{array}$ & \\
\hline $\begin{array}{l}\text { LACOSTE, } \\
\text { Yves }\end{array}$ & A grande obra de Ibn Khaldum & $\begin{array}{l}n^{\circ} 69, \\
1956\end{array}$ & \\
\hline $\begin{array}{l}\text { PRENANT, } \\
\text { André }\end{array}$ & $\begin{array}{l}\text { África do Norte e Oriente Médio } \\
\text { nas publicações recentes }\end{array}$ & $\begin{array}{l}n^{\circ} 70, \\
1956\end{array}$ & \\
\hline $\begin{array}{l}\text { BRUNET, } \\
\text { Roger }\end{array}$ & $\begin{array}{l}\text { Crônica geográfica: os } \\
\text { documentos EDSCO }\end{array}$ & $\begin{array}{l}n^{\circ} 70, \\
1956\end{array}$ & $\begin{array}{l}\text { Comentários sobre } \\
\text { a enciclopédia } \\
\text { didática organizada } \\
\text { por A. Sève }\end{array}$ \\
\hline $\begin{array}{l}\text { BRUNET, } \\
\text { Roger }\end{array}$ & O petróleo e a crise mundial & $\begin{array}{l}n^{\circ} 71, \\
1957\end{array}$ & \\
\hline $\begin{array}{l}\text { BRUNET, } \\
\text { Roger }\end{array}$ & $\begin{array}{l}\text { Crônica geográfica: dois } \\
\text { estudos regionais sobre a crise } \\
\text { rural }\end{array}$ & $\begin{array}{l}n^{\circ} 72, \\
1957\end{array}$ & \\
\hline $\begin{array}{l}\text { BRUNET, } \\
\text { Roger }\end{array}$ & $\begin{array}{l}\text { Europeus e proletariado urbano } \\
\text { no Sul tunisiano. A cidade } \\
\text { mineradora de Redeyef }\end{array}$ & $\begin{array}{l}n^{\circ} 67, \\
1957\end{array}$ & \\
\hline $\begin{array}{l}\text { DRESCH, } \\
\text { Jean }\end{array}$ & A geografia de ontem e de hoje & $\begin{array}{l}n^{\circ} 239, \\
1984\end{array}$ & \\
\hline $\begin{array}{l}\text { LÉVY, } \\
\text { Jacques }\end{array}$ & Os lugares dos homens & $\begin{array}{l}n^{\circ} 239, \\
1984\end{array}$ & \\
\hline
\end{tabular}

A primeira resenha anônima da obra de George é apenas o início de uma ampla gama de resenhas de seus trabalhos que serão publicadas durante toda a década de 1960 naquele periódico. Outro texto importante é o de 1939, sobre o historiador eslavista francês, pois muito provavelmente esse é o momento de engajamento de George no partido e seu redirecionamento para a especialização no mundo russo/soviético.

Podemos ver ainda os artigos de Tricart, comentados acima, além do texto de Marcel, pai de André Prenant, que era biólogo de formação e que em 1948 publica o livro Marxismo e Biologia. Observamos ainda a contribuição de seu filho, que posteriormente publica uma obra extensa sobre a Argélia, com Lacoste. Este último, por sua vez, divulga seu trabalho sobre o norte da África e Khaldum na revista marxista. 
Brunet aparece através de três trabalhos que, segundo relatos, marcam sua frustração com o marxismo, embora tenham sido publicados no periódico. Um ano antes Brunet havia criticado o relatório sobre América Latina escrito por Lacoste e Salomon nos documentos EDSCO. Este atrito pode ter contribuído para as diversas querelas que ambos autores terão em função da disputa de um projeto modernizador para geografia francesa em outro contexto.

Nessa onda de publicações, Suret-Canale tem um artigo sobre ensino de geografia recusado e dedica-se à crítica da obra de Pierre Gourou ${ }^{117}$, sua visão dos países tropicais e do gênero de vida. No contexto da guerra fria, a relação entre professores e alunos podia tornar-se tensa, pois havia um questionamento das ideias da velha guarda vidaliana. Gugliemo, por exemplo, desafia Max Sorre, o que prejudicou sua carreira universitária (MEMÓRIAS, 1990, p. 42). Como relata Rochefort, essa era a situação de desafio típica que reafirmava a identidade militante marxista no plano institucional, dando uma coesão ao grupo e seu projeto intelectual diante da desconfiança aos comunistas de Sorre ${ }^{118}$ e Blanchard (ROCHEFORT, 1983, p. 70).

Em 1954, Bernard Kayser entrevista Maurice Thorez ${ }^{119}$ e envia o resumo para o círculo de geógrafos (SURET-CANALE, 1981, p. 15). Nesse mesmo ano, como havíamos dito, Tricart publica seu tomo sobre o habitat urbano, cuja principal inovação é considerar os imóveis como unidade básica de estudo. Além disso, ele recupera as contribuições de Christaller e "tom[a] da sociologia urbana americana as relações forma-conteúdo, mas desenvolveu a ideia de estrutura urbana e sobretudo a de processo sócioespacial" (MAMIGONIAN, 2005, p. 216). Claval complementa:

No início dos anos 1950, as referências às ideias de Christaller fazem-se mais precisas na geografia francesa. Jean Tricart menciona-o no seu curso sobre o hábitat, mas interessa-se mais às fontes utilizadas para medir o raio de ação das cidades - as rotas telefônicas, por exemplo - que o estatuto da teoria (CLAVAL, 2011, p. 193).

Christaller influencia e redireciona os trabalhos de George, M. Rochefort, B. Kayser e Tricart, não sem a ausência de críticas. Dugrand, Rochefort e Kayser incorporam a teoria de Christaller, pois desejam compreender qual a relação entre

117 Pierre Gourou, que mesmo reproduzindo uma visão um tanto colonialista era tributário de LéviStrauss, utiliza a ideia de estrutura e publica na revista L'Homme de Lévi-Strauss (DOSSE, 2007 a, p. 387).

118 Lembrando que no momento da Segunda Guerra, Sorre era simpático ao front populaire.

119 Secretário geral do Partido Comunista Francês de 1930 a 1964. 
as cidades e o campo, ou ainda entre as cidades e a organização regional francesa (BATAILLON, 2006, p. 12). Reforça-se, portanto, a temática da cisão cidade/campo, tradicional no âmbito do marxismo e uma tendência desde o encontro da UGI de 1931:

\begin{abstract}
A dicotomia cidade-campo marca ainda a percepção do território pelos geógrafos do pós-guerra (...). A oposição cidade-campo constitui também o elemento essencial da tomada de consciência do espaço em Marx, que insiste na dominação das cidades e no peso da rende fundiária. Verdadeiramente, Pierre George, comunista na época, influenciou com essa aproximação e conduziu a análise das relações da cidade com o espaço ao redor (BOYER, 2008, p. 271) ${ }^{120}$.
\end{abstract}

Se o modelo de Christaller e a aproximação com a escola de Chicago trazem inovação para o campo da geografia urbana, George faz a "introdução das relações sociais como elementos determinantes da estrutura dos meios urbanos" (PAILHÉ, 1981, p. 24). Para Pailhé, George teria procurado um modelo alternativo ao funcionalismo da sociologia urbana, e o que dá a tônica desta fuga é a busca de diferenciações espaciais dos grupos sociais no meio urbano (PAILHÉ, 1981, p. 24). George manifesta um receio que pode ter influenciado seus discípulos acerca da ideia de rede de Christaller. Ele acredita que essa concepção está associada à economia liberal, opção original da construção do modelo do geógrafo alemão, o que acaba por não ressaltar as contradições sociais (BOYER, 2008, p. 273).

No que diz respeito ao terceiro mundo, o objetivo de George e seus alunos é compreender minuciosamente o dualismo latente: de um lado as cidades apresentam uma área mais rica e ocidentalizada, e do outro são mais pobres tradicionais. O êxodo rural é chave para compreender o processo de proletarização das massas rurais (TROIN, 2008, p. 19), o que denota a associação entre geografia social, da população e urbana, além de esboçar uma ideia terceiro-mundista importante que inspirará seus discípulos, como por exemplo, Yves Lacoste.

Ainda em 1954, Tricart e George escrevem o livro L'Europe Centrale em que identificam a ausência de concentração dos grandes complexos industriais neste território, ao contrário do que ocorria na França, que apresenta de uma grande aglomeração fabril (MAMIGONIAN, 2005, p. 214). Diferentemente de George, Tricart não poupa críticas a alguns problemas do planejamento da Europa central socialista (PAILHÉ, 1981, p. 21). Como George (1990, p. 232-233) relata em sua autobiografia, o período de 1940-1950 proporcionou trabalhos de campo durante o processo de 
implementação dos regimes soviéticos na Europa central, alguns na companhia de Tricart. Por meio da análise do leste europeu, ele percebe que o planejamento havia perdido uma relação dialética com a sociedade e estava no controle da casta burocracia. A URSS e os países satélites apresentavam:

\begin{abstract}
uma economia central e planejada, onde 'se concentra em mãos do Estado, de modos sem precedentes, os meios de produção, os transportes, as finanças, etc. (...) qualquer cálculo equivocado e qualquer erro repercutem numa dimensão social correspondente'. Não estava sendo levada em conta uma 'verdade histórica': ou venceremos mediante a liderança econômica e científica, ou então não venceremos (COHEN, 1990, p. 344).
\end{abstract}

Na década de 1950 Guglielmo (1980121, p. 28-30) aponta para os abusos cometidos pela geopolítica, que se apresentou como subterfúgio para diversas ações imperialistas. Da mesma forma que Dresch, Guglielmo também tenta distanciar-se da geografia francesa tradicional ao admitir que esta se deixa seduzir pelas aparências dos fenômenos, resultando numa espécie de esquematismo estéril. A geografia física não sai ilesa do ataque, pois lhe é atribuído o papel recenseadora dos recursos naturais para uso futuro do capitalismo.

Guglielmo (1980, p. 50-51) acrescenta que o papel ideológico da geografia seria cometer falsificações teóricas, justificando a ação da classe dominante, o que indica um forte prenúncio da grande "descoberta" de Lacoste.

Guglielmo também havia lutado na resistência francesa e ao término de seu diploma de estudos ganhou uma bolsa para ir ao Marrocos. No confrontamento com a realidade colonial ele percebe a ação exploradora do império francês, o que provoca sua radicalização (MEMÓRIAS, 1990, p. 20). Ele foi aluno direto de George e estuda a indústria química francesa, seus processo de concentração e a formação de monopólios. Nunca chegou a defender sua tese, mas alguns anos depois lamentaria o fato de estudar as indústrias sem os trabalhadores, ou seja, apenas os processos econômicos sem visitar os locais de produção para conversar com os operários. Essa era, sem sombra de dúvidas, uma orientação dos trabalhos de George que Guglielmo questionará após os eventos de maio de 68 (MEMÓRIAS, 1990, p. 2).

Sendo assim, a geografia física deveria ser revista de acordo com o método dialético, levando em conta as relações entre os elementos da paisagem (GUGLIELMO, 1980, p. 34-35). Inclusive são citados Marx, Engels e Stálin para

121 Como ocorre no caso de Dresch, o texto de Guglielmo é de 1955 e foi reeditado. 
resgatar a dialética da natureza e a necessidade de se procurar as leis naturais, uma vez que homem e meio formariam um par contraditório unido concretamente por leis diferentes de funcionamento (GUGLIELMO, 1980, p. 36-37). Dessa maneira, com os raciocínios não dialéticos:

\footnotetext{
Chega-se assim à importância do homem diante da natureza - portanto, à influência determinante do meio natural sobre a vida dos grupos sociais. É a porta aberta a todos os erros em geografia humana e as suas utilizações neomalthusianas, racista, colonialista ou geopolítica (...) R. Dion, A. Demangeon e A. Cholley mostraram a inutilidade destas teses e encaminharam a pesquisa das explicações válidas para vias mais frutíferas (GUGLIELMO, 1980, p. 38-39).
}

Além disso, Guglielmo critica a ideia de gênero de vida, demonstrando sua incompatibilidade com a modernidade, porque na geografia humana a produção é quem ocupa um papel central através das seguintes questões: "as relações unem e ao mesmo tempo opõem - as classes sociais entre si? Quem possui, quem utiliza esses meios de produção?" (GUGLIELMO, 1980, p. 42). A partir disso, temas como o desenvolvimento desigual nos diversos países e as discrepâncias sociais nos centros urbanos aparecem na sua agenda de pesquisa. A segregação social e racial, a especulação imobiliária e as condições urbanas desumanas são postas em questão juntamente com o imperialismo e a busca de lucros nos países subdesenvolvidos (GUGLIELMO, 1980, p. 45).

Nesse mesmo artigo, existe um elogio ao crescimento econômico da União Soviética, mesmo que os motivos do milagre econômico não apareçam claramente (GUGLIELMO, 1980, p. 45). Certamente, isso se relaciona com a descoberta das leis que regem a economia, pois Guglielmo dá ênfase à geografia econômica de forma um pouco divergente do desenvolvimentismo de George:

\footnotetext{
As teses tecnicistas, que veem na evolução dos meios materiais de produção o fator essencial de explicação dos fatos da geografia humana, têm o efeito de mascarar os processos mais importantes, que são econômicos. Os fatores técnicos têm certamente um papel importante na oposição entre os 'gêneros de vida' urbanos e rurais, mas não constituem senão um dos elementos pelos quais se exprime a exploração dos campos pelas cidades, característica do sistema capitalista. O reconhecimento e a utilização da lei econômica do socialismo permitem, ao contrário, na URSS, um desaparecimento progressivo da oposição essencial entre a cidade e o campo (GUGLIEMO, 1980, p. 48-49).
}

Para além da racionalização do planejamento, a associação entre desenvolvimento das forças produtivas e leis econômicas é uma fórmula típica do stalinismo, pois só o conhecimento das leis permitiria a superação das contradições 
sociais. Mesmo após a divulgação dos crimes políticos, Guglielmo se mantém teoricamente ao lado de Stálin, pois sua grande ruptura ocorre com os eventos de 1968. Veremos agora que em meados da década de 1950 o stalinismo estava prestes a sofrer um duro golpe.

\subsection{6: a crise do marxismo e seus desdobramentos}

Em 1953 Kruchov assume o poder e durante o XX⿳亠口冋 Congresso do Partido Comunista da União Soviética e apresenta o famoso relatório sobre dos crimes de Stálin. Tais denúncias representam uma segunda crise profunda do marxismo, que desmobiliza uma parte importante da intelectualidade simpatizante da esquerda. $A$ deliberação de Kruchov sobre a destalinização produz a célebre querela com Mao Tsé Tung, que não aceita as críticas do relatório. Em seguida, a invasão da Hungria no ano 1956 contra a demanda de mais liberdade e melhoramento das condições gerais de vida agrava o quadro de abandono da intelectualidade de esquerda. $\mathrm{Na}$ França, as consequências foram alarmantes, mas na Inglaterra resultaram em uma desarticulação mais profunda, enfraquecendo o partido comunista da Grã-Bretanha, que nunca mais desfrutará do mesmo vigor. Como demonstra Watts (2001, p. 174), o descrédito do stalinismo faz com que a esquerda britânica volte-se para as tradições radicais do século XIX, para o socialismo independente, para o marxismo teórico e para o marxismo continental. Entretanto, isso não evita uma grande desmobilização política.

Dosse (1994, p. 217) demonstra que no campo da história a dispersão dos pensadores engajados em função desses eventos foi grande. A partir das reflexões de Lipovetsky, Dosse nos coloca:

\footnotetext{
Se essa nova era inicia um período soft, descontraído, ela também se traduz pela fragmentação do corpo social, pelo desengajamento, pela desindicalização e desemboca na indiferença, ou seja, na expressão da impotência para agir. O campo político perde sua razão de ser, a não ser para o corpo de especialistas, o da classe política, como dizem os politólogos (DOSSE, 1994, p. 230).
}

Contraditoriamente aos abandonos, Márek (1987, p. 309) demonstra que surge um período de redescobertas para esquerda, pois além do stalinismo no $\mathrm{XX}^{\circ}$ Congresso estava implícita "toda a problemática do policentrismo e, de certo modo, já se anunciava nela o próprio debate sobre o eurocentrismo na interpretação 
marxista" (MÁREK, 1987, p. 309). Em 1953 temos a publicação dos Grundisse ${ }^{122}$ e um interesse maior acerca do tema da alienação, devido em parte à obra de Lukács. Essas publicações terão influência sobre a geografia crítica futuramente.

Enquanto isso, nos anos 1950 Jean Dresch continua sua luta anticolonial, publicando em revistas fora do âmbito da geografia como Politique Étrangère, Revue Politique e Presence Africaine.

Em 1952, ele funda a Associação de Amigos Franco-Chineses que divulga a revista Paris-Pekin (JULLIARD e WINOCK, 1996, p. 371). No acervo da Biblioteca Nacional da França conseguimos consultar os números dessa revista de 1952 até 1958 que se consolida como um importante veículo de divulgação do maoísmo na França. Jean Dresch escreve em boa parte dos números e no primeiro exemplar a luta é para que a França reconheça e trave relações diplomáticas com a República Popular da China. Apesar de inicialmente Dresch defender que a associação não é política e que o interesse é reunir informações sobre a China antes e depois da revolução, gradualmente a revista vai se revelando um meio de propaganda do comunismo chinês.

A associação organiza uma petição de reconhecimento para o governo francês que conta com a assinatura de Dresch, Guglielmo e Gurvitch (Paris-Pekin, ${ }^{\circ}$ $7,1954)$. Outros números contam com relatos de Jean Chesneaux $\left(n^{\circ} 4,1953\right)$ que também envolve-se no grupo, curtos textos literários de Mariel J. BrunhesDelamarre, filha de Jean Brunhes ( $\left.n^{\circ} 4,1955\right)$, e ainda um texto sobre as escolas na China feito por Paul Ricœr ( $\left.n^{\circ} 6,1955\right)$, que acompanha uma delegação da associação durante uma viagem em 1955. No mesmo ano, Simone Beauvoir visita a China comunista e publica o livro A longa marcha, o que divulga a China entre a esquerda francesa (CHANG e HALLIDAY, 2006, p. 567). Durante os anos de 1957 e 1958, Sartre participa dos debates sobre a China comunista dentro do periódico. Jean Dresch permaneceu como presidente da associação durante todos os anos de publicação da revista.

Junto à crise do stalinismo, questiona-se o zdanovismo, o que influencia os geógrafos de esquerda. Suret-Canale (1981, p. 14) demonstra como as ciências naturais foram amenizadas dessa classificação que colocava de um lado as ciências proletárias e de outro as ciências burguesas. Portanto, mesmo que as ciências

\footnotetext{
122 Antes dessa data houve uma publicação no final da Segunda Guerra que ficou mais restrita à
} URSS. 
naturais fossem distorcidas pelo positivismo ou pelo idealismo, elas continham elementos mais ou menos neutros que poderiam ser utilizados de maneira universal.

Ainda em 1956 desdobram-se os debates sobre geomorfologia entre J. SuretCanale, Tricart e R. Guglielmo. Suret-Canale discorda da visão de Tricart que a geomorfologia climática seria uma ciência proletária, pois pensa que o seu desenvolvimento ocorreu a partir da geomorfologia estrutural de Davis. A renovação dessa disciplina não teria origem no materialismo dialético, segundo sua opinião. $O$ artigo de crítica a Tricart é publicado na La Pensée como um anexo à parte da revista, enviado posteriormente. A resposta pública de Tricart a Suret-Canale não foi publicada (SURET-CANALE, 1981, p. 16).

No entanto, no contexto francês e mundial, a crise provocada pela denúncia dos crimes de Stálin agrava-se fortemente pela invasão da Hungria. Como nos coloca Dosse:

O ano de 1956, marcado pela invasão soviética da Hungria, é de máxima importância para uma geração de intelectuais marxistas que vão encontrar refúgio em um marxismo estruturalizado, um 'marxismo a vácuo', como disse Jean-Marie Domenach, que escapa ao peso dos desastres do comunismo real. Vários dentre esses intelectuais romperão com a cultura comunista, abandonarão a história nas pontas dos pés e se refugiarão na interioridade do texto, na ciência, na dissolução do sujeito e do significado (DOSSE, 2007, p. 15).

Daí o crescimento, a longo prazo, da hermenêutica, da reflexão epistemológica internalista, da volta ao indivíduo e ao cotidiano. Yves Lacoste, que após sua agregação atuou em um liceu no Marrocos entre 1952-1954, volta para Paris e torna-se assistente no Instituto de Geografia quando a situação política do Magreb e da esquerda se complicam. Pouco tempo depois, sai do partido comunista francês, mas não devido à invasão. Segundo suas palavras:

\footnotetext{
Eu saí do Partido Comunista Francês em 1956, não por causa do que ocorreu em Budapeste, eu o confesso, com muita pena, mas não compreendi nada de Budapeste. Naquela época me deixei iludir por certas coisas que me contaram. Saí do Partido Comunista Francês, porque, em 1956, ele votou - acreditando estar fazendo uma coisa boa, eu não o estigmatizo - os poderes especiais solicitados pelo presidente do conselho, Guy Mollet, para levar adiante a guerra na Argélia (ZANOTELLI, 2005, p. 57-58).
}

Suret-Canale indica que:

É próximo de 1955-1956, que esses debates se tornam sonolentos. Com a conjuntura criada pelas revelações do $X^{\circ}$ Congresso do PCUS, se tinha 
um espírito, sem dúvidas voltado para outro sentido. A isso, deve-se juntar o itinerário da maioria dos participantes... Quantos deles hoje em dia se consideram marxistas? (SURET-CANALE, 1981, p. 16).

Em nota de rodapé, Suret-Canale responde sua pergunta e coloca que apenas Dresch e Prenant continuaram marxistas na década de 1980. DurandDastès, pertencente a uma geração mais jovem, se desliga lentamente do partido após 1958. Seu trabalho acadêmico, desenvolvido a partir do estudo da Índia, insiste na possibilidade de uma terceira via, nem reformista, nem revolucionária, para a emancipação dos países subdesenvolvidos (BATAILLON, 2009, p. 62) ${ }^{123}$.

Brunet rompe com o partido em 1956, após ler o relatório de Kruchov. Seu desligamento foi doloroso, resultando em um divórcio, na completa apatia acerca do partido comunista e da União Soviética, além de três anos de isolamento em um liceu distante do meio estudantil (BATAILLON, 2009, p. 64). O seu interesse pela geografia humana também cessa temporariamente e Brunet começa a estudar a geografia do petróleo enquanto trabalha em Redeyef na Tunísia124 (BRUNET, 2003, p. 14). Curiosamente, todos os textos frutos da crise são publicados no La Pensée, como vimos anteriormente.

A saída do partido para Guglielmo, apesar de ser mais tardia, também adquire dimensões dramáticas, pois ele retira do currículo alguns textos publicados em La Nouvelle Critique (MEMÓRIAS, 1990, p. 40).

Com o crescimento da destalinização, Pierre George adapta-se às mudanças, reeditando seu livro sobre a União Soviética e modificando os nomes das cidades (PAILHÉ, 1981, p. 21). Tal mudança busca atenuar a força ideológica do culto à personalidade, todavia "enquanto P. George toma distância, a partir de 1956 da análise marxista, observa-se um prolongamento de seu discurso" (PAILHÉ, 1981, p. 28).

Contraditoriamente, é no período auge da guerra fria que George ganha mais força entre os estudantes e pesquisadores, conscientes das limitações da geografia

\footnotetext{
123 Durand, como vimos acima, esquivou-se de falar sobre a geografia humana da Índia para não se comprometer politicamente. Contudo, Pierre George o convida para escrever um volume na coleção Que sais-je? em que mostra a Índia em veloz movimento de urbanização e industrialização, contrastando com a estagnação oriental. Esse volume da coleção obtém grande sucesso (BATAILLON, 2009, p. 69).

124 A ruptura com o partido, a longo prazo, representou também uma cisão com o próprio grupo de George. Brunet (2003, p. 15) coloca "mantive-me sempre distanciado do meio parisiense, dominado pelos alunos de Pierre George, meio pelo qual eu tive uma simpatia inicial, mas que me pareceu finalmente muito mais conservador do que progressista" principalmente de $1970 \mathrm{em}$ diante, segundo seu relato.
} 
tradicional (PAILHÉ, 1981, p. 29). Pierre George entra no comitê editorial dos Annales de Géographie em janeiro de 1956, mesmo ano em que se desvincula do partido comunista, e só deixará o cargo em 1992. Ao procurarmos as contribuições de George desde o início de sua carreira nos Annales de Géographie, aparecem mais de 650 ocorrências como notas de pesquisa, artigos, resenhas, entre outros (HOMMAGE, 2006, p. 3). Ao observamos os sumários dos Annales ${ }^{125}$, de 1969 até 1989, existe uma divisão bem mercada entre a velha guarda da geografia de esquerda: George resenha, discute e apresenta trabalhos sobre a União Soviética e a Europa oriental, reafirmando sua postura de pesquisador do mundo eslavo com um distanciamento gradual do marxismo; enquanto Tricart resenha e publica textos relacionados à ecologia, à geomorfologia e ao planejamento.

Ainda encontramos o seguinte excerto: "Ingresso no partido comunista em 1935, ele se distancia definitivamente em 1956, em seguida da invasão da Hungria pela URSS, sem por isso rejeitar totalmente os aportes do marxismo no estudo da sociedade" (HOMMAGE, 2006, p.4) ${ }^{126}$. Mais uma evidência que reforça o argumento de Pailhé de que George seria uma espécie de conciliador do marxismo e da geografia lablachiana, pois uma vez na comissão de redação da revista reafirma claramente sua aliança com o status quo da geografia universitária francesa.

No mesmo ano o termo "subdesenvolvimento" é incorporado como índice de indexação de artigos na biblioteca do Instituto Geográfico da Sorbonne, o que indica uma produção significativa sobre o assunto. O termo "geografia tropical", por exemplo, só irá ser incorporado em 1972 (JOSEPH, 2010, p. 10-11).

Se o ano de 1956 foi um retrocesso para a esquerda devido à invasão na Hungria, não podemos esquecer que um evento promovido pela UGI e ocorrido no Rio de Janeiro vai gerar um intercâmbio profundo e grande enriquecimento da geografia brasileira e francesa. O ano de 1956 marca a entrada oficial da União Soviética na UGI e tanto o congresso realizado no Brasil como o de Lisboa, em 1949, são lembrados pela diversidade de idiomas utilizados, pois é somente após esses dois eventos que se estabelecem as línguas oficiais (ROBIC et al., 1996, p. 301).

O grupo de geógrafos de esquerda vai ter um papel fundamental na participação do congresso, que tem como enfoque principal o recorte tropical, tanto

\footnotetext{
${ }^{125}$ A grande maioria dos números dos Annales de Géographie podem ser acessados pelo portal www.persee.fr .
}

126 Tradução nossa. 
na geografia física como na humana, envolvendo ambientes tropicais úmidos, semiáridos e subtropicais úmidos.

Da comissão oficial francesa constam Pierre George e Jean Dresch, mas não Tricart e Rochefort (COMPTES RENDUS, 1956, p. 6-9). Os trabalhos apresentados pelo grupo da geografia de esquerda serão publicados nos quatro volumes dos anais do encontro impressos entre 1956 e 1966:

Quadro 2 - Publicações do grupo de geógrafos de esquerda no Congresso da UGI realizado no Brasil em 1956 (tradução nossa).

\begin{tabular}{|c|c|c|}
\hline Autor & Título & $\begin{array}{l}\text { Volume e } \\
\text { página } \\
\text { nos anais }\end{array}$ \\
\hline DRESCH, Jean & $\begin{array}{l}\text { Depressões fechadas e encaixadas em } \\
\text { regiões secas, especialmente na África do } \\
\text { norte }\end{array}$ & $1^{\circ}$, p. 222 \\
\hline DRESCH, Jean & $\begin{array}{l}\text { Observações sobre as superfície de } \\
\text { aplainamento e os relevos residuais da } \\
\text { África tropical }\end{array}$ & $2^{\circ}$, p. 213 \\
\hline $\begin{array}{l}\text { GEORGE, } \\
\text { Pierre }\end{array}$ & $\begin{array}{l}\text { Ensaio de classificação dos fatores de } \\
\text { diferenciação dos bairros [quartiers] } \\
\text { urbanos em diferentes tipos de grandes } \\
\text { cidades }\end{array}$ & $3^{\circ}$, p. 315 \\
\hline $\begin{array}{l}\text { ROCHEFORT, } \\
\text { Michel }\end{array}$ & $\begin{array}{l}\text { Determinação dos tipos de cidade de uma } \\
\text { rede urbana }\end{array}$ & $3^{\circ}$, p. 426 \\
\hline TRICART, Jean & $\begin{array}{l}\text { Pesquisas de geografia aplicada do } \\
\text { Instituto de Geografia da Universidade de } \\
\text { Estrasbrugo em AOF [Aerofotografia (?)] }\end{array}$ & $1^{\circ}$, p. 368 \\
\hline TRICART, Jean & $\begin{array}{l}\text { Correlações dos períodos pluviais e } \\
\text { úmidos no norte e sul do Saara }\end{array}$ & $2^{\circ}$, p. 594 \\
\hline TRICART, Jean & $\begin{array}{l}\text { Tipos de assoalho fluvial e zonas } \\
\text { bioclimáticas na África ocidental }\end{array}$ & $3^{\circ}$, p. 35 \\
\hline TRICART, Jean & $\begin{array}{l}\text { Tipos de sistemas agrícolas e níveis de } \\
\text { vida na África ocidental francesa }\end{array}$ & $4^{\circ}$, p. 166 \\
\hline TRICART, Jean & $\begin{array}{l}\text { Fatores determinantes no lugar respectivo } \\
\text { de diversos meios de transporte na } \\
\text { economia comercial da Costa do Marfim e } \\
\text { do Senegal (África ocidental francesa) }\end{array}$ & $4^{\circ}$, p. 374 \\
\hline
\end{tabular}


Ao conferirmos a sugestão de temática por eixo, é possível encontrar a geografia da energia, dos capitais e investimentos econômicos, centros industriais e comércio mundial. No eixo sobre população destacam-se a descentralização industrial como fator de limitação do crescimento das cidades, 0 hábitat e 0 problema da colonização tropical (COMPTES RENDUS, 1956, p. 53-54).

Além dos franceses, é possível observar a participação de grandes nomes da geografia mundial, como Carl Troll da Alemanha, Guerassimov e Saushkin da União Soviética, Preston James e James J. Parsons, dos Estados Unidos, e Orlando Valverde, Bertha Becker, Ary França, Delgado de Carvalho, Milton Santos, Aziz Ab'Saber e Pedro Geiger, do Brasil, para citar somente os mais célebres na atualidade dentro da geografia humana. É nessa ocasião inclusive que Aziz e Milton aproximam-se de Tricart, que orientará seus trabalhos futuramente. Sternberg, que era organizador do encontro, proíbe que Tricart e provavelmente outros geógrafos de esquerda lecionassem nas universidades brasileiras, ainda que na Bahia ele tenha realizado alguns cursos ${ }^{127}$.

Os geógrafos pertencentes ao bloco comunista apresentavam livremente suas conferências sobre os processos de planificação, geografia econômica e geografia da população. Além desses aspectos, é importante lembrar que a UGI consolidou muitos processos de modernização e de transferência de conhecimento entre as escolas nacionais. Vejamos algumas de suas comissões de trabalho: no intervalo de 1949-1952, existe uma comissão sobre planificação regional; de 1964-1976, uma sobre métodos quantitativos e uma geografia aplicada; e, entre 1968-1984, uma sobre processos e características da urbanização. A temporalidade das comissão não são alheias aos ritmos da geografia na França e no mundo anglosaxão (ROBIC et al., 1996, p. 301-310).

Se, para a geração mais antiga, o ano de 1956 possibilitou a participação do congresso em terras brasileiras, o período significou aos mais jovens a mobilização para a Guerra da Argélia (1954-1962). Tal evento impele os geógrafos a estudarem a África do Norte, auxiliando na formação de uma base documental ou preparando elementos para instrução militar. Enquanto Bataillon trabalha com aerofotogrametria, Claval e Frémont elaboram lições e reflexões sobre o subdesenvolvimento e a

127 Destacamos ainda a viagem que Rochefort faz à Bahia por convite de Milton Santos em 1956. Entre 1960-1961 ele volta por intermédio da Embaixada da França e leciona na Universidade de Pernambuco. Em 1964 coordena com Lysia Bernardes um grupo sobre o Rio de Janeiro (BOMFIM, 2007, p. 122). 
colonização (BATAILLON, 2009, p. 60). Em 1955, através do serviço militar, Brunet vai para a fronteira da Tunísia e Argélia (ALLEMAND, 2007, p. 56). A experiência prática e fora do continente europeu marcou profundamente essa geração. Curiosamente, Lacoste no futuro alardeará o mundo sobre a importância da geografia para se fazer uma boa guerra, mas fala muito pouco sobre o episódio argelino e o papel do nosso campo disciplinar.

Dentro do partido comunista o quadro é caótico com Thorez doente e em desacordo com Kruchov. A Guerra da Argélia impulsionava o anticomunismo no quadro da guerra fria, e o partido se abstém assumindo um tom comedido diante do conflito no Magreb (LIAUZU, 2010, p. 434). Nessa conjuntura, Dresch de forma independente:

(...) publica na La Pensée de julho um artigo afirmando a realidade do 'fato nacional argelino' tomando distância da tese de Thorez sobre o melting-pot argelino em formação, que permaneceu imutável desde 1939, tese retomada ainda em 1955 nos Cahiers du Communisme por um texto de Léon Felix em 2 de fevereiro. A população europeia da Argélia é um dos motivos deste constrangimento (LIAUZU, 2010, p. 434).

A postura oficial do partido enfraquecido é de lutar na guerra enquanto, Dresch continua a fazer oposição. Como coloca Liauzu (2010, p. 438), as colônias nunca foram pensadas a partir da perspectiva da revolução.

Enquanto a guerra acontecia no norte da África, no início da década de 1960, Boudeville revisa as ideias de Perroux com o objetivo de lhe atribuir um caráter ainda mais prático. Jean Labasse também acaba fazendo críticas ao modelo dos polos ao envolver-se no planejamento. Labasse é um dos geógrafos que dirige seu pensamento para a apreensão da ação dos atores. Os desequilíbrios regionais surgem em sua análise como oposição entre o planejamento, que é qualitativo e espacial, e o desenvolvimento, que é quantitativo e econômico. O resultado perverso são os espaços negligenciados (COUZON, 2003, p. 96-98) pelos polos de crescimento:

(...) polos de crescimento, sob o ângulo da economia, se calam frente a desorganização, ou ainda, quando as estruturas de origem rural, industrial e citadinas não foram cuidadosamente preparadas, e o investimento positivo em um primeiro momento se torna negativo no segundo (COUZON, 2003, p. 98) $)^{128}$.

128 Tradução nossa. 
Labasse indica a problemática de integração de determinados planos em conjunto com a dinâmica regional que existia anteriormente.

Nesse momento, George realça suas diferenças para com as teoria dos polos. Ele destaca a presença das atividades terciárias, o que "conduz ao estudo dos fluxos visíveis e invisíveis e as relações de poder econômico, social e político" (BOYER, 2008, p. 12). A reedição da ideia de região coincide com um novo ciclo do planejamento territorial, pois paralelamente a uma visão mais econômica da região é possível identificar uma aproximação mais geográfica e clássica deste conceito, visto como um produto da ação humana compreendida através da história social e natural (BOYER, 2008, p. 12).

Diferentemente de um enfoque mais abstrato do espaço econômico, ou buscando o concreto na atividade das empresas, como faziam os economistas, George e seus alunos analisam a cidade como centro de serviços e elemento organizador do espaço regional. Essa tendência marcou a geografia da época, pois "contrariamente aos economistas dos anos 1950, [alguns] geógrafos não insistem tanto nos 'polos de crescimento'” (BOYER, 2008, p. 13), mas na concepção mais próxima de Christaller. Como veremos, esse tipo de trabalho será desenvolvido por M. Rochefort, que substitui a tradicional monografia urbana pelo estudo de rede de cidades (BOYER, 2008, p. 13).

O quadro completo compõe uma tensão e uma complementaridade entre a região geográfica e a região econômica inspirada por Perroux. Na geografia o ideal de crescimento econômico advindo das ideias de Perroux gera um legado tão forte no período, que o geógrafo brasileiro exilado, Manoel Correia de Andrade, escreve um livro sobre os polos de desenvolvimento publicado em 1967129. São fatos conhecidos que Andrade leu Reclus - influente no pensamento anarquista brasileiro na década de 1930 -, que era amigo pessoal de Caio Prado Jr. e que estudou Kautsky para a preparação de sua mais célebre obra Terra e homem no Nordeste. Entretanto, o exílio o confrontou com esse legado que permitiu pensar a situação nordestina e dinamizar a geografia econômica (ANDRADE, 2008, p. 200).

\subsection{A nova geografia e o contexto da guerra fria nos Estados Unidos}

\footnotetext{
129 Trata-se de ANDRADE, Manuel C. Espaço, polarização \& desenvolviemento publicado em Recife no ano de 1967 e depois reeditado em São Paulo, pela editora Atlas em 1987.
} 
$\mathrm{Na}$ Europa, os chamados anos dourados do pós-guerra são sinônimo de crescimento econômico e ação do planejamento devido à experiência da reconstrução dos territórios destruídos financiados através do Plano Marshall. Enquanto isso, nos Estados Unidos também existia a preocupação com a ação estatal visando resolver problemas sociais e econômicos, e este é um dos estopins para o surgimento em meados da década de 1950, da nova geografia. O status quo norte-americano tem a preocupação de elaborar modelos de planejamento e análise geográfica que pudessem ser aplicados fora de seu território, além de desenvolver tecnologias que pudessem oferecer vantagens militares e socioecônomicas no contexto da guerra fria. A geografia, assim como várias outras ciências, foi convocada para dar sua contribuição.

Peet (1985a, p. 328) destaca o esgotamento explicativo do darwinismo e das metáforas naturalizantes dentro da geografia. Os novos fenômenos empíricos e a necessidade de planejamento não necessitavam tanto da ideologia, que relacionava o nacionalismo, a natureza, o destino latente e até o desígnio divino com a formação territorial, nação, Estado e povo, pois tais ideais já estavam consolidados na superestrutura. O Estado como organismo esvanece na história após o nazismo e a geografia alinha-se com um novo ciclo de metáforas baseadas na física, que aos poucos mostra-se inaplicável, pois o espaço se recria, a superfície da terra é variável e o comportamento humano nem sempre é previsível (PEET, 1985a, p. 328) ${ }^{130}$.

A nova geografia é uma das primeiras correntes que rompe amplamente com a dinâmica das escolas nacionais, ou das geografias mais ou menos isoladas, ganhando uma abrangência internacional (SANTOS, 2002, p. 61). De acordo com Claval:

\begin{abstract}
A corrente de reflexão epistemológica que nasceu em Viena no começo dos anos 1920, e que transforma a ideia que se faz de ciência em todo o mundo anglo-saxão após 1935, tem apenas um impacto bem limitado até a metade dos anos 1960: Fred K. Schaefer é sem dúvida o único geógrafo na América a tirar partido das teses do círculo de Viena e Popper. Mas seu artigo permaneceria desapercebido sem a polêmica que Hartshorne inicia. William Bunge ressalta seu alcance após sua publicação - mas as novas orientações já são fortes (CLAVAL, 1984, p. 93) ${ }^{131}$.
\end{abstract}

\footnotetext{
130 Segundo Barnes (2001, p. 548), William Warntz, da Universidade de Princeton, nos anos 1950, foi um dos primeiros a usar os modelos da física para pensar a geografia econômica a partir de seu laboratório de pesquisa interdisciplinar.
}

131 Tradução nossa. 
Ironicamente, Schaefer era militante do partido socialista alemão e teve que migrar diversas vezes devido às perseguições políticas. O pai fundador da nova geografia, considerada reacionária, era socialista e polemiza sobre a necessidade de leis gerais e da relativização da unicidade dos lugares. Filho de um operário, até 1925 ele era secretário da juventude do partido social-democrata alemão. Frustrado com a política, Schaefer resolve estudar geografia e ao mesmo tempo trabalha em uma associação para o auxílio de desempregados (BUNGE, 1979, p. 128-129). Na pós-graduação interessa-se pela geografia econômica, e devido à sua vinculação partidária atua na prefeitura de Berlim como estatístico até ser afastado pelos nazistas (BUNGE, 1979, p. 129).

Schaefer exila-se na Inglaterra, onde o reconhecimento de seu trabalho intelectual e seu capital militante permitem o desenvolvimento de pesquisas na New Fabian Research Bureau ${ }^{132}$ e o aprimoramento de sua formação na London School of Economics. Em 1938 ele se refugia nos Estados Unidos, onde continua denunciando a ameaça nazista na Alemanha e na Ingleterra (BUNGE, 1979, p. 189).

Entretanto, fora seu célebre artigo, não existem muitas outras obras de sua autoria com destaque. Schaefer entra em contato com o positivismo a partir de seu relacionamento com Gustav Bergman, que participou do grupo original do Círculo de Viena e que também migrou fugindo do nazismo.

Os dois intelectuais se conhecem na Universidade de lowa nos Estados Unidos (UNWIN, 1995, p. 161). Schaefer, envolvido com marxismo, continuava ligado à esquerda e não sairia impune da atmosfera macarthista que cassava comunistas em diversos setores da sociedade. Dessa maneira, ele sofreu pressões do $F B I$ e Unwin indica que devido às suas afinidades socialistas Schaefer e Bunge foram pressionados pelo status quo da universidade (UNWIN, 1995, p. 175).

Em uma época de poucos geógrafos de esquerda, Schaefer ousava introduzir o debate político na geografia. Em 1947 ele troca cartas com Christaller e traduz A. Lösch para o inglês. Em 1950 organiza um curso que aborda a obra dos dois geógrafos, além de Hoover e von Thünen, e concomitantemente leciona sobre a geografia da União Soviética com materiais que havia recolhido no percurso do exílio (BUNGE, 1979, p. 130).

132 Órgão da Sociedade Fabiana, um grupo socialista que defende o reformismo e compõe a esquerda inglesa desde o século XIX. Seu símbolo é uma tartaruga, que representa o gradual e firme avanço das reformas rumo ao socialismo. 
Segundo Bunge (1979, p. 130), seu texto sobre o excepcionalismo seria um capítulo metodológico de um livro sobre geografia política que tinha como objetivo demonstrar a centralidade do capital através de modelos matemáticos. Entretanto, a morte prematura de Schaefer mobilizou seu amigo Bergman, que organizou e publicou seu texto metodológico (BUNGE, 1979, p. 132).

A crítica de Schaefer no artigo confronta o pensamento de Hettner, que possui uma postura kantiana de que a geografia seria uma ciência idiográfica, sem leis rígidas, e relacionada com um historicismo estéril (MARTIN, 1989, p. 74). A consequência é o surgimento de uma disputa entre Schaefer, falecido, e o maior representante do pensamento de Hettner nos Estados Unidos, R. Hartshorne.

A controvérsia de Schaefer e Hartshorne gravita em torno do dilema se a geografia seria uma ciência nomotética ou idiográfica. Ou seja, Schaefer acredita que a descrição não explica a distribuição dos fenômenos e a tarefa do geógrafo seria encontrar leis geográficas que explicam as estruturas espaciais como resultados de processos (BUNGE, 1979, p. 130). O espaço ganha mais importância que o recorte regional, seja devido às relações espaciais entre os fenômenos, seja por conta de seus resultados morfológicos englobados em três categorias: centralidade, extensão e forma (BUNGE, 1979, p. 132).

Curiosamente, Hartshorne tem uma postura anticomunista e produz estudos com viés geopolítico, apesar de serem comumente interpretados como geografia política (VESENTINI, 2008, p. 12) ${ }^{133}$. Vesentini, com base nessa polarização simplifica o debate indicando que Hartshorne representa a democracia conservadora e Schaefer um "autoritarismo" que anseia a uma dimensão universal - denominação que insinua o stalinismo (VESENTINI, 2008, p. 13). Entretanto, como vimos, os antecedentes de Schaefer relacionam-no muito mais com a social-democracia do que com o stalinismo e o marxismo ortodoxo, apesar de sua simpatia pela União Soviética vencedora do nazismo que o oprimiu diretamente.

Contudo, é possível que a disputa entre os dois tenha ido além da epistemologia, atingindo dimensões institucionais. Um fato pouco conhecido é que Hartshorne trabalhou para CIA. A grande dúvida é se ele utilizou sua influência para afetar Schaefer e seus partidários durante a guerra fria. Isso porque:

\footnotetext{
133 Bowman foi um dos geógrafos que durante a ascensão da geopolítica optou por afastar o termo do uso corrente para evitar associações com sua geografia política e não auxiliar o fortalecimento do ideário nazista. Hartshorne, herdeiro desse contexto, tenta criar em 1950 uma geografia política como conhecimento cívico, neutro, científico, livre de controvérsias e consensual. Ou seja, uma geografia política sem conflitos (TUATHAIL, 1994, p. 324).
} 
Durante a Segunda Guerra Mundial, um dos mais influentes geógrafos do século - Richard Hartshorne - trabalhou no OSS (Escritório de Serviços Estratégicos que foi o precursor da $\mathrm{ClA})^{134}$ ao lado de economistas, sociólogos e figuras da escola de Frankfurt, como Hebert Marcuse, Carl Schorke e Franz Neumann, com absoluta ausência de sua influência teórica (SMITH, 2001, p. 7) $)^{135}$

Um dos economistas que participaram da comissão era o marxista Paul Sweezy. Mesmo assim o pensamento de Hartshorne parece insensível ao contato com os marxistas e com a teoria que sem sombra de dúvidas estava na vanguarda da pesquisa social.

Comentadores, como Martin (1989), indicam que Bunge (1979) exagera na natureza do conflito entre Hartshorne e Schaefer, dando a entender que o primeiro havia usado sua influência no governo para perseguir e prejudicar o segundo ${ }^{136}$. Segundo Martin, faltariam provas concretas de tal fato, embora a situação permaneça ambígua.

Isso não evitou que as ideias de Schaefer consolidassem um grupo de pesquisa na geografia. Os space cadets como ficaram conhecidos os geógrafos que impulsionaram boa parte da nova geografia nos Estados Unidos eram Garrison, R. Morrill, B. Berry, W. Bunge, Ullman e Mayfield (MARTIN, 1989, p. 74-75). Assim:

\begin{abstract}
Dentro da geografia o trabalho de Christaller começou a ser revisto, e o de Ackerman, Crowe, Garrison, Hägerstrand, Hoover, Isard, Kendall, Lösch e Warntz começaram a despertar a atenção, especialmente daqueles que queriam redirecionar a geografia americana. Os jovens acadêmicos produziram um 'nova geografia' que não estava em oposição ao que foi publicado em The Nature, talvez sem perceber que existiram várias outras 'novas geografias' na história da geografia americana. A 'nova geografia' representou o crescimento e foi uma parte do processo da evolução disciplinar (MARTIN, 1989, p. 7) 137
\end{abstract}

Sinteticamente, com o aparecimento da nova geografia temos a aplicação de teorias matemáticas para o estudo do espaço, buscando leis gerais e formas de estudar espaços e variáveis discrepantes através de um método mais ou menos semelhante para todos os ramos da geografia. Ganha força a teoria geral dos

\footnotetext{
134 Segundo Barnes e Farish (2012), mais de 100 geógrafos trabalharam para o escritório.

135 Tradução nossa.

${ }^{136}$ A controvérsia complica-se cada vez mais porque Hartshorne teria supostamente reprovado Bunge numa tentativa de entrar no pós-doutorado em Wisconsin (MARTIN, 1989, p. 83).
}

137 Tradução nossa. 
sistemas, o método hipotético-dedutivo, a teoria dos jogos e o conceito de espaço geométrico/cartesiano.

Alguns conceitos, como o de paisagem, são colocados em suspenso. Através da obra de Isard cria-se a chamada ciência regional, uma geografia aplicada ao estudo regional de potencialidades econômicas de acordo com as análises quantitativas (CLAVAL, 1984, p. 93-106).

Segundo Holton-Jenson (2009, p. 142-143), o rápido crescimento da nova geografia nos Estados Unidos gera uma tecnoburocracia eficiente dedicada aos sistemas de controle espacial, ao mesmo tempo que oferecia aos geógrafos uma zona neutra das investigações promovidas pela era McCarthy.

Para aqueles que deixaram de lado a geografia regional, abre-se um novo horizonte de ideias, e a leitura de Habermas, Kuhn, Popper, Stewart, Toulmin e Zipf tornava-se obrigatória (MARTIN, 1989, p. 81).

Hartshorne continuou trabalhando para o governo dos Estados Unidos, mas paralelamente o grupo da nova geografia também começou a atuar entre os militares norte-americanos durante a guerra fria. Através de um projeto militar, William Garrison e Waldo Tobler desenvolveram os sistemas de informação geográfica, mais conhecidos pela sigla SIG ou em inglês GIS (BARNES e FARISH, 2012, p. 89). Da mesma forma que seu antecessor, os dois geógrafos montavam projetos que eram essencialmente interdisciplinares, porém, diferentemente de Hartshorne, eles se envolveram com as ciências e com as teorias empregadas no projeto.

Assim, o primeiro curso sobre estatística em geografia lecionado por Garrison em 1955, na Universidade de Washington, em Seattle, estava ligado ao Ministério da Defesa e tinha como alunos B. Berry e R. Morrill. O Estado divulgava a nova geografia, mas a iniciativa privada também a valorizava, uma vez que vários geógrafos interessam-se pelas novas técnicas com o objetivo de se qualificarem para o mercado de trabalho (MUIR, 1978, p. 323).

Além de projetar modelos, o arranjo regional deveria compor-se de um processo econômico racional, representado e analisado matematicamente. O desejo dos comandantes da guerra fria era de que a região fosse racional, aplicável, comparável, generalizada e fundamentada em critérios rígidos de delimitação (BARNES e FARISH, 2012, p. 101). Decididamente essas características estavam todas em aberto no pensamento de Hartshorne. 
A tecnificação da inteligência militar ofereceu resultados "científicos" e pragmáticos, diminuindo o número de cientistas empregados. Garrison participa da elaboração de um plano para evacuação de Washington em caso de ataque, enquanto William Bunge, convocado para lutar na Guerra da Coreia, acaba trabalhando em uma escola de guerra. O resultado é a publicação alguns anos depois de um atlas sobre a guerra nuclear, resultado da simulação de cenários de ataque e da avaliação dos pormenores destrutivos de tal conflito (BARNES e FARISH, 2012, p. 101-102).

A boa formação em matemática de Bunge e sua disputa com Hartshorne o colocavam quase que naturalmente na dinâmica de Seattle, base institucional dos space cadets. Sua primeira obra de importância foi Theoretical Geography, de 1962, edição de sua tese de doutorado e publicada com a ajuda de Hägerstrand, uma vez que o clima de rivalidade com Hartshorne resultou em um pedido de retirada do reconhecimento da tese de Bunge (BUNGE, 2011, p. III).

A carreira de jovem tecnocrata caminhava bem até que uma grande caça aos comunistas em lowa ocorreu entre 1960 e 1961. Bunge muda-se para a Wayne State University, em 1962, onde estuda o gueto de Fitzgerald na cidade de Detroit e se distancia dos space cadets em função da guerra do Vietnã e de sua preocupação com os problemas sociais dos Estados Unidos. Essa mudança provoca uma transformação gradual na sua perspectiva do conhecimento, porque Bunge vai se afastar cada vez mais da abordagem nomotética e aproximar-se do viés idiográfico a partir do estudo do gueto (BUNGE, 2011, p. III). Veremos mais adiante como isso ocorre.

\subsection{Edgar Kant, Hägerstrand e a escola de Lund}

Outro polo importante de difusão da nova geografia é a escola de Lund, na Suécia, que estabelece fortes laços de troca com geógrafos ingleses e norteamericanos, formando uma rede. Hägerstrand desenvolverá modelos para o estudo dos domínios geográficos dos indivíduos, além de seu célebre texto sobre a difusão de inovações tecnológicas no espaço ${ }^{138}$. O modelo matemático de Monte Carlo foi um elemento que influenciou suas teorias e Hägerstrand toma conhecimento dele através de seu amigo de infância Erik Fröberg. Físico, ele construiu o primeiro difusão é homogeneizadora e admite que as culturas tradicionais não são capazes de inovações. 
computador da escola de Lund e traz o modelo depois de uma visita aos Estados Unidos (GOULD e STROHMAYER, 2004, p. 9).

Além disso, Unwin (1992, p. 170-171) demonstra que a escola de Lund foi influenciada pelas ideias urbanísticas da escola de Chicago. Através da teoria da difusão técnica, a concepção de um ponto de força local que se espraia no espaço aparece mais uma vez e é retrabalhada. Na teoria de Von Thünen, de Christaller, da escola de Chicago e na obra de Franz Boas, para citar alguns exemplos, o espaço organiza-se por um ponto central, e a partir de seu afastamento existe uma diversificação de fenômenos e/ou um enfraquecimento de seu dinamismo original. Portanto, sua teoria recria mais uma vez uma ideia própria da geografia alemã, que já havia elaborado modelos altamente explicativos.

Seu trabalho chega aos Estados Unidos traduzido por Allan Pred, que se interessa sobre a difusão espacial. Veremos que Härgerstrand será uma peça importante na crítica feita ao estruturalismo por parte dos geógrafos anglo-saxões, além de inspirar A. Giddens em suas reflexões teóricas. A originalidade da escola de Lund remete parcialmente a Edgar Kant:

\footnotetext{
O trabalho de Christaller, August Lösch e outros foi introduzido na Suécia por Edgar Kant (1902-78), um estoniano que havia testado suas teorias em sua terra natal, refugiando-se em Lund depois da Segunda Guerra Mundial (...) Seu assistente de pesquisa entre 1945-46 foi Torsten Hägerstrand (1916-2004). Além de sua esposa, Hägerstrand teve contatos com o etnólogo suéco Sigfrid Svensson, que produziu numerosos estudos sobre a relação entre inovação e tradição em áreas rurais utilizando a metodologia em voga na época (HOLTON-JENSEN, 2009, p. 87-88) ${ }^{139}$.
}

Edgar Kant foi o geógrafo que cuidou do planejamento da Estônia durante a década de 1930, ocupando altos cargo de comando. Ele foge de seu país depois da invasão soviética, em 1944, uma vez que durante a ocupação nazista entre 1941 e 1944 Kant era reitor da Universidade de Tartu. Extremamente nacionalista, voluntário na guerra da independência estoniana, seus estudos do hábitat cantam as glórias da pátria (JAUHIAINEN, 2005, p. 199)

Seu interesses, todavia, são muito parecidos com os temas desenvolvidos por Hägerstrand: ecologia humana, estudos do hábitat, fluxos de migração, influência das cidades no arranjo regional, dinâmica e economia regional, e no final da vida linguagem e termos utilizados pela geografia (BUTTIMER, 2005, p. 175-177).

139 Tradução nossa. 
Sua geografia urbana sintetiza um pouco seu projeto intelectual como um todo, uma vez que na sua obra a cidade é vista como: (1) a vida cotidiana em seu sentido orgânico e sua organização espacial; (2) como um conjunto de instituições que organizam o espaço; e (3) como um discurso permeado por concepções socialmente produzidas - este último item é desenvolvido no final de sua carreira. $O$ estudo dos centros regionais e seu hinterland permitiram oferecer um retrato da divisão do trabalho (JAUHIAINEN, 2005, p. 193).

Kant está desvinculado da política científica de Febvre e recebe influência de Ratzel, bem como de Vidal de la Blache e seu aluno Max Sorre. É amigo de Demangeon e pautado na matriz francesa realiza uma geografia aplicada ligando economia e consumo à ecologia ou ainda gênero de vida e hábitat (BUTTIMER, 1991, p. 177). Conhecedor da obra de Kropotkin e interessado na autonomia local, tem grande preocupação com a distribuição dos serviços públicos. Durante a ascensão da nova geografia, Kant vê a matematização como um instrumento que torna a disciplina mais precisa e rigorosa.

Ao ter esse panorama da geografia de Kant podemos entender melhor o projeto de Härgerstrand e seu conceito operacional de domínios espaço-temporais, um grande chamariz que atraiu o sociólogo Giddens: "Durante os anos 1960, Hägerstrand passou a realizar estudos detalhados do comportamento individual, usando modelos tridimensionais para enquadrar o movimento individual no tempo e espaço" (HOLTON-JENSEN, 2009, p. 89).

Antes de Giddens, Allan Pred também recupera a geografia espaço-temporal em 1977. Para Pred (1977, p. 207-209), essa abordagem permite analisar as estruturas sociais por um viés humanístico, pois busca a diagramação da existência humana em uma trajetória no espaço e no tempo com estágios e domínios representados por um pequeno território onde os eventos ocorrem. Pred (1977, p. 209) destaca os níveis observados: (1) o tempo biológico, o tempo de reprodução natural (comer, dormir, etc.) e as limitações impostas pela tecnologia de transporte disponível juntamente com o tempo de deslocamento; (2) o local e o período em que o indivíduo se sociabiliza através de pessoas, grupos ou objetos; e (3) limitações espaciais relacionadas às leis, normas, barreiras econômicas e relações de poder. Assim:

Os detalhes corográficos de uma população-sistema e o processo de atividade-sistema correspondente são principalmente o resultado da: indivisibilidade de cada população-sistema membro; dos requisitos de 
competência específica de cada função; da imobilidade das estradas e construções; dos requerimentos de tempo no movimento das interações espaciais, e do fato de que uma vez que todas as funções de atividade do conjunto estejam preenchidas, o conjunto torna-se fechado para participantes adicionais (PRED, 1977, p. 209).

A segunda escala de análise, mais ampla, permite compreender o sistema de uma população dentro de uma área, analisando onde habitam e qual sua demanda por recursos (PRED, 1977, p. 209). O delineamento geográfico permite ver as barreiras dos fenômenos sociais, criando uma sincronia entre o local e um conjunto espacial mais amplo. O método de Hägerstrand preenche uma lacuna da ecologia humana e segundo Pred (1977, p. 210-211) ele foi usado para melhorar a distribuição e acesso dos serviços públicos no planejamento, além de permitir uma geografia histórica a partir da observação da paisagem, estudos sobre migração e crescimento urbano. A abordagem de Hägerstrand é sociológica, ecológica e técnica, e sem pressupostos na análise social, apesar de privilegiar certas variáveis ${ }^{140}$.

Além de Edgar Kant, Hägerstrand também trabalha com Gunnar Myrdal, que, inspirado pela escola de Frankfurt, é cético em relação à neutralidade científica. A projeção da teoria de Hägerstrand permitiu que ele ocupasse vários cargos no governo e com sua geografia aplicada criou um nicho de atuação profissional para os geógrafos. Ele trabalha com Myrdal no Ministério do Interior em um projeto interdisciplinar de longa duração sobre urbanização (LENNTORP et al., 2004, p. $325-326)^{141}$.

É importante ter em mente que a partir da nova geografia populariza-se, principalmente na geografia norte-americana, a ideia de sistema, que posteriormente será associada à estrutura. Devido a busca por leis gerais, a nova geografia tentou compreender os mecanismos que criam os padrões espaciais (GREGORY, 1978, p. 42).

Se Hägerstrand elaborou um modelo para os indivíduos e depois para pequenos agrupamentos, Parsons e Chorley nos Estados Unidos querem um modelo de sistema social. Para isso postulam que esse sistema deve adaptar-se ao

\footnotetext{
$140 \mathrm{Na}$ transição entre a nova geografia e a geografia crítica nos Estados Unidos, Pred (1977, p. 218) diz que o modelo de Hägerstrand será criticado por ter uma postura individualista e burguesa.

141 Como mostram Benko e Scott (2004, p. 55), Myrdal, Petrella e Hirschman serão alguns economistas influenciados por Perroux e seu grupo. Inclusive Myrdal sempre será um economista de centro-esquerda, até converter-se completamente depois da ascensão do neoliberalismo (THERBORN, 2012, p. 131).
} 
meio ambiente e suas mudanças, além de manter uma integração interna, atender metas específicas e resolver suas tensões internas. São conjuntos que se reestruturam e representam uma tentativa de superar a dualidade entre sociedade e natureza na geografia (GREGORY, 1978, p. 42). O princípio unitarista de Comte ou a busca por um método científico que fosse universal endossa essa perspectiva.

Entretanto, com o passar dos anos a geometria espacial não apresentou resultados satisfatórios para os problemas sociais. Quando esses geógrafos que buscavam leis imutáveis deparam-se com o marxismo, começam a perceber que as leis científicas não são eternas, mas estão historicamente submetidas à dialética social. Talvez essa seja uma explicação possível para a identificação entre sistema e estrutura enquanto modelo social, já que ambos possuem uma composição mais ou menos estável em suas lógicas internas.

Se o estruturalismo será criticado por sua falta de dinamismo ao captar as transformações sociais e sua tendência a uma reprodutibilidade estável, a análise dos sistemas oferecia uma perspectiva ainda mais rígida de leis quase eternas ligadas à dinâmica de troca de energia entre os elementos integrantes, muitas vezes desprovida de dimensão histórica (GREGORY, 1978, p. 74). Independente da união entre sistema e estrutura, segundo Bird:

\footnotetext{
Pode-se prontamente entender por que os geógrafos tornaram-se interessados nas estruturas, e isso inclui o movimento em busca dos sistemas na geografia física. O desejo de responder a questão 'como?', o interesse nos processos, desenvolvem a questão 'por quê?' na geografia humana e finalmente no debate 'para quê?' e 'para quem' (...) atrás do mundo das aparências há o mundo das estruturas, e estas, escondidas primeiramente, podem ser reveladas pelo pensamento lógico e testada contra o funcionamento do sistema. (BIRD, 1989, p. 87) ${ }^{142}$.
}

\subsection{O início tardio da nova geografia na França e a reorganização da} esquerda

De acordo com Robic e Pumain (2002, p. 130), é apenas tardiamente que a nova geografia aflora com força na França, fruto da consciência de conceitos universais e de uma ruptura com a geografia idiográfica. O processo buscou uma renovação teórica, mas apresentou muitas características semelhantes ao que havia ocorrido nos outros países:

142 Tradução nossa. 
(...) a rapidez da tomada de consciência coletiva que uma reforma da geografia era necessária, fez com que nos anos 1970-1972 acontecessem eventos dentro disciplina; o papel de referência que tem inicialmente os desenvolvimentos da 'nova geografia' nascida nos Estados Unidos e em Lund em meados dos anos 1950; a ampliação do esforço de formação que mobilizou uma rede informal de jovens professores-pesquisadores a partir da década de 1970; a conjugação de uma reflexão sobre a quantificação e sobre a teorização em geografia; a ênfase colocada sobre o interesse da modelização acerca das necessidades metodológicas de análise espacial e sobre a noção de sistema (ROBIC e PUMAIN, 2002, p. 138) ${ }^{143}$.

Amplamente difundida, a nova geografia busca neutralizar o debate político conferindo um caráter técnico e científico às questões de reverberação social. $A$ instrumentalização do conhecimento geográfico justifica a ação do Estado ou de outros atores sociais e confere à ciência uma suposta idoneidade. A ciência instrumentalizada é supostamente a melhor maneira de resolver os problemas sociais, no entanto, os agentes sociais transformam os problemas políticos em questões técnicas e muitas vezes a comunidade não é considerada na construção da ciência.

O grupo Dupont foi essencial para a consolidação da nova geografia na França e na Suíça, liderado por de J.-B. Racine e Antoine Bailly (ALLEMAND, 2007, p. 28). Contando com Durand-Dastès como um de seus animadores, em 1976 o grupo organiza um colóquio em Genebra sobre teoria e geografia e sofre críticas feitas pelos geógrafos da Espace Temps - analisados abaixo - por serem supostamente de direita. Os membros do Dupont que envolviam geógrafos suíços, fomentavam ataques e discussões com os membros do grupo da revista Hérodote ao mesmo tempo em que insinuavam aproximações entre o estruturalismo marxista e a teoria geral dos sistemas (CHAMUSSY, 1997, p. 138 e 143) ${ }^{144}$. Contudo, vários membros do grupo participaram da revista L'Espace Geographique, um dos mais importantes vetores de modernização da geografia francesa.

Paul Claval, entretanto, já havia muito antes se ligado à nova geografia através da geografia econômica, em 1958. Ele sofre influência dos trabalhos de Isard através da economia espacial e da abordagem microeconômica (ALLEMAND, 2007 , p. 77). A primeira edição de seu livro, A nova geografia, de 1977, constitui-se como obra de divulgação.

\footnotetext{
143 Tradução nossa.

144 Sediado na cidade de Avignon, o grupo continua a promover os colóquios pelo nome Géopoint até os dias de hoje. O site do grupo é http://www.groupe-dupont.org (acessado dia 07/01/2013).
} 
Se a nova geografia alastrava-se pelo mundo, na França, em determinados núcleos, não é possível apagar a força do pensamento de esquerda. Mesmo com o alto nível de tecnicismo e cientificismo, o envolvimento ideológico marxista de alguns geógrafos repercute no planejamento e na geografia voltada para o Estado - quadro que se altera com a denúncia da geografia cúmplice do Estado, pela geografia crítica.

Se, por um lado, depois da invasão da Hungria o marxismo perde muita força na França, de outro o maoísmo e a revolução chinesa atraem a militância apresentando-se como um modelo alternativo ao soviético. Ocorre então um degelo do marxismo, que começa novamente a ser debatido pela intelectualidade. $O$ estruturalismo althusseriano surge com força e permanece entre o marxismo soviético e o maoísmo (DOSSE, 2007, p. 366-388). Nesse contexto, o althusserianismo, com seu aporte positivista, serviria como forma de manter distância das querelas políticas que envolviam a União Soviética - como o estigma do stalinismo.

Enquanto Kruchov combatia o fantasma stalinista e buscava diminuir a intensidade da guerra fria com os EUA, Mao via nesse contexto uma oportunidade de ser o centro do comunismo mundial, opondo-se às reformas propostas e investindo na ideia de que a revolução no terceiro mundo era possível e necessária. Mao começa a polarizar as guerrilhas rurais na África e criará um sistema de auxílio à Albânia, Cuba e Argélia. No caso albanês, existia uma comum aversão à política anti-Stálin, e no caso de Cuba e Argélia a possibilidade de construção de um regime socialista a partir da guerrilha rural, o modelo revolucionário chinês. No entanto, Mao não queria ficar distante da ajuda militar e dos equipamentos de ponta proporcionados pela União Soviética (CHANG e HALLIDAY, 2006, p. 566-567).

O momento de crise, anunciado desde meados da década de 1950 transforma-se em uma situação de renovação durante a década de 1960, porque temos a redescoberta da obra de Lukács, Rosa Luxemburgo e Korsch, e uma ampliação do debate sobre a estética, sobre o realismo socialista e sobre a obra de Kafka (MÁREK, 1987, p. 314-315). Existe também a redescoberta do freudomarxismo da escola de Frankfurt, de Marcuse, de Reich, Eric Fromm e a obra do italiano A. Gramsci. Enquanto a maioria da esquerda fazia um esforço para formar um marxismo humanista, Althusser fazia um esforço para elaborar sua antítese para além do humanismo burguês e dos valores morais. 
Lembremos que todas essas redescoberdas nada mais são do que buscas alternativas ao colapso do stalinismo. Nesse contexto, os processos sociais na China e em Cuba engendraram fôlego novo no debate sobre a prática política e a construção do socialismo (MÁREK, 1987, p. 315-319)145. Entretanto, para analisarmos o surgimento da geografia ativa e posteriormente da inserção do estruturalismo althusseriano na geografia, faz-se necessário compreender alguns eventos e obras que envolvem o grupo de geógrafos de esquerda.

Retrocederemos então à década de 1960, época em que a nova geografia já desfrutava de sua influência mundial e local, apresentando-se como um desafio para a escola francesa de geografia, mas ainda não tinha recrutado um corpo acadêmico suficientemente forte para fazer sentir sua presença como nos anos de 1970.

No ano de 1960, Yves Lacoste, André Prenant e André Nouschi publicam um livro sobre a Argélia (LACOSTE et al., 1960). O livro é publicado pela Éditions Sociales, editora ligada ao partido comunista francês, e é prefaciado por Jean Dresch o que evidencia a ligação da rede. No prefácio, Dresch reafirma a luta antiimperalista de maneira que as relações entre Argélia e França tornem-se mais igualitárias.

O livro apresenta três partes e cada um dos autores escreve sobre um aspecto da Argélia. Lascoste escreve sobre sua pré-história, estendendo-se até meados do século XVI e toma como fio condutor a ideia de que o povo argelino tem uma história própria e que sofreu uma sucessão de invasões - romanos, cartaginenses, árabes e turcos. Neste livro Lacoste (1960) debate muito com as contribuições de Ibn Khaldum, geógrafo árabe da Idade Média, que será seu objeto de estudo de maneira mais aprofundada. Temos através desse livro, e do artigo publicado em La Pensée, o germe de seu futuro Ibn Khaldum, publicado em 1966.

André Prenant, por sua vez, escreve sobre o quadro físico da Argélia, ressaltando o clima árido ou semiárido e a existência abundante de recursos

\footnotetext{
145 É na década de 1960 que boa parte dos autores do marxismo heterodoxo chegam ao Brasil. Em parte, devido ao ISEB (Instituto Superior de Estudos Brasileiros). Sobre a revolução cubana, ela é símbolo do que poderia ser uma possível revolução armada na América Latina e inspira parte da esquerda latino-americana. No entanto, Régis Debray, estruturalista e posteriormente seguidor de Che na Bolívia, escreve obras sobre sua experiência, tornando o divulgador francês do guevarismo. É nessa época, como indica Paulo Arantes (1994, p.43-46 e p. 234-300), que o estruturalismo althusseriano chega ao Brasil e é criticado por filósofos e sociólogos. Destacam-se José Arthur Gianotti e Ruy Fausto, inspirados por Bento Prado, ou ainda, Leandro Konder. No caso de Gianotti, a preocupação suscitada por Bento gerou um interesse pela constituição categorial refutando a constituição epistemológica de Althusser e substituindo-a pela busca ontológica. Daí deriva o interesse por Lukács e os hegelianos que interpretaram Marx. O grupo critica ainda a fraca presença da política prática do althusserianismo ou a dualidade do estruturalismo econômico vindo da CEPAL.
} 
naturais, que poderiam ser fontes de energia ou matérias-primas para a industrialização. Mais adiante, Prenant (LACOSTE et al., 1960, p. 140-173) ressalta as disputas endógenas do império turco e das diversas correntes religiosas do islã para finalmente analisar o processo de tomada de poder pela França em meados do século XIX. Sua tese é que a colônia consolidou-se a partir da pilhagem, da

destruição e do aproveitamento das disputas internas de poder. Destaca-se o processo de ruralização de algumas regiões que outrora obrigaram grandes cidades, manufaturas e larga tradição comercial. Não vemos nessa obra nem sinal do maoísmo que Lacoste deflagrará na sua participação da Geografia ativa. Entretanto, percebemos que o Magreb é um espaço-modelo, que permite pensar a situação colonial e terceiro-mundista de outras partes do globo. Não é a primeira vez que essa região da África servirá como uma espécie de espaço ensaístico/experimental para os geógrafos franceses.

Uma espécie de prenúncio do surgimento da geografia ativa foi a inserção de vários geógrafos que eram marxistas no Ministério da Construção. Rochefort, que em 1960 defendeu sua tese sobre a A organização urbana da Alsácia, em 1962, morava em Paris e trabalha no Ministério. Dammet e Scheibling (1984, p. 22) confirmam que nos anos 1960 P. George tornou-se mais focado na organização espacial e no planejamento, através de seu longo processo de distanciamento do marxismo. Independente disso, George sugere que Lacoste faça uma tese secundária sobre a indústria de cimento na França, e esta ideia vira sua tese primária e é estendida para o estudo da industria da construção para logo após ser abandonada (LACOSTE, 2010, p. 227). A sugestão de tais temas mostra que talvez George quisesse preparar uma equipe para o Ministério, ou ainda, que Lacoste seguisse uma trajetória mais ou menos parecida com a de Michel Rochefort.

\subsection{Rochefort e a síntese ativa do planejamento}

Em 1964 é publicada A geografia ativa e Rochefort é eleito para a cadeira de geografia humana aplicada na Sorbonne, o que demonstra uma aceitação institucional da geografia ativa (BATAILLON, 2006, p. 13). "Entre as meias de George, é sem dúvida Rochefort que aparece como o mais convival (o que lhe permite 'ascender' em Paris, enquanto Kayser e talvez Dugrand são ainda figuras 
marxizantes no começo dos anos 1960)" (BATAILLON, 2006, p. 13) ${ }^{146}$. Acrescentase a declaração de que "nem Kayser, nem Lacoste, nem George, estão mais no partido comunista" (BATAILLON, 2006, p. 15).

Como vimos, do ponto de vista do planejamento George, que em 1930 e 1940 reinava soberano, de 1950 em diante teve que enfrentar o desenvolvimento do planejamento no interior de várias outras disciplinas científicas e em outros grupos da geografia. Certamente, a Geografia Ativa é uma tentativa de recuperar parte do capital cultural frente ao prestígio da economia. A estratégia institucional de George, no entanto, continua muito parecida àquela feita anteriormente: aliar-se ao concorrente, absorver parte de suas formulações e tentar fazer uma síntese aproveitando as contribuições que a geografia pode oferecer ${ }^{147}$.

O ponto de vista de que a geografia ativa está distante da ideologia e que deve ser aplicada pelo Estado, representando uma espécie de consciência técnica crítica, é uma ideia que ele defenderá até o final de sua vida - por uma geografia da ação e por um geógrafo ativo (GEORGE, 1990, p. 236).

Antes de adentrar na discussão do livro e do projeto da geografia ativa de George e seus alunos é preciso compreender o contexto do planejamento francês. Em 1963 é criado a Delegação Interministerial de Planejamento do Território e Atratividade Regional (DATAR) em substituição do Comitê Interministerial para o Planejamento Territorial (CIAT), que havia sido criado no pós-guerra. No ano de fundação, a DATAR está impregnada profundamente pela ideias de Perroux trabalhando em três eixos: (1) ação estatal; (2) racionalização do poder central estruturado na comuna local ou nos grandes centros urbanos; e (3) criação de polos secundários com as metrópoles de equilíbrio que deveriam contrabalanciar o poder de Paris na oferta de serviços (MONTRICHER, 1995, p. 15). O planejamento remediaria o crescimento desequilibrado do capitalismo.

No ano seguinte, além da escala local, a regional seria acrescentada na gama de atuação do poder central, buscando impactar os departamentos administrativos da França e oferecendo equipamentos pesados para as populações de fora de Paris. Seria o início de um lento processo de democratização e descentralização do planejamento que culmina em 1982. Porém, durante duas décadas o poder central ainda manteve o monopólio quase exclusivo da ação (MONTRICHER, 1995, p. 13).

\footnotetext{
146 Tradução nossa.

147 Estratégia que foi utilizada também por Vidal de la Blache na disputa contra a sociologia e as correntes da geografia exteriores e contemporâneas às suas formulações (BERDOULAY, 1981).
} 
Entretanto, a escala regional fomentou uma série de estudos que buscam averiguar o estado social e econômico concreto dos territórios a serem planejados (MONTRICHER, 1995, p. 52).

A longo prazo o resultado seria uma nova disputa entre poder central e regional, que se torna mais complexa ainda pela presença de empresas públicas potentes e pela resistência das empresas privadas em mudar suas estratégias de mercado por medidas do planejamento (MONTRICHER, 1995, p. 78). Obviamente tais medidas desagradaram os empresários, que não viam a intervenção estatal de suas receitas com bons olhos.

Concomitante a esse contexto, Claval (2011, p. 260) define a geografia ativa como uma crítica à geografia aplicada e associada a governos liberais, reacionários ou que oferecem perspectiva às grandes empresas para obterem fontes de lucro. Michel Philipponneau, por exemplo, realizou planos para o setor privado com estratégias espaciais para cadeias de supermercado (LACOSTE, 2010, p. 76). Toda a controvérsia se avoluma justamente na defesa de Philipponneau, em que George critica um plano que buscava manter o caráter rural da periferia de Paris. Para George, o geógrafo não poderia prever o futuro ou traçar sozinho o destino da sociedade, pois o planejamento deve ser concebido coletivamente (COUZON, 2001, p. 164). O plano concebido por profissionais e políticos é aplicado pelo poder central na escala de ação regional.

No entanto, sua crítica ecoará mais fora da geografia do que no interior da disciplina. Contrastando com a crítica ao liberalismo, identificamos a busca por uma neutralidade científica e a demanda do Estado francês, que na década de 1960 continua a pedir estudos aplicados sobre a cidade e sobre regionalização (BATAILLON, 2009, p. 24).

Nessa fase mais ou menos concomitante à geografia ativa, Claval indica qual seria a geografia produzida por Michel Rochefort:

\footnotetext{
Na França, por exemplo, não existe escalão intermediário entre a capital nacional $e$ as cidades médias que organizam regiões de pequena dimensão. Faltam as grandes metrópoles regionais que organizam regiões de pequena dimensão. Faltam as grandes metrópoles regionais e os espaços que normalmente elas estruturam. É o que justifica, nos anos 1960, e na sequência os trabalhos de Hautreux e Rochefort, e a política em prol das metrópoles de equilíbrio (CLAVAL, 2011, p. 193).
}

A visão de que a capital administrativa é um fator estruturador e central da região gerando hierarquias e constituindo o motor de sua atração econômica ainda 
persiste, pois não é contrária à tendência do planejamento para o pensamento de Perroux e do DATAR. Como Brun e Paix (2002) indicam, no momento da tese Rochefort dá um caráter central ao papel da rede de cidades no processo de formação regional e seu reflexo na relação centro-periferia:

\begin{abstract}
Quanto à noção de rede urbana como princípio de organizações regionais, não haveria ainda nenhuma análise aprofundada. Ela implicaria na ideia que a partir do estudo das cidades e suas relações é possível elencar as modalidades de inscrições do sistema econômico no espaço e de apreender a dinâmica dos sistemas regionais. Não é portanto muito espantoso que um geógrafo marxista, interessado pelo desenvolvimento das cidades e curioso por compreender as desigualdades espaciais do desenvolvimento econômico e social, não tenha dedicado o conjunto de suas pesquisas sobre as relações cidade/industria, mesmo que Pierre George se esforce para fazer das relações de produção o paradigma de uma nova geografia (BRUN e PAIX, 2002, p. 5) ${ }^{148}$.
\end{abstract}

Com base nesse panorama, a tese de Rochefort se estruturaria em torno do planejamento regional, da modernização e do equilíbrio do território, e do plano como consenso político. Como indicam Brun e Paix, realmente parece que as relações entre cidade e indústria ficam em um segundo plano em detrimento dos serviços que têm um papel central. Ao contrário das redes urbanas de Labasse, Rochefort oferecia uma malha de relações entre as cidades e suas áreas de influência. Junta-se a isso um método rigoroso de descrição das relações entre campo e cidade, demonstrando as configurações espaciais contemporâneas, o que permite traçar o funcionamento da vida econômica regional que estava "mais próximo dos objetivos da análise geográfica clássica. Poder-se-ia igualmente fazer o papel de modelo no domínio, então nascente, da geografia aplicada" (BRUN e PAIX, 2002, p. 6).

Dugrand é outro geógrafo desse período que trabalha com rede urbana regional analisando os processos de assimilação das cidades potentes economicamente e dos capitais de Paris e Lyon (BRUN e PAIX, 2002, p. 6-7). O setor de serviços terá grande importância e será o foco da análise, juntamente com a totalidade dos problemas de desenvolvimento regional econômico.

Outro nicho de interesse é o conflito entre os grupos sociais locais ou regionais identificados com uso de dados estatísticos que pudessem demonstrar as desigualdades geradoras de confronto. O resultado dessa frente de pesquisa dos

148 Tradução nossa. 
alunos de George é o surgimento da ideia de armadura urbana (armature, no original), que refletiria o funcionamento da vida regional. Assim:

(...) eu cheguei ao estado atual pelo espaço urbano, mas sempre pelo papel da cidade na organização do espaço exterior. 'O capital e seu espaço' de Lipietz é muito mais precioso para mim que Lefèbvre ou Lojkine...que me ajudaram somente para direcionar outros trabalhos (ROCHEFORT, 1983, p. 72).

A partir da visão de Rochefort, com a colaboração de Chabot e George, a região vai deixar de ser um quadro externo e preexistente, onde as cidades se desenvolvem. Agora o fenômeno sofre uma inversão, pois são as cidades com base nas suas zonas de atração que definem os limites de uma região. Ela ganha uma unidade funcional que se insere em uma hierarquia maior, formando uma rede (BRUN e PAIX, 2002, p. 9).

A concentração de capitais estrutura a organização urbana, o que cria os enclaves regionais. A ideia de metrópole de equilíbrio une-se a essa grande síntese, buscando desconcentrar o desenvolvimento econômico - no planejamento brasileiro, ela tem um papel central. O aprofundamento da hipótese de Rochefort é a aplicação do modelo da armadura urbana para os países subdesenvolvidos (BRUN e PAIX, 2002, p. 9-12). Como podemos perceber, as metrópoles de equilíbrio não possuem um objetivo tão discrepante dos polos de crescimento. No entanto, a ideia de harmonia regional se consolida por inspiração de George:

\footnotetext{
Ora, sabe-se que a geografia regional clássica fizera o uso extremamente importante das noções de harmonia e de equilíbrio, e que é uma das ideias força dos alunos de Pierre George, sobretudo quando eles vão adquirir a cultura oferecida pelos historiadores, como Pierre Labrousser, Fernand Braudel, ou pelos filósofos como Hypolite, sendo precisamente que toda estrutura, toda combinatória é simultaneamente organizada segundo o princípio de coesão e de equilíbrio no qual cada elemento tem sua função, e é atravessada pelas tensões internas, pelas contradições (BRUN e PAIX, 2002, p. 10) $)^{149}$.
}

Brun e Paix (2002, p.14) dizem ainda que mesmo depois de renovar os modelos de acordo com as formações socioespaciais diferentes, a postura de Rochefort continua sendo semelhante à de seu mestre: tenta conciliar o pensamento marxizante e os historiadores da escola dos Annales, principalmente os mais voltados para a análise das fases econômicas. Aliás, Rochefort estremece suas 
relações com George após sofrer pressão para manter-se dentro do escopo de seu pensamento no momento de sua tese de doutorado (CLOUT, 2010, p. 48).

Como vemos, a ideia de estrutura surge mais uma vez. Não podemos negar que Rochefort, imbuído pelo espírito da geografia ativa, faz uma síntese grandiosa da contribuição dos historiadores, dos economistas que se dedicaram ao planejamento, da escola vidaliana de geografia e do pensamento de seu mestre George em contato com os refluxos marxistas. Tal perspectiva demonstra a presença do pensamento braudeliano.

O arcabouço proporcionado por Braudel e incorporado pelos geógrafos ligados a George não só relembra as relação entre a escola dos Annales com a geografia vidaliana, como oferece uma concepção de estrutura em que o ambiente geográfico fundamenta os acontecimentos históricos. Para Braudel, os acontecimentos são inimigos da história, porque o que se deve observar são os fenômenos profundos, de longa duração, que se alteram apenas aparentemente (DOSSE, 2004, p. 130-131) ${ }^{150}$. Para Deprest:

\footnotetext{
O historiador François Dosse mostrou que essa concepção braudeliana de 'tempo longo' fica em grande parte incompreensível fora do conceito vidaliano de permanência do gênero de vida resultante da junção do homem e do solo (DEPREST, 2009, p. 257) (151. $^{151}$
}

Quando a geografia crítica eclode, Rochefort vai ser duramente criticado pelos marxistas por não se calcar no pensamento marxiano e por ter utilizado pouco o estruturalismo de Althusser. Brun e Paix (2002, p. 15) acrescentam que Rochefort raramente revela a citação dos sociólogos marxistas que utiliza como pano de fundo.

\subsection{A tentativa de neutralização da geografia ativa}

O aporte da geografia ativa será fundamental não apenas para delimitar a ação social da geografia, mas para posicionar George contra a nova geografia que estava em ascensão no mundo e que em breve chegaria a França. A controvérsia entre a geografia ativa e a aplicada foi tão intensa que ela alcança até mesmo a esfera da UGI. Durante a década de 1960, dentro da Comissão de Desenvolvimento

\footnotetext{
150 Braudel será frequentemente acusado de determinismo geográfico, posição que não responde com veemência.

151 Tradução nossa.
} 
Regional ambas as geografias travam uma batalha pela visão dos planejadores: a primeira mais voltada ao pragmatismo e ao favorecimento empresarial; e a segunda centrada no Estado e em um projeto de desenvolvimento nacional justo (ROBIC et al., 1996, p. 276).

Para George, o método matemático constituiria um novo tipo de determinismo, estimulando uma armadilha tecnocrática. A geografia se tornaria uma ciência documentalista, com dificuldade de elaborar seus próprios dados e dependente de informações dadas pelos próprio Estado. Essa armadilha não seria uma solução de método, pois é a variável técnica como objeto de análise - e não exclusivamente como componente de método - que permite a superação da cisão entre geografia física e humana (GEORGE, 1976, p. 50-54). A geografia deve ser neutra, mas não pode abrir mão do trabalho de campo e das entrevistas, porque os dados estatísticos são sempre parciais.

No artigo inaugural d'A Geografia Ativa ${ }^{152}$ (GEORGE et al., 1966, p.13) vemos uma mudança de postura de George: "Uma preocupação mais ou menos consciente de uma apresentação dialética das coisas levava do determinismo naturalista ao racismo e à Geopolítica". É dessa maneira que Pierre George culpa a dialética sem tocar no nome do marxismo, e retoma a velha querela entre a escola francesa e alemã da geografia. Ele demonstra como na verdade o determinismo foi culpado pela gênese da geopolítica alemã, que resultou no nazismo, não considerando todas variáveis sociais e psicológicas ao estudar a relação entre homem e meio.

Logo em seguida, George (1966, p. 12-14) tenta demonstra que na geografia existem duas correntes básicas: uma procura estabelecer leis e a outra é a geografia aplicada, e classifica-se dentro desta última. Contudo, ressalta que a geopolítica também era geografia aplicada e preocupa-se, portanto, em isolar a geopolítica ao mesmo tempo em que as atrocidades do uso político e ideológico da ciência servem de justificativa para reforçar sua postura neutra diante da dialética social. São os políticos que tomam as decisões políticas, ao cientista cabe apenas apresentar o estudo neutro.

\footnotetext{
152 No Brasil essa obra foi traduzida muito rapidamente e chega ao público em 1966. Ela é traduzida por Gil Toledo, Manoel Seabra, Nelson de la Corte e Vincenzo Bochicchio, e publicada pela Editora da Universidade de São Paulo e pela Difel - esta última braço da Presses Universitaires de France. Se na França ela pode ser lida como um momento de crise dos geógrafos de esquerda, na América Latina, de uma maneira geral, $A$ Geografia Ativa foi propulsora de uma conscientização do papel da geografia na transformação social, convocando os geógrafos a darem sua contribuição para um sistema social mais justo. Isso criou uma associação com o marxismo. Como veremos abaixo, alguns geógrafos defendem pontos explicitamente de esquerda.
} 
Da mesma maneira, deve-se ter cuidado para não perder o caráter de síntese da geografia e aprofundar-se exageradamente nas ciências auxiliares. A geografia humana seria a ciência que estuda o espaço enquanto meio de vida humana, é uma "ciência de conjunturas e do resultado de sucessões de conjunturas" (GEORGE et al., 1966, p. 16-17). O enfoque da geografia seria eminentemente regional - o que demonstra a velha liturgia vidaliana - e seu objetivo é a síntese de vários processos naturais e sociais.

George (et al., 1966, p. 38-39) fala sobre desenvolvimento desigual e concebe a região como um equilíbrio de forças, o que denota a presença de Perroux. A geografia seria uma continuação da história ou uma história do atual, sendo que "as técnicas fornece[m] a chave das modificações das relações entre coletividades humanas e ambiente" (GEORGE et al., 1966, p. 20).

George recupera também a ideia de situação. A geografia é:

(...) objeto de uma descrição qualitativa muito precisa pelo geógrafo. Essa localização acompanha a pesquisa de relações consideradas hoje como relações recíprocas e recorrentes, e também como relações insuficientes para explicar a totalidade dos dados. O conjunto destas relações contribui para construir uma situação. (GEORGE et al., 1966, p. 23)

A situação ${ }^{153}$ desemboca no espaço relativo que está relacionado com as especificidades de cada região. A descrição geográfica revelaria essas características regionais específicas e daria possibilidade de hierarquizar os problemas mais ou menos urgentes a serem resolvidos. Após a descrição e a comparação entre os conjuntos regionais entra em cena a ação, permitindo assim "passa[r] do descritivo ao prospectivo e ao perspectivo, do estudo geográfico puro ao plano de organização regional” (GEORGE et al., 1966, p. 37).

George (et al., 1966, p. 27) já percebia que "a geografia se orgulhava de não se interessar a não ser pelos dados estáveis. Isto era um verdadeiro certificado de sua vocação científica". Entretanto, sua nova geografia dinâmica está carregada de utilitarismo dedicado à ação estatal:

O objetivo da Geografia ativa é perceber as tendências e as perspectivas de evolução a curto prazo, medir em intensidade e em projeção espacial as relações entre as tendências de desenvolvimento e seus antagonistas,

153 Se encararmos a situação como uma ideia mais geral, ou ainda de um ponto de vista filosófico, veremos que ela se relaciona com o existencialismo de esquerda de Sartre e de Merleau-Ponty. Essa nos parece uma relação importante, mesmo que não tenhamos na atualidade espaço para explorar as eventuais relações entre essas concepções. Cabe ressaltar, no entanto, que a ideia de situação estará sempre presente com esses geógrafos de esquerda do pós-guerra. 
definir e avaliar a eficácia dos freios e dos obstáculos. É por aí que a geografia pode desembocar na aplicação. E se afirmar a vontade de criar; criar para libertar-se de um passado que se repudia, criar para satisfazer necessidades imperiosas nascidas do crescimento do consumo, criar para afirmar que se possuem as melhores garantias de uma construção e de um domínio do futuro (GEORGE et al., 1966, p. 30).

A mentalidade em prol do desenvolvimento das forças produtivas continua mesmo que o marxismo tenha entrado em crise e a própria geografia esteja sob uma atmosfera de desprestígio. Tal fato, deve-se entre vários fatores, a uma metodologia arcaica se comparada com outras ciências sociais.

A geografia ativa, portanto, não deixa de ser uma tentativa de fazer voltar o geógrafo à ação do Estado, ao lado do sociólogo ou do economista (GEORGE et al., 1966, p. 37). A estratégia de George sempre foi a da conciliação, mesmo que se ocupe um status secundário, diante das ideias correntes que ele acredita serem importantes. O diálogo com as elaborações de Perroux e Boudeville permeia a maioria dos textos de $A$ geografia ativa. A tentativa de neutralização feita por George contrasta fortemente com os outros textos presentes no livro.

Após o texto introdutório de George, Yves Lacoste escreve um artigo que demonstra toda sua simpatia pelo maoísmo. Sua reflexão articula o subdesenvolvimento, o subemprego e o subproletariado. No entanto, o antídoto para estes problemas seria seguir a China: "A vitória de um movimento camponês revolucionário, com dirigentes do partido comunista chinês foi o que engatilhou um formidável esforço de desenvolvimento" (GEORGE et al., 1966, p. 127). Após contar brevemente a história do movimento comunista chinês, seus progressos e desenvolvimentos, Lacoste conclui que o modelo chinês é ideal para ser aplicado em qualquer país subdesenvolvido respeitando as diferenças locais, mas seguindo suas diretrizes principais. Observar os chineses é necessário para que:

(...) diferentes países do Terceiro Mundo estejam preparados para construir para si mesmos um sistema de desenvolvimento que procederá de uma adaptação às particularidades nacionais dos princípios gerais que é possível tirar da experiência chinesa (GEORGE et al., 1966, p. 135).

Apesar dessa confluência com algumas tendências da esquerda francesa, suas concepções metodológicas ainda estão muito próximas da tradicional geografia francesa. Isso fica evidente no excerto:

Uma região é sobre a terra um espaço preciso, mas não é imutável, inscrito em um quadro natural determinado, e que responde a três características essenciais: os laços existentes entre seus habitantes, sua organização em 
torno de um centro dotado de certa autonomia e sua integração funcional em uma economia global. Ela é o resultado de uma associação de fatores ativos e passivos de intensidades variáveis, cuja dinâmica própria está na origem dos equilíbrios internos e da projeção espacial (GEORGE et al., 1966, p. 135).

Existe uma busca do equilíbrio regional e um foco na relação entre grupo e meio no estabelecimento da região. Apesar do maoísmo de Lacoste não aparecer no futuro, ele está presente nos artigos sobre a guerra do Vietnã que o tornarão célebre - inclusive no mundo anglo-saxão - e no seu interesse pelo modelo chinês para a solução do subdesenvolvimento. Claramente, a revolução no Vietnã foi inspirada pela China, e como se sabe em determinados momentos Mao Tse Tung auxiliou Ho Chi Minh antes de ele se alinhar com a União Soviética.

No restante da obra, R. Guglielmo dedica-se à geografia ativa demonstrando uma espécie de consenso que permeia o estudo regional, em que primeiramente se estuda a população, seguida dos recursos naturais com seus usos e consumo, para finalmente abordar as relações exteriores. Ao seguir essa ordem de estudo revelarse-iam as estruturas geográficas (GEORGE et al., 1966, p. 306).

A geografia ativa talvez seja um momento final de coesão entre o grupo dos geógrafos de esquerda, pois pouco antes de 1968 Lacoste rompe relações com Pierre George devido à divergências ideológicas (ZANOTELLI, 2005, p. 97). Esse momento de ruptura com um dos líderes de sua antiga rede, no entanto, não representou um desprestígio profundo de sua imagem ${ }^{154}$. Veremos que Lacoste, aproveitando-se das consequências institucionais do maio de 1968, terá força para lançar seu próprio grupo, mesmo que ainda não tenha defendido seu doutorado. Quanto à relação com o maoísmo, talvez isso seja apenas refluxo ou um modismo ligado à busca de um modelo alternativo ao marxismo soviético. O flerte de Lacoste com o maoísmo foi muito rápido e se dilui pelo seu interesse sobre a geopolítica, e é importante ter em mente que ele se interessa apenas por alguns de seus aspectos.

Independentemente desse quadro, um elemento que se contrapõe à tentativa de despolitização é a presença do planejamento soviético no pensamento de George. Desde o início da esquerdização sempre existiu na França uma demanda

\footnotetext{
154 Há uma tentativa de reencontro entre Lacoste e George em 1994, quando George vai até o programa de rádio Bon plaisir dar um testemunho sobre Lacoste. Após a entrevista, George convida Lacoste para participar da reedição do Dictionaire de la géographie, publicado pela primeira vez em 1970. Esse dicionário, organizado por George, já havia sido atualizado em 1992. Porém, devido a brigas e disputas internas na organização do novo dicionário, Lacoste sai do grupo e organiza um dicionário com a editora Larousse, lançado em 2003, com o título Da geopolítica às paisagens (ZANOTELLI, 2005, p. 97-99).
} 
de diálogo com a geografia soviética, e esta troca está em consonância com o planejamento porque na União Soviética existe uma grande preocupação com a solução de problemas econômicos em várias escalas de análise e a geografia tem um papel importante nisso.

Ao observarmos a resenha de George (1959, p. 156-157) da obra de mais importante de Saouchkine ${ }^{155}$, traduzida para o francês sob o título de Introduction à la Géographie Economique em 1958, vemos que suas análises buscam mostrar as modificações do meio natural através das técnicas, evidenciando as novas possibilidades de desenvolvimento econômico. Pode-se deduzir que a influência da análise da técnica, valorizada por George na geografia ativa, seja também uma influência soviética. Obviamente, esse destaque relaciona-se ainda com o legado vidaliano que sempre valorizou a técnica na transformação do meio.

O resultado disso, é a ideia de complexos de múltiplas determinações (ações e reações) que caracterizam as ocupações ativas do meio geográfico. Sua ênfase também caminha em direção ao ambiente material do processo de produção, de transporte e comércio, privilegiando seus aspectos qualitativos (GEORGE, 1959, p. 156). Muito provavelmente, a geografia soviética foi outro elemento importante para sua ideia de planejamento, mesmo com o afastamento do marxismo ${ }^{156}$.

Em uma entrevista para a revista Villes en parallèle, alguns anos depois, Lefèbvre dirá que a década de 1960 representou a ascensão da tecnoburocracia francesa. O processo de reconstrução do pós-guerra havia se esgotado e a revolução social foi substituída por uma revolução político-científica, representada em boa parte pelo discurso de eficiência dos novos funcionários que integram o

155 Ou Saushkin, se seguirmos a transliteração do russo para o inglês.

156 O período da década de 1960 também marca mudanças importantes na geografia soviética. Depois da segunda guerra mundial, os geógrafos estavam mais focados na análise das forças produtivas e gradualmente a geografia econômica tornava-se sinônimo de geografia humana. $\mathrm{O}$ interesse geral era o planejamento sustentado pelos planos quinquenais, a organização do território urbano, rural e natural (SANGUIN, 1979, p. 274). No entanto, a ideia que fundamentava todo o debate da geografia era que o homem não se dobrava perante a natureza. Stálin havia interferido pessoalmente na questão do determinismo ambiental, repudiando-o. Com o determinismo fora de jogo, aprofunda-se a dicotomia entre a geografia humana, que se preocupa com as leis econômicas e a geografia física, que trata da dialética da natureza. Nos anos 1950, os seguidores do modelo de localização industrial de A. Weber (autor que postula a teoria da localização ótima da indústria entre as matérias-primas e o mercado consumidor) são presos, provocando uma fuga da pesquisa em geografia humana fruto do medo de retaliações políticas (SANGUIN, 1979, p. 275). No quadro institucional, Guerassimov era a figura central e reafirma a visão stalinista (SANGUIN, 1979, p. 274). Surge Anuchin que tenta reabilitar o determinismo geográfico e provoca a maior controvérsia científica da União Soviética desde o caso Lyssenko. Após alguns tentativas de defesa de sua tese de doutorado e contando com o auxílio de figuras iminentes como Saushkin, Anuchin atinge seu objetivo e propõe uma maior ligação entre geografia humana e física. A insatisfação popular com o planejamento é outro elemento que ajuda na aceitação de sua tese e no reconhecimento acadêmico de Anuchin. 
Estado e propõem seus projetos para sociedade. Lefèbvre (1983, p. 52) diagnostica a própria difusão do estruturalismo como uma faceta da revolução científica e técnica que substituiu a revolução social e política.

No entanto, ao falar sobre a geografia urbana, acusa Rochefort de ser excessivamente dogmático e não ter compreendido que o marxismo é um método de análise. Lefèbvre, todavia faz parte do movimento tecnocrata, pois trabalhou para - DATAR, que segundo sua opinião não teria pensado a França em sua especificidade, mas apenas proposto modelos e prospectos com alto grau de previsibilidade, o que resultou em um retrato funcional e fragmentário da cidade (LEFĖBVRE, 1983, p. 57).

A entrevista ainda é reveladora, pois quando é indagado sobre a geografia urbana Lefèbvre não faz grandes considerações além dizer que ela teve uma aproximação descritiva, de acusar Rochefort e concordar com os balizamentos do interlocutor. Certamente ele trabalhou com alguns geógrafos no DATAR, mas o verdadeiro contato e aprofundamento com a cultura do campo geográfico talvez seja baixa, uma vez que ele quase não comenta as obras dos geógrafos (LEFÈBVRE, 1983, p. 51-52).

\subsection{O subdesenvolvimento}

No período entre a publicação de $A$ Geografia Ativa e o surgimento da geografia crítica, Lacoste (1971, p. 10-48) publica em 1965 A geografia do subdesenvolvimento como uma crítica à ideia de que os países do terceiro mundo não seriam capazes de se desenvolverem por conta própria, por isso deveriam ser colônias. Na busca por uma definição justa e criteriosa sobre o subdesenvolvimento, Lacoste observa mais os fatores qualitativos que quantitativos. Contudo, contraditoriamente vê o setor terciário como parasitário e tenta demonstrar como a industria é um elemento que desequilibra os arranjos da economia tradicional. Isso porque ainda está muito presente a concepção de uma burguesia privilegiada associada ao imperialismo nas ex-colônias, o que gera uma profunda desigualdade social.

Devido a ênfase no tema, Dresch também escreve um texto sobre o assunto em que cita Lacoste e lamenta existir um distanciamento entre economistas e sociólogos ao abordar o subdesenvolvimento. Dresch faz uma recuperação histórica e relaciona o sistema colonial e o mercantilismo às raízes do subdesenvolvimento, 
sugerindo como agenda um estudo comparado que mostre a diferença do subdesenvolvimento nos diversos continentes, ou ainda que relacione as dificuldades econômicas aos fatores naturais. A busca das origens das desigualdades e sua ligação com algum tipo de arcaísmo local é importante para compreensão do fenômeno (DRESCH, 1967, p. 643).

Ao contrário de Dresch, Suret-Canale critica duramente Lacoste, retornando às definições mais clássicas de imperialismo segundo Lênin:

\begin{abstract}
O autor rejeita a assimilação entre subdesenvolvimento e o fato colonial a partir de uma concepção restritiva do fato colonial, concebido como simples dependência política; ele não faz nenhuma distinção entre a colonização mercantil dos séculos XVI e XVIII e a colonização imperialista do fim do século XIX, que certamente se tratam de fatos sociais e econômicos profundamente diferentes (SURET-CANALE, 1967, p. 19).
\end{abstract}

O subdesenvolvimento para Suret-Canale (1967, p. 19) seria um nome novo para o imperialismo, confusão gerada pela mistificação da ideologia burguesa. Adverte ainda que Lacoste subestima os elementos internos aos países subdesenvolvidos, pois Argentina e Brasil são países que criaram uma burguesia nacional independente do capital internacional.

Scheibling (1977, p. 45), por sua vez, ressalta que Lacoste, que outrora criticava o ruralismo e o nacionalismo no ensino da geografia, teve sua obra sob o subdesenvolvimento aceita pelo ensino fundamental com o efeito prático de propagar uma visão "sentimental-caridosa" sobre o subdesenvolvimento. Lembrando que Dresch, em seus estudos sobre o imperialismo, é o responsável pelo crescimento pela ênfase no papel da burguesia nacional na estruturação de classe dos países subdesenvolvidos, observando seu intercâmbio com o capitalismo global (HEPPLE, 2000, p. 271).

O subdesenvolvimento na década de 1960 estava na moda. O tema anticolonial gera o sucesso de vendas do livro Ibn Khaldum que Lacoste publicou em 1966. Isso permite anos mais tarde a Maspero editar a revista Hérodote (LACOSTE, 2010, p. 149-150) ${ }^{157}$. Não por acaso, François Maspero é ligado ao trotskismo e já havia publicado uma coleção de livros organizada por Althusser.

Apesar de Lacoste não se lembrar da adesão ao partido comunista argelino, foram os seus colegas da geografia de esquerda na Argélia que lhe apresentam a

\footnotetext{
$157 \mathrm{Na}$ mesma época a Maspero edita Os condenados da terra de Franz Fanon, que também atinge um grande número de vendas.
} 
obra de Khaldum - mais precisamente Sakes Hadjeres. Na obra do geógrafo medieval, Lacoste identifica o modelo magrebiano de relação entre cidade e tribos nômades do interior (LACOSTE, 2010, p. 64-54). O contato com Khaldum faz Lacoste pensar a formação histórica nacional, mas, como vimos, ele preferiu um modelo geral de subdesenvolvimento ao invés de relacionar a condição periférica dos países com um contexto histórico profundo.

O esforço inicial de Lacoste para o estudo do subdesenvolvimento dura de 1965 até 1968 e nas suas palavras:

\begin{abstract}
Eu defini o subdesenvolvimento não como um fenômeno antigo retardamente econômico, mas como uma situação relativamente recente, caracterizada por uma distorção entre um forte crescimento demográfico e um crescimento econômico bem menos rápido (LACOSTE, 2010, p. 69) ${ }^{158}$.
\end{abstract}

A associação entre estrutura populacional e econômica não nega a influência de George. Paralelamente, no mundo anglo-saxão, Keith Buchanan introduzia na década de 1960 o debate sobre o subdesenvolvimento tendo como referência $C$. W. Mills, F. Fanon e A. G. Frank. Ela estudou a África do Sul, trabalhou na Nova Zelândia e finalmente no País de Gales. Formada na Universidade de Birmingham, na Inglaterra, com uma tese sobre geografia agrícola, ela percebe que o colonialismo drena matérias-primas, desarticulando o artesanato local e acabando com a propriedade comunal no campo (POWER e SIDAWAY, 2004, p. 585-590).

Buchanan chega a contribuir para New Left Review e a Monthly Review, com textos que defendem o desenvolvimento e a modernização da periferia capitalista. 0 surgimento da geografia radical consolida o estudo da temática, uma vez que o marxismo estruturalista reforça o interesse pela dependência estrutural entre centro e periferia. Buchanan tem um papel importante, posicionando-se contra o eventual racismo e determinismo geográfico ligados à geografia tropical (POWER e SIDAWAY, 2004, p. 591-593).

Iremos agora fazer um balanço desse período que abordamos, para a seguir tratar da geografia crítica na segunda parte de nosso trabalho.

\title{
3.8 Balanço do período
}


Anos depois, Suret-Canale se perguntaria porque a revolução epistemológica não ocorreu nos anos de pós-guerra e no auge da guerra fria. Ele indica pelo menos três elementos básicos para isso: (1) os geógrafos tinham uma formação tradicional empirista distante de questionamentos teóricos; (2) apesar do ingresso institucional precoce, cedo ou tarde os intelectuais marxistas são cooptados pelas instituições de ensino e sofrem uma desradicalização ${ }^{159}$; (3) o stalinismo direcionou as ciências humanas mais para a economia política do que para outros ramos do conhecimento ou para reflexão epistemológica.

Para Suret-Canale (1981, p. 13) o lugar dos geógrafos dentro do partido comunista era predominantemente como assessores em economia, uma vez que quase não haviam marxistas nas faculdades de economia e direito:

\begin{abstract}
Eles se encontravam dessa maneira orientados muito mais no sentido de estudos e levantamentos de materiais concretos indispensáveis para elaboração da política do Partido Comunista do que no sentido de uma reflexão sobre os problemas teóricos de sua disciplina (SURET-CANALE, 1981, p. 13).
\end{abstract}

Contudo, mais adiante complementa: "As questões colocadas nos anos setenta e que a gente pode pensar que eram 'novas' já haviam sido colocadas vinte anos antes" (SURET-CANALE, 1981, p. 14). Eis aí os laços históricos que por vezes foram negados. Apesar desse prognóstico, a avaliação de Suret-Canale é positiva, porque a esquerdização impulsionou a geografia dos capitais e das indústrias que praticamente inexistia, a não ser por alguns esforços de Max Sorre. Poderíamos acrescentar outros ramos da geografia, como a geografia da população, a renovação da geografia urbana e até mesmo a presença da dialética na geomorfologia.

Suret-Canale também ressalta a necessidade da renovação epistemológica e consequentemente da ruptura com a geografia "tradicional" em que o marxismo daria uma contribuição maior nas décadas seguintes, pois é chamado para suprimir uma insuficiência epistemológica (SURET-CANALE, 1981, p. 17). Um dos problemas segundo essa visão de Suret-Canale é que os geógrafos analisaram o marxismo a partir de seu referencial oriundo da geografia tradicional francesa.

Claval (2011, p. 250-261) tem uma visão completamente diferente do período, pois, em sua opinião, na geografia de esquerda predomina um caráter ideológico ligado ao marxismo dogmático e a um sistema partidário opressivo. Raymond

159 É evidente que, e Suret-Canale o admite, isso não ocorre no caso de Dresch. 
Rochefort (1981, p. 32) concorda com essa visão ressaltando que não ocorreu uma discussão teórica devido à repressão ideológica. Como vimos, Dresch e George tinham posturas contrárias às orientações do partido, o que não causou um prejuízo grande. Vários motivos podem explicar esse fato, como sua posição acadêmica ou o capital militante acumulado nos aparelhos do partido. No que diz respeito a Claval, essa é uma questão delicada, pois no momento de sua inscrição na faculdade ele viu militantes comunistas intimidarem estudantes para assinarem o apelo de Estocolmo contra o armamento nuclear (BATAILLON, 2009, p. 39; CLAVAL, 2007, p. 43). Essa experiência pouco intensa parece ter gerado uma aversão ao marxismo, o que não o impedirá de incursões no resplandecer da geografia crítica.

Lamicq afirma e relembra a visão de Lacoste e Prenant de que havia uma falta de questionamentos metodólogicos e vontade de mudar. A sua conclusão é que existe mudança de temas, porém não da estrutura metodológica da geografia. Entretanto, contraditoriamente diz:

(...) eles restabeleceram as fronteiras, banalizaram a introdução das estruturas sociais na análise geográfica. Eles deram um estatuto explicativo para fatores tais como o papel do Estado, que não existia antes deles (MEMÓRIAS, 1990, p. 26) ${ }^{160}$.

Alguns acusam George de não ter inovado, já que sua obra consistiu em retrabalhar objetos de estudo que haviam sido identificados por outros geógrafos contemporâneos ou do passado.

Apesar de todas essas colocações, pensamos que de uma forma geral a geografia sofreu um processo de renovação. Em última instância, ocorreu uma mudança no seu habitus, pois no final da década de 1960 o campo disciplinar não valorizava nem se organizava como no início da década de 1930. O marxismo e a cultura de esquerda tiveram um papel fundamental nesse processo, seja pela ideia de estrutura, seja pela politização da geografia ou pela sua busca pela ação social no planejamento.

Mesmo que Suret-Canale ressalte negativamente o empirismo como fruto do pensamento vidaliano, acreditamos que uma das vocações da geografia é o estudo do concreto. Veremos que a geografia crítica adota de maneira mais ou menos generalizada o estruturalismo como teoria geral de entendimento do mundo, porém

160 Tradução nossa. 
ele será criticado justamente por ser generalizante demais e ignorar as ações dos indivíduos.

Novamente a questão do debate sobre o empirismo ressurgirá, pois esse é um elemento que sempre teve força na história da geografia, mesmo antes de ela se consolidar como ciência moderna.

Apesar de não existir uma ruptura epistemológica drástica que negue a tradição da geografia francesa, não podemos ignorar uma renovação das agendas de pesquisa que envolve os seguintes elementos: Pierre George cria ou renova o tema da geografia da população, geografia da energia, geografia urbana, geografia das indústrias e o planejamento. Para isso pauta-se em Gurvitch, além de incorporar elementos da geografia soviética, de Sauvy, Christaller e Perroux. Seus discípulos, como Rochefort, darão continuidade às inovações que fogem do escopo clássico vidaliano. Tricart reafirma a concepção de hábitat, a lógica dialética na análise geomorfológica e no planejamento ambiental, enquanto Dresch, além de trabalhos sobre geomorfologia, agrega o tema do imperialismo, que também será desdobrado pelos herdeiros do pós-guerra.

Vemos ainda que George investiu mais na carreira dentro da academia, comprometendo-se com grupos e tentando conciliar tradições, enquanto Dresch apostou mais no partido comunista enquanto instituição, permanecendo como membro por um longo tempo e participando de várias de suas atividades. Os três alunos principais de Cholley acumulam um capital cultural na academia, no partido comunista e no Estado - nos órgãos de planejamento - que será passado para as próximas gerações.

Se não existiu mudança epistemológica total, é evidente a alteração radical dos critérios de cientificidade, preâmbulo que engendrou fôlego para a transformação ocorresse. Se a geografia não foi lançada imediatamente no front do debate marxista, houve uma aproximação além do reconhecimento de sua instrumentalização a serviço do status quo e do Estado. Apesar dessa consciência, a opção foi continuar atuando dentro do Estado e da academia para a construção de uma sociedade mais justa, igualitária, racional e sustentável. Alguns argumentam que a ação estatal submete-se aos interesses da burguesia, entretanto, como tentamos demonstrar em algumas situações, o planejamento foi coercitivo ao grande capital e tentou engendrar um projeto nacional/social maior em detrimento dos interesses de grupos restritos, o que acabou por consolidar seu insucesso em alguns casos. 
Todas essas transformações não têm pouco significado, porque são resultado de uma renovação combinada a um desprendimento da geografia vidaliana no que diz respeito aos temas, à organização institucional, às mudanças na educação e de relações do grupo de pesquisadores que permitirão o desenvolvimento da geografia crítica, que terá como estratégia a negação do passado. Se pensarmos na geografia anglo-saxã, que analisaremos a seguir, ela se radicaliza rapidamente devido ao contexto da época, à presença do althusserianismo, mas também devido à obra de Yves Lacoste, resultado dos debates da geografia de esquerda.

Nos Estados Unidos, a consolidação da nova geografia e de uma geografia aplicada para solução dos problemas sociais é a origem formadora da geografia crítica, mesmo que as contribuições do neopositivismo sejam em parte negadas e em parte descaracterizadas. Em ambas as escolas nacionais a ação do geógrafo na sociedade é um elemento importante para o crescimento do marxismo. Iremos agora esclarecer melhor esses processos. 


\title{
Parte II - A invenção da geografia crítica
}

Com as inovações da nova geografia a maioria das escolas nacionais, inclusive o Brasil, vão se focar no desenvolvimento da geografia norte-americana. Se podemos identificar os meados da década de 1950 como o início do desenvolvimento da nova geografia, já na década seguinte existe uma gama de críticas e insatisfações por parte de alguns geógrafos que participaram de seu surgimento. Como vimos no capítulo anterior, no caso francês é só na década de 1970 que a nova geografia ganha força total e consolida na França um amplo esforço de renovação epistemológica e metodológica. Não por acaso, Claval atribui o corte epistemológico à nova geografia e não ao marxismo - nem ao pensamento de George, nem ao da geografia crítica. Todavia:

\begin{abstract}
$\mathrm{Na}$ França, as referências situam-se de boa vontade, perto do estruturalismo. Enfim, o marxismo, que até agora tinha apenas jogado um papel secundário no pensamento geográfico, interessa-se por estes desenvolvimentos. Jovens teóricos clamam a necessidade de abrir, através de um corte epistemológico à maneira de Althusser, o continente geográfico de conhecimento científico. $\mathrm{O}$ que aqui desejamos rapidamente fazer, é demonstrar que o corte epistemológico já teve lugar, e que deu à geografia um novo estatuto: tornou-a mais indispensável ao desenvolvimento das outras ciências humanas e sociais, confirmando ao mesmo tempo, as estreitas relações com as ciências do meio. Por trás da proliferação das obras e tendências, já é possível discernir a estrutura de conjunto da disciplina renovada (CLAVAL, 1987, p.11-12).
\end{abstract}

Ora, a geografia francesa havia se "quantificado" mesmo face ao debate do estruturalismo, no entanto, para Claval, nem o antigo nem o novo marxismo teriam a mesma profundidade nas alterações da disciplina como a nova geografia. Uma ideia que certamente tem sentido, mas que não pode ser encarada até as últimas consequências.

Como veremos abaixo, a partir das concepções da nova geografia, a geografia crítica agregará elementos de suma importância que certamente provocarão uma ruptura do ponto de vista epistemológico. O grande problema de compreender a ciência a partir dos cortes epistemológicos é que eles ocorrem em 
situações contraditórias e têm reverberações de acordo com a história e o ritmo do lugar - ou da escola nacional. O importante é pensar que sem sombra de dúvida a nova geografia inovou, mas pensamos que é impossível subestimar as contribuições da geografia crítica, porque as referências, os debates, os temas, o direcionamento e os critérios científicos do campo modificaram-se. Apesar de negar o passado, ao mesmo tempo a geografia crítica toma-lhe emprestado vários elementos para reestruturar o campo de estudos, assim como a nova geografia fizera. O corte não significa fazer tábula rasa dos antecedentes disciplinares, e a prática científica nem sempre significa ter total clareza das ideias e pensamentos que baseiam seu desenvolvimento.

Claval sintetiza o processo de desenvolvimento global da geografia marxista, ressaltando os geógrafos ingleses:

\begin{abstract}
No decorrer dos anos 1950, os geógrafos marxistas se encontram quase todos na França, na Itália ou nos países da América Latina. Nos anos 1970 , eles se tornaram mais discretos onde eles eram primeiramente ilustres, mas eles começam a se tornar influentes na Grã-Bretanha e nos Estados Unidos - aliás os geógrafos marxistas são frequentemente de origem britânica. A sua inspiração vem, em parte, dos sociólogos e economistas franceses ou sul-americanos que tentam, após 1968, apresentar uma análise crítica da sociedade contemporânea e de seus problemas: Manuel Castells é traduzido rapidamente (CLAVAL, 1984, p. $112-113)^{161}$.
\end{abstract}

Ou ainda segundo Capel: "O progresso recente da teoria marxista e o eco da teoria crítica da escola de Frankfurt permitem o desenvolvimento de uma geografia marxista com uma ênfase também claramente historicista" (CAPEL, 1988, p. 264) ${ }^{162}$. Lembrando que o grupo de Horkheimer com a maioria de seus membros alinhados com a social-democracia, não se identificava com o marxismo ortodoxo, mas com a crítica da superestrutura ou a "crítica concreta das relações sociais alienadas e alienantes" (WIGGERHAUS, 2002, p. 37), ou ainda, aquilo que mais tarde Althusser classifica como uma parte do legado do jovem Marx. Existem, portanto, movimentos intelectuais amplos que permitirão a institucionalização da geografia crítica em escala mundial.

Outro fato importante para compreender o contexto da época, é que a partir da década 1960, devido ao avanço tecnológico, existe uma queda do recrutamento de trabalhadores manuais permitindo um crescimento de profissionais responsáveis

\footnotetext{
161 Tradução nossa.

162 Tradução nossa.
} 
pela instrução social, como professores, estudantes e funcionários públicos. A expansão do pensamento crítico no centro do sistema direcionou-se lentamente para os aspectos sociais e culturais, distanciando-se dos operários no contexto do desaquecimento econômico (HOBSBAWN, 1991, p. 42-43).

Do ponto de vista do marxismo, temos o surgimento de importantes revistas que reativariam os debates e são propagadores do pensamento de esquerda em todo mundo. Vemos surgir nessa década publicações importantes até hoje, como a Monthly Review, a New Left Review, e a Review of Radical Political Economics (CAPEL, 1988, p. 409). Segundo Jacoby (1987, p. 186) a Monthly, que envolveu Baran, Sweezy, Braverman e Magdoff, não conseguirá continuar por um longo prazo o desenvolvimento inicial que promoveu ricas discussões públicas. Na década de 1960, ela concentrou o debate sobre a nova teoria do subdesenvolvimento, vista não como falta de desenvolvimento, mas como um polo constituinte do próprio capitalismo (THERBORN, 2012, p. 89).

Além disso, o debate público de Adorno com Popper simboliza o confronto entre uma metodologia sociológica marxista versus o positivisto e remete à discussão anterior entre Horkheimer e o Círculo de Viena. Popper:

\begin{abstract}
(...) excluía que observações isoladas, ricas em conteúdo, fossem possíveis apenas numa relação constante com uma representação, mesmo provisória, da totalidade social. Ela excluía o fato de que teorias não dedutivas pudessem constituir a forma de saber apropriada para sociedades contraditórias e antagonistas. Excluía as experiências pessoais de indivíduos da possibilidade de serem mais exatas do que os resultados que se estabelecem no meio científico oficial e organizado. Excluía a ideia de que o juízo de valor em sociologia não era algo neutralizável pelo conhecimento em si, e sem algo que constituía mais ou menos o conhecimento (WIGGERHAUS, 2002, p. 604).
\end{abstract}

Posteriormente, Habermas, que será uma referência na geografia norteamericana, ataca justamente o axioma da neutralidade positivista e defende que o vivido é uma dimensão da realidade concreta que escapa à objetividade científica (WIGGERHAUS, 2002, p. 606-607).

Maio de 1968 e da mobilização civil nos Estados Unidos são eventos históricos que explicam uma radicalização que se desdobra em escala mundial. Não podemos esquecer que esses eventos estão ligados à desaceleração econômica mundial, marcando o final dos anos dourados de crescimento que vinham desde o final da Segunda Guerra. Em 1973, apenas cinco anos depois das mobilizações radicais no centro do sistema, ocorre o choque do petróleo, com o encarecimento 
significativo desta matéria-prima. A fase de crescimento do ciclo de Kondratiev encerra-se, consolidando a fase prolongada de recessão com busca por novas tecnologias produtivas e novas formas de organização social da produção.

A crise se reflete nas mudanças drásticas das políticas econômicas de cada nação, além do início do processo de dissolução da guerra fria e da financeirização da economia mundial. Todas essas mudanças mundiais incitam transformações no campo da geografia.

Entretanto, não é apenas no mundo capitalista que assistimos às manifestações da população. A primavera de Praga em 1968, no bloco socialista, suscitou novas ondas de repressão. Contudo, no capitalismo e no socialismo temos diferenças significativas entre os movimentos. Nos países do bloco soviético, muitos grupos abandonam o marxismo tradicional alinhando-se com ideias próximas do anarquismo ou mesmo formando uma "dissidência cultural apolítica ou antipolítica" (HOBSBAWN, 1991, p. 32). Enquanto isso, nos países capitalistas, o evento aumenta a cisão entre ortodoxia e heterodoxia, dando força política para o trotskismo e o maoísmo em um momento inicial.

Parte da pequena burguesia ilustrada que se engaja na luta social afasta-se do proletariado e vê sua postura reformista como uma traição ao socialismo. O resultado prático dessa contradição que se acentua no maio de 1968 é a criação de novas organicidades políticas e uma maior divulgação de teorias e ideias acadêmicas revolucionárias (HOBSBAWN, 1991, p. 44).

Para Hobsbawn (1991, p. 47-51), o resultado generalizado do processo em curso é a formação de uma nova esquerda, mais heterogênea, pluralista e intelectualizada, contando com adesões intelectuais tardias, como no caso de Althusser, ou, na geografia, de David Harvey. Apesar de terem nuances diferentes, o advento da nova esquerda consolida-se com algumas caraterísticas semelhantes na França, Estados Unidos e na Inglaterra. Nesse sentido, Althusser e outros revisores de Marx ganham força fundamental, pois "a revisão das bases da teoria marxista era um elemento essencial do necessário exame crítico do trabalho de Marx e do marxismo enquanto corpo de pensamento coerente e homogêneo" (HOBSBAWN, 1991, p. 46).

No contexto dos Estados Unidos, mais ou menos contemporâneo às movimentações na França, surge o movimento hippie e a contracultura na busca de 
alternativas sociais $^{163}$. Johnston (et al., 2008, p. 670-671) indica três elementos básicos para a ascensão da geografia radical: (1) a guerra do Vietnã; (2) a luta pelos direitos sociais; e (3) o crescimento da pobreza entre a população dos Estados Unidos.

Contudo, há uma grande distância do poder de Moscou nos Estados Unidos, país que devido a guerra fria não pôde desenvolver um partido comunista forte, apesar de possuir muitos intelectuais migrantes que continuaram suas pesquisas no âmbito do marxismo.

A crise econômica mundial, a crise do marxismo após 1968, a crise dos intelectuais frente à complexidade do mundo encaminha a crise do campo de estudos da geografia. Capel (1988, p. 245-246) refere-se ao colapso do pensamento científico como um todo dentro do campo geográfico, que no caso francês foi um efeito provocado pela obra de Y. Lacoste. O caminho da geografia para ser uma ciência útil e reconhecida pela sociedade seria renovar-se e fazer uma avaliação de suas contribuições passadas.

\subsection{Maio de 1968}

A geografia crítica constitui-se enquanto movimento através dos conjuntos de geógrafos aglutinados em torno do marxismo que se manifestaram nas suas próprias escolas nacionais, mas em diálogo com o debate da esquerda no mundo. Dessa forma, recupera-se parte do arcabouço teórico-metodológico do marxismo e do anarquismo. Como vimos, os geógrafos anarquistas retomados são principalmente Reclus e Kropotkin, no entanto, eles servem como uma espécie de genealogia histórica das raízes radicais da geografia, portanto uma alternativa à história clássica da disciplina e ao conhecimento ligado aos interesses da burguesia. Kropotkin, com suas ideias de autogestão, pode ter influenciado alguns geógrafos norte-americanos, e existem atualmente muitos trabalhos sobre a geografia reclusiana, mas cremos que o marxismo impôs-se com mais peso servindo de referencial metodológico e filosófico. Isso deve-se à aproximação entre marxismo e anarquismo, como dissemos acima, e também devido à experiência socialista na União Soviética e na China, por exemplo.

163 Ligada à ideia de terceira via, nem capitalista, sem socialista. 
Sendo assim, a geografia consegue consolidar grupos de geógrafos mais ou menos coesos que se empenham para a inserção do marxismo, advindos parcialmente da revisão da obra de Marx e da discussão do marxismo contemporâneo da década de 1960/1970. Nesse cenário, deve-se considerar de um lado o contexto histórico de lutas ao redor do mundo, reativado a partir Maio de 68, e, de outro lado, o amplo debate do pensamento marxista empreendido por todo o século XX.

Do ponto de vista da universidade, os eventos de 1968 acabaram por delinear um novo rompimento com o marxismo stalinista que ainda persistia nos partidos políticos ou na universidade. Paralelamente, os quadros acadêmicos alteram-se, pois como mostra Bourdieu (2001, p.129) havia uma "insatisfação individual e coletiva engendrada sobretudo pela desclassificação estrutural decorrente da 'desvalorização' dos títulos escolares e dos descompassos entre o título e cargo". Esses elementos provocam uma mudança na estrutura universitária francesa que era extremamente rígida. Para Dosse:

\begin{abstract}
A velha Sorbonne, no limiar dos anos [19]60, continua desfrutando de um domínio absoluto sobre a cidade do espírito. Essa hegemonia presta-se pouco a uma reavaliação crítica de sua orientação. (...) Em face do positivismo triunfante e do atomismo do seu método, a investida estruturalista vai fazer-se ouvir, sob o registro de uma verdadeira guerra nas trincheiras anti-mandarinato, tendo por arma de combate a construção de modelos mais recentes de cientificidade, de inspiração holística. Esses combates conhecerão o seu auge em maio de 1968, com o desmoronamento do velho edifício. O peso da Sorbonne impunha a marginalidade aos contestadores e obrigava-os a procurar apoios, pontos de sutura, alianças novas entre disciplinas, a definição de um programa ambicioso e de um leitorado/eleitorado o mais vasto possível, a fim de contornar, desviar e desprezar os mandarins existentes (DOSSE, 2007, p. 257).
\end{abstract}

Se observamos os geógrafos selecionados por Bataillon (2009, p. 78) no seu estudo da geração de 1930, veremos que todos, ou ingressam no ensino superior deixando os liceus, ou mudam-se para universidades maiores durante os acontecimento de maio de 68.

Outra mudança importante diz respeito à exclusividade da pesquisa: dentro da universidade tradicional existia um código de ética informal que garantia uma divisão política dos temas de pesquisa sem que houvesse invasões alheias. Pelo menos dentro de cada campo do conhecimento esse código era forte e o período de exploração monopolística do tema deveria durar cerca de dez anos. Após as revoltas 
estudantis, essa ética informal passa a ser mais flexível e negociável (BATAILLON, 2009, p. 66) ${ }^{164}$.

O início e os meados da década de 1960 marcaram a ascensão do pensamento de Althusser, que representou uma nova proposta para o marxismo, como vimos. Diferentemente de outras disciplinas, a geografia demora um tempo maior para absorver seu debate teórico. O pensamento althusseriano teve um papel político muito importante na revolução de 1968 e seu debate teórico inspirou toda uma geração.

A economia também foi um campo atingido pelo radicalismo dos anos 1960 . Dessa forma, muitos geógrafos se pautarão nas obras que tem como proposta criticar os pressupostos do cientificismo na economia, analisando o estudo 0 desenvolvimento econômico, a distribuição de renda e de recursos. O enfoque geográfico dos economistas estimulou o campo geográfico através da obra de Paul Baran, Paul Sweezy e seu discípulo André G. Frank, nos Estados Unidos, Maurice Dobb, na Inglaterra, Bethelheim e Samir Amim, na França, Ernest Mandel, na Bélgica e Napoleoni, Labini e Pasenti, na Itália (SCARIM, 2000, p. 72). A intensificação e as mudanças na dinâmica do mercado financeiro são um incentivo ao debate econômico.

Nas ciências humanas aparecem trabalhos que releem a obra de Marx, além do destaque a Nicos Poulantzas, na ciência política, Godelier, na antropologia, Lefèbvre, Touraine e Castells na sociologia (direcionada ao estudo do urbano, particularmente), e, no urbanismo, o grupo chamado Espaces et société (CAPEL, 1988, p. 410-411). Greimas aplica as ideias estruturalistas na semiótica, Godelier na antropologia, Castells no urbanismo, Poulantzas na teoria geral do Estado. A maioria deles influenciados mais por Althusser do que por Lévi-Strauss.

Juntamente com a renovação do marxismo, todo esse movimento é fundamental para o surgimento das correntes pós-marxistas, ou então o desenvolvimento das teorias pós-modernas e pós-estruturalistas. Anderson (2004, p. 115) aponta maio de 68 como um momento em que a teoria encontra-se com a prática - portanto uma reativação plena da práxis - em que realmente ocorre um processo de transformação social. Contudo, após o momento de ápice do movimento, o que se instaura novamente é a dissociação entre os dois elementos,

\footnotetext{
${ }^{164}$ Ao conferir a produção de Jean Chardonnet (MAMIGONIAN, 2003, p. 41), notamos que existe uma sobreposição de sua geografia econômica com a de Pierre George. Talvez isso possa explicar em parte sua marginalidade na geografia francesa.
} 
havendo um retrocesso. A falta de um direcionamento do movimento revolucionário provocou uma dissolução e uma vez que alguns objetivos foram alcançados a revolução é institucionalizada. Mesmo na Alemanha, Wiggerhaus (2002, p. 688) aponta que a teoria crítica da escola de Frankfurt falha em orientar os movimentos sociais estudantis.

Marcuse, que a partir de certo momento teve uma relação ambivalente com seus colegas da escola de Frankfurt, tem forte influência no radicalismo de fins de 1960, defendendo a mobilização dos excluídos e marginais, como estudantes, militantes do terceiro mundo e negros do gueto, posicionando-se contra o capitalismo sob a égide da tecnocracia e o consumismo de uma sociedade doente (HERMAN, 1999, p. 339-340). Sua crítica social contribui na formação da nova esquerda americana. Baudrillard e Virilo que terão uma presença importante nos Estados Unidos e no movimento pós-moderno, também veem a dissolução do homem através da técnica (CUSSET, 2005, p. 21).

Nos Estados Unidos como coloca Jacoby:

\begin{abstract}
Os intelectuais ausentes da vida pública são principalmente aqueles que atingiram a maioridade nos anos 60 - um nome curto para as sublevações que duraram quase quinze anos. Como é possível que esses ativistas veteranos - que com frequência criticavam a universidade, escarneceram de seus professores e ridicularizaram os pensadores do passado tenham, ao amadurecer, se tornando esses profissionais sérios, mais silenciosos que os intelectuais mais velhos? (...) Nos anos 60, as universidades praticamente monopolizaram o trabalho intelectual; uma vida intelectual fora do campus parecia quixotesca. Quando a poeira baixou, muitos intelectuais jovens jamais haviam deixado a escola; outros descobriram que não havia nenhum outro lugar para ir. Tornaram-se sociólogos radicais, historiadores marxistas, teóricos feministas, mas não exatamente intelectuais públicos (JACOBY, 1987, p. 21).
\end{abstract}

Jacoby lamenta a dissolução do intelectual público, tradição da democracia, e demonstra como a pobreza do ambiente intelectual impele os pensadores à vida acadêmica e ao trabalho não remunerado nas publicações. Nos períodos de radicalidade, os marginais desenvolveram-se próximos ao centro, mas muitos acabaram sendo absorvidos.

Entretanto, é importante perceber que após 1968 existe uma dissociação cada vez maior entre a esfera da produção e a cultura do consumo na interpretação imaginativa de alguns. Eagleton (2011, p. 56) remonta à geração que dá origem a pós-modernidade, como por exemplo, Lyotard, que abandona o marxismo porque acredita que ele não pode contribuir para teoria da informação e a vanguarda 
artística, ou ainda Derrida, que pensa no pós-estruturalismo como uma ultrarradicalização do pensamento de esquerda e alternativa ao socialismo real.

Michel Foucault, apesar de participar dessa onda, após desligar-se do partido comunista ainda passa muito tempo em contato com os círculos maoístas de extrema esquerda. A sinergia entre estudos culturais e marxismo vem desde essa época e tem desdobramentos importantes, pois como Eagleton (2011, p. 58) afirma esses pensadores eram novos companheiros de viagem do marxismo, porém distantes do comunismo soviético. Dessa forma:

(...) a crise do marxismo não começou com a queda do muro de Berlim. Ela podia ser sentida bem no cerne do radicalismo político do final dos anos 60 e início dos 70. Não apenas isso, mas era também, em medida, a força motora por trás da cascata de novas ideias provocativas. Quando Lyotard rejeitou o que chamou de grandes narrativas, primeiro usou o termo para significar simplesmente, marxismo. A invasão soviética da Tchecoslováquia ocorreu na mesma época das celebradas revoltas estudantils de 1968. Se o carnaval estava no ar, assim também estava a Guerra Fria (EAGLETON, 2011, p. 61).

É o início do uso do método hermenêutico não apenas para o estudo literário, mas para a cultura e posteriormente a sociedade. O estruturalismo, que já havia se inspirado na linguística "ofereceu um insight sobre os códigos e convenções ocultas que governavam o comportamento social, fazendo com que parecesse menos natural e espontâneo" e a fenomenologia - não sem contato com o existencialismo passa a ser um instrumento de análise do cotidiano (EAGLETON, 2011, p. 84). A ligação entre arte, literatura e ciência é cada vez mais forte.

As mobilizações sociais do período representam um rompimento com a estrutura universitária, com a esquerda nos moldes da URSS e com a sociedade capitalista democrática estabelecida. Para Claval, o marxismo depois de 1968 vai estar livre de um dogmatismo partidário, porém "muitos permanecem marcados pelo que aprenderam" (CLAVAL, 2011, p. 286). O rompimento com uma esquerda mais ortodoxa impulsiona a busca de novas fontes, o que curiosamente reabilitará autores e ideias de direita no contexto da esquerda política, como expõe Schwanitz:

(...) uma oficina subterrânea de teoria rotulou de esquerdistas antigos comportamentos da direita, como a veneração da natureza, a crítica da cultura e a mentalidade de reformulação da vida fazendo, assim, com que uma autocompreensão de esquerda se reconciliasse com uma mentalidade de direita (SCHWANITZ, 2009, p. 175).

Herman complementa essa visão: 
O marxismo crítico [advindo da teoria crítica], o multiculturalismo, o pósmoderismo e o ambientalismo radical não só partilham muitos dos mesmos heróis como na 'revolução da direta' - Friedrich Nietzsche, George Sorel, Martin Heidegger, Arthur Schopenhauer - mas também o mesmo desprezo pelas tradições liberais e racionais da Europa pós-iluminista. Eles rejeitam qualquer noção de progresso social 'normal' de acordo com o padrão ocidental. Como os precurssores de direita, eles veem a crença na autonomia do indivíduo; na pose da propriedade privada como direito fundamental, na ciência e na tecnologia como favoráveis à felicidade humana, e na busca da felicidade como uma atividade essencialmente racional - como uma fonte de corrupção, exploração e morte. Se Hebert Marcuse, Tom Morrison, Ronald Takaki, Michel Foucault, Noam Chomsky, Edward Said e Murray Bookchin parecem surpreendentemente novos e radicais para seus admiradores, suas palavras soam muito familiares para outros (HERMAN, 1999, p. 464).

Certamente deriva daí um retorno a Heidegger e Nietzsche por parte da nova esquerda ${ }^{165}$. Também nos parece plausível o foco na crítica da cultura em detrimento de aproximações com a economia política, além da consolidação dos temas filosóficos no marxismo, como aponta a concepção de marxismo ocidental.

O movimento de circulação das ideias da crítica pós-estruturalista na França para os Estados Unidos é um percurso tortuoso e que tem um impacto direto em várias ciências humanas, inclusive na geografia na década de 1980.

O percurso inusitado do pós-estruturalismo começa no campo da crítica literária norte-americana, que na década de 1930, em um quadro de diversidade intelectual, defronta-se com o surgimento do New Criticism. Tal escola coloca a crítica literária no centro da vida intelectual norte-americana, analisando os textos de forma hermética abstraindo seus contextos sociais. Esse movimento de longa duração dentro do campo prolongou-se até a década de 1960. Desde sua fundação até sua crise diluidora, tornou-se cada vez mais apolítico a ponto de tardiamente celebrar o trabalho de Ezra Pound, envolvido com o fascismo e o antissemitismo (CUSSET, 2005, p. 60-62).

O ambiente intelectual dos Estados Unidos assimilou facilmente a centralidade de Nietzche, ao contrário do Hegel iluminista e marxista que teve uma importância grande durante meados do século XX na França. O pragmatismo e a filosofia analítica norte-americana tradicionalmente sempre combateram a violência totalizante do hegelianismo (CUSSET, 2005, p. 108).

Esse ambiente intelectual acabou por facilitar a penetração do estruturalismo francês e sua filosofia da teoria literária. Rapidamente a palavra de ordem de Derrida

165 Além de ser influenciado por Nietzsche, ao realizar uma sociologia dos corpos, Foucault também incorpora Heidegger - no que ele chama de $A b b a u$ - para a demolição ou dilaceração das ideias através da desconstrução (HERMAN, 1999, p. 368). 
"não existe fora do texto" torna-se o lema da crítica americana. Como sabemos, dos diversos campos influenciados pelo estruturalismo, a teoria literária é uma das primeiras a migrar para o pós-estruturalismo, desconstruindo as ideias consolidadas historicamente e buscando sua genealogia (CUSSET, 2005, p. 60-65).

Dessa forma, a teoria francesa representava uma via alternativa entre o formalismo crítico, os bloqueios da universidade submissa ao Estado e os interesses do mercado frente à efervescência das contradições sociais da sociedade norteamericana. Na virada para década de 1970, a contracultura norte-americana está impregnada pelo pensamento francês fruto dos acontecimentos de 1968. Dessa forma:

\begin{abstract}
Vários movimentos contraculturais e antimodernos [surgem entre $1960 \mathrm{e}$ 1968]. Antagônicas às qualidades opressivas da racionalidade técnoburocráticas da base científica manifesta nas formas corporativas e monolíticas e em outras formas de poder institucionalizado (incluindo as dos partidos políticos e sindicatos burocratizados), as contraculturas exploram os domínios da autorrealização individualizada por meio de uma política distintivamente 'neoesquerdista' da incorporação de gestos antiautoritários e de hábitos iconoclastas (na música, na linguagem e no estilo de vida) e da crítica da vida cotidiana (HARVEY, 2005, p. 57) ${ }^{166}$.
\end{abstract}

Isso provocou um total desprezo pelas normas acadêmicas, já que uma parte da população não estava ligada diretamente à universidade e divulgava as ideias radicais francesas em revistas livres. Porém, esse movimento de desprezo conquista também o mundo acadêmico, pois a sinergia entre universidade e contracultura provoca a absorção de parte das figuras ligadas aos movimentos de contestação pela universidade e/ou pelo campo artístico. Não conseguimos compreender a falta de rigor formal dos primeiros números da Antipode fora desse contexto.

No entanto, enquanto o maoísmo desfrutava de alta estima na França, nos Estados Unidos entre 1970 e 1974:

(...) os calouros americanos, nascidos sob os campus desmobilizados mais festivos, exploram de Derrida a Deleuze na pista de um pensamento que concebem como 'pós-político', alternativa intelectual à herança marxista mais do que sua continuação intensiva (CUSSET, 2005, p. 70)167.

Devido as ligações entre literatura e filosofia provocadas pela presença do estruturalismo, a teoria francesa funde ou aproxima fortemente os dois campos. Os

\footnotetext{
166 Tradução nossa.

167 Tradução nossa.
} 
filósofos franceses são lidos e incorporados ou aplicados na teoria literária. Uma vez conquistada a filosofia, o pós-estruturalismo e as posturas políticas da nova esquerda migram facilmente para a teoria social e daí para ciências humanas. Os estudos culturais foram os primeiros a serem catequisados, exercendo influência no cinema, no direito e na teologia (CUSSET, 2005, p. 94). Além disso, a figura de Fredric Jameson é central nesse processo, pois ele é um dos principais renovadores teóricos a partir da França, intensificando a literatura comparativa entre o inglês e o francês (CUSSET, 2005, p. 88). As modificações foram tão intensas, que no cume dos acontecimentos:

(...) tendo limitado-se ao quarteto Barthes-Lacan-Foucault-Althusser, demonstra-se que a partir de 1980, data de fixação disciplinar definitiva, mais de $50 \%$ dos artigos que Ihe são consagrados nos Estados Unidos são publicados dentro das revistas do campo literário (CUSSET, 2005, p. 87).

Uma parte significativa dos periódicos de esquerda, como a própria New Left Review ou a Partisan Review, acompanharam a moda intelectual e acabam ecoando o textualismo pequeno burguês, paralelamente ao maoísmo e à radicalização do mundo em crise devido ao choque do petróleo (CUSSET, 2005, p. 74-75). A teoria literária abriu margem para criticar as ciências duras, o imperialismo cultural e o pensamento colonial, o que fabricou os novos "campeões da subversão" (CUSSET, 2005, p. 95).

Esse processo culmina na importação da intelectualidade francesa, que atuou nos Estados Unidos seja nas universidades, seja em seminários de intercâmbio intelectual: Lyotard, Baudrillard, Derrida, Bruno Latour, Louis Marin, Michel de Certeau, Foucault, Deleuze, Virilo, entre outros. Conta-se ainda com a presença de Lacan, Barthes e Althusser (CUSSET, 2005, p. 82-83). No processo de tradução do pensamento desses autores que escrevam em francês, a dificuldade de tradução para o inglês oferecia mais um convite para a hermenêutica.

Os estudos culturais na década de 1960 e 1970 surgem como uma resposta ao marxismo clássico e como reflexo dos engajamentos heterodoxos. Contudo, não podemos ignorar o fato de existir precocemente uma influência desse grupo na geografia cultural em meados da década de $1980^{168}$. Acerca dos Cultural Studies:

\footnotetext{
168 Os estudo culturais serão importantes na ascensão dos estudos pós-coloniais e terão relação com a geografia fora do período que delimitamos como análise - notadamente nos fins da década de 1990.
} 
Os pesquisadores desse grupo que influenciam os trabalhos de Althusser, Barthes e mais recentemente Bourdieu invalidam a abordagem marxista ortodoxa: a cultura não é um simples reflexo superestrutural, mas um campo de lutas específicas pela hegemonia (donde existe uma referência forte a Gramsci); a classe social por si só não é um dado histórico bruto, mas uma construção simbólica (portanto cultural); e a hierarquia cultural não tem um sentido único, uma vez que é complexificada por uma nova cultura de massa (com a televisão comercial) e seus modos de apropriação pelas classes populares (CUSSET, 2005, p. 145).

Diante da radicalização das ciências humanas, na geografia encontramos aqueles que não seguiram a nova geografia, pois pensaram que a ênfase matemática seria uma simplificação, e os geógrafos neopositivistas, que começaram a rever suas posições políticas a respeito da produção do conhecimento. Dessa forma, alguns desses geógrafos neopositivistas e tradicionais irão vincular-se ao marxismo.

\subsection{Maio de 68 e a geografia}

Nesse processo de ascensão de um novo grupo de professores e criação de novas universidades, um fato não muito evidenciado é o ingresso de Yves Lacoste e Raymond Guglielmo na Universidade de Vincennes, criada no furor de 1968 e com o predomínio dos maoístas (DOSSE, 2004, p. 18). Como vimos, Lacoste era maoísta e foi indicado por Dresch para Vincennes (LACOSTE, 2010, p. 267), enquanto Guglielmo nesse período oscilava entre "um marxismo de protesto e um protesto ecológico" (BATAILLON, 2006, p. 14-15). No caso de Lacoste:

(...) que pertence a essa geração de geógrafos formada por Pierre George, pôde sair do economicismo tingido de marxismo de uma geografia essencialmente descritiva graças ao contexto coletivo da Universidade de Vincennes do pós-1968, graças à visão estrutural-marxista que aí dominava e que permitiu abrir a geografia para um diálogo teórico com François Châtelet, Michel Foucault e os althusserianos em geral dos diversos departamentos de Vincennes-a-estrutralista (DOSSE, 2007a, p. 392).

Mesmo após os abandonos de 1956, Guglielmo continua tendo contato com os meios de esquerda. Os eventos de maio de 1968 são fundamentais não apenas pelo seu ingresso em Vincennes, mas em função de sua nova aproximação metodológica que rompe com alguns aspectos herdados do pensamento de Pierre George. A relação de pesquisa com operariado através da tentativa de aplicação de questionários não o satisfez, devido à resistência dos próprios trabalhadores que se viam em uma situação de dominação (MEMÓRIAS, 1990, p. 4). 
Guglielmo, diferentemente de outros geógrafos, preocupa-se com a crise do marxismo, reflexão que foi solapada na geografia uma vez que a teoria estruturalista e dos sistemas fez com que o campo percebesse seu "atraso" epistemológico, consolidando a crise da geografia (MEMÓRIAS, 1990, p. 4-5). Ao contrário de Lacoste, Gugliemo nunca defenderá sua tese de doutorado. Contudo, Lacoste, Kayser e Guglielmo apostam na interdisciplinaridade, projeto que está muito próximo ao althusserianismo (MEMÓRIAS, 1990, p. 23).

Nesse momento, muitos pensadores tentam unir carreira política e acadêmica, como a geração passada tinha feito, uma política que poderia aumentar o capital cultural entre os pares. Porém, a grande novidade é que agora a instituição acadêmica oferecia muitos meios para o desenvolvimento da atividade científica, o que diminuía o peso da rede comunista paralela com suas revistas, centros de pesquisa independentes e publicações.

Após 1968 a geografia francesa rompe com alguns regimes de mandarinato e a tese de doutorado (thèse d'État) perde parte do prestígio e peso institucional. Lacoste, por exemplo, torna-se professor sem ter defendido a tese. Segundo Bataillon:

\begin{abstract}
Primeiramente a geografia francesa perdeu no início dos anos 1970 seus grandes mandarins: explosão numérica, renovação geracional, maio de 1968, lei de orientação universitária contribuíram para isso. Grande novidade em uma profissão estabelecida relativamente tarde e regida por um só guia: E. de Martonne, depois A. Cholley e depois o ínterim menos unívoco de G. Chabot e J. Dresch. Essas altas figuras reuniam de uma só vez a orientação de toda equipe: agregação, comitê consultivo, CNRS ${ }^{169}$, AGF ${ }^{170}$, Annales de géographie, etc. Essa situação explicava-se em uma profissão pouco numerosa até 1950 , composta principalmente por homens novos (pouca presença de dinastias), muitas vezes vindos de classes médias e não da burguesia que fornece os quadros de Estado através das grandes escolas (BATAILLON, 2009, p. 23) 171 .
\end{abstract}

Depois da revolução, a esquerda ganha poder institucional nas universidades, entretanto, como ocorre também nos Estados Unidos, pouco a pouco vão se tornar os campeões da academia submetidos à sua lógica. Contudo, na geração anterior, Dresch, que havia sido eleito membro da Academia de Ciências de Moscou, era conhecido por sua boa gestão, pois ele "dirige o Instituto de Geografia da

\footnotetext{
169 Conselho Nacional de Pesquisa Científica.

170 Associação dos Geógrafos Franceses.

171 Tradução nossa.
} 
Universidade de Paris. Poder sem abuso, sem sectarismo, espírito aberto: essas são as marcas de seu mandarinato" (BATAILLON, 2009, p. 119).

É justamente no ano de 1968 que todos os poderes são questionados e que por uma ironia do destino, Dresch assume a presidência da UGI aumentando ainda mais sua base institucional (BOMFIM, 2007, p. 121). Dresch não concorda com todos os aspectos do movimento, porém consegue manter-se na direção do Instituto de Geografia (MATHIEU e CARTIER, 2002, p. 3-6). Sua eleição na UGI não é barrada por ser comunista, mas significou o veto para Guerassimov, que almejava o cargo e que usufruía de influência no meio da UGI, apesar de ser visto como uma figura autoritária (ROBIC et al., 1996, p. 310).

A ruptura de 1968 causou uma verdadeira reorganização dentro do antigo grupo dos geógrafos de esquerda. Enquanto Dresch teve uma postura positiva diante dos eventos, tentando apoiar, negociar e dar voz aos revolucionários da universidade, George optou por isolar-se completamente numa casa de campo e desaprovar a postura de seus alunos que participaram de atividades contestadoras ${ }^{172}$. Segundo Rochefort (2008, p. 252) "é depois de 1968 que ele opta mais claramente por uma posição que retira todas suas relações de engajamento anteriores"173. Apenas após essa desradicalização, ele vai deixar de acreditar na visão de estruturas econômicas e sociais como uma boa forma de síntese da sociedade. (ROCHEFORT, 2008, p. 252).

Lacoste, por exemplo, acredita que sua própria posição no movimento desagradou George e sua esposa, além de causar sua exclusão do grupo (LACOSTE, 2010, p. 160).

George decide então não apoiar a produção da tese de Lacoste, que conta com a ajuda de Michel Rochefort. Desde seu ingresso em Vincennes, ele tem um prazo de dez anos para apresentar sua tese e opta por reunir os materiais de pesquisa sobre o terceiro mundo. No final das contas, em 1979 Lacoste apresenta a defesa de uma extensa tese de três volumes intitulada Unidade e diversidade no Terceiro Mundo. Apesar da aprovação, George continua a vê-lo com maus olhos e o Conselho Nacional de Universidades o rebaixa ao cargo de mestre-assistente, o que

172 Claval (1998, p. 332) elenca os cargos que George ocupava em 1968: diretor da Bibliografia Geográfica Internacional até 1972, domina o Comitê Editorial dos Annales de Géographie, membro da diretoria das Presses Universitaires de France, presidente da Seção de Geografia do Comitê de Trabalhos Científicos e Históricos, além de ser presença obrigatória em congressos científicos e orientador das publicações no campo geográfico.

173 Tradução nossa. 
faz com que sua ascensão para professor só se concretize em 1983 (LACOSTE, 2010, p. 160).

Rochefort, por sua vez, participa de maio de 68 para manter seu cargo em uma espécie de jogo de militância. A ruptura com o partido em 1956 representou a perda de um referencial importante, fomentando o cinismo intelectual, mesmo que ele nunca tenha abandonado um viés reformista (MATHIEU e CARTIER, 2002, p. 3-6). A mágoa de George também atinge Rochefort, que fica um longo período sem promoção universitária.

Diante dessas mudanças, em 1968 aparece um volume dos Annales de Géographie repleto de autores e textos que remetem ao marxismo. O primeiro deles é de Jean Dresch (1968, p. 513-515), que ressalta os progressos da geografia soviética, sua importância seminal no planejamento e a grande quantidade de recursos que a geografia dispõe por parte do governo. Ressalta o papel de Guerassimov e a construção do conhecimento acerca do planejamento territorial, pois na União Soviética existe o trabalho geográfico complexo com equipes de especialistas em vários ramos da geografia (DRESCH, 1968, p. 514).

Em seguida encontramos artigo de Guerassimov, que destaca as três linhas gerais de pesquisa da geografia soviética após a revolução de 1917: (1) estudo das condições naturais e dos recursos; (2) estudo da divisão territorial da indústria e do desenvolvimento das forças produtivas; e (3) geografia nacional, regional e cartografia (GUERASSIMOV, 1968, p. 517-518). Relembra ainda a criação de uma série de órgãos públicos voltados para geografia e refere-se à nova geografia econômica fundamentada nas obras de Marx, Engels e Lênin. Esses geógrafos ficaram incumbidos de organizar a divisão regional do trabalho, mensurar os recursos e desenvolver os meios de produção. A proposta seria não fazer somente uma geografia "construtiva" ou aplicada, mas integrar os estudos naturais e sociais. O enfoque regional permite esse encadeamento, partindo da ideia de hábitat humano (GUERASSIMOV, 1968, p. 525-526).

Pierre George também contribui nesse volume, debatendo as críticas ao stalinismo que ocorrerem no congresso do partido comunista de 1958. Ele aponta as grandes perdas de vidas humanas, de recursos naturais e a dificuldade de organizar as cadeias produtivas. Entretanto, George (1968, p. 578) coloca-se claramente a favor do centralismo da União Soviética, levando em conta as consequências políticas e sociais da destruição no pós-guerra. Indica ainda que somente nos anos de 1956 e 1957 haveria um ajustamento em favor das cadeias produtivas e um salto 
tecnológico que tornaria a economia soviética competitiva em nível internacional (GEORGE, 1968, p. 578). Ressalta que o processo de descentralização do planejamento após 1958 não teve sucesso.

De certa forma, a argumentação do artigo é uma defesa da política econômica stalinista. A defesa da centralização do planejamento talvez represente uma tentativa de reaproximação com sua trajetória de esquerda nos velhos moldes. Isso certamente malogrou devido à vitória de uma concepção mais heterodoxa do marxismo no interior das agitações de 1968. Indicamos que talvez esse retorno vise recuperar seu prestígio para com o Partido Comunista Francês ou entre a esquerda francesa. Ainda nessa época George debate e rejeita as posições do Clube de Roma sobre o problema ambiental, que previa um colapso do meio ambiente, provocando crescimento econômico zero em grande parte dos países do mundo (VEYRET, 2008, p.29).

No entanto, o fato de esses artigos terem sido publicados é um elemento muito importante. Isso porque Annales de Géographie é uma publicação tipicamente conservadora, distante do marxismo, fundada pela escola vidaliana de geografia e seu principal veículo de divulgação. A presença da velha guarda da esquerda no número de 1968 responde a uma radicalização maior, contudo permanece nos moldes em que foram gestadas no pós-guerra. Pontuados os aspectos do refluxo, vamos acompanhar agora o que ocorreu posteriormente.

\subsection{0 surgimento da geografia crítica}

Sinteticamente, poderíamos dizer que em um período inicial do ano de 1969 a 1970 os principais temas da geografia crítica foram: pobreza, os grupos sociais marginais (negros e indígenas), as periferias e os guetos urbanos, a crise do cotidiano, serviços públicos básicos e a discussão sobre o processo de planificação; e, secundariamente, a violência e os conflitos sociais (CAPEL, 1988, p. 433).

Se, por um lado, podemos observar todo esse radicalismo no pensamento francês, por outro é interessante ressaltar um seminário que ocorreu em Bordeaux, em novembro de 1968, sobre geografia tropical envolvendo seu principal defensor Pierre Gourou. O evento contou com a presença de Milton Santos, Manoel C. de Andrade, Celso Furtado, e Pedro P. Geiger, do Brasil, além de uma lista significativa de geógrafos de esquerda, como Pierre George, Claude Bataillon, Michel Foucher, Bernard Kayser e Michel Rochefort. Nessa verdadeira arena de debates existiam 
dois pressupostos gerais: (1) o subdesenvolvimento deve ser superado para o melhoramento econômico e social; e (2) o mundo tropical oferece modelos civilizatórios derivados de seu ambiente e de sua situação terceiro mundista (BOMFIM, 2007, p. 131-132).

Mesmo que haja uma diferença significativa entre a geografia tropical de Gourou e de Dresch, a começar pelo fato de um estudar o trópico úmido e outro estudar o semi-árido, o capital cultural dos participantes do seminário de Bordeaux demonstra a relevância do evento. Mesmo que Gourou mantenha o contato com seu aluno, o general Vô Nguyên Giap ${ }^{174}$, durante toda a vida, sua visão é um tanto apolítica, pautada fortemente nas variáveis culturais e nos obstáculos naturais do mundo tropical que acabam conformando um conjunto pessimista para o desenvolvimento humano nos trópicos (ROBIC, 2008, p. 51-57).

Na melhor moda francesa, a região é a escala de ação do Estado e a ocasião permite o debate entre Kayser, Rocherfort e George acerca do trabalho de planejamento do IBGE ${ }^{175}$ na década de 1960. O Brasil, que havia servido como uma espécie de laboratório para a aplicação das teorias de Rocherfort, poderia ser dividido em cinco regiões homogêneas, onde se instalariam polos de desenvolvimento que por sua vez estimulam a hierarquização das cidades fomentando o surgimento de serviços e infraestrutura (BOMFIM, 2007, p. 134). A região homogênea teria uma coerência do ponto de vista econômico, histórico e natural.

Kayser questiona essa concepção de planejamento, pois percebe que o Brasil possui regiões ligadas ao exterior e não à dinâmica interna, além de ressaltar os fluxos superficiais gerados pelo subdesenvolvimento e uma concentração terciária nas cidades, com exclusividade de serviços sofisticados nas grande metrópoles. Diante da economia fragmentada do Brasil, os polos acabavam reconcetrando os fluxos econômicos na metrópole nacional (BOMFIM, 2007, p. 134).

Milton justifica as discrepâncias na hierarquia urbana de acordo com a estrutura demográfica e a dinâmica econômica de cada região - o intercruzamento de tais variáveis permite identificar a presença de George. Enquanto Lysia Bernardes defende um planejamento de base regional, George defende a ação regional com um plano centralizado (BOMFIM, 2007, p. 136). Como vemos, o Brasil

\footnotetext{
174 Um dos principais generais de Ho Chi Minh na República Popular do Vietnã.

175 Instituto Nacional de Geografia e Estatística.
} 
foi paradigma e um espaço de experimentação para os geógrafos de esquerda através de uma postura que buscava combater o subdesenvolvimento ativamente, através da ação estatal, melhorando os níveis sociais mesmo frente a um governo autoritário. Certamente, essa postura terceiro mundista contrastou com posições mais naturalistas e pessimistas da geografia tropical nos moldes de Gourou.

Entretanto, a era de ouro de influência do plano francês em território brasileiro estava no final:

\begin{abstract}
A virada para a década de 1970 demonstrou uma grande mudança na produção do Instituto [IBGE] - e mesmo na produção geográfica brasileira -, marcada, a partir daí, por formulações de autores como Bunge, B. Berry, P. Cole, Harvey, dentro outros (BOMFIM, 2007, p. 139).
\end{abstract}

Dresch estava ausente nas discussões da geografia tropical no seminário de 1968, mas não da sua preocupação com o terceiro mundo. Poucos anos depois, em 1972, Dresch estimula Lacoste a estudar os bombardeamentos norte-americanos no Vietnã. A KGB facilita o acesso de Lacoste por Moscou, possibilitando-lhe ver de perto o bombardeamento do rio Vermelho, além de conhecer parte do comando de guerra vietnamita. Após essa incursão Lacoste publica um artigo no jornal Le Monde que Ihe confere uma projeção internacional (LACOSTE, 2010, p. 95-96) ${ }^{176}$.

Dresch ainda aproveita seu cargo de presidente do congresso da UGI em Montreal para, no ano de 1972, manifestar-se contra o bomboardeamento do rio Vermelho no Vietnã. O encontro em Montreal e o texto de Lacoste no mesmo momento contribuíram para a aproximação entre a geografia francesa e a norteamericana (JULLIARD e WINOCK, 1996, p. 371).

Enquanto todas essas transformações alteravam a paisagem intelectual da geografia francesa, nos Estados Unidos, Bird oferece um quadro geral dos temas que radicalizam a geografia norte-americana, resultando na emancipação relativa dos métodos matemáticos: (1) o contato com o marxismo e o ataque às correntes hegemônicas na geografia ocidental; (2) o papel das classes sociais no Estado ocidental capitalista; (3) a análise urbana; (4) as minorias e desigualdade social; (5) a questão da moradia; (6) o rural e os estudos ambientais; (7) desigualdades

\footnotetext{
176 Futuramente, logo no início de sua existência, a revista Hérodote $\left(\mathrm{n}^{\circ} 11\right.$ de julho-setembro de 1978) fará uma homenagem a Jean Dresch. O exemplar da revista destaca seu anticolonialismo e encontramos uma série de memórias, relatos e trechos escolhidos de suas obras sobre a África. Apesar da grande importância de Dresch enquanto geógrafo, militante e professor universitário, não podemos deixar de ver essa homenagem como uma retribuição à oportunidade que projetou Lacoste e os estudos do subdesenvolvimento.
} 
regionais nos países capitalistas; e (8) dependência, imperialismo e colonialismo (BIRD, 1989, p. 94).

Segundo Peet ${ }^{177}$ (1982, p. 226) a geografia crítica nos EUA data dos anos 1960, ligada a uma grande heterogeneidade de pensamento. Em 1967, ela se institucionaliza, assumindo compromissos em congressos e perante a Associação de Geógrafos Americanos (PEET, 1982, p. 232). Além disso, é possível identificar o início de articulações relevantes no final da década: "Em 1968, William Bunge ${ }^{178}$ fundou a Sociedade para a Investigação Humana, chamando para a redescoberta do longo esquecimento da arte de exploração e do seu uso para novos propósitos" (PEET, 1982, p. 234) ${ }^{179}$. Seu objetivo maior era promover excursões para áreas pobres com discussões e participação ativa para solucionar os problemas da população carente. Existia uma necessidade de engajamento local e uma preocupação em ensinar geografia para as pessoas e permitir que elas pensassem o planejamento (PEET, 1998, p. 73). Na época, a comissão ainda possuía cursos abertos e um sistema dedicado às publicações (PEET, 1982, p. 234). Bunge é um caso de geógrafo adepto da nova geografia que aos poucos percebeu que esta só contribuía para reproduzir ou apenas amenizar os problemas sociais.

O engajamento dos geógrafos foi algo muito presente, porém a vontade de ajudar levou muitos ao pragmatismo e não à revolução ou à transformação social profunda. Para Peet (1982, p. 228), o que marca a ruptura é a necessidade de um posicionamento político-científico e a queda do mito de ciência neutra, causando um direcionamento para "o estudo de problemas sociais urgentes" e "para a ação, a busca de modelos organizacionais para a promoção da mudança social" (PEET, 1982, p. 230-231).

É importante ressaltar que no caso da geografia norte-americana, não é só o marxismo que oferece uma alternativa à quantificação. A fenomenologia, de forma mais ou menos concomitante ao marxismo, oferece uma alternativa epistemológica para ser explorada. Nas palavras de Peet (1998, p. 34): "a crítica social da geografia humanística tem um tom ético e moral, com uma política mais implícita”. Dentro do

177 Peet publica em 1998 um manual sobre história do pensamento geográfico que até o presente momento não foi muito comentado no Brasil, chamado Modern Geographial Thought. Na introdução desse manual, Peet declara-se um anarco-marxista que incorporou contribuições da pósmodernidade, principalmente de Baudrillard, mas que continua descrente com a maioria dos pósmodernos ou pós-estruturalistas.

178 Devido a suas atividades "suspeitas", Bunge teve um contrato recusado na Wayne State University, sob a alegação de obscenidades no ano 1967 (PEET, 1982, p. 234).

179 Tradução nossa. 
espectro da fenomenologia alguns aproximam-se do existencialismo, fortemente influenciado pelo marxismo e pela análise da subjetividade a partir da existência material.

Isso permite vários geógrafos humanísticos radicalizarem-se e dialogar com a geografia crítica, como é o caso de Derek Gregory e Nigel Thrift no início de suas carreiras. Não por acaso, Peet (1998, p. 40-66), ao contar a história da geografia crítica e ao tentar elucidar seus aportes teóricos-metodológicos, gasta muitas folhas para sintetizar a filosofia de Sartre, Merleau-Ponty e Heidegger. Nesse contexto, dentre as figuras do existencialismo, ele dedica uma atenção especial a Heidegger, um dos inspiradores do pós-estruturalismo e com ampla influência na geografia por indicar a espacialidade como importante elemento filosófico.

Entretanto, devido ao distanciamento do marxismo no contexto dos Estados Unidos, Peet nega a ortodoxia vinculada ao partidarismo e ao socialismo real dizendo que "o radicalismo nos EUA é único em certo sentido, tornando-o humanístico $^{180}$ e não dogmático quando comparado com seu correspondente europeu" (PEET, 1982, p. 229). O fato era que muitos já estavam desiludidos com os fracassos e as distorções sociais na URSS (PEET, 1982, p. 228). Claval também confirma com essa visão e diz que nos Estados Unidos e na Inglaterra a presença partidária no mundo intelectual era fraca, diferentemente da França (CLAVAL, 2011, p. 291).

É difícil imaginar porque Claval acredita tanto que o partido é uma instituição que prejudica o avanço do conhecimento, como se ele fosse distinto de outros atores sociais que direcionam direta e indiretamente a produção conhecimento. Uma visão dialética da produção científica é encará-la como reflexo das disputas de força presentes na sociedade concreta. Os partidos comunistas defenderam a União Soviética, mas talvez ainda não seja claro o papel histórico do socialismo real e as causas de sua distorção. O silêncio que algumas vezes envolve as explicações acerca da natureza do stalinismo e do enrijecimento do socialismo real por parte da esquerda combativa pode revelar uma face derrotista no campo das ideias. Retomaremos essa problemática.

\footnotetext{
180 Cabe ressaltar que na Europa há uma longa querela entre aqueles que defendem um marxismo "humanista" e Althusser que via no humanismo uma ideologia burguesa de dominação de classe. Sua posição era de uma historiografia que não se pautasse nessa ideologia, mas visse o devir histórico através da cientificidade de seu estruturalismo, que seria capaz de se apresentar sem as influências burguesas. A noção de homem perde a significância e o sujeito não teria mais fundamental importância, pois sua leitura d'O Capital é anti-humanista (DOSSE, 2007, p. 398-400).
} 
Contudo, se Dosse afirma que a geografia francesa foi a última a chegar no debate do marxismo estruturalista quando este encontrava-se em declínio, para Jacoby (1987, p. 193-194) o mesmo ocorre com a geografia norte-americana e inglesa.

A fundação da revista Antipode, em 1969, marca o processo de divulgação do quadro heterogêneo de críticos sociais dentro da geografia norte-americana. Inicialmente, o núcleo duro da revista é constituído por J. Blaut, R. Peet, Ben Wisner e David Stea. Bunge também faz parte do grupo inicial, porém é afastado: "a presença gratificante mas às vezes opressiva de Bill Bunge encontra-se sempre em segundo plano" (HARVEY, 2000, p. 159). Gradualmente, o marxismo se consolida eclipsando outras tendências e forma-se um projeto de leitura das obras marxistas de teor filosófico (PEET, 1982, p. 230-231). De acordo com Capel (1988), a fundação dessa revista, remonta ao encontro da $A A G^{181}$, promovido em 1969 na cidade de Ann Arbor. No entanto, as contradições do processo estão ligadas à diversidade dos grupos participantes:

A maior parte dessas pesquisas desenvolveu-se sob o paradigma liberal, que tende a ver os problemas como resultante de causas imediatas e, então, propõe ver os problemas de melhoria que conservam intacto o funcionamento do capitalismo. A falta de uma tradição marxista nas ciências sociais nos EUA, especialmente a ausência de estruturas teóricas ligando os problemas superficiais às profundas contradições sociais, tornou esta tendência duplamente forte (PEET, 1982, p. 236).

Aproveitando-se da perda de fôlego da nova geografia, ela foi atacada:

A ideia de uma geografia que deveria intervir na realidade, capaz de dar respostas objetivas, neutras e justas aos problemas sociais, foi então firmemente contestada, e ação dos geógrafos nos planos de gestão do território foi interpretada como sendo tão-somente uma tentativa de preservar o status quo (GOMES, 2005, p. 277).

O exame de consciência da geografia questiona o conhecimento gerado para legitimar a ordem estabelecida, extremamente desigual, com o uso de modelos teóricos que eram abstratos e pretensamente funcionavam melhor que a própria realidade. O comportamento humano, por exemplo, era visto de forma muito racional e a partir dessa problemática buscaram-se modelos que refletissem a realidade de

${ }^{181}$ Associação dos Geógrafos Americanos. 
maneira mais fiel ${ }^{182}$. A geografia crítica partiria da realidade para conhecer o mundo e não dos modelos ideais para uma infinidade de estudos de caso (GOMES, 2005, p, 277-278).

$\mathrm{Na}$ Alemanha, críticas duras são feitas no ano de 1969 , em Kiel no $37^{\circ}$ Congresso de Geógrafos Alemães. A tradição regional paisagista é acusada de não cumprir com as suas responsabilidades sociais. As principais revistas nessa época são a Roter Globus, Geografiker, Neuer Globus e Geographische Hocshulmanuskripte, que refletiam os avanços nos principais núcleos da Alemanha (CAPEL, 1988, p. 436).

Nos Estados Unidos, no início da década de 1970, a geografia marxista afirma-se e a geografia liberal, preocupada com a simples solução de problemas sociais, é superada (PEET, 1982, p. 236-237). Durante a década de 1970, a revista Antipode trabalha principalmente por melhorias de comunidades, mais ou menos pontuais, auxiliando as pessoas a atuarem junto ao Estado na luta por seus direitos (PEET, 1982, p. 235). Segundo Capel, os principais temas nessa década serão:

(...) os trabalhos teóricos e informativos sobre os mecanismos econômicos básicos da sociedade capitalista, ou sobre a relação dialética entre o desenvolvimento e imperialismo, por um lado, subdesenvolvimento e dependência por outro, contribuirão para difundir entre os geógrafos os enfoques marxistas (CAPEL, 1988, p. 434).

E ainda complementa:

Trabalhos sobre o imperialismo e a acumulação primitiva capitalista, discussões sobre a aplicação na geografia do conceito de modo de produção asiático, críticas da geografia industrial burguesa, investigações sobre novas experiências de planejamento urbano, ou sobre a função da ciência geográfica como formação política, assim como tentativas de reescrever a história da geografia humana por uma perspectiva que incorpore conceitos marxistas (CAPEL, 1988, p. 436).

\subsection{Bunge, Harvey e a geografia do gueto}

Em 1971 W. Bunge publica Fitzgerald, um estudo de caso sobre um gueto negro na cidade de Detroit. Esse trabalho é resultado dos trabalhos de campo organizados em 1967-1969 sob o nome de Detroit Geographical Expedition and

\footnotetext{
182 A persistência da busca de modelos, na geografia crítica, pode ter impulsionado o uso da obra de Althusser. Seu projeto intelectual era o estabelecimento de uma ligação entre marxismo e a noção de estrutura, o que vinha muito a calhar para geógrafos que tinham uma formação neopositivista, ou que estavam abandonando trabalhos desse teor em busca de uma perspectiva mais crítica. A compreensão de alguns fenômenos históricos por estruturas evidencia a aproximação entre estrutura e modelo.
} 
Institute. Pouco tempo depois da organização dos trabalhos de campo, Bunge foi demitido sob circunstâncias pouco claras da State Wayne University, o que resultou em uma vida profissional instável devido suas posturas e opções políticas. A Universidade de Michigan patrocinou seu curso sobre planejamento urbano, porém depois de sua demissão "mudando-se para o Canadá, ele ensinou por um ano na Universidade de York e um na de Ontário Ocidental, mas nenhuma posição transformou-se em algo de longo prazo. Sem trabalho, ele dirigia um táxi em Toronto" (BUNGE, 2011, p. V) ${ }^{183}$.

Ao folhear e ler as páginas desse trabalho, recentemente reeditado, nos deparamos com uma obra científica de formato inteiramente inusitado. Fotos, cartas, entrevistas, charges estão todas dispostas de maneira muito distinta do habitus convencional da academia em um estilo revolucionário e questionador das formas de representação do conhecimento, como na Antipode dos primeiros anos. O livro tornou-se um clássico entre os radicais, mas foi mal recebido pela comunidade científica, que o classificou como desorganizado e indisciplinado (BUNGE, 2011, p. I).

Bunge, que havia sido formado no ambiente nomotético da nova geografia lutando institucionalmente com Hartshorne por sua posição e pela herança de Schaefer, apresenta um típico estudo regional sobre um bairro de Detroit. Bunge segue o itinerário diacrônico-sincrônico, resgatando a história local e traçando um panorama das relações atuais. A unicidade do lugar é destacada e a postura militante do pesquisador leva a uma práxis que o impulsiona na investigação participativa junto da comunidade (BUNGE, 2011, p. IV). A matemática não era mais capaz de proporcionar uma visão total e universal da realidade.

Logo na introdução da obra, Bunge defende a geografia regional, acusa os geógrafos de não regionalizarem as cidades, e ao mesmo tempo critica o uso da tecnologia na geografia, ressaltando a necessidade da observação, da exploração em campo, da cartografia e da geografia histórica. Além disso, defende que observar os fenômenos a partir de uma escala grande não descarta a possibilidade de generalizações (BUNGE, 2011, p. 1).

Através da narrativa do bairro negro, procura-se atribuir um caráter econômico ao problema racial, demonstrando que a pobreza e a escravidão estão associadas à degradação das relações e referências sociais. A miscigenação racial 
não ameniza o racismo presente na comunidade. Toda a obra perpassa a questão racial, a formação da identidade e os grupos minoritários frente aos brancos. É impossível não identificar um gosto sociológico que flui ao lado dos valores contraculturais e a apologia à cultura e ao modo de ser do negro norte-americano (BUNGE, 2011, p. 90-132). No período de publicação e feitura do livro, os panteras negras e os movimentos negros estavam em evidência.

Mesmo assim, Bunge não abre mão de pensar a renda, o preço dos imóveis e seus aluguéis a partir do modelo de von Thünen, ou seja, considerando o gueto e sua distância do centro da cidade pelos meios de transporte. Ele também desenvolve um mapa que procura identificar as transferências de dinheiro do centro de Detroit para a periferia, além de comparar preços dos mantimentos no bairro e a dinâmica do comércio local. Bunge não deixa de fazer inserções na geografia eleitoral, na falta de infraestrutura, no retrato da violência policial, na paranoia da pequena burguesia branca que convive com os negros, e nas representações produzidas sobre o bairro que procuram esconder a história dos migrantes que não são ingleses (BUNGE, 2011, p. 154-243).

Como veremos abaixo, não é por acaso que essa obra é reeditada na atualidade. Se, por um lado, podemos identificar vários elementos de um marxismo mais tradicional interessado na discussão sobre a luta de classes, sobre o preço do solo, a reprodução da vida do trabalhador ou ainda resquícios da nova geografia nos modelos espaciais, por outro, Barnes, que escreve o prefácio do livro de Bunge, ressalta a dimensão cotidiana e o fato de:

\footnotetext{
(...) sua atenção direcionar-se para as políticas de identidade em busca de um melhor entendimento das relações do poder material e discursivo que sustenta a desigualdade urbana e a sobrevivência humana que ainda é um grande assunto a se falar (BUNGE, 2011, p. VI).
}

Uma agenda muito afim com aquilo que futuramente se consolida como pósestruturalismo. Certamente esses interesses podem derivar das inspirações de um marxismo não-ortodoxo ou do contato com a nova esquerda. Entretanto, Fitzgerald é uma espécie de exceção nesse momento histórico em que o denominador comum recai sob a perspectiva estruturalista, que legitima uma postura mais nomotética e generalista para a geografia que acabara de emancipar-se do aporte regional hartshorniano e do neopositivista. Somos levados a pensar que Bunge faz o caminho inverso da tendência do campo e por conta disso viu-se numa situação de 
isolamento relativo do resto do grupo. Ele parece um pouco afastado da rede de geógrafos radiciais, e mesmo assim seu trabalho intelectual não perde a importância.

No entanto, a busca de modelos parece ser a grande descoberta e o caminho para geografia tornar-se radical e sistemática, ganhando a respeitabilidade de outros campos das ciências humanas. Se na França o viés estruturalista já vinha sendo gestado pelos geógrafos de esquerda, nos Estados Unidos os sistemas representaram uma perspectiva de modelar a sociedade. Em ambos conjuntos nacionais, os geógrafos procuram um corte epistemológico que permita modernizar a disciplina e ao mesmo tempo torná-la aplicável e útil para sociedade. Nesse sentido, como vemos em Bunge, a práxis tem um apelo muito forte na transformação do mundo.

Também entra em cena David Harvey, inglês nascido na cidade de Kent, filho de um estivador ${ }^{184}$ que se tornou supervisor no porto. Sua tese de doutorado foi sobre a exploração do lúpulo nos arredores de Londres no século XIX. Harvey fez sua graduação em Cambridge e pertence a uma geração que alcançou o nível universitário mesmo tendo se formado na escola pública (PESCHANSKI et al., 2011, p. 11-14). Simpatizante da social-democracia inglesa, Harvey ascendia na academia, porém não tinha reconhecimento de seus pares devido ao elitismo que permeava Cambridge. Alia-se a essa conjuntura a adoção do anticolonialismo, principalmente depois da invasão inglesa no Suez. A aversão ao império inglês e à elite intelectual estava relacionada intimamente, uma vez que os "professores, na geografia haviam vindo do exército ou das colônias, e minha geração não aceitava essa ligação" (PESCHANSKI, 2011, p. 14). Segundo seu próprio relato, o ano de 1956 que representaria a desarticulação da esquerda, teve um efeito muito mais destrutivo na Grã-Bretanha do que na França. Contudo, o debate desperta Harvey para política:

A geração dos 'jovens homens revoltados' da Inglaterra se rebelou contra a
política pérfida deste império em declínio que apenas buscava seus
próprios interesses e que não valia mais que os assustadores comunistas
designados como os inimigos número 1 . O ano de 1956 foi decisivo para
mim. Eu tinha 21 anos e estava no meu último ano de licença. Eu
abandonei meus estudos durante todo um trimestre a fim de discutir

${ }^{184}$ Seu avô, porém, ocupava o mais alto cargo possível para quem não detinha um título de nobreza dentro da marinha britânica (HARVEY, 2000, p. 137). 
apaixonadamente a política e tornei-me decididamente anti-imperialista (HARVEY, 2000, p. 139) ${ }^{185}$

Harvey só tem contato com a obra de Marx aos 35 anos de idade, ou seja, após a formação básica. Sua participação nas agitações de maio de 1968 é nula (PESCHANSKI, 2011, p. 14-16), pois ele estava ocupado trabalhando em Explantion in Geography na Universidade de Bristol após ter morado um ano na Suécia, o que revela suas ligações com a escola de Lund. Nesse período, em Bristol, Harvey debate com geógrafos de peso, dentre eles Hagget, Harner e Chisholm. Todavia já no final da década de 1960, este grupo começava a questionar a validade de algumas técnicas estatísticas (PATERSON, 1984, p. 22). Os textos mais politizados encontraram uma resistência grande da comunidade científica, e Peter Haggett, eminente geógrafo quantativista, auxilia Harvey quando seus artigos são recusados em Bristol (HARVEY, 2000, p. 160).

Em 1969 Harvey publica Explanation in Geography, que teve ampla repercussão na discussão sobre modelos em geografia e na fundamentação metodológica da nova geografia. Apesar da influência de Schaefer, para Peet (1998, p. 27) Harvey não deixa de lado as contribuições de Hartshorne na definição do objeto da geografia. Mesmo tendo em vista a busca de leis gerais, ele concebe a geografia com duas partes: a diferenciação de áreas através do estudo concreto e um método geral englobando a descrição e a explicação. Esse método procura explicações através de leis gerais, ideia introduzida pelo excepcionalismo de Schaefer, que acompanha Harvey em toda sua carreira.

Apesar do respeito e do diálogo com Hartshorne, a posição de Harvey é que a ciência corológica trata apenas de espaços relativos que só podem existir inseridos no espaço absoluto, que possui um sentido euclidiano, ou seja, geométrico, e que se refere à localização de fenômenos diversos e sua classificação. $O$ espaço relativo tem poder de explicação porque engloba as distâncias horizontais e as relações espaciais, porém, ele só existe se inserido no espaço absoluto total, o que coloca Harvey ao lado de Schaefer (HOLTON-JENSEN, 2009, p. 117-118).

Além disso, a própria obra é dividida em duas partes argumentativas. A primeira dedica-se a explicação científica, teorias, hipóteses, leis e modelos, e a segunda no uso de modelos para a descrição e explicação na geografia (PATERSON, 1984, p. 37). Com essa obra Harvey proveu uma "base filosófica e 
metodológica para um paradigma baseado no modelo, sugerindo uma estratégia, usando modelos a priori, para produzir leis científicas e teorias" (PATERSON, 1984, p. 53).

Outro fato relevante é que Harvey tenta aplicar o modelo de Thomas Kuhn para a história da geografia, mostrando que a ascensão da nova geografia seria decorrente dos tempos de mudança paradigmática na disciplina. As transformações viriam a reboque das mudanças sociais e essa seria uma estratégia de reafirmação dos critérios científicos da nova geografia dentro do contexto metodológico das ciências exatas, o que era muito desejável para um campo que queria renovar-se através do neopositivismo (PEET, 1998, p. 28).

Em 1970, Harvey vai para Baltimore, nos Estados Unidos, onde se casa e arruma um novo emprego. Na Universidade John Hopkins, ele encontra um quadro social em ebulição devido a discriminação racial, a pobreza urbana e as más condições de moradia. Os aluguéis estavam vinculados intimamente ao mercado financeiro devido à demanda por investimentos no centro da cidade (PESCHANSKI, 2011, p. 15). Harvey percebe a necessidade de estudar as condições urbanas de "modo sistêmico" e encontra a inspiração para isso no trabalho de Engels $A$ situação da classe operária inglesa, obra que evidencia a relação entre "cidade e valor, mercadoria" (PESCHANSKI, 2011, p. 16). Conjuntamente, no programa de pósgraduação, ele organiza um grupo de leitura d'O Capital.

O resultado disso é a obra A justiça social e a cidade, publicada originalmente em 1973 (CLAVAL, 2011, p. 290), e que contém uma parte dedica à segregação urbana seguida de uma leitura marxista da exclusão social de acordo com a lógica capitalista de urbanização. Alguns anos antes da publicação desse livro, Baltimore sofre uma caça às bruxas macarthista, o que ensina Harvey (2000, p. 159) a ser mais "temperado", segundo seu próprio relato.

No entanto, cabe ressaltar que nessa obra ainda vemos uma forte presença da teoria da renda marginal da terra, sendo que a teoria do valor de Marx aparece em segundo plano. Isso torna-se evidente quando vemos as discussões do valor marginal na constituição do preço do solo urbano em detrimento de reflexões aprofundadas sobre o papel do trabalho morto, por exemplo (HARVEY, 1980).

A teoria da renda marginal da terra está ligada a aproximações neoclássicas dentro da economia. A crítica à nova geografia parte inicialmente dos geógrafos insatisfeitos com as limitações com essa corrente da economia, porque aos poucos 
perceberam que ela permanecia somente na superfície dos verdadeiros fatores de produção:

(...) entre 1971 e 1975, foi feito um debate publicado no Area, uma revista do Instituto de Geógrafos Britânicos sobre a contribuição da disciplina para a solução de problemas sociais urgentes. Debates sobre a 'estrutura interna da explicação', aproximações behavioristas e a questão da relevância em geografia foram procedimentos ocorridos ao mesmo tempo em que uma política radical e perspectiva filosófica começou a ser desenvolvida na geografia humana da América do Norte (PATERSON, 1984 , p. 6$)^{186}$.

Nessa obra Harvey é influenciado pelo estruturalismo de Piaget e mesmo que esse aporte metodológico não inspire seguidores Justiça social e a cidade acaba se tornando uma espécie de estandarte da geografia crítica (UNWIN, 1995, p. 227-230). Contudo, a concepção de estrutura não é alheia ao debate na época, como coloca Johnston (1986, p. 100), pois ela se compõe como um sistema movido por três ideias fundamentais: (1) a totalidade interliga todos elementos; (2) a transformação ou incorporação de novos elementos proporciona sua auto-regulação; e (3) a estrutura é um sistema fechado, em constante movimento de equilíbrio. Assim, estrutura e sistema aproximam-se, tendência que permeia várias escolas nacionais e geógrafos:

\footnotetext{
Uma totalidade é constituída de um número de 'estruturas' separadas, de acordo com Harvey. Uma 'estrutura' não é uma coisa ou uma 'ação' e ela não pode ser estabelecida através da observação. Assim como a totalidade, uma estrutura é 'um sistema com relações internas que estão em um processo de ser estruturado através de sua próprias regras de transformação' (PATERSON, 1984, p. 88-89).
}

Da relação com Piaget temos a ideia de que as estruturas estão sempre em transformação, aproximação que encara o urbano como produtor da cidade analisado de maneira autônoma (PATERSON, 1984, p. 92)

De forma inovadora, Harvey utiliza a divisão entre espaço absoluto para referir-se à moradia fixa espacialmente e o espaço relativo para abranger seu conteúdo social através de seus atores, da mobilidade física e social (PATERSON, 1984, p. 79).

Apesar do valor de referência atribuído a esse trabalho, o próprio Harvey diz que não estava diretamente engajado com o marxismo na época (PESCHANSKI, 2011, p. 17). Um outro detalhe importante é que Justiça social na realidade é a 
reunião de quatro artigos publicados e dois inéditos. Mesmo que alguns argumentem que ele apresente uma estrutura de tese (formulações liberal neoclássica), antítese (formulações socialistas) e síntese (considerações gerais) é importante ter em mente que a obra não foi exatamente premeditada com uma concepção clara antes de ser escrita (PATERSON, 1984, p. 85). Por uma ironia do destino, isso não impediu que ela fosse tomada como um grande modelo para a geografia crítica.

Comparando Justiça social e Explanation in Geography Paterson ressalta a continuidade de alguns elementos chave do pensamento de Harvey:

\footnotetext{
O mais fundamental é a crença no poder da análise racional. Outra continuidade concerne a relação entre forma e processo, a importância geral da teoria e a transcendência dos limites disciplinares em busca de explicações satisfatórias (PATERSON, 1984, p. 163).
}

Outro contexto importante de surgimento dessa obra advém do debate que Folke fazia juntamente com Harvey sobre os guetos. Essa discussão expõe e critica as ações da social-democracia na Suécia, que defendia uma transição reformista capitalismo-socialismo, o que na verdade mantinha as desigualdades sociais (JOHNSTON, 1997, p. 213).

Steen Folke também debate com Richard Morill, defendendo a revolução, enquanto Morill é a favor de reformas ou da transição gradual das instituições do poder (CAPEL, 1988, p. 431). A tendência de Morill, Knox e Wohlenberg consolida a chamada geografia do bem-estar social, que se localizam dentro da tendência liberal referida acima. Peet (1982, p. 242) diz que entre 1972 a 1974 é quando a geografia radical tolheu os liberais guiados principalmente pelo pragmatismo. Eles serão atacados pelos marxistas principalmente pela gradual adoção de um sistema de análise que desassocia produção e o consumo, por analisarem os atores isolados das relações estruturais no modo de produção e devido a sua afinidade com o fetiche espacial (JOHNSTON, 1986, p. 120).

Mais adiante veremos que o texto de Anderson sobre o fetiche espacial é extremamente impactante, mas a controvérsia entre indivíduo e estrutura será reativada sem que se dê muito enfoque à fração liberal.

\subsection{Da análise urbana ao capitalismo mundial}

O próprio Richard Peet (1982, p. 231-232) admite que a geografia radical "significou mudar o tópico focal da disciplina, mantendo ainda a metodologia de 
pesquisa existente". Da mesma maneira que a geografia francesa teve dificuldade de abrir mão completamente das metáforas naturalizantes na análise da sociedade, a norte-americana também terá para romper completamente com o pragmatismo da nova geografia. Por outro lado, é claro o enriquecimento técnico que a geografia sofreu com a revolução quantitativa. Apesar disso, o esforço para compreender os aportes marxistas são significativos:

A partir de 1972, a ênfase da geografia radical mudou de uma tentativa de engajar a disciplina em pesquisa socialmente relevante para uma tentativa de construir uma filosofia radical e uma base teórica para uma disciplina engajada social e politicamente (PEET, 1982, p. 238).

E complementa:

Em vez de continuar com outra investigação empírica sobre as condições sociais nos guetos, os radicais deveriam engajar-se na construção de um novo paradigma para o pensamento geográfico social através de uma crítica profunda dos construtos analíticos presentes (...) Rejeitando o idealismo para a teoria revolucionária proposta, ele propôs, para ser usado, mais do que uma área de sobreposição entre positivismo, materialismo e fenomenologia. O sistema que sugeriu foi o marxismo, que incorporou uma base fenomenológica nos últimos escritos de Marx, recobrindo uma base materialista e um método analítico em comum com o positivismo, e ainda foi mais além do que ambos para submeter a própria base da sociedade capitalista a um exame crítico e rigoroso (PEET, 1982, p. 238).

Os resquícios do neopositivismo ficam evidentes ao buscar modelos sociais com base no marxismo. Richard Peet, por exemplo, é um geógrafo que se apoia na especialização do espaço, defendendo-o como objeto particular que diferencia a geografia de outras ciências, mesmo que seu objetivo maior seja a realização da síntese de processos sociais (PEET, 1982, p. 243). Assim, os modelos e a noção de estrutura relacionam-se ao desenvolvimento do trabalho dos geógrafos:

\footnotetext{
Para se constituir, a nova geografia imprime na sociologia e na economia e se direciona na fabricação de modelos que, frequentemente, aplicará no exame de problemas sociais. A aproximação sistemática vai trazer consigo uma grande influência do estruturalismo (...) O conceito de estrutura designa 'uma organização de elementos ordenados em vista do funcionamento do conjunto'; numerosos geógrafos vão portanto se direcionar para a identificação de estruturas espaciais (KONINK, 1995, p. $146)^{187}$.
}

No seu manual sobre a história da geografia, Johnston (1997, p. 214-215) dedica um subitem do capítulo sobre geografia radical somente para explicar como a

187 Tradução nossa. 
estrutura foi apropriada pelos geógrafos marxistas. Recupera, então, o pensamento de Lévi-Strauss que demonstra o jogo dialético entre superestrutura (contingências psicológicas), infraestrutura (materialidade da produção) e a estrutura profunda, que tem um caráter "trans-histórico" e carrega consigo elementos que persistem por um longo período. Entretanto, a temática urbana, o subdesenvolvimento e o imperialismo continuam a ser assuntos importantes que atraem os geógrafos para o projeto da geografia crítica.

Confluindo com a temática urbana, na década de 1970 aparecem artigos na Antipode sobre as implicações espaciais da obra de Marx e dos teóricos marxistas (PEET, 1998, p. 97). O resultado é o interesse na compreensão da lógica do capital, ou seja:

(...) o movimento teórico se deu a partir das contradições na história dinâmica da acumulação do capital para a manifestação dessas contradições no espaço, e então retorna novamente, como efeito espacial tornando-se um dos aspectos que contribuem no desenvolvimento desigual. Um dos componentes principais dessa posição foi a noção de construção de crises internas às regiões, expressas nos movimentos no espaço (PEET, 1998, p. 97-98).

A partir da grande temática do desenvolvimento desigual teremos duas correntes dentro dos Estados Unidos que não necessariamente se contrapõem: (1) estudos sobre o desenvolvimento desigual, com Harvey e seus discípulos: Lata Chatterjee, Richard Walker e Neil Smith; e (2) uma corrente inspirada na produção do espaço por $\mathrm{H}$. Lefèbvre e sua dialética socioespacial, que dará o fundamento para a geografia pós-moderna de E. Soja.

Dentro dessa perspectiva, Harvey trata da dialética interna e externa (local e global) do capitalismo e demonstra como as estruturas geográficas impõem empecilhos e facilidades para a acumulação do capitalista. Ele procura entender como surge a negociação entre o moderno e a tradição para existirem novas perspectivas de investimento. A ação imperialista é de suma importância, assim como a busca de novos loci de investimento e acumulação (PEET, 1998, p. 96-99) que se articulam com o crescimento urbano: "Revoluções nas forças produtivas, o aumento da escala de produção, da concentração e da centralização do capital são paralelas às aglomerações urbanas em um ampliamento do espaço capitalista internacional" (PEET, 1998, p. 99).

Peet (1982, p. 237 e JOHNSTON, 1997, p. 210) confere demasiada importância à obra de Harvey e diz que ele foi uma espécie de liderança na 
consolidação do marxismo como base metodológica para a geografia. Entretanto, o próprio Peet tem um peso importante nesse processo, não só no processo de contar a história do movimento, mas também direcionando a Antipode.

Peet (1982, p. 232-233) e Unwin (1992, p. 231) destacam também os trabalhos de Keith Buchaman e James Blaut sobre imperialismo e sobre o sistema de colônias na mesma época do debate sobre justiça social. O desdobramento desses estudos abarcam a relação entre imperialismo e subdesenvolvimento, tarefa realizada por Slater, Santos e Buchman (UNWIN, 1995, p. 231).

James M. Blaut é outra figura central para o entendimento da geografia crítica norte-americana. Pesquisador de uma grande diversidade de temas ${ }^{188}$, ele faz seu doutorado na Universidade de Columbia, onde estuda a agricultura tropical da América Central. Ligado a Robert S. Platt e sob o auspício do método da geografia cultural de Carl Sauer, Blaut radicaliza-se ao debater o problema da escravidão na Jamaica e em Trinidad. Em contato com a antropologia marxista de Sidney Mintz o apelo anti-imperialista o torna cada vez mais crítico, a ponto de acusar os sauerianos de conformistas (MATHEWSON, 2008, p. 111-114).

Blaut ajuda a fundar a revista Antipode e se envolve nas atividades contra a guerra do Vietnã. Através do contato com os políticos do terceiro mundo - sobretudo da América Central e Angola - Blaut desenvolve importantes trabalhos sobre nacionalismo, imperialismo e eurocentrismo envolvendo o processo histórico de colonização. Seu aporte teórico para pensar o subdesenvolvimento é a teoria de A. Gunder Frank e a escola da dependência (MATHEWSON, 2008, p. 119). Quando ascendem as teorias pós-modernas, Blaut volta aos estudos culturais.

A introdução de André G. Frank na geografia representa a incorporação de ideias importantes acerca do subdesenvolvimento: (1) a negação do difusionismo positivista do desenvolvimento econômico; (2) o abandono das análises funcionalistas que veem o subdesenvolvimento como persistência dos aspectos feudais; e (3) ruptura com a ortodoxia marxista que defendia a revolução democrático-burguesa antes da revolução socialista. Paralelamente, Frank é influenciado pela interpretação de Celso Furtado e da Cepal, concebendo a periferia

\footnotetext{
188 Ao consultar sua nota bibliográfica verificamos trabalhos em: pedologia, teorias do nacionalismo, análises microrregionais das fazendas tropicais, o papel do colonialismo e do eurocentrismo na geografia, estudo da filosofia marxista e das ideias do pragmatismo, estudos de difusão cultural, da psicologia e percepção espacial das crianças e a desconstrução da ideia de raça e de classe na onda mais contemporânea da pós-modernidade (MATHEWSON, 2008, p. 107).
} 
capitalista como um choque entre estruturas arcaicas e o capitalismo moderno (BROWETT, 1980, p. 96-97).

O origem do capitalismo se daria pelo comércio, como na interpretação de Sweezy no célebre debate com Maurice Dobb. A mera circulação das mercadorias deflagra o capitalismo nas colônias, criando um laço de dependência com a metrópole. O capitalismo apropria-se de modos não capitalistas de produção explorando-os o máximo possível para a produção e para um possível superlucro (BROWETT, 1980, p. 107).

Ligada à geografia econômica e com uma trajetória similar a de Harvey, Doreen Massey é oriunda de uma família operária de Manchester e consegue ingressar em Oxford com uma bolsa de estudos em 1963. Em 1968, estuda meio ambiente e em 1969 participa do Congresso Feminista, preocupando-se em inserir a abordagem em seus trabalhos (ENTREVISTA, 2006, p. 202). Entre 1971-72 ela vai aos Estados Unidos para estudar economia neoclássica e a partir desta experiência critica a economia da nova geografia. Com os seus estudos sobre ambiente e urbanismo, Massey é indicada para trabalhar em um órgão governamental de planejamento, no entanto, assim como vários outros serviços, sua seção é fechada pelo governo Thatcher.

Como destaca Smith (2001, p. 6), o governo Thatcher e a ascensão do neoliberalismo foi outro elemento que radicalizou muitos geógrafos, principalmente no Reino Unido. Thatcher começa a atuar na Secretaria do Estado para Ciência e Educação em 1970 e seu sucesso institucional a longo prazo causa na GrãBretanha uma união entre os neoliberais e a social-democracia, o que teve graves consequências políticas (SMITH, 2005, p. 888).

Em 1979, Massey engaja-se na Open University, uma universidade para operários surgida no contexto de 1968, e entra em contato com o pensamento de Althusser (ENTREVISTA, 2006. p.196-198). Em meados da década de 1980 ela vai para Nicarágua estudar o sandinismo, a seu ver, uma forma de militância e de reação ao neoliberalismo. Massey manifesta uma desconfiança com relação ao desenvolvimentismo econômico como solução para os problemas sociais (ENTREVISTA, 2006, p. 200).

Smith sintetiza a configuração inicial de geografia radical:

Alguns, como David Harvey, focaram diretamente em Marx, enquanto outros, como Richard Peet e Myrna Breitbart, redescobriram Kropotkin e outras influências anarquistas. Doreen Massey e outros na Grã-Bretanha 
voltaram-se para as novas influências do marxismo continental e Louis Althusser em particular, enquanto Jim Blaut e Bill Bunge misturaram amplamente as teorias marxistas com alguns interesses da geografia tradicional quantitativa. Com pouca presença do feminismo nos anos 1970, geógrafas feministas, como Suzanne Mackenzie, encararam o duplo desafio de fundir geografia e teoria marxista com a análise feminista (SMITH, 2001, p. 8).

Em pouco tempo as tendências elencadas por Smith misturam-se, pois a procura de uma explicação sistemática de cunho filosófico alinha muitos com a interpretação estruturalista. Traçado o quadro inicial e apresentada a trajetória de parte importante dos membros do movimento que surge, temos elementos para compreender como o althusserianismo contribuiu para geografia.

\subsection{0 estruturalismo althusseriano}

No final da década de 1960, o estruturalismo althusseriano terá muita força nas ciências sociais da França e da Inglaterra. Hobsbawn (1991, p. 45) indica que sua obra entra na moda intelectual e desenvolve-se entre 1965 e 1975 em uma escala internacional com forte afeição pelas abstrações teóricas. Cabe então compreender seus processos de constituição e quais seriam os motivos que explicam sua força de atração.

Um ponto comum em todo movimento estruturalista seria a concepção de "um mundo empírico dos fenômenos observáveis determinados pelas estruturas subjacentes" (UNWIN, 1995, p. 236). Contudo, como destaca Ípola (2012, p. 26-27), Althusser trava um diálogo tenso com o estruturalismo de Lévi-Strauss. Um elemento fundamental que podemos indicar é a centralidade que Althusser atribui às condições históricas e à contingência, ao invés de suspender a dimensão histórica como Lévi-Strauss faz em várias de suas obras. Lévi-Strauss analisa a estrutura para dimensionar o aparente movimento da realidade, enquanto de uma maneira mais direta e materialista Althusser busca o movimento real da sociedade através da mudança e da emancipação da classe proletária (GREGORY, 1978, p. 106-107). Althusser não dissocia a lógica e a análise histórica, ou a lógica, tempo e espaço para universalizar alguns aspectos do pensamento humano como faz Lévi-Strauss.

Após o conflito sino-soviético depois da destalinização, Althusser posiciona-se contra o antimarxismo de Raymond Aron ${ }^{189}$, contra a ortodoxia do partido comunista 
francês e contra os pensadores da heterodoxia, como Sartre e Lefèbvre (ÍPOLA, 2012, p. 21).

Dosse (2007a, p. 211) indica o marxismo de Althusser como uma tentativa de distanciar-se do stalinismo ou de interpretações mecanicistas. Em sua autobiografia, Althusser (1992, p. 177) coloca: "quando vem a moda da ideologia 'estruturalista', que apresentava a vantagem de romper com todo psicologismo e historicismo, eu apareço seguindo o movimento"190. Para Peet (1998, p.120) o marxismo de Althusser seria uma espécie de terceira via alternativa ao stalinismo e ao marxismo humanista, permitindo novas possibilidades discursivas. Independente disso, de fato a iniciativa de Althusser buscava reverter a crise do marxismo na França e no mundo:

\begin{abstract}
As condições desta dupla ofensiva foram ditadas, segundo Althusser e seus discípulos, quase exclusivamente pela necessidade de uma resposta política. O próprio Althusser põe em primeiro plano sobretudo a crise do movimento comunista mundial, na sequência do XX Congresso do PCUS, ao passo que seus seguidores críticos sublinham a desorientação dos comunistas franceses em face da atitude assumida pelo partido durante a crise argelina. Por nossa parte, importa mais sublinhar os 'efeitos do conhecimento' dos trabalhos de Althusser, partindo das premissas teóricas da reforma althusseriana do marxismo. Estas premissas consistem na recomposição 'estruturalista' das ciências humana na França, nos anos 60, e no neorracionalismo anti-idealista e antiempirista da epistemologia histórica de Bachelard. Ambas as premissas são (...) não condições externas em relação ao marxismo althusseriano, e sim funcionais, internos, de sua problemática do 'trabalho de transformação' da teoria marxista (KALLSCHEUER, 1989, p. 54).
\end{abstract}

\title{
Segundo Dosse:
}

Para Fougeyrollas, o althusserianismo é um resultado direto do $20^{\circ}$ Congresso do PCUS, inscrevendo-se nos limites estritamente estabelecidos e estreitos de uma crítica do dogmatismo sem subversão do aparelho, postura essa que induz a um regresso às fontes, aos pais fundadores: Lênin e Marx (DOSSE, 2007a, p. 235).

O quase silêncio sobre o socialismo real, a volta aos clássicos e o casamento com os critérios de cientificidade do positivismo possibilitam uma reabilitação do marxismo com a intelectualidade perante as várias contradições do socialismo e do capitalismo. O reflexo do retorno às origens do marxismo aparece em Por Marx, publicado em 1965, Ler o Capital, em 1965, e Lênin e a filosofia, de 1969.

Não por acaso, os textos que deram origem ao Por Marx foram publicados inicialmente na revista La Pensée, na década de 1960, e após 1968 o texto de 
Aparelhos ideológicos do Estado também é publicado nesta revista, que sempre manteve um distanciamento do stalinismo (JULLIARD e WINOCK, 1996, p. 871).

Assim, sua agenda de pesquisa dedica-se aos mecanismos de controle da classe hegemônica no capitalismo (DOSSE, 2007a, p. 212), ideia que the permite relacionar o tema da reprodução social com as ideologias de classe. Tal aproximação inspirou a renovação e os movimentos da esquerda em 1968, reinventando o marxismo ortodoxo sem discuti-lo diretamente e afastando-se da economia política e do economicismo.

Aparelhos ideológicos é duramente criticado pela ortodoxia do partido no momento de sua publicação. Se, por um lado, Althusser fala pouco sobre a União Soviética, por outro, esse texto corresponde a uma concepção revolucionária em que a vanguarda esclarecida teoricamente conduz as massas ao socialismo. Constitui-se então como uma resposta direta à revolução cultural chinesa e impulsiona esta alternativa no seio da esquerda francesa (ÍPOLA, 2012, p. 25). Como Lacoste fará tardiamente na geografia, a linguagem militar funde-se com o campo epistemológico propondo um front teórico na guerra entre ideologia mistificadora e ciência verdadeira - polarização muito próxima do zdanovismo. Nessa obra:

\footnotetext{
Althusser distingue - como ele explica, fazendo parecer um retorno à ortodoxia por um momento - de um lado a infraestrutura (a base econômica composta pelas forças produtivas e as relações de produção) e de outro, a superestrutura (o Estado, o direito, a ideologia) ligando um a outro sob a dupla regra da determinação em 'última instância' pela base econômica e pela autonomia relativa da superestrutura (ÍPOLA, 2012, p. $43)^{191}$.
}

A diferenciação de Althusser possibilita perceber a diferença entre a determinação da base econômica e a dominação da superestrutura nas esferas sociais dentro de um modo de produção. A concepção geral do stalinismo postula que a base econômica determinaria a sociedade, mas o esforço de Althusser busca mostrar como as superestruturas também são importantes na constituição da sociedade, funcionando de maneira relativamente independente da infraestrutura. Ela funciona de maneira autonôma, porém não está fora da luta de classes, da reprodução social e muito menos da sobredeterminação econômica.

Apesar de Althusser dar novo fôlego aos estudos da superestrutura, avaliando de maneira mais rigorosa as intermediações entre infra e superestrutura, a 
sobredeternimação, no entanto, não abandona o determinismo econômico. Cada formação social apresentaria uma reprodução simples (econômica strito senso) que em sua escala estendida envolve a reprodução da força de trabalho através da produção científica, ideológica, moral e técnica (superestrutura).

É devido a essa postura que acreditamos na tese da reformulação do marxismo ortodoxo dentro de seu pensamento, conjuntamente a um distanciamento do contexto político da época. Essa associação não é negativa, do nosso ponto de vista, pois mostra processos de longa duração dentro do marxismo francês que mesmo depois de eventos importantes de ruptura mantém modos de operar o pensamento - zdanovismo, economicismo, etc. Ou seja, a classificação de ciência burguesa não desapareceu no althusserianismo.

O processo de assujeitamento dos indivíduos é fundamental para a reprodução social, porque o indivíduo imerso na ideologia acaba cumprindo seus deveres sociais sem necessidade de coerção exterior já que ele está assujeitado ao Absoluto ou às relações sociais dentro do meio em que se insere (ÍPOLA, 2012, p. 78). A mesma lógica aplica-se à revolução feita pela massa assujeitada, subordinada à luta de classes e ao repúdio do individualismo burguês heróico (ÍPOLA, 2012, p. 110).

Os livros mais importantes de Althusser receberam reedições na primeira metade da década de 1970 e é possível encontramos nas obras os conceitos de modo de produção e de formação social que são centrais na sua reflexão sobre a história. Assim: "Enquanto o modo de produção constitui um modelo de realização econômica e social, a formação econômica e social constitui a realização concreta da produção com sua lógica e com suas contradições" (CRUZ, 2009, p. 71).

O modo de produção seria uma espécie de modelo geral de explicação do funcionamento das sociedades, ou seja, uma variável universal. Enquanto a formação social seria seu aspecto particular, ou ainda a síntese do processo histórico de concreção de determinado modo de produção em uma determinada sociedade - ou país se preferirmos ${ }^{192}$.

Gregory (1978, p. 110-111) ainda destaca que cada modo de produção apresenta especificamente a força de trabalho, os meios de produção, o objetivo do

\footnotetext{
192 O debate sobre a sucessão dos modos de produção - comunismo primitivo, escravismo, feudalismo, capitalismo, socialismo e comunismo - sempre foi um tema de muitas querelas. Na Segunda Internacional havia uma leitura de continuidade entre um modo de produção e outro. Contudo, Lênin insere uma nova variável com a defesa do socialismo direto, ou seja, na Rússia seria possível a construção do socialismo mesmo com a presença intensa de aspectos feudais.
} 
trabalho e o modo de apropriação da natureza, este último muito interessante para geografia.

Se nos primeiros textos sobre a juventude e maturidade de Marx, Althusser estabelece uma clivagem rígida entre os dois momentos do pensador, já em 1973, a partir da crítica de John Lewis, ele reconhece que o corte epistemólogico não é tão intenso, e que as categorias mais filosóficas do jovem Marx estão ligadas à reflexão econômica presente n'O capital. Contudo, a maturidade ainda pode ser pensada como um ponto de não-retorno, uma vez que alguns temas não serão mais desenvolvidos (ALTHUSSER, 1973, p. 53). Dessa forma:

(...) o jovem Marx acertou suas contas com sua 'consciência filosófica anterior' (1845), abandonou definitivamente suas posições teóricas de classe burguesa liberal e pequeno-burguesa revolucionária para adotar (isso foi somente no princípio, no momento onde ele larga as velhas amarras) as novas posições teóricas de classe revolucionárias-proletárias que ele pode lançar as bases da teoria científica da história como história da luta de classes (ALTHUSSER, 1973, p. 57) ${ }^{193}$.

A estratégia da autocrítica foi muito frequente no pensamento de Althusser, que a utilizou para desculpar-se sobre o corte epistemológico, sobre a concepção de prática teórica e o distanciamento da ação concreta, pelo fato de ter classificado a filosofia como uma ciência com objeto definido e finalmente por não ter explorado o papel da luta de classes em seus primeiros escritos (JACOBY, 1981, p. 22).

Outro ponto polêmico que vai na direção da obliquidade política é a postura anti-humanista de Althusser, desenvolvida a partir da ideia de que Marx não iniciaria sua análise científica a partir do homem, mas do período histórico enquanto objeto científico (ALTHUSSER, 1992, p. 203). O humanismo seria então um produto da ideologia burguesa e estaria ligado aos valores da falsa democracia, que na realidade conforma um sistema de dominação determinado historicamente.

Althusser debate com Sartre, dizendo que o homem não faz suas próprias condições de existência para transcender a história. O voluntarismo existencialista é somente uma versão pequeno-burguesa da liberdade individual idealista. A liberdade para Althusser é limitada pelas condições históricas dadas, concepção inspirada no 18 do Brumário de Marx. A história para Althusser é um processo sem sujeito, porque o indivíduo analisado de forma isolada representa o nascimento da ideologia burguesa no campo político (ALTHUSSER, 1973, p. 21-25). As massas fazem a história e não os indivíduos: 
A história é um 'processo sem Sujeito nem Fim(s)' cujas circunstâncias estão dadas, onde 'os homens' agem como sujeitos sob a determinação das relações sociais, são o produto da luta de classes. A história não tem, portanto, no sentido filosófico do termo, um Sujeito, mas um motor: a luta de classes (ALTHUSSER, 1973, p. 98).

O culto à personalidade, a declaração dos direitos humanos são vistos como alienantes e relacionados com traços da sociedade burguesa, e o marxismo humanista representa uma penetração destes valores na esquerda (ALTHUSSER, 1973, p. 82).

Sua postura epistemológica é convencionalista, ou seja, a realidade é determinada pelas evidências empíricas ou pelo pensamento formal que constituem as ideias (PEET, 1998, p. 120-121). As convenções referem-se aos acordos sociais, as normas e valores socialmente estabelecidos e legitimados. Segundo Gregory (1978, p. 57), o convencionalismo atribui uma centralidade à estruturação cognitiva da teoria, o que impossibilita a comparação com a percepção de análises em outras teorias.

A ideologia, nessa perspectiva, é fundamental para luta de classes. Nas palavras de Johnston:

Foi o estruturalismo de Althusser dos anos 1960 que foi crítico ao empiricismo, e que afirmou o status científico, focado na primazia do modo de produção e na escolha da perspectiva holísta, mais do que o individualista - o humanismo do jovem Marx é rejeitado (JOHNSTON, 1986, p. 102) ${ }^{194}$.

A ciência aparece como esfera distante da sociedade em nome de um desenvolvimento crítico autônomo. A ideologia refere-se à aparência dos fenômenos, porém a verdadeira ciência remete à explicação estrutural. A ciência é neutra e independente das pressões do modo de produção e dos contextos, enquanto a ideologia são os discursos influenciados pelos agentes e processos de produção (GREGORY, 1978, p. 116). Na sua interpretação:

As configurações das forças produtivas em movimento envolvem a exploração do proletariado pela burguesia, e o antagonismo que isso gera é um problema contínuo na realização da mais-valia. A resolução desse antagonismo, ou ao menos sua contenção, envolve a criação de uma formação social, uma estrutura societal (incluindo o Estado) em que exista harmonia suficiente para que as relações de produção possam empregar as forças (assim, um estrutura legitima as relações capitalistas) (JOHNSTON, 1986, p. 106-107).

194 Tradução nossa. 
Outra questão importante para a compreensão do marxismo de Althusser é a sua ideia de totalidade social, constituída por estruturas contraditórias formadas por várias instâncias diferentes. A totalidade seria a composição de todas essas instâncias e das suas contradições resultaria o movimento histórico:

\begin{abstract}
As várias instâncias de uma totalidade (econômica, política, ideológica) possuem uma certa ordem hierárquica, organizada pela determinação econômica, ainda que se goze de uma relativa autonomia. A noção de Althusser de 'sobredeterminação' resume esta concepção do marxismo dialético: na complexa e estruturada unidade da totalidade social, o movimento de diferentes contradições estão articuladas umas as outras, determinadas em uma direção particular afirmada pelo todo. O todo é uma unidade de instâncias desenvolvidas desigualmente em um diferente escala de tempo - o termo 'conjuntura' expressa o complexo específico do desenvolvimento em qualquer tempo (PEET, 1998, p. 121).
\end{abstract}

A totalidade é sobredeterminada pela esfera econômica, visão que é fonte de críticas. No entanto, sua discussão no contexto do marxismo denota grande capital cultural a seus pensadores - seus contemporâneos e rivais, Sartre e Lefèbvre, não deixam de debatê-la.

A articulação recai entre totalidade - e suas instâncias -, os modos de produção e a formação social, tríade que permite uma profunda análise histórica e de conjunturas sociais. Ao nosso ver, ela oferece uma análise diacrônica e sincrônica concomitante, operação que o estruturalismo de Lévi-Strauss fazia com certa dificuldade.

Alguns autores, como Assiter (1984, p. 278-279), colocam que Althusser tenta descartar o empirismo, substituindo-o pela análise totalizante, onde cada parte dependente é determinada por sua função na totalidade. As instâncias interdependem e relacionam-se. Todavia, a totalidade de Althusser é uma abstração, um modelo de sociedade que comporta quatro níveis de atuação: a prática econômica envolvendo a produção; a política, que remete às relações sociais; a ideológica, que diz respeito à composição da consciência social; e a teórica, que refere-se a ciência e a produção das ideias.

Um elemento importante é o cuidado para com a interpretação e leitura de textos - o que se refere à sua releitura de Marx -, pois "para Althusser, o texto e a teoria da cientificidade são necessariamente efeitos de uma leitura textual", tendência encubada no estruturalismo que fornece subsídios para a hermenêutica (ASSITER, 1984, p. 287). A obsessão textual que a hermenêutica provoca no pós- 
estruturalismo causa na década subsequente uma retorno a Hegel, Marx e Engels em busca do discurso "verdadeiro" ou uma interpretação mais fidedigna, distante da ortodoxia (JACOBY, 1981, p. 7-8).

O retorno a Marx será uma constante no final do século $X X$, muitas vezes sem observar a história e os movimentos do marxismo. Na sua autobiografia, no entanto, Althusser manifesta sua infelicidade com a política na URSS ou mesmo com a do partido dentro da França. Sua esposa, por exemplo, sofre um processo de expulsão do partido comunista, e Jean Dresch é um dos responsáveis pelo caso. Porém, sabendo da inocência da companheira de Althusser, ele não comparece ao julgamento (ALTHUSSER, 1992, p. 149-170).

A partir do contato com essa grande teoria, a preocupação da geografia é projetar espacialmente a formação social, o modo de produção ou o jogo entre infra e superestrutura. Consequentemente, existe um reforço na introdução da categoria de espaço na ciência proposta por Marx (JOHNSTON, 1986, p. 123). A dialética entre infra e superestrutura é a responsável pela aproximação de Soja e Lefèbvre.

Um resultado importante dessa relação é que "a análise estruturalista mostrou como as estruturas espaciais intranacionais desenvolveram-se e como elas reproduziram-se como um exemplo de dialética socioespacial" (JOHNSTON, 1986, p. 127). Contudo, gradualmente as análises vão enfocando a dinâmica urbana, onde a mais-valia e os fluxos de capital tomam forma localmente.

Outro resultado importante foi a articulação entre formação social e modo de produção:

\begin{abstract}
Nesse processo, a estrutura começou a ser observada como algo mais abstrato, um princípio de ordenamento que separou a sociedade em diferentes 'esferas' de produção, circulação e consumo. Os geógrafos sociais marxistas devidamente identificaram as divisões espaciais de um dado país, região ou cidade como correspondente de alguma maneira a essa esfera estrutural (PHILO e SODERSTROM, 2004, p. 129).
\end{abstract}

No entanto, mesmo diante dos refluxos do marxismo real, a obra de Althusser representou a esperança de uma ciência unitária do homem - ciências humanas e sociais juntas. Esse projeto só é abandonado em 1975, e tem como base original a inauguração da descoberta do "continente" história, pois assim como os grandes científicas inauguraram novos campos de estudos, Marx revela a história como fundamento de todas ciências humanas. Sendo assim: 
A inovação teórica, a transdisciplinaridade, conduziram-se bem no âmbito universitário depois de 1968, na época em que se recrutavam jovens docentes na base de perfis de carreira inovadores, em ruptura pelo contrário, em meados da década de 1970, a universidade não renova mais seus quadros após sua cura de rejuvenescimento de 1968. Entra-se num período de austeridade de restrições das nomeações na gestão dos orçamentos. Essa contração dos cargos docentes vai acompanhar e acelerar o fenômeno de frio recuo no plano teórico (DOSSE, 2007a, p. 338-339).

Se Vincennes era marcada pelo maoísmo, não é possível compreende-la fora do contexto da interdiciplinaridade, como observaremos abaixo no contexto da revista Hérodote. Em 1975, a época de tolerância acadêmica advinda de 1968, acaba e inicia-se o processo de desarticulação de seu aparato epistemológico, que culmina no ostracismo, após Althusser assassinar sua própria esposa. Tal fato ocorre em 1980 e ele sai de cena, porém só falece em 1990 (DOSSE, 2007a, p. 476).

Paul Claval sintetiza bem a crítica ao estruturalismo e refere-se aos geógrafos de esquerda como simpatizantes do viés estruturalista. Se, de um lado, essa tendência deveu-se a De Martonne e a inspiração da sociologia, não podemos ignorar a presença de Lévi-Strauss ou a F. Braudel. Assim:

A geografia estrutural francesa esquece os homens e as sociedades. Não fala mais de atores, iniciativas, de história: ela elabora um quadro de estruturas que evoluem, certamente, mas demonstram uma superfície de permanência para justificar a empresa geográfica (CLAVAL, 2011, p. 182).

\footnotetext{
Apesar das críticas que surgiram na filosofia de maneira mais ou menos concomitante à expansão do estruturalismo, seu papel na geografia não foi pequeno:
}

O estruturalismo produziu um tipo diferente de geografia marxista, ressaltando certas categorias analíticas, como modo de produção e formação social, e enfatizando inter-relações entre elementos em cadeias de significantes. O movimento de incorporação do estruturalismo, nunca completo no pensamento geográfico, representou a busca por um maior rigor e coerência teórica. Ele também se é o período mais mal representado e mal analisado do pensamento social e geográfico (PEET, 1998, p. 112).

O diagnóstico de Smith é que:

Muito da exploração inicial na teoria marxista foi dominada pela aproximação com a economia política buscando a revelação das estruturas profundas das geografias capitalistas, mas mesmo uma leitura casual da Antipode nos anos 1970 e 1980 sugere que este nunca foi um projeto exclusivo (SMITH, 2001, p. 10). 
Apesar da carência de análises, o estruturalismo formou uma espécie de antecedente generalizado para uma parte significativa dos estudos geográficos, seja pelo seu caráter positivista ou sistêmico, seja devido a sua presença generalizada nas ciências humanas.

Contudo, a inspiração estruturalista nunca ficou isolada do diálogo com outras tendências. Uma das originalidades que a geografia introduz no debate do estruturalismo é a ideia de prático-inerte, como no caso da obra de Milton Santos. Essa ideia que remete ao pensamento sartreano e se refere às estruturas e o ambiente material dado em um determinado grupo social que contém um conteúdo histórico e uma intencionlidade que influencia seu uso e sua apropriação (PEET, 1998, 113).

Cabe ressaltar que a obra de Milton Santos aparece no exterior como uma fonte de inspiração, porque ela combina a ideia de estrutura com a dialética do existencialismo (PEET, 1998, p. 128-129). A totalidade permanece em relação com a formação socioespacial, porém Milton busca valorizar a vida social e o projeto existencial dos indivíduos, dos grupos sociais e das instituições, que podem fomentar contraracionalidades ou reafirmar as estruturas econômicas estabelecidas. Veremos adiante que o crepúsculo do althusserianismo conhecerá reações diferentes da de Milton Santos.

Dentro da geografia, essas contribuições ajudaram a discutir o espaço:

Com a análise do espaço como uma expressão da estrutura social muitos são levados a estudar suas transformações através de elementos dos sistemas econômicos, políticos e ideológicos em suas combinações, e a prática social derivada deles. Com efeito, pode-se 'ler' o espaço de acordo com os sistemas econômicos, políticos e ideológicos os quais o formam (...) Sob o sistema ideológico, o espaço é carregado de sentidos, suas formas e organização sendo articuladas umas com as outras em uma estrutura simbólica (PEET, 1998, p. 126).

Mesmo com essas contribuições para a geografia e para as ciências sociais, o estruturalismo foi criticado paralelamente ao seu processo de expansão. As críticas recaíram sobre seus principais aspectos: (1) o anti-humanismo e a concepção de sujeito histórico; (2) relacionado a isto a estrutura diminuindo a importância do indivíduo frente à história; (3) a sobredeterminação econômica.

No final de sua carreira, Althusser dá mais preferência à ideia de conjuntura acerca da questão da determinação, mas o ostracismo social sofrido pelo pensador 
causa uma quase ausência acerca desse debate sobre a nova possibilidade de análise. Althusser indica "a oposição metafísica entre o determinismo e a liberdade o que sugere, no campo da história, um primado resoluto da 'conjuntura' (dos casos e situações singulares) sobre a 'estrutura' " (ÍPOLA, 2012, p. XVIII).

\subsection{A crise da geografia}

Dizer que o estruturalismo é uma referência em comum na difusão da geografia crítica não significa que exista uma ausência de diferenças, já que o próprio althusserianismo é amplo e multifacetado. Contudo, no campo da geografia o geógrafo que de maneira sistemática e geral voltou aos textos de Marx foi David Harvey. Talvez devido à ausência de uma tradição marxista no campo político, a geografia anglo-saxã se voltou mais para o retorno à obra marxiana - mesmo sendo influenciada pelo althusserianismo - enquanto a geografia francesa se acomodou nas interpretações exteriores ao campo ${ }^{195}$.

Em um primeiro momento, a geografia crítica preocupa-se em constituir um corpo teórico com base no um raciocínio indutivo juntamente com uma aproximação do marxismo. Com a hegemonia da interpretação althusseriana, os geógrafos não pararam de fazer trabalhos que partiam da realidade para a teoria, estabelecendo uma relação dialética entre teoria e prática de pesquisa, o que estimulou a crítica ao althusserianismo nos Estados Unidos. Isso não evitou uma abstração exacerbada dos estudos empíricos ao relacionar teoria e interpretação de fatos. Se na França, Lacoste denunciava o Estado e a geografia da guerra, no caso norte-americano a crítica ao Estado surgia da constatação que parte da população era segregada ou não tinham acesso aos serviços públicos, por exemplo196.

Nesse sentido, devemos encarar a ideia de Peet (1977a, p. 17) sobre uma a divisão entre debate metodológico e ideológico como tendências dentro da geografia

\footnotetext{
195 Gregory (1978, p. 114) ressalta que a ideia de modo de produção na obra de Harvey remeteria à obra de K. Polanyi, em que a reprocidade, a redistribuição e as trocas de mercado são mais importantes do que a produção. Entretanto, somos levados a pensar que Polanyi foi uma inspiração importante para pensar a esfera da distribuição, que é facilmente relacionada ao espaço, mas não podemos deixar de pensar que 0 althusserianismo teve um peso importante no seu pensamento. Apesar de Harvey reler a obra de Marx, fica evidente seu relacionamento com a escola regulacionista, que deriva fundamentos importantes de sua teoria de Althusser.
}

196 Vários números da revista Antipode continham artigos sobre o acesso aos serviços públicos. 
crítica e não como grupos rigidamente separados ${ }^{197}$. A situação vista do ponto de vista do marxismo é mais complexa e Peet indica as tendências com o objetivo de analisar a reestruturação recente do campo. Alguns geógrafos aproximam-se mais explicitamente da política, como no caso de Lacoste, porém se alguns criticam os geógrafos de esquerda por não terem feito uma revolução epistemológica, Lacoste apropriou-se do estruturalismo sem fazer um debate profundo e explícito de sua epistemologia. Entretanto, o silêncio e até um vazio metodológico a respeito de uma visão completa da geografia não nos parece uma aproximação "ideológica" em contraposição a uma "teórica". Aliás, um dos grandes motes da geografia crítica é a busca de uma teoria da sociedade.

A obra de Yves Lacoste na França também tem importância seminal, e apesar de ter sido muito discutida seu grupo de alunos e contribuidores, ficou mais ou menos restrita aos participantes da revista Hérodote. O impacto de suas publicações, nesse momento, gira em torno da denúncia de uma geografia a serviço do Estado, da dominação de classes, da crítica aos regionalismos e da depreciação da geografia regional francesa vidaliana (LACOSTE, 1988).

Além disso, sua estratégia de reafirmação na comunidade científica é depreciar Vidal de la Blache para depois retratar-se e encontrar um "outro" Vidal ignorado pela geografia francesa. Sua relação com George é delicada, pois reconhece o caráter inovador de sua geografia. No entanto, não explora toda a novidade contida no pensamento de seu mestre e no seu grupo ligado ao marxismo desde o final da Segunda Guerra.

Faz-se clara a influência de Althusser na agenda de pesquisa de Lacoste, ligada à análise dos aparelhos ideológicos do Estado, ou, se preferirmos, da geografia como um conhecimento-ideologia adequado para a dominação social. $\mathrm{O}$ geógrafo foi cúmplice da dominação burguesa, das distorções políticas do conhecimento e do ensino nacionalista nas escolas. Entretanto, a forma mais

\footnotetext{
197 Na bibliografia sobre a história da geografia crítica nos deparamos com a questão das classificações de grupos e frações. Segundo Gomes (2005, p. 274-275) poderíamos pensar em dividir a geografia crítica em dois tipos uma teórico-metodológica e outra com um caráter mais ideológico. Talvez essa divisão não seja completamente adequada, mas essa corrente "ideológica" poderia encaixar-se perfeitamente nas elaborações de Yves Lacoste. Claval (2011, p. 282) também corrobora com essa visão de "ideologização" ao dizer que "os geógrafos marxistas franceses em geral não se dedicaram muito à leitura de Marx e Engels; foram seduzidos mais por Lênin ou por Mao do que por intelectuais como Lukács ou Gramsci". Pensamos que essa divisão não é adequada, porque a corrente teórica pode ter relação com o rigor científico do althusserianismo, enquanto a corrente militante estava ligada às possibilidades revolucionárias do contexto da década de 1970 . No entanto, ambas não estavam separadas rigidamente. Além disso, tratar o marxismo como ideologia é uma armadilha ardilosa, pois pressupõe que exista uma visão de mundo verdadeiramente livre da dimensão ideológica.
} 
adequada de reverter esse jogo seria a reabilitação da geopolítica, campo do conhecimento aplicado à política e ação, agora não mais do Estado, mas dos grupos revolucionários, como os vietcongs.

Em paralelo à todas as mudanças, na geografia francesa, em 1970, Pierre George organiza um dicionário sobre geografia com ajuda de vários geógrafos. Porém, de seus antigos alunos, apenas R. Guglielmo o auxilia nessa tarefa. Apesar de haver um distanciamento, como havíamos dito, no dicionário existe uma série de termos que se referem ao marxismo, como imperialismo, modo de produção, forças produtivas, revolução, crise, além de termos que se referem ao universo da União Soviética e dos países socialistas. Na sua primeira edição o dicionário não possui um verbete para espaço, somente espaço econômico, o que remete a Perroux. No verbete sobre imperialismo há um resgate da teoria de Lênin sobre o imperialismo, e no termo estrutura encontramos a referência a Saussure e Lévi-Strauss. Obviamente alguns termos deveriam constar obrigatoriamente em um dicionário de tal porte, porém a persistência dos elementos marxistas e principalmente do termo estrutura é um fato a ser considerado ${ }^{198}$.

Mesmo com o lançamento de um dicionário como tentativa de reafirmar uma visão estável do campo da geografia, o espectro da crise rondava a disciplina e será um argumento importante na estratégia de depreciação da tradição consolidada. Mesmo antes do lançamento do célebre livro de Lacoste, a atmosfera intelectual da década de 1970 imersa na destopia nuclear da guerra fria e da retração econômica colaboravam para destruição criativa:

\footnotetext{
Para os radicais, no entanto, a ideia principal era a de crise. Crise do capitalismo, crise política, crise da ciência política, do positivismo, como vimos anteriormente, a ideia de crise tornou-se uma imagem-força da modernidade que, em seu nome, legitima a adoção do 'novo' para substituir o que é então considerado como superado e em choque com os novos tempos (GOMES, 2005, p. 279).
}

A crise da geografia enquanto ciência liga-se diretamente com o caráter de crítica às ideologias presentes nos discursos do Estado e de dominação social (BERDOULAY, 1988, p. 21), concepção que ajuda na crítica da geografia de Estado,

\footnotetext{
198 Alguns anos antes, em 1966, George tornava-se responsável pela organização da Bibliografia Geográfica Internacional que demanda uma atualização acerca da documentação global disponível para geografia da época (BATAILLON, 2009, p. 84).
} 
feita pelo grupo de George, da geografia chamada tradicional e também a nova geografia $^{199}$ (GOMES, 2005, p. 279).

Os quase 60 anos de produção geográfica do início do século $X X$ até seus meados são colocados de lado, negados e por vezes ignorados, acusados de serem positivistas, empiricistas e em alguns casos reacionários. Se por um lado temos a tentativa de avanço com a inserção da temática marxista, de outro existe um retrocesso causado pela redescoberta de alguns fenômenos, conceitos e processos tradicionalmente estudados pela geografia clássica com profundidade. Contraditoriamente a esse retrocesso, apresenta-se o avanço da rediscussão do objeto da disciplina, o que demonstra uma tentativa de reestruturação científica. A mudança de objeto representa uma refundação enquanto campo de estudos, resultando na gravidade do "corte epistemológico" provocado pela geografia crítica (BOURDIEU, 1984).

O resultado desse processo contraditório de negação e ruptura é a liberdade epistemológica, muito comum no desenvolvimento da ciência, como mostra Lukács:

\begin{abstract}
Com isso quero demonstrar que a crítica ontológica da ciência não é uma simples crítica atribuída a qualquer professor, mas um grande processo histórico no qual, mediante o trabalho e a atividade histórica, certos modos de representação, ontologicamente falsos, vão sendo gradualmente superados. Surge assim, na ciência, uma consciência da realidade que tende cada vez mais fortemente a destacar-se dos fundamentos históricosontológicos que determinam sua gênese (KOFLER et al., 1969, 26).
\end{abstract}

O movimento, como vemos, tem dois aspectos: o primeiro é de atender as demandas de sua época e o segundo é de afrouxar o peso histórico do passado, ou seja, emancipar-se de uma inércia histórica. Para Bourdieu (1984, p. 117), a crise do campo de estudos da geografia representa um desprezo do reconhecimento da ciência geográfica na sociedade em geral e na sociedade científica. O conflito entre o velho e o novo representa a possibilidade da ascensão dos jovens pesquisadores do ponto de vista institucional:

\footnotetext{
199 A geografia tradicional são todas aquelas tradições nacionais no campo da geografia, como a geografia regional la Blache ou a geografia cultural de C. Sauer, portanto antes da expansão da nova geografia em escala mundial. Com as mudanças mundiais e a demanda por novas temáticas não podemos esquecer dos desenvolvimentos paralelos, pois se existe a insurgência de novas tendências, as velhas formas de fazer geografia continuaram a caminhar e renovar-se. Um caso interessante é a ecologia das paisagens, impulsionada no início do século por Otto Schlüter e por outros geógrafos alemães, que produziu por todo o século XX e chegou ao século XXI gozando vigor acadêmico. Apesar de ter passado por renovações, a ecologia da paisagem não foi abandonada mesmo com a presença da teoria dos geossistemas, mais nova e sofistica. De fato, geossistema e ecologia da paisagem são duas abordagens que não necessariamente entram em contradição.
} 
A crise das relações entre os velhos e os novos que chegam, nasce de uma ruptura da harmonia que se estabelece na grande maioria daqueles que chegam, entre as estruturas incorporadas de expectativas (os que esperam) e as estruturas objetivas (as trajetórias prováveis). Essa ruptura opera sob o efeito simultâneo de uma transformação da estrutura das probabilidades de ascensão e de uma modificação das disposições dos agentes. Em uma tal conjuntura, os 'velhos' e os 'jovens' se encontram 'defasados', os primeiros visando uma ambição carreirista naquilo que se viveu como uma reivindicação normal, e os segundos um conservadorismo mandarinal naquilo que aparecera como um apelo a ordem ética (BOURDIEU, 1984, p. 117) ${ }^{200}$.

A ruptura consiste no questionamento, seguido do estabelecimento de uma nova ordem política do conhecimento científico. Assim, surgem as novas possibilidades de ascensão acadêmica e novos valores de uma ascensão possível. A geografia crítica agregou, por exemplo, a militância política nos partidos ou em movimento sociais como nova uma perspectiva de ascensão acadêmica e ganho de capital cultural, ou seja, autoridade e reconhecimento. Capel demonstra como no processo de institucionalização de um novo grupo, os critérios de cientificidade são retificados:

Cada comunidade científica, uma vez institucionalizada, cria suas próprias normas e sistemas de valores que se convertem no elemento de coesão e estabilidade da mesma. Em seguida, para formar parte da comunidade institucionalizada, a geográfica neste caso, exige-se um período de preparação, de disciplinamento, que conduz à aprendizagem destas normas e valores a respeito do objeto da ciência, os problemas relevantes, o método para abordá-los, os antecedentes e precursores (...) (CAPEL, 2010, p. 78-79).

A ascensão da geografia crítica representa um novo processo de institucionalização e de disciplinamento, com mudanças no objeto de estudos, nos valores e nas normas da disciplina. Em um momento inicial, esse processo se dá de uma maneira muito mais aberta, e conforme a geografia vai ganhando reconhecimento institucional - não sem obstáculos - existe um fechamento e a consolidação de determinadas posturas e questões científicas. O estruturalismo escolhido entre os vários projetos possíveis de crítica teve um papel importante no disciplinamento dos geógrafos.

Contudo, existe um processo de negociação entre os critérios de cientificidade antigos e os novos que atinge a agenda de pesquisa, as normas formais e informais e cria projetos disciplinares que disputam a hegemonia. Nesse sentido, a relação entre marxismo e anarquismo, ou ainda as mudanças editoriais da revista Antipode, analisadas abaixo, são um excelente exemplo. O anarquismo e/ou 
o pós-estruturalismo poderiam ter captado uma força maior desde o início do processo de consolidação, mas quem o fez foi o estruturalismo, quadro que só se reverte com a crise do marxismo na década de 1980.

Como a geografia é uma disciplina muito ampla, estimula a elaboração do que Bourdieu chama de subcampos disciplinares, envolvendo pequenos grupos que se apropriam de pedaços menores de um objeto maior, como por exemplo, a geografia urbana $^{201}$. Os desenvolvimentos internos dos subcampos influenciam no campo geral, pois a própria geografia urbana estimulou críticas e mudanças de enfoque captando mais capital cultural dentro da comunidade. A centralidade da geografia urbana revela desde $A$ justiça social e a cidade e Fitzgerald, tornando-se cada vez maior na geografia crítica mundial.

\subsection{A confluência de temas}

Gomes (2005, p. 284) é da opinião de que o marxismo é concebido fortemente ligado ao conhecimento científico moderno, que busca estabelecer verdades (socialismo científico) com uma racionalidade e métodos próprios. Devido ao foco positivista, ele se esquece de explorar as outras fontes do marxismo, como o pensamento utópico social francês de uma forma ampla, a economia política inglesa e a filosofia alemã, com forte influência de Hegel (MANDEL, 2001, p. 7-40 e LÊNIN, 1979). Para além de uma leitura positivista, o pensamento marxiano é a síntese do moderno e do antimoderno.

Apesar de os marxismos terem alguns pontos de partida em comum, e dos geógrafos críticos terem preocupações mais ou menos semelhantes, alguns autores apontam distanciamentos mais ou menos profundos. Poderíamos pensar que existem diferenças entre a geografia crítica feita na França, nos EUA e Inglaterra:

De um lado, um grupo de geógrafos, sobretudo franceses, trabalhou para reavaliar o peso das tradições geográficas e impor um novo ponto de vista sobre o uso político do espaço. De outro lado, a crítica radical abertamente inspirada do marxismo, muito desenvolvida nos Estados Unidos, se conferiu com a tarefa fundamental adaptar os instrumentos desta doutrina à análise espacial (GOMES, 2005, p. 284-285).

E acrescenta:

201 Certamente alguém que estuda a hierarquia urbana ao moldes de Rochefort e alguém que analisa a questão urbana nos moldes de Castells tem visões diferentes do método e do objeto particular. Surgem daí diferentes critérios de cientificidade e a possibilidade de subcampos dentro do campo maior da geografia. 
A geografia radical anglo-saxã, talvez pela aceitação quase irrestrita do marxismo, valoriza num primeiro momento a questão econômica, antes de verdadeiramente penetrar no terreno da análise política, enquanto os geógrafos franceses, talvez por influência do movimento de maio de 68 , se lançaram neste terreno desde o começo (GOMES, 2005, p. 287).

Essa polarização entre o político e o econômico também não pode ser levado às últimas consequências, porque havia um diálogo entre os temas de pesquisa entre a corrente francesa e anglo-saxã ${ }^{202}$. Se observamos o sumário da coletânea Radical Geography, organizada por Richard Peet (1977), poderemos ver a presença do pensamento francês com a inclusão de artigos importantes de Yves Lacoste e Henri Lefèbvre 203 .

Além disso, não sabemos se o termo reavaliação seria a melhor palavra para refletir sobre a geografia crítica francesa, porque talvez num primeiro momento o impulso de negação tenha sido mais intenso do que o de revisão. No caso francês marxismo e neopositivismo estavam em ascensão quase de forma concomitante em prol de uma renovação teórica da disciplina.

Contudo, a partir do momento de consolidação, aceitação e institucionalização, a procura pela historiografia com afinidades ao projeto da geografia crítica redescobre e revisa Reclus ${ }^{204}$ e Kropotkin ${ }^{205}$. A legitimidade da geografia crítica em seu período de afirmação é buscada no passado, mostrando o

202 Retomando o problema de classificação, Scarim (2000, p. 78-80) também divide a geografia em duas tendências, ecoando a divisão utilizada por Gomes e o texto original de Peet. Para Scarim, uma tendência busca criticar os paradigmas existentes da geografia e desmascarar as ideologias presentes nas teorias geográficas. A outra tendência quer formular a partir do marxismo novas teorias e metodologia. Scarim classifica os primeiros de liberais e os segundos de radicais, retomando discretamente a terminologia de Peet (1982, p. 236). Enquanto os liberais querem apenas rearranjar as peças da teoria, os radicais desejam constituir a geografia marxista. Ressaltamos aqui que na concepção de "liberais" de Peet (1977a, p. 17-22) a teoria não estaria presente, pois no início da geografia radical norte-americana alguns geógrafos pragmáticos estavam preocupados apenas em amenizar os problemas sociais e acabaram por não privilegiar preocupações mais teóricas. Peet $(p$. 22-23), parafraseando King, diz que eles seriam positivistas a meio caminho do socialismo científico. No entanto, esse é um grupo minoritário dentro dos EUA e que se diluiu no desenvolvimento da geografia marxista em escala mundial. Portanto essas tendências caminharam na maioria das vezes juntas e não estabeleceram uma relação de alteridade ou dividiram grupos grandes de pesquisadores, pois, como indica o próprio Peet, são tendências e não correntes opostas.

203 Os artigos presentes no livro são, Yves Lacoste "An illustration of Geography Warfare: Bombing of the Dikes on the Red River, North Vietnam" (PEET, 1977, p. 244-262) e Henri Lefèbvre "Reflections on the Politics of Space" (PEET, 1977, p. 339-352).

204 A exaltação da obra de Reclus se dá pelo fato dele buscar um projeto de conhecimento emancipatório, ou seja, que pudesse libertar determinados grupos de condições socialmente não favoráveis. O próprio Reclus apontava Humboldt e Heródoto como críticos das representações geográficas que lhes eram contemporâneas (KONINK, 1995, p. 145).

205 Na coletânea de Peet (1977) Radical Geography existe, no início do livro, uma dedicatória a Kropotkin, que é apresentado como revolucionário e geógrafo. Como epígrafe do livro há um pequeno trecho de sua obra intitulada Ética. 
símbolo da permanência de uma luta epistemológica e busca de uma paternidade alternativa (GOMES, 2005, p. 289). Essa reafirmação é crucial, pois, como tentamos demonstrar, dos geógrafos anarquistas para a geografia marxista alemã e depois da geografia de esquerda para a geografia crítica existem continuidades e descontinuidades. Christaller foi assimilado pela geografia francesa ao contrário dos geopolíticos e de Wittfogel. Mesmo que exista a descontinuidade, isso não significa que certas ideias como, por exemplo, uma concepção economicista entre homem e meio não tenham exercido uma influência importante nesse percurso histórico.

O final da década de 1970 já oferecia acontecimentos e fatos suficientes para Richard Peet escrever uma história da geografia radical. Obviamente, essa atitude faz parte de uma estratégia de consolidação do campo e impulsiona seu processo de institucionalização. Como destaca Muir (1978, p. 322), a ideia divulgada por Peet entre 1973 e 1974 de que a geografia radical era eminentemente marxista eclipsa outras correntes de radicalidade - os anarquistas e as primeiras manifestações da esquerda alinhadas ao pós-estruturalismo em fase de formação. Entretanto, em meados da década de 1980 o cordão de isolamento institucional se romperia.

Mesmo diante desse quadro de ruptura, quando Lacoste se vê no papel de discutir epistemologia e filosofia na geografia na coleção organizada por Châtelet, não vemos uma grande quantidade de novidades. Ele constata primeiramente que não deveria existir uma cisão entre geografia física e humana e entre geografia geral e regional (LACOSTE, 1974, p. 224-225), fato que os geógrafos de esquerda haviam defendido exaustivamente. Contudo, ataca a geografia regional francesa, acusandoa de enciclopedismo, de existir falta de clareza nos critérios de regionalização de La Blache, além de seu objeto de estudo estar voltado para o passado rural da França (LACOSTE, 1974, p. 260-264).

Para Lacoste (1974, p. 227) a geografia sempre usou termos conceitualmente mal definidos, como "país" ou "região" e se apropriou de conceitos de outras disciplinas. Faltam definições próprias, uma vez que a pluralidade metodológica que havia sido defendida por Dresch e George - permitiria pensar apenas superficialmente as categorias e conceitos de outras disciplinas, sem se inserir verdadeiramente em um debate ou numa reflexão epistemológica (LACOSTE, 1974, p. 228). Sinteticamente:

Para descrever certa porção do espaço terrestre, o geógrafo encontra-se, pois, levado, a fazer uma gama de raciocínios que se assemelham mais ou menos desajeitadamente com a abordagem de cada uma das 
disciplinas utilizadas. Esta tarefa tão complexa e delicada, fundamental na abordagem geográfica, normalmente deveria ter sido uma razão suficientemente poderosa para que os geógrafos viessem a se preocupar com os caracteres epistemológicos das outras ciências, cujos trabalhos deveriam interpretar e completar. De fato, na maioria dos casos não foi isto o que ocorreu, e os geógrafos tentam, mais ou menos bem e do modo mais empírico possível, evitar a questão, à força de faro e de experiência, tomando no discurso das outras disciplinas o que lhes parece útil ou digno de interesse, sem todavia terem estabelecido claramente as razões dessas escolhas (LACOSTE, 1974, p. 228).

A crise da geografia não se fundaria tanto nesse "vazio" epistemológico, mas nas suas bases políticas e ideológicas. Além disso, as relações entre homem e natureza só poderiam ser entendidas enquanto relações dialéticas.

Lacoste (1974, p. 238), nesse momento, reconhece o papel de P. George como um geógrafo marxista de importância, que em 1950 pôs em evidência as diferenças entre os países comunistas e capitalistas, assim como boa parte dos empréstimos de conceitos da economia, dos urbanistas e dos sociólogos. George também marca o início da libertação ideológica da geografia, livrando os geógrafos de conceitos-obstáculo, e os obrigou a pensar questões fundamentais para disciplina (LACOSTE, 1974, p. 268). Lacoste (1974, p. 259) também continua a utilizar a ideia de situação, como é apresentada por George em Geografia ativa. Curiosamente, cita Dresch, mas ressalta apenas seu caráter anticolonialista sem mencionar o marxismo em suas obras (LACOSTE, 1974, p. 269).

No entanto, Lacoste descarta a ideia de geografia como ciência de síntese e finca os pés no objeto espaço, mas refere-se ao espaço tout court, sem fazer nenhuma elucubração epistemológica. Ele apenas menciona as combinações geográficas em diversas escalas - sem citar A. Cholley (LACOSTE, 1974, p. 248-253). Cita explicitamente Althusser e a ideia de fenômenos de longa e curta duração, muito utilizada por Braudel, além de adotar o modelo centro-periferia proposto por Samir Amin. A conclusão principal do artigo é que a carência epistemológica da geografia foi o que levou bons geógrafos às mistificações ideológicas nocivas (LACOSTE, 1974, p. 270).

Essa sua posição encerra uma polêmica sobre a tradição da disciplina, absolve uma geração de geógrafos e não estimula a nova geração ao debate epistemológico profundo. Entretanto, Lacoste acaba absorvendo os debates de fora do campo como nas gerações passadas. Dosse sintetiza bem quais os caminhos e opções da obra de Lacoste: 
Lacoste entrevê as portas da salvação para a geografia na retomada do estudo metódico dos espaços no quadro das funções que aí exerce o aparelho de Estado, e recorda a esse respeito o papel dos geógrafos alemães do século XIX no estabelecimento de uma geopolítica cuja utilização foi levada ao paroxismo com Hitler, o que contribuiu para o descrédito dessa opção no pós-guerra. Lacoste preconiza a definição de diferentes escalas de conceituação antes de pensar em articular, em distinguir o espaço como objeto real e como objeto de conhecimento. Sobre esse ponto, assim como o da ligação necessária entre a teoria e prática política, a referência epistemológica essencial de Lacoste é Althusser, citado explicitamente, e que serve manifestadamente de modelo epistemológico para repensar ou pensar o espaço. A geografia terá sido, portanto, o último continente a ser influenciado pelo althusserianismo (DOSSE, 2007a, p. 388-389).

O ganho epistemológico elogiado por Lacoste, e que se torna ponto de ruptura, nada mais é do que uma corrida contra o atraso. O objetivo de compreender o espaço deixa a desejar uma elaboração epistemológica mais rica. O espaço apresenta-se limitado à concepção de escala diferencial e ao uso político simplesmente.

Curiosamente, no ano de 1974, portanto próximo dessas elaborações de Lacoste, Pierre George, já muito distante do marxismo, publica o livro L'ère des technique [A era das técnicas], sem tradução para o português. Quando George vê o crescimento da nova geografia na França e a gradual consolidação da geografia crítica, volta-se para o fenômeno técnico como um elemento de suma importância para a transformação do espaço. Entretanto, agora a escala da paisagem no estudo da técnica - como sempre foi feita através dos gêneros de vida - não seria mais útil (DUPUY, 2008, p. 25). Entram em jogo as ideias de J. Ellul, G. Simondon e B. Giller, concebendo a técnica como construção humana que constitui e altera o espaço humano 206 .

No abandono do marxismo, a técnica aparece como uma espécie de escape para a restauração de seu antigo capital cultural. Juntamente a essa nova variável, George vai apoiar-se nas elaborações de F. Braudel, que também será caro ao seu discípulo Lacoste. George estuda os períodos históricos e os processos sociais de longa duração e os de duração conjuntural (BASTIDE, 1971). Claval (2011, p. 182) também chama atenção para esse estruturalismo, ressaltando que Braudel encadeia a estrutura temporal e a espacial através do meio geográfico, o que é muito adequado tendo em vista o antigo projeto geográfico da rede de George.

206 Para todos esses autores, a centralidade das técnicas será fundamental, bem como para Milton Santos, no Brasil. Dupuy (2008, p. 26) não cita Milton, mas faz referências a Heidegger para acrescentar elementos possíveis ao debate. Vale lembrar que Sorre também dava ênfase para as técnicas - Os fundamento técnicos, de 1950, era o título do segundo tomo de seu Fundamentos da geografia humana, dividido em três volumes. 
Nesse período, devido aos trabalhos sobre geografia urbana, aumenta a influência de Castells, um autor que estará presente tanto na França como nos EUA:

\begin{abstract}
Manuel Castells, (...) um professor de planejamento urbano na Universidade de Califórnia, em Berkeley, torna-se altamente influente na geografia anglo-saxã em meados da década de 1970, propondo formalmente a adaptação de conceitos marxistas para a esfera urbana utilizando o raciocínio althusseriano (PEET, 1998, p. 125) 207.
\end{abstract}

Anteriormente ligado ao círculo de Lefèbvre, Castells rompe com o antigo grupo e torna-se althusseriano rapidamente, dedicando-se aos temas da relação entre os modos de produção, a produção urbanística, mudança do espaço urbano e as alterações estruturais de uma sociedade. Ele foi criticado por Lefèbvre, em primeiro lugar por aceitar o "reducionismo", e em segundo por preocupar-se muito com a reprodução do espaço sem compreender seu momento de produção como parte da acumulação capitalista. Ver só a reprodução seria estudar o espaço em si mesmo, sem compreender a gênese do processo social (MERRIFIELD, 2000, p. 172). Castells conhecia as obras de geografia urbana de George, mas argumenta que eram demasiadamente descritivas (MANZAGOL, 2008, p. 326).

Castells foi um dos pioneiros da aplicação das teorias de Atlhusser nos estudos urbanos. Para Gregory (1978, p. 118), as divisões utilizadas na sua análise refletem as do estruturalismo: (1) análise da instância econômica, que envolve no caso das cidades a produção, o consumo e a troca; (2) o político e suas respectivas instituições; e (3) o nível ideológico, que organiza simbolicamente o espaço com suas redes de significados e conteúdos ideológicos.

É importante ressaltar que esse período é concomitante ao aprofundamento do processo de aburguesamento de boa parte da população européia. Sendo assim, Castells que inicia uma luta política em prol da moradia digna para os operários espanhóis logo vê esta demanda parcialmente contemplada, com a disposição de equipamentos urbanos nas regiões mais pobres da cidade.

Aqui a questão da moradia e do equipamento urbano é compreendida como um elemento fundamental para a reprodução dos trabalhadores. Assim, existe uma politização através da luta pela reprodução da força do trabalho, cobrando melhorias do Estado em função consumo público coletivo.

Benko e Scott sintetizam bem o desenvolvimento da geografia crítica no seu momento de maior prestígio: 
Os geógrafos radicais conceberam sua missão primária como nada mais que uma descrição da paisagem econômica nos termos das categorias da economia marxista (valor, mais-valia, lucro, acumulação, etc.) em combinação com a explícita invocação da fundação social do capitalismo e sua expressão na luta de classes. Como tal, eles deram uma atenção especial ao problemas como conflitos pelos bens públicos urbanos, as desigualdades regionais e as relações centro-periferia. Com o surgimento da crise nos anos 1970, a questão da perda de emprego, desemprego e reestrutração industrial também vieram ocupar sua atenção (...). Ao mesmo tempo, os geógrafos radicais dos EUA e da Grã-Bretanha foram influenciados por um número de sociólogos e economistas marxistas, muitos deles trabalhando nas universidades franceses e suas organizações de pesquisa. De um lado, eles trouxeram muitas ideias do urbano, como Castells (1972), Lefèbvre (1974), Lipietz (1974) e Topalov (1973) sobre os movimentos sociais urbanos, teoria da renda da terra e a dinâmica capitalista da propriedade privada. Por outro lado, economistas marxistas como Amin (1973), Frank (1968) e Emmanuel (1969) também tiveram um impacto maior através de seus escritos sobre o desenvolvimento regional/ internacional e sobre a troca desigual na sociedade capitalista. Os trabalhos dos geógrafos radicais sobre o tema regional/internacional foram futuramente fortificados pela referência da tradição heterodoxa de estudos sobre o desenvolvimento (Hirchman 1958; Myrdal 1959) que sublinhou a causação cumulativa como mecanismo de persistência das desigualdades espaciais no capitalismo (BENKO e SCOTT, 2004, p. 58-59) ${ }^{208}$.

Até o presente momento buscamos delimitar quais foram os principais autores e debates do início da geografia crítica. Pudemos observar que Althusser está presente em muitos debates, que Harvey torna-se uma referência, que Lacoste ainda faz um balanço de suas antigas raízes, que Castells oferece uma reflexão sobre o urbano, e que George agora escolhe, para pensar a sociedade, outros métodos distantes do marxismo. A geografia muda, se disciplina em um movimento rumo à institucionalização, porém delimitar esse processo seria inútil sem discutir como periódicos importantes surgiram e transformaram-se de 1969 até 1976 . Essas revistas, em grande medida, foram os veículos da geografia crítica ao redor do mundo.

\subsection{Os novos periódicos e suas transformações}

Em 2002 alguns geógrafos se dispuseram a discutir a trajetória da revista da Antipode, desde sua fundação até os dias de hoje. Avaliamos o artigo de Hague (2002, p. 655-661), cujo o teor histórico permite uma visão de conjunto de seu desenvolvimento.

Antipode foi fundada em 1969, resultado do desejo de existir um espaço para publicações e resenha de livros que oferecesse aos geógrafos liberdade para 
difundir suas ideias e mapas. Ela buscava reunir informações sobre a própria geografia crítica e propunha-se como alternativa aos Anais da Associação Americana de Geógrafos (AAG). Constituiu-se também como uma luta pela maior liberdade de expressão, que busca se libertar do linguajar e da forma de apresentação rígida do cientificismo da nova geografia.

Em 1972, R. Peet analisa o primeiro exemplar da revista e faz um comentário sobre a qualidade e o rigor do que é publicado, demandando um seleção mais criteriosa de quem e do que poderia ser publicado. Até o último número de 1972, a revista era distante dos padrões acadêmicos e apresentava uma série de desenhos e quadrinhos que buscavam criticar a sociedade ${ }^{209}$. O início da Antipode é extremamente aberto e com muitas propostas estéticas e éticas ligadas à nova esquerda e ao pós-estruturalismo.

Mesmo com o disciplinamento provocado por Peet, o objetivo da revista continuava a ser a criação de uma alternativa na geografia, escapando dos assuntos que sempre eram discutidos e das normas de apresentação dos trabalhos geográficos.

A Antipode da década de 1970 foi produzida e distribuída de forma autossuficiente, abrangendo um grande número de temas e tendo uma periodicidade de publicação irregular. Entretanto, no final da década a revista sofreria mudanças. Nesse contexto, Phil O'Keefe também ressalta a consolidação das ideias marxistas na geografia crítica.

Em 1980 foi estabelecido um limite de 50 páginas para os artigos e um padrão para a publicação dos textos, o que pode ser interpretado como um sinal de normatização da geografia crítica. A partir do volume 13, lançado em 1981, a AAG considerou que nem tudo o que estava no periódico era sem valor acadêmico e os novos organizadores decidiram fazer um esforço para acabar com a fama de revista mal estruturada e com artigos de má qualidade.

Em 1986, a partir do volume 18, a Antipode é englobada pela Blackwell Publishers e desaparece o logotipo tradicional da capa do periódico (um homem quebrando correntes presas a um globo) sendo que as regras de publicação se tornaram extremamente rígidas, com número máximo palavras e entrega formal dos artigos com cinco cópias para avaliação. Não por acaso, John Davey editor de Harvey desde a publicação de Explanation in Geography, trabalha na Blackwell.

209 Dos desenhistas destacou-se o literário Jack Eichenbaum. 
Hague deixa claro que não faz um ataque pessoal ao periódico, mas desafia os geógrafos críticos a manterem e retornarem à ideia original da revista. Ele demonstra na época muitos volumes estavam recheados de artigos e textos no estilo da AAG e da Transaction of the Institute of British Geographers, que refletem um conservadorismo e uma prática disciplinada e definida, sem espaço para os antigos debates. Diante do quadro apresentado, a revista modificou muito sua linha editorial.

Hague propõe um comitê que consiga tornar a publicação livre e crítica novamente, não só politicamente, mas também na forma de escrever. $O$ autor aponta que em um número de 2002 existe um editorial otimista e audacioso, porém ainda muito modesto em suas ambições e perspectivas de mudança. Hague acreditava que Antipode se tornou mais um periódico na prateleira sem nada de inusitado, mas continuava apresentando conteúdos marxistas e problemas sociais de um ponto de vista geográfico.

Ao final de suas considerações sobre a revista, reforça a ideia de que um periódico que nos ajude na carreira acadêmica é bom, mas faz uma série de indagações: O que se pode fazer acerca as pessoas que vivem no mundo? Até que ponto Antipode continua crítica? Até onde tem ambições não acadêmicas? Se afastar do academicismo é tornar a publicação acessível a todos? Quem está apto para julgar o polêmico critério da qualidade da revista? O conteúdo radical da revista não deve estar apenas nas ideias que ela reproduz, mas estimular o debate com a sociedade 210 .

Jacoby expõe a mesma problemática que Hague, afirmando que nos anos 1980 existe uma especialização da Antipode e uma integração entre os radicais e a AAG. Existe o clima de obrigação ao redor do lema "militar e ser marxista" como forma de ganhar capital cultural, o que pode induzir engajamentos a contragosto e explicar o processo de desarticulação do marxismo na teoria geográfica. De fato, se observarmos os Anais buscando publicações dos geógrafos críticos ou temas da geografia radical, encontraremos o seguinte panorama:

\footnotetext{
210 Como poderemos ver, algumas características das transformações da geografia norte-americana são muito semelhantes ao que ocorreu no Brasil. Podemos pensar em um paralelo entre a Antipode e a Terra Livre.
} 
Gráfico 1 - Artigos de geógrafos ou temática radial nos Anais da Associação Americana de Geógrafos de 1970 a 1989.



Ano

O período de maior participação é a passagem dos anos 1970 para 1980, na mesma época em que a Antipode se profissionaliza e especializa. Como afirma Jacoby muito acertamente, a instituicionalização sem o debate do modus operandi empobrece o movimento revolucionário, que acaba entrando no debate científico "pela porta dos fundos".

A revista Hérodote também sofreu uma série de mudanças desde sua fundação. De acordo com Scarim (2000, p. 76-77): "A revista Hérodote, lançada por Yves Lacoste em 1976, e que é descendente da Antipode, é o símbolo do pensamento crítico na França", ou seja, as revistas estavam de alguma forma interligadas apesar das diferenças editoriais. As diferenças entre o desenvolvimento da geografia marxista nos dois países caminhou mais em função de seus contextos locais, mas a articulação em nível mundial possibilitou uma maior confluência de temas e debates.

De acordo como aporte althusseriano, Hérodote surge de um grupo interdisciplinar:

(...) composto de geógrafos, mas também de etnólogos, de urbanistas, de filósofos e jornalistas. Hérodote retoma, portanto, o projeto crítico do paradigma estruturalista sobre o declínio, e as estratégias revisitadas devem permitir decifrar o terceiro termo do subtítulo da revista: as ideologias (DOSSE, 2007a, p. 391).

O tema althusseriano do estudo dos aparelhos ideológicos do Estado foi recorrente na Hérodote. Um dos resultados da troca interdisciplinar é o contato com Foucault, fruto de uma entrevista realizada em 1976, que influenciará tanto geógrafos quanto o próprio filósofo, e vai conferir um grande prestígio à revista 
(DOSSE, 2007a, p. 391). É nessa época que Raffestin, professor suíço, começa a desenvolver seus trabalhos com base na semiótica e na ideia foucaultiana de microfísica do poder. Esse geógrafo fortemente influenciado pela nova geografia terá uma aproximação importante com o marxismo (CLAVAL, 2011, p. 282).

Resultado dos primeiros debates da revista, Lacoste lança A Geografia, isso serve primeiro lugar para se fazer a guerra, voltada para a ação política e iniciando a tendência de valorização da geopolítica em sua obra. Para Claval (2011, p. 281), isso só é possível devido ao seu afastamento do partido comunista francês. A Hérotode acaba polarizando o debate, principalmente sobre a geografia política/ geopolítica.

É importante ressaltar que o percurso de Lacoste e de parte dos intelectuais de Vincennes, e de outros intelectuais, como Jean Chesneaux, estava ligado a "um Maio de 1968 tardio" que resurgiu no ano de 1976 (JULLIARD e WINOCK, 1996, p. 665). A nova radicalização estava ligada a uma relação marginal que esses intelectuais mantinham com o maoísmo e o grupos políticos de ultraesquerda inspirados por ele, como, por exemplo, a Gauche Prolétarienne (GP). É justamente esse tipo de inspiração que leva Foucault (1979) a escrever seu texto sobre a soberania da população em detrimento da justiça estatal. Apesar de não haver uma referência direta ao maoísmo e a revolução cultural, Foucault era ligado aos membros do grupo (MILLER, 1996, p. 176-189). Fica evidente que Lacoste, devido ao seu passado maoísta, a influência de Foucault e a presença em Vincennes, esteja na perspectiva da mesma atmosfera intelectual.

Como já havíamos mencionado anteriormente, a Segunda Guerra Mundial traz um grande desprezo pela a geopolítica, sendo que Gottmann na opinião de Claval (2000, p. 239), é um dos únicos que continua a praticá-la. O surgimento da revista Heródote será o ápice da carreira de Lacoste, como indica Claval, envolvendo temas de análises de guerra, fundamentalismo, nacionalismo e mudanças da ordem mundial. Entretanto, é possível identificar um uso pouco criterioso da palavra geopolítica, pois existe uma preocupação propagandista de seu uso que ignora a realidade histórica da disputa entre geopolítica e geografia política (COSTA, 2010, p. 245-246). Em outra ocasião, Giblin (1985, p. 287) explora essa controvérsia dizendo que a geopolítica apenas expõe o caráter prático escondido na geografia política.

Segundo Claval (2000, p. 241), para Lacoste a geopolítica diz respeito às diferentes razões e atores dentro de um determinado território, que podem ou não 
serem ligados ao Estado. Quais são as disputas de poder? Historicamente, como o poder evolui ou se retrai dentro de um determinado território? Qual o papel das ideias influenciando a opinião pública (CLAVAL, 2000, p. 241)? Esses são alguns questionamentos típicos de sua geopolítica, que se intensifica após o início da Guerra do Cambodja, ao colocar a autodeterminação dos povos novamente em debate.

Contudo, não podemos esquecer do antigo interesse de Lacoste pelo subdesenvolvimento e na mudança de enfoque geográfico para Ásia, já que anteriormente ele se interessava mais em estudar a América Latina e o Norte da África. Talvez sua passagem pelo maoísmo tenha lhe inspirado a estudar as antigas colônias da França na Ásia. Claval (2000, p. 244) também indica que nesse período de interesse pela opinião pública, o ensino e os materiais de didáticos começam a ser objeto de suas preocupações. Concomitantemente, surge a oportunidade editorial para publicar $A$ geografia na editora Maspero, sua velha conhecida, combinando a análise de geografia e poder (CLAVAL, 2000, p. 245).

Nesse sentido, Hepple é bem menos complacente com Lacoste e refere-se a ele como um pós-marxista inspirado pelo pensamento anarquista. Diz que muitos comparam a natureza do A Geografia de Lacoste ao Livro Vermelho de Mao Tsé Tung, o que nos parece um tanto inusitado. De qualquer forma, o livro de Lacoste é um ataque frontal à geografia universitária, e para Hepple (2000, p. 272) enquanto todos estavam imersos no estruturalismo, Lacoste já caminhava rumo ao pósestruturalismo. A tese central de Lacoste e seu grupo é que:

\footnotetext{
(...) a geografia foi a forma de estratégia e de conhecimento político, central para a estratégia militar e o exercício do poder político, mas que esse discurso estratégico se tornou escamoteado atrás da 'cortina de fumaça' da geografia acadêmica. Geógrafos precisavam aniquilar as limitações de seu 'discurso mistificado mistificante' e tornar-se um analista crítico e militante da estratégia, trabalhando para desmascarar a estruturação geográfica do poder e ajudando no desenvolvimento de estratégias (CLAVAL, 2000, p. 268).
}

Apesar disso, o termo geopolítica só é incorporado no título da revista em 1983. O primeiro número da revista defende guerras revolucionárias, como a de Cuba, destacando o espírito nacional e a luta anti-imperialista, bem como a ideologia que se encadeia com a estratégia e a opinião pública (CLAVAL, 2000, p. 245). Dentro da revista, logo nos primeiros números existe uma releitura de $\mathrm{E}$. Reclus feita pelo doutorado de Beátrice Giblin, que servirá como uma espécie de modelo para 
trabalhos futuros. Reclus se torna um ícone devido ao seu engajamento político e suas preocupações ambientais, tema em ascendência no período.

Michel Foucher é outro autor que ganha destaque através do estudo da América do Sul e o problema das fronteiras. Ainda na fase inicial, Michel Korinman integra-se com seu trabalho acerca da geopolítica de Haushofer e o filósofo François Châtelet, colega de Lacoste em Vincennes, também traz colaborações (CLAVAL, 2000, p. 245). A esposa de Lacoste proporciona um diálogo com o sociólogo Pierre Bourdieu, pois Camille Lacoste-Dujardin é etnóloga e estuda a cultura Kabyl na Argélia (CLAVAL, 2000, p. 246-247). É realmente lamentável que Bourdieu não tenha influenciado a geografia de uma maneira profícua, já que as possibilidades históricas permitiam trocas nesse momento. Giblin oferece um retrato do novo grupo:

\begin{abstract}
Michel Foucher trabalha nesse movimento de geografia das fronteiras, contudo sem esquecer suas pesquisas sobre a 'geografia da geografia' "; Michel Koriman - germanista, curioso pela geografia - interessa-se sobre os escritos dos geopolíticos de língua alemã; Beatrice Giblin teve a chance de exumar a obra de Élisée Relus (1982), e sua dupla formação de historiadora e geógrafa a conduziu durante um tempo a interessar-se pela história da geografia e sua epistemologia; atualmente suas pesquisas são orientadas sobretudo pela política regional; Yves Lacoste, conhecido por seus trabalhos sobre o terceiro mundo, trabalha sobre as situações geopolíticas mais confusas do mundo e prepara um tratado de geopolítica (GIBLIN, 1985, p. 283) ${ }^{211}$.
\end{abstract}

Como podemos observar, Lacoste reuniu seu próprio grupo de pesquisadores. De guerrilheiro epistemológico rebelde, Lacoste torna-se aos poucos o madarim da geopolítica ao reduzir a geografia à geopolítica. Numa Broc critica a ideia de Lacoste remetendo à produção geográfica do século XIX, e argumentando que o papel da geografia como instrumento de dominação é muito mais complexo, e que se dá de uma maneira muito mais indireta do que a simplificação que ele propõe (HEPPLE, 2000, p. 274).

Com o objetivo de legitimar seu capital simbólico e sua nova proposta de campo de estudos para a geografia - centrada na geopolítica - Lacoste vai reescrever a história da geografia. O primeiro movimento, como vimos, é a da região-obstáculo e o caráter reacionário da geografia vidaliana que o formou como geógrafo. O segundo movimento, após ser criticado duramente pela comunidade geográfica, será a "redescoberta" do Vidal de la Blache político, o que é uma espécie

211 Tradução nossa. 
de embuste, pois a obra de Vidal sempre esteve disponível na França (HEPPLE, 2000, p. 274). O terceiro movimento é tangenciar os geopolíticos sem o medo da mácula que os rondava, indicando que as ideias de Mahan e Mackinder - como, por exemplo, o "pivô central" - não possuem utilidade prática, postura que tenta esgotar a possibilidade de uma teoria geral de explicação da geopolítica mundial. Ou seja, não existem mais grandes teorias capazes de explicar a totalidade, apenas a abordagem regional permite explicar o mundo em toda sua complexidade. A vantagem é que Lacoste rompe com uma separação de que a geopolítica norteamericana seria aceitável e que a nazista é intolerável, execrando ambas (HEPPLE, 2000, p. 278).

Esse rompimento com a dicotomia da geopolítica também se reflete no desprezo por outras dicotomias, como EUA e URSS, poder terrestre contra poder marítimo, Heartland (Mackinder) versus Crescente Marítimo (Mahan) e poder versus território. Tais rupturas consolidam o enfoque regional, uma escala que seria verdadeira, prática. Não podemos esquecer que sua primeira análise geopolítica regional foi justamente o conflito no Cambodja e no Vietnã.

Os fenômenos de longa duração encaixam-se nos quadros geopolíticos regionais, mais estáveis, mas a observação minuciosa do seus estudos de caso revelam a ausência de um modelo de explicação geral, pois as medidas práticas da geopolítica quase sempre são explicadas tautologicamente pelos contextos regionais (HEPPLE, 2000, p. 283-284). O pragmatismo é fundamental dentro de seu grupo, pois confere uma possibilidade superação entre teoria e mundo empírico (GIBLIN, 1985, p. 285). Lacoste introduz o estruturalismo tardiamente na geografia, mas após criar uma base institucional sólida desloca-se para longe dele incorporando muitos elementos pós-estruturalistas - por exemplo, a análise hermêutica aplicada à geopolítica regional ou o abandono de narrativas explicativas totalizantes.

Para Lacoste, a região é a escala geográfica que apresenta uma unidade e coerência política, sendo que em sua opinião no mundo anglo-saxão não existe debate sobre geopolítica, somente análise das relações internacionais (LACOSTE, 2010, p. 132-141).

A história desenvolvida por Lacoste contrapõe-se à de Raffestin, que de maneira mais correta não deixa de relacionar o nascimento da geopolítica ao fascismo, ao nacionalismo e ao expansionismo imperialista (HEPPLE, 2000, p. 279). 
A escala diferencial é outra ideia desenvolvida por Lacoste e privilegia uma sucessão escalar de espaços cartesianos do "aqui e agora", ao invés de repensar e criticar o cartesianismo, como fez grande parte da geografia crítica (HEPPLE, 2000, p. 281). A fuga de um modelo teórico se justifica através de uma tentativa de tornar a geografia acessível a todos, mas configura uma grande contradição perante a exigência de superar o vazio epistemológico. Hérodote, que no início abarcaria um público geral interessado na desmistificação ideológica, aos poucos passou a ser uma publicação interessante apenas para os especialistas em geopolítica.

Concomitantemente ao desenvolvimento da revista, em 1976 Broc lança uma provocação ao projeto intelectual do grupo. A Hérodote trata os geógrafos de maneira reducionista como espiões ou traidores, sob um tom policialesco, e apesar de propagar a ideia de guerrilha epistemológica não é totalmente claro quem é o inimigo mesmo que Vidal de la Blache tenha sofrido vários danos colaterais: "Insconscientemente ou não, o geógrafo trabalharia para o exército, o governo, os

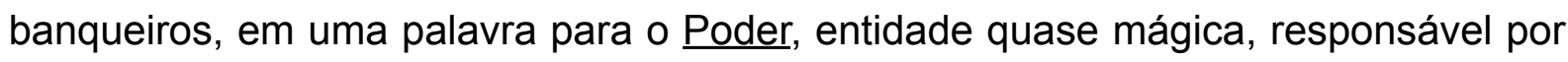
todos os males da infeliz humanidade" (BROC, 1976, p. 504)212. Essa postura, em sua opinião, acaba induzindo ao imobilismo.

Ao contrário de Antipode, Hérodote não passou por uma processo de comercialização, pois nasce dentro de uma editora independente. Como ressalta Bataillon (2009, p. 18), a década de 1970 é um período de privatização generalizada dos periódicos da geografia que deixam as editoras universitárias e passam para privadas. Esse processo ocorre com os Annales de Géographie, que começam a publicar mais artigos de geografia física ou ainda no nascimento da L'espace geographique, inicialmente veículo da nova geografia e do planejamento, que tenta modernizar e inserir o debate teórico na geografia francesa.

Paralelamente à Hérodote, um grupo ligado a Guglielmo tenta, em 1978, fundar uma revista chamada Espace et luttes. Ela teve apenas cinco números e com uma preocupação interdisciplinar tratou da relação entre espaço e política, questionou o planejamento oficial e defendeu sua democratização. A divulgação das lutas ligadas aos movimento sociais era outra frente da revista.

Em 1978, por exemplo, Guglielmo e seus alunos envolveram-se nas lutas sociais em Larzac ao lado de sindicatos e movimentos sociais que auxiliavam os camponeses na luta pela terra. Guglielmo deu uma espécie de ajuda técnica, 
produzindo mapas além de participar ativamente das disputas que englobavam um quadro complexo de militantes de esquerda (MEMÓRIAS, 1990, p. 202).

No entanto, em 1980, a revista deixa de existir mas não podemos deixar de pensar na posição de Guglielmo em Vincennes e a possibilidade dessa revista ter vingado (MEMÓRIAS, 1990, p. 54-56). O espírito de sua revista é muito próximo a da Hérodote - interdisciplinaridade, relações poder, política.

No entanto, é interessante notar que Hérodote e Antipode inicialmente tinham um formato mais ou menos livre e aos poucos vão se enquadrando em um modelo fixo de publicação, mas não deixam de ser centrais nos debates da década de 1970 até os dias de hoje.

Um exemplo da centralidade são os debates travados entre David Harvey e Brain Berry2 ${ }^{213}$ na revista Antipode, que evidenciam o declínio da nova geografia (SCARIM, 2000, p. 70). Para Berry, o problema do gueto seria apenas político e não seria fruto do sistema capitalista, porque o capitalismo estaria mudando, tornando-se um sistema de distribuição de renda rumo a uma sociedade pós-industrial ${ }^{214}$. Mais adiante veremos que esse debate tem importância fundamental, pois quando a cultura torna-se uma das variáveis privilegiadas na análise social a concepção de sociedade pós-industrial ganha força.

Outro argumento de Berry é que marxismo estrutural em geografia humana apresentaria soluções passivas e abstratas, não verificáveis na realidade (JOHNSTON, 1997, p. 256-259). Obviamente Harvey mostra que o gueto é um problema econômico e político, e que a exploração do trabalho e a indústria não estavam por acabar. Através de A justiça social e a cidade, Harvey explicitaria a

213 Berry $(2000$, p. 38) tinha excelentes antecedentes para entrar no grupo dos radicais: criado em uma família da pequena burguesia, frequentou e teve amigos do partido comunista da Grã-Bretanha. Durante sua formação, estudou e ao mesmo tempo trabalhou em uma fábrica.

214 Nessa época, o debate sobre a sociedade pós-industrial estava muito em voga. Inicialmente impulsionado por Daniel Bell, consistia em apontar uma desproletarização dos trabalhadores em função da automatização das linhas de produção e do inchamento do setor terciário. De acordo com esse raciocínio, os trabalhadores sairiam das linhas de produção e trabalhariam nos escritórios com atividades "intelectuais" supostamente mais complexas. O Estado desempenharia um papel de distribuidor de renda e isso causaria a ascensão social da população. $\mathrm{O}$ ápice do processo seria a transformação de grande parte da classe trabalhadora em tecnocratas, funcionários de escritórios ou serviços de decisão e controle. No entanto, o trotskista norte-americano H. Braverman (1977, p. 12-41) demonstrou como na verdade esses trabalhadores do setor terciário também sofriam um processo de proletarização. Não haveria, como pensavam os pós-industriais, um fim da degradação do trabalho, mas sua intensificação, pois nos escritórios o trabalho continuava a ser organizado através do taylorismo. Para Braverman existiria ainda uma desqualificação com a fragmentação do tempo da formação do trabalhador o que rebaixaria o valor do seu trabalho, bem como uma superexploração através da organização científica do trabalho oriunda do taylorismo. 
capacidade analítica do marxismo em geografia e aqui o sucesso da obra é inegável (JOHNSTON, 1997, p. 256-259).

Temos na Antipode especificamente a persistência de alguns temas da nova geografia, principalmente os referentes à geografia econômica. No momento da eclosão da geografia crítica, a metodologia da nova geografia ainda permanece e dilui-se aos poucos, como havíamos indicado. Na revista de 1974, volume 6, número 2, por exemplo, temos vários artigos criticando o modelo de Perroux e o de Christaller, além do debate entre Berry e Harvey. Na revista francesa e na norteamericana, o questionamento do objeto da disciplina acompanha uma preocupação social com o uso do conhecimento.

Surge também a revista L'espace geographique, que talvez seja igualmente ou mais importante que Hérodote porque resgata a originalidade do debate sobre a renovação da geografia, além de absorver teorias e ideias de fora da França. Essa revista representa uma ruptura com a ortodoxia do pensamento vidaliano (CLAVAL, 1998, p. 347).

Brunet é um dos autores que participam de sua articulação e que dá voz para geógrafos das universidades no interior da França. Logo no primeiro número, lançado em 1972, utiliza-se o termo espaço em contraste à região e ao terreno (terrain). O espaço "é dotado de estruturas que convém construir e/ou descobrir, segundo as regras de organização da ação humana sobre o planeta, regras comparáveis àquelas que os geomorfólogos estabeleceram para o relevo" (BATAILLON, 2009, p. 30). Observemos a associação entre regras e a ideia de estrutura, bem como a comparação com o relevo. Lembremos ainda da comparação metafórica amplamente conhecida que Lévi-Strauss faz de sua ideia de estrutura antropológica e geológica, ou ainda da translação, na explicação regional de De Martonne, da estrutura física para a social.

Para elaboração de sua tese, Brunet (2003, p. 14-15) começa a estudar cibernética, o que o encaminha para a ideia de sistema autoregulado e o estudo da teoria geral dos sistemas de Bertalanffy. O sentido que ele atribuiu a sua obra tenta explorar uma forma alternativa de representar as estruturas espaciais dinâmicas no espaço geográfico.

Devido essas aproximações, Brunet foi julgado como neopositivista, apesar de o marxismo continuar a influenciar fortemente seu pensamento: 
Os fundamentos do pensamento sistêmico permitiam por sua vez aprofundar e situar as forças e relações de produção, apreciar o jogo das estruturas e das memórias, suas próprias deformações e transformações, eles ajudam a definir precisamente os processos de dominação ao invés, de adivinhá-los, vendo no cerne o papel da mais-valia e do lucro (BRUNET, 2003, p. 15) $)^{215}$.

Contudo, como o próprio autor afirma, o sistema não se encaixa perfeitamente com a ideia de estrutura. Existem algumas contradições quanto à sobredeterminação, à hierarquia e à divisão entre infra e superestrutura. Brunet não desenvolve nessa ocasião quais seriam os conflitos, todavia a aproximação dos dois conceitos inspirou um grande número de geógrafos no interior da França e na Suíça. Brunet, H. Reymond, Jean-Bernard Racine trabalharam nessa perspectiva.

É a partir da reflexão sobre o caráter sistemático-estruturalista que Brunet idealiza a fórmula dos coremas, que visa renovar a cartografia, mapeando os fenômenos e tentando abarcar seu dinamismo (BATAILLON, 2009, p. 104). Eles são resultado do interesse pela teoria sistêmica e a tradição da geografia de representar os fenômenos graficamente através de mapas resulta que aspiram ser representações das estruturas espaciais (BRUNET, 2003, p. 15). Segundo o próprio Brunet:

\begin{abstract}
(...) eu pude meditar sobre as ciências humanas e notadamente os trabalhos dos estruturalistas a começar por Lévi-Strauss cujo modelo das aldeias correspondiam exatamente aquilo que eu tentava mostrar. A noção mesma de corema é em parte inspirada por minhas leituras na linguística e na sociologia. O corema é para o espaço aquilo que a partícula é para a linguagem, uma estrutura elementar que se combina a outras, resultando em uma paisagem (ALLEMAND, 2007, p. 59) ${ }^{216}$.
\end{abstract}

Os coremas articulam-se em eixos, alvéolos, franjas, redes, pontos. Entretanto, o fundamento dessas formas é mostrar a dinâmica espacial.

Racine e Bailly também trabalham com a possibilidade de unir estrutura e sistema. Admitindo que o espaço é um produto social, "totalidade, hierarquia, diferenciação e finalidade podem definir um geosistema, refletindo a oposição entre espaço e sociedade" (RACINE e BAILLY, 1993, p. 125)217. Essa aproximação suscitou o interesse dos autores justamente por proporcionar uma saída ao espacialismo formalista.

\footnotetext{
215 Tradução nossa.

216 Tradução nossa.

217 Tradução nossa.
} 
A influência de Isnard, geógrafo francês que tinha contato com o marxismo, é marcante e sua concepção dialética da relação entre teoria e método em um ciclo de observação empírica e teorização é realizado a cada momento da pesquisa, trazendo um equilíbrio metodológico que procura conservar a tradição disciplinar (RACINE e BAILLY, 1993, p. 129-134).

Cabe ressaltar que a união entre estrutura e sistema foi uma ideia forte dentro da geografia brasileira. O balanço de Carlos Augusto Figueiredo Monteiro (1978) sobre a geografia, divulgado originalmente no encontro da AGB de 1978, em Fortaleza, propõe a união dos dois métodos. De um lado a análise sistemática para o estudo da natureza seria complementada pela perspectiva estrutural na geografia humana. O mesmo ocorre com a obra de Milton Santos (2002), também de 1978, Por uma geografia nova. Apesar de haver uma aproximação eminentemente estrutural no debate sobre o espaço, não é possível ignorar as metáforas advindas da física, que complementam a explicação sobre o espaço, como, por exemplo, os vetores espaciais. Como discutimos anteriormente, essa era uma tendência que também estava presente na geografia norte-americana, mesmo que a grande maioria opte por um abandono do sistema. Veremos agora as consequências entre o contraste de uma aproximação mais sincrônica e outra mais diacrônica.

\subsection{A organização categorial}

A tentativa de espacializar as análises históricas e econômicas causou uma série de mudanças conceituais. Devido à depreciação do conceito de região, amplamente negado em um momento inicial, ocorre o uso do conceito de território que deixa a esfera política e ganha várias acepções. A dimensão histórica do território cria uma sinergia com a ideia de formação sócioeconômica.

Paralelamente ao território, à sua acepção histórica e de dominação social, desenvolve-se a ênfase no espaço ou na espacialização das variáveis, tendência que continua o debate acerca do espaço advindo da nova geografia.

Nesse sentido, existe uma ampla discussão sobre o espacialismo, ou seja, a suposta existência autônoma de arranjos, processos relações e fatos espaciais, criticado por alguns geógrafos como fetichismo espacial (KONINK, 1995, p. 148). Dessa forma, de um lado seria possível pensar no espaço englobando as dinâmicas de fluxos ou de circulação e a localização de atores ou objetos; e por outro, o 
território mais histórico, que pode ser desmembrado a partir das instâncias sociais para dar origem a uma análise social mais minuciosa.

Konick (1978, p. 132-134) coloca que o humanismo e a geografia regional são constituídos pelo idealismo, assim como o espacialismo afasta o homem do objeto da disciplina e pretensamente atribui a ela um caráter mais científico. Entretanto, o refúgio disciplinar na categoria de espaço é ilusório, pois ele é essencialmente uma forma sem conteúdos. O capital, por exemplo, é uma relação social antes de se transformar em relação espacial (KONICK, 1978, p. 134). Em franco diálogo com a tentativa de Claval de invalidar o marxismo na geografia por sua ausência espacial, para Konick o objeto da disciplina deveria ser a estrutura espacial, seu modo de produção e classes sociais em um projeto que remonta à obra de Althusser.

A ideia de espaço vinda da nova geografia e das discussões da obra do filósofo Kant oferecem um salto qualitativo ao encontrar o pensamento marxista, como nos aponta Berdoulay. O espacialismo seria a base para se pensar um espaço "social":

Portanto, Kant, privilegiando como uma possibilidade do espírito humano o ponto de vista espacial, abriu o caminho para uma ciência de relações espaciais entre os fenômenos observáveis na superfície da terra. Esse é o porquê e faz comumente remontar a ele a ideia de que a geografia seria uma ciência do espaço, ou a ciência espacial única. Trata-se de uma definição muito popular da geografia. Hartshorne se faz notadamente o defensor desse argumento. Paradoxalmente, os detratores de suas posições metodológicas não fazem nada mais que acusar a tendência de reduzir a geografia a uma ciência das relações espaciais, procurando ver somente os aspectos geométricos. Esse tipo de discurso espacialista, fortemente preso ao neopositivismo, se espalhou com o emprego das teorias quantitativas. Sem ir sempre em direção de posições estreitas, esses métodos relançaram a fascinação dos geógrafos pelas relações espaciais de tipo geométrico, ou topológico. O estreitamento da visão é comumente evitado quando a atenção vai para os processos sociais extraídos de tais arranjos espaciais. Sabe-se, por exemplo, que a ideia de produção do espaço teve ecos na geografia. E é por esse ângulo, por essa ancoragem no social, que o discurso espacialista é renovado de maneira que o espaço apareça cada vez mais como um sistema de relações. Paralelamente, no mundo soviético (...) se continuou a considerar a geografia como uma mistura de ciências espaciais. Mas é verdadeiramente possível fundar epistemologicamente uma ciência sob a consideração exclusiva do espaço? (BERDOULAY, 1988, p. 52) ${ }^{218}$.

O salto é estabelecido no momento que a geometria espacial dá lugar às relações sociais, mesmo que seu estatuto epistemológico seja mal elucidado. Em seguida, Berdoulay (1988, p. 53) defende um ponto de vista moderado, pois 
considerar o espaço apenas como produto espacial é desconsiderar a geometria. $\mathrm{O}$ inverso cria um determinismo geométrico. Entretanto, ao contrário do território, a análise espacial frequentemente induz o investigador a uma análise mais sincrônica do que diacrônica ou histórica.

Paul Claval, além de interessar-se pelos debates sobre a geografia crítica, dá sua contribuição em Espace et pouvoir, encaminhando uma discussão entre marxismo e política. Sobre a questão do espaço, afirma: "A apreensão direta do espaço se acha pouco a pouco reduzido na obra de Marx... É no momento em que se efetua uma análise do fetichismo da mercadoria que Marx elimina de seu sistema as dimensões espaciais" (SCHEIBLING, 1977, p. 49-50). Esse argumento de distanciamento da problemática do espaço e do marxismo também vai ser usado por Lacoste.

Para aqueles que escolhem o território, o espaço aparece como uma categoria vazia, não científica e sem história, ligado a uma noção abstrata. O território pelo contrário seria concreto, historicamente constituído, sem a característica geométrica-abstrata (DAMMET e SCHEIBLING, 1984, p. 26). O território refere-se ao concreto e apresenta as potencialidades naturais de um recorte político. Observamos que:

O território é um domínio socializado que se define em função do modo de organização sóciopolítico e do modo de regulação social. O território é o substrato modelado e remodelado constantemente por uma sociedade em perpétua transformação que produziu as formas 'espaciais' servindo de quadro ao seu funcionamento e a sua produção. $O$ território remete a esse fato e também à organização do poder (DAMMET e SCHEIBLING, 1984, p. $22)^{219}$.

O território auxilia o estudo porque:

(...) com o capitalismo moderno, o das últimas décadas, assiste-se a uma dissolução das estruturas territoriais anteriores assentadas nas relações sociais de longa duração, ao mesmo tempo que o capital reconcentra-se e internacionaliza-se, mobilizando novos reservatórios de força de trabalho (DAMMET e SCHEIBLING, 1984, p. 26-27).

Naturalmente, o território engaja-se com a formação social, ambos abrangendo a escala nacional e como manifestação específica do modo de produção. Apesar de ter essa importância fundamental, aos poucos o território passar a englobar outras instâncias sociais para além da política, fragmentando-se 
em econômico, cultural e político, abandonando a dimensão nacional e chegando, a longo prazo, na escala do indivíduo ou dos grupos sociais, o que desvirtua seu sentido original ligado estritamente ao Estado, como na geografia clássica de Ratzel. Nesse sentido, a ideia de microfísica do poder de Foucault tem uma influência importante.

Apesar de existir uma ligação entre espaço e território, parece que alguns geógrafos acabam escolhendo uma das duas categorias para privilegiá-la em seus estudos.

Nesse contexto, James Anderson (1973) discute o papel da ideologia em distorcer a realidade e ocultar os interesses de classe, adotando a ideia marxista clássica de que a ideologia é a falsa consciência. Mesmo com essa ressonância althusseriana, ele baseia-se em Lefèbvre (ANDERSON, 1973, p. 43-52). A grande novidade do artigo é que através dos estudos sobre a mente mistificada pela ideologia, Anderson chega à concepção de fetichismo espacial. Existe uma crítica à retórica espacial que acaba tomando as relações entre lugares como se fossem relações sociais, o que pode obscurecer relações dialéticas entre forma (uma região) e conteúdo (uma sociedade, por exemplo) (PEET, 1982, p. 240). Essa ideia é muito importante na crítica contra o espaço abstrato ou de certas visões políticas que veem consenso sociopolítico através da unidade territorial (PEET, 1998, p. 74).

Se, por um lado, a crítica do fetiche espacial enfraqueceu o espacialismo, de outro é fácil perceber que ela separou a dialética entre forma e conteúdo. Quase sempre falar de um espaço é referir-se ao povo que lá habita ou algo que pode ser apropriado em função do interesse social. O fetiche espacial é uma forma de alienação que se manifesta desde que o homem se torna sedentário e relaciona-se até mesmo com a ideia de propriedade privada, concepção não explorada por Anderson. Não nos parece que ele seja apenas uma mero problema teórico da geografia, mas uma característica da prática social em geral.

Nesse mesmo ano, a antiga sociedade para trabalhos de campo Bunge para de funcionar devido a sua mudança para outra cidade. Os estudantes envolvidos se dispersam e a universidade recusa-se a dar continuidade ao projeto (PEET, 1982, p. 135). De 1972 até 1976 Bunge organiza algumas expedições sob o nome de Expedições Geográficas de Toronto, no entanto, seu desligamento da universidade denota uma perda de fôlego da geografia crítica. As críticas ao espacialismo e posteriormente ao althusseriano economicista dão margem para novos desenvolvimentos. 
Nesse mesmo ano de 1976, Harvey lança uma série de artigos criticando o Estado e o planejamento como uma ferramenta de reprodução da ordem capitalista (PATERSON, 1984, p. 135). Sua postura não vai em direção ao abandono do planejamento, mas procura recuperar uma dialética social da negociação entre Estado, empresas e população local para encontrar elementos que favoreçam todas as partes e proporcione um desenvolvimento menos contraditório e impactante.

Entretanto, essa desaceleração vai dar lugar a uma ampliação da quantidade de temas abordados. Contudo, alguns geógrafos convencidos de que o marxismo não abarca o espaço, distanciam-se da disciplina. Como mostra Claval:

\begin{abstract}
Entre os geógrafos marxistas, assistimos a uma evolução que é coerente com seus princípios: muitos terminam por cessar de se reivindicar da geografia, pois lhes parece que o espaço não é mais do que um aspecto secundário - e segundo - da realidade social que eles procuram apreender. Não valeria mais, nessas condições, se consagrar ao problema fundamental da análise das forças produtivas e dos modos de produção? (CLAVAL, 1984, p. 222).
\end{abstract}

Portanto, seria mais adequado dizer que não houve uma crise profunda de um primeiro ciclo de debates e produções, mas um ajustamento epistemológico, pois muitas das normas, objetivos e temas da geografia crítica já haviam se institucionalizado. Mesmo que encontremos uma diversidade de projetos disciplinares, de uma forma geral, existe uma necessidade de maior alinhamento entre a epistemologia marxista e as categorias clássicas da geografia. Uma evidência que logo a geografia crítica se recompôs após esse é debate é o fato de que:

Nos meados da década de 1970, a teoria revolucionária e os grupos de ação tinham-se tornado muito comuns nas universidades e entre certos movimentos minoritários e sindicais, e o apoio cresceu para várias centenas de milhares de pessoas (PEET, 1982, p. 227).

Apesar das dificuldades em 1974 é criada a Union of Socialists Geographers (União dos Geógrafos Socialistas) e a Socially and Ecologically Responsible Geographers (Geógrafos socialmente e ecologicamente responsáveis):

Dentro da disciplina de geografia, a União dos geógrafos socialistas (USG), fundada em 1974, organizou 200 membros na América do Norte em seus primeiros anos e mais 100 membros na Grã-Bretanha logo após (...) Os membros da USG organizaram sessões especiais nas convenções da Associação de Geógrafos Americanos (AAG) e nos encontros anuais do Instituto de Geógrafos Britânicos sobre temas como imperialismo, 
feminismo e teoria revolucionária, para o desânimo da velha guarda da disciplina (PEET, 1998, p. 73).

Nesse mesmo ano, a Union realiza um encontro de geografia que resultou na criação de grupo de trabalho sobre imperialismo, feminismo e minorias ${ }^{220}$. Contudo, segundo Smith (2001, p. 12), a partir do momento que a USG se institucionaliza na AAG ela se desradicaliza e se desfaz.

Aglutina-se ao redor da imagem de Harvey uma série de ideias muito importantes em função de sua obra $A$ justiça social e a cidade, de 1973, considerada uma obra paradigmática. Após refletir sobre os guetos, descartar o modelo de Kuhn para a história da ciência e criticar a teoria econômica liberal, Harvey continua a relacionar formas urbanísticas e modo de produção (PEET, 1998, p. 77). Assim:

\begin{abstract}
Objetos existem em redes de relações espaciais intrínsecas à sua constituição e a formação de sua potência. Contextos espaciais, deste ponto de vista, não são superfícies passivas, mas na verdade criam a natureza dos objetos, investindo-os com poderes casuais. As sociedades estão ligadas ao ambiente natural através de relações internas, dispondo suas mais básicas características nos aspectos da paisagem (PEET, 1998, p. 90).
\end{abstract}

Em 1975, além de Antipode e Hérodote, surge a revista Espace Temps no horizonte da geografia crítica, fundada em função da insatisfação com a formação recebida pelos alunos do curso de geografia e de história da Escola Normal Superior de Ensino Técnico. Inclusive, é no subtítulo dessa revista que o termo geografia crítica tem uma das suas primeiras aparições (GINTRAC, 2012, p. 6), o que a livra do peso ou comprometimento com a teoria estritamente marxista. Lévy havia frequentado cursos noturnos do partido, militara durante a época de liceu e na década de 1960 tinha visitado vários países comunistas (ALLEMAND, 2007, p. 141).

Na primeira edição, J. Lévy publica uma crítica ao Dicionário de Geografia organizado por Pierre George, referindo-se à grande quantidade de verbetes sobre geografia física se comparados à teoria social. O "artigo tenta fazer uma demonstração 'lingüística' da inconsistência teórica da geografia através da escolha das palavras e de suas definições" (SCHEIBLING, 1977, p. 47). Logo a reação de Maurice Le Lannou viria através de uma nota no jornal Le Monde, cujo o título é "Os geógrafos contra a geografia".

\footnotetext{
220 Curiosamente, esses temas dos primeiros congressos da geografia crítica do mundo anglo-saxão é um anúncio do que ela irá ser no futuro. Ou seja, esses temas ainda permanecem no topo da pauta da discussão, mas com novos referenciais teórico-metodológicos.
} 
Após esse evento, o diretor do instituto proíbe a publicação de um novo número da Espace Temps: "Os membros da revista iniciam uma campanha, recolhem numerosas assinaturas subscrevem uma petição de protesto e recebem importantes apoios, como o de Milton Santos" (DOSSE, 2007a, p. 394). Assim a revista torna-se independente e agregava-se na onda althusseriana, pois era necessário:

(...) libertar o saber geográfico do seu conteúdo ideológico e permitir a sólida ancoragem da disciplina geográfica como ciência. Reconhece-se aí nessa perspectiva refundadora, o trabalho impulsionado nos anos 60 pelos althusserianos no sentido do deslocamento das fronteiras disciplinares e da crítica das aparências enganadoras, a fim de fazer emergir a ciência, a teoria, após a realização do corte epistemológico, já assinalado no interior da obra de Marx, e que os geógrafos de Espace Temps também esperam apreender, mas no interior do saber geográfico (DOSSE, 2007a, p. 394-395)

Segundo J. Lévy:

A crise da geografia se caracteriza como 'sendo' a tomada de consciência do impasse em que se encontrava 'um saber essencialmente précientífico' não seguro de seu objeto, de sua definição, de seus conceitos e de seus métodos. O estado da disciplina é aquele de uma impregnação de ideologia 'naturalista', reacionária e empírica (SCHEIBLING, 1977, p. $46)^{221}$.

Além de encontrar seu objeto próprio - por isso o debate sobre espaço social na Espace Temps - era fundamental explorar mais sistematicamente a filosofia em busca um substituto para ideologia e para a falta de uma base teórica (SCHEIBLING, 1977, p. 49). Para Lévy, a criação da revista relaciona-se à escola suíça de geografia e à influência da nova geografia:

\begin{abstract}
Sua criação corresponde a uma ebulição sobre o plano da reflexão epistemológica ligado a formação de uma escola suíça ao redor de Raffestin, Jean-Bernard Racine e Antoine Bailly, aberta à geografia quantitativa anglo-saxônica e à filosofia (...) a maior parte pôde ser qualificada de positivista, nesse sentido eles acreditavam um pouco ingenuamente em uma transparência entre a realidade e os modelos teóricos que eles buscavam na matemática e na física. Eles eram também muito ambíguos quanto ao posicionamento da geografia frente as ciências sociais (ALLEMAND, 2007, p. 142)222.
\end{abstract}

A revista Espace Temps tem um papel importante na discussão do espaço como produto social, constituindo uma categoria dialética. A definição de espaço

\footnotetext{
221 Tradução nossa.

222 Tradução nossa.
} 
social feita por J. P. Pfertzel pautada na dinâmica de acumulação e combinação de capital será uma ideia importante que guiou a revista desde os primeiros anos de sua existência (KONINK, 1995, p. 153). Ainda no início de seu desenvolvimento, o tema da estrutura social, as reflexões de Lojkine sobre o urbano têm grande relevância. Contudo, a revista tem um caráter mais interdisciplinar do que a Antipode e a Hérodote. Dosse detecta uma diferença sutil de orientações porque Espace Temps envolve-se na:

(...) difícil busca do objeto próprio da geografia, definido como espaço social que deve tornar-se crisol de todo estudo numa perspectiva que se quer essencialmente 'científica', diferentemente de Hérodote, que prefere a categoria de ciência à de 'saber pensar o espaço' (DOSSE, 2007a, p. 395).

O grupo da revista quer provocar um corte epistemológico nos moldes de Bacherlard através da aproximação com a teoria social, porém aos poucos viram que o estruturalismo marxista era estático, economicista e holístico. A visão das instâncias compondo a realidade não seria suficiente para cobrir a multidimensionalidade social e a partir de 1979 existe uma ruptura com essa abordagem (PAILHÉ, 2003, p. 56).

O espaço caminha para longe da geometria, alguns desejando que ele se torne uma instância social, como a economia ou a cultura. Konick (1995, p. 148-149) demonstra que existiram duas correntes sobre o espaço ao redor do althusserianismo: a primeira procura uma coerência espacial interna das estruturas, explicando as estruturas espaciais pelos fatores materiais e sociais; e a segunda vê o espaço como um produto social e concentra-se na análise da sua funcionalidade, postura que dialoga com a tradição de Perroux e do pensamento sociológico. No entanto, como afirma Racine (1981, p. 121), esses dois pontos de vista não são necessariamente excludentes, porque o espaço é produzido socialmente, oferecendo as condições da base material da vida, porém envolvendo estruturas mais ou menos funcionais.

Em 1976, com a inspiração vinda do estrangeiro, Massimo Quaini (1981, p. 1-10) funda um coletivo chamado Geografia Democrática, e dirige, pela editora Bertani de Verona, a revista Hérodote/Itália que passa a ser chamada de Erodoto. Como aponta Atkinson, é importante ressaltar que diferentemente do que ocorreu na França, devido ao fascismo italiano existiu um grande imobilismo no que diz respeito à geopolítica. Ou seja, diferentemente de sua correlata francesa, o termo não 
compôs o título da revista e retomou-se o debate acerca da geografia, poder e política sem recuperar a tradição da geopolítica italiana (ATKINSON, 2000, p. 108).

Um ano antes desses fatos, Quaini publica obras importantes: Geografia e marxismo e A construção da geografia humana. A segunda obra tenta recontar a história da geografia sob uma óptica marxista em oposição ao pensamento dominante, o que coloca em suspenso a visão linear da evolução disciplinar com seus grandes precursores de caráter heróico. Em uma postura externalista da história da ciência, Quaini defende que história evolutiva da geografia nunca buscou compreender o desenvolvimento do conhecimento em conjunto com seus contextos político, social, cultural, etc. O modelo cumulativo de conhecimento não serviria para se fazer uma história concreta da disciplina geográfica (QUAINI, 1981, p. 21-22).

Acrescentam-se ataques às fraquezas das correntes contemporâneas da nascente influência do marxismo com uma postura contra a nova geografia, crítica à especialização da geografia e ao desinteresse acerca do desenvolvimento das ciências humanas críticas aplicadas (QUAINI, 1981, p. 12-14).

Ainda em busca de reconstituir a história da geografia, Quaini reúne materiais sobre figuras postas em segundo plano, como Jean Gottmann ${ }^{223}$, um dos primeiros geógrafos que buscou as origens das ideias geográficas fora do âmbito da geografia oficial.

Além disso, critica Paul Claval principalmente devido a sua base historiográfica foucaultiana e a sua incapacidade de explorar suficientemente os contextos (QUAINI, 1981, p. 50-62). Com base na obra de Adorno, põe em evidência os pontos fracos da nova geografia e aponta os riscos do pensamento naturalizante da geografia, destacando a obra da escola de Chicago e de S. Huntington nos Estados Unidos (QUAINI, 1981, p. 72). Outro caminho interessante seguido por Quaini (1981, p. 104-106) é a discussão de filósofos e pensadores do lluminismo, como por exemplo, a comparação que ele realiza entre Kant, Hegel, Marx e os geógrafos da época, o que encaminha para uma reflexão sobre a geografia física e para o fato de os métodos das ciências naturais serem direcionados para as ciências humanas gerando muitas consequências (QUAINI, 1981, p.107-108).

\footnotetext{
223 Quaini não somente cita Gottmann como segue o seu roteiro. No livro de Jean Gottmann, La politique des Étas et leur géographie (Paris: Armand Colin, 1952), ele vai até as obras de Vauban, Montesquieu, Turgot e Buffon (p. 20-39) em busca de ideias políticas com reverberações geográficas e geopolíticas. Quaini faz algo muito semelhante, porém a ênfase nos pensadores iluministas lhe dá lastro para observar o pensamento geográfico fora da comunidade científica dos geógrafos modernos institucionalizados nas universidades.
} 
Por fim, existe todo um esforço para chamar atenção de Rousseau como percursor da geografia, enfatizando suas ideias subversivas e revolucionárias baseadas no pensamento geográfico ${ }^{224}$. Nessa obra, Quaini apoia-se muito nos filósofos italianos, principalmente Colleti e em menor grau em Croce e Gramsci (QUAINI, 1981, p. 159).

\title{
2.6 A Escola do regulacionismo
}

Em meados da década de 1970 consolidam-se os regulacionistas. A fertilidade da obra de Althusser não para na história, sua absorção e crítica reforça novos pontos de vista sobre o funcionamento da economia:

\begin{abstract}
Mas a grade estruturalista foi, sobretudo, pelas ciências econômicas através do althusserianismo. A chamada escola da regulação (da qual fazem parte, entre outros, Michel Aglietta, Hugues Bertrand, Robert Boyer, Benjamin Coriat, Alain Lipietz, Jacques Mistral e Carlos Ominami) é fruto dessa corrente de pensamento estrutural-marxista e, simultaneamente, de um distanciamento crítico das teses althusserianas. (...) Alain Lipietz descobre Marx graças a Althusser e consagra seu DES [diploma superior de estudos] a este último em 1972. Diante da crise de meados dos anos 70 , tem de corrigir certas orientações iniciais para compreender a evolução da situação econômica. Insistirá, então, ele e aqueles que se organizarão no que se denominou escola da regulação, no caráter contraditório das relações sociais de produção, que obstrui os mecanismos simples de produção e, por outro lado, toma consciência de um horizonte morto do althusserianismo baseado num processo sem sujeito (DOSSE, 2007a, p. 354).
\end{abstract}

A tendência é analisar os mecanismos minuciosos das estruturas econômicas locais ou regionais e a crítica é tentar afastar-se do estruturalismo que se esquece dos indivíduos. Tal visão também será incorporada na geografia, principalmente nos EUA, feita por Storper e Scott, demonstrando que o estruturalismo é muito abstrato e não observa as novas estratégias concretas das empresas, em uma economia globalizada, através do desenvolvimento tecnológico e da criatividade social. É como se a noção de estrutura predeterminasse o desenvolvimento sem observar as mudanças nas relações de classe (PEET, 1998, p. 134).

\footnotetext{
224 Marx (2006a) escreve, em 1846, o ensaio Sobre o suicídio, no qual é possível verificar uma certa influência de Rousseau. Entretanto, enquanto o filósofo busca um reencontro com a natureza, Marx pensa na superação/melhoramento da natureza através do moderno. Mesmo que ele tenha utilizado Rousseau para demonstrar como as condições sociais desiguais podem conduzir ao suicídio, Marx não vê a natureza como uma espécie de espaço de libertação. Quaini (1981, p. 192-193) mostra como as paisagens industriais incomodam Marx e Engels, resultado da contradição do capital que poderia ser superada pelo desenvolvimento das forças produtivas e das relações de trabalho, porém não é central na sua reflexão a ideia de retorno à natureza e ao homem natural não corrompido pela sociedade.
} 
De acordo com Benko (1995, p. 197), a ideia de regulação da economia vem de De Bernis, um economista não-ortodoxo influenciado por Marx. Ele substituiu a ideia de equilíbrio de mercado pela regulação inspirado por um seminário de Perroux de 1977. O ponto crucial é que as instituições convergem perante a economia, possuindo uma coerência que permite o crescimento econômico mesmo frente as forças contraditórias do capitalismo e da sociedade.

Apesar desses elementos de crítica, a escola não realiza uma ruptura drástica com o althusserianismo. Ela não deixa a estrutura de lado, mas existe a tentativa de compreender o funcionamento da economia global concretamente em uma escala local. Lipietz diz em uma entrevista que os regulacionistas são os filhos rebeldes de Althusser, porque utilizam sua referência mas querem ir além e compreender como as relações sociais contraditórias transformam-se em relações de produção através da regulação social. Posteriormente, analisam como essas relações continuam a se reproduzir e quais são os fatores que as alteram (JENSON, 1987, p. 4).

Para os regulacionistas, a divergência fundamental com o pensamento althusseriano é que são as relações de produção que determinam as forças produtivas e não o contrário. O compromisso político determina o modo de regulação, entretanto, economicamente, as forças produtivas não são neutras, elas também têm um caráter político (JENSON, 1987, p. 5).

A escola da regulação parte de algumas hipóteses básicas para debater a economia de sua época. A primeira delas é que existiria uma discrepância entre produção e consumo, e a segunda é a diminuição da mais-valia de acordo com o aumento dos salários e do uso de maquinário industrial (SANTOS, 2011, p. 1 e 2).

A partir desse diagnóstico geral, cada crise sistêmica inaugura um novo modo de regulação e um regime de acumulação coerente e funcional de acordo com a realidade do modo de produção. O regime insere-se em uma forma de regulação que abrange as normas, leis, hábitos e comportamento social - e aqui o diálogo com a teoria de Bourdieu não é um fator menor.

O modo de regulação mais estudado pela escola foi o fordismo a partir do pós-guerra. Ele se caracteriza pela sinergia com o Estado de bem-estar social que intermedeia os conflitos institucionais, além das empresas realizarem negociações e barganhas coletivas entre empresas e trabalhadores. Os líderes empresariais do fordismo, extremamente paternalistas, exercem monopólios locais ou regionais com o controle tecnológico e a regulação do consumo e da demanda através de altos salários (JENSON, 1987, p. 3-4 e SANTOS, 2011, p. 3-4). 
Cada regime de acumulação deve negociar com pelo menos quatro problemas básicos:

(...) (1) o desenvolvimento de processos de produção como processos de criação de valor, (2) a divisão do valor adicionado que modifica a reprodução de diferentes classes e grupos sociais, (3) a articulação de setores capitalistas e não capitalistas correspondente às transferências de valor e (4) a composição da demanda social que depende da validação da capacidade de produção (DUNFORD e PERRONS, 1995, p. 181-182)225.

Apesar de serem instáveis, os regimes de acumulação são organizações racionais de produção, distribuição e consumo dentro de um recorte territorial com normas específicas. Tais normas remetem ao modo de regulação com o seguintes fatores:

(...) (1) sistema monetários e mecanismos monetários, (2) mecanismos conectados com a regulação das relações salariais, (3) modos de competição dentro dos setores do capitalismo e entre outras esferas nãocapitalistas e (4) o caráter e o papel do estado (DUNFORD e PERRONS, 1995, p. 183).

A estabilidade da regulação econômica tende a criar uma inércia nas estruturas e nas instituições, porém a mudança de regime deflagra novos conflitos de classe que geralmente necessitam de outras soluções institucionais mediadas pelo Estado.

Os regulacionistas chegam a um esquema próximo aos ciclos econômicos de Kondratiev, utilizando periodizações de acordo com as fases expansivas e regressivas do capitalismo e suas renovações tecnológicas inspiradas por E. Mandel (PEET, 1998, p. 134). Contudo, a teoria neoschumpeteriana, que tem aproximações com os ciclos econômicos, também deu contribuições importantes (DUNFORD e PERRONS, 1995, p. 177). O capitalismo entre as crises cíclicas compõe períodos em que as atividades econômicas funcionam de maneira estável, formando os regimes de acumulação (JENSON, 1987, p. 3). A tecnologia aparece dentro do contexto das relações sociais, ela reproduz ou organiza novos regimes de acumulação.

Outra referência importantíssima nesse contexto é a obra de Gramsci:

Através de um encontro crítico do pensamento marxista e a interação produtiva que ocorreu entre estruturalismo e noções de hegemonia derivadas do marxista italiano Antonio Gramsci, produziu-se a tendência

225 Tradução nossa. 
'neoestrutural' conhecida como a escola francesa da regulação (PEET, 1998, p. 131 $)^{226}$.

Os momentos de estabilidade e a expansão de um regime de acumulação mais geral, como o fordismo - que não deixa de ter nuances nas diversas localidades - acaba consolidando um projeto político hegemônico que forma uma estratégia institucional e moral em toda a esfera civil e em várias escalas geográficas (DUNFORD e PERRONS, 1995, p. 184). Esse projeto permite a hegemonia da classe dominante, ou de determinadas frações da classe, com seus aliados, e traduz-se em projetos políticos, alianças e acordos eleitorais. Mais contemporaneamente, no toyotismo, acreditamos que os consensos do neoliberalismo podem ser vistos como aspirantes ao projeto hegemônico, com uma proposta política e moral que tenta se impor em escala mundial.

Surge a concepção de que as relações complexas entre as classes são organizadas em instituições fundadas a partir da luta de classes compostas de morfologias espaciais desigualmente desenvolvidas ${ }^{227}$. As relações reproduzidas em estruturas particulares determinam a integridade do sistema sociopolítico, geram pontos fracos no sistema e possibilidades de alianças de classe (PEET, 1998, 131).

A partir dessas mudanças, os mecanismos de regulação econômica podem enfraquecer, o que gera uma reação total em todo regime de regulação, reorganizando-o a partir da criatividade social e do redimensionamento da funcionalidade das instituições e da economia. De modo próximo a Althusser, incorpora-se a concepção de Gramsci em que a estrutura domina a superestrutura impondo sua racionalidade (PEET, 1998, p. 131).

Além disso, Gramsci ganha centralidade através do debate acerca do fordismo e da análise das classes hegemônicas, servindo de ponto de partida para regulacionistas compreenderem o pós-fordismo, ou seja, as transformações do fordismo depois da crise da 1973. Conjuntamente a esse esforços, verificam quem são as classes dominantes na hegemonia cultural, o que permite um paralelo entre a ideia de aparelhos ideológicos do Estado dentro do capitalismo.

Lipietz tem um valor especial para geografia, pois inicia sua carreira estudando:

\footnotetext{
226 Tradução nossa.

${ }^{227}$ Aqui é interessante uma comparação com o espaço econômico assimétrico de Perroux.
} 
A divisão econômica e social do espaço e perguntando-se qual mecanismo autorreproduz o espaço ou o transforma sob a iniciativa dos desenvolvedores privados. Ele mostrou o papel do preço das terra e das instituições para o planejamento urbano, mas sublinhou (especialmente Lipietz, 1975) dois modelos de regulação e produção urbana do espaço: o competitivo e o monopolístico, de acordo com a propriedade do desenvolvedor ou a ação pública submetida ou organizada (BENKO, 1995, p. 199).

Paralelamente a Lipietz na França, nos Estados Unidos os estudos dos geógrafos Allen Scott, Michel Storper e Richard Walker formam a escola da Califórnia.

O fordismo enquanto modo de regulação industrializou a periferia do capitalismo através do endividamento dos governos subdesenvolvidos e em alguns casos provocou mudanças nas instituições e nas relações de trabalho (SANTOS, 2011, p. 8). Lipietz atribui muita importância às mudanças espaciais, e a crise do fordismo enquanto modo de regulação acontece a partir da abertura dos mercados locais e das sucessivas inovações tecnológicas que causam a reestruturação produtiva. Essa transformação dá margem para o surgimento da acumulação flexível que ocorre fora da rigidez institucional do fordismo. Assim:

\footnotetext{
Acordos como o de Bretton Woods, a criação do Banco Mundial, do Fundo Monetário Internacional e por fim, da OCDE (Organização para a Cooperação e Desenvolvimento Econômicos), que agregou o bloco dos países mais prósperos do fordismo, formaram um corpo institucional entre os países fordistas, ou seja, o modo de regulação necessário para a coerência na formatação do modelo de desenvolvimento (SANTOS, 2011, p. 5).
}

Entretanto, com a defasagem do fordismo a partir das mudanças das técnicas de organização das fábricas (pós-fordismo), Lipietz destaca a flexibilidade defensiva baseada na mão de obra barata desorganizada sindicalmente, e a ofensiva pautada na tecnologia, na engenharia de produção e nos avanços sociais (SANTOS, 2011, p. $6)$.

Outro processo importante que começa a intrigar a geografia é o deslocamento industrial para áreas suburbanas, cidade médias ou pequenas e até mesmo áreas rurais (DUNFORD e PERRONS, 1995, p. 180). Aglietta, por exemplo, é um dos economistas que em 1974 estuda a sociedade americana na crise e percebe as primeiras mudanças no regime de acumulação (JENSON, 1987, p. 4).

A ideia de pós-fordismo acaba manifestando-se entre os regulacionistas como uma controvérsia debatida por um longo período, sem que em um primeiro momento imponha-se a ideia de toyotismo. Assim: 
O debate [sobre a mudança do regime de acumulação no pós-fordismo] provocou uma tempestade entre os geógrafos, sociólogos e economistas regionais que dividiram-se em dois campos que desenvolveram diferentes versões da herança regulacionista: existem aqueles que privilegiaram a estrutura local; e aqueles que privilegiaram as forças do global e foram críticos da 'geografia mítica da acumulação flexível' (Amin e Robins, 1992), destacaram o peso das estruturas oligopolísticas (Martinelli e Schoenberger, 1992) e a dominância das megalópoles (Veltz, 1992) (...) (BENKO, 1995, p. 203).

Apesar da divisão destaca por Benko ocorrer somente no início da década de 1990, quando o fordismo foi obrigado a abrir espaço para a competição toyotista, é importante frisar que a geografia norte-americana já encontrava-se, em meados da década de 1980, no dilema escalar entre a estrutura e o indivíduo, entre o particular e o global ou ainda entre o estudo regional integrado à uma análise global ou o estudo do lugar. Tal controvérsia no campo dentro os regulacionistas tem relação com a postura que os geógrafos haviam tomado.

O balanço de Lipietz sobre o movimento da regulação é que ele constituiu uma alternativa ao neoliberalismo (JENSON, 1987, p. 2). A referência a Gramsci é como uma espécie de defesa dentro contexto da esquerda, devido sua inspiração leninista, seu martírio nas mãos do fascismo, e porque ele não gravitava diretamente ao redor do marxismo soviético. Em um contexto que o marxismo começava a perder força, e que o stalinismo estava desmoralizado, sua referência estava acima de qualquer suspeita. Seu pensamento original, carregado de valores democráticos vinha a calhar naquele contexto, uma vez que seu legado político daria origem ao eurocomunismo na década de 1970 como uma tentativa de ruptura com o pensamento soviético ${ }^{228}$. No entanto, dentro da escola regulacionista a dualidade entre marxismo totalizante e explicação regional persiste:

\footnotetext{
Na teoria da regulação que elabora, dois níveis são distinguidos: teorias de escala média dão conta da vida econômica como se apresenta aos observadores durante os períodos normais; uma teoria mais geral, o marxismo permite interpretar as mutações que tomam lugar ocasionalmente (CLAVAL, 2011, p. 284).
}

Outro problema fundamental para a escola é: "substituir mecanismos transhistóricos da reprodução social coerente com modos de regulação específicos

\footnotetext{
${ }^{228}$ A ideia de que o Gramsci poderia representar um marxismo revolucionário distante dos problemas do socialismo real evidencia-se na biografia de Lênin (1984) que consultamos editada no final do regime soviético. Existe um abrupto corte na narrativa para indicar que quando Lênin faz uma viagem a Itália fica muito próximo de encontrar o jovem Gramsci, configurando uma clara tentativa de ligar as duas figuras históricas e comparar sua honestidade e vontade revolucionária.
} 
histórica e geograficamente nas quais economias e sociedade são ativas e institucionalmente reguladas" (PEET, 1998, p. 131). Para Lipietz não existiria uma teoria da regulação, mas "modelos de desenvolvimento em termos de acumulação e regulações" (JENSON, 1987, p. 2).

Essa escola forma o grupo CEPREMAP ${ }^{229}$, com Boyer, em Paris, Joachim Hirsch, na Alemanha, Dunford e Perrons, na Grã-Bretanha e Scott e Storper, nos EUA (PEET, 1998, p. 132). Destacam-se ainda Aglietta e Lipietz, que não estão na lista do grupo CEPREMAP, porém:

\begin{abstract}
Muitos de nós somos politécnicos - aqui eu estou pensando em Robert Boyer, Michel Aglietta, Bernard Billandot, Hugues Bertrand, Jasques Mistral e eu mesmo - e trabalharam em instituições que foram encarregadas pela implementação do modelo fordista na França depois do plano Marshall (JENSON, 1987, p. 4) $)^{230}$.
\end{abstract}

Alain Lipietz, que era na juventude influenciado pelo maoísmo e pela questão regional na esfera política e econômica, vincula-se ao partido verde e à causa ambiental, abandonando em boa parte o marxismo (LUNG, 1988, p. 48). Ele é uma figura importante entre os regulacionistas, e desenvolve muito a relação entre espaço e regulação econômica como vimos. Assim:

\footnotetext{
O espaço é a forma material das relações socioeconômicas aos quais formam as estruturas espaciais. O espaço socioeconômico concreto pode assim ser analisado em termos de articulação de 'espacialidades' de diferentes instâncias dos modos de produção presentes em qualquer formação social; por isso, existe uma economia legal, e outras espacialidades (PEET, 1986, p.126).
}

O espaço estrutura-se a partir das instâncias, modos de produção e das relações espaciais dos componentes sociais presentes. Assim, a construção social do espaço faz-se da sobreposição das instâncias sociais, o que não depende exclusivamente da esfera econômica. Lipietz posiciona-se contra aqueles que pensam nas mudanças sociais a partir de uma radicalização, da desaceleração ou do aquecimento econômico (PEET, 1998, p. 131-132). Não seria um absurdo indicar o vulto de Perroux diante das articulações de espacialidades diferentes pelo espaço econômico na obra de Lipietz.

\footnotetext{
229 Centre d'Études Propectives d'Économie Mathématique Appliquées à la Planification.

230 Tradução nossa.
} 
Para a geografia, ganha força a ideia do território como espaço humano diferenciado e possuidor de uma maneira específica de reprodução da vida material e social. No entanto, o território subentende uma distribuição desigual de recursos e economias de aglomeração que criam mais desigualdades (PEET, 1998, p. 135).

Essas repercussões na geografia econômica, inspiradas pela escola da regulação, unem-se à nossa argumentação inicial: o espaço social ou econômico aparece de forma mais abstrata, referindo-se aos modos de produção ou estruturas ligadas na escala internacional, enquanto o território remete a uma dimensão mais concreta, ao recorte regional, aos regimes de acumulação mais específicos. O território tem uma dimensão concreta e histórica mais imediata. Apesar dessas nuances, não existe uma divisão estanque:

Por isso, cada instância da totalidade social muda o espaço de um certo jeito enquanto as instâncias combinadas pela economia em uma organização específica supera os padrões espaciais (regiões, cidades, paisagens). Essa teorização permite uma análise cautelosa e específica das estruturas territoriais ou espacialidade, que é o termo estruturalista para os conjuntos espaciais correspondentes às formações sociais (PEET, 1998, p. 148).

O que está em jogo para a escola são os sistemas de equilíbrio e seus processos de transformação, pois a partir do fordismo existe a análise de paradigmas tecnológicos, regimes de acumulação vistos a partir da relação entre produção e consumo, além dos modos de regulação com seus agentes e normas (PEET, 1998, p. 133). Apesar disso, os regulacionistas demoraram para perceber o fenômeno do toyotismo solapando o fordismo, talvez devido a um certo eurocentrismo.

Outro elemento importante da escola da regulação que influencia a geografia - e que pode estar na raiz do debate de Harvey sobre o imperialismo - é a preocupação de estudar o mundo como sistema. Os modos de regulação tornam-se hegemônicos mundialmente sob a égide dos Estados Unidos, o que gera um comportamento consensual das instituições. Apesar de os regimes de acumulação terem especificidade nacionais, eles estão permanentemente em contato com 0 nível mundial (JENSON, 1987, p. 8-9).

Nessa mesma época, Harvey reinterpreta a teoria do desenvolvimento capitalista dando ênfase aos contextos geográficos. Outros autores se envolvem no debate da dependência entre centro e periferia, dando inicio às reflexões sobre a teoria do desenvolvimento desigual de Trotsky, ainda que aplicada somente para a 
região (PEET, 1982, p. 244). Fruto dessas reflexões mais aprofundadas, temos um aprimoramento e crítica do modelo centro-periferia, resultando em análises mais complexas das relações sociais e espaciais, tendência que se desdobrará na década de 1980 (GOMES, 2005, p. 300-301 e PEET, 1982, p. 244).

Nesse mesmo período, Harvey aproxima-se dos regulacionistas, principalmente através da ideia de regimes de acumulação. Entretanto, essa não é a única novidade incorporada, pois Harvey estreita relações com Wallerstein e adota alguns elementos do sistema-mundo, conjunto de análise que se propõe como um caminho do meio entre as ciências nomotéticas e idiográficas. Essa aproximação afasta Harvey da reabilitação do debate cada vez mais forte entre os dois tipos de ciência devido ao enfoque no lugar e às críticas ao estruturalismo (JACOBY, 1987, p. 198).

Entretanto, o apelo ao empírico estava ligado ao alto nível de abstrações que o estruturalismo havia inspirado na geografia. A divisão da ciência crítica em dimensões de análise oferece um exemplo de como a metodologia tornara-se obscura para os não iniciados no debate:

(...) (1) a explicação estrutural: uma forma de inquirir quais são as estruturas explicativas locais fora do domínio da experiência imediata e quais problematizam a relação entre teoria e observação; (2) explicação reflexiva: uma forma de inquirir quais são as mediações entre diferentes quadros de referência e quais problematizam sua autossuficiência; (3) explicação efetiva: uma forma de inquirir quais são as especificidades da cognição e quais problematizam sua legitimação (GREGORY, 1978, p. 76-77) 231 .

Obviamente, tal excerto mostra a própria visão de Gregory sobre a geografia e o que seria o pensamento crítico. Isso envolve sua preocupação com a geografia humanística, ainda que tais divisões nos pareçam distantes do que os geógrafos de fato fizeram.

\subsection{A crítica que se inicia na história}

Além dos regulacionistas, o historiador inglês $\mathrm{E}$. P. Thompson foi outro crítico do estruturalismo que impactou fortemente a geografia anglo-saxônica. Seu livro de 
1978 A pobreza da teoria ${ }^{232}$ ressalta o desaparecimento do sujeito diante das estruturas, uma crítica recorrente feito pelos ingleses a Althusser.

A sua obra $A$ formação da classe operária inglesa coloca novamente os indivíduos no centro na análise. Seu valor está na revalorização de uma tradição humanista frente ao "mecanicismo" estruturalista, Thompson influencia muitas gerações nas ciências humanas. Essa controvérsia suscita na geografia um questionamento sobre qual elemento seria mais importante: o contexto social de relação entre as classes ou a ação dos indivíduos provocando a acumulação capitalista (CHOUINARD, 1997, p. 364).

Entretanto, não seria um exagero dizer que o estruturalismo na geografia não explorou todas as perspectivas de análise, atendo-se demasiadamente nos processos urbanos e regionais, o que provocou uma teoriazação exagerada deixando a luta de classes em segundo plano (CHOUINARD, 1997, p. 366). A aproximação com Thompson, Giddens e a escola de Frankfurt oferecem uma nova possibilidade de estudo centrada no indivíduo e não em processos abstratos do capitalismo, além de proporcionar uma lista de forças que influenciam a sociedade, mas não a determinam diretamente.

Consolidando a postura de Thompson, em 1980 o sociólogo Gouldner populariza a ideia dos dois marxismos com rápida penetração entre a esquerda anglo-saxã:

\footnotetext{
O marxismo científico, como um 'tipo ideal', enfatiza, por exemplo, as regularidades das leis inerentes na sociedade, a descontinuidade entre Marx e Hegel e uma visão estruturalista da sociedade segundo a qual estruturas impessoais são os verdadeiros atores. O marxismo crítico, por outro lado, enfatiza a importância das decisões humanas para trazer a mudança, a continuidade entre Marx e Hegel e a unicidade da sociedade e o caráter distinto em diferentes estágios de seu desenvolvimento como uma totalidade orgânica com a ação do povo (PATERSON, 1984, p. 103).
}

Tal divisão reforçou a polarização entre Althusser e Thompson na sociologia e na geografia. O final dos anos 1970 também marca um novo ciclo de diálogos entre os geógrafos marxistas e os sociólogos da sociologia urbana. Lefèbvre, Pickvance e Castells reencontram a geografia através do estudo urbano. O resultado desse processo é a criação do Internacional Journal of Urban and Regional Research, em 1977 (PATERSON, 1984, p. 106). O objetivo desse periódico seria preencher o vazio existe sobre estudos urbanos marxistas. As discussões suscitadas pela revista, bem 
como a publicação, em 1972 d'A questão urbana, de Castells, são elementos que impulsionam Harvey a aprofundar a análise sobre o urbano e ir para França estudar. O resultado desse processo é o livro The urbanization of Capital, de 1985 (HARVEY, 2000, p. 161-162), e ainda uma série de artigos sobre Paris, capital of modernity, reunidos em 2006.

Contemporaneamente, Lefèbvre (2008, p. 130) também criticou o althusserianismo por não considerar os signos do espaço e a lógica que eles exprimem. A produção material e simbólica devem andar juntas e aparentemente Lefèbvre não se satisfaz apenas com a análise dos aparelhos ideológicos do estado. Ele também remete a outras críticas, como a questão do indivíduo e a sobredeterminação econômica.

Gregory (1978, p. 105), no mesmo ano da crítica de Thompson, utiliza a ideia de Lefèbvre para considerar que a estrutura espacial organiza-se em função de um determinado modo de apropriações materiais que secundariamente, através de "descolamentos históricos específicos", consegue simbolizá-los. Assim, apropriação e dimensão simbólica manifestam-se concomitantemente no espaço. Em função da reflexão de Gregory, Dear (2001, p. 14) afirma que o ano de 1978 foi, na geografia, uma espécie de ápice das discussões teóricas e filosóficas na geografia norteamericana.

Para além dessas contribuições, se consolidam trabalhos sobre 0 subdesenvolvimento, imperialismo, evolução cultural e desigualdade social, sem que haja perda dos antigos temas da habitação, pobreza, economia política da cidade e ação do Estado (PEET, 1982, p. 245).

Contudo, contraditoriamente "a renovação de assinaturas para Antipode, pelos geógrafos norte-americanos, diminuiu quando artigos marxistas começaram a aparecer regularmente" (PEET, 1982, p. 248). Se no início da década de 1970 existiu uma desaceleração que estava associada a um processo de disciplinamento, no final da década a relação entre marxismo e geografia deixa de ser a grande novidade e começa a se adequar à rotina no trabalho científico.

Não é por acaso que Jacoby critica David Harvey, por ser um autor hermético para os que não são iniciados academicamente ou não conhecem o debate do urbanismo. Harvey não seria um intelectual público, mas um especialista sério que pratica a autocitação e não oferece à sociedade um debate amplo. Os especialistas e acadêmicos substituem os intelectuais independentes, os boêmios vanguardistas e o que se impõe é a hierarquia universitária cautelosa, zeladora da "ciência normal" e 
pobremente inventiva (JACOBY, 1987, p. 68-85). Certamente a desaceleração da geografia crítica relaciona-se com esse fenômeno.

No contexto francês:

\begin{abstract}
A inspiração marxista não desaparece, mas é bastante discreta nos anos que seguem 1970. Ela se afirma mais após 1975, mas sem que as contribuições do marxismo sejam muito ricas, e sem que os geógrafos franceses se mostrem muito sensíveis à fraqueza do marxismo no domínio espacial (CLAVAL, 2011, p.283).
\end{abstract}

Para Claval, os geógrafos franceses se acomodaram nas contribuições dos sociólogos sem observar as contribuições dos pós-estruturalistas inicialmente, afirmação curiosa para quem nesse período revisou o marxismo como veremos abaixo.

Em 1977, ano de publicação do célebre artigo de Peet que faz um balanço do desenvolvimento da geografia radical, Tricart $\left(1980\right.$, p. 97) ${ }^{233}$ também faz uma avaliação através do texto $O$ campo da dialética em geografia, elaborado como resposta ao corte de verbas para trabalho de campo no Instituto Louis Pasteur. Uma das ideias centrais do artigo é a defesa do trabalho de campo associado a uma concepção dialética de ciência. Durante sua trajetória, Tricart não perde de vista, os pressupostos do materialismo dialético operacionalizados para geografia física:

(...) para nós não existem métodos próprios da geografia, mas métodos de aplicação mais gerais cujo uso pela geografia só é um caso entre outros. Esses métodos do conhecimento associam-se a conceitos que se inserem numa taxonomia onde os níveis mais altos estão reservados a um amplo grupo de disciplinas, e só os níveis inferiores, subordinados, são específicos de uma disciplina ou de um ramo de disciplinas. Para nós, uma disciplina define-se por seu objeto, que é um elemento do conhecimento (TRICART, 1980, p. 98).

Apesar de uma solução muito semelhante à "conjunção de métodos", vemos que Tricart tem uma posição interdisciplinar argumentando que a geografia é uma ciência de síntese que recorre a níveis de fenômenos abrangentes e estudados por vários campos. Sua óptica sintética apoia-se na teoria geral dos sistemas, que para Tricart (1980, p. 98) engloba e incrementa a dialética da natureza, não se restringindo a um fenômeno específico. Seguidamente a isso, Tricart faz uma série de reflexões que remontam à prática da geomorfologia e discute modelos físicos de terreno. Ele tenta estabelecer uma analogia entre modelos matemáticos e físicos em

${ }^{233}$ Aqui temos o mesmo caso de outros textos que foram republicados em português da coleção da AGB em 1980. 
que a dialética permitiria passar do modelo quantitativo ao qualitativo (TRICART, 1980, p. 100 e 107). Vemos então uma visão sistêmica que incorpora relações dialéticas no seu interior.

Ao assumir essa postura da teoria dos sistemas e da dialética da natureza, Tricart coloca-se em oposição a um outro geógrafo crítico importante, Yves Lacoste:

É evidente que a posição da geografia no tríplice ponto de encontro das ciências do homem, da vida e da matéria (Y. Lacoste), de acordo com nossa tese, dificulta a explanação dessa tese, fazendo surgir o perigo de generalizações inadequadas. Portanto, vamos nos limitar inicialmente a certos aspectos do estudo do meio natural (TRICART, 1980, p. 99).

No entanto, os dois autores concordam em alguns pontos. Principalmente na denúncia dos erros cometidos pela geografia da escola vidaliana:

\begin{abstract}
Lacoste estava com razão ao sublinhar o caráter pouco claro da noção de região e as petições de princípio vidalianas nesse sentido. Essas petições de princípio são contemporâneas das de W. M. Davis e se inserem no mesmo contexto filosófico e político. Tal convergência não é obra do acaso: seu estudo devia atrair aos historiadores da ciência (TRICART, 1980, p. 114).
\end{abstract}

De uma forma um tanto injusta, ao nosso ver, Capel (1988, p. 442) define o marxismo de Tricart como positivista, o que não considera sua a ampla formação marxista e seus diversos esforços para inserir a dialética da natureza na geografia. Capel não deixa claro quais são os traços positivistas dentro do marxismo de Tricart, já que suas elaborações surgem muito antes da influência althusseriana.

Também em 1977, Dresch escreve um texto posicionando-se acerca da crise da geografia e reafirmando seus pontos de vista do passado. A geografia estaria em crise, pois teria perdido seu caráter de síntese, ou seja, ela se especializa e estimula a separação entre geografia física e humana. Os geógrafos não saberiam manejar o conjunto de sua disciplina devido à profunda especialização.

A geografia regional, que faria a junção entre geografia humana e física, estaria relegada ao esquecimento e à estigmatização (DRESCH, 1977, p. 19-20). Apesar de apresentar limitações, ela seria o ponto de encontro das leis da natureza e do homem, uma vez que estudar somente a dinâmica social ou dos modos de produção isolados, empobreceria a geografia, que tem um escopo mais amplo (DRESCH, 1977, p. 22). A posição de Dresch (1977, p. 24) é clara: "A dualidade do objeto corresponde a uma dualidade do método. Essa dualidade contraditória é precisamente a particularidade específica da geografia". A geografia humana seria 
estudada e entendia através do materialismo histórico, e a geografia física seria estudada através do materialismo dialético. Os dois campos de estudo apresentariam leis e dialéticas diferentes (DRESCH, 1977, p. 24).

Scheibling adota essa mesma posição, entretanto adverte que a geografia não pode se definir "negativamente pela ausência de análise espacial das outras ciências" (SCHEIBLING, 1977, p. 52). Ele vê os mesmos riscos dos diversos ramos da geografia se especializarem demasiadamente e se tornarem autônomos, mas discorda de Dresch no sentido em que a geografia não pode ser uma ciência natural e social ao mesmo tempo, porque devemos escolher uma das duas dialéticas. Ele define: "A geografia é o estudo das formas e das estruturas espaciais produzidas historicamente e específicas de cada modo de produção" (SCHEIBLING, 1977, p. $56)$.

Veremos agora um debate que se arrasta na revista L'Espace Geographique e reflete a dificuldade do debate interdisciplinar e de acomodação das categorias da geografia nos aportes marxistas. Uma série de eventos pouco discutidos, mas que demonstra a trajetória do marxismo no campo disciplinar.

\subsection{A controvérsia Claval}

A partir de 1977, temos uma série de artigos que representam um debate importante acerca da relação entre geografia e marxismo. O debate da geografia francesa acontece dentro da revista L'Espace Geographique e se estende até o início da década de 1980, e Paul Claval é uma figura chave na disputa.

Ele publica um primeiro texto sobre espaço e marxismo, enfatizando que esta relação é antiga e influenciou o estudo do subdesenvolvimento e o debate sobre o modo de produção asiático. Comparando a geografia soviética e a francesa, para Claval, N. Kolosovsky, J. Aleksandrov e N. Baransky ${ }^{234}$ formulam estudos frustrantes sobre complexos territoriais das forças produtivas, porque considera-se a dinâmica espacial da divisão territorial do trabalho sem analisar as lógicas externas, as ligações entre os locais e os fatores sociais de localização (CLAVAL, 1977, p. 146).

Para Claval, o marxismo tenta fazer um corte epistemológico nos moldes de Bachelard, a partir da crítica da ciência burguesa, o que provocaria em certa medida uma tabula rasa da geografia que existia anteriormente. Evoca ainda a interpretação

234 Lembrando que Baransky, Anuchin e Sauskhin são os defensores do determinismo ambiental (MATLEY, 1966, p. 97). 
de Althusser de que Marx teria descoberto o continente da história através dos conceitos d'O Capital, abrindo uma nova perspectiva para as ciências humanas. Ressalta a geografia de Marx através de suas fontes documentais, análises de países e culturas estrangeiras (CLAVAL, 1977, p. 147-148). No entanto:

\begin{abstract}
Para alguns, o corte epistemológico fundamental já está feito e é aquele que Marx realizou no domínio da história, o que significa para as ciências sociais: basta aplicar os princípios de explicação que foram colocados em evidência nas sociedades reais para compreender todos os seus aspectos. Para outros, o corte epistemológico deve ser realizado em cada disciplina para prolongar a intuição marxiana: a geografia deverá ser fundada (CLAVAL, 1977, p. 147).
\end{abstract}

Nas ciências humanas, o corte já teria ocorrido pela descoberta do continente história. Apesar de Claval ter uma leitura claramente althusseriana, essa aparente dúvida só serve para reafirmar que a principal mudança ocorreu com a nova geografia.

Entretanto, ele defende que uma das principais colaborações entre marxismo e geografia é a inserção da economia política, que engloba a diversificação do trabalho e a formação das classes sociais de maneira truncada com a composição do quadro natural, resultando na divisão territorial do trabalho que se articula com outras escalas dentro de um modo de produção capitalista (CLAVAL, 1977, p. 148). Compreender a transição feudalismo-capitalismo exige compreender as novas configurações da divisão do trabalho que envolvem a afirmação da burguesia enquanto classe dominante e a cidade como centro econômico do espaço.

Além disso, nos Grundrisse, Marx estuda a circulação do capital e a esfera da distribuição, que no capitalismo resulta no processo de concentração de capitais e no modo de produção asiático, e revela os aspectos internacionais da concorrência demonstrando a importância das relações metrópole-colônia (CLAVAL, 1977, p. 149). Finalmente, nos Grundrisse encontramos as mais refinadas reflexões sobre a relação entre campo e cidade, segundo Lefèbvre, citado por Claval (1977, p. 149)

A interpretação geral de Claval é de que dos manuscritos de 1844 (Manuscritos histórico-filosóficos) até O Capital, Marx esboça uma teoria geográfica: "ela dá conta dos transtornos da ocupação do espaço pela sucessão de modos de produção, ela mesma ligada à dialética das forças produtivas e as relações sociais de produção" (CLAVAL, 1977, p.149) ${ }^{235}$. No caso capitalista, o desenvolvimento causa a cisão entre cidade e campo, e no urbano encontramos o motor da história,

235 Tradução nossa. 
resultando na criação do centro e da periferia, o que projeta as tensões de classe em várias escalas e as dimensões geográficas como os conflitos entre nações ou entre os antigos feudos e a burguesia urbana nascente (CLAVAL, 1977, p. 149).

No caso do 18 do Brumário, o estudo da formação da consciência de classe ganha importância na geografia social (CLAVAL, 1977, p. 149). Finalmente, n'O Capital existe "a elaboração científica que elimina o espaço do marxismo" na opinião de Claval (1977, p. 150), porque este livro dedica-se ao estudo sistemático do capitalismo como modo de produção através de uma concepção renovada de homem social. Dentro dessa análise, o enlace maior recai sobre a teoria do valor que "conduz a mostrar, sob as aparências nas quais a maior parte dos pesquisadores ficam estagnados, uma realidade profunda, a das relações de classe" (CLAVAL,1977, p. 152). A insistência na teoria do valor resulta em uma paralisação e abstração exacerbada da geografia, e Claval refere-se ao artigo de Milton Santos sobre formações socioespaciais como uma saída para falta de concretude em função da teoria do valor ${ }^{236}$. Ainda sobre o assunto:

\footnotetext{
Marx oculta a série de processos que se desenrolam no espaço e no tempo; ele faz desaparecer a dimensão espacial. O nascimento da economia de relação implica em colocar na ordem do dia uma linguagem universal - a da forma-moeda, cuja lógica Marx sublinha - mas ela não pode se conceber fora do quadro espacial que a torna vantajosa e difícil (CLAVAL, 1977, p. 155).
}

A insistência em esquemas abstratos afasta a geografia de sua tradição e a liga ao marxismo ortodoxo, ocultando a realidade histórica e geográfica. Talvez a interpretação de Claval seja um pouco exagerada, focando muito na primeira parte do livro I d'O Capital.

Para Garnier (1993, p. 100), Claval não percebe que a mais-valia não é abstrata, mas uma concepção que remete à história e à política. A concepção de mais-valia como uma entidade metafísica vem do economista keynesiano Joan Robinson, e serve como subsídio para Claval no objetivo de demonstrar que o verdadeiro conhecimento científico esvazia-se através do marxismo, prendendo-se à ideologia e às abstrações que se aproximam de modo descuidado e a todo custo da exploração social.

\footnotetext{
236 Trata-se de Santos (1977) com certeza um dos textos mais complexos acerca das apropriações das teorias althusserianas.
} 
Apesar da simpatia ao marxismo, sabemos que no futuro ele vai desprezá-lo em prol da geografia humanística, valorizando o etnográfico e antropológico. Entretanto, faz questão de reafirmar ou inventar as tendências totalitárias de Marx, uma vez que não haveria verdade fora do esquema filosófico pensado, pois toda consciência seria alienada e imersa na ideologia. $O$ indivíduo não seria mais o parâmetro do bem e do belo (CLAVAL, 1977, p. 155). O resultado inevitável desse processo é o centralismo democrático e o poder partidário que controla as ideias e é fiel à ortodoxia. Suas críticas futuras seguem o mesmo fatalismo.

Na continuação de sua análise, Claval defende que a união entre geografia e marxismo valoriza pouco a relação entre o homem e o meio ambiente frente ao foco nos aspectos sociais e econômicos (CLAVAL, 1977, p. 157). A geografia crítica significa uma ascensão da ideia de espaço produzido como já debatemos, porém a recepção de tal debate significa uma perda de referência sobre onde se inicia o processo de produção, pois o espaço é visto estritamente como uma mercadoria entretanto, ele não explora muito o papel do trabalho morto. O espaço produzido nas grandes cidades representa para Claval as forças monopolistas funcionando como choque entre interesses públicos e privados sob o intermédio do Estado (CLAVAL, 1977, p. 158).

Claval ressalta ainda o tema do imperialismo surgido a partir de Lênin e Rosa Luxemburgo - e acrescentaríamos Bukharin - que em 1955 e 1960 formaram a base para a continuação do debate sobre desenvolvimento desigual. Claval enfatiza as ideias de André G. Frank:

Para A. G. Frank o foco coloca-se sobre a tendência da superprodução inerente ao sistema capitalista: aqui não se pode defender contra a crise de exportação de bens e capitais. A gênese do subdesenvolvimento está então ligada à circulação da mais-valia. Para os autores como Laclau, a ênfase é sobretudo colocado sob a pesquisa direta de uma mais-valia elevada pela superexploração dos recursos naturais e humano do terceiro mundo (CLAVAL, 1977, p. 159).

Após essas digressões sobre o pensamento marxista, Claval tenta fazer uma síntese dos principais debates, destacando Harvey e Bunge, que buscam esquemas para a divisão do trabalho e as causas da desigualdade e Blaut e Harvey, que analisam os Grundrisse procurando uma teoria espacial mais sistemática da circulação e acumulação de capitais. Claval ressalta o grupo de estudos sobre guetos, movimentos sociais e favelas do terceiro mundo, e finalmente indica Lacoste com os usos estratégicos do espaço, na guerra e no controle social, e - um pouco 
distante do recorte lacostiano - na crítica ao planejamento (CLAVAL, 1977, p. 160-162). No tocante a esse último ponto, a geografia ativa de George representa uma crítica, mas também uma justificação:

\begin{abstract}
Existiam algumas reservas dentre certos marxistas: na França a atitude crítica de Pierre George [1961] na visão da geografia aplicada encontra sua justificação: ele duvida se a geografia se compromete, sob o pretexto do planejamento, com as tarefas duvidosamente realizadas para o interesse do privado ou do Estado monopolista. Ele demandava aos geógrafos para ficarem atentos: esse é o sentido de sua geografia ativa (CLAVAL, 1977, p. 162).
\end{abstract}

Ao finalizar todo seu balanço, Claval argumenta que a crítica é somente uma das fases da pesquisa que deve ser seguida pela busca da prática social, entretanto, critica a hagiografia de Che Guevara, na época, muito valorizada no pensamento francês como modelo revolucionário. Sua conclusão geral conduz à ideia de que a geografia crítica não poderia reestruturar o campo disciplinar, pois o marxismo não inclui o espaço em suas análises (CLAVAL, 1977, p. 163-164). Apesar de reconhecer as inovações e ainda dialogar com um ponto de vista althusseriano, sua ideia principal é que o corte epistemológico teria sido feito pela nova geografia. Contraditoriamente, isso não descarta a perspectiva de admitir um corte epistemológico com a descoberta do continente da história nos moldes de althusserianos, porém Claval não resolve essa situação dúbia.

Como demonstra Pailhé (2003, p. 55-56), o artigo causou um grande malestar na comunidade, principalmente porque sua proposta de geografia social usava o marxismo muito limitadamente, e porque na França os marxistas de fora da geografia aplicavam o espaço com facilidade às suas análises. Aliás, a proposta de utilizar classe para fazer uma geografia social não era nenhuma novidade na França, tendo em vista os trabalhos dos geógrafos do pós-guerra. A visão pouco dialética de Claval acerca da geografia social e do marxismo, reduzido a um maniqueísmo ingênuo, não é combatida com base na tradição do pós-guerra, segundo Pailhé (2003, p. 57), devido à fraca formação radical dos geógrafos e a valorização exacerbada do ativismo militante.

A resposta ao texto de Claval vem no mesmo número e ano da revista L'Espace Geographique, e quem a organiza é um coletivo de pesquisadores sediados em Bordeaux que não tem seus nomes identificados. A primeira crítica apresentada é um argumento grave: o coletivo acusa Claval de não ter lido todos os 
textos e artigos citados e diz que fará um esforço para demonstrar como espaço e tempo estão integrados no sistema de Marx (COLLECTIF, 1977, p. 165-166).

Em contrapartida, o coletivo esforça-se para demonstrar que a teoria do valor, que Claval estigmatiza, é o ponto de partida para a luta de classes. A forma valor (forma mercadoria) concederia concretude ao conceito abstrato de valor, que apesar de não ser o equivalente universal, remete à existência de mercadorias em geral (COLLECTIF, 1977, p. 166). Para o coletivo, a tendência de Claval é tentar desarmar o marxismo de seu potencial revolucionário, esquecendo das contradições internas do modo de produção capitalista, como a tendência da queda da taxa de lucros.

O coletivo ainda rememora que a concepção da geografia como ciência que estuda o espaço não é universalmente aceita (COLLECTIF, 1977, p. 168). Contudo, para a teoria marxista existiria um consenso de que o tempo e o espaço estão integrados na dinâmica da sociedade e compõem os vários fatores determinantes do preço de produção e de mercado.

Outra questão pouco tratada por Claval é a renda fundiária, presente no tomo 3 do livro III d'O Capital. Para destacar as limitações da argumentação, os autores indicam a necessidade de ir mais profundamente na obra de Lefèbvre e nas relações entre cidade e campo, porque cabe mencionar a questão do déficit habitacional e a relação entre monopólios e a promoção imobiliária (COLLECTIF, 1977, p. 171-172). Remetem ainda ao direto à cidade e seu papel segregador que reforça a miséria social do hábitat e a exploração social.

Existe a cobrança de outras indicações sobre a dinâmica centro-periferia como a obra de Samir Amin, e, contrariamente à valorização da temática ambiental, o coletivo reafirma uma postura contra a geografia física (COLLECTIF, 1977, p. 171-173). Os autores veem no pensamento de Claval uma ideologia do Estado de bem-estar social polarizada através de sua visão dogmática e stalinista do marxismo.

Finalmente, o coletivo ressalta o tabu acerca da relação entre geografia e marxismo, pois apesar de Claval ter reverenciado Dresch e George no seu artigo, não falou das censuras de caráter político e ideológico que eles sofreram, nem das figuras esquecidas, como J. Poncet ou Suret-Canale. Destacam, mais atualmente, os cortes de projetos de pesquisa ou as censuras em 1975 e 1976 à revista Espace Temps, e concluem "o marxismo não é nem dogma, nem um livro de receitas, e menos ainda um menu à la carte" (CLAVAL, 1977, p. 175). 
Dois anos depois, Beuningen (1979, p. 263) também escreve um texto em resposta a Claval, frisando sua interpretação eminentemente althusseriana e essencialista do marxismo. Beuningen admite que o espaço tenha realmente sido excluído do sistema de conceitos do marxismo, porém cabe construir uma possibilidade que o englobe novamente ou ainda encará-lo como espaço produzido. Beuningen (1979, p. 265) argumenta que Claval encara a geografia e a teoria marxista por um viés possibilista e volta-se sobre a visão epistemológica tradicional, separando espaço natural e espaço produzido, o que seria uma artificialidade.

O espaço não é uma variável independente da sociedade, porém ele é construído e recebe uma valorização social que está ligada à formação socioespacial (cita e usa o conceito de Milton Santos). O espaço concebido deve ser visto historicamente confluindo com as formas de gestão anteriores (BEUNINGEN, 1979, p. 264-265). Ao modo de Althusser, ele se preocupa com os modos de produção e as formações espaciais como momentos históricos específicos.

Em sua análise, Beuningen associa o pensamento de Claval ao espacialismo, pois ele "entende a pretensão de poder explicar a configuração espacial, permanecendo no nível 'espacial'. Assim, se postula tipicamente, a existência de fatos espaciais, processos, estruturas, relações espaciais que constituem o objeto da geografia", como ocorria com Schaefer e a nova geografia (BEUNINGUEN, 1979, p. 268).

Contudo, Beuninguen admite que o althusserianismo criou um conhecimento dogmático, uma vez que ele é autorreferente, porque a visão científica de Althusser referencia-se fora da ideologia, e, portanto, constitui e avalia a si mesmo. Claval, esquece que Althussser é somente um intérprete de Marx e a "significação e o alcance da crítica clavaliana foca a atenção sobre as consequências necessárias da interpretação althusseriana no nível epistemológico, a saber um dogmatismo racionalista. Mas Claval o faz insconscientemente" (BEUNINGUEN, 1979, p. 270).

Em sua opinião, Marx teria uma postura realista frente ao conhecimento resultado da crítica ao racionalismo de Hegel e o empirismo da economia política inglesa. Entretanto, o próprio Beuninguen identifica-se com o estruturalismo e acredita que os avanços da relação entre geografia e marxismo podem desenvolverse a partir da noção de estrutura em detrimento do espacialismo formal.

Em mais um texto da controvérsia, Claval utiliza-se do termo neomarxismo para referir-se ao pensamento geográfico surgido dos radicais anglo-saxões ligados a David Harvey que repensaram o estruturalismo. Dessa forma, ele monta uma lista 
de pensadores dos anos 1960/1970 que tiveram grande influência nos estudos urbanos: Lefèbvre, Castells, Lojkine, Lipietz e Préteceille (CLAVAL, 1987a, p. 161).

Estranhamente, Claval rebate à crítica de Harvey de que poucos marxistas falaram sobre o espaço, ao indicar as análises entre centro e periferia realizadas pelo próprio Marx, por Lênin e Rosa Luxembrugo, apesar de haver falta de rigor científico em sua opinião. Harvey, para Claval, preocupa-se muito em completar as noções expostas n'O Capital e em outras obras que apresentam elementos implícitos e abstratos (CLAVAL, 1987a, p. 162).

Além disso, acusa Harvey, Storper e Scott de fugirem da realidade concreta rumo a uma dimensão histórica particularizante, e indaga se a incorporação da crítica de Giddens (analisado abaixo) acerca do estruturalismo não cria uma nova dualidade metodológica: de um lado o controle das forças materiais e de outro os agentes sociais de ação e controle (CLAVAL, 1987a, p. 163). Mesmo com essa crítica, existe uma conciliação entre o peso das estruturas e a iniciativa humana ou, em sua opinião, uma harmonia entre o pensamento de Thompson e Althusser. Entretanto, Claval novamente defende que o marxismo é uma doutrina dogmática.

Claval demonstra que Harvey e outros marxistas franceses se esforçam para compreender as vicissitudes do capitalismo frente à globalização, mas deixa claro sua preferência pela renovação da geografia crítica norte-americana, que se pautou nos modelos de Hägerstrand e da escola de Lund - ou seja, através de Giddens recuperou-se parte da tradição da nova geografia que o encantava no passado. Cita os trabalhos de Allan Pred, Robert Sack e Denis Cosgrove, que possuem esse viés histórico e reforçam a ligação entre estrutura e iniciativa humana.

Sete anos depois, Lung publica mais uma resposta a Claval no que diz respeito ao neomarxismo, elencando as obras de Perrons, Massey, Scott e Storper como marxismo escolástico se comparadas aos avanços teóricos dos althusserianos, apesar das novidades que seus estudos apresentam. Em sua visão, falta teorização sobre as transformações do capitalismo atual e seu jogo de forças, ou seja, quais são os fatores revolucionários e restauradores de sua dinâmica (LUNG, 1988, p. 48).

Lung também demonstra que enquanto os anos de 1960 foram plenos de trabalhos com enfoque sociológico, devido a Castells e Lojkine, o regulacionaismo redireciona novamente a ênfase para os estudos econômicos através, por exemplo, do conceito de acumulação intensiva-extensiva e dos modos de regulação concorrencial e monopolista. No entanto, eles têm dificuldades ao tentarem 
compreender o debate regional, pois se concentram na planificação descentralizada e não percebem a dimensão política, cultural e social da região (LUNG, 1988, p. 48). Para Lung, o legado de Perroux cria uma dualidade entre espaço abstrato e o espaço geoeconômico (géonomique), que reverbera no pensamento de Claval:

\begin{abstract}
A contradição entre os dois aspectos do espaço é mais comumente 'resolvido' pela dualidade entre duas formas de leitura: uma teórica, permitindo anunciar os mecanismos espaciais que se deduzem do funcionamento do modo de produção capitalista; e outra, empírica, relativa às lições extraídas da confrontação entre modelos e a realidade mais complexa. Haveria aí uma simplificação pela abstração, e uma complicação no terreno da aproximação concreta (LUNG, 1988, p. 49).
\end{abstract}

Essa simplificação/complicação também afeta os regulacionistas, e no final de sua argumentação Lung (1988, p. 49-50) propõe a combinação da dinâmica espacial e dinâmica territorial: na esfera do espaço global encontramos o desenvolvimento desigual, a divisão espacial do trabalho e os novos desenvolvimentos técnicos, enquanto o território evidencia a estrutura econômica local, com sua morfogênese e seus processos de estruturação local. Esses dois níveis possuem temporalidades distintas e estão inseridas em um quadro historicamente dado.

Garnier (1993, p. 102-104) também rebate as críticas de Claval, colocando que o espaço remete à organização concreta das relações sociais dentro de uma distribuição do sistema produtivo congruente com o modo de produção. Complementa ainda dizendo que "os fatos não são 'esquemas abstratos' impostos por um marxismo arbitrário que ordena os fatos no espaço e no tempo, mas as leis reais são simplesmente modos de tornar inteligível por meio de conceitos" (GARNIER, 1993, p. 100)237.

Muitos anos depois, Claval (2007, p. 48), baseado em Lefèbvre, acaba por admitir que o concreto pensado permite espacializar os objetos geográficos revertendo a tendência do pensamento marxiano das abstrações gerais. Mesmo com essa possibilidade de reconciliação, continua sua convicção de que o marxismo é extremamente ideológico, com o complemento de que ele desconsidera os indivíduos na história (CLAVAL, 2007, p. 49). Anos mais tarde, com a "derrota" do marxismo, Claval dirá confortavelmente:

É claro que o engajamento nessa geografia cultural era uma maneira de se destacar da leitura marxista que dominava então nas ciências sociais. Os

237 Tradução nossa. 
A controvérsia entre Claval e seus colegas franceses mostra que se acompanhava o que estava sendo debatido pelos anglo-saxões e ao mesmo tempo que o althusserianismo estava perdendo espaço para os regulacionistas e para as inovações de Giddens. Entretanto, conseguimos perceber que a geografia francesa e a norte-americana estavam discutindo temas mais ou menos semelhantes. A natureza e as referências do debate mostram como a França perdia seu liderança intelectual mundial no campo geográfico. Veremos adiante que esse processo desembocará na ascensão do pensamento pós-moderno.

\subsection{A crise do pensamento marxista no início da década de 1980}

A década de 1980 conhece refluxos revolucionários significativos. Dosse (2007a, p. 331-332) acrescenta que na França pós-1968 existe um abandono do maoísmo e do marxismo soviético em função da divulgação de materiais sobre a vida nos gulags e pela revelações da revolução de Pol-Pot no Cambodja. Lentamente os valores democráticos que estavam tipicamente associados aos ideais burgueses vão ganhando importância e vão se tornando mais resistentes às críticas, substituída por uma visão positiva a respeito da democracia representativa. Foucault, por exemplo, começa a defender os direitos humanos e organiza com apoio de Sartre protestos contra a violência cometida na União Soviética (DOSSE, 2007a, p. 416). Dosse complementa:

O intelectual orgânico já estava morto há muito tempo, é agora o intelectual hipercrítico que conhece uma crise de abatimento. Não surpreende que se tinha podido falar em seguida do 'silêncio dos intelectuais', acentuado ainda depois de 1981 (DOSSE, 1981, p. 332).

Como ressaltamos acima, em 1975 o clima institucional se fecha para os pensadores inspirados em Althusser, e em 1980, após o assassinato de sua mulher, o seu pensamento submerge no isolamento. O colapso psicológico estava ligado ao antimarxismo:

Pierre Macherey (...) imputou essas tragédias ao clima de violência antimarxista que se desencadeou no mundo intelectual parisiense com a 
Sintomaticamente, nos anos de 1980, Pierre George reescreve o seu livro Geógraphie sociale du monde sob o novo título de Sociétés en mutation. Na nova edição encontramos um completo abandono do marxismo e acusações explícitas à União Soviética:

\begin{abstract}
'Desde cerca de 60 anos atrás, a ideologia socialista é invocada como justificação da reestruturação autoritária da Rússia' e algumas linhas adiante 'Após a segunda guerra mundial, o 'modelo soviético' foi transferido tal qual era nos países ocupados pelo Exército vermelho e posto a frente mesmo na Tchecoslováquia' (GEORGE apud PAILHÉ, 1981, p. 21-22).
\end{abstract}

Agora somente três páginas do livro são dedicadas ao socialismo (CLOUT, 2010, p. 43). Como George (1990, p. 103) coloca em sua autobiografia, no final de sua carreira aumenta a aproximação com Braudel para compreender os processos regionais de longa e curta duração, buscando uma ferramenta de negociação para a ação planificadora. A volta ao estruturalismo braudeliano continua uma alternativa para seu abandono do marxismo.

Após maio de 1968 inicia-se um processo gradual de transferência do centro gravitacional do marxismo da França para os Estados Unidos, afastando-o cada vez mais do debate e da realidade política (THERBORN, 1991, p. 402). Nos Estados Unidos, o governo Eisenhower mantém a esquerda acomodada na máquina acadêmica estatal, e a velha guarda depara-se com uma situação sem desafios onde predomina o ethos da guerra fria e do anticomunismo (JACOBY, 1987, p. 89). Assim:

A nova esquerda que permaneceu na universidade revelou-se trabalhadora e bem comportada. Numa transição quase sempre indolor, eles passaram da condição de estudantes aos postos iniciais na carreira docente, e, em seguida, às nomeações estáveis (...) adapte-se, use o tempo determinado para obter as credenciais acadêmicas; oculte-se na corrente dominante (JACOBY, 1987, p. 148).

O ácido comentário de Jacoby quer demonstrar os efeitos da revolução silenciosa da institucionalização. A longo prazo os subvertores adotam a lógica dos subvertidos. O problema fundamental em sua concepção é que a eficiência acadêmica substitui a intencionalidade e o projeto da militância. Obviamente, não seria bom abrir mão do ganho institucional, contudo: 
A trajetória é típica e seria irresponsável desafiar as realidade inevitáveis ou negar o que foi conquistado. O florescimento dos estudos esquerdistas, o enfraquecimento do protesto político e a defesa dos bastiões universitários parecem uma evolução quase natural e inevitável que afetou radicais, marxistas e neomarxistas em todas disciplinas. Além disso, os ganhos parecem, senão irregováveis, sem precedentes. Pela primeira vez, as tradições marginais ou esquecidas da geografia, da sociologia, da história radicais e de outras disciplinas começaram a receber destaque onde podem ser examinadas e ensinadas, e onde podem atrair mais estudantes. A longo prazo, isso pode se mostrar decisivo. Mas um assunto desagradável deve ser ventilado: os intelectuais de esquerda sucumbiram aos imperativos que os agruparam nas universidades, mas eles não são vítimas inocentes. Os intelectuais de esquerda não aceitaram ingenuamente ou de má vontade o regime acadêmico; eles próprios adotaram a universidade. A crítica da academização por uma esquerda universitária é curiosamente débil mais do que a crítica conservadora (JACOBY, 1987, p. 194-195).

Na década de 1980 a institucionalização possui uma trajetória mais antiga, ela proporciona uma teoria espacializada no funcionamento das sociedades capitalistas, além da estruturação de uma metodologia marxista que permitiu uma melhor compreensão dos processos sociais (JOHNTSON, 1997, p. 209). Entretanto:

\begin{abstract}
Na década de 1980 ela [geografia radical] se tornou 'mais calma e menos combativa' (...) assim como marxismo foi sujeitado ao criticismo, pois a recessão de 1980 levou às análises mais disciplinadas, a um maior conhecimento dos problemas das economias socialistas e foram feitos os prospectos das mudanças revolucionárias menos prováveis. Os geógrafos se tornaram mais direcionados à profissionalização, e muitos dos 'radicais jovens contraestablishment' juntaram-se ao establishment (JOHNSTON, 1997, p. 210).
\end{abstract}

Se, por um lado, alguns reconhecem a acomodação institucional, por outro, entre 1977 e 1986, três departamentos de geografia foram fechados nos Estados Unidos, na universidade de Michigan, Chicago e Columbia (SMITH, 2001, p. 9-10). Talvez esse processo tenha impulsionado os geógrafos a pensarem sua situação e a inovarem. Smith ainda esboça um quadro rico de transformações na geografia que não apenas colocou a cultura no centro da análise, mas ligou a disciplina com o pósestruturalismo:

Esse aprofundamento e alargamento depois da metade dos anos 1980 seguiu cinco caminhos identificáveis através dos muitos casos entrelaçados. Primeiro foi a exploração das questões culturais que representaram uma parte significativa dos trabalhos marxistas recentes, mas que tiveram sempre como plano secundário a economia política. Em harmonia com a ampla virada cultural nas humanidades e ciências sociais durante esse período, as fronteiras da pesquisa mudaram decididamente por uma nova geografia cultural. Segundo, relacionado à teoria pósmoderna importada da arquitetura e dos estudos culturais começaram a influenciar o tipo de teorias sociais que os geógrafos adquiriram para explicar as diferenças espaciais em várias escalas, enquanto a pesquisa geográfica, ela mesma, influenciou a linguagem espacializada da pós- 
modernidade (...). Terceiro, a pesquisa feminista, dentro e fora da geografia construiu um poderoso corpo de teoria que enfatizou a diferença dos gêneros. Quarto, a teoria multicultural envolvida fora dos movimentos de direito civis, anti-imperialismo e feminismo, da década de 1970 também permeou a pesquisa geográfica. Finalmente, o foco do marxismo nas estruturas do capitalismo aumentou pela teoria pós-estruturalista derivada principalmente da França. Juntas, todas essas influências inclinaram para um exame do 'local' desembocando em um intenso debate sobre as 'localidades' no final dos anos 1980 e no início dos 1990. Nesse período, a geografia, que foi uma das disciplinas mais fechadas e insulares nas duas décadas passadas, torna-se agora uma das mais abertas e heterogêneas. Essa realização da geografia seguiu os passos do radicalismo pós década de 1960 e foi encabeçado primeira e principalmente pela análise marxista (SMITH, 2001, p. 10).

No início da década de 80, Henri Lefèbvre engendra ideias novas:

A influência de Henri Lefèbvre foi fundamental para a constituição desta transformação na análise geográfica marxista. Ele distinguiu uma dimensão essencial da construção social da realidade, a produção do espaço, através de um novo modelo definido por uma análise fundada sobre a dinâmica própria à espacialidade (GOMES, 2005, p. 300).

Como demonstra Unwin (1987, p. 13), o espaço produzido atualmente está muito associado a Lefèbvre, e mesmo que Soja tente associar sua ideia a experiência pós-moderna, o objetivo primeiro de Lefèbvre é discutir a construção do espaço moderno.

Na passagem para os anos 1980, os marxistas são criticados duramente pelo economicismo e pelas abstrações teóricas que não seriam capazes de explicar as particularidades históricas e geográficas. A categoria de totalidade, com grande tradição no marxismo, é atacada nesse mesmo sentido (JOHNSTON, 1997, p. 251-252).

Eliot Hurst e Slater, na passagem da década de 1970 para 1980, após estudarem várias definições de geografia e considerarem o fetiche espacial, acabam por:

(...) argumentar que a geografia não pode ser incorporada com o marxismo, mas tem que transcender e ser substituída pelo marxismo (...) Ele[s] conclu[em] que a 'geografia é irrelevante para a sociedade contemporânea por dois motivos básicos' (JOHNSTON, 1997, p. 214).

Desdobram-se então dois motivos básicos: no primeiro, a geografia teria falhado em elaborar teorias capazes de superar o capitalismo e no segundo o marxismo não possui uma teoria do conhecimento com categorias espaciais 
fetichizadas e não-científicas (como, por exemplo, espaço, diferenciação espacial, etc.) (JOHNSTON, 1997, p. 214).

Nesse contexto inicia-se a era dos abandonos:

Nos anos 1980 a geografia tornou-se menos combativa por quatro razões: (a) o marxismo foi, por ele mesmo, tema de críticas poderosas; (b) na falta de Estados inspirados pelo socialismo as vitórias revolucionárias se tornam menos certas; (c) a disciplina se tornou mais profissional e aceita menos os radicalismos; e (d) boa quantidade dos radicais da década de 1960-1970 uniu-se ao 'establishment' disciplinar (JOHNSTON et al., 2008, p. $670-671)^{239}$.

E Peet ainda complementa:

Com a passagem da década de 1970 para 1980, o criticismo ao estruturalismo no mundo intelectual anglo-saxão envolve principalmente a eficácia da ação humana diante da necessidade estrutural. Na França, a crítica do estruturalismo se encaminhou em direção às noções do pósestruturalismo e do pós-moderno (PEET, 1998, p. 144).

Capel, em posição semelhante a Claval, diz que o problema do marxismo é a ausência de uma teoria do espaço, o que dificulta seu desenvolvimento dentro da geografia. A saída para o problema encontra-se na ideia de espaço como produto social, elaboração inspirada pela sociologia e pelo urbanismo marxista, o que supostamente vai ao encontro com as contribuições de Lefèbvre (CAPEL, 1988, p. 436-437).

Durante a década de 1980 (e 1990), David Harvey, por exemplo, continua a desenvolver os mesmos temas do passado: escreve ensaios sobre a urbanização, sobre o capitalismo, acerca dos problemas da geopolítica mundial e da relação entre sociedade e natureza. No início e em meados da década de 1990, Harvey volta ao tema da justiça social ao mesmo tempo em que se defende de seus críticos. "Além disso, ele avançou na questão do marxismo como uma aproximação holística que necessariamente coloca os problemas materiais no centro de sua análise" (JOHNSTON, 1997, p. 213). Curiosamente Claval coloca que em sua opinião, Harvey continua sendo um marxista ortodoxo e o associa aos regulacionistas, sendo que sua grande novidade é inserir a variável tecnológica nas análises (CLAVAL, 2011, p. 293-295).

Em 1982, sua obra The urbanization of capital demonstra historicamente como o modo de produção capitalista constitui o urbano e como a constituição da 
cidade é inerente ao desenvolvimento deste modo de produção (JOHNSTON, 1986, p.133).

Contudo, talvez devido à sua ligação com o regulacionismo e à análise do pensamento marxiano, Harvey não é um crítico feroz do estruturalismo. Ele acaba admitindo em 1982 que nos diferentes tempos e espaços, o local apresenta diferentes culturas e variações sociais - portanto, cede lentamente ao multiculturalismo pós-moderno (HOLTON-JENSEN, 2009, p. 157).

Ainda nesse momento de transição, gradualmente Castoriadis e Lefèbvre vão ocupando posições, inserindo elementos da reflexão pós-estrutralista e constituindose como sucessores de autores como Thompson e Raymond Williams, que criticaram o estruturalismo e tiveram desenvolvimentos originais (CLAVAL, 2011, p. 292). Pierre Bourdieu também ganhou destaque unindo o debate da estrutura estruturada e estruturalizante, ou seja, ao mesmo tempo em que ela estrutura os indivíduos também altera-se lentamente devido à ação das pessoas e das instituições, por exemplo.

Observaremos mais detalhadamente como o pós-modernismo relacionou-se com a geopolítica na França, para logo após seguir o itinerário das ideias que se propuseram como alternativas ao estruturalismo na geografia, para, por último, mostrar a adoção em larga escala do pós-estruturalismo em detrimento do marxismo.

\subsection{A teoria da estruturação e a volta ao regionalismo}

Na década de 1980, entra em cena o pensamento de Anthony Giddens na geografia, autor que defendeu a terceira via, nem capitalista e nem comunista, e viu na cidadania um substituto ao socialismo. Teórico do novo-trabalhismo, persiste em sua posição mesmo depois das dramáticas derrotas para o neoliberalismo (THERBORN, 2012, p. 138).

Giddens segue uma preocupação da teoria social em que o uso da escala da comunidade intensifica-se com a inserção dos debates sobre as atitudes dos indivíduos frente a localidade, pois a espacialidade constitui-se a partir dessa relação. Assim, o local e sua comunidade resultam na ideia de locale, que procura reconstituir a dialética socioespacial analisando a estrutura espacial como um meio de produção e de reprodução das relações sociais. O local refere-se apenas ao 
padrão geográfico das relações que se sobrepõem, manifestando as regras e os mecanismos da estrutura em transformação (HOLTON-JENSEN, 2009, p. 163).

Alguns geógrafos recusam a ideia de localidade (locale), pois pensam que ela não enfatizava a continuidade espacial e a vida cotidiana, o que provoca uma reorientação para o estudo de indivíduos sem essa abordagem local (JOHNSTON, 1997, p. 243). Apesar disso, as ideias de Giddens são muito influentes na geografia e sua teoria da estruturação busca integrar agentes humanos capazes de conhecer e a estrutura social em que se inserem (UNWIN, 1995, p. 300). Holton-Jensen (2009, p. 160-161) destaca alguns pontos centrais dessa concepção: (1) os agentes sociais não são passivos, conhecem apenas parcialmente os mecanismos sociais do quadro estrutural e na maioria das vezes tomam decisões racionais; (2) os agentes interpretam e transformam o mundo empírico e assim alteram as estruturas econômicas e ideológicas; e (3) as estruturas são dadas de geração em geração, mas as regras sociais são sempre reproduzidas sendo interpretadas e modificadas. Assim, as estruturas têm regras e recursos para ação que podem ser formais ou informais, conscientes ou inconscientes, baseados em recursos materiais ou em valores como, por exemplo, a autoridade.

A estrutura condiciona a ação ao mesmo tempo em que é resultado da atividade humana. A escala de análise adotada por Giddens é o cotidiano e aqui as considerações de Hägerstrand sobre os domínios espaço-temporais são fundamentais para instrumentalizar empiricamente sua teoria. A comunicação e o conhecimento têm um papel chave para as negociações da comunidade local. Os domínios permitem observar a ação dos atores e da comunidade empiricamente, analisando sua dinâmica e delimitando os recortes espaciais de sociabilidade.

A análise do conhecimento e das representações levam a uma dupla análise hermenêutica: "Em primeiro lugar, as ciências humanas devem levar em consideração [que] as representações das ações pelos atores estão imbuídas de um conhecimento pertinente", e, em segundo, que as ciências humanas são interpretativas (DOSSE, 2004, p. 194). A metalinguagem científica, que pauta e explica a ação dos atores é uma variável muito importante no seu esquema de ideias (JOHNSTON, 1986, p. 115).

Giddens faz questão de afirmar que sua teoria tem pouco a ver com o marxismo e a adoção do método hermenêutico reflete uma tentativa de desconstruir a sociedade e seus indivíduos (DOMINGUES et al., 1992, p. 1-2). Giddens não acredita em atores coletivos e define: 
No estruturalismo, o significado é uma relação entre itens dentro de um sistema semiológico ou de um código semiótico, de modo que ele é organizado internamente, como, por exemplo, no caso da linguagem ou outro sistema de comunicação. Isso está errado, pois a linguagem se desenvolve no contexto de seu uso, e prefiro muito mais uma teoria wittgensteiniana da linguagem (DOMINGUES et al., 1992, p. 4).

Essa tentativa de demarcação clara rechaça a teoria da linguagem de Sausurre, grande inspiradora do estruturalismo. A estrutura para Giddens, assim como a linguagem para Wittgenstein, só se realiza na prática social em uma situação dinâmica e permanente de renegociação dos usos.

Outro elemento que está presente em sua teoria como pano de fundo é a consolidação da modernidade, que segundo sua concepção institui-se a partir da expansão do capitalismo e da formação dos Estados-nação. Esse processo causa o desenraizamento social com as migrações e a perda cultural. A longo prazo, tal evento altera a constituição institucional da sociedade com a recomposição ou o desaparecimento de determinadas culturas (DOMINGUES et al., 1992, p. 6).

As ideias de Giddens, desenvolvidas a partir das elaborações Hägerstrand, foram utilizadas para o estudo da realocação e reestruturação industrial, visando saber qual é o impacto no local da instalação ou transferência das indústrias em determinadas comunidades (JOHNSTON, 1997, p. 238-239).

Derek Gregory esforçou-se para inserir as colaborações de Giddens na geografia ao analisar a escala dos indivíduos, tratando-os como atores sociais de determinados fenômenos (JOHNSTON, 1997, p. 260). Apesar de adotar a teoria, Gregory faz uma crítica acerca de como os significados sociais são concebidos e representados. Contudo, a teoria ajudaria a observar como os processos de longa duração articulam-se no espaço e influenciam as classes sociais (CHOUINARD, 1997, p. 368).

Através dos aspectos culturais da estrutura e da ação individual, como os discursos, Gregory desenvolve a ideia de imaginações geográficas que se relacionam com a noção de sociedade do espetáculo e com a dinâmica cultural do capitalismo em escala global (CHOUINARD, 1997, p. 370). O controle do discurso e da imaginação pode ser generalizada para escala global, bem como o controle mundial da produção e distribuição de conhecimento.

Nigel Thirft é outro geógrafo que adere ao modelo de Giddens e Hägerstrand. Na sua opinião, a região seria a base para a ação local, entretanto ela é limitada ao 
espaço vivido, ou seja, ao domínio espaço-temporal (PEET, 1998, p. 150). A região torna-se, portanto, uma ferramenta aplicada para o estudo da vida do indivíduo, seu cotidiano e suas ações.

Aluno de Allan Pred e influenciado por Hägerstrand, Nigel Thirft começa a explorar a relação entre as biografias e os aglomerados locais. Assim, ele tece uma teoria socioeconômica que se limita à vivência dos indivíduos, evidenciando as mudanças espaciais de acordo com as escalas temporais conjuntamente ao imbricado jogo de mudanças das regras culturais e legais. Cria-se então uma rede de indivíduos que empregam o tempo de uma maneira diferenciada, de acordo com suas necessidades físicas, sociais e psicológicas e também para comunidade como um todo preocupando-se com as necessidades comuns.

O conceito de projeto existencial-fenomenológico é detectado no local através das ideias comuns e das possibilidades de mudanças sociais que remetem à inserção de novas concepção, causando a transformação da mentalidade dos habitantes (PEET, 1998, p. 150-153). Com vemos, Thrift percorre um longo caminho para explicar a disputa entre tradição e modernização nas comunidades. HoltonJensen (2009, p. 163) destaca que a teoria da regulação recebe críticas pela falta de estudos empíricos que realmente a comprovem.

Além desse trabalho, em 1983 Thrift (2002, p. 107-110) lança um manifesto ressaltando o caráter dual entre estrutura e ação humana. Mais uma vez ele defende a teoria da estruturação de Giddens e diz que a discussão agora concentra-se no determinismo ou na vontade livre para o desenvolvimento. A teoria social como um todo varia entre dois espectros: no determinismo capitalista ou no voluntarismo do capitalista individual. Se a primeira resposta dada por Thompson para a emancipação do determinismo foi um humanismo que colocava o homem no centro da análise, a segunda resposta possível seria focar a unicidade dos lugares (THRIFT, 2002, p. 110). A teoria de Giddens, fundamentada nas instituições sociais, valoriza a individualização frente às estruturas, resultando em situações únicas.

A retomada da obra de Hägerstrand não foi feita apenas por Giddens. Blaut também recupera o modelo de difusão tecnólogica criticando-o e posteriormente redirecionando seu trabalho para além de uma geografia cultural tradicional. A meta agora é a desconstrução da história eurocêntrica. O conjunto difusão cultural, colonização, eurocentrismo e nacionalismo foi essencial para o desenvolvimento de seus trabalhos em uma perspectiva pós-estruturalista e ligada aos estudos culturais (MATHEWSON, 2008, p. 121). 
A abordagem regional também renova-se na geografia econômica através de estudos locais realizados na década de 1980 por Scott, Storper e Christophesson. Partindo do legado marxista, os geógrafos vão gradualmente abandonando a teoria geral e estudam a região do Veneto, Paris e finalmente a Califórnia. Inspirados por Marshall, os distritos industriais e as economias externas tornam-se elementos de análise empírica para compreender o funcionamento regional (BENKO e SCOTT, 2004, p. 61-62).

Se a teoria de Giddens reforça a escala local/regional, paralelamente nos Estados Unidos e na Inglaterra recupera-se a escola dos Anais e a tradicional geografia regional francesa após críticas à superteorização da geografia radical. Entretanto, o argumento de defesa da geografia radical é o reconhecimento de "que os processos regionais dependem mais da dialética do que de teorias naturalistas; e na importância da ação humana na criação, recriação e transformação das regiões" (JOHNSTON, 1997, p. 250). Novamente, a renovação da geografia regional tem um viés prático e pretende-se útil para sociedade como um todo.

Derek Gregory, influenciado por Thompson, critica profundamente a volta da geografia regional de Vidal de la Blache por parte dos geógrafos humanistas, pois seu foco é a relação entre estrutura e ação individual para encontrar novos horizontes de pesquisa. Contudo, ele não deixa de se interessar pela vida prática e a escala do indivíduo (PEET, 1998, p. 149). Gregory, no melhor estilo thompsoniano, havia analisado anteriormente o processo de ascensão histórica do capitalismo na Grã-Bretanha, assim como o fizeram os regulacionistas Perrons e Dunford (UNWIN, 1995, p. 231).

Peet (1998, p. 154) coloca ainda que a crítica ao estruturalismo e a influência da geografia humanística resulta numa série de novos autores, tais como Castoriadis e seu conceito de imaginário social, Touraine e a noção de lutas sociais no processo de construção da sociedade, Habermas e a teoria da ação comunicativa, e Bourdieu com o hábitus social.

Habermas agora ganha nova força, já que no passado ofereceu uma argumentação contra o positivismo (UNWIN, 1995, p. 188-189). Sua teoria da comunicação expõe o caráter autoritário da tecnificação burocrática do Estado moderno e acredita na comunicação e no consenso social como formadores de razões constituintes da esfera pública democrática. Essa racionalidade negocia com a dialética social da identidade e do meio ambiente, sendo maleável historicamente, 
o que a distingue de uma outra racionalidade exclusivamente técnica e autoritária que domina a vida pública (WIGGERHAUS, 2002, p. 606-609).

No entanto, é possível notar que, no contexto dos Estados Unidos, cada vez mais ocorrem trocas entre as tendências humanísticas e existencialistas de esquerda e a geografia radical estruturalista. O sentido dessas trocas é a redução escalar, ou seja, cada vez mais a geografia focava-se no lugar, o que provoca um contrapeso na balança das agendas de pesquisa. Se antes as estruturas ofereciam uma explicação economicista, abstrata e global, a teoria da estruturação e seus derivados proporcionam o enfoque no local e nas ações dos indivíduo:

Mas certamente toda a questão do marxismo nos moldes de Thompson, a teoria da estruturação de Giddens, o marxismo humanista de Gregory, a ação de [Allan] Pred de se integrar no lugar, é para mostrar não como a história faz o povo (global, estrutural), mas como (local, ativo) o povo faz a história, embora sob condições que eles não escolham (PEET, 1998, p. 162).

\title{
3.3 O realismo filosófico
}

$\mathrm{Na}$ onda de todas essas transformações, a geografia norte-americana ainda incorpora o realismo filosófico de Bhaskar através da obra de Andrew Sayer como uma forma de reelaboração das bases do materialismo histórico. Da mesma forma que o pós-modernismo, o realismo desconfia do objetivismo ingênuo diante da realidade, porém recusa o idealismo ou o relativismo (SAYER, 1994, p. 323). É interessante destacar que o realismo usa uma estratégia evolutiva para argumentar sua ascensão na geografia:

\begin{abstract}
Parece haver uma progressão clara: o marxismo científico, o marxismo crítico, a estruturação e o realismo transcendental, com cada um permitindo uma progressiva diminuição do papel coercitivo das estruturas. A ideia que tudo acontece ao mesmo tempo para todos elementos conectados entre si não é fácil de explicar em sentenças discorridas de maneira linear; e isso pode contar para o fato de que, onde os geógrafos tentaram vender a estruturação ou o realismo transcendental, eles foram uma leitura difícil (BIRD, 1989, p. 114) 240.
\end{abstract}

Bhaskar propõe a abordagem de questões ontológicas ao invés de epistemológicas, o que significa buscar conceitos e definições sobre a natureza básica das entidade e estruturas concretas (UNWIN, 1995, p. 244-245). Similarmente a Giddens, esse debate introduz a ideia de um nível estrutural 
intermediário entre a estrutura e o indivíduo. Johnston (1986, p. 115) ainda destaca a preocupação de Giddens e Bhaskar com a situação dos atores, o contexto histórico, a vida social do objeto de estudo, as leis e normas sociais.

Contudo, para Bhaskar as estruturas mais importante são as do capitalismo e as das relações de poder. Diferentemente de Giddens, em sua teoria nem sempre os agentes atuam racionalmente, porque sua ação depende de suas percepções de mundo que geram um intencionalidade. O seu realismo baseia-se em três categorias fundamentais: (1) o real que abarca os mecanismos de funcionamento estrutural que não se revelam simplesmente pela aparência; (2) a atualidade dos eventos e fenômenos observados; e (3) o empírico referente aos eventos experienciados (HOLTON-JENSEN, 2009, p. 164). Entretanto, ao contrário do que se poderia pensar o realismo não é puramente dedutivo, pois na geografia Sayer "recomenda a pesquisa concreta intensiva, tendo como base considerações abstratas de algumas estruturas e mecanismos, analisando seus possíveis efeitos em limitados estudos de caso empíricos" (HOLTON-JENSEN, 2009, p. 168).

Assim, a verdade para o realismo baseia-se no mundo prático e tem uma dimensão social intersubjetiva. O conhecimento é constituído dos consensos sociais cristalizados através da linguagem, encarando permanentemente a diferença entre o objeto em si e o objeto pensado - concepção que também tem certa afinidade com a visão de Wittgenstein (SAYER, 1994, p. 330). Ao abordar a realidade como sistema, pretende-se ordenar conceitos plurais e suas relações causais, estabelecendo uma ontologia das estruturas e suas múltiplas determinações. Contudo, as estruturas são mutáveis dinâmicas e abertas (SAYER, 1994, p. 333).

Outra ruptura importante é o fato de o realismo admitir que não existe uma centralidade da análise, ao contrário do marxismo, que privilegia a estrutura capitalista ou o proletariado com sua capacidade de emancipação histórica. Isso não significa que o realismo não hierarquize suas variáveis de análise. Conforma-se então uma estratégia de emancipação do legado histórico no marxismo, acusando-o de dogmatismo e de centrar-se demasiadamente no capitalismo (SAYER, 1994, p. 334).

O realismo tenta estabelecer uma teoria do conhecimento diferente, que supostamente romperia com o materialismo histórico e sua postura com o pósmodernismo é de oposição, pois existe uma grande preocupação na formulação de grandes narrativas de síntese. Sayer afirma que a "fragmentação e o relativismo são iguais a guetização. O relativismo não é amigo do feminismo, do antirracismo ou 
outros tipos de teoria social crítica" e finaliza "Diferenciação e independência sim; fragmentação não" (SAYER, 1994, p. 337 e 339).

Acrescenta-se ainda o fato de o realismo não descartar a importância da racionalidade, como ocorre no pós-modernismo. Resumidamente, "existe um mundo estruturado, independente do pensamento humano, que é gerado por mecanismos causais empiricamente observáveis (FOOT et al., 1989, p. 117)241. As leis científicas oriundas do estudo ontológico por parte do realismo são apenas tendências dos fenômenos e estão distantes de qualquer interpretação mecanicista.

É importante destacar que no final das contas, assim como o estruturalismo, o realismo oferece um modelo geral fechado, mesmo que sua tendência seja de aplica-lo em casos concretos (BIRD, 1989, p. 127). Apesar de todos os malabarismo filosóficos não nos parece que o realismo seja radicalmente diferente do materialismo histórico.

A partir da consolidação desses modelos alternativos do estruturalismo, alguns vão acusar Harvey de ser estruturalista. Diante de todos desses ataques e mudanças, Harvey afirma que nunca foi althusseriano e que sua obra busca leis gerais de funcionamento do capitalismo, elaboradas a partir de abstrações de processos concretos que envolvem o capitalismo. O processo de acumulação de capital acontece de maneira abstrata, uma vez que os lugares não têm especificidade diante desses processos mais gerais de funcionamento da sociedade. Finalmente, a categoria de totalidade tem uma função meramente operacional auxiliando a cognição do mundo atual, sendo que a padronização das relações sociais nada mais é do que a concretização da totalidade no lugar. Leis teóricas e totalidade, na opinião de Harvey, são o centro de uma geografia preocupada com um projeto político de fácil entendimento para a população e voltada para o socialismo (PEET, 1998, p. 188-189). Entretanto, parece que diante de tal acusação, ele assume uma postura defensiva.

Consonante ao projeto de Harvey, difunde-se o tema da geografia do capital analisando as estratégias, consequências e contradições da mobilidade dos investimentos capitalistas. J. L. Klein no Quebec e R. Guglielmo na França desenvolvem essas ideias, enquanto J. Lokjine continua a debater as formas de urbanização capitalistas e a divisão territorial do trabalho. M. Bruneau debruça-se sobre os modos de produção e a articulação entre espaços regionais e nacionais 
enquanto A. Reynaud trabalha com o debate entre classes sociais e espaço (KONINK, 1995, p. 153-154).

Entretanto, as acusações a Harvey e aos geógrafos que trabalham em sua perspectiva dão visibilidade a David Ley e James Duncan que escrevem um artigo, em 1982, criticando o marxismo e o estruturalismo. A crítica recai sobre o caráter holístico, ou seja, a totalidade que pré-determina o funcionamento e o desenvolvimento da sociedade, o que constituiria um obstáculo para realização do trabalho empírico. O marxismo se apresenta como uma determinação econômica fechada e o estruturalismo como um modelo abstrato distante da realidade (PEET, 1998, p. 140-141). Segundo Paterson:

Duncan e Ley (1982) argumentaram que alguns dos escritos marxistas de Harvey assumiram uma 'postura estruturalista' e são caraterizados por um modo holístico de explicação, o qual reifica entidades, como o 'capital', tratado como uma causa formal em que as pessoas são efetivamente observadas como meras portadoras de uma lógica estrutural (PATERSON, 1984, p. 5).

Essa crítica exterior ao marxismo acabou influenciando alguns geógrafos marxistas, como Julie Graham (1990, p. 55), que a partir do final da década de 1980 vai posicionar-se contra o essencialismo economicista como uma simplificação da teoria. Ela critica a sobredeterminação econômica de Althusser, caminho nada inovador, mas que ganha o apelo da queda do muro e da ascensão do pensamento pós-moderno. O abandono das metanarrativas e da análise centrada na economia e da ideia de classe como essência da vida social "nos permite gerar um conhecimento contraditório e fragmentário mais do que se apropriar de uma verdade essencial" (GRAHAM, 1990, p. 63) 242.

A partir de meados da década de 1980, a revista Society and Space, que era um periódico que não tinha um reconhecimento internacional tão grande, mas que publicava textos ligados à geografia crítica, alinha-se à geografia pós-moderna, devido às críticas ao estruturalismo:

A revista Society and Space, que levava muito do novo trabalho, tornou-se gradativamente diferente da Antipode que permanecia amplamente marxista em sua orientação; no entanto, Society and Space recusa-se a publicar artigos marxistas. Nesse caso, o grupo de Harvey 'foi julgado por uma série de contrapartidas, algumas simpáticas [ao marxismo] (de Smith e Archer) e outras defendendo o realismo (Sayer) e outras perspectivas críticas (PEET, 1998, p. 189). 
Nigel Thirft, por exemplo, critica Harvey por desconsiderar a subjetividade dos indivíduos e não considerar outros aspectos da vida social além do econômico. O desdobramento desse processo, como dissemos, é um ambiente intelectual a favor do localismo, o que vai catalisar o surgimento das geografias pós-modernas.

\subsection{Os debates em meados da década de 1980}

Em 1984, Dresch atento à crise e às transformações da geografia, publica um texto que basicamente remete aos seus pontos de vista expostos em um trabalho anterior de 1977. Mais uma vez lamenta o abandono da geografia regional, até mesmo no ensino, e demonstra que a incapacidade do geógrafo de manejar a disciplina em sua totalidade concretizou-se (DRESCH, 1984, p. 20). Dresch continua a defender que "os trabalhos de pesquisa eficientes só podem se conceber ou prosseguir em equipes de geógrafos diferentemente orientados, ou melhor, entre equipes multidisciplinares" (DRESCH, 1984, p. 20) ${ }^{243}$.

Enquanto Dresch defende e atualiza suas ideias, George publica o livro Geopolítica das minorias. A impressão é que tal guinada tem o objetivo de agradar o público ou entrar no fluxo da moda das publicações em ciências sociais. É um fato consumado que George desaprovava radicalmente o uso do termo geopolítica, tinha aversão ao pensamento oriundo dos movimento de maio de 68 e se contrapunha ao trabalho de Lacoste. Em todo caso, a obra tenta traçar as origens das minorias, trata dos judeus, dos refugiados e dos trabalhadores imigrantes (GEORGE, 1984).

No mesmo ano, Lévy contribui para o debate sobre a crise da geografia defendendo que a disciplina só pode progredir a partir do momento que esclarecesse os significados dos termos "ciência", "espaço", "sociedade" (LÉVY, 1984, p. 33). Agora sua perspectiva próxima ao debate pós-estruturalista é discutir os atores sociais, seus discursos e sua organização em rede. Quase dez anos após a fundação de Espace Temps, Lévy reconhece a importância do marxismo, mas coloca-se contra uma militância "necessária" ou uma política que envolve uma suposta unidade da práxis (LÉVY, 1984, p. 38-39).

No entanto, ele continua a defender seu ponto de vista de que a geografia é uma ciência separada das outras ciências sociais, possuindo um objeto próprio e 
sujeita à processos particulares de desenvolvimento. Lévy reafirma a ideia de um espaço ativo, ou no espaço como instância social, o que certamente conflui com as ideias de Milton Santos no Brasil:

\begin{abstract}
Pode-se, portanto, pensar que é sob as solicitações convergentes da vida social que é progressivamente imposta a ideia que o espaço não era somente a projeção das diversas instâncias, mas constituía de uma estrutura ativa. produtora da sociedade ao mesmo passo que ela era produto dela mesma. Essa tomada de consciência foi portanto paradoxalmente atrasada por sua semelhança aparente com os velhos demônios da geografia clássica: o espaço considerado como uma realidade independente da sociedade e teleguiado pela natureza ou a geometria, impondo sua exterioridade em uma pseudo dialética espaço/ sociedade. É somente depois do reconhecimento sem ambiguidade da interioridade, da 'intraestruturação' do espaço social face a face da sociedade que a dimensão espacial pode manifestar todas suas significações (LÉVY, 1984, p. 42) 244 .
\end{abstract}

O espaço é encarado simultaneamente como estrutura estruturada e estruturante e guarda em si a inércia histórica. A concepção de Lévy (1984, p. 43-44) procura romper com a ideia de estrutura de Perroux e da teoria das regiões polarizadas, além de valorizar as inovações tecnológicas como as telecomunicações e os transportes que são dinamizadores do espaço. Finalmente, Lévy provoca Dresch e se coloca contra uma "unidade" de fachada entre geografia humana e física (LÉVY, 1984, p. 44).

Enquanto isso, na geografia norte-americana temos, em 1984, a publicação do Desenvolvimento desigual, de Neil Smith, que busca analisar a relação entre homem e meio pelo viés da economia política e investigar a ideia de natureza para o pensamento ocidental dentro do processo histórico de desenvolvimento desigual (PHILLIPS, 2008, p. 71). Na base de sua argumentação existem três temas de investigação: (1) o que é a segunda natureza ou a natureza produzida socialmente; (2) como ocorre a produção do espaço pelo trabalho; e (3) como o processo de desenvolvimento que é necessariamente desigual se espacializa. Dessa maneira, o trabalho do homem transforma a natureza e constitui o espaço, porém de uma maneira não controlada, gerando a contradição entre a emancipação das condições naturais e as formas de dominação social inerentes ao capitalismo (PEET, 1998, p. 93-95).

Mesmo que haja um certo consenso no campo disciplinar de que a concepção de que a primeira natureza seria uma natureza natural e a segunda natureza um 
quadro físico transformado pelo homem, é importante lembrar que nos Manuscritos histórico-filosóficos (MARX, 2006b, p. 100-137) a interpretação que nos parece mais fiel é que a primeira natureza da qual fala Marx é um espaço físico herdado de geração para geração, ou ainda de uma conjuntura social para outra. A primeira natureza estaria mais ligada então à inércia espacial ou inércia do trabalho morto do que à natureza natural 245 .

De qualquer maneira, Neil Smith propõe a ideia de espaço absoluto (natural) e relativo (social) (PEET, 1998, p. 100). O trabalho humano teria a capacidade de relativizar o espaço natural modificando-o segundo sua intencionalidade. Dentro do modo capitalista de produção, esse processo de diferenciação passa pelas vicissitudes das formas de investimento capital, do Estado e das relações de propriedade do solo. O interesse nas diferenças de renda de acordo com a produção do espaço será a mola propulsora para suas investigações sobre o processo de gentrificação 246 das cidades no futuro (PHILLIPS, 2008, p. 76-77).

Todavia, sua análise do pensamento marxiano leva a uma concepção muito próxima do materialismo geográfico que situamos no início do trabalho. Ao mesmo tempo em que Marx aceita a ideia de seus antecessores modernos de que natureza é algo externo à sociedade, também admite que o homem universalmente está situado na natureza. Dessa maneira:

\begin{abstract}
Sociedade e natureza são, argumenta Smith, levados à unidade através da atividade natural do trabalho humano na natureza, o que por sua vez cria, ou produz, novas formas de natureza humana e não-humana (PHILLIPS, 2008, p. 73$)^{247}$.
\end{abstract}

Alguns o criticaram por atribuir à natureza um papel meramente passivo, sendo somente um elemento produtivo. Smith estabelece relações dialéticas entre a produção do espaço, a produção geral e a natureza, o que inclui ainda a lógica de diferenciação e homogeneização do espaço capitalista. Para sua proposta de método e análise, Smith defende o uso de três escalas básicas: o urbano, o Estadonação e o global (PHILLIPS, 2008, p. 77).

\footnotetext{
245 Agradecemos ao professor Élvio Martins por ter tratado longamente sobre essa questão em seu curso de pós-graduação e ter nos chamado atenção para essa controvérsia.

246 A gentrificação é a revalorização e reforma das estruturas urbanas no centro das grande metrópoles. Isso causa uma novo processo de aburguesamento dos centros outrora degradados e a expulsão das classes populares para periferia das grandes cidades.
}

247 Tradução nossa. 
Enquanto seu discípulo discute a desigualdade, Harvey publica The Limits to Capital, obra concebida para tratar da questão financeira por um viés geográfico, abordando os fluxos de capitais, a teoria do preço e renda na cidade, assim como as diversas concepções do imperialismo (PESCHANSKI, 2011, p. 17). Seu interesse surgiu da necessidade compreender elementos ontológicos da obra de Marx, especialmente a centralidade da acumulação capitalista e a luta de classes (PATERSON, 1984, p. 154). Apesar do baixo impacto no lançamento, essa obra proporcionou uma agenda de pesquisa para a geografia anglo-saxônica na década de 1980, segundo Castree (2008, p. 66 e 69). No entanto, o ápice de sua influência só ocorre perto de 1999.

De forma sintética, o livro está organizado em três cortes principais que ordenam sua teoria sobre a crise econômica: (1) superacumulação de capital, que é solucionada de uma forma destrutiva; (2) a crise produtiva expressa-se através da moeda e das finanças, sendo que os picos especulativos exigem a interferência do Estado; e (3) Harvey "integra geograficamente o desenvolvimento desigual: as desvalorizações do capital são sistematizadas em uma reestruturação contínua através da competição entre os espaços inter-regionais" (PEET, 1998, p. 99), o que demonstra como as crises locais geram as globais e como as relações internacionais afetam estruturas geográficas locais alterando as alianças de classes. Nesse contexto, surge uma guerra entre vários imperialismos nacionais.

Assim, seu diagnóstico é que, de um lado, o circuito financeiro capitalista oferece um ajuste temporal, e, de outro, um ajuste espacial como trabalho morto cristalizado na perspectiva de obter lucros futuros a partir da competitividade do lugar. O capitalismo é uma nota promisória de investimentos futuros, e, assim como Lefèbvre, Harvey vê a construção civil ou as infraestruturas como medidas de procastinação da crise (CASTREE, 2008, p. 66). Obviamente, o excesso de investimento de fixos espaciais em todo o mundo tem como resultado uma abundância de capitais sem possibilidade de investimento que entram em contradição com a expectativa de lucros acima da média para determinados empreendimentos imobiliários, causando um efeito inflacionário. Ou seja, o capitalismo tenta combater a queda tendencial da taxa de lucro expandindo-se geograficamente, aumentando o crédito disponível e procurando novas fontes de lucro. Quando esse capital cristaliza-se no lugar na forma de trabalho morto, ele torna-se um fixo espacial vulnerável as mudanças tecnológicas. 
Através dessa abordagem, Harvey cria o materialismo histórico-geográfico, postulando que o desenvolvimento desigual é inerente ao capitalismo (CALLINICOS, 2006, 45-49). Um nome novo para ideias que remetem a Lênin, Bukharin e Rosa Luxemburgo.

Segundo Johnston (1986, p. 131-132) o debate estruturalista na década de 1980 aproxima Wallerstein da geografia política. As relações econômicas entre os países e as grandes transformações econômicas mundiais passam a interessar cada vez mais. A análise do sistema-mundo, pensada por Arrighi e sua rede de pesquisa, concebe o mundo em três escalas básicas de análise: (1) um minissistema delimitado de acordo com a divisão do trabalho; (2) o mundo-império que trata das relação interiores ou entre as diversas nações; e (3) a economia mundo ligada aos ciclos econômicos, ao mercado mundial e à concorrência entre Estados organizados espacialmente em centro e periferia (JOHNSTON,1986, p. 117). Podemos notar que o trabalho de Harvey tem grande afinidade com essa teoria, e, segundo Peet e Lyons (1981, p. 203), essa teoria influenciou muitos geógrafos, pois apresenta-se como um sistema de formações sociais em escala global.

A partir desse aporte, Harvey concebe o imperialismo como uma aliança de classes, pautada no nacionalismo, em que burguesia e proletariado unem-se para a expansão da influência territorial do "império" nacional. Quando uma nova área é conquistada, o pacto nacional protege a burguesia estrangeira como forma de manter o controle econômico. O Estado é um instrumento fundamental nessa dinâmica de exploração (JOHNSTON, 1986, p. 131). Como demonstra Amin (1991, p. 317-318), essa postura é um abandono do imperialismo na visão do pensamento leninista.

Assim, o imperialismo teria acabado porque no terceiro mundo a burguesia chegou ao controle alçado por um poder independente do centro através da industrialização da periferia. A prova dessa situação seria a possibilidade do centro do poder econômico capitalista mudar-se para o Japão, um país da periferia que industrializou-se rapidamente. A teoria da dependência também estaria superada, havendo uma interdependência generalizada ${ }^{248}$. Vemos então que supostamente dilui-se a cisão entre centro e periferia. Tal postura será revista futuramente, depois

248 Em entrevista recente, Harvey admite é que possível falar de hegemonias regionais que se inserem em hegemonias nacionais e que o Brasil não é mais a periferia do capitalismo, mas uma potência dentro da disputa pela hegemonia (PASTI et al., 2012, p. 188). 
das ações ultraimperialistas cometidas pelos Estados Unidos no início do século $\mathrm{XXI}$.

Ainda em 1984 é publicado Spatial Division of Labour, de Doreen Massey, obra que parte da crítica ao althusserianismo e volta-se para a compreensão da organização do capital em larga escala. Masey e Meegan já haviam aplicado o realismo filosófico de Bhaskar em 1979 para compreender a geografia das indústrias, o que ofereceu uma outra perspectiva para sua análise; e, se por um lado houve uma aproximação com a teoria social, por outro existiu uma aproximação maior com a abordagem idiográfica (BIRD, 1989, p. 112).

A teoria econômica locacional combina-se com a ideia de desenvolvimento desigual nessa obra, que em boa parte é uma resposta às políticas neoliberais e à desindutrialização da Inglaterra (PHELPS, 2008, p. 84). Massey analisa o lugar e suas relações sociais com as dinâmicas mais amplas de funcionamento do capitalismo, o que remete às novas estruturas sociais e relações de classe, ou ainda, regiões que estão mais ligadas com o exterior do que com o território nacional (PEET, 1998, p. 177-179).

O funcionamento das instituições só pode ser interpretado na concretude, gerando uma nova conexão com estruturalismo através da investigação empírica. Dessa forma, "os lugares são considerados como o conjunto da estrutura social e da ação humana no espaço, como centros da consciência coletiva e como expressões do interesse social e político" (UNWIN, 1995, p. 243). Massey preocupa-se menos com os indivíduos isolados e mais com a influência dos capitais na mudança da divisão espacial do trabalho e da rotina administrativa dos atores.

A autora já havia anteriormente feito críticas à teoria da localização industrial, argumentando que observar somente o comportamento dos atores e o resultado do processo social da localização industrial não são suficientes para a compreensão da recriação do espaço. Deve-se observar também o contexto regional e estrutural em que os atores inserem-se (JOHNSTON, 1986, p. 125).

Barnes e Sheppard atribuem a essa obra um valor fundamental dentro do mundo anglo-saxão. O livro de Massey, que em um momento inicial não foi profundamente debatido, incentivou o conflito entre opiniões discrepantes. Ele evidenciou a pluralidade que existia na geografia e contrapôs diversas visões:

Tais conflitos e rancores são bem conhecidos e incluem o ataque do marxismo ao projeto da localidade (Smith 1987), a crítica feminista ao marxismo (ou ao menos a versão de David Harvey; Deutsche 1991; 
Massey, 1991), a discordância entre o pós-estrutural e o regulacionismo (Gibson-Graham, 1996) e a decolagem institucional da nova geografia econômica de Krugman (Martin, 1999). Talvez, ainda mais danosos tenham sido os silêncios que voltam a acontecer (BARNES e SHEPPARD, 2010, p. 201).

Além disso, essa obra marca a presença da teoria feminista na geografia, pois Massey demonstra:

(...) algumas das formas em que relações de gênero e classe foram transformadas pela reestruturação industrial na Grã-Bretanha: o declínio da indústria tradicional de mineração na região do carvão, por exemplo, não significou apenas mudanças na relações de classe e conflitos (i. e., crescimento do controle das indústrias locais pelo capital 'externo' a região, declínio nas uniões tradicionais dominadas por homens), mas também uma transformação nos papéis masculinos e femininos no lar e no local de trabalho com o desemprego masculino e o novo emprego de mulheres nas plantas de produção (CHOUINARD, 1997, p. 368) ${ }^{249}$.

Tal debate impulsiona a ideia de identidade próximo à teoria pós-moderna, a concatenação entre gênero e classe vai contra essencialismos e reducionismos de uma visão de classe social homogênea que não considera o indivíduo. Assim, a identidade é pensada através da combinação de vários fatores sociais que resultam em sua constituição.

Harvey é ignorado no percurso da obra, porém comenta e critica Massey por deixar as categorias do marxismo inertes, uma vez que ela não explorou o sentido da reprodução capitalista como um todo. Mesmo que Massey tenha se esforçado para construir uma ligação entre as aproximações nomotéticas e idiográficas, no final das contas sua obra "foca as estruturas espaciais produzidas pela divisão técnica do trabalho interno das companhias" (PHELPS, 2008, p. 87-88).

Da nova releitura da controvérsia geográfica surge um debate entre estudos dos lugares em uma dinâmica mais ampla, contra o estudo empírico com uma teoria a posteriori não dogmática (PEET, 1998, p. 182-185). Tal discussão faz reavivar a controvérsia entre Hartshorne e Schaefer, ou entre a concepção de ciência idiográfica ou nomotética. Smith afirma que a crítica ao estruturalismo e a ascensão da pós-modernidade reabilitam o pensamento de Hartshorne e do kantismo em vários aspectos:

Em primeiro lugar, existe a crítica humanística do positivismo recolocado no humano individual como um tema geográfico coerente; isso significa que a unicidade e a individualidade são centrais para esses trabalhos e que a 
tradição kantiana e neokantiana foram exploradas. (...) Segundo, existe uma reação ao marxismo. Em retrospecto, a habilidade da teoria marxiana de definir boa parte das fronteiras de pesquisa na década de 1970 e início da década de 1980 é surpreendente, dado o crescente conservadorismo político do período. A escassez de teorias sociais competentes, mesmo depois da emergência do positivismo, significa que na geografia, para uma extensão desproporcional, a pesquisa marxista e teoria social foram por um curto período de tempo sinônimos. (...) Dentro da geografia existiu uma certa convergência, incorporando alguns conceitos inicialmente adotados pelos humanistas, mas com uma demanda por mais investigação teórica. O esforço de Giddens para recolocar a ação individual contra o estruturalismo, a sugestão de Massey $(1985,19)$ de que 'o único está de volta à agenda' ressoa fortemente entre geógrafos de perspectivas muito diversas. O ressurgimento do interesse de Hartshorne deve ser entendido nesse contexto (SMITH, 1989, p. 115) ${ }^{250}$.

A volta do neokantismo acaba estimulando posturas antimodernas e representa um retorno ao dualismo entre a formação do indivíduo e a construção de seu mundo através de discursos e a dominância do local sobre o global. Smith (1989, p. 116) associa diretamente a despolitização, o combate ao marxismo, a virada cultural e o retorno à visão disciplinar pelo viés de Hartshorne.

Enquanto isso, em 1985, Lacoste (1991) escreve o livro Contra os antiterceiro mundistas e contra certos anti-terceiros mundistas, o que obviamente representa uma retomada dos temas do subdesenvolvimento, estudados na mesma época da geografia ativa. A linha geral do livro é uma argumentação crítica contra a direita política e a esquerda. Ele cobra dos países do terceiro mundo que se preocupem mais com seus próprios interesses no cenário internacional. Muitas ideias dos terceiro mundistas contribuem para atitudes passivas dos líderes e a elite dos novos países, diante disso Lacoste retoma uma ideia, que já havia enunciado, de que cada país deve particularmente encontrar a maneira de resolver seus próprios problemas e seu caminho para o desenvolvimento (CLAVAL, 2000, p. 250-251). Um trajetória longa para demonstrar que o fim da propriedade privada ou a ajuda internacional mostram-se ineficientes para solucionar o subdesenvolvimento (CLAVAL, 2000, p. 252).

Se, entre 1986 e 1995 Lacoste dedica-se ao estudo da geopolítica no estilo dos casos particulares, a partir de 1990 ele se debruça sobre os conteúdos políticos da paisagem e defende que "os geógrafos empenharam-se, inconscientemente, em restringir, mutilar e, em particular, excluir tudo que tinha uma relação com a ação, o político, os destinos da nação, etc." (ZANOTELLI, 2005, p. 31).

Paralelamente, Tricart (1985, p. 267-302) publica um curto artigo teórico sobre geomorfologia, em que recupera e critica à modelização geomorfológica de Davis, 
Penk e Lester King, dizendo que estes modelos não levavam em conta a história natural e social do lugar, ou seja, eram modelos abstratos. Assim, a dialética na geomorfologia consiste em montar o mosaico de influências e ver os processos naturais em contradição. O modelo para Tricart é um nível taxionômico hierarquizado que tem que se concretizar pela biocene, ou seja, por uma escala de análise mais local. De um ponto de vista mais elaborado, Tricart nada mais faz do que reafirmar as suas ideias do passado.

\subsection{A geopolítica e o pós-modernismo}

Se na revista L'Espace Geographique encontramos debates que buscavam renovar os aportes teóricos da geografia, na revista Heródote, a partir de 1977 até 1982, existem muitos estudos sobre a paisagem, o trabalho de campo, o conceito de tempo desenvolvido pelos geógrafos, a cartografia e seu uso como ferramenta de poder, a geografia física e a geografia dos riscos ambientais - temas dispostos cronologicamente (CLAVAL, 2000, p. 247). Como vimos anteriormente, a Hérodote e o grupo de Lacoste são uns dos pioneiros na aproximação das ideias pósestruturalistas. Observamos anteriormente algumas características importantes, como o abandono de metanarrativas e a análise hermenêutica da geopolítica através da escala regional. Todavia, existiam elementos internos que colaboram para isso. Claval complementa:

\footnotetext{
Na opinião de Lacoste, não há necessidade de desenvolver bases gerais e/ ou universais sobre a natureza da geografia política ou humana, porque, de acordo com a linha neo-vidaliana que ele herdou de Pierre George, o objetivo da disciplina era a análise do contexto geográfico e não observar as regularidades científicas (CLAVAL, 2000, p. 247).
}

Somente dentro dos contextos acontece a ação, no entanto, essa vinculação fundamental entre Lacoste e George demonstra como não houve necessariamente um enriquecimento epistemológico em relação ao que havia sido feito anteriormente - apesar da aproximação com o pensamento de Althusser. A geopolítica torna-se importante porque "é saber como pensar a espacialidade de maneira a permitir uma ação mais eficiente" (CLAVAL, 2000, p. 248), demonstrando a complexidade das relações de poder. Contudo, o geopolítico funda-se no geográfico e, no caso de Lacoste, ambos equiparam-se restringindo o campo disciplinar da geografia no geopolítico. Claval complementa: 
Oito anos depois do primeiro número, a agenda da revista está claramente definida. De 1984, o estilo da revista não mudou muito. Cada número da revista cobria, e ainda cobre um tema, geralmente os problemas geopolíticos de uma área particular. Mesmo se a linha editorial não tenha sido muito alterada, a natureza da 'geopolítica' na revista continuou a ser adaptada (CLAVAL, 2000, p. 249).

Neste momento desenvolve-se uma rivalidade entre Roger Brunet e Yves Lacoste. Ambos são sensíveis à questão do ensino público de geografia. Brunet coordena a revista L'Éspace Géographique desde 1972, quando desenvolve a teoria dos coremas, propondo uma nova cartografia em que elementos gráficos representariam as estruturas espaciais, como vimos. Lacoste opõe-se ao projeto, acusando-o de ser simplista e de deturpar o poder de representação dos mapas. A postura de Lacoste refletia críticas da comunidade geográfica:

\begin{abstract}
A simplificação gráfica que implica o desenvolvimento dos coremas parece frequentemente caricatural: deve-se nesse ponto esquematizar o mundo para torna-se compreensível? Não se arrisca sacrificar uma parte significativa da realidade e deixar de lado relações importantes? Essas críticas são justificadas e explicam as reticências de muitos dos pesquisadores no que diz respeito a um método sedutor. Não se crê que ele ajude verdadeiramente na descoberta, mesmo que possua virtudes pedagógicas. É dentre os mestres de ensino secundário que a coremática encontra maior sucesso (CLAVAL, 1998, p. 368).
\end{abstract}

A situação que impulsiona a controvérsia sobre os coremas é o mapa da "banana azul", feito pelo grupo de Brunet. Esse mapa causou grande impacto no debate público, pois pretendia representar as áreas economicamente mais dinâmicas da Europa e o resultado final - um eixo, no mapa representado na cor azul, que cobre do sul da Inglaterra até o norte da Itália - deixa Paris de fora. Essa controvérsia faz Lacoste reafirmar o caráter ilusório dos coremas, que não consideram a dimensão política, histórica, representam mal os dados naturais e escamoteiam a realidade (LACOSTE, 2010, p. 227).

Em 1981, Roger Brunet publica um texto sobre a geografia dos gulags na União Soviética que utiliza fontes complexas e explora elementos além da experiência literária de Soljenítsin e seu Arquipélago gulag. Brunet (1981, p. 220-224) exibe vários mapas e gráficos sobre onde ficavam os gulags e qual o seu papel social. Em primeiro lugar, ele ressalta a tarefa colonizadora dos gulags, que ocupam o território inóspito e desconhecido, geralmente associados à atividades de extração de matérias-primas. 
Logo após, demonstra como os campos eram planejados a partir da ideia de lugares centrais, o que permite a ocupação de lugares importantes na hierarquia urbana, principalmente nas áreas isoladas dos conjuntos territoriais mais dinâmicos (BRUNET, 1981, p. 224). Após dissecar a topologia, Brunet reforça a concepção de Lefort afirmando que a União Soviética é dominada por uma classe burocrática e que os gulags são um trunfo econômico e político: constituem um sistema punitivo ao mesmo tempo em que formam sistemas de produção de matérias-primas, artigos militares e eletrônicos. Os campos eram peças fundamentais na divisão social e espacial do trabalho.

$\mathrm{O}$ artigo sobre os gulags, segundo o próprio autor, marca o contato com a literatura pós-moderna e um retorno a autores marxistas, como os escritos de Arendt sobre o totalitarismo (BRUNET, 2003, p. 16). Entretanto, ele não se rende à teoria pós-estruturalista, pois acredita ser anticientífico substituir os métodos de pesquisa pela análise do discurso.

Esse texto é nova fonte de atritos entre Lacoste e Brunet. Alguns sugerem que a Hérodote e a L'Espace Geographique representam dois projetos diferentes de modernização da geografia francesa, o primeiro ligado ao pensamento crítico e o segundo à nova geografia. Entretanto, basta observar alguns índices de L'Espace para perceber que após os anos iniciais, ligados à nova geografia, o periódico insere-se fortemente no debate marxista - publicando, por exemplo, a controvérsia Claval.

Lacoste pede para que o texto dos gulags seja publicado em sua revista, porém julga que Brunet escreveu uma introdução ruim que não destaca os expurgos stalinistas. A resposta de Brunet é provocar Lacoste com a associação entre geopolítica e nazismo (LACOSTE, 2010, p. 175). Essa situação de disputa na verdade revela também a disputa pela vanguarda no campo geográfico nacional entre duas figuras que polarizavam redes de pesquisadores diferentes. Se a L'Espace em um determinado momento foi radical, seu momento de relação com a nova geografia marcou muito Brunet e parte de sua geração.

As controvérsias não diminuem a importância de Brunet, que articula a partir de 1984 o grupo RECLUS (Rede de Estudos das Mudanças de Localizações e Unidades Espaciais) com a associação de Raymond Dugrand (ALLEMAND, 2007, p. 60). Eles estão ligados a uma concepção mais técnica e sistemática da geografia.

No ano de 1982, por influência de Jean-Claude e Beatrice Giblin, Lacoste e sua esposa ingressam no partido socialista. Michel Philipponeau, tradicional opositor 
da geografia ativa de George e defensor do projeto da geografia aplicada, também era do partido socialista e chegou a trabalhar como acessor de François Mitterrand (BOMFIM, 2007, p. 100). Enquanto o discípulo tornava-se socialista, o mestre George, um pouco antes, era eleito para a conservadora Academia de Ciências Morais e Políticas (HAMELIN, 2008, p. 243).

Alguns anos mais tarde, Giblin (1985, p. 287-288), ao recapitular o projeto da Hérodote, demonstra como marxismo é economicista e fonte de problemas epistemológicos para a geografia. A obra de Lacoste A geografia dos países subdesenvolvidos seria a prova disso. O mais importante para a geografia seria a análise das características ideológicas e políticas, além da dimensão estratégica do conhecimento que compõe um elemento epistemológico fundamental para o novo conhecimento. Através de processo extremamente restritivo dos estudos de casos regionais, das abordagens sobre o cotidiano que englobam práticas e estratégias dos grupos sociais, o grupo de Lacoste estaria fazendo um esforço para superar o marxismo. Talvez o único contratempo é que a revista Hérodote parece não fazer parte das prateleiras da maioria dos marxistas ao redor do mundo.

Segundo Koninck:

Giblin, afirmando que o marxismo na geografia estaria ultrapassado, deixa uma porta aberta na medida em que sua crítica repousa sobre dois argumentos insuficientes. O primeiro reside no reconhecimento do fracasso dos regimes de inspiração marxista, aqueles mesmos que se apropriaram de Marx. O segundo concerne a inadmissibilidade do discurso economista marxista (KONINCK, 1985, p. 178) 251 .

Polarizando o monopólio da geopolítica, entre 1975 e 1980 surgem as novas obras elaboradas por Paul Claval, André-Louis Sanguin e Claude Raffestin, além do debate com Lévy sobre o marxismo (CLAVAL, 2000, p. 261 e HEPPLE, 2000, p. 271). Nessa mesma época, Lacoste ganha muita influência na América Latina e nos países ibéricos, porém sua obra mais recente ficará desconhecida nesses lugares:

\footnotetext{
Muitos desses países tiveram experiências fascistas trágicas, ainda que antes da Segunda Guerra Mundial, durante a Guerra ou depois. A maioria desses geógrafos olharam para a França buscando direções antifascistas e anti-imperialistas e esse otimismo apareceu bem fundado devido aos geógrafos franceses associados a Pierre George que proviam este foco. As ideias de Yves Lacoste e Heródote cresceram preparadas por essa base intelectual. De fato, o impacto vem principalmente do panfleto inicial - La géographie, ça sert, d'abord, à faire de la guerre - e dos artigos dos primeiros cinco anos (1976-1981) (CLAVAL, 2000, p. 261).
}

251 Tradução nossa. 
Entretanto, de uma forma geral no mundo anglo-saxão e na Itália algumas ideias de Lacoste têm pouca força direta mesmo que algum tipo de debate geopolítico permaneça (CLAVAL, 2000, p. 262). As ideias que terão mais força advém de uma descoberta tardia da entrevista de Foucault, que apenas reforça a presença dos pós-estruturalistas nos Estados Unidos. Apenas Ó Tuathail e seu grupo mantêm um diálogo solitário com a geopolítica de Lacoste no mundo anglosaxão (HEPPLE, 2000, p. 269). Se comparamos a reabilitação da geopolítica, ela ocorre primeiramente na França e apenas algum tempo depois no mundo anglosaxão, por Dalby, Ó Tuathail, Agnew, Taylor e outros.

Mesmo com o lapso no tempo, muitas das características presentes nessa reabilitação da geopolítica são semelhantes a alguns aspectos da obra de Lacoste, pois advêm da matriz pós-estruturalista, por exemplo, a preocupação com a complexidade interdisciplinar, com a diferença social e identitária e o ceticismo quanto às metanarrativas explicativas. No pensamento do grupo de Lacoste, de maneira similar ao de J. B. Harley existe uma concepção do papel de controle e vigilância através da cartografia (HEPPLE, 2000, p. 270).

Temos aí a gênese das geopolíticas pós-modernas em uma lenta convergência de duas escolas nacionais que se tangenciaram timidamente. A tradução de livros do grupo de Lacoste são feitas tardiamente e poucos anglosaxões escreveram para a Heródote.

As contribuições de Hérodote, e principalmente de Lacoste, pensam em um espaço da prática política esvaziado de uma elaboração epistemológica profunda. Temos um pragmatismo subversivo que por vezes flerta com o discurso panfletário, que nessa época está descolado do projeto dos partidos de esquerda.

Scheibling (1977, p. 44) ressalta a incapacidade de Lacoste de considerar conjuntamente as estratégias de dominação e os movimentos de contra-hegemonia que também são dotados de estratégias e de saberes sobre o espaço. Ele não considera as flutuações de ganho e perda de poder em função das contradições da luta de classes que se transferem para a política. Nos anos de 1983-1984, a Hérodote volta-se para os problemas internos da França, e quer compreender os fundamentalismos, o nacionalismo e a questão da independência nacional. Nessa época, temos a ascensão dos movimentos islâmicos, por vezes organizados de uma maneira menos sistemática se comparados aos partidos políticos (CLAVAL, 2000, p. 254). 
Lacoste tenta aumentar as relações com ideias braudelianas, afirmando que a geopolítica é baseada em um sistema-mundo, ideia que não deu certo na comunidade geográfica pois não foi totalmente operacionalizada. Futuramente, Jacques Lévy e seu grupo irão criticar as concepções de Lacoste e repensar a comparação entre geopolítica e geografia política (CLAVAL, 2000, p. 264). Não obstante, existe um silêncio na Hérodote sobre a China ou sobre o fim da União Soviética. A revista analisou o surgimento de novos países, mas não as consequências da dissolução do bloco socialista em escala global.

Paralelamente à tendência da Hérodote, Koninck (1985, p. 181) demonstra como Raffestin adaptou o marxismo para a geografia política, incorporando elementos pós-estruturalistas como o estudo da dominação e das relações de poder. Diferentemente de seus contemporâneos, ele não abre mão de estudar o Estado.

De acordo com o próprio Raffestin (1985, p. 271), sua obra procura engajar elementos do marxismo e o espacialismo em busca de uma contribuição original, e ainda nesse período ele se preocupa com um marxismo inovador. Se a fórmula clássica do marxismo, dinheiro-mercadoria-dinheiro' é essencial para geografia econômica, a geografia política pode munir-se da equação informação-energiainformação'.

A atualidade do marxismo reside na categoria de totalidade e em seu caráter sistêmico:

(...) todo pensamento marxista apoia-se em sistemas de relação e ligações: relações entre exploração, dominação e hegemonia, relações entre formação econômica, formação política e formação ideológica através da formação social (RAFFESTIN, 1985, p. 274) ${ }^{252}$.

Raffestin insere-se na tradição que tenta relacionar a ideia de estrutura, marxismo e sistema em um novo método para geografia. Lefèbvre também inspira sua obra, principalmente por ressaltar a ligação entre circulação e poder. As trocas desiguais e a equivalência entram em jogo como variáveis fundamentais (RAFFESTIN, 1985, p. 275).

A vida econômica e política estão ligadas e o Estado consolida-se mais rigidamente a partir da fundação das cidades, instituindo uma nova divisão política do trabalho: o campo produz energia e a cidade organiza a informação e a técnica, o que permite uma maior emancipação da natureza (RAFFESTIN, 1985, p. 277). 
Em contraste com seu Por uma geografia do poder, de 1980, em que o projeto da microfísica do poder possui um papel significativo, o Estado não perde força, porque dispõe de uma gama de aparelhos que "marcam o espaço e o tempo nos quais se desenrola a vida social. Eles são localizáveis e localizados, situados e situáveis; combinam recursos e códigos; eles seguem estratégias" (RAFFESTIN, 1985, p. 278).

No entanto, na sua obra pode-se perceber a ênfase localista e hermenêutica da análise do poder. A mais-valia informacional, fruto da sociedade informacional globalizada é um novo campo de estudos para ser explorado. A tipologia de redes impõe-se como forma importante de controle e circulação de informações. A luta política na atualidade passa necessariamente pelo acesso e divisão da informação. Nesse sentido, o marxismo surge como antídoto de um espacialismo que cai necessariamente em explicações tautológicas (RAFFESTIN, 1985, p. 280)253. Chama atenção o fato de Raffestin, ao contrário de muitos, não atacar o marxismo frontalmente, mas exaltá-lo como essencial para a continuação da modernização da geografia e sua contribuição social.

Paralelamente, a geopolítica anglo-saxã dá muita ênfase à questão cultural, como, por exemplo, a microfísica do poder, problemas de gênero, feminismo e identidade políticas.

Essas políticas da diferença foram analisadas, mas não completamente adotadas por Lacoste (HEPPLE, 2000, p. 289-290). O grande refundador da geopolítica afasta-se da esquerda e recebe provocações de Numa Broc, que ironiza a desradicalização da Hérodote. Broc (1983, p. 708) acusa a revista de estar perdida no pântano da centro-esquerda, e de publicar textos dos mandarins da geografia. Não existe mais o ódio visceral ao poder estatal, e a integração do grupo ao status quo do campo disciplinar apenas causou uma síndrome de culpa no que diz respeito às parcas atividades do geógrafo. Mesmo numa época de retração dos periódicos, o balanço monetário da Hérodote caminha sem grandes abalos.

Enquanto isso, Raffestin ataca a geopolítica, argumentando que ela é uma ciência nacional francesa. No entanto, isso não surte grande efeito, já que o pensamento lacostiano segue o raciocínio de que a identidade francesa é um

\footnotetext{
253 Curiosamente, nesse mesmo texto Raffestin (1985, p. 281) trabalha com um processo de territorialização, desterritorialização e reterritorialização comandado pela comunicação e pela informação que entra em contradição direta com a região clássica. Esses processos todos, na nossa interpretação, referem-se a uma maior mobilidade dos processos econômicos que tem vantagens a partir do acesso a informação.
} 
antídoto contra o imperialismo e permite uma geoestratétia contra a globalização. Raffestin, por outro lado, absorve a microfísica do poder enquanto Lacoste continua a afirmar que o poder sempre é exercido por militares, políticos e empresários (HEPPLE, 2000, p. 291-292). Finalmente, Hepple argumenta:

\begin{abstract}
Para os anglófilos, os geógrafos franceses negligenciam seus teóricos sociais acerca do [...] pós-estruturalismo, o que parece perverso; por outro lado, alguns suspeitam que Lacoste-Hérodote quase se diverte com essa atenção aos teóricos sociais franceses, o que pode ser visto como uma distração da torre de marfim que se afasta de uma análise geopolítica séria (e possivelmente, também, de uma política séria) (HEPPLE, 2000, p. 294).
\end{abstract}

Nosso balanço, diferente de Hepple, é que o grupo de Lacoste absorveu uma boa dose de teoria pós-estruturalista, mesmo que de maneira mais comedida e oculta sob um suposto manto de independência intelectual. Ao mesmo tempo, sua obra reforçou o nacionalismo francês e permitiu um encastelamento no forte aparato mandarinal na universidade.

\title{
3.6 A consolidação da pós-modernidade
}

Se na França existe a reafirmação dos pontos de vista de alguns geógrafos marxistas, no mundo anglo-saxão a geografia crítica se encaminha para uma exacerbação de estudos empíricos, refletindo a atmosfera intelectual de antes da queda do muro de Berlim e o enfraquecimento do marxismo em todo o Ocidente. Para Johnston (1997, p. 227): "Os eventos de 1989 na ex-União Soviética e nos regimes ligados a ela na Europa oriental provocaram um problema considerável para os geógrafos de convicção marxista bem como para muitos de seus programas políticos".

Mesmo com debates importantes em meados da década de 1980, com a inserção de novos temas e revisão teórica, a insatisfação de alguns continua:

\footnotetext{
Apesar de ter havido uma crescente desilusão com o enfoque radical e marxista, continuou-se a sua promoção por Harvey e um pequeno número de pessoas (principalmente, Peet, Sayer, Walker e Neil Smith), porque havia uma crença implícita na análise e no progresso [dessa corrente] (...) [Existe um] limitado tratamento dos indivíduos; a classe era vista como a categoria dominante através da análise marxista, por exemplo, jogando em segundo plano (se não excluindo amplamente) outros fatores, principalmente raça, gênero e orientação sexual, temas em que a atenção foi crescentemente focada. (...) Geógrafos, especialmente, mas não exclusivamente os das gerações jovens, produziram um enfoque que evitava o implícito direcionamento ao determinismo materialista do positivismo e do marxismo/realismo. Eram teoricamente ricos, como o
} 
A reorientação de gênero, raça e classe vai ser fundamental para a geografia social anglo-saxã, porque busca-se agora a análise e a transformação social através de pequenas mudanças, na forma de se pensar, agir e conceber a vida social (JOHNSTON, 1997, p. 290). Essa reviravolta é um novo estímulo ao pósmodernismo e à inserção teorias feministas na geografia.

Como observamos anteriormente, o pós-estruturalismo e os estudos culturais nos acompanham na narrativa como uma espécie de ator de bastidores até o presente momento, pois vimos apenas alguns indícios de sua presença e aproximações que possibilitaram sua consolidação. No entanto, é com o movimento de decadência do socialismo real e com o descrédito do estruturalismo que eles entram em cena e tornam-se elementos fundamentais da paisagem intelectual da geografia. Devemos ter em mente que na geografia, tanto na França como nos Estados Unidos, essas teorias também consolidam-se tardiamente como outrora ocorrera com o marxismo. Em contrapartida, temos que ter em mente que, após seu desenvolvimento inicial na França, a valorização da teoria pós-estruturalista acontece nos Estados Unidos de maneira mais intensa. Cabe lembrar ainda que a chamada nova esquerda incorpora muitos elementos desses debates.

Diferentemente de um projeto racional e lluminista, as culturas não são baseadas na razão, elas simplesmente são o que são. A tentativa de apreensão da cultura e da vida cotidiana através de uma teoria aberta encaminha os pensadores para uma fusão cada vez maior entre filosofia, teoria literária, literatura, arte e poesia.

Eagleton coloca Barthes, Foucault, Kristeva e Derrida como artistas modernistas retardatários que se dedicam à filosofia, mas com uma forte vocação literária em que "as fronteiras do conceitual e [d]o criativo começaram a se esfumaçar" (EAGLETON, 2011, p. 98). Ao mesmo tempo, a intelectualidade rende-se ao sensacionalismo, à instabilidade, à desordem e à perversidade que começam a invadir as representações midiáticas (EAGLETON, 2011, p. 99) e que podem muito bem estar associadas a histeria da guerra fria. O sensacionalismo e a perda da objetividade científica começa trazer a tona um mar de temáticas de pesquisa que muitas vezes não têm relevância social, a não ser o mero prazer do pesquisador (EAGLETON, 2011, p. 189). 
A concepção sobre a teoria social muda, pois inspirada pelo pensamento de Heidegger ela calca-se em uma visão de que delimitar um objeto de estudo adiantadamente é uma operação que empobrece e limita o raciocínio teórico. Assim, a teoria torna-se um discurso fragmentário, uma exposição incompleta de toda a multiplicidade existencial (CUSSET, 2005, p. 116). O pensamento não deve fixar-se em definições prévias. Consequentemente:

Se a lei é sempre trabalhar no interior pela escritura, se a descrição objetiva é somente um efeito dessa 'diferença', se o tema de conhecimento não saberia ser mantido na sua integralidade diante das evidências desses deslocamentos, se finalmente a estrutura por si só é 'simulacro', o 'estruturalismo ordinário' e seu desenvolvimento 'unificado-unificante' vivido, deve ser desconstruído (CUSSET, 2005, p. 121).

O próprio Fredric Jameson enxerga a estrutura como uma redução da realidade social, porque a obsessão pela apreensão do real é desvirtuada por modelos de síntese.

A principal crítica dos pós-modernos consiste no fato do marxismo ser um projeto iluminista moderno composto por uma grande "narrativa totalizante" que polariza grande parte dos interesses sociais em torno de uma só classe social dominante (JOHNSTON, 1997, p. 274). Johnston ainda complementa:

O pós-modernismo ofereceu uma crítica alternativa, uma perspectiva antiessencialista ${ }^{254}$ que promoveu a apreciação das diferenças multifacetadas, oferecendo ao feminismo e a outros enfoques (muitos deles derivados das humanidades) a contemplação das fontes maiores da diferença (JOHNSTON, 1997, p. 269).

Mesmo com a evidente decadência da geografia marxista no final da década de 1980, Johnston (1997, p. 250) ressalta que a geração seguinte de geógrafos norte-americanos dialogará de alguma forma com a geografia marxista. Dentro do contexto mais amplo das ideias, Schwanitz, um antimarxista nítido, afirma:

Cada cliente recebia um cenário grandioso, no qual podia desempenhar um papel de herói. E como a oferta atraía principalmente os intelectuais, que satisfazem suas necessidades de sentido por meio do cumprimento zeloso de certas missões, o marxismo ia se difundindo por meio dos sucessos de venda e ao colocar simultaneamente o adversário sob suspeita. Após o colapso do socialismo real, houve uma nítida crise. Isso era inimaginável, já que até então o marxismo se mostrava imune a contestações por parte da realidade. Mas passou a ser out. (SCHWANITZ, 2009, p.313).

254 Segundo Johnston, no essencialismo os fenômenos seriam todos sobredeterminados (overdetermined, no original). 
Com um golpe letal no triunfalismo, a pós-modernidade ganha cada vez mais força e Jameson é um dos responsáveis por colocar o espaço no centro do debate das ciências sociais. As sucessivas viradas linguística, cultural e espacial - esta última muito próxima da contemporaneidade - são redirecionamentos que influenciarão todas as ciências humanas.

A espacialidade de Heidegger e Lefèbvre entram na moda e a geografia fica um pouco à parte desse processo inicialmente, no entanto, ela é cada vez mais importante na arquitetura, nas artes, no cinema. Ao mesmo tempo em que esse movimento ascende, o capitalismo tardio de Jameson se desdobra como uma continuação do alto modernismo, em que a variável cultural integra-se cada vez mais na dinâmica social de seu funcionamento calcada no pastiche ${ }^{255}$.

O próprio capitalismo ganharia uma lógica cultural, centrado na espacialidade e no imediatismo através da ideia de que tudo já foi inventado e que agora cabe fazer novas combinações do que está posto - o que reforça o esvaziamento do fim da história, das ideologias, das classificações rígidas e das metanarrativas (JAMESON, 2006, 30-44). Assim:

\begin{abstract}
Acredito que o surgimento do pós-modernismo está intimamente relacionado com o surgimento desse novo momento do capitalismo tardio de consumo ou capitalismo multinacional. Creio também que os seus aspectos formais expressam de muitos modos a lógica profunda desse sistema social particular. Entretanto, só serei capaz de demonstrar isso em relação a um único tema maior, a saber, o desaparecimento do sentido da história, o modo pelo qual todo o nosso sistema social contemporâneo começou, pouco a pouco, a perder a capacidade de reter o seu próprio passado, começou a viver em um presente perpétuo e em uma mudança perpétua, que obliteram as tradições do tipo preservado, de um modo ou de outro, por toda a informação social anterior (JAMESON, 2006, p. 43-44).
\end{abstract}

O novo capitalismo incorpora o não-normativo em sua dinâmica, por isso a esfera cultural é importante. Atualmente tudo é permitido e as regras sociais são flexíveis, a única norma que se mantém estável é o dinheiro (EAGLETON, 2011, p. 32). Tais ideias têm influência direta no nosso campo, Barnes (1989, p. 144-147),por exemplo, demonstra que após a controvérsia entre a estrutura e ação humana, a geografia econômica começa a discutir a teoria do valor de Sraffa, de origem liberal, na qual o preço de uma mercadoria só é avaliado no contexto de sua troca. Nem a

255 O pastiche é uma fórmula advinda da arte que incentiva a mistura e a imitação de diversos valores e obras conhecidas, buscando a sátira e a exploração dos elementos comuns da intersubjetividade cultural. 
utilidade, nem o tempo de trabalho seriam variáveis importantes para definir o valor de troca.

Como admite o próprio Jameson, a situação inverte-se de tal maneira que agora a política pura desaparece, porque domina na sociedade uma burocracia despolitizada em que "as posições aparentemente culturais se revelam como formas simbólicas da moralização política" (JAMESON, 2006, p. 62). Para Baudrillard, por exemplo, o verdadeiro pode não estar na economia ou na política, mas nos códigos de comunicação, na mídia de massa e na cultura, que manipulam e são capazes de criar simulacros da realidade formadores de opinião. Essa ideia está na raiz do pósestruturalismo, pois o consumo cultural das massa cria uma super-realidade percebida como realidade concreta. Daí deriva o cinismo, a concepção de que tanto capitalismo como socialismo são regimes totalitários e o elogio à anarquia social, características advindas do pensamento inicial do pós-modernismo de Lyotard (HOLTON-JENSEN, 2009, p. 169).

A ênfase nos temas de gênero, classe social, raça e preferência sexual é uma tentativa de transcendência dos tabus ocidentais tentando deconstruí-los (HERMAN, 1999 , p. 340). Acrescenta-se que a preocupação com a heterogeneidade e o multiculturalismo, segundo Herman (1999, p. 384-385), é uma forma de compensação ao eurocentrismo e uma ascensão do não-ocidental. Entretanto, o autor complementa:

O multiculturalismo se inspirou em uma larga galeria de pessimistas culturais: W. E. B. Du Bois, Marcus Garvey, Adorno, Marcuse e a Escola de Frankfurt ${ }^{256}$ além de Sartre, Foucault e Franz Fanon. No multiculturalismo, os sintomas clássicos da decadência ocidental - a sua racionalidade a esmagar a vitalidade, as suas instituições políticas totalizantes, a economia capitalista e a degenerada cultura de massa -, assim como os recentes antídotos à decadência - o racismo, o imperialismo, o nacionalismo darwiniano, o fascismo - juntam-se para configurar o Ocidente como uma força maligna sem par na história. Para o multiculturalista, a civilização ocidental é totalmente Zivilisation; não há Kultur em seu cerne (HERMAN, 1999, p. 379-380).

O multiculturalismo, a heterogeneidade e a identidade ligam-se ao lugar e remetem à concepção de que os grupos atrasados economicamente possuem um vitalismo cultural, na melhor moda nietzscheana. Já que invariavelmente as utopias tornaram-se regimes totalitários, a busca da cultura local pode ser um antídoto para

256 Jacoby (1981, p. 115) lembra: "Tardiamente, na longa carreira de Lukács, ele denunciou Adorno e outros intelectuais marxistas pelo pessimismo e pela distância das organizações revolucionárias. Ele cobrou a preferência em permanecer no que foi chamado de 'Grande Hotel Abismo', um lindo hotel onde poderia-se contemplar o vazio no conforto da primeira-classe". 
a decadência do ocidente (HERMAN, 1999, p. 400). Harvey manifesta-se sobre isso, pois acredita que a culpa dessas distorções utópicas é do mercado e da sociedade capitalista (BARNES, 2002, p. 4-5). Contudo, esse imbroglio conduz à raciocínios que algumas décadas atrás seriam completamente rechaçados e combatidos pela esquerda marxista:

A ênfase do lluminismo na 'polidez' também assume uma nova relevância, que se traduz na esperança pela tolerância da 'diversidade' e por uma nova fraternidade (...) O vitalismo romântico e o super-homem de Nietzsche ressurgem como a energia e a vitalidade que uma identidade racial saudável e 'holística' fornece ao indivíduo (HERMAN, 1999, p. 380).

De maneira polêmica Herman complementa:

Foi essa visão holística da sociedade que a tradição decadentista herdou e explorou. Ela encorajava o uso de metáforas como 'parasita', 'doença', e 'câncer' para descrever as mudanças indesejáveis no tecido social. Todas sustentavam os conceitos do vitalismo romântico e do pessimismo racial, desde as idéias de Gobineau e Nietzsche àquelas do afrocentrismo, além do pessimismo cultural contemporâneo, o existencialismo de Sartre, a filosofia do Ser de Heidegger, a análise da vontade de poder de Foucault e a observação do Ocidente totalizante de Edward Said, tudo partia da premissa de que a sociedade ocidental moderna formava um todo interligado ou um processo total que não pode ser entendido em parte mas apenas por meio de uma 'fratura' radical (HERMAN, 1999, p. 466).

Uma visão pessimista das técnicas como fonte de desumanização do homem vai em direção ao vitalismo identitário e localista. A humanidade estaria em "uma escuridão cultural, iluminada por uma luz fluorecente artificial” (HERMAN, 1999, p. 423). Contudo, enquanto a direita analisava a "degeneração da sociedade" como resultado da decadência ocidental, na pós-modernidade existe uma valorização e exaltação desses resultados das contradições sociais. A ideia de progresso é abandonada completamente dando força ao pensamento antimoderno. A identidade pessoal tornou-se um tema da moda, porém o sofrimento social passa a ser intolerado nos círculos de discussão (EAGLETON, 2011, p. 98).

Contudo, a crítica ao desenvolvimento e a crença de que o lugar e sua tradição não degenerada pela técnica seria uma alternativa adequada na contemporaneidade encontram pouco apelo popular:

Entre as críticas ao progresso e ao desenvolvimento, há uma que acompanhou a Revolução Industrial: a defesa do modo de vida tradicional de artesões, camponeses, pequenos agricultores, pescadores e comunidades tribais. [Crítica apoiada facilmente pela esquerda anticapitalista] Mas quando colocado em termos fortes e não qualificados, isso não faz sentido para as massas do mundo que estão lutando para sair da pobreza. Como movimento, o anticapitalismo fragmenta-se com 
frequência em batalhas isoladas de minorias com apoio ineficiente e limitado (THERBORN, 2012, p. 38).

O Nietzsche reapropriado dos anos 1980 em diante, que influencia a geografia, não é totalmente o "pensador niilista, anti-humanista, livre de aporias do imperativo da verdade, carrasco da face escondida de uma metafísica a desvendar" como na década de 1960 (DOSSE, 2004, p. 234). Agora Nietzsche é um desconstrutor que desmonta a verdade e a encaminha para um outra distinta, conduzindo a discussão "sobre a estética, sobre o corpo, o pensador de uma moral biológica que prefigura a atual bioética" (DOSSE, 2004, p. 235). Nesse momento, o uso de seu pensamento visa transcender a dialética de Hegel e Marx (PEET, 1997, p. 74).

O fim da guerra fria e da utopia do socialismo real reforçam a pósmodernidade, que encontra apoio no melhoramento das condições de vida das classes pobres no interior do centro do sistema. O retorno da Rússia ao capitalismo significa a falta de uma referência e de uma organização social alternativa por mais degradada que fosse a imagem do socialismo.

Em contrapartida, a política neoliberal que se apresentou como receita contra a crise gerada pelo choque do petróleo de 1973 torna-se mais agressiva e tenta a hegemonia no cenário mundial até o final da década de 1990. Na Inglaterra, Thatcher uniu-se os pensadores de esquerda na década de 1980 e o resultado foi o fim do partido comunista da Grã-Bretanha em 1991.

$\mathrm{Na}$ década de 1980, o governo Reagan toma medidas que visam reverter o desaquecimento do economia norte-americana, liberalizando o capitalismo econômico, combinando ações que internamente protegiam as empresas e com uma política externa agressiva de captação de recursos. No âmbito intelectual, a teoria francesa, ligada a um anticominusmo de esquerda, aliava-se ao naturalismo político neoconversador associado às ideias de Strauss. O niilismo e o multiculturalismo criam uma espécie de imobilismo perante o quadro políticoeconômico que acaba por se ausentar da crítica à política externa norte-americana (CUSSET, 2005, p. 199). Se anteriormente os comunistas deveriam ser cassados, na década de 1980 eles não causam grandes preocupações com a displicência da nova esquerda.

Em contrapartida, o antiamericanismo fortíssimo na França durante parte significativa do século XX começa a ser assimilado por uma espécie de Cavalo de 
Tróia às avessas: a intelectualidade francesa se americaniza cada vez mais. Deuleuze e Derrida começam a dizer que o capitalismo é mais revolucionário que o socialismo, pois conseguiu substituir a crença pelo desejo (CUSSET, 2005, p. 174). Confluindo com esse panorama, o governo Miterrand alinha-se cada vez mais com os Estados Unidos, inclusive no que diz respeito à política contra a União Soviética.

Nessa perspectiva, o Estado de bem-estar social e os monopólios empresariais na Europa e nos Estados Unidos foram gradativamente desmantelados sob a bandeira da competitividade econômica e pela busca de novos lucros. Isso significou uma reativação lenta das lutas sociais, principalmente a partir do momento que a população não tem dinheiro para pagar os serviços públicos privatizados ou quando se percebe a perda dos direitos sociais conquistados anteriormente.

Todos esses processos sociais desarticulam o pensamento utópico da construção de uma sociedade que agora vincula-se à frustração ou ao autoritarismo para parte significativa da intelectualidade (JACOBY, 1999, p. 140-151). movimento geral das ciências sociais é ater-se à análise cultural, aos valores democráticos modelares e ao reconhecimento das culturas locais (JACOBY, 1999, p. 76-79). A análise da antropologia cultural solapa a análise da economia política.

Com a vitória do pós-estruturalismo uma das armas do marxismo agora voltase contra ele próprio: o marxismo é classificado como uma ideologia, pois os crimes cometidos pela esquerda não tem outra origem social senão a alienação ideológica. Como Jacoby demonstra, essas tendências existem desde 1960, como vimos, com a primeira grande crise do socialismo real, mas só se tornam hegemônicas no mundo anglo-saxão após 1989 e estão relacionadas à nova esquerda:

\footnotetext{
Este novo marxismo se aproxima de (na verdade em parte promove) um 'pós-estrutralismo' que se concentra em textos, signos e significantes como a matéria-prima da interpretação. Na medida em que este método, inspirado por Jacques Derrida e Roland Barthes, coloca que 'não há nada externo ao texto' e a 'interpretação de qualquer cadeia de significantes é necessariamente apenas outra cadeia de signos', ele tanto abdica da preocupação de um contexto social ou material - ou deixa de avaliar sua importância - quanto encoraja infinitas espirais de comentários (JACOBY, 1987, p. 185).
}

Outra arma que se volta contra o próprio marxismo é o fato do chamado marxismo ocidental ter uma grande gama de autores que fazem análises culturais e filosóficas, deixando a economia política de lado. Na prática, isso significa uma desradicalização do pensamento de Gramsci, uma vez que sua ideia de hegemonia cultural é utilizada livremente pela antropologia sem seu sentido político original. 


\title{
3.7 0 pós-modernismo na geografia
}

Como expõem Gould e Stronmayer (2004, p. 15), é nesse contexto que os pós-modernos ganham força na geografia, com a grande maioria dos autores vindos do debate marxista. A cultura e o cotidiano também tornam-se o centro do debate da geografia acompanhados na negação das metanarrativas. Ambos autores admitem que às vezes é difícil reconhecer algum aspecto geográfico nas preocupações científicas que se legitimam nessa tendência. Para Claval e Entrikin:

\begin{abstract}
A 'virada cultural' borrou as fronteiras internas da geografia. Geógrafos econômicos e sociais consideram a produção de mercadorias culturais, tais como filmes e músicas, e a produção da paisagem cultura, tais como a histórica ou as zonas de preservação do entretenimento urbano, as particularidades dos locais de produção e as trocas da globalização da cultura (CLAVAL e ENTRIKIN, 2004, p. 45) ${ }^{257}$.
\end{abstract}

Aparentemente o tema econômico ficou vinculado de alguma forma à ortodoxia, enquanto os temas ligados à cultura, à alienação e aos fundamentos filosóficos de Marx se vincularam mais à heterodoxia. Contudo, a maleabilidade da filosofia permite que ela se mescle com outras fontes, pois, se de um lado existe a crítica ao estruturalismo, a revalorização dos direitos humanos, o capitalismo cultural de consumo e a valorização das culturais locais que promoveram uma centralização do indivíduo na teoria e na prática, por outro a intelectualidade passa a valorizar a famosa morte do sujeito, como nos indica Jameson (2006, p. 29-42). Isso reforça o silêncio dos intelectuais sobre o estado atual geral da sociedade, com a tendência à especialização e com o esforço pós-moderno de apagar, ocultar, perder, despersonalizar cada vez mais o indivíduo que produz o conhecimento e sua subjetividade.

Essa estratégia do conhecimento nega os modelos vinculados aos autores e com isso "liberta-se" do historicismo linear moderno, rumando para o tempo cíclico do pós-moderno em que a falência do novo aprisiona o homem no passado e na auto-referência impessoal. Não existem mais autores ou contextos, apenas obras que devem ser analisadas em si, pelo método hermenêutico, já que suas lógicas internas podem ser comparadas com outras obras - ou situações sociais e lugares no caso de sua aplicação às ciências humanas. 
A morte do autor liberta historicamente o pensamento complementada pela ênfase na espacialidade que busca o mesmo fim:

\begin{abstract}
O espaço não parece exigir uma expressão temporal; se ele não for precisamente aquilo que existe sem nenhuma figuração temporal, então ao menos podemos dizer que o espaço é o que reprime, de maneira absoluta, a temporalidade e a figuração temporal em benefício de outras figuras e códigos. Se a Diferença e a Identidade estão em jogo tanto na antinomia temporal quanto na espacial, então a diferença preeminente nas considerações sobre o espaço não é tanto a mudança em qualquer compreensão temporal da forma, mas, antes, a da variedade e da infinitude, a da metonîmia e - para alcançar uma versão um pouco mais influente e, ao que tudo indica, definitiva e abrangente - da heterogeneidade (JAMESON, 2006, p. 109-110).
\end{abstract}

A espacialidade suspende a temporalidade, liberta de seu peso acontecimental e reafirma a análise sincrônica, encaminhando o pensamento moderno para a infinitude da diversidade do aqui e agora da existência. Certamente, um enfoque encantador do ponto de vista cultural e estético, mas Jameson não esclarece os limites de sua capacidade explicativa.

Contudo, espacialidade e hermenêutica textual apresentariam sinergias: da mesma forma que um elemento do discurso só tem sentido dentro do texto, o aspecto cultural só pode ser entendido no lugar (DOSSE, 2004, p. 44).

A influência de Jameson foi importante na geografia, e a publicação de seu artigo sobre a Pós-modernidade, ou a lógica cultural do capitalismo ${ }^{258}$ suscitou uma série de debates em vários periódicos nos Estados Unidos e no Reino Unido (DEAR, 2001, p. 13).

Além disso, o método hermenêutico encaminha para desconstrução e a análise do discurso, buscando indicar algumas formas de como a verdade e as ideias se constituem. A análise textual convida para a concepção de sistemas e estruturas sempre "em aberto", ou seja, que não possuem elementos absolutos e bem definidos, que estão sempre em movimento, agregando novos componentes ou os recombinando internamente para vislumbrar novas interpretações (HOLTONJENSEN, 2009, p. 180). No contexto da geografia, a paisagem também pode ser vista como um discurso em aberto através da metáfora linguística ou da valorização de seu aspecto simbólico.

258 Publicado na New Left Review, $n^{\circ} 146,1984$. Em 1991, Jameson publica um livro com o mesmo título. 
Foucault, com sua hermenêutica, integra os pós-estruturalistas, porém mantém um diálogo com estruturalismo e com a filosofia de Kant, principalmente nas suas obras sobre a teoria do conhecimento. Assim o:

\begin{abstract}
(...) discurso tem uma estrutura esquemática que pode ser analisada arqueologicamente (identificando seus elementos composicionais e as relações desses elementos com o todo) e genealogicamente (a formação de discursos pelo não-discursivo, como práticas especialmente das instituições de poder) (PEET, 1997, p. 74) ${ }^{259}$.
\end{abstract}

A ideia de discurso como elemento chave das relações de poder introduz gradualmente a análise hermenêutica na teoria das ciências sociais. O poder começa a tornar-se uma entidade geral captada no contexto do discurso verbal e performático.

As "diferentes formas e bases do poder num questionamento geral do poder funde posições conflituosas do desenvolvimento em um único discurso desenvolvimentista" (PEET, 1997, p. 79-80). Mesmo que os países do terceiro mundo não tenham vivido toda a plenitude da experiência moderna, a crítica pósmoderna do subdesenvolvimento orienta vários geógrafos a participarem de micro movimentos de resistência contra a dominação da racionalidade iluminista ligada umbilicamente ao capitalismo (PEET, 1997, p. 82-83).

Dear (1988, p. 263), que já havia trabalhado com a teoria da estruturação (CHOUINARD, 1997, p. 366), rapidamente mobiliza-se para contar a história e defender o programa da geografia pós-moderna, que se intensifica como processo a partir de 1986. Neste ano, a AAG ainda mantinha o grupo sobre geografia socialista e as disputas institucionais entre as diversas visões da disciplina eram muito intensas - estruturalismo contra teoria da estruturação versus realismo filosófico, etc. Apesar desse cenário, existe um clima de otimismo intelectual, já que a geografia crítica havia provocado uma aproximação com as ciências sociais, além do surgimento de subcampos, novos grupos de pesquisa e revistas (DEAR, 1988, p. 265). No entanto, para Dear todas essas disputas são por um nicho que não existe mais, uma vez que a racionalidade moderna deve ser abandonada. Assim:

A filosofia pós-moderna deflagrou sua recente proeminência devido ao que se chamou de 'virada linguística'. Ela se refere à realização/crença de que a linguagem relaciona-se intimamente com o conhecimento. A ordenação de nossas concepções, postula-se, não está na natureza das coisas, mas refletida nos nossos sistemas filosóficos. Esses, por sua vez, contêm 
consciente e inconscientemente estratégias de exclusão e repressão, estando frequentemente ligados às contradições internas e a supressão de paradoxos. A tarefa da desconstrução expõe essas contradições e paradoxos (DEAR, 1988, p. 266).

As raízes da desconstrução estão na hermenêutica, que utiliza a análise textual como dimensão do autoentendimento. O grande objeto da análise passa a ver o local, onde "desmoronam" várias escalas e processos sociais. O local:

(...) como pensamento é uma sequência de várias camadas de eventos multi-determinados colocados deliberadamente no telescópio de uma única dimensão; muitos níveis e escalas de processos simplesmente desabam e um único locale. E com o tempo, vários horizontes de cada locale acumulam como sedimentos sob padrões de passado. O locale é, portanto, um amálgama complexo de passado, presente e novos padrões que estão se formando na coexistência da paisagem. Isso é precisamente o desafio intelectual colocado pelo 'enigma geográfico': destrinchar o complexo locale em seus elementos constituintes (DEAR, 1988, p. 270).

A geografia aparece então como uma condição/situação social, utilizando o relativismo cultural para interpretar o conhecimento científico. As análises não são finais, a hermenêutica é somente uma parte da conversão que continua e caminha pelas múltiplas dimensões disciplinares (DEAR, 1988, p. 272). A referência do locale e o foco na vida social de grande escala evidencia a influência de Giddens.

Alguns anos mais tarde, Dear define a virada da pós-modernidade com três ideias principais:

(...) (1) uma série de distinções culturais e práticas estilísticas que são intrinsecamente e por si só interessantes; (2) a totalidade de tais práticas, vistas como um conjunto cultural são característicos da epopéia contemporânea do capitalismo (comumente distinguido pelo termo pósmodernidade); (3) um discurso filosófico e metodológico antagônico aos preceitos do pensamento lluminista, mais especificamente a hegemonia de qualquer persuasão intelectual singular (DEAR, 2001, p. 1-3) 260 .

Através de uma defesa da docilidade do pensamento pós-moderno, Dear argumenta que não existe nada de novo no seu advento, nenhuma ruptura e nem mesmo o presságio de uma nova fase do capitalismo. O seu papel foi meramente de produzir a relatividade onde ecoam vários discursos difíceis de serem distinguidos (DEAR, 2001, p. 10-11). Contudo, quando o pós-estruturalismo transita mais livremente nos círculos científicos ele se contradiz dizendo que a pós-modernidade é sim uma ruptura. 
Soja desconstrói o pensamento associado ao planejamento na cidade de Los Angeles, enquanto Dear vê na pós-modernidade um estilo arquitetônico e uma novo método que se põe contra a racionalidade moderna (PEET, 1998, p. 218). Dentro dessa proposta pós-moderna, Soja abandona o marxismo e quer constituir uma ontologia do espaço com base na teoria da estruturação de Giddens. A lição fundamental de seu salto teórico é considerar a especificidade do lugar, sua singularidade no contexto espacial - relação com o entorno - e sua diferença com outros lugares (UNWIN, 1995, p. 249). A ontologia constitui-se a partir da diferença e da singularidade.

A transformação do estruturalismo para o pós-estruturalismo é clara:

É a essa verdadeira mutação que assistimos: os termos estrutura, reprodução, estática, combinatória, invariável, universais, lógica binária se apagam em prol de noções de caos organizador, fractal, acontecimento, processo, sentido, complexidade, autonomia, enaction ${ }^{261} \ldots$ Trata-se portanto, com efeito, de um questionamento radical do ideal de objetivismo e de determinismo (DOSSE, 2004, p. 44).

Symanski (1994, 301-302) preocupa-se com o biocentrismo advindo do holísmo organicista da geografia e lista as obsessões pós-modernas: análise textual, modos de ver, contemplação sinóptica, significação, o outro, a diferença, a relação global-local e o meio ambiente. Contudo, o pós-modernismo seria extremamente reacionário ao reduzir o mundo em uma pequena sala de conferências, com uma conversação contínua onde qualquer opinião ou suposição mal fundamentada pode ser dita.

Smith coloca que:

Os novos caminhos de pesquisa adotados crescentemente colocam-se mais em oposição do que em simpatia ao marxismo: a análise cultural veio para ser vista como uma superação e substituição da economia política como objetivo e modo de análise, o pós-modernismo promoveu paradoxalmente uma moda binária alternativa ao modernismo que preenchia o descrédito do lluminismo; a teoria feminista e o multiculturalismo foram crescentemente colocados como uma alternativa, mas do que uma colaboração à análise de classe; e o pós-estruturalismo como uma alternativa à análise estrutural. Nos anos 1990, a teoria marxista mantém-se influente na geografia anglofônica, mas não goza mais de uma dominância indisputável (SMITH, 2001, p. 11).

Smith (2001, p. 11-12) ainda ressalta que essas contribuições gestaram um marxismo mais sofisticado, ou ainda que essas demandas culturais são fruto do

261 Refere-se a um tipo de conhecimento que se forma por práticas prolongadas que geralmente envolvem algum tipo de técnica e desenvolvem habilidades, como, por exemplo, os esportes. 
próprio marxismo. Contudo, o esquecimento da economia política e da análise de classe fere o nódulo central do marxismo como proposta de explicação da dinâmica social.

\subsection{A Escola de Los Angeles e o pensamento de Lefèbvre}

Um epíteto importante desse processo é a publicação da obra E. Soja em 1989 fortemente influenciada por Lefèbvre antes mesmo da tradução de $A$ Produção do Espaço - que ocorre em 1991 no caso da língua inglesa. Soja indica que os marxistas, principalmente Harvey e Lefèbvre, querem compreender como o capitalismo consegue sobreviver com tantas contradições internas. Porém, Lefèbvre confere mais foco às relações espaciais do que aos movimentos do capital, projeto que segue em As geografias pós-modernas (PEET, 1998, p. 106). Para Soja, é fundamental:

\footnotetext{
(...) repensar os fundamentos ontológicos da ciência social européia moderna, para inaugurar uma geografia humana crítica baseada na nova ontologia espacial e focada naquilo que ele descreveu como 'dialética socioespacial' (MINCA, 2008, p. 136) 262 .
}

Edward Soja, que no início de sua trajetória era marxista, incorpora a ideia de Mandel de que o desenvolvimento desigual é fundamental para o capitalismo, assim como a exploração da força de trabalho. Contudo, identifica uma nova fase do capitalismo tardio, que se pauta nas transferências de divisas através da superexploração do trabalho.

Sua crítica ao marxismo nesse momento se dá em função do fetichismo espacial, pois a geografia teria criado estruturas geográficas que se tornaram independentes da sociedade. De acordo com seu raciocínio: "Uma vez que se reconhece que o espaço é organizado localmente, não existe mais a questão de ele ser uma estrutura separada com regras de transformação independentes de um quadro social mais amplo" (PEET, 1998, p. 107); ou seja, espaço e sociedade estão ligados dialeticamente. A nova ontologia pauta-se no entendimento da ligação entre espaço, tempo e ser social, sendo que todos elementos da equação têm igual peso. Une-se a essa intenção as mudanças do mundo contemporâneo, como o pós- 
fordismo e a condição urbana de parte significativa da população do mundo (MINCA, 2008, p. 140).

A ascensão dos estudos pós-modernos também significam uma exacerbação dos estudos urbanos, porque a maioria da população mora das cidades, mas também porque o rural gradativamente transforma-se no industrial. A cidade torna-se o grande nó do capitalismo que se pauta no consumo:

(...) é possível vender o capitalismo contemporâneo como algo próximo ao carnaval bakhtiniano de hetereogeneidades, de diferenças, de excitação libidinosa e de uma hiperindividualidade que descentraliza, com eficiência, o antigo sujeito individual por meio de um hiperconsumo individual (JAMESON, 2006, p. 122).

Enquanto as cidades do primeiro mundo são interpretadas como degradadas e sem futuro, as do segundo são autoritárias e sem possibilidades de consumo. Johnston (1986, p. 128) destaca precocemente a tendência da centralização do debate urbano na geografia. Se, de um lado, as críticas ao estruturalismo fazem com que os geógrafos se concentrem cada vez mais no local, por outro os métodos da geografia regional de abordagem crítica (como o desenvolvimento desigual regional, por exemplo) se direcionam cada vez mais para o urbano, nó de grandes concentrações populacionais e onde vários processos capitalistas materializam-se mercado imobiliário, bolsa de valores, centro de decisões, serviços raros, fluxo de mercadorias, etc. David Harvey, por exemplo, chega a afirmar que desligar as cidades é desligar o capitalismo (PASTI et al., 2012, p. 192).

O resultado da abordagem de Soja foi a criação da escola de Los Angeles que logo fragmentou-se:

[A] escola de L. A. de geografia urbana e econômica foi construída a partir de uma poderosa e espirituosa aplicação do marxismo analítico na década de 1980. Na medida em que esse grupo tinha alguma breve coerência no final nos anos de 1980 e 1990, ele reuniu figuras como Michael Davis, Michael Dear, Allen Scott e Edward Soja, mas ele agora dividiu-se inteiramente, sendo que apenas Davis mantém uma análise marxista vibrante e em constante renovação (...) Alguns gravitaram ao redor de políticas críticas, liberais e públicas, enquanto outros triunfaram com o novo idealismo dos estudos culturais. (...) Outros ainda recuaram para um anti-marxismo reacionário e estridente (SMITH, 2001, p. 13).

Nascida em meados da década de 1980, a escola de Los Angeles é um grupo de pesquisa que percebe que esta cidade não se encaixa no modelo tradicional da escola de Chicago. Los Angeles é policêntrica e passa a ser analisada por um ponto de vista pós-estruturalista, sendo "conflituosa, radicalmente aberta, e como um 
espaço que produz constantes rupturas, crises e mudanças" (NICHLLOS, 2011, p. 189-190) ${ }^{263}$. A análise estrutural direciona-se para forças que provocam a diferenciação espacial, das classes sociais, dos lugares surgidos a partir das contradições e crises do capitalismo (NICHLLOS, 2011, p. 192).

O desenvolvimento desigual e a necessidade constante de explorar novos lugares engendram crises sistêmicas, restruturando as formas e a economia da cidade, o que oferece medidas paliativas para uma crise mais ampla do capitalismo. O pós-estruturalismo estimula a escola com quatro elementos básicos: (1) os poderes plurais diluídos nas instituições e nos grupos sociais (homossexuais, prisioneiros, loucos); (2) a subjetividade pauta a diferença, que é uma força plural e ativa sem um centro estrutural coerente ou hierarquia presente no sistema social ou na mente dos indivíduos; (3) as relações de poder criam necessariamente resistências sociais, posições políticas e discursos; os múltiplos poderes geram uma multiplicidade de expressões políticas; (4) o lugar é a desordem, pois sobrepõe diferenças incompatíveis tornando-o incontrolável, único e imaginativo em sua prática social (NICHLLOS, 2011, p. 193).

Sendo assim, uma das ideias básicas da escola é que a própria crise capitalista fragmentou a cidade e a tornou plural, "isso emerge com a pluralidade de diferentes lugares, com cada lugar produzindo diferentes subjetividades com seus equivalentes conflitos desdobrados em vários ritmos" (NICHLLOS, 2011, p. 194). O resultado da fragmentação é a heterotopia e a criação das identidades híbridas fruto da cacofonia de múltiplas subjetividades. O método e a hipótese da fragmentação podem ser generalizadas para vários estudos de caso, considerando a autonomia do lugar como catalisador da fragmentação socioespacial (NICHLLOS, 2011, p. 194).

A cidade consolida-se como um dos principais centros de concentração e dispersão do capital, raciocínio alimentado pelas obra de Harvey sobre geografia. Os regulacionistas também são uma inspiração importante, uma vez que toda a cidade de Los Angeles foi reestruturada do ponto de vista produtivo, inserindo-a nas redes das empresas. O fluxo informacional global, a predominância dos serviços em detrimento da indústria são outros elementos relevantes para compreensão do urbano. Entretanto, a escola não se esquivou de analisar as migrações, com sua segregação social e a integração econômica do novo proletariado urbano (NICHLLOS, 2011, p. 195). 
A arquitetura, o desenho urbano e o aparato policial unem-se em uma atmosfera de segurança que se encaixa na hiperealidade do simulacro de Baudrillard. Os fenômenos da pós-modernidade apresentam toda sua pungência na periferia e o velho centro urbano é gerido por uma prefeitura fraca que segue a lógica gestora transposta da administração de empresas. Esse quadro geral é complementado por instituições regionais limitadas, um Estado de bem-estar social parcialmente privatizado e dependente da repressão policial (NICHLLOS, 2011, p. 196-197). Los Angeles passa a ser o grande espaço de referência para compreensão de outras metrópoles globais dos Estados Unidos e do mundo.

Entretanto, a crítica ao planejamento, a aproximação e diálogo com a arquitetura, o fato de a geografia não participar da grade básica do ensino nos Estados Unidos impeliram a geografia pós-moderna a participar dos grandes empreendimentos capitalistas outrora criticados pela base teórica supostamente crítica: O "clientelismo na arquitetura transformou a pós-modernidade em um dispositivo de mercado; praticam-se planos ao invés de escolher o 'novo urbanismo'

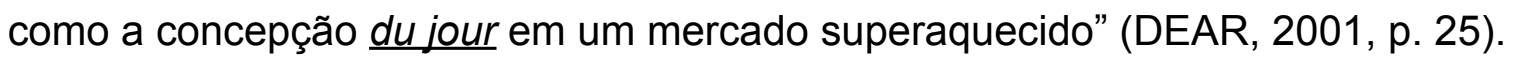

Enquanto isso ocorria nos Estados Unidos, na melhor moda americana Méo na França apropria-se de um conceito tradicional do marxismo e o transmuta na teoria pós-moderna. Méo utiliza o conceito de formação socioespacial que em meados da década de 1970 havia sido elaborado por Milton Santos sob um viés althusseriano, transferindo-o para uma escala intraregional aplicado para a gestão política como proposta de descentralização do planejamento. Sem citar em nenhum momento Milton Santos em seu artigo, Méo (1985, p. 664-665) tem o cuidado de manter a aparência do debate de Althusser com a terminologia de infra e superestrutura.

Em sua visão a formação socioespacial constitui núcleos de geografia social em que a identidade dos indivíduos é formada pelos laços socioespaciais e pela diferença. A formação remonta às relações familiares, econômicas e de trabalho. Compõe ainda sua análise a dinâmica de Bourdieu acerca do hábitus dos indivíduos e a conjuntura estrutural local, além de uma tentativa de classificar os modos de produção localmente - artesanato, campesinato familiar, etc. (MÉO, 1985, p. 671).

Novamente a escala individual predomina e curiosamente o autor não nos fala sobre as controvérsias do anti-humanismo ou da negação do indivíduo para Althusser. $\mathrm{O}$ atropelamento desses debates podem revelar uma estratégia de inserir o debate pós-moderno, com forte apelo ao pensamento crítico internacional, sem 
tocar em assuntos que podem desagradar a velha guarda do campo que se engajou no estruturalismo.

Feita essa observação, exploraremos agora um dos principais autores utilizados pela escola de Los Angeles e os geógrafos pós-modernos. Apesar de Lefèbvre possuir um importante papel na geografia norte-americana, a tradução de A produção do espaço ocorre somente em 1991, o que permite o acesso às suas ideias de uma maneira mais aprofundada. Segundo Peet (1998, p. 101), produz-se então uma espécie de reavivamento do pensamento lefebvriano que é uma alternativa ao estruturalismo e está fortemente impregnado com ideias pósestruturalistas:

\footnotetext{
Para Lefèbvre, o fim, objetivo, e o sentido da industrialização, e a crise nessa sociedade de consumo e a racionalização tomam uma forma urbana. Nessa crise focada no urbano, Lefèbvre não explora o sentido econômico convencional, mas as ligações entre o aumento contínuo do consumo de símbolos, resultando no desejo de fazer acreditar, e suas inevitáveis frustrações. Lefèbvre acredita na ressurreição de uma nova vida cotidiana através de uma revolução cultural com uma implicação política e econômica (PEET, 1998, p. 102).
}

A tríade básica que fundamenta o pensamento lefebvriano é Hegel, Marx e Nietzsche, sendo este último muito polêmico dentro do âmbito marxista. Para Lefèbvre, é Nietzsche quem mantém o sentido original do espaço, não como resíduo do tempo, mas como espaço absoluto pleno de energia e de forças (PEET, 1998, p. 103). Curiosamente, não encontramos em Lefèbvre um comentário sobre a opinião de Nietzsche (2008, p.151-212) em A vontade de poder, onde ele critica o socialismo como o triunfo da mediocridade social. Outra ideia tipicamente nietzschiana que aparece em seu sistema de análise é escala social do corpo, concepção também utilizada por Foucault.

O pensamento de Lefèbvre concebe ainda algumas diferenciações que podem ser estranhas para os não iniciados. O urbano, por exemplo, é entendido como o oposto à cidade, que tem sua origem antes da industrialização e representa o espaço da cidadania integrada.

O urbano é o esfacelamento do espaço da cidade, sua fragmentação. A partir da revolução industrial, o capital, o solo e o trabalho unem-se através da técnica para a formação do urbano, que se legitima através de um discurso. Esse espaço produzido relaciona-se diretamente com a produção e a reprodução da sociedade (LEFĖBVRE, 2008, p. 52). Contudo, as relações citadinas, que anteriormente eram 
baseadas em valores sociais, no urbano transformam-se em relação alienadas baseadas na propriedade privada. A diluição da cidade pré-moderna implode os centros urbanos e expulsa a população para a periferia através de seu processo de crescimento. A indústria piora significativamente a qualidade de vida das cidades de vários pontos de vista. O excesso de capitais acabam sendo aplicado no setor imobiliário como refúgio contra crises e eventuais desvalorizações (LEFEVBRE, 2008, p. 60-76).

Aqui não podemos deixar de pensar em uma idealização da cidade antes da modernidade como composição social que possui elementos importantes para um futuro utópico. A pólis da Antiguidade ou a cidade medieval como um espaço de liberdade da servidão camponesa dão subsídio para a utopia urbana. Nesse contexto, a ideia de direito à cidade aparece como uma agenda de reivindicações e como movimento de construção de uma sociedade urbanocêntrica. Nos perguntamos até que ponto essas apologias às cidades do passado não refletem uma postura antimoderna, e até onde sua utopia urbana de direito à cidade rompe com a lógica do sistema capitalista ${ }^{264}$. Será que a cidade não moderna era o espaço da liberdade diante da escravidão da Antiguidade ou da Idade das Trevas medieval ou será que isso é uma idealização do passado a partir de uma análise que vê só a cidade hermeneuticamente e não o modo de produção e a formação socioespacial como uma totalidade? De qualquer maneira, seu foco central é crítica e a compreensão do espaço moderno.

As construções públicas e privadas auxiliam na luta contra a queda tendencial da taxa de lucro e ainda concedem aos investidores um superlucro, já que o setor da construção civil envolve uma grande quantidade de mão de obra ou capital variável. Tais perspectivas de lucro com o investimento imobiliário possibilitam o retorno da disponibilidade de crédito, por exemplo. O Estado tem um papel fundamental nisso, pois segundo Lefèbvre (2008, p. 119) ele auxilia a instrumentalização do espaço pelo capital ao idealizar o planejamento territorial e seus discursos.

Dessa maneira, o espaço não é geométrico mas instrumental e intencional com elementos ativos. No mundo atual ele ganha cada vez mais importância como

\footnotetext{
264 Quando Lefèbvre fala sobre a cidade medieval pitoresca ele "não consegue esconder seu carinho por ela. Mas essa nostalgia não é uma volta ao passado. Isso não é o modelo atávico de Heidegger da autenticidade e da boa vida. A nostalgia de Lefèbvre firma-se no futuro e ele usa o passado apenas como um veículo para ir além e avante, através de uma alto plano de consciência e pensamento crítico" (MERRIFIELD, 2000, p. 177). Um futuro, como é próprio de seu pensamento, aberto, vazio, livre, ou seja, sem proposição concreta.
} 
antídoto contra a crise, que se torne cada vez mais raro, envolvido umbilicalmente com os fluxos e refluxos do capital (LEFĖBVRE, 2008, p. 153).

Mesmo que sua ideia de espaço produzido esteja vinculada muito fortemente ao urbano, Lefèbvre trabalhou em sua carreira com a sociologia rural. Portanto, defende a ideia de uma descentralização industrial, mesmo que isso signifique um processo de colonização interna com novas contradições (LEFĖBVRE, 2008, p. 76-77).

De acordo com Peet (1998, p. 103), para Lefèbvre o espaço é composto de vários contextos sociais, resultando em uma hipercomplexidade. O problema do espaço teria superado ou deslocado o da industrialização, compondo uma tríade de conceitos: espaço percebido, concebido e vivido.

A prática espacial refere-se ao espaço percebido, uma vez que a produção e reprodução do espaço são coerentes com a formação social que agrega conhecimento acumulado e processos de significação histórica. O espaço concebido, ou espaço representacional está diretamente associado a conceitos abstratos, ideológicos, discursivos e à representação (mapas, esboços) que atuam no papel de dominação social prática. Esse aspecto espacial é sempre relativo, mutável e relacionado a imagens e símbolos. Por fim, o espaço vivido refere-se à vida cotidiana das pessoas, à reprodução imediata da vida e às possibilidades revolucionárias contidas no dia a dia (PEET, 1998, p. 103-104). Unwin (1987, p. 131) foge um pouco desse esquema e coloca o espaço lefebvriano em cinco perspectivas: abrangendo a linguagem e o sentido; superando a separação entre espaço e tempo; como processo de construção e produção; como apropriação da terra; e como valor incluído em um lugar.

Entretanto, sua concepção não escapa de um certo viés vitalista, típico do pós-modernismo, como coloca Merrifield (2000, p. 171): "Nas mãos de Lefèbvre o espaço redescreve-se não como morto, uma coisa inerte ou objeto, mas como orgânico, fluido e vívido; ele tem um pulso, palpita, flui e colide com outros espaços”.

O concreto abstrato, como as relações sociais de produção, só se manifestam no espaço. Além disso, o jogo entre espaço do consumo e consumo do espaço é fundamental e estruturante, assim como as contradições do capitalismo que se manifestam espacialmente, o que Ihe atribui um caráter estratégico e revolucionário (UNWIN, 1987, p. 17). Isso leva a uma centralização no urbano das análises, como, por exemplo, nas obras de Soja e do próprio Harvey. 
No pensamento de Lefèbvre ainda encontramos uma tensão entre o espaço presente e o futuro, através da ideia de devir e da possibilidade da consolidação de novas perspectivas sociais. No entanto, Unwin $(1987$, p. 22) adverte que ver o espaço apenas como produto é arriscar cair em um novo fetichismo espacial. Mesmo ao admitir que ele é um produto social, sua explicação beira a tautologia.

Como podemos observar, os sistemas abertos de Lefèbvre elaborados no final de sua carreira passam por uma espécie de esquematização que busca tornar seu pensamento mais palatável e prático para um público mais amplo. O mesmo ocorre com o pós-estruturalismo nos Estados Unidos de uma maneira geral.

Unwin (1987, p. 24-25) também aponta algumas críticas ao pensamento de Lefèbvre, como, por exemplo, a pouca atenção dada às desigualdades e à miséria social. Além disso, existe uma inconstância escalar sem uma definição rígida entre o que seria o espaço e o lugar.

Lefèbvre abandona a ideia de que o proletariado é a classe com a missão histórica de emancipação da sociedade, principalmente a partir da publicação do seu livro O fim da história de $1972^{265}$. A revolução se daria, portanto, a partir da mobilização das diferenças sociais e não só de uma classe (PEET, 1998, p. 106) e caminha rumo à liberdade, uma alternativa que é no mínimo extremamente abstrata e vaga enquanto projeto.

Dosse (2007, p. 454-455) coloca que na interpretação de Lefèbvre sobre a ascensão do estruturalismo é uma resposta adequada à sociedade de consumo que se burocratiza através da técnica. Sua visão é que Althusser representa o indivíduo que se vê paralisado diante da coerção ideológica, e que, portanto, sem alternativa revolucionária, vê a ideia de cidadão ser substituída pelo de consumidor, realizandose socialmente através do consumo de mercadorias privadas. Daí a necessidade de um retorno ao cotidiano e sua constituição que remete ao "reino, ele diz, o qual é colonizado pela mercadoria e por isso está coberta de todas as maneiras pela mistificação. Ao mesmo tempo, permanece um lugar primordial pleno de significados para a resistência social" (MERRIFIELD, 2000, p. 176)266.

Entretanto, a lógica do capitalismo, com a ajuda do Estado, penetra na vida cotidiana com o planejamento da tecnocracia, que se afirma através da efetividade e impõe sua intencionalidade maximizando a vivências das pessoas. Na mesma toada

\footnotetext{
265 Utilizamos a edição de 2001 citada no final.

266 Tradução nossa.
} 
de Marcuse, o cotidiano é programado, projetado, e a racionalidade externa é imposta, indicando o que é melhor fazer ou saber. O controle técnico da rotina impele o indivíduo à rotina opressora (MERRIFIELD, 2000, p. 177). Mais uma vez a crítica à razão surge, porém nos parece que Lefèbvre não vê que a tecnocracia também passa por processos dialéticos de constituição e contestação com a existência de grupos, concepções e ideias em disputa dentro da representação do poder social.

Essa mesma dialética, no entanto, está presente na dualidade entre a dimensão apolínea e o dionisíaca do cotidiano, onde as relações de produção contrastam com os momentos de liberdade do mundo do trabalho, valores que Lefèbvre transpõe do teatro grego e da literatura para análise do mundo moderno.

Abaixo reproduzimos um esquema que sintetiza alguns dos conceitos que Lefèbvre utiliza e que concernem principalmente à ligação entre a produção do espaço e a crítica da vida cotidiana - o quadro tem um caráter eminentemente sintético. Apesar de alguns, como Unwin (1987), acreditarem que a produção do espaço deixa o nível do cotidiano um pouco apartado da análise, o esquema abaixo tenta remontar tais ilações:

Quadro 3 - Esquema conceitual de H. Lefèbvre

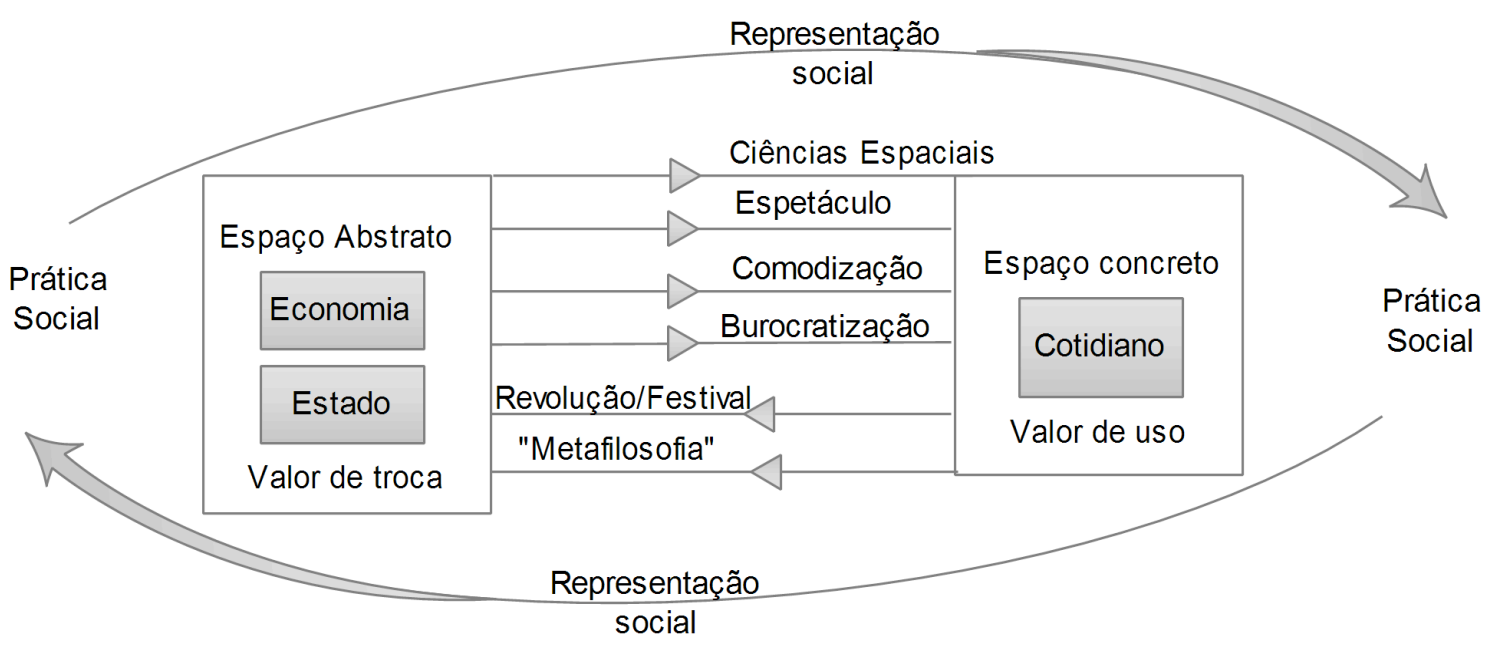

Fonte: Gregory, 1978, p. 18.

Diante de tal quadro, o historicismo aparece como algo que singulariza o passado e recupera aquilo que foi perdido e reprimido na História, surgindo no presente como perspectiva de mudança do presente. São essas várias perspectivas que possibilitam o devir, ou seja, o leque de possibilidades do presente em aberto que pode realizar-se a partir das situações concretas que se apresentam. 
Refletir sobre a obra de Marx sobre O dezoito do Brumário (1997), em que ele analisa e narra a ascensão de Napoleão III, talvez nos conceda uma boa ideia do que seja o devir. Obviamente, ele sempre se projetará no futuro, mas a análise de Marx regressa nas situações latentes dentro das instituições políticas e demonstra quais eram as classes em jogo, quais seus interesses, seus representantes e as possibilidades de arranjo que poderiam derivar diferentes conjunções políticas. Entretanto, o arremate final da obra explica como o sufrágio levou Napoleão III ao poder e o início do Segundo Império. A recuperação histórica rumo ao presente, perpassando as possibilidades possíveis de desenvolvimento histórico, é o que Lefèbvre chama de método regressivo-progressivo.

Na obra de Soja, intitulada Thirdspace [Terceiro-espaço], de 1996, sem tradução para o português, existe uma utilização exacerbada dos três conceitos de espaço de Lefèbvre. Soja utiliza a chamada trialética, ou seja, a relação dialética entre esses três conceitos de espaço. Seu aparato lefebvriano dedica-se a compreender a cidade de Los Angeles e Amsterdã, com suas transformações e levantes sociais ligados ao espaço urbano. Unwin sintetiza uma das concepções centrais da obra:

Para Soja, o primeiro espaço foi explorado 'primeiramente através de seus
textos e contextos legível' e o segundo espaço 'através de prevalência dos
discursos representacionais'. Em contraste, sua intenção para a exploração
do terceiro espaço é ser guiado por uma prática emancipadora que é
conscientemente espacial, e designada para 'melhorar o mundo de alguma
maneira significante'. Paradoxalmente no centro de sua crítica ao
modernismo, pode ser encontrado ainda um eco do lluminismo radical na
crença que é possível fazer do mundo um lugar melhor (UNWIN, 1987, p.
$18)^{267}$.

A seguir veremos alguns contrapontos da ascensão da pós-modernidade e sua relação com o pensamento crítico.

\subsection{Contragolpe e assimilação: reações à pós-modernidade}

Uma das reações mais importantes ao pensamento pós-moderno, e que extravasa o campo da geografia, é a obra de Harvey, também de 1989, A condição pós-moderna. No período de produção do livro, Harvey estava em Oxford e incomodava-se com a desmoralização do marxismo frente ao neoliberalismo. $O$

267 Tradução nossa. 
grande problema é que a obra inicia-se pelo reconhecimento de um novo período pós-capitalista ou pós-industrial (HARVEY, 2005, p. 7).

Harvey primeiramente versa sobre as modificações de natureza empírica no capitalismo como o enfraquecimento do fordismo e o aumento da acumulação flexível, um tema que já havia sido explorado pelos regulacionistas. Entretanto, ele ressalta um novo fenômeno, que denomina compressão espaço-temporal, gerado a partir de um melhoramento geral dos meios de comunicação e de transporte.

O novo fenômeno da compressão introduz gradativamente uma mudança que possui reverberações culturais, porém atinge intensamente a esfera econômica: a aceleração tecnológica diminui o tempo socialmente necessário para a produção de mercadorias e para sua circulação. Daí surge a ideia de acumulação flexível advinda das "novas técnicas produtivas, tais como o just-in-time", que evitam as possibilidades de superacumulação do fordismo (CALLINICOS, 2006, p.50)

Harvey reconhece o poder das culturas frente às transformações políticas e econômicas no mundo, e assim como Baudrillard percebe o poder contemporâneo do simulacro, da alienação ou da ilusão provocados com finalidades econômicas e políticas (PEET, 1998, p. 220-221). Em função da compressão espaço-temporal, as empresas têm cada vez mais poder de acompanhar os concorrentes locais. A partir do debate pós-estruturalista e a descoberta do "outro", abre-se a possibilidade de uma nova dialética social:

O tratamento da diferença e do outro deveria ser onipresente desde o começo em qualquer tentativa de apreender a mudança da dialética social - por isso, a importância de recuperar a raça, o gênero e a religião como um quadro do materialismo histórico enfatizando o capital, o dinheiro e a classe. (...) O materialismo histórico tem que reconhecer essa produção de imagens e discursos que deveriam ser analisados como parte de ordens simbólicas de importância prática da estética e da cultura (PEET, 1998, p. 221).

Não é necessário ressaltar que nesse contexto as obras de Baudrillard e de Foucault ganham força. David Harvey passa pelo desafio dos pós-modernos, mas eles deixam algumas marcas em seu pensamento. Muitos marxistas julgam que ele incorpora elementos, pois acaba por "mostrar que uma boa parte daquilo que se passa por pós-moderno era compreensível em termos de dinâmica urbana, de dinamismo espaço-temporal e de geopolítica do capitalismo" (HARVEY, 2000, p. 170). 
Harvey, que anteriormente havia debatido com Berry sobre as ideias de Daniel Bell, volta ao assunto quando discute a pós-modernidade. Concordando com o raciocínio de Jameson e Bell, destaca a inauguração de uma nova dinâmica de produção capitalista baseada na informação e na produção cultural, além das mudanças profundas na linguagem e nas técnicas de comunicação como destacado por Lyotard (HARVEY, 2005, p. 53).

Contudo, Harvey combate a leitura pós-moderna, demonstrando o caráter esquizofrênico de seu pensamento. Essa caraterística tenta constituir-se como elemento ontológico na teoria da análise social através do colapso e da fragmentação da identidade social. Para o autor:

(...) o pós-modernismo tipicamente descarta essa possibilidade ao concentrar-se nas circunstâncias esquizofrênicas induzidas pela fragmentação e por todas as instabilidades (inclusive linguísticas) que nos impedem até mesmo de representar coerentemente, para não falar de conceber estratégias para reproduzir, algum futuro radicalmente diferente (HARVEY, 2005, p. 57).

Uma das mais importantes consequências dessa perspectiva é uma ideologia de sucessão de tempos presentes sem relação com a ordem cronológica, e uma redução da experiência histórica. Mais uma vez a espacialidade prepondera sobre a historicidade.

O capitalismo agora reorganiza-se em função da dispersão, da mobilidade geográfica, com a nova arquitetura das instituições, diminuição dos direitos trabalhistas, inovações tecnológicas e a financeirização (HARVEY, 2005, p. 150-151). Apesar dessas mudanças produtivas inseridas na dinâmica capitalista pelo novo paradigma do toyotismo em substituição do fordismo, Harvey não descarta a importância da produção cultural como uma nova estratégia de armazenamento do valor diferente dos habituais mecanismos financeiros (HARVEY, 2005, p. 268).

Harvey critica ainda aqueles que acreditam que o local é a escala da mudança política por excelência, pois ele não conseguiria suportar mudanças históricas mais amplas (HARVEY, 2005, p. 273).

Finalmente, o triunfo da estética sobre a ética marca um novo panorama nas ciências humanas, pois o fato de os modelos representativos da sociedade não serem cópias exatas de seu funcionamento resulta em um derrotismo epistemológico segundo o qual os intelectuais não se importam tanto com a veracidade das explicações científicas, já que elas são sempre imparciais, incompletas ou simulacros da sociedade. A impossibilidade da apreensão do objeto 
social em sua totalidade e complexidade resulta na desistência de uma representação ampla através do conhecimento. Por isso, a vitória da estética sobre a ética numa busca supostamente mais próxima da verdade.

No passado Harvey havia desarticulado o conceito de centro e periferia, divulgando consequentemente o fim do imperialismo, porém é obrigado a rever suas posições em função dos conflitos externos dos Estados Unidos. A ressurreição do imperialismo para Harvey está ligada às táticas de acúmulo neoliberais. A partir da teoria do sistema-mundo, Harvey relembra o antigo debate marxista sobre imperialismo, recuperação que já estava presente em The limits to capital (CALLINICOS, 2006, p. 58).

Se existiu uma radicalização diante do "novo" reconhecimento do imperialismo, o futuro releva uma assimilação do pós-moderno. Reafirmando o espírito de reconhecimento do "outro", Harvey publica Justice, nature and the geography of difference [Justiça, natureza e a geografia da diferença] em 1996, que resulta na evidente conclusão que a identidade social muda de acordo com os contextos e a fluidez dos locais (PEET, 1998, p. 221-222). Diante de tudo isso, Harvey não abre mão de uma metateoria para a geografia que explicaria também o funcionamento do capitalismo. Para Chouinard, na geografia:

\footnotetext{
Nós agora temos concepções de estrutura e ação sobrepostos por gênero, raça, sexualidade e habilidade alinhados com as relações sociais, práticas e identidades. A capacidade das pessoas para provocar mudanças sociais é o resultado de processos de formação de identidades e práticas que estão em constante negociação com estruturas de poder múltiplas e qualitativamente diferentes associadas à diferentes tipos de agentes sociais que pode ser criados. A 'dança dialética' da estrutura e da ação preenche o plano divergente, porém sempre sobreposto do processo social (CHOUINARD, 1997, p. 373).
}

Outra inflexão importante é quando Harvey adota a ideia de Raymond Williams de "particularismo militante", cuja essência consiste em delimitar um horizonte de ação política em um contexto histórico e social local. A ação só faz sentindo dentro desse contexto, o que pode aligeirar a prática política de uma agenda global (CALLINICOS, 2006,p. 51).

Outra questão fundamental que tem sua gênese com a queda o muro de Berlim e marcará toda a década de 1990 é a fabricação de uma ideologia de que a terra é plana, ou seja, todos os lugares são acessíveis depois da compressão espaço-tempo, e que não existiriam mais vantagens geográficas na competição entre os lugares. Essa concepção é fruto da proliferação da ideia de redes não 
hierarquizadas advinda dos pós-estruturalistas: "Enquanto os geógrafos neocríticos não veem hierarquia, então eles não podem nos mostrar uma localização do poder que precisa ser discutida, mudada ou transformada" (SMITH, 2005, p. 894).

Smith afirma que boa parte dos intelectuais europeus não problematizaram essa ideia e acabaram americanizando sua vida intelectual, através de uma vanguarda que difundiu essa ideia e fez carreira nos Estados Unidos: Latour e sua teoria da rede de atores; Paul Virilo e a 'morte da geografia'; Castells e a sociedade em rede; ou ainda Baudrillard e o 'fim da geografia' são os pensadores citados, responsáveis pela circulação e consolidação do mundo plano (SMITH, 2005, p. 895). Reforçando a tendência imaginária do fim da história, dos Estados nacionais e do território essa concepção acompanha uma recusa da realidade hierárquica da sociedade capitalista e a maneira específica que cada espaço reproduz suas relações sociais. "Aderir o retrato de uma terra plana e unidimensional é nos ligarmos a uma visão caolha e recusarmos a paralaxe que nos permite discernir a cena profunda, a multidimensionalidade do mundo" (SMITH, 2005, p. 895).

A grande contradição é que os adeptos da mundo plano estão ligados ao multiculturalismo, defendendo uma igualdade falsa que se pauta exclusivamente no pluralismo. Como Smith (2005, p. 896) expõe, essa postura induz a uma tolerância com os neoliberais, oferecendo uma justificativa política para o modelo único global de democracia e capitalismo.

O lançamento d'A sociedade em rede, de Castells, marca uma ruptura e uma tentativa de formulação teórica através das redes aplicadas à administração e à tecnologia da informação:

\begin{abstract}
As redes são mais dissolutas e mais abertas que os grupos e as organizações. Elas se focam mais em atores individuais e seus recursos do que as coletividades constituídas, e criam canais tanto para mercados quanto para burocracias, movimentos e classes. Como tal, as redes são importantes conexões sociais que unem sistemas sociais complexos, fragilmente integrados (THERBORN, 2012, p. 127).
\end{abstract}

A nova concepção de rede sintetiza um pouco o espírito do mundo plano. Apesar de serem um dado concreto da realidade, na grande maioria das vezes elas apresentam uma hierarquia definida.

O exemplo de Harvey e Smith representam posturas diferentes acerca das reações sobre a pós-modernidade. Enquanto o primeiro tem uma postura mais defensiva, absorvendo parte das implementações da teoria pós-moderna, o segundo combate a despolitização científica por trás de novos modelos aparentemente 
ingênuos e interessantes na explicação do mundo globalizado. Pensamos que Peet tenha uma postura muito semelhante a de Harvey, apesar de ter aceitado menos elementos do pós-estruturalismo.

Como vimos, mesmo com o acerto de conta de Harvey com a pósmodernidade, a queda do muro de Berlim e o fim do socialismo real vai diminuir muito a influência do marxismo na academia e no mundo. A década de 1990 será marcada pelo crescimento das teoria pós-estruturalistas e da política econômica do neoliberalismo que ganha espaço em uma arena de disputa das ideias extremamente despolitizada. A lista de teóricos pós-marxistas só aumenta após a queda do muro: Habermas, Castells, Debray, Bauman, para citar alguns (THERBORN, 2012, p. 147).

O pluralismo aplicado à ciência, de acordo com Barnes e Sheppard (2010, p. 194-203), cria na comunidade científica da geografia nos Estados Unidos uma desaprovação geral de quem não concorda com o relativismo intelectual e cultural. O resultado é o desaquecimento do debate, a criação de falsos consensos e a fragmentação do campo de pesquisas. Para usar os termos dos autores, criam-se pequenos monismos de verdade. Ou seja, os critérios de pesquisa pósestruturalistas tornam-se hegemonônicos na década de 1990, mesmo que a proposta da teoria seja a dissolução de hierarquias e relações de poder. Não ser favorável a transvalorização e ao relativismo cultural é uma postura eticamente errada, já que ela representa a postura mais avançada no debate filosófico.

Será preciso esperar o final da década de 1990 para observar novas reflexões acerca da geografia crítica. Antes de passarmos para a conclusão, gostaríamos de mostrar alguns aspectos superficiais dessas aproximações de reativação da geografia crítica encontradas no processo da pesquisa.

Na década de 1990, é o momento de o feminismo institucionalizar-se e passar pelo por um processo de desradicalização similar ao geografia crítica (SMITH, 2001, p. 13). Esse ainda é um período de reflexão histórica e busca de um novo sentido para ação do geógrafo. Mais do que em outros momentos, a institucionalização incomoda os funcionários da academia:

Em um ensaio recente, Noel Castree (2000) fala sobre a transição da geografia radical como ela foi chamada quando foi inventada no final da década de 1960 e no início dos anos 1970, para a geografia crítica, como ela é atualmente conhecida. Para Castree essa mudança de nome está ligada a um processo maior de profissionalização no qual antigos geógrafos 
radicais entraram e eventualmente emergiram no final como geógrafos críticos (BARNES, 2002, p. 5) ${ }^{268}$.

Começa a consolidar-se aí um vocabulário anacrônico que tenta periodizar as fases da geografia crítica como "radical" e "crítica". Essa maneira de recontar a história da disciplina para radicalizá-la novamente não olha o contexto maior do marxismo e reforça uma visão centrada essencialmente na disciplina e na situação norte-americana.

Contudo, Castree não é o único incomodado com a institucionalização da geografia e a desradicalização do marxismo. Blomley é um outro representante da nova geração que participa de um resgate do sentido original do movimento depois da década de 1990. A crítica de Blomley (2007, p. 3-4) é muito parecida com a de Jacoby, com a obediência à institucionalização. Entretanto, ele vê com otimismo as ideias orgânicas que o marxismo consegue engendrar na universidade e nos movimentos sociais, valoriza a criação de novos órgãos da geografia crítica na década de 1990, a saber a Rede Internacional de Pesquisa Urbana, criada em 1991, e, em 1997, o Grupo Internacional da Geografia Crítica (ICGG), que organiza conferências ao redor do mundo ${ }^{269}$. Mitchell também participa da discussão e mesmo que haja um a acomodação institucional coloca:

As vezes a melhor coisa que nós podemos fazer como acadêmicos radicais é conhecimento radical - o que algumas vezes os ativistas e outros nãoacadêmicos mais precisam é uma análise científica minuciosa. Para fazer a diferença além da universidade é preciso fazer trabalhos importantes, bons e comprometidos dentro da academia (MITCHELL, 2012, p. 81) ${ }^{270}$.

Mitchell complementa seu raciocínio dizendo que a força do acadêmico de esquerda está no tempo que ele usa para a atividade intelectual e para a divulgação das ideias. O pós-modernismo significa uma derrota da esquerda e a ascensão de um falso criticismo ou uma crítica despolitizada (MITCHELL, 2012, p. 85).

Em outro artigo, Blomley (2007a, p. 58) também ressalta o fechamento do pensamento utópico e o processo de apropriação de boas ideias da esquerda pelo pós-estruturalismo e pelo neoliberalismo. Depois de todas essas críticas, sua conclusão geral é que a militância das ideias é um catalisador importante na transformação social.

\footnotetext{
268 Tradução nossa.

269 O site da organização é <http://internationalcriticalgeography.org>.

270 Tradução nossa.
} 
$O$ processo de pesquisa ainda revelou outros nichos de transformação importantes da geografia crítica da primeira década do século XXI. Em 2002 temos a fundação da revista eletrônica $A C M E^{271}$, que contribui bastante com a divulgação e debate das temáticas pós-estruturalistas apesar de manter o caráter de estudos "críticos". No ano de 2010, por exemplo, ela lança um número especial sobre Nietzsche e a geografia. Outra mudança importante é que a Antipode, que a partir de 2011 torna-se uma fundação com a produção de outros materiais para além da revista ${ }^{272}$. É importante ressaltar que além do pós-estruturalismo, uma das tendências da $A C M E$ e da Antipode é revalorizar o legado do pensamento anarquista.

271 Todos os números estão disponíveis em <http://www.acme-journal.org>.

$272 \mathrm{O}$ site da fundação é <http://antipodefoundation.org > 


\section{Conclusão}

Pode-se dizer não há e nem houve uma concepção antihistórica e antissocial do mundo que não tenha lançado ao primeiro plano precisamente a ideia de indivíduo integral

M. Bakhtin

Com o objetivo de fazer uma síntese de tudo o que foi discutido até agora elaboramos dois quadros conceituais. O primeiro quadro busca demonstrar o itinerário da geografia de esquerda e crítica, coordenando os eventos históricos com as principais acepções e usos do termo estrutura. Temos as divisões representando os três períodos e a menção de algumas ideias importantes para cada corrente de pensamento.

\section{Quadro 4 - Concepções de Estrutura}

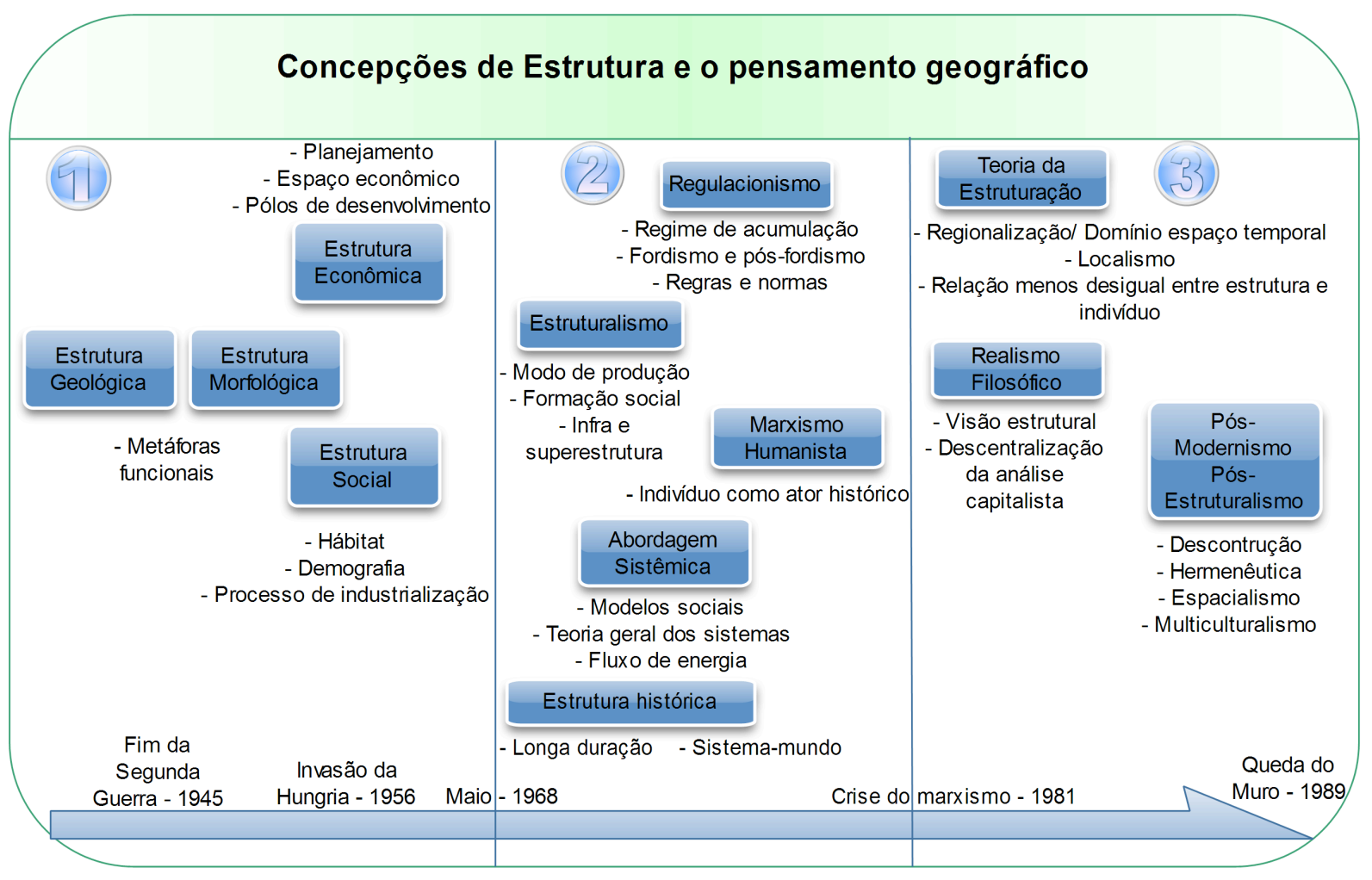


Quadro 5 - Os geógrafos, temas e áreas de pesquisa

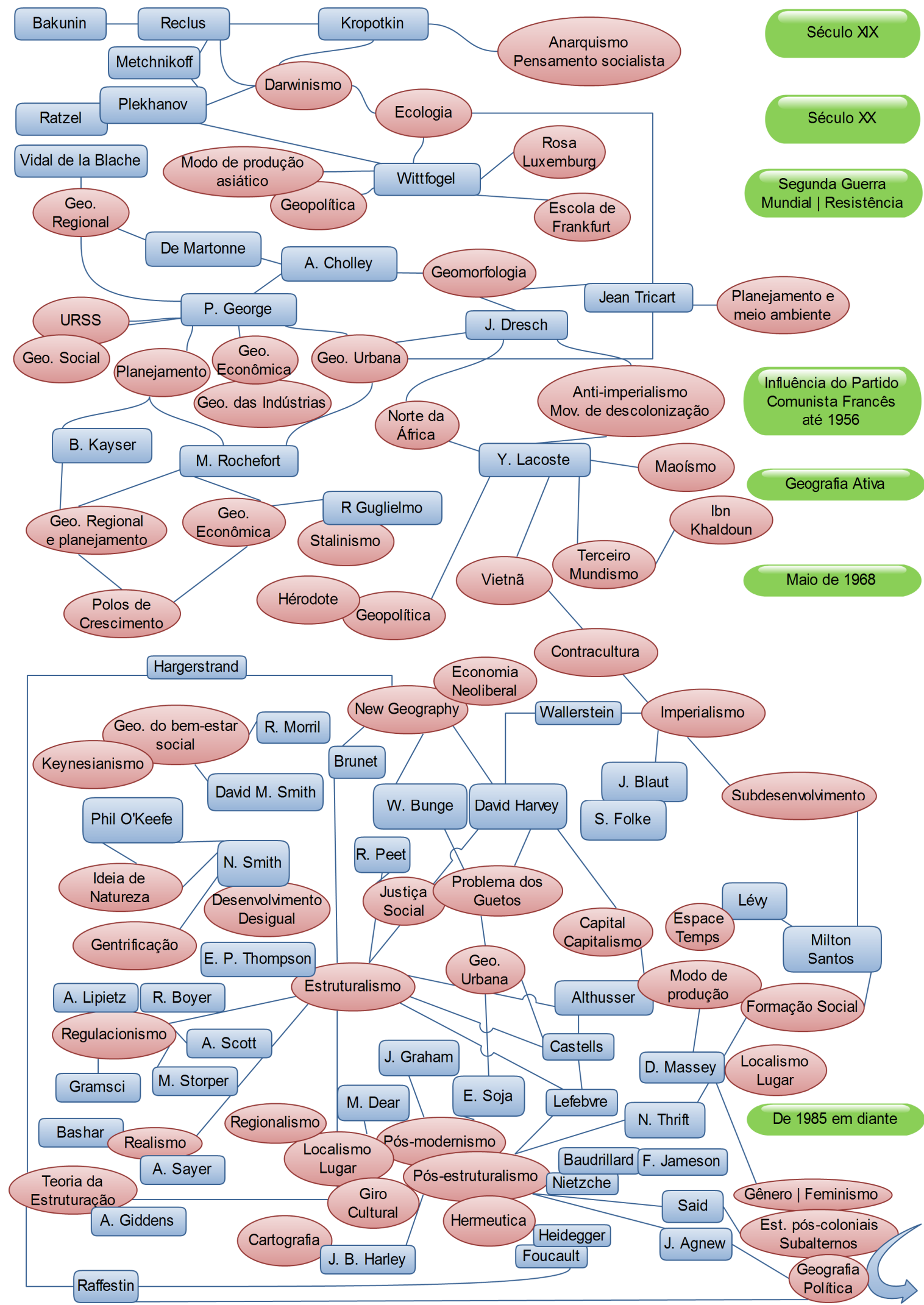

O segundo procura de uma maneira sintética relacionar os geógrafos com os temas de pesquisa em uma linha de tempo. Obviamente, buscamos enfocar mais os 
pensadores abordados no trabalho. Tais sínteses não se pretendem completas e definitivas, pois é muito difícil concatenar uma volume de informação que cobre praticamente 60 anos de produção acadêmica, com todas suas vicissitudes e disputas perante à transformação do mundo. Contudo, pensamos que essas representações auxiliam na compreensão do campo geográfico e da posição de cada um de seus autores. Podemos identificar em ambos quadros os múltiplos desdobramentos do estruturalismo e a inflexão para o pensamento pós-moderno.

Durante nosso percurso vimos como a geografia crítica transforma-se e adentra as instituições acadêmicas, colaborando na constituição de novos conceitos e na formação da ideia do espaço como objeto da disciplina. Categorias como espaço, território e região passam por diversas modificações e discussões.

Esse panorama indica um processo de mudanças disciplinar e epistemológica que tem sua força diminuída pelas diversas crises do marxismo, culminando no fim do socialismo real e no desgaste do pensamento marxista dentro da academia. Pouco a pouco o marxismo passou a ser desvalorizado dentro da geografia e das ciências sociais, visto como uma abordagem limitada pelos vários motivos arrolados acima.

Vimos ainda que alguns geógrafos do pós-guerra têm fortes ligações com o marxismo e lutaram ativamente pela construção do socialismo e de uma sociedade mais justa. Infelizmente, esses autores têm sido tratados ingenuamente pelos geógrafos, pois a análise de suas obras e contextos revelam uma militância política complexa e inovações disciplinares importantes. Um aspecto que não pudemos verificar profundamente, mas que pode revelar mais ligações entre o contexto filosófico dos geógrafos de esquerda e o althusserianismo é o uso da ideia de "tensão harmônica" por P. George. Essa ideia, utilizada por Althusser e elaborada por Hyppolite, explica como determinados conjuntos sociais funcionam no limite de uma transformação social. Tal indicação é só um exemplo de diversas searas que podem ser exploradas acerca de uma geografia de esquerda esquecida, mas que possibilitou o surgimento e institucionalização da geografia crítica.

A negação do estruturalismo althusseriano é um outro elemento importante para ser comentado. Pensamos que esse conjunto teórico foi abandonado, mas ele proporciona uma série de reflexões importantes sobre o papel do marxismo e sua instrumentalização no estudo da história e da geografia. Cheio de controvérsias e debates que mobilizaram toda uma geração de intelectuais marxistas, ele hoje é visto como algo ultrapassado, que apenas deturpou as ideias de vários intelectuais. 
No entanto, cremos encontrar ainda uma riqueza na sua reflexão sobre os aparelhos ideológicos do Estado, sobre o modo de produção e a formação social para enumerar alguns elementos.

O que foi feito de todo o esforço dos geógrafos para incorporar disciplinarmente o desafio proposto por Althusser? Alguns elementos estão entre nós, mas outros foram completamente ignorados e substituídos sem necessariamente sofrer comparações e críticas, o que poderia ser demasiadamente construtivo. Mesmo que Althusser tenha mantido uma certa distância da política, os geógrafos preocuparam-se em aplicar a sua ciência "desalienada" na sociedade através do planejamento ou da denúncia social.

A sua nova versão do zdanovismo soviético, que elenca vários valores burgueses, permite criar uma desconfiança sobre os direitos humanos, a democracia e o humanismo em geral. Será que o pós-estrututralismo tentou verdadeiramente desconstruir essas ideias consensuais da cultura ocidental para criticá-las? Talvez esses temas políticos e interessantes, que aparentemente não resvalam em aspectos culturais, tenham uma imunidade crítica ou uma inviolabilidade. Entretanto, em determinadas situações, posturas como essas fazem aceitar acriticamente ações imperialistas, como, por exemplo, o valor humanitário atribuído à guerra do Iraque que se iniciou em 2003. Um pensamento que se propõe crítico não pode aceitar a ação deliberada do imperialismo norte-americano, muito menos admitir que certas concepções de mundo sejam intocáveis.

Muitos podem pensar que a ideia de estrutura ocupou um papel coadjuvante na narrativa que propomos contar sobre a história da geografia crítica. Isso é um sintoma de uma ciência que entrou em crise e buscou em outros campos de estudo as soluções para seus problemas internos. A crítica ao althusserianismo na geografia, foi encaminhada pela história (Thompson), pela economia (teoria da regulação), pela filosofia e a sociologia (Lefèbvre), mas repercutiu de maneira mais restrita no exterior quando foi feita pela própria geografia (Milton Santos).

Apesar dos geógrafos discutirem a estrutura, pouco ou nada se comenta explicitamente sobre as contribuições que a geografia deu ao uso e ao estatuto epistemológico que o termo ganhou. Houve uma assimilação silenciosa e um esquecimento dos usos que eram originais e inovadores na época da geografia de esquerda. Não é possível ignorar que, de fato, com o início da geografia crítica, a geografia começa a dialogar de uma maneira mais profunda com a teoria social. Contudo, é clara a ideia que a estrutura coordenada com outras categorias clássicas 
da geografia (território, região, etc) tem um papel importante e significou a análise de um horizonte mais profundo do mundo social. Não são somente as formas, nem simplesmente as relações sociais, mas a estrutura dá uma tonalidade totalizadora para a análise.

Dessa forma, acreditamos que diferentemente do criticismo surgido nos Estados Unidos a concepção presente em alguns teóricos que encadeia a dialética da estrutura estruturada e a estrutura estruturante na compreensão da dinâmica social ainda tem uma contribuições importantes para dar a geografia. A incorporação da pós-modernidade, diga-se passagem, de maneira atrasada em relação a outras ciências sociais, reforça tendências fragmentárias e simplifica a explicação científica, pois abre mão da discussão de totalidade.

O pós-estruturalismo desorganizou e desarticulou o pensamento de esquerda, apesar de abrir novas formas de criticismo. Como acreditamos ter demonstrado durante o percurso da tese, o pós-estruturalismo também não é um pensamento homogêneo e monolítico. Entretanto, queremos agora destacar alguns de seus aspectos que acreditamos serem negativos e que apresentados para a comunidade acadêmica em um bloco mais ou menos sistemático de raciocínios e posturas acabam criando um novo nicho de valorização de capital cultural. Ou seja, algumas ideias são valorizadas a medida em que reproduzem discursos considerados mais avançados por determinadas comunidades. Destacar os aspectos negativos só pode encaminhar a uma indagação: mesmo que o pós-estruturalismo tenha absorvido muitas contribuições do marxismo, qual sua contribuição para a teoria social e para construção de uma sociedade mais justa? Será que a despolitização e a perspectiva de ver o fenômeno social pelo espectro da cultura é o caminho adequado ou representa uma limitação da teoria social?

O movimento contra o lluminismo e a postura contra a razão dominadora talvez não leve em consideração que o pensamento autoritário também advém da falta de razão, e que nem sempre a tradição local oferece um sistema justo socialmente e equilibrado com o meio ambiente. A ignorância também é fonte de autoritarismo, opressão e injustiça, sendo muito complexa a diluição das relações de poder entre os indivíduos na sociedade. Apenas abandonar o projeto da civilização não é suficiente, pois a história é um movimento aberto e apenas o desmantelamento de nossa organização social atual não é garantia que algo melhor existirá no futuro. 
O lugar como uma nova utopia localizada que permite uma ação concreta nem sempre é a melhor escala de projeção da práxis. Muitas eventos que reforçam o conservadorismo ocorrem devido ao isolamento local e sua exaltação pode, em última instância, reavivar os velhos sentimentos de pertencimento como o nacionalismo, caudilhos e tribalismos. Ou seja, o lugar é uma aposta sem garantias de vitória e não pode substituir um sentido utópico maior existente, por exemplo, na ideia de construção do socialismo.

O filme Dogville, de Lars von Trier, de 2003, pode servir como uma alegoria das deturpações do lugar. No enredo, uma fugitiva da metrópole vai para um pequeno vilarejo, onde, para ser aceita, passa por uma série de dificuldades, tais como humilhações, escravidão e estupros. Sem um poder mediador, e fragilizada pelo fato de ser uma fugitiva, sua única opção é aceitar as ações da comunidade extremamente fechada.

A integração tecnológica não significa necessariamente uma interação social com o mundo. Se há cerca de 50 anos a comoção com eventos internacionais como a própria guerra do Vietnã, moviam manifestações em diversas partes do mundo, na atualidade o debate e a mobilização política voltam-se cada vez mais para a comunidade local, como é o caso da União Européia. A crítica pós-moderna encontra-se em uma contradição fatal, pois de um lado reforça os tribalismos políticos e de outro lado luta cada vez mais intensamente pela aceitação do "outro" através da heterotopia. No entanto, nos países do centro do sistema acreditamos que a tendência é o reforço de um preconceito cada vez maior contra os migrantes e as minorias. Além disso, não é possível ignorar que o pensamento acadêmico dirigese cada vez mais para a intermediação social local, esquivando-se da discussão de totalidade.

Essa política de debruçamento sobre si, da análise científica do irrelevante, de um encantamento com o cotidiano, que pode denotar um alheamento do que acontece no mundo de uma forma mais total, já fez com que a cultura francesa não percebesse a gravidade da ascensão do nazismo no entre guerras, e se surpreendesse com a deflagração da Segunda Guerra Mundial, como mostrou muito bem Merleau-Ponty ${ }^{273}$. Nos últimos anos, a ultradireita tem ganhado cada vez mais força nos países ricos e o campo minado da esfera cotidiana prática por vezes 
convida a população para a falta de reflexão e para soluções violentas, falsamente eficazes.

Como argumenta Cusset (2005, p. 198), o desdobramento do pósestruturalismo é a formação de uma mentalidade neoconversadora advinda da esquerda não comunista, de filiação social-democrata, e que se nutre no pensamento de H. Arendt, G. Orwell e A. Koestler. Obviamente, Cusset refere-se a uma parte significativa desse movimento extremamente diversificado.

Pontualmente, será que essa inflexão representa progressos para geografia? Pensamos que não, pois além do conversadorismo político temos o reavivamento de velhos problemas epistemológicos. A espacialidade, por exemplo, pode criar uma nova cisão entre as concepções de espaço e tempo que na geografia uniram-se apesar da resistência de alguns geógrafos em não desenvolver a geografia histórica. Ainda é possível vislumbrar um retorno intenso das metáforas naturalizantes através do vitalismo pós-moderno. Ou seja, todo o esforço da fundamentação histórica e dialética que o marxismo tentou atribuir ao nosso campo disciplinar perde-se na análise cultural e no retorno ao vitalismo.

O marxismo ortodoxo deixou lacunas sobre a análise cultural e bons trabalhos foram feitos pela tradição conservadora, como Spengler e Nietzsche, pois faltam estudos sobre os aspectos secundários, como a superestrutura (JACOBY, 1981, p. 32). O resultado é uma confusão dos valores de esquerda entre multiculturalistas, teóricos do texto e marxistas.

Apesar de alguns acharem que a geografia torna-se mais complexa e pluralista nessa perspectiva, é impossível negar que gradualmente as escalas de análise que sob o marxismo eram a totalidade concreta, o Estado-nação histórico e a região/lugar tornam-se a cultural geral abstrata, a cidade com a análise urbanocêntrica locacional e o indivíduo com sua subjetividade, identidade e classe. Essa mudança nos parece uma restrição e não um enriquecimento e mesmo que parte dos intelectuais neguem o eurocentrismo, uma quantidade significativa da população mundial na África e na Ásia, por exemplo, ainda habita o campo.

Como vimos, o individualismo forma um argumento moral e humanista para aceitação das teorias pós-estruturalistas. Todavia, será que o indivíduo pode ser compreendido hermeneuticamente, ou seja, apenas através de sua própria subjetividade sem levar em conta seus contextos sociais e econômicos? Pensamos que não. A classe social se relaciona com o indivíduo, mas tornou-se uma categoria esvaziada porque não se discute mais a consciência de classe. Bourdieu demonstra 
que mesmo do ponto de vista estético as classes sociais têm uma consciência. Entretanto, boa parte dos pós-estruturalistas não operalicionalizam generalizações por acreditarem que elas são autoritárias e reducionistas. Nesse sentido, acreditamos que a história das classes é mais importante que a dos indivíduos, uma vez que ela remete a uma dimensão histórica maior.

No que diz respeito ao capitalismo cultural, ou o capitalismo pós-moderno, muitas pesquisas da geografia têm mostrado a reestruturação produtiva e o papel dos produtos culturais nos lucros (venda de programas de computador, filmes, revistas digitais, etc.). Contudo, até que ponto estuda-se a exploração do trabalho e a especulação desses produtos, que, fora o reconhecimento social, possuem um valor de uso muito limitado e restringido? Nesse sentido, o trabalho de Braverman (1977) nos parece exemplar, pois desde muito cedo ele percebeu a tendência de precarização do trabalho diante da renovação tecnológica do capitalismo financeiro. No mundo das aparências cria-se toda uma ideologia de que todos são iguais e que para obter dinheiro não é mais necessário trabalhar para grandes empresas, basta ter um boa ideia para se ganhar dinheiro. Os novos trabalhadores sem vínculo agora são estimulados a financiar seus próprios meios de produção para colocar em funcionamento suas ideias - as empresas não querem mais comprar o trabalho, mas soluções prontas que demandam pouco investimento. $O$ trabalho não remunerado integralmente ganha uma importância cada vez maior nesse tipo de exploração e qualquer esboço de sucesso por tal ou qual inovação de um pequeno grupo é rapidamente assimilado pelo grande capital e produzido em grande escala.

Entretanto, para além das considerações da exploração do trabalho, qual é a representatividade do montante do capital baseado em produtos culturais frente ao capital total do mundo? A mesma pergunta aplica-se ao capital imobiliário: qual é seu grau de importância diante do capital agrícola ou do industrial? Essas são perguntas que a geografia procura responder apenas timidamente e que podem relevar muito sobre a dinâmica do capitalismo, mas mesmo sem saber a importância de seu objeto muitos continuam estudando essas dinâmicas e não as relacionando com outros setores econômicos.

A fusão entre ciência e arte no pós-modernismo engendrou critérios distantes pensamento científico positivista e de seu compromisso de apreensão do mundo. É a vitória da estética sob a ética, como aponta Harvey. A longo prazo isso só significará um descrédito da ciência, que tendencialmente preza por uma concepção de mundo que aceita todas as explicações possíveis e que considera a verdade 
necessariamente apenas como um ponto de vista ou leitura possível. Todo método científico ou representação social tem defeitos e limitações, mas lidar dialeticamente com isso é aceitar suas contradições epistemológicas. A finalidade da representação artística é distinta da ciência e a preocupação com a veracidade das interpretações cai em um segundo plano desestimulando o debate.

Nossa postura é que essas problemáticas são importantes e atuais, mas que devemos manter uma postura dialética segundo o pensamento marxiano, ou seja, saber lidar com as contradições do mundo concreto e do pensamento, pois elas são o motor necessário da crítica e da construção de um mundo melhor.

Lidar com a contradição é uma agenda essencial, pois o pensamento de Marx fez, em seu tempo, a síntese das tendências modernas e antimodernas para construção de um conhecimento aplicado à realidade para transformá-la. Se o marxismo de Althusser ligou-se fortemente ao modernismo através do positivismo, o pós-estruturalismo agora quer radicalmente propagar o antimodernismo.

A preocupação com o pensamento pós-moderno impregna não somente a ciência, pois devido a explosão da divisão entre os campos artístico-filosóficocientífico ela domina a superestrutura contemporânea. O resultado é uma espécie de cortina de fumaça que encobre a política e a economia através da análise da cultura, reforçando valores como o hedonismo, o consumismo e o niilismo. A ciência que deveria propor um outro mundo, menos desigual, interessa-se por temas cada vez menos relevantes. Contraditoriamente, o pensamento esquizofrênico do irracionalismo combina-se muito bem com o discurso da eficiência, desejando transferir o padrão de gerência empresarial para todas as esferas da sociedade, inclusive para a academia.

Assim, a crítica e o conhecimento científico profissionalizam-se e devem ter altos padrões de produtividade:

\footnotetext{
O sociólogo Alvin Gouldner analisa o fenômeno, desde 1979, em uma perspectiva marxista: ele percebeu a irrupção de uma 'burguesia cultural internacional', composta por universitários poliglotas vindos da 'intelligentsia técnica' bem como da 'estrutura de poder burocrática' (das universidades e da sociedade política), mas para defender 'seus próprios interesses', e formando uma 'classe universal viciada' detentora de um verdadeiro 'monopólio mundial do saber geral e dos discursos críticos' (CUSSET, 2005, p. 303-304).
}

Uma alternativa à "institucionalização pelas portas dos fundo", para usar os termos de Jacoby, não surge com facilidade. A vinculação entre o intelectual e a academia é muito forte, o que reforça a tendência de seguir a moda do que está 
sendo mais valorizada pelos pares dentro de um campo. A independência intelectual fica em suspenso diante desse panorama. Entretanto, acreditamos que se desprofissionalizar não seja a solução, mas refletir acerca de um projeto científico político que recupere os valores da revolução em detrimento das metas e dos mecanismos de funcionamento universitário. A melhor maneira de se fazer isso é discutir sobre como aconteceu o próprio processo de institucionalização. Obviamente, atuar dentro da academia produz ideias importantes para a sociedade; porém, como elas se popularizam?

Portanto, um programa político integrado, que proponha um combate a forma que a ciência é produzida hoje, nunca foi tão atual. Da mesma maneira, o desmascaramento e a crítica de algumas ideias pós-estruturalistas são essenciais. Devido à despolitização, ao apelo humanista e a relação com à esquerda, cada vez mais a intelectualidade aceita as ideias pós-estruturalistas sem fazer uma avaliação de sua natureza ou de como elas se posicionam nas disputas pela representação do mundo. Nesse sentido, vemos o texto de Smith sobre o mundo plano da globalização como uma crítica fértil e primorosa.

Esses elementos indicam que a disputa no campo teórico nunca foi tão atual. A vitória da destopia e a concepção de que vivemos uma eterna sucessão de tempos presentes é uma estratégia do capitalismo, que na atualidade centraliza o controle de capitais gigantescos formados por pequenas propriedades individuais, como fundos de pensão ou outros artifícios da esfera financeira. O ganho de força de ideias liberais é cada dia mais intenso e o pós-estruturalismo em algumas situações representa não uma social-democracia recalcitrante, mas a pior face do neoliberalismo.

Acreditamos que o levantamento realizado nesta tese ajuda a compreender a geografia brasileira, que é influenciada pelo pós-estruturalismo, mas que ainda mantém nichos importantes de radicalidade marxista. A geografia brasileira acompanhou as tendências internacionais até o segundo período, quando o marxismo althusseriano era o modelo dominante. Nesse período ela conseguiu produzir trabalhos interessantes e originais, não reproduzindo apenas o que estava sendo feito no exterior. Um exemplo importantíssimo, como argumentos acima, foi o caso de Milton Santos e Carlos Augusto Figueiredo Monteiro. No segundo caso, a proposta de unir a teoria dos sistemas na geografia física e o estruturalismo na geografia humana acompanha a tendência dos centros de vanguarda da produção geográfica mundial. Entretanto, será que a geografia brasileira explorou todas as 
possibilidades dessa proposta de método que pode utilizar, por exemplo, os geossistemas e a ideia de formação socioespacial?

Independentemente dessa proposta, depois desse período original e de forte reflexão sobre a geografia do estrangeiro, os pensadores brasileiros não seguiram por discussões como a teoria da estruturação ou o realismo filosófico. Contudo, a queda do muro também afetou fortemente a nossa geografia e a esquerda política.

As ideias da virada cultural adentram o campo geográfico e muitas antigas concepções da França ou dos Estados Unidos chegam ao Brasil como novidades de vanguarda enquanto as traduções de obras essenciais para o campo são procrastinadas ao infinito. A recolonização ou o processo de abrir mão da independência conquistada no passado não é interessante, mas a falta de diálogo com o que ocorre no exterior não favorece a difusão de ideias acompanhada pelo desenvolvimento de uma consciência de sua origem dentro da tradição disciplinar do campo.

Não seria exagero indicar que a escola francesa de geografia desenvolve-se em função da grande controvérsia da questão regional, enquanto nos Estados Unidos o debate é entre a geografia nomotética e idiográfica. Nesse contexto, cabe avaliar o que se aprendeu com essas questões e decidirmos se vamos continuar acompanhando-as ou se queremos a partir delas propor novas problemáticas de acordo com nosso desafio e realidade social. 


\section{Referências Bibliográficas}

ABREU, Maurício de Almeida. "Pierre Monbeig e os primórdios da geografia urbana no Brasil" in SALGUEIRO, Heliana Angotti (org.). Pierre Monbeig e a geografia humana brasileira. Bauru: Edusc, 2006.

AGOSTI, Aldo. "O mundo da Terceira Internacional: os 'estados-maiores"” in HOBSBAWN, Eric J. (org.). História do Marxismo - volume 7. Rio de Janeiro: Paz e Terra, 1988.

ALLEMAND, Sylvain (org.). Comment je suis devenu géographe? Paris: Le Cavalier Bleu, 2007.

ALTHUSSER, Louis. L'avenir dure longtemps. Paris: Stock/Imec, 1992. , Louis. Réponse à John Lewis. Paris: Maspero, 1973.

AMIN, Samir. "A vocação terceiro-mundista do marxismo" in HOBSBAWN, Eric J. (org.). História do marxismo - volume XI. Rio de Janeiro: Paz e Terra, 1991.

ANDERSON, James. "Ideology and geography: an introduction" in Antipode, Worchester, volume 5, $\mathrm{n}^{\circ} 3,1973$.

ANDERSON, Perry. Considerações sobre o marxismo ocidental - Nas trilhas do materialismo histórico. São Paulo: Boitempo editorial, 2004 [1979/1983].

ANDRADE, Manuel C. "Faces de uma Amizade: Manuel Correia de Andrade e Caio Prado Jr." in SEABRA, Manoel; HEIDEMANN, Heinz Dieter; IUMATTI, Paulo T. (org.). Caio Prado Jr. e a Associação de Geógrafos Brasileiros. São Paulo: Edusp, 2008.

, Manuel C. (org.). Élisée Reclus. São Paulo: Editora Ática, 1985.

, Manuel C. "O pensamento geográfico e a realidade brasileira" in SANTOS, Milton (org.). Novos rumos da geografia brasileira. São Paulo, Hucitec, 1982. 
ANDREUCCI, Franco. "A difusão e vulgarização do marxismo" in HOBSBAWN, Eric (org.). História do Marxismo - volume 2. Rio de Janeiro: Paz e Terra, 1989.

ARANTES, Paulo Eduardo. Um departamento francês de ultramar. São Paulo: Paz e Terra, 1994.

ASSITER, Alison. "Althusser and struturalism" in The British Journal of Sociology, vol. $35, n^{\circ} 21,1984$.

ATKINSON, David. "Geopolitical imaginations in modern Italy" in DODDS, Klaus e ATKINSON, David (org.). Geopolitical Traditions. Londres Nova York: Routledge, 2000.

BARNES, Trevor J. "Critical notes on economic geography from an aging radical. Or radical notes on economic geography from a radical age" in ACME, vol. $1, n^{\circ} 1$, 2002.

, Trevor J. "Retheorizing Economic Geography: from the quantitative Revolution to the 'Cultural Turn"' in Annals of the Association of American Geographers, vol. 91, n 3, 2001.

, Trevor J. "Structure and agency in economic geography and theories of economic value" in KOBAYASHI, Audrey e MACKENZIE, Suzanne (org.). Remaking human geography. Boston: Unwin Hyman, 1989.

BARNES, Trevor J. e SHEPPARD, Eric "'Nothing includes everything': towards engaged pluralism in Anglophone economic geography" in Progress in Human Geography, nº 34 (2), 2010.

BARNES, Trevor e FARISH, Matthew. "Between regions: science, militarism, and America Geography from world war to cold war" in GREGORY, Derek e CASTREE, Noel (org.). Human Geography - volume 1. Londres: Sage, 2012. 
BASSIN, Mark. "Nature, Geopolitcs and Marxism: ecological contestations in Weimar Germany" in Transactions of the Institute of British Geographers, nova série, vol. 21, $n^{\circ} 2,1996$.

, Mark. "Geographical determinism in fin-de-siècle marxism: Georgii Plekhanov and the environmental basis of russian history" in Annals of the Association of American Geographers, vol. 82, n 1, 1992.

BASTIDE, Roger (org.). Usos e sentidos do termo estrutura. São Paulo: EDUSP e Editora Herder, 1971.

BATAILLON, Claude. Géographes génération 1930. Rennes: Presses Universitaires de Rennes, 2009.

, Claude. "Six géographes en quête d'engagement: du communisme à l'aménagement du territoire - Essai sur une génération" in Cybergeo, Paris, $n^{\circ} 341$, 27 junho, 2006.

, Claude. Pour la géographie. Paris: Flammarion, 1999.

, Claude. "Table ronde imaginaire sur la géographie universitaire française 1930-1940" in Hérodote le temps des géographes, Paris, Maspero, $\mathrm{n}^{\circ}$ 20/28, 1981.

BEAUGUITTE, Laurent. "Os periódicos acadêmicos da geografia francesa de 1940-1945. Entre a pobreza material e a resistência intelectual" in Confins, São Paulo, $n^{0}$ 10, 2010.

BEAUJEU-GARNIER, Jacqueline. "Les choses et le pourquoi des choses" in Villes en parallèle, Nanterre, Laboratoire de géographie urbaine/CERCEAU, $n^{\circ}$ 7, 1983.

BENKO, Georges. "Theory of regulation and territory: an historical view" in BENKO, Georges e STROHMAYER, Ulf. Geography, history and social sciences. Dordrecht: Kluwer academic publishers, 1995. 
BENKO, Georges. e SCOTT, Allen. "Economic geography: tradition and turbulence" in BENKO, Georges e STROHMAYER, Ulf (org.). Human geography - a history for 21st Century. Londres: Arnold, 2004.

BERDOULAY, Vincent. Des mots et des lieux, la dynamique du discours geographique. Paris: Editions du CNRS, 1988.

, Vicent. La formation de l'école française de géographie (1870-1914). Paris: Bibliothèque Nationale, 1981.

BERRY, Brain J. L. "Clara voce cognito" in GOULD, Peter e BAILLY, Antoine (org.). Mémoires des géographes. Paris: Antophos, 2000.

BEUNINGEN, Cor van. "Le marxisme et l'espace chez Paul Claval. Quelques réflexions critiques pour une géographie marxiste" in L'Espace Geographique, $\mathrm{n}^{\circ} 4$, 1979.

BIRD, James. The changing worlds of geography. Oxford: Clarendon Press, 1984.

BLAUT, James. "Diffusionism: a uniformitarian critique" in Annals of the Association of American Geographers, vol. 77, n 1, 1987.

BLOMLEY, Nicholas. "The spaces of critical geographies" in Progress in Human Geography, vol. 1, n 30, 2007.

, Nicholas. "Critical geography: anger and hope" in Progress in Human Geography, vol. 1, n 31, 2007a.

BOMFIM, Paulo R. de A. A ostentação estatística (um projeto geopolítico para o território nacional: Estado e planejamento no período pós-64). São Paulo: tese de doutorado do programa de geografia humana, FFLCH-USP, 2007.

BOURDIEU, Pierre. O poder simbólico. Rio de Janeiro: Bertrand Brasil, 2010 [1989]. 
, Pierre. Os usos sociais da ciência: por uma sociologia do campo científico. São Paulo: Editora Unesp, 2003 [1997].

, Pierre. Meditações pascalianas. Rio de Janeiro: Bertrand Brasil, 2001 [1997].

, Pierre. Homo Academicus. Paris: Les Éditions de Minuit, 1984.

BOUQUET, Christian. "Géographie coloniale, géographie tropicale, géographie zonale: slalom entre les tabous" in VELASCO-GRACIET, Hélène (org.). Les tropiques des géographes. Pessac: MSHA, 2008.

BOYER, Jean-Claude. "Pierre George et la géographie régionale" in Annales de géographie, Paris, vol. 59, nº 6, 2008.

, Jean-Claude. "Pierre George et l'analyse des réseaux urbains" in Cahiers de géographie du Québec, vol. 52, n 146, 2008a.

BOYER, Jean-Claude; BURGEL, Guy; DENEUX, Jean-François. "Marxisme et géographie urbaine" in Villes en parallèle, Nanterre, Laboratoire de géographie urbaine/CERCEAU, n $7,1983$.

BRAVERMAN, Harry. Trabalho e capital monopolista: degradação do trabalho no século XX. Rio de Janeiro: Zahar, 1977 [1974].

BROC, Numa. Une histoire de la géographie physique en France (XIX $X^{\circ} X X^{\circ}$ siècle) tome 2. Perpignan: Presses Universitaires de Perpignan, 2010.

, Numa. "Homo geographicus: radioscopie des géographes français de l'entredeux-guerre" in Annales de géographie, Paris, n 571, t. 102, 1993.

, Numa. "Hérodote à l'eau rose" in Annales de géographie, Paris, n 514, t. 92, 1983. 
, Numa. "La géographie française face à la science allemande (1870-1914)" in Annales de géographie, Paris, n² 473, t. 86, 1977.

, Numa. “Hérodote' à la sauce tartare” in Annales de géographie, n 470, t. 85, 1976.

, Numa. "L'établissement de la géographie em France; definition, instituitions, projets (1870-1890)" in Annales de géographie, Paris, n 459, t. 83, 1974.

BROWETT, John. "Into the cul de sac of the dependency paradigm with A. G. Frank" in PEET, Richard (org.). An introduction to marxist theories of underdevelopment. Camberra: The Australian Nacional University, 1980.

BRUN, Jacques. "Pierre George, un précurser dans les études urbaines?" in Cahiers de géographie du Québec, vol. 52, n 146, 2008.

BRUN, Jacques e PAIX, Catherine. "La place de Michel Rochefort dans la recherche urbaine française" in Strates, fora de série, 2002.

BRUNET, Roger. "Raisons et saisons de géographie" in Geocarrefour, vol. 78/1, 2003.

, Roger. "Géographie du goulag” in L’Espace Geographique, número 3, tomo $\mathrm{X}, 1981$.

BUNGE, William. Fitzgerald: geography of a revolution. Athens, Georgia: The University of Georgia Press, 2011 [1971].

, William. "Fred K. Schaefer and the Science of Geography" in Annals of the Association of American Geographers, vol. 69, $\mathrm{n}^{\circ}$ 1, 1979.

BUTTIMER, Anne. "Edgar Kant (1902-1978): a baltic pionner" in Geografiska Annaler, série B, geografia humana, vol. 87, $n^{\circ} 3,2005$. 
CABANNE, Claude. Lexique de géographie humaine et économique. Paris: Dalloz, 1992.

CALLINICOS, Alex. "David Harvey and Marxism" in CASTREE, Noel e GREGORY, Derek (org.). David Harvey: a critical reader. Oxford: Blackwell, 2006.

CAPEL, Horacio. Geografia contemporânea, ciência e filosofia. Maringá: Eduem, 2010.

, Horacio. Filosofía y ciencia en la geografía contemporánea. Barcelona: Barcanova, 1988.

CARVALHO, Adalberto Dias de. "O materialismo racional de Bachelard: perspectivas epistemológicas e antropológicas" in Revista da Faculdade de Letras: Filosofia, Universidade do Porto, série II, vol. 3, 1986.

CASTREE, Noel. "The limits to capital (1982): David Harvey" in HUBBARD, Phil; KITCHIN, Rob; VALENTINE, Gill (org.). Key texts in human geography. Londres: Sage, 2008.

CHAMUSSY, Henry. "Le groupe Dupont ou les enfants du paradigme" in KNAUFOU, Rémy (org.). L'État de la géographie. Paris: Belin, 1997.

CHANET, Jean-François. "Les géographes et la question de l'avenir des campagnes françaises (années 1930-1940)" in GUESLIN, André. Les facs sous Vichy. Estrasburgo: Institut d'Études du Massif Central, Université Blaise-Pascal, 1993.

CHANG, Jung e HALLIDAY, John. Mao, a história desconhecida. São Paulo: Companhia das letras, 2006 [2005].

CHOLLEY, André. Les puissances économiques du monde. Classe de philosophie, enseignement du second degré. Paris: J.-B. Baillière \& fils editeurs, 1953. 
CHOUINARD, Vera. "Structure and agency: contested concepts in human geography" in The Canadian Geographer, Canadian Association of Geographers, $\mathrm{n}^{\circ}$ 4, t. 41, 1997.

CLAVAL, Paul. Epistemologia da geografia. Florianópolis: Editora da UFSC, 2011.

, Paul. "Le marxisme en arrière-plan" in Geócarrefour, vol. 78, nº 1, 2007.

, Paul. "Hérodote and the French left" in DODDS, Klaus e ATKINSON, David (org.). Geopolitical traditions. Londres e Nova York: Routledge, 2000.

, Paul. Histoire de la géographie française de 1870 à nous jours. Paris: Éditions Nathan, 1998.

, Paul. La géographie au temps de la chute des murs. Paris: L'Harmattan, 1993.

, Paul. "En relisant Pierre George" in L’Espace Géographique, n 2, 1992.

, Paul. A nova geografia. Coimbra: Livraria Almedina, 1987 [1977].

, Paul. "Le néo-marxisme et l'espace" in L'Espace Géographique, $\mathrm{n}^{\circ} 3$, 1987a.

, Paul. Géographie humaine et comtemporaine. Paris: Presses Universitaires de France, 1984.

, Paul. "Marxisme et géographie urbaine: quelques réflexions" in Villes en parallèle, Nanterre, Laboratoire de géographie urbaine/CERCEAU, $n^{\circ} 7,1983$.

, Paul. "Le marxisme et l'espace” in L'Espace Géographique, n 3, 1977.

, Paul. La pensée geographique. Paris: Société d'édition d'enseignement supérieur, 1972. 
CLAVAL, Paul e ENTRIKIN, J. N. "Cultural geography: place and landscapes between continuity and change" in BENKO, George e STROHMAYER, Ulf (org.). Human geography - a history for 21st Century. Londres: Arnold, 2004.

CLOUT, Hugh. "Pierre George 1909-2006" in Geographers, biobliographical studies, Londres, Continuum, vol. 29, 2010.

Hugh. "Geographers in their ivory tower: academic geography and popular geography in Paris 1931" in Geografiska Annaler, série B, geografia humana, vol. 87, $\mathrm{n}^{\circ} 1,2005$.

COHEN, Stephen. Bukharin: uma biografia política. Rio de Janeiro: Paz e Terra, 1990 [1971].

COLLECTIF de chercheurs de Bordeaux. "A propôs de l'article de P. Claval 'Le marxisme et l'espace'" in L'Espace Geographique, n 3, 1977.

COMPTES RENDUS du XVIII ${ }^{\circ}$ Congrès Internacional de géographie. Rio de Janeiro: Comité national du Brésil, volume I, 1956.

COSTA, Wanderley M. Geografia política e geopolítica. São Paulo: Edusp, 2010 [1991].

COUTINHO, Carlos Nelson. "Gramsci no Brasil: recepção e usos" in MORAES, João Quartin de. História do marxismo no Brasil - volume III Teorias e Interpretações. Campinas: Editora Unicamp, 1998.

COUZON, Isabelle. 'Les espaces économiques' de François Perroux (1950). Organisation de l'espace et aménagement du territoire dans l'economie et la géographie française au milieu du XXème siècle" in Revue d'histoire des sciences humaines, Paris, $\mathrm{n}^{\circ}$ 9, 2003.

, Isabelle. "La figure de l'expert-géographe au mirroir de la politique d'aménagement du territoire en France (1942-1950)" in ROBIC, Marie-Claire; 
OZOUF-MARIGNIER, Marie-Vic; BAUDELLE, Guy (org.). Géographes en pratiques (1870-1945). Rennes: Presses Universitaires de Rennes, 2001.

CRUZ, Maria Clara da. "O conceito de formação espacial: sua gênese e contribuição para a geografia" in Geographia, Rio de Janeiro, ano V, nº 9, 2009.

CUSSET, François. French theory. Paris: La Découverte, 2005 [2003].

DAMETTE, Félix e SCHEIBLING, Jacques. "Vingt ans après: la géographie et sa crise ont la vie dure" in La Pensée, Paris, $n^{\circ} 239,1984$.

DEAR, Michael. "The postmodern turn" in MINCA, Claudio (ed.) Postmodern Geography: theory and praxis. Londres: Blackwell, 2001.

, Michael. "The postmodern challange: reconstructing human geography" in Transactions of the Institute of British Geographers, nova série, vol. 13, nº 3, 1988.

DELFOSSE, Claire "Le rôle des instituitions culturelles et des missions à l'étranger dans la circulation des idées géographiques. L'exemple de la carrière de Pierre Deffontaines (1894-1978)" in Finisterra, Lisboa, vol. XXXIII, nº 65, 1998.

DEPREST, Florence. Géographes en Algérie (1880-1950). Paris: Belin, 2009.

DESHAIES, Laurent. "La nature de la géographie comme science sociale selon Pierre George" in Cahiers de géographie du Québec, vol. 52, n 146, 2008.

DESMARAIS, Gaëtan e RITCHOT, Gilles. La géographie structurale. Paris: L'Harmattan, 2000.

DOMINGUES, José M.; HERZ, Mônica; RESENDE, Cláudia. "Entrevista com Anthony Giddens" in Estudos Históricos, Rio de Janeiro, vol. 8, n 16, 1992.

DOSSE, François. História do estruturalismo - volume 1, o campo do signo. Bauru: Edusc, 2007. 
, François. História do estruturalismo - volume 2, o canto do cisne. Bauru: Edusc, 2007a.

, François. História e ciências sociais. Bauru: Edusc, 2004.

, François. A história em migalhas. Campinas: Editora da Unicamp e Editora Ensaio, 1994 [1987].

DRESCH, Jean. "Géographie d'hier et d'aujourd'hui" in La Pensée, Paris, Institut de recherches marxistes, $n^{\circ} 239,1984$.

, Jean. "Reflexões sobre a geografia" in Reflexões sobre a geografia. São Paulo: Edições da AGB São Paulo, 1980 [1948].

, Jean. Un géographe au déclin des empires. Paris: François Maspero, 1979.

, Jean. "Crise de la geógraphie" in La Pensée, Paris, n 194, 1977.

, Jean. "Cinquante ans de géographie soviétique" in Annales de géographie, vol. 77, nº 423, pp. 513-515, 1968.

, Jean. "Géographie et sous-developpement" in Annales de géographie, Paris, n 418, t. 76, 1967.

, Jean. "Ce que nous voulons..." in Paris-Pekin, bulletin de L'Association Franco-Chinoise, Paris, $\mathrm{n}^{\circ}$ 1, 1952.

DULLIN, Sabine. "Les interprétations françaises du système soviétique" in DREYFUS, Michel (org.). Le siècle des communismes. Paris: Les editions de l'atelier, 2000.

DUNFORD, Mick e PERRONS, Diane. "Structural change, theories of regulation and regional development" in BENKO, Georges e STROHMAYER, Ulf (org.). Geography, history and social sciences. Dordrecht: Kluwer academic publishers, 1995. 
DUPUY, Gabriel. "Pierre George: un géographe à l'ère des techniques" in Annales de géographie, Paris, $n^{\circ}$ 6, vol. 59, 2008.

EAGLETON, Terry. Depois da teoria - um olhar sobre os Estudos culturais e o pósmodernismo. Rio de Janeiro: Editora civilização brasileira, 2011 [2003].

ENTREVISTA “com a professora Doreen Massey" in Geosul, Florianópolis, vol. 21, $n^{\circ} 42,2006$.

FERRETTI, Federico. "They have the right to throw us out': Elisée Reclus' new universal geography" in Antipode, DOI 10.111/anti-12006, 2013.

FOOT, Simon; RIGBY, David; WEBBER, Michael. "Theory and measurement in historical materialism" in KOBAYASHI, Audrey e MACKENZIE, Suzanne (org.). Remaking human geography. Boston: Unwin Hyman, 1989.

FOUCAULT, Michel. "Sobre a justiça popular" in FOUCAULT, Michel. Microfísica do poder. Rio de Janeiro: Graal, 1979.

GALLISSOT, René. "O imperialismo e a questão colonial e nacional dos povos oprimidos" in HOBSBAWN, Eric (org.) História do marxismo - volume VIII. Rio de Janeiro: Paz e Terra, 1991.

GARNIER, Jean Pierre. "Marxist space, Marxian space" in L'espace géographique: two decades of L'espace géographique. Montpellier: GIP Reclus, 1993.

GEORGE, Pierre. Le métier de géographe. Paris: Armand Colin, 1990.

, Pierre. Geopolitique des minorités. Paris: Presses Universitaires de France, 1984.

Pierre. Geografia Urbana. São Paulo: Difel, 1983. 
, Pierre. "Difficultés et incertitudes de la géographie" in Annales de géographie, t. 85, n 467, 1976.

, Pierre. "Max Sorre" in Bulletin de la section de géographie - les géographes français. Paris: Bibliotèque nacionale, 1975.

, Pierre. Os métodos da geografia. São Paulo: Difusão européia do livro, 1972.

, Pierre. Sociologia e Geografia. São Paulo: Editora Forense, 1969 [1966].

, Pierre. "Cinquantes ans d'expérience économique socialiste: centralisme, régionalisme, décentralisation économique" in Annales de Géographie, Paris, $\mathrm{n}^{\circ} 423$, vol. 77, 1968.

, Pierre. "Introduction à la géographie economique d'après Ju. G. Saouchkine" in Annales de Géographie, Paris, vol. 68, n³ 366, 1959.

, Pierre. Géographie économique \& sociale de la France. Paris: Éditions Hier \& aujourd'hui, 1946.

, Pierre. Cours d'économie politique. Paris: Éditions Sociales, 1945.

GEORGE, Pierre; KAYSER, Bernard; LACOSTE, Yves; GUGLIELMO, Raymond. A geografia ativa. São Paulo: Difusão Européia do livro, 1966 [1964].

GETLZER, Israel. "Gueorqui V. Plekhânov: a danação da ortodoxia" in HOBSBAWN, Eric (org.). História do marxismo - volume III. Rio de Janeiro: Paz e Terra, 1989.

GIBLIN, Béatrice. "Hérodote, une géographie géopolitique" in Cahiers de géographie du Québec, vol. 29, n 77, 1985.

GINTRAC, Cécile. "Géographie critique, géographie radicale: comment nommer la géographie engagée?" in Carnets de géographes, n 4, 2012. 
GODELIER, Maurice. "O marxismo e as ciências do homem" in HOBSBAWN, Eric J. História do marxismo - volume XI. Rio de Janeiro: Paz e Terra, 1991.

GOMES, Paulo César da Costa. Geografia e modernidade. Rio de Janeiro: Bertrand Brasil, 2005 [1996].

GOTTMANN, Jean. "French Geography in Wartime" in Geographical review, vol. 1, número 1, 1946.

GOULD, Peter e STROHMAYER, Ulf. "Geographical visions: the evolution of human geographic thought in the twentieth century" in BENKO, George e STROHMAYER, Ulf (org.). Human geography - a history for 21st Century. Londres: Arnold, 2004.

GOULD, Stephen Jay. Darwin et les grandes énigmes de la vie. Paris: Éditions du Seuil, 1997 [1977].

GOULEMOT, J. M. Pour l'amour de Staline. Paris: CNRS Editions, 2009.

GRAHAM, Julie. "Theory and essentialism in marxist geography" in Antipode, vol. 22, $\mathrm{n}^{\circ} 1,1990$.

GRAS, Jacques. "André Cholley" in Bulletin de la section de géographie - les géographes français. Paris: Bibliotèque nacionale, 1975.

GREGORY, Derek. "Lefèbvre, Lacan and the production of space" in BENKO, Georges e STROHMAYER, Ulf (org.). Geography, history and social sciences. Dordrecht: Kluwer academic publishers, 1995.

, Derek. Ideology, science and human geography. Londres: Hutchnison \& Co., 1978.

GRUNDMANN, Reiner. Marxism and Ecology. Oxford: Clarendon press, 1991.

GUERAMISSOV, I. P. "La géographie soviétique au cours des cinquante dernières années" in Annales de Géographie, Paris, n 423, vol. 77, 1968. 
GUGLIELMO, Raymond. "Pierre George, promoteur de la géographie industrielle" in Cahiers de géographie du Québec, vol. 52, nº 146, 2008.

Raymond. "Geografia e dialética" in Reflexões sobre a geografia. São Paulo: Edições da AGB São Paulo, 1980 [1955].

HAGUE, Euan. "Intervention Roundtable Antipode, Inc?" in Antipode, vol. 34, n 4 , 2002.

HAMELIN, Louis-Edmond. "Traits de la carrière de Pierre George" in Cahiers de géographie du Québec, vol. 52, nº 146, 2008.

HARVEY, David. A condição pós-moderna. São Paulo: Edições Loyola, 2005 [1989].

, David. "Souvenirs et désirs" in GOULD, Peter e BAILLY, Antoine (org.). Mémoires des géographes. Paris: Antophos, 2000.

, David. Justiça social e a cidade. São Paulo: Hucitec, 1980 [1972].

HERMAN, Arthur. A ideia de decadência na história ocidental. São Paulo: Record, 1999.

HEPPLE, Leslie W. "Géopolitique de gauche: Yves Lacoste, Heródote and French radical geopolitics" in DODDS, Klaus e ATKINSON, David (org.). Geopolitical traditions. Londres e Nova York: Routledge, 2000.

HOBSBAWN, Eric. "O marxismo hoje: um balanço aberto" in HOBSBAWN, Eric J. (org.). História do Marxismo - volume XI. Rio de Janeiro: Paz e Terra, 1991 [1982].

Eric. "A cultura européia e o marxismo entre o séc. XIX e o séc. XX" in HOBSBAWN, Eric (org.). História do Marxismo - volume II. Rio de Janeiro: Paz e Terra, 1989. 
, Eric. "Os intelectuais e o antifacismo" in HOBSBAWN, Eric (org.). História do Marxismo - volume IX. Rio de Janeiro: Paz e Terra, 1989a.

HOLTON-JENSEN, Arild. Geography: history and concepts, a student's guide. Londres: Sage, 2009.

HOMMAGE des Annales de géographie. "Pierre George (1909-2006): un géographe témoin de son temps" in Annales de géographie, n 6, vol. 59, 2008.

HOTTES, Karlheinz; HOTTES, Ruth; SCHÖLLER, Peter. "Walter Christaller" in Geographers, biobibliographical studies, Londres, vol. 7, Mansell Publishing e UGI, 1983.

HUNT, Tristan. Comunista de casaca. Rio de Janeiro: Editora Record, 2010.

ÍPOLA, Emilio. Althusser, l'adieu infini. Paris: Presses Universitaires de France, 2012.

IUMATTI, Paulo T. "Caio Prado Jr. e as ciências naturais: sua apreensão das transformações epistemológicas da virada do século XIX" (CD-ROM) in SEABRA, Manoel; HEIDEMANN, Heinz Dieter; IUMATTI, Paulo T (org.). Caio Prado Jr. e a Associação de Geógrafos Brasileiros. São Paulo: Edusp, 2008.

JACOBY, Russell. O fim da utopia. São Paulo: Record, 1999.

, Russell. Os últimos intelectuais. São Paulo: Edusp e Trajetória Cultural, 1987.

, Russell. Dialectic of defeat: contours of western marxism. Cambridge: Cambridge University press, 1981.

JAMESON, Fredric. Pós-modernismo: a lógica cultural do capitalismo tardio. São Paulo: Editora Ática, 2007. 
, Fredric. A virada cultural: reflexões sobre o pós-moderno. Rio de Janeiro: Civilização brasileira, 2006.

JAUHIAINEN, Jussi. "Edgar Kant and the rise of Modern Urban Geography" in Geografiska Annaler, série B, geografia humana, vol. 87, nº 3, 2005.

JENSON, Jane. "Rebels sons: the regulation school - entretien avec Alain Lipietz" in French Politics and Society, Universidade de Harvard, vol. 5, nº 4, 1987.

JOHNSTON, R. J. Geography \& geographer - $5^{a}$ edição revista e ampliada. Londres: Arnold, 1997.

, R. J. Philosophy and Human Geography. Londres: Edward Arnold, 1986 [1983].

JOHNSTON, R. J.; GREGORY, Derek; PRATT, Geraldine; WATTS, Michael. The dictionary of Human Geography. Singapura: Blackwell Publishing, 2008.

JOSEPH, Bernadette. "A biblioteca do Instituto de Geografia reflete a história do pensamento geográfico: estudo sobre o período 1925-1960" in Confins, n 10, 2010.

JUDT, Tony. Passado Imperfeito: um olhar crítico sobre a intelectualidade francesa no pós-guerra. São Paulo: Nova Fronteira, 2007 [1992].

JULLIARD, Jacques e WINOCK, Michel (org.) Dictionnaire des intellectuels français. Paris: Éditions de Seuil, 1996.

KALLSCHEUER, Otto. "Marxismo e teorias do conhecimento" in HOBSBAWN, Eric J. (org.). História do marxismo - volume XII. Rio de Janeiro: Paz e Terra, 1989.

KLEINSCHMAGER, Richard. "Géographie et idéologie entre deux guerre" in L'Espace Geographique, nº 1, 1988.

KOFLER, Leo; ABENDROTH, Wolfgang; HOLZ, Hans Heinz. Conversando com Lukács. Rio de Janeiro: Paz e Terra, 1969. 
KONINK, Rodolphe de. "La geógraphie critique" in BAILLY, Antoine S. (org.) Les concepts de la géographie humaine. Paris: Masson, 1995.

, Rodolphe de. "Idées, idéologies et débats en géographie" in Cahiers de géographie du Québec, vol. 29, nº 77, 1985.

, Rodolphe de. "Contre l'idealisme en géographie" in Cahier de géographie du Québec, vol. 22, nº 56, 1978.

KORSCH, Karl. Marxismo e filosofia. Porto: Edições Afrontamento, 1966 [1930].

KRIEGEL, Annie. Aux origines du communisme français. Paris: Flammarion, 1978 [1969].

KROPOTKIN, Piotr. La conquista del pan. Buenos Aires: Libros de Anarres, 2007.

Piotr. O Estado e seu papel histórico. São Paulo: Editora Imaginária, 2000.

LACOSTE, Yves. La géopolitique et le géographe: entretiens avec Pascal Lorot. Paris: Choiseul Éditions, 2010.

, Yves. Contra os antiterceiro-mundistas e contra certos terceirosmundistas. São Paulo: Ática, 1991.

, Yves. A geografia isso serve, em primeiro lugar, para fazer a guerra. Campinas: Papirus, 1988 [1976].

, Yves. "A Geografia" in CHÂTELET, François. A história da filosofia volume 7, a filosofia das ciências humanas. Rio de Janeiro: Zahar, 1974.

, Yves. Geografia do subdesenvolvimento. São Paulo: Difusão européia do livro, 1971 [1965]. 
LACOSTE, Yves; NOUSCHI, André; PRENANT, André. L'Algérie passé et présent. Paris: Éditions Sociales, 1960.

LEFĖBVRE, Henri. Espaço e política. Belo Horizonte: Edições UFMG, 2008. , Henri. La fin de la histoire. Paris: Antrophos, 2001 [1972].

, Henri. "Répond à villes en parallèle" in Villes en parallèle, Nanterre, Laboratoire de géographie urbaine/CERCEAU, $n^{\circ}$ 7, 1983.

LÊNIN, Vladimir. Biografia. Moscou: Edições Progresso, 1984.

, Vladimir. As três fontes e as três partes constitutivas do marxismo. São Paulo: Global, 1979.

LENNTORP, Bo; TÖRNQVIST, Gunnar; WÄRNERYD, Olof; ÖBERG, Sture. "Torsten Hägerstrand 1916-2004" in Geografiska Annaler, série B, geografia humana, vol. 86, $n^{\circ} 4$, número especial, 2004.

LÉVY, Jacques. "Les lieux de hommes: un nouveau départ pour la géographie" in La Pensée, Paris, Institut de recherches marxistes, nº 239, 1984.

LIAUZU, Claude. Histoire de l'anticolonialisme en France. Paris: Pluriel / Librairie Arthème, 2010 [2007].

LÖWY, Michael. As aventuras de Karl Marx contra o Barão de Münchhausen. São Paulo: Editora Cortez, 2003.

LUNG, Yannick. "Le neo-marxisme et l'espace: réponse à Paul Claval" in L'Espace Geographique, n 1, 1988.

MACHADO, Carlos E. J. "Ernst Bloch e 'o sonho de uma coisa"' in ALMEIDA, Jorge de e BADER, Wolfgang (org.). Pensamento alemão no século $X X$ - volume 1. São Paulo: Cosacnaify e Goethe-institut, 2009. 
MACHADO, Lia Osório. "Origens do pensamento geográfico no Brasil: meio tropical, espaços vazios e idéia de ordem" in CORRÊA, Roberto L.; CASTRO, Iná E. de; GOMES, Paulo César da C. (orgs.). Geografia: conceitos e temas. Rio de Janeiro: Bertrand Brasil, 2007 [1995].

MAMIGONIAN, Armen. "A Geografia Francesa nos meados do século XX e a contribuição de Jean Tricart" In Memorial de livre-docência. São Paulo: Faculdade de Filosofia Letras e Ciências Humanas - Universidade de São Paulo, 2005.

Armen. "A escola francesa de geografia e o papel de A. Cholley" in Cadernos Geográficos. Florianópolis: UFSC/Dep. de Geociências, 2003.

, Armen. "Notas sobre a geografia urbana no Brasil" in SANTOS, Milton (org.) Novos rumos da geografia brasileira. São Paulo, Hucitec, 1982.

MANDEL, Ernest. O papel do marxismo na história. São Paulo: Xamã, 2001.

MANZAGOL, Claude. "Quelques points de controverse dans l'oeuvre de Pierre George" in Cahiers de géographie du Québec, vol. 52, n 146, 2008.

MÁREK, Franz. "A desagregação do stalinismo" in HOBSBAWN, Eric (org.). A história do Marxismo - volume X. Rio de Janeiro: Paz e Terra, 1987.

MARRAMAO, Giacomo. "Entre o bolchevismo e a social-democracia: Otto Bauer e a cultura política do austro-marxismo" in HOBSBAWN, Eric (org.). A história do Marxismo - volume V. Rio de Janeiro: Paz e Terra, 1989.

MARTIN, Geoffrey J. "The nature of geography and The Schaefer-Hartshorne debate" in Reflections on Richard Hartshorne's the nature of geography. Washington: Association of American Geographers, 1989.

MARX, Karl. O capital, crítica da economia política - livro 1, volume 1. Rio de Janeiro: Civilização Brasileira, 2006.

, Karl. Sobre o suicídio. São Paulo: Boitempo editorial, 2006a. 
, Karl. Manuscritos econômico-filosóficos. São Paulo: Boitempo editorial, 2006b.

, Karl. O 18 do brumário e cartas a Kugelmann. São Paulo: Paz e Terra, 1997.

MATHEWSON, Kent. "James Morris Blaut" in Geographers, biobibliographical studies, Norfolk, Editora Continuum, vol. 27, 2008.

MATHIEU, Nicole e CARTIER, Stéphanie. "Mai 68: ruptures à l'institut de géographie" in Strates, fora de série, 2002.

MATLEY, lan M. "The marxist approach to the geographical environment" in Annals of the Association of American Geographers, vol. 56, n 1, 1966.

MAUREL, Marie-Claude. "Pierre George compagnon de rôute, une trajectoire d'engagement" in Cahiers de géographie du Québec, vol. 52, nº 146, 2008.

MEGALE, J. (org.). Max Sorre. São Paulo: Editora Ática, 1984.

MEMÓRIAS do colóquio. Géographie et contestations: autour de Guglielmo. Paris: Colloque organisé par le laboratoire périphéries urbaines, espaces verts, et environnement, Éditeur CREV, 1990.

MÉO, Guy di. "Pierre George, géographe des sociétés humaines" in Annales de géographie, Paris, $n^{\circ}$ 6, vol. 59, 2008.

, Guy di. "Les formations socio-spatiales ou la dimension infra-régionale en géographie" in Annales de géographie, nº 526, t. 94, 1985.

MERCIER, Guy. "Legs vidalien et romantisme scientifique" in Cahiers de géographie du Quebec, vol. 52, n 146, 2008.

MERRIFIELD, Andy. "Henri Lefèbvre, a socialist in space" in CRANG, Mike e THRFIT, Nigel (org.). Thinking space. Londres: Routledge, 2000. 
MÉSZÁROS, István. "Marx Filósofo" in HOBSBAWM, Eric (org.). A história do Marxismo - volume I. Rio de Janeiro: Paz e Terra, 1983.

MEYNIER, André. Histoire de la pensée géographique en France (1872-1969). Paris: Presses Universitaires de France, 1969.

MILLER, James. The passion of Michel Foucault. Nova York: Anchor books, 1994.

MONTEIRO, Carlos. A. F. "Apontamentos para uma avaliação da Geografia no Brasil (1934-1977): um apelo à filosofia da ciência para esclarecer o papel do método na solução de uma crise de identidade epistemológica" in Simpósio Metodologia na Geografia, $3^{\circ}$ Encontro Nacional de Geógrafos, p. 1-255, 1978.

MORAES, Antonio Carlos Robert e COSTA, Wanderley Messias. "A geografia e o processo de valorização do espaço" in SANTOS, Milton (org.) Novos rumos da geografia brasileira. São Paulo, Hucitec, 1982.

MINCA, Claudio. "Postmodern Geographies (1989): Edward Soja" in HUBBARD, Phil; KITCHIN, Rob; VALENTINE, Gill (org.). Key texts in human geography. Londres: Sage, 2008.

MITCHELL, Don. "Radical Scholarship: a polemic on making a difference outside the academy" in GREGORY, Derek e CASTREE, Noel (org.). Human Geography volume 3. Londres: Sage, 2012 [2004].

MONTRICHER, Nicole de. L'aménagement du territoire. Paris: Éditions la Découverte, 1995.

MORAES, João Quartin de. "Concepções comunistas do Brasil democrático: esperanças e crispações" in MORAES, João Quartin de (org). História do marxismo no Brasil - volume III Teorias e Interpretações, Campinas, Editora Unicamp, 1998.

MOREIRA, Ruy. "Repensando a geografia" in SANTOS, Milton (org.) Novos rumos da geografia brasileira. São Paulo, Hucitec, 1982. 
, Ruy. "Assim se passaram dez anos (A renovação da Geografia Brasileira no Brasil no período 1978-1988)" in Geographia, Niterói, n 3, p. 27-49, 2000.

MUIR, Richard. "Radical geography or a New Orthodoxy?" in Area, vol. 10, $n^{\circ} 5$, 1978.

NEGT, Oskar. "O marxismo e a teoria da revolução no último Engels" in HOBSBAWN, Eric (org.) História do marxismo - volume II. Rio de Janeiro: Paz e Terra, 1989.

NICHOLLS, Walter J. "The Los Angeles School: difference, politics, city" in Internacional journal of urban and regional research, vol. 35.1, 2011.

NIETZSCHE, Friedrich. A vontade de poder. Rio de Janeiro: Contraponto, 2008.

OAKES, Timothy. "Place and the paradox of modernity" in Annals of the Association of American Geographers, vol. 87, n 3, 1997.

OLIVEIRA, Ariovaldo Umbelino. "Discussões sobre o objeto da geografia científica" in SANTOS, Milton (org.) Novos rumos da geografia brasileira. São Paulo, Hucitec, 1982.

ORAIN. Olivier. "Emmanuel de Martonne, figure de l'orthodoxie épistémologique postvidalienne" in ROBIC, Marie-Claire; OZOUF-MARIGNIER, Marie-Vic; BAUDELLE, Guy (org.). Géographes en pratiques (1870-1945). Rennes: Presses Universitaires de Rennes, 2001.

PAILHÉ, Joël. "Références marxistes, empreintes marxiennes, géographie française" in Géocarrefour, vol. 78/1, 2003.

, Jöel. "Pierre George, la geógraphie et le marxisme" in Espace-temps, Paris, L'Assossiation Espaces-temps, nº 18-19-20, 1981. 
PATERSON, John L. David Harvey's Geography. Londres: Croom helm e Barnes \& Noble books, 1984.

PASTI, André; DUARTE, Luciano; STEDA, Melissa; NABARRO, Wagner. "Entrevista com David Harvey" in Boletim Campineiro de geografia, vol. 2, n 1, 2012.

PEET, Richard. Modern Geographical Thought. Oxford: Blackwell Publishing, 1998.

, Richard. "Social theory, Postmodernism, and the critique of development" in BENKO, Georges e STROHMAYER, Ulf (org.). Space and social theory. Oxford: Blackwell, 1997.

, Richard. "Introduction to the life and thought of Karl Wittfogel" in Antipode, vol. $17, \mathrm{n}^{\circ} 1,1985$.

, Richard. "The social origins of environmental determinism" in Annals of the Association of American Geographers, vol. 75, $\mathrm{n}^{\circ}$ 3, 1985a.

, Richard. "O desenvolvimento da geografia radical nos Estados Unidos" in CHRSITOFOLETTI, Antônio (org.) Perspectivas em Geografia. São Paulo: Difel, $1982[1977]$.

, Richard (org.). Radical Geography, alternative viewpoints on contemporary social issues. Chicago: Maaroufa Press, 1977.

, Richard. "The development of radical geography in the United States" in PEET, Richard (org.). Radical Geography, alternative viewpoints on contemporary social issues. Chicago: Maaroufa Press, 1977a.

PEET, Richard J. e LYONS, James V. "Marxism dialectical materialism, social formation and the geographic relations" in HARVEY, Milton E. e HOLLY, Brain P. (org.). Themes in geographic thought. Londres: Croom helm, 1981.

PELLETIER, Philippe. Elisée Reclus: géographie et anarchie. Paris: Éditions du monde libertraire, 2009. 
PEREIRA, Raquel M. F. do A. Da geografia que se ensina à gênese da geografia moderna. Florianópolis: Editora da UFSC, 2009.

PESCHANSKI, João; CALINITSKY, David; e PETERSON, Sigrid. "Entrevista - David Harvey" in Margem esquerda, n 16, São Paulo, 2011.

PHELPS, Nick "Spatial divisions of labour (1984): Doreen Massey" in HUBBARD, Phil; KITCHIN, Rob; VALENTINE, Gill (org.). Key texts in human geography. Londres: Sage, 2008.

PHILLIPS, Martin. "Uneven development (1984): Neil Smith" n HUBBARD, Phil; KITCHIN, Rob; VALENTINE, Gill (org.). Key texts in human geography. Londres: Sage, 2008.

PHILO, Chris e SODERSTROM, Ola. "Social geography: looking for society in its spares" in BENKO, Georges e STROHMAYER, Ulf (org.). Human geography - a history for 21st Century. Londres: Arnold, 2004.

POURTIER, Roland. "Pierre George et les questions de population" in Annales de géographie, Paris, $n^{\circ}$ 6, vol. 59, 2008.

POWER, Marcus e SIDAWAY, James D. "The degeneration of tropical geography" in Annals of the Association of American Geographers, vol. 94, nº 3, 2004.

PRED, Allan. "The choreography of existence: comments on Hägerstrand timegeography and its usefulness" in Economic Geography, vol. 53, n² 2, 1977.

QUAINI, Massimo. Marxismo e Geografia. Rio de Janeiro: Paz e Terra, 2002 [1974]. , Massimo. La construccíon de la geografía humana. Barcelona: Oikos-tau, 1981 [1975]. 
RACINE, Jean-Bernard. "Problematiques et méthodologie de l'implicite à l'explicite" in ISNARD, H.; RACINE, J.-B.; REYMOND, H. (org.). Problématiques de la géographie. Paris: PUF, 1981.

RACINE, Jean-Bernard e BAILLY, Antoine S. "Geography and geographical space: towards an epistemology of geography" in L'espace géographique: two decades of L'espace géographique. Montpellier: GIP Reclus, 1993 [1979].

RAFFESTIN, Claude. "Marxisme et géographie politique" in Cahiers de géographie du Québec, vol. 29, nº 77, 1985.

RECLUS, Elisée. A evolução, a revolução e o ideal anarquista. São Paulo: Editora Imaginário / Editora Expressão \& Arte, 2002 [1897].

RENARD, Jean. "Pierre George et la géographie rurale ou la géographie rurale de Pierre George" in Cahiers de géographie du Québec, vol. 52, n 146, 2008.

ROBERT, Jean. "Theoretical problems of geography de V. A. Anuchin' une contribuition soviétique essential au débat sur l'únite de la géographie" in L'espace géographique, $\mathrm{n}^{\circ}$ 4, 1979.

ROBIC, Marie-Claire. "Tropicalisme, zonalité, géographie tropicale. Les paradoxes d'une émergence" in VELASCO-GRACIET, Hélène. Les tropiques des géographes. Pessac: MSHA, 2008.

Marie-Claire. "A crise dos anos 30 e a emergência de novos temas na geografia" in SALGUEIRO, Heliana Angotti (org.). Pierre Monbeig e a geografia humana brasileira. Bauru: Edusc, 2006.

, Marie-Claire. "Des vertus de la chaire à la tentation de l'action" in CLAVAL, Paul e SANGUIN, André-Louis (org.). La géographie française à l'époque classique (1918-1968). Paris: L’Harmattan, 1996. 
ROBIC, Marie-Claire e PUMAIN, Denise. "Le rôle des mathématiques dans une 'révolution' théorique et quantitative de la géographie française depuis les anées 1970" in Sciences humaines, vol.1, n 6, 2002.

ROBIC, Marie-Claire; BRIEND, Anne-Marie; RÖSSLER, Mechtild (org.). Géographes face au monde. Paris: L'Harmattan, 1996.

ROCHEFORT, Michel. "Les structures sociales dans la pensée géographique de Pierre George” in Cahiers de géographie du Québec, vol. 52, nº 146, 2008.

, Michel. "Répond à villes en parallèle" in Villes en parallèle, Nanterre, Laboratoire de géographie urbaine/CERCEAU, $\mathrm{n}^{\circ} 7,1983$.

ROCHEFORT, Raymond. “'Changer nos têtes?' entretien avec Raymond Rochefort” in Espace-temps, Paris, L'Assossiation Espaces-temps, nº 18-19-20, 1981.

RÖSSLER, Mechtild. "Géographie et nacional-socialisme" in L'espace geographique, $\mathrm{n}^{0} 1,1988$.

RUPKE, Nicolaas. "Alexander von Humboldt and revolution: a geography of reception of the Varnhagen von Ense Correspondence" in LIVINSTONE, David N.; WITHERS, Charles W. Geography and Revolution. Chicago: The University of Chicago Press, 2005.

SALGUEIRO, Heliana Angotti (org.). Pierre Monbeig e a geografia humana brasileira. Bauru: Edusc, 2006.

SANGUIN, André-Louis. "La controverse Anuchin (1960-1976) en tournant dans I'histoire de la pensée géographique en URSS" in L'espace géographique, $\mathrm{n}^{\circ} 4$, 1979.

SANTOS, Eliane Carvalho dos. "A escola da regulação e a construção para o debate da crise" in Anais da XII Semana da Geografia, Presidente Prudente, Unesp, 2011 
(disponível em: http://docs.fct.unesp.br/semanas/geografia/2011-ensino\%20e \%20epistemologia/Eliane\%20carvalho.pdf - acessado em 20/12/12).

SANTOS, Milton. Por uma geografia nova. São Paulo: Edusp, 2002 [1978]. , Milton (org.). Novos rumos da geografia brasileira. São Paulo: Hucitec, 1982.

, Milton. "Alguns problemas atuais da contribuição marxista à geografia" in Novos rumos da geografia brasileira. São Paulo: Hucitec, 1982a.

, Milton. "Sociedade e espaço: a formação socioespacial como teoria e método" in Boletim Paulista de Geografia, AGB São Paulo, nº 54, 1977.

SAYER, Andrew. "Postmodernist thought in geography: a realistic view" in Antipode, vol. 25, n 4, 1993.

SCARIM, Paulo César. Coetâneos da crítica: contribuição ao estudo do movimento de renovação da geografia brasileira. São Paulo: Dissertação de mestrado, FFLCH Geografia/USP, 2000.

SCHAEFER, F. K. "Exceptionalism in Geography" in AGNEW, John; LIVINGSTONE, David N.; ROGERS, Alisdair. Human Geography. Oxford: Blackwell, 1996.

SCHEIBLING, Jacques. "Débats et combats sur la "crise de la géographie"' in La Pensée, Paris, n 194, 1977.

SCHWANITZ, Dietrich. Cultura Geral. São Paulo: Martins Fontes, 2009.

SEABRA, Manoel. "Caio Prado Jr. e os primeiros anos da AGB" in SEABRA, Manoel; HEIDEMANN, Heinz Dieter; IUMATTI, Paulo T. (org.). Caio Prado Jr. e a Associação de Geógrafos Brasileiros. São Paulo: Edusp, 2008.

SENNETT, Richard. A nova cultura do capitalismo. Rio de Janeiro: Record, 2006. 
SHAW, Brain J. "Karl Marx" in Geographers, biobibliographical studies, Londres, Mansell, vol. 19, 2000.

SHUB, David. "Kropotkin and Lenin” in Russian Review, vol. 12, n 4, 1953.

SILVA, Altiva Barbosa da. "A renovação da geografia na Alemanha nas primeiras décadas do século XX" in Revista Acta Geográfica, ano I, vol. 1, 2007

SILVA, Armando Corrêa. "Contribuição à crítica da crise da geografia" in SANTOS, Milton (org.). Novos rumos da geografia brasileira. São Paulo, Hucitec, 1982.

SINGER, Peter. Hegel. São Paulo: Edições Loyola, 2012 [1983].

SMITH, Neil. "What's left? Neo-critical geography, or, the flat pluralist world of Business class" in Antipode, vol. 5, n 5, 2005.

, Neil. "Marxism and geography in the anglophone world" in Geographische Revue, jahrgang 3, heft 2, 2001.

, Neil. "Geography as museum: private history and conservative idealism in The nature of geography" in Reflections on Richard Hartshorne's the nature of geography. Washington: Association of American Geographers, 1989.

, Neil. "Academic war over the field of geography: the elimination of geography at Harvard" in Annals of the Association of American Geographers, vol. 77, $\mathrm{n}^{\circ} 2$, 1987.

SOJA, E. "The socio-spatial dialetic" in Annals of the Association of American Geographers, nº 70, 1980.

SURET-CANALE, Jean. "Géographe, marxiste" in Espace-temps, Paris, L'Assossiation Espaces-temps, nº 18-19-20, 1981.

, Jean. "Sur la 'géographie du sous-developpement"' in La Pensée, Paris, n 131, 1967. 
STEINBERG, Hans-Josef. "O partido e a formação da ortodoxia marxista" in HOBSBAWN, Eric (org.) História do marxismo - volume II. Rio de Janeiro: Paz e Terra, 1989.

SYMANSKI, Richard. "Why we should fear postmodernists" in Annals of the Association of American Geographers, vol. 84, n² 2, 1994.

THERBORN, Göran. Do marxismo ao pós-marxismo? São Paulo: Boitempo, 2012 [2008].

, Göran. "A análise de classe no mundo atual: o marxismo como ciência social" in HOBSBAWN, Eric J. História do marxismo - volume XI. Rio de Janeiro: Paz e Terra, 1991.

THRIFT, Nigel. "On the determination of social action in space and time" in DEAR, Michel e FLUSTY, Steven. The spaces of postmodernity. Londres: Blackwell, 2002.

THRIFT, Nigel e WHATMORE, Sarah (orgs). Cultural Geography, critical concepts in the social sciences - volume I e II. Nova York: Routledge, 2007 [2004].

TISSIER, Jean-Louis. "Rendez-vous à Uriage (1940-1942). La fonction du terrain au temps de la révolution nacionale" in ROBIC, Marie-Claire; OZOUF-MARIGNIER, Marie-Vic; BAUDELLE, Guy (org.). Géographes en pratiques (1870-1945). Rennes: Presses Universitaires de Rennes, 2001.

, Jean-Louis. "Front pionnier des géographes?" in FOURCAUT, Annie (org.). Banlieu rouge 1920-1960. Paris: Éditions Autrement, 1992.

TRICART, Jean. "Dialectique de la geomophorlogie climatique, quelques réflexions suscités par un 'avocat du diable' bien naif' in Finisterra, volume XX, n 40, 1985.

, Jean. "O campo da dialética em geografia" in Reflexões sobre a geografia. São Paulo: Edições da AGB São Paulo, 1980 [1977]. 
, Jean. Cours de géographie humanine - fascicule II l'hábitat urbain. Paris:

Centre de Documentation Universitaire, 1957.

Jean. Cours de géographie humaine. Paris: Centre de documentation universitaire, 1949.

TROIN, Jean-François. "Pierre George et la ville" in Annales de géographie, Paris, $\mathrm{n}^{\circ}$ 6 , vol. 59, 2008.

TROLL, Carl. "Geographic science in Germany during the period 1933-1945: a critique and justification" in Annals of the Association of American Geographers, vol. 39, número 2, 1949.

TUATHAIL, Gearóid O'. "The critical reading/wrinting of geopolitics: re-reading/writing Wittfogel, Bowman and Lacoste" in Progress in Human Geography, $n^{\circ} 18$, vol. 3, 1994.

UNWIN, Tim. El lugar de la geografía. Madrid: Ediciones Cátedra, 1995 [1992].

, Tim. "A waste of space? Toward a critique of the social production of space" in Transactions of the Institue of British Geographers, nova série, vol. 12, n 2, 1987.

VAZ, Henrique C. de Lima. Antropologia filosófica - volume I. São Paulo: Edições Loyola, 2009 [1991].

VESENTINI, José W. "Controvérsias geográficas: epistemologia e política" in Confins, $n^{\circ} 2,2008$.

VEYRET, Yvette. "Pierre George, pionnier de l'environnement en géographie" in Annales de géographie, $n^{\circ}$ 6, vol. 59, 2008.

VILAR, Pierre. "Marx e a história" in HOBSBAWN, Eric (org.) História do marxismo volume I. Rio de Janeiro: Paz e Terra, 1983. 
WALDENBERG, Marek. "A estratégia política da social-democracia alemã" in HOBSBAWN, Eric (org.) História do marxismo - volume II. Rio de Janeiro: Paz e Terra, 1989.

WALICKI, Andrzej. "Socialismo russo e populismo" in HOBSBAWN, Eric (org.) História do marxismo - volume III. Rio de Janeiro: Paz e Terra, 1989.

WATTS, Michel. "1968 and all that..." in Progress in Human Geography, vol. 2, n 25, 2001.

WINOCK, Michel. O século dos intelectuais. Lisboa: Terramar, 2000 [1997].

WHEEN, Francis. Karl Marx. São Paulo: Editora Record, 2001.

WIGGERHAUS, Rolf. A escola de Frankfurt. Rio de Janeiro: Bertrand Brasil, 2002 [1986].

WITTFOGEL, Karl. "Geopolítica, materialismo geográfico e marxismo" in Seleção de textos, São Paulo, Associação dos geógrafos brasileiros, n 20, 1992.

, Karl. Le despotisme oriental. Paris: Editions Minuit, 1977 [1959].

ZANOTELLI, Cláudio Luiz. Yves Lacoste: Entrevistas. São Paulo: Annablume, 2005. 